\title{
Bioarchaeological Investigations of Nineteenth-Century African American Burials at the Pioneer Cemetery (41B0202) in Brazoria, Texas
}

Aaron R. Norment

AmaTerra Environmental, Inc.

Jeremy W. Pye

Cory J. Broehm

Douglas K. Boyd

Prewitt and Associates, Inc.

Follow this and additional works at: https://scholarworks.sfasu.edu/ita

Part of the American Material Culture Commons, Archaeological Anthropology Commons, Environmental Studies Commons, Other American Studies Commons, Other Arts and Humanities Commons, Other History of Art, Architecture, and Archaeology Commons, and the United States History Commons

Tell us how this article helped you.

This Article is brought to you for free and open access by the Center for Regional Heritage Research at SFA ScholarWorks. It has been accepted for inclusion in Index of Texas Archaeology: Open Access Gray Literature from the Lone Star State by an authorized editor of SFA ScholarWorks. For more information, please contact cdsscholarworks@sfasu.edu. 


\section{Bioarchaeological Investigations of Nineteenth-Century African American Burials at the Pioneer Cemetery (41B0202) in Brazoria, Texas}

\section{Licensing Statement}

This is a work for hire produced for the Texas Department of Transportation (TxDOT), which owns all rights, title, and interest in and to all data and other information developed for this project under its contract with the report producer. The report may be cited and brief passages from this publication may be reproduced without permission provided that credit is given to TXDOT and the firm that produced it. Permission to reprint an entire chapter, section, figures or tables must be obtained in advance from the Supervisor of the Archeological Studies Branch, Environmental Affairs Division, Texas Department of Transportation, 125 East 11th Street, Austin, Texas, 78701 


\title{
BIOARCHEOLOGICAL INVESTIGATIONS OF NINETEENTH-CENTURY AFRICAN AMERICAN BURIALS AT THE PIONEER CEMETERY (41BO202) IN BRAZORIA, TEXAS
}

\author{
by \\ Aaron R. Norment, Jeremy W. Pye, \\ Cory J. Broehm, and Douglas K. Boyd \\ with contributions by \\ Leslie L. Bush, Helen Dewolf, Haley Streuding, \\ Angela L. Tiné, and Jennifer K. McWilliams
}

Principal Investigators: Douglas K. Boyd, Aaron R. Norment, and Timothy B. Griffith

\author{
REPORTS OF INVESTIGATIONS, NUMBER 180 \\ Prewitt and Associates, Inc. \\ Cultural Resources Services \\ Austin, Texas
}

ARCHEOLOGICAL STUDIES PROGRAM, REPORT NO. 174
Texas Department of Transportation
Environmental Affairs Division
Archeological Studies Branch
Austin, Texas

February 2016

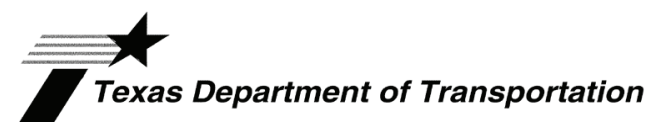

TEXAS ANTIQUITIES PERMIT NO. 5058 


\title{
BIOARCHEOLOGICAL INVESTIGATIONS OF NINETEENTH-CENTURY AFRICAN AMERICAN BURIALS AT THE PIONEER CEMETERY (41BO202) IN BRAZORIA, TEXAS
}

\author{
COPYRIGHT @ 2016
}

\section{Texas Department of Transportation (TxDOT)}

This is a work for hire produced by the Texas Department of Transportation (TxDOT), which owns all rights, title, and interest in and to all data and other information developed for this project under Contract No. 577XXSA001 (Work Authorization No. 57728SA001), Contract No. 579XXSA002 (Work Authorization Nos. 57913SA002 and 579SA14SA002), and Contract No. 575XXSA004 (Work Authorization No. 57501SA004). Brief passages from this publication may be reproduced without permission provided that credit is given to TxDOT and Prewitt and Associates, Inc. Permission to reprint an entire chapter, section, figures, or tables must be obtained in advance from the Supervisor of the Archeological Studies Program,

Environmental Affairs Division, Texas Department of Transportation, 125 East 11th Street, Austin, Texas, 78701.

Copies of this publication have been deposited with the Texas State Library in compliance with the State Depository Requirement.

jointly published by the

Texas Department of Transportation Environmental Affairs Division Archeological Studies Program Scott Pletka, Ph.D., Supervisor

Archeological Studies Program, Report No. 174

CSJ No. 1524-01-065

and

Prewitt and Associates, Inc. Cultural Resources Services Austin, Texas

PAI Project Nos. 208024, 210033, 210039, and 215004

Reports of Investigations, Number 180

Printed by OneTouchPoint/Ginny's in Austin, Texas

ISBN: 978-1-935545-41-5 


\section{DEDICATION}

This report is dedicated to

the African American community

of Brazoria County, Texas.

The full story of the many generations of enslaved blacks and freedmen who lived and died there in the nineteenth and twentieth centuries has yet to be fully told. It is hoped that the African American community will ultimately benefit from what has been learned in this bioarcheological research, and that this report contributes to the history of the people whose remains are buried at Pioneer Cemetery and to the greater story of the African diaspora in Texas. 


\section{TABLE OF CONTENTS}

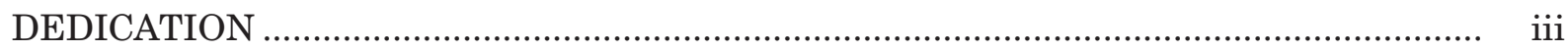

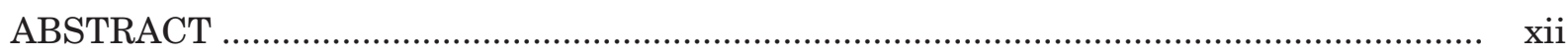

ACKNOWLEDGMENTS ....................................................................................... xii

CHAPTER 1: INTRODUCTION ………………………............................................ 1

Cemetery Location and Environmental Setting …………………………………... 3

Report Organization ............................................................................................ 5

CHAPTER 2: HISTORICAL AND ARCHEOLOGICAL BACKGROUND ............................ 7

History of African Americans in Brazoria and Brazoria County ............................. 7

History Of Pioneer Cemetery and State Highway 332 ………………………....... 8

Previous Historical and Archeological Investigations at Pioneer Cemetery ............ 13

CHAPTER 3: PROJECT SUMMARY AND METHODS OF INVESTIGATION .................. 15

Legal Mandate for Protection of Graves............................................................... 15

State Highway 332 Project History and Coordination ........................................... 16

Phase I: Investigations East of SH 332 Centerline.................................................. 19

THC and TxDOT Consultation ....................................................................... 21

Phase II: Investigations East of SH 332 Centerline ………………….................... 25

Interim Construction Period ............................................................................ 26

Phase III: Investigations West of SH 332 Centerline ............................................ 26

Archeological Field Methods ................................................................................ 26

Re-location of Previously Discovered Unmarked Graves .......................... 27

Elevation Control and Burial Mapping ................................................... 27

Burial Excavation Procedures ............................................................... 27

Analyses of Pioneer Cemetery Burials ...................................................... 29

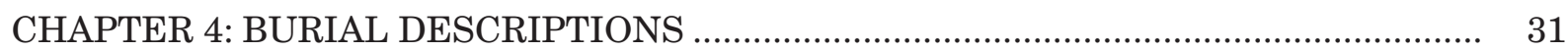

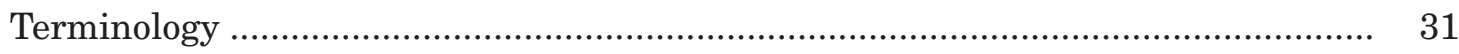

Burial Descriptions .......................................................................................... 33

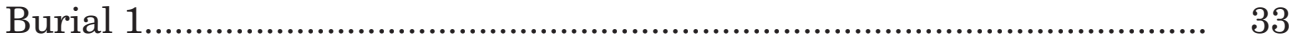

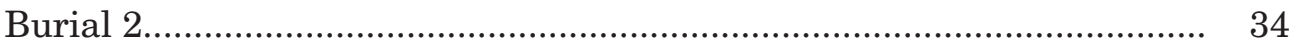

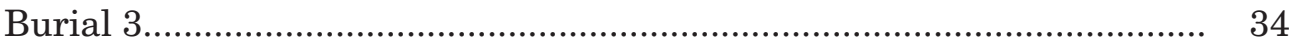

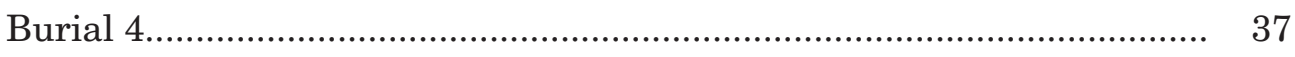

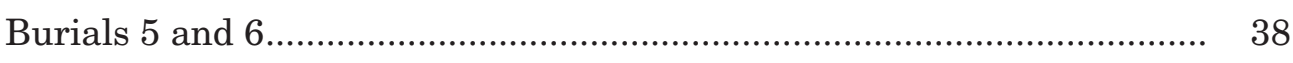

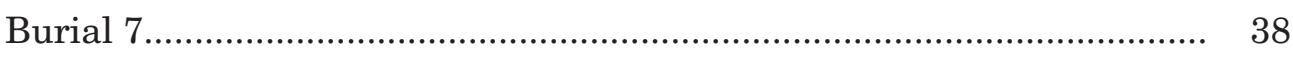

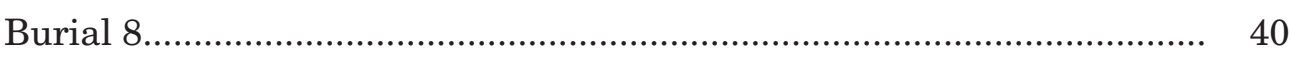




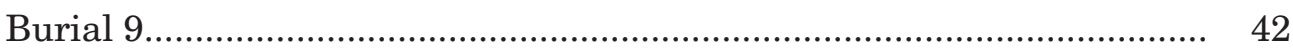

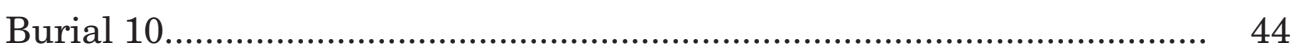

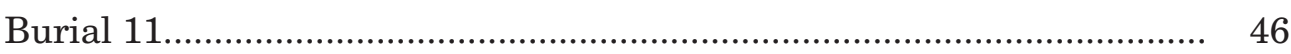

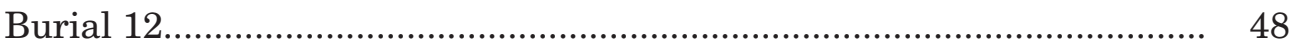

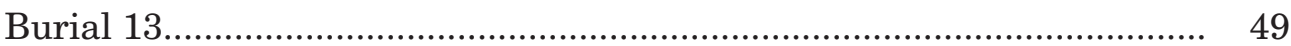

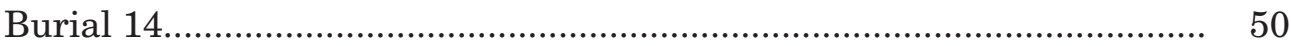

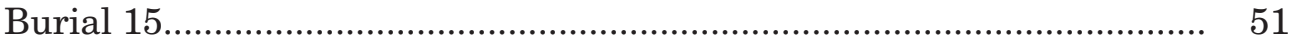

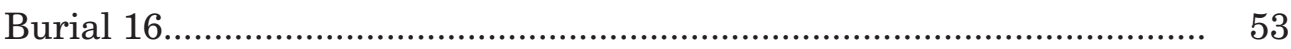

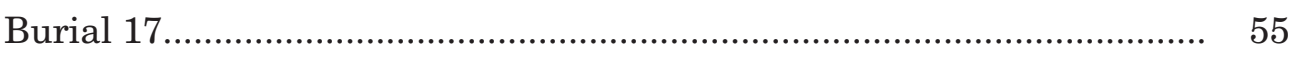

Discussion of Burial Containers ............................................................................. 56

CHAPTER 5: ANALYSIS OF BURIAL CONTAINER HARDWARE .................................. 63

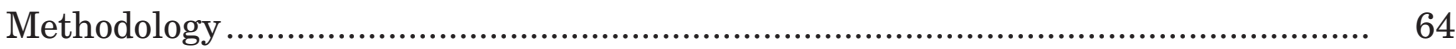

Hardware Descriptions and Typology ………………………………………….... 65

Burial Container Handles .................................................................... 65

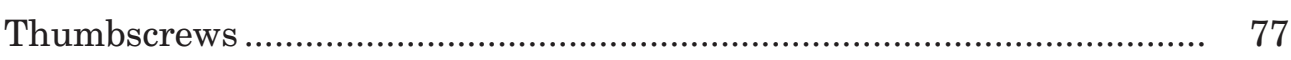

Escutcheons .................................................................................. 78

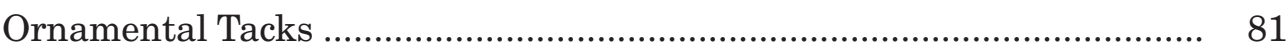

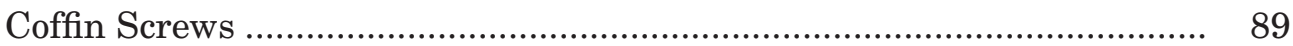

Burial Chronology and Socioeconomic Implications............................................... 94

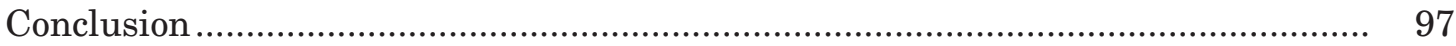

CHAPTER 6: ANALYSIS OF PERSONAL ITEMS ......................................................... 99

Clothing and Adornment................................................................................... 99

Prosthetic Leg Hardware ……………………………….................................. 107

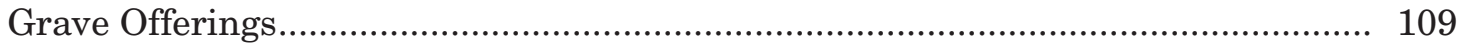

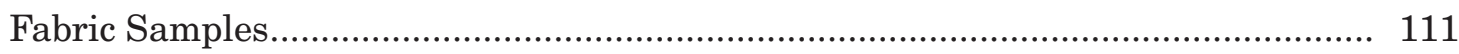

CHAPTER 7: OSTEOLOGICAL ANALYSIS OF HUMAN REMAINS ................................. 115

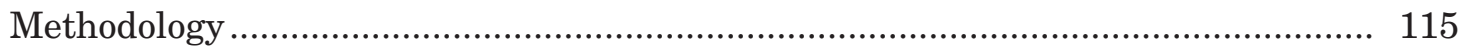

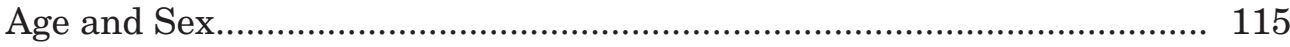

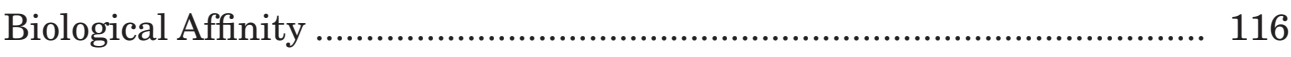

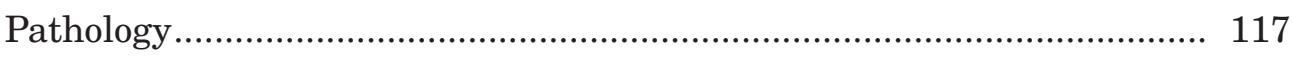

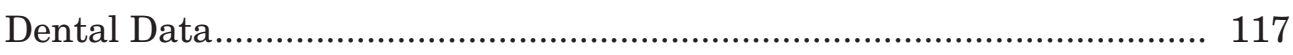

Discussion of the Pioneer Burial Population............................................................ 117

Comparative Analysis of Late-Nineteenth- and Early-Twentieth-Century African American Life in Texas.................................................................... 123

African American Life in Texas: Emancipation to $1900 \ldots \ldots \ldots \ldots \ldots \ldots \ldots \ldots \ldots \ldots . . . . . . .125$

African-American Life in Texas, 1900 to 1920 .......................................... 134

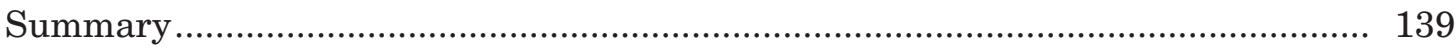


CHAPTER 8: AFRICAN AMERICAN GRAVEYARDS, PIONEER CEMETERY, AND THE AFRICAN DIASPORA

African Americans in Texas and Brazoria....

What are the Origins of African Americans in

Texas and Brazoria County?

150

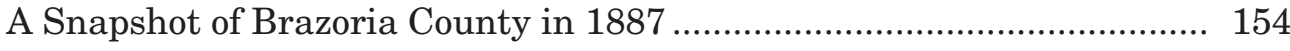

Washington Edwards: Portrait of an African Slave ............................... 155

Historic Black Cemeteries in Brazoria .............................................................. 158

Old Brazoria Cemetery.................................................................. 158

Origins of Pioneer Cemetery ............................................................. 158

Estimating Death Rates for Brazoria................................................. 159

How Big is Pioneer Cemetery and Where are all the Graves?............... 166

Where Did the Graves Exhumed in 1939 Get Relocated?...................... 170

Why are so Many African American Cemeteries Lost? ....................................... 170

Misconceptions about "Marking" of African American

Graves and Cemeteries .............................................................. 171

Case Studies of Forgotten African American

Cemeteries in Texas........................................................................ 175

Understanding Lost and Forgotten Black Cemeteries ........................ 187

The Pioneer Cemetery Burials and the African Diaspora.................................... 190

Health and Pathology Issues ............................................................ 190

Mortuary Remains and Economic Status........................................... 192

African American Mortuary Customs and Possible Spiritual

Symbolism in Pioneer Cemetery ............................................................ 200

Arrangement and Orientation of Unmarked Graves ............................ 211

Protecting Lost African American Graves..................................................... 211

CHAPTER 9: REINTERMENT AND FINAL THOUGHTS ON PIONEER

CEMETERY AND AFRICAN DIASPORA STUDIES ............................... 213

Pioneer Cemetery Reinterment ........................................................................... 213

Historic Cemetery Archeology and Burial Reinterments ..................... 213

Reburial Planning and Plot Preparation.............................................. 215

Reinterment Ceremony ................................................................... 215

Marking the Reburial Plot ............................................................... 216

After the Reburial.......................................................................... 218

Pioneer Cemetery and African American Burial Research ................................. 218

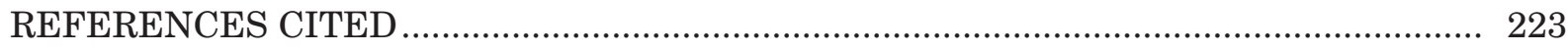


APPENDIX A: Published Historic Cemetery Archeological Reports Consulted for the Pioneer Cemetery Burial Container Analysis ..................................... 267

APPENDIX B: Historic Mortuary Hardware Catalogs Consulted ….............................. 277

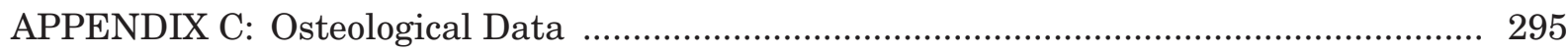

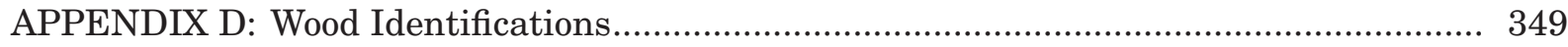

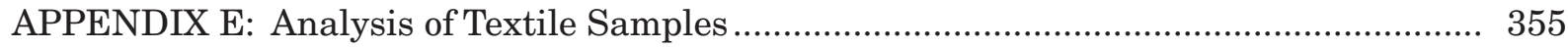

APPENDIX F: Recorded Graves at Pioneer Cemetery .................................................. 363 


\section{LIST OF FIGURES}

1.1. Aerial photo and plan map showing the location of Pioneer Cemetery in Brazoria, Texas, in 2003.....

2.1. Map of Pioneer Cemetery in relation to the town lots of the "Townsite of Old Brazoria"-.....

3.1. Map of approximate locations of Graves 7-9 showing their spatial relationship to previously identified Graves 1-6.

3.2. Map showing new area assignments as defined in the December 2008 THC/TxDOT letter of agreement

4.1. Shapes of common nineteenth-century burial receptacles and schematic cross sections of outer boxes and grave arches

4.2. Photographs of Burial 7 showing the wooden grave arch and coffin outline............. 60

4.3. Photograph of Burial 17 showing the glass viewing window ................................. 61

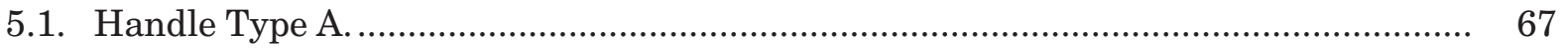

5.2. Handle Type A size grades as illustrated on page 17 in the circa 1885 Illustrated Catalog of Harrisburg Burial Case Company.

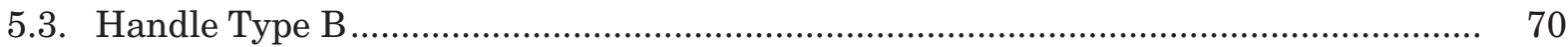

5.4. Handle Type B size grades as illustrated on page 17 in the circa 1885 Illustrated Catalog of the Harrisburg Burial Case Company

5.5. Handle Type $\mathrm{C}$ from Burial 17 at Pioneer Cemetery ............................................. 73

5.6. C. Strong 1869 Patent No. 97,827 for coffin handle showing early short bar ........... $\quad 75$

5.7. Handle Type D from Burial 16 at Pioneer Cemetery ............................................ 76

5.8. Thumbscrew and Escutcheon Set Type A from Burial 11 at Pioneer Cemetery ....... 77

5.9. Thumbscrew and Escutcheon Set Type B from Burial 16 at Pioneer Cemetery ....... 78

5.10. Ornamental Tack Type A from Burial 16 at Pioneer Cemetery .............................. 82

5.11. Examples of studs illustrated on page 185 of the circa 1904 Gate City Coffin Company Illustrated Catalog.

5.12. Possible match for Ornamental Tack Type A as illustrated on page 8 of the 1894 W. D. Wilmarth \& Company Catalog.

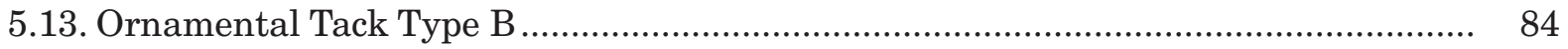

5.14. W. H. Nichols 1859 Patent No. 24,911 for coffin screw and tack ............................. 87

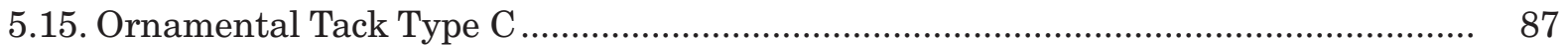

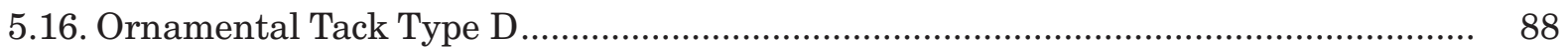

5.17. Coffin Screw Type A ......................................................................................... 90

5.18. Coffin Screw Type B from Burial 17 at Pioneer Cemetery ...................................... 92

5.19. Coffin Screw Type C ...................................................................................... 93 
6.1. Composite overhead view (three photographs) of Burial 15 showing the wooden casket outline and the jumbled remains within the casket 104

6.2. Buttons from Pioneer Cemetery burials .............................................................. 105

6.3. Jewelry and clothing items from Pioneer Cemetery burials.................................... 106

6.4. Iron pieces and buckle of prosthetic leg from Burial 9 ........................................... 108

6.5. Marine shell from Burial 3 .................................................................................. 110

6.6. White milk glass bottle from Burial 8 .................................................................. 110

6.7. Gilded bird toe bone/claw from Burial 15 ............................................................. 111

6.8. Undecorated whiteware saucer from Burial 15..................................................... 112

8.1. Graphs comparing the black population of Texas and Brazoria County from 1825 through 1870

8.2. Bar graphs of historical U.S. census data from 1850-1930 comparing the black populations of Texas (top) and Brazoria County (bottom)

8.3. Line graph of U.S. census data from 1850-1930 illustrating the percentage of blacks within the total populations of Texas and Brazoria County

8.4. Photograph taken in 1889 of Washington Edwards, an African man who was brought into Texas as a slave

8.5. Map of Pioneer Cemetery showing the locations of 16 unmarked graves in relation to the city lots within Block 42 .

8.6. Graph of chronology and age at death for 56 marked graves at Pioneer Cemetery

9.1. Photographs of the reinterment gravesite and newly installed marker 


\section{LIST OF TABLES}

1.1. TxDOT work authorizations for the bioarcheological investigations at Pioneer Cemetery

2.1. Summary of lot ownership and deed transactions pertaining to Pioneer Cemetery, Block 42, of the "Townsite of Old Brazoria".

3.1. Summary of historical and bioarcheological investigations at Pioneer

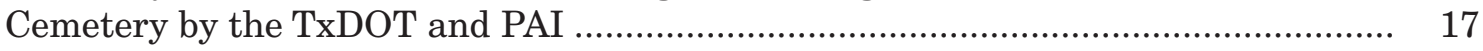

3.2. Summary of unmarked graves excavated at Pioneer Cemetery, 2003-2009 ............ 20

4.1. Summary of 14 excavated burials at Pioneer Cemetery .......................................... 32

4.2. Summary of burial container attributes for the 14 excavated Pioneer Cemetery burials.

5.1. Summary of burial container hardware associated with the Pioneer Cemetery burials....

5.2. Description of Handle Type A. 68

5.3. Description of Handle Type B.......................................................................... 71

5.4. Description of Handle Type C........................................................................... 74

5.5. Description of Handle Type D ........................................................................... 76

5.6. Description of Thumbscrew Type A.................................................................... 78

5.7. Description of Thumbscrew Type B..................................................................... 79

5.8. Description of Escutcheon Type A ….................................................................. 80

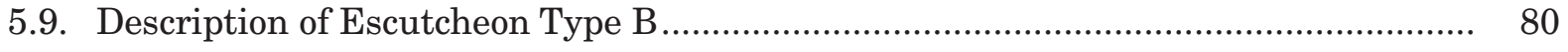

5.10. Description of Ornamental Tack Type A............................................................... 83

5.11. Description of Ornamental Tack Type B............................................................... 85

5.12. Description of Ornamental Tack Type C.............................................................. 88

5.13. Description of Ornamental Tack Type D.......................................................... 89

5.14. Description of Coffin Screw Type A ...................................................................... 91

5.15. Description of Coffin Screw Type B …................................................................. 92

5.16. Description of Coffin Screw Type C................................................................... 93

5.17. Type descriptions, measurements, and observations for casket handles,

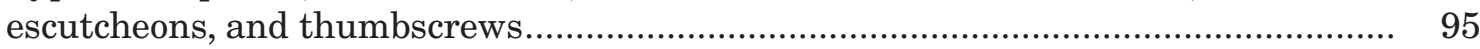

5.18. Type descriptions, measurements, and observations for coffin screws and

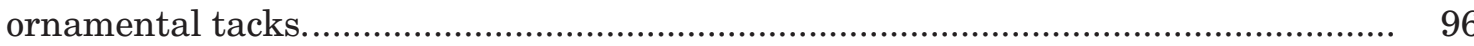

6.1. Clothing, adornment, and personal items associated with Pioneer Cemetery burials 100

6.2. Fabric samples from Pioneer Cemetery burials 113

7.1. Demographic and pathological data for the Pioneer Cemetery burials 118 
7.2. Rates of dental caries and calculus in the Pioneer Cemetery burials

8.1. Chronology of excavated Pioneer Cemetery burials.

8.2. Comparison of the enslaved populations of Texas and Brazoria County from 1836 through 1864 .

8.3. Increase in the enslaved population of Brazoria County from 1837 through $1864 \ldots 146$

8.4. Summary of U.S. census population data by "Color" for the "Town of Brazoria" in 1870 and 1880

8.5. Comparison of the numbers and causes of death for Texas and Brazoria County in 1887 .

8.6. Summary of population, deaths, and death rates for Texas and Brazoria County in 1887

8.7. Comparison of population data for Brazoria and Brazoria County for the years 1870,1880 , and 1887 .

8.8. Estimated black population of Brazoria and hypothesized number of deaths, 1837 through 1940

8.9. Group affiliations of people buried at Pioneer Cemetery.

8.10. Archeological occurrences of grave vaulting in historic cemeteries in Texas 204

9.1. 1980s archeological cemetery relocation projects in Texas

A.1. Historic cemetery projects consulted $(\mathrm{N}=155)$.

B.1. Mortuary and general hardware catalogues consulted for comparison $(\mathrm{N}=218)$...... 280

C.1. Skeletal inventory for Pioneer Cemetery 298

C.2. Adult sex determinations for Pioneer Cemetery 302

C.3. Adult age determinations for Pioneer Cemetery 303

C.4. Bone union and ephiphyseal closure for Pioneer Cemetery .................................... 304

C.5. Cranial measurements in adults for Pioneer Cemetery .......................................... 305

C.6. Postcranial measurements in adults for Pioneer Cemetery .................................... 306

C.7. Primary nonmetric traits for Pioneer Cemetery ..................................................... 307

C.8. Dental inventory, development, wear, pathology, and measurement of permanent teeth for Pioneer Cemetery 309

C.9. Dental inventory, development, wear, and pathology of deciduous teeth for Pioneer Cemetery 320

C.10. Biological affinity for Pioneer Cemetery 321

C.11. Dental nonmetrics for Pioneer Cemetery 322

C.12. Degenerative joint disease for Pioneer Cemetery 329

D.1. Wood samples from Pioneer Cemetery..... 352

F.1. Alphabetical listing of people buried at Pioneer Cemetery, Brazoria, Texas 366

F.2. Chronological listing of people buried in Pioneer Cemetery, Brazoria, Texas 369 


\begin{abstract}
A search for unmarked graves in the state-owned right of way and underneath the pavement of State Highway 332 resulted in the discovery and archeological excavation of 11 unmarked graves associated with Pioneer Cemetery, an African American burial ground in Brazoria, Texas. Prewitt and Associates, Inc., conducted the fieldwork for the Texas Department of Transportation's Archeological Studies Program. Between 2008 and 2012, the 11 unmarked graves were discovered, exhumed, analyzed, and then reinterred in Pioneer Cemetery in September 2012. This report describes the bioarcheological investigations of those burials along with 3 other unmarked burials that were previously exhumed and reburied in 2003.

The mortuary remains, especially the manufacturing dates on the coffin hardware, indicate that the 14 exhumed burials date to the late-nineteenth century and early-twentieth centuries. Based on the osteological evidence, the deceased persons were 5 women, 2 men, 2 indeterminate adults, and 5 children. Seven of the 14 individuals display skeletal traits indicating that they are of African descent, but 2 indeterminate adults and 5 children do not. Based on historical evidence, it is likely that all 14 individuals were African Americans, and several of the older individuals may have been born into slavery.

These 14 burials do not constitute a representative sample of the African Americans in Brazoria County or the town of Brazoria, but they are an interesting and historically significant burial population nonetheless. The overall health status of these people was generally good, with no evidence of abnormally high pathologies. However, skeletal remains of several older individuals exhibited evidence of various forms of degenerative joint disease indicative of lives spent doing hard labor. One adult male had an amputated leg and an iron and wooden prosthesis; it is not known if the loss of his leg was due to violence, accidental trauma, or disease. Several of the Pioneer burials exhibit traits that may represent mortuary behaviors of African origin. Three individuals had vaulted burials, with the casket or coffin located inside a shaft under a protective wooden arch. One adult female was buried with a complete whiteware saucer and a bird talon that was partially wrapped in gold plating and may have been worn as a necklace.
\end{abstract}

\title{
CURATION
}

All cultural materials and human remains recovered during the burial excavations were reinterred during a reburial ceremony in 2012. No cultural materials were collected during this project, so curation consists only of project records. The digital photographs and papers records for this project will be submitted for permanent curation to the Texas Archeological Research Laboratory at the University of Texas at Austin. 


\section{ACKNOWLEDGMENTS}

As is typical for projects spanning several years, many individuals and organizations had a hand in the successful completion of this work. The overall project was supervised and coordinated with the Texas Department of Transportation's (TxDOT) Archeological Studies Program in Austin. Archeologist Allen Bettis served as Prewitt and Associates' primary contact with TxDOT for the entire project, and he also acted as the liaison between PAI and the various TxDOT offices. Other TxDOT staffers who provided important support include Michael J. Christley, P.E., assistant area engineer for Brazoria County; Mike McGuire, maintenance section supervisor for the Brazoria area office; and Billy Horky, also in the maintenance section of the Brazoria area office. Kent Harland, a road construction subcontractor, was one of the machine operators who assisted during the grave searches. W. W. Weber, Inc., of Houston, Texas, another road construction subcontractor, performed the survey work for mapping the archeological excavations and unmarked graves.

At Prewitt and Associates, Inc. (PAI), Doug Boyd, Aaron Norment, and Tim Griffith served as co-principal investigators for various phases of the work at Pioneer Cemetery, from the initial planning and burial excavations through the analysis and reporting. During the field investigations, the following PAI archeologists helped monitor the machine excavations during the grave searches and excavated unmarked graves:

Doug Boyd (2009)

Weldon Hammond (2010)

Virginia Hatfield (2009)

Mark Holderby $(2008,2009$, and 2010)

Tim Griffith (2008, 2009, and 2010)

Chris Kugler (2009 and 2010)

Aaron Norment (2009)

Jennifer McWilliams (2009)

Beth Sain (2009)

Robert Thrift (2010)

This report incorporates the work of many people. The lead authors are Norment and Boyd, but many other people conducted analyses of the burial remains and contributed chapters to this report. Cory Julian Broehm (Chapters 4, 7, and Appendix C) analyzed the human skeletal remains, for PAI in 2010 and 2011 while he was enrolled in medical school. He has since become a medical doctor and is a pathology resident at the University of New Mexico's School of Medicine. Jeremy Pye (Chapter 5 and Appendixes A and B) was an independent consultant when he conducted the analysis of the burial container hardware for PAI in 2011. He has since received his Ph.D. from the University of Florida and is now with Cultural Resources Analysts, Inc. in Louisiana. Descriptions of the burials excavated in 2003 are excerpted from Tiné and Boyd 2003. Tiné ,then with Geo-Marine, served as PAI's project archeologist and osteologist during the 2003 Pioneer Cemetery investigations. Dr. Leslie Bush, of Macrobotanical Analysis in Manchaca, Texas, identified the burial container wood samples (Appendix D). Haley Streuding 
and Dr. Helen Dewolf of the Conservation Research Laboratory at Texas A\&M University analyzed the textiles (Appendix E).

Jenny McWilliams wrote some of the field method descriptions and took the photographs of the burial hardware and personal items that are illustrated in this report (Chapters 5 and 6). Brian Wootan and Sandy Hannum produced most of the figures, but Jeremy Pye produced some of the illustrations in Chapter 5. This report was edited by Boyd and Elaine Robbins.

Special thanks go to the Pioneer Cemetery Association, the Cemetery Committee of the Brazoria County Historical Museum, the Texas Historical Cemetery Guardianship Association, the City of Brazoria, and the local African American community. These groups were all involved with the planning and execution of the grave search and burial investigations, and they helped plan and participated in the reburial ceremony. Nancy Howard served as our liaison with the cemetery committee and the association, and she provided us with a complete list of the marked burials in Pioneer Cemetery (Appendix F). Curator Michael Bailey and Information Services coordinator Jamie Murray at the historical museum provided additional historical data on Pioneer Cemetery. City of Brazoria mayor Ken Corley and city manager Teresa Borders were our key contacts for planning and hosting the reinterment ceremony. Gerald Robertson was TxDOT's backhoe operator for the gravesite reburial. Three local clergymen-Pastor Ricky Jones, Reverend Lonnie Dews, and Minister Albert Thompson-attended and officiated at the reinterment ceremony held on September 12, 2012. 


\title{
CHAPTER 1: INTRODUCTION
}

\author{
Douglas K. Boyd and Aaron R. Norment
}

A search for unmarked graves in the state-owned right of way and underneath the pavement of State Highway 332 resulted in the discovery and archeological excavation of 11 unmarked graves (and a few displaced remains from a grave previously excavated in 2003) associated with Pioneer Cemetery, an African American burial ground in Brazoria, Texas. Prewitt and Associates, Inc. conducted the fieldwork for the Texas Department of Transportation (TxDOT), Archeological Studies Program. Between 2008 and 2012, the 11 unmarked graves were discovered, exhumed, analyzed, and then reinterred within Pioneer Cemetery. This report describes the bioarcheological investigations of those burials along with 3 other unmarked burials that were previously exhumed and reburied in 2003 .

These investigations were conducted in conjunction with road improvements on SH 332, just south of the Brazos River in the town of Brazoria (CSJ No. 1524-01065). The work complied with cultural resources regulations in Section 106 of the National Historic Preservation Act and its associated regulations (54 USC §100101 and 36 CFR 800) and the Texas Antiquities Code and its associated rules (NRC Title 9, Chapter 191 and 13 TAC 26). It also followed Texas Health and Safety Code requirements relating to historic cemeteries (HSC Title 8, Section 711).

Pioneer Cemetery was officially established in 1888 as a burial ground for the use of members of local African American churches, and it was expanded in 1891. Other churches began to use the cemetery in the twentieth century, and Pioneer Cemetery continued to be used mainly by African Americans throughout its history. As of 2003, 59 graves were marked with headstones, and the cemetery was still in use, with some graves dating to the 1990 s or 2000 s. At that time, multiple lines of evidence indicated that there are many, perhaps hundreds, of unmarked graves within the 0.87-acre Pioneer Cemetery, and TxDOT archeologists commented on the high probability that unmarked graves remained under the SH 332 roadway. That suspicion would turn out to be well founded.

The archeological investigations conducted by PAI were performed over a period of almost seven years, from 2008 through 2015. The search for unmarked graves and the subsequent burial excavations in 2008-2009 were a continuation of a long series of historical and archeological investigations by TxDOT's Archeological Studies Program and PAI that began years earlier. The field investigations were coordinated closely with TxDOT's schedule of road construction activities so that archeological investigations were done in sequence as construction proceeded. Consequently, this work was undertaken 
in several different phases and was authorized under four contracts and five work authorizations (Table 1.1). All of the work conducted under these work authorizations is documented in this report.

Table 1.1. Texas Department of Transportation (TxDOT) Work Authorizations issued to Prewitt and Associates, Inc. (PAI) for bioarcheological investigations at Pioneer Cemetery

\begin{tabular}{|c|c|c|c|}
\hline $\begin{array}{l}\text { TxDOT WA No. } \\
\text { (PAI Project No.) }\end{array}$ & \begin{tabular}{|c|} 
Date of Work \\
Authorization \\
\end{tabular} & Project Description & References \\
\hline $\begin{array}{l}\text { 57304SA001 } \\
(203011)\end{array}$ & March 2003 & $\begin{array}{l}\text { Machine excavations to re-locate and investigate seven } \\
\text { possible burial features previously found by TxDOT. } \\
\text { Five of the seven features were found to be unmarked } \\
\text { graves. Hand excavations were done to exhume three } \\
\text { unmarked graves (Burials } 1,3 \text {, and } 4 \text { ) found within } \\
\text { the state right of way. These burials were reinterred at } \\
\text { Pioneer Cemetery. }\end{array}$ & $\begin{array}{l}\text { Tiné and Boyd } \\
(2003)\end{array}$ \\
\hline $\begin{array}{l}\text { 57728SA001 } \\
(208024)\end{array}$ & May 8, 2007 & $\begin{array}{l}\text { PAI began coordinating with TxDOT for a mechanical } \\
\text { grave search and possible removal of unmarked graves } \\
\text { at Pioneer Cemetery. TxDOT scraping then discovered } \\
\text { three unmarked graves (Burials 7, 8, and 9). } \\
\text { In October 2008, PAI excavated the three graves } \\
\text { and continued the search for unmarked graves. PAI } \\
\text { archeologists excavated Burials 7, 8, and 9, and } \\
\text { discovered more unmarked graves designated Burials } \\
\text { 10-18. Burial } 10 \text { was excavated and removed, but the } \\
\text { others were left unexcavated while TxDOT, the Texas } \\
\text { Historical Commission, and PAI coordinated the next } \\
\text { phase of work. } \\
\text { PAI continued fieldwork in January } 2009 \text {, excavating } \\
\text { Burials } 11-17 . \text { (Burial } 18 \text { was found to be the remnants } \\
\text { of Burial 3, which had been excavated in } 2003 . \text { ) } \\
\text { In October-November } 2010 \text {, PAI completed extensive } \\
\text { and deep scraping of the entire area under the } \\
\text { northbound traffic lanes of SH } 332 \text { (east of the road } \\
\text { centerline). No additional unmarked graves were found. }\end{array}$ & none \\
\hline $\begin{array}{l}\text { 57913SA002 } \\
(210033)\end{array}$ & $\begin{array}{l}\text { September } \\
17,2010\end{array}$ & $\begin{array}{l}\text { PAI reviewed the status of the Pioneer Cemetery } \\
\text { project and prepared a work plan for the second phase } \\
\text { of fieldwork (for the west half of the project area), data } \\
\text { analysis, and reburial of all excavated burials. }\end{array}$ & $\begin{array}{l}\text { Unpublished } \\
\text { work plan, } \\
\text { October } 2010\end{array}$ \\
\hline $\begin{array}{l}\text { 57914SA002 } \\
(210039)\end{array}$ & $\begin{array}{l}\text { October 19, } \\
2010\end{array}$ & $\begin{array}{l}\text { TxDOT removed the western half of the SH } 332 \\
\text { pavement, and PAI conducted an extensive grave } \\
\text { search (mechanical scraping) focused in the western } \\
\text { half of the project area (from the SH } 332 \text { centerline } \\
\text { to the west edge of the state right of way). No more } \\
\text { unmarked graves were found. } \\
\text { PAI conducted the preliminary analyses and } \\
\text { descriptions of the burials, burial containers, burial } \\
\text { container hardware, and personal items associated with } \\
\text { the } 14 \text { excavated burials (including } 3 \text { from } 2003 \text { ). } \\
\text { PAI also arranged for the reinterment of the } 11 \text { burials } \\
\text { excavated from Pioneer Cemetery in } 2008-2009 \text {. The } \\
\text { reburial ceremony was held on September } 12,2012 \text {. }\end{array}$ & $\begin{array}{l}\text { Draft chapters } \\
\text { completed }\end{array}$ \\
\hline $\begin{array}{l}\text { 57501SA004 } \\
(215004)\end{array}$ & $\begin{array}{l}\text { March 9, } \\
2015\end{array}$ & $\begin{array}{l}\text { Completion of a final report and curation of project } \\
\text { records for all work since } 2008 \text {. }\end{array}$ & this report \\
\hline
\end{tabular}


The SH 332 bridge over the Brazos River was constructed in 1939, and the SH 332 roadway adjacent to Pioneer Cemetery was built in the 1940s. In the late 1990s, TxDOT began planning to replace the historic bridge over the Brazos River and widen the highway approaches to the bridge. In 1999, TxDOT archeologists used a Gradall to search for unmarked graves inside the highway right of way along the east side of the cemetery. Seven possible graves were found in or near the right of way. In 2003, TxDOT contracted PAI to re-locate the graves and exhume, analyze, and rebury the remains. The fieldwork was done in March-April 2003. One possible grave feature could not be found, and another turned out to be noncultural (a tree stump). Five of the seven features were found to be unmarked graves. Of these unmarked graves, two were left in place, and three that were completely within the highway right of way were excavated. These burials were subsequently reinterred at Pioneer Cemetery during a reburial ceremony on April 4, 2003. The 2003 PAI investigations are reported by Tiné and Boyd (2003).

The next phase of the project was to search for unmarked graves under the paved portion of SH 332 and the right of way on the west side the paved road. PAI archeologists returned to Pioneer Cemetery three times: in October 2008, in January-February 2009, and in October-November 2010. As a result of these efforts, 11 more unmarked graves were discovered and subsequently exhumed. This brought the total number of archeologically discovered unmarked graves to 16 and the total number of archeologically excavated burials to 14. This report presents results of the bioarcheological investigations at Pioneer Cemetery, including the bioarcheological data and interpretations of all 14 of the excavated burials.

Following the 2008-2009 burial excavations and data analyses, PAI archeologists coordinated with city officials, local community leaders, and African American church leaders to plan and conduct a reburial. A ceremony for the reinterment of the 11 additional graves was held in September 2012. This event provided a degree of closure for this multi-year burial exhumation project.

\section{CEMETERY LOCATION AND ENVIRONMENTAL SETTING}

Pioneer Cemetery occupies a large city block in Brazoria, a town south of the Brazos River, about $29 \mathrm{~km}$ (18 miles) upstream from where it empties into the Gulf of Mexico (Figure 1.1). The cemetery appears on modern aerial photographs as a trapezoid that covers an area ca. $8,243 \mathrm{~m}^{2}$ or 2.04 acres. It is bounded on all four sides by roads or railroads: by SH 332 on the west, by the Union Pacific Railroad on the east, by County Road 400 (identified as Camp Street on Old Brazoria townsite plat maps) on the north, and by an ephemeral unimproved road on the south. The Old Brazoria townsite maps show Travis Street on the south side of the cemetery, but Travis Street currently stops on the west side of SH 332 .

Pioneer Cemetery is situated within the broad Brazos River alluvial valley close to the head of the river delta. The river valley is approximately $25 \mathrm{~km}$ (15.5 miles) wide at this point, and the cemetery is approximately $20-25 \mathrm{ft}$ above sea level and 13-15 ft above the mean water level of the Brazos River. The valley is inset into the Pleistocene deltaic clays that comprise the Beaumont Formation 


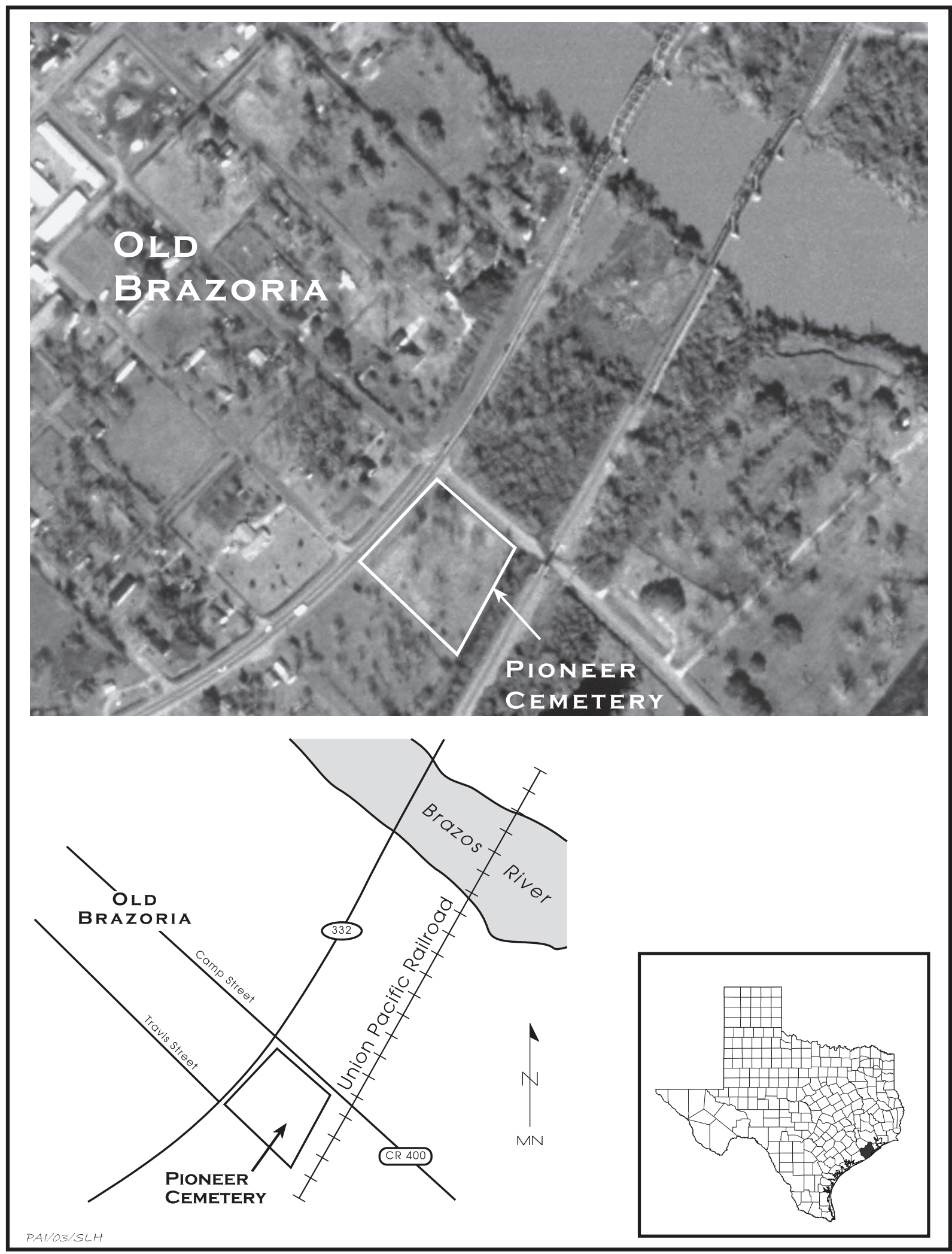

Figure 1.1. Aerial photo and plan map showing the location of Pioneer Cemetery in Brazoria, Texas, in 2003. Figure is reproduced from Tiné and Boyd (2003:Figure 1.1). 
(Barnes 1982), and the inset soils in the vicinity of the cemetery are classified as Asa silty clay loam. This Asa soil is described by the Soil Survey of Brazoria County, Texas (United States Department of Agriculture 1981:10) as follows:

Typically, this soil has a surface layer of neutral, very dark grayish brown silty clay loam about 14 inches thick. The subsoil from 14 to 60 inches is moderately alkaline, calcareous silty clay loam that is reddish brown in the upper part and yellowish red in the lower part.

Aronow (1981:81) notes that the Holocene deposits of the Brazos River have "a characteristic reddish-brown or yellowish-red color" that is seen in the Asa series soils. He also states: "This reddish ferric-oxide pigment is traditionally thought to be derived from the Permian red beds into which the drainage basins of these streams penetrate several hundred miles to the north and west." This color stratification is significant because it made it easy for previous investigators to see grave shafts when the reddish topsoil was present. Below about $40 \mathrm{~cm}$ deep, the grave shafts at Pioneer Cemetery appeared as dark mottled fill surrounded by the undisturbed reddish brown clay loam. More detailed climatic, geologic, and environmental data for the Brazoria area are found in Dismukes and Bettis (2002) and the United States Department of Agriculture (1981) soil survey.

\section{REPORT ORGANIZATION}

The bioarcheological investigations at Pioneer Cemetery are rather typical of historic cemetery investigations that have now become common in American archeology. These investigations have generated a variety of historic and bioarcheological evidence that is described and interpreted herein.

This report presents the results of the investigations. It details the field methods used to excavate and document the burials, the laboratory methods used to analyze the data, and a discussion and interpretation of the bioarcheological and historical evidence. Chapter 2 provides a historical and archeological background for Pioneer Cemetery. Chapter 3 summarizes the project history and the methods of investigations used during all phases of the bioarcheological investigations. Chapter 4 provides detailed burial descriptions and a complete analysis of associated burial containers. The burial container hardware is analyzed and described in Chapter 5 . Chapter 6 describes the personal items found with the excavated graves. Chapter 7 presents a bioarcheological analysis of the human remains.

Chapter 8 summarizes the project and places the Pioneer Cemetery burials into broader historical perspectives pertaining to Brazoria County, the Texas Gulf Coast, and African Diaspora studies. Although the 14 excavated graves constitute a small burial population for historical analysis, these burials display many unusual characteristics that are of historical significance. Chapter 9 describes the reinterment ceremony that took place in 2012, during which the remains of the 11 individuals excavated in 2008 and 2009 were laid to rest in Pioneer Cemetery.

The report concludes with six appendixes that offer detailed supporting data in the form of: historic cemetery reports and mortuary hardware catalogs consulted (Appendixes A and B); detailed osteological data for the 14 unmarked 
graves at Pioneer Cemetery (Appendix C); identification of wood samples (Appendix D); analysis and identification of textile samples (Appendix E); and a listing of all known burials in Pioneer Cemetery based on headstone data (Appendix F). 


\section{CHAPTER 2: HISTORICAL AND ARCHEOLOGICAL BACKGROUND}

Aaron R. Norment and Douglas K. Boyd

This chapter provides background information on the history of the town of Brazoria and Brazoria County, the history of Pioneer Cemetery, and the history of the historical and archeological work that preceded this project. From its inception, Pioneer Cemetery has been associated primarily with the African American community, so the history summarized here focuses on this perspective.

\section{HISTORY OF AFRICAN AMERICANS IN BRAZORIA AND BRAZORIA COUNTY}

Brazoria, Texas, is a town on the banks for the Brazos River in a region once dominated by cotton and sugarcane plantations. ${ }^{1}$ The townsite of Old Brazoria, on the Stephen F. Austin land grant, was initially laid out by John Austin in 1828. Due to its proximity to the Brazos River, Brazoria became a major regional shipping center and hub for commerce. The surrounding region was dotted with agricultural plantations producing goods that eventually made their way to New Orleans and Europe via the Brazos River at Brazoria. By the 1830s, cotton and sugar cane were the primary goods grown on plantations within Austin's "Old Three Hundred." For many decades, steamboats ferried goods out of Brazoria and down the Brazos River, where they were loaded onto larger ships at the port of Velasco. Conversely, a wide variety of commodities also came into Old Velasco and other Texas ports from American cities, Europe, and other parts of the world. Expensive luxury items were often shipped to the port at Old Velasco, loaded onto steamboats, transported up the Brazos River, and delivered to wealthy plantation owners in Brazoria and all across Brazoria County.

Brazoria was founded under Mexican rule but suffered greatly at the hands of Mexican troops in 1836 after Texas declared its independence. Brazoria County was established in March 1836 under the new Republic of Texas, and its current boundaries were set by 1838. Cotton gins, sugar mills, and a school were operating by 1838, and the first post office was established in 1846. The town continued to grow and prosper during the middle and latter half of the nineteenth century.

Before the Civil War, the region's agricultural economy relied on slave labor to work the many cotton and sugar cane plantations. The rich alluvial soils of Brazos River bottomlands were well suited for large-scale farming, an economic enterprise supported by slave labor. Between 1850 and 1860, 46 plantations produced cotton and sugar, and according to 1860 census data, the county had grown to 2,027 Anglo Americans,

1 This historical overview is derived primarily from these sources: Dismukes and Bettis (2002); Hallstein (2010); Long (2010); McLain (2009); and Tiné and Boyd (2003:3-6). 
5,110 slaves, and only 6 free black residents. By 1860, Brazoria County had more large slaveholding plantations than any other county in Texas, with 10 individuals owning more than 100 slaves each (Campbell 1989:Appendix 4).

After the Civil War, plantations were broken into smaller farms or ranches, but agriculture remained the dominant economic venture for most residents of Brazoria County. African American freedmen continued to live and work in the county, and by 1870 the population had grown to 7,527 people, with 5,736 (76 percent) being African American. By 1880 the population of the county had grown to 9,774, with the majority (7,524; 77 percent) being African American. The same was true in 1900, when African Americans accounted for 8,219 people (55 percent) out of a total population of 14,861.

The population of Brazoria County continued to grow, but the demographics changed by 1910, when whites outnumbered blacks in the county for the first time. Out of a total population of 13,299, there were 6,237 African American (47 percent) and 7,051 Anglo American residents. By 1920, the Anglo American population had swelled to 12,484, while African Americans accounted for only 32 percent of the population. The African American population of Brazoria County continued to increase, albeit slowly, over the next several decades, but its percentage of the total population continued to decline (Tiné and Boyd 2003:Figures 1.2 and 1.3). This reflects a trend in the African American population across Texas. While there was general slow and steady growth in the numbers of African Americans through time, this growth became overshadowed by the rapid growth of the Anglo American population as large numbers of Anglos moved to the region. Pioneer Cemetery became an official burial ground in Brazoria at a time when the African American population was increasing (1880-1890), and the first two decades of its use occurred as the African American population in the county reached its peak.

While the population of Brazoria County continued to grow slowly, the population of Brazoria began to decline after the railroad bypassed the town in 1897, as was common with many small Texas towns. Despite the city's declining population, the African American population remained steady within the county. As a result of people leaving Brazoria, the county seat was moved in 1897 to Angleton, which quickly became the major city in Brazoria County.

\section{HISTORY OF PIONEER CEMETERY AND STATE HIGHWAY 332}

Pioneer Cemetery was officially established in 1888, when the land was first acquired. The cemetery has been expanded twice, in 1891 and again in 1986. Over the past 125 years, the cemetery has served as the burial place for at least seven African American churches. Figure 2.1 is a map of Pioneer Cemetery superimposed on the lots in Block 42 of the "Townsite of Old Brazoria." Table 2.1 summarizes the property deed transactions that occurred when these lots became recognized as part of the cemetery. The map and table are derived from a TxDOT map produced for the SH 332 highway improvement project (Landtech Consultants, Inc. n.d.), which was reproduced in Dismukes and Bettis (2002:Figure 26). 


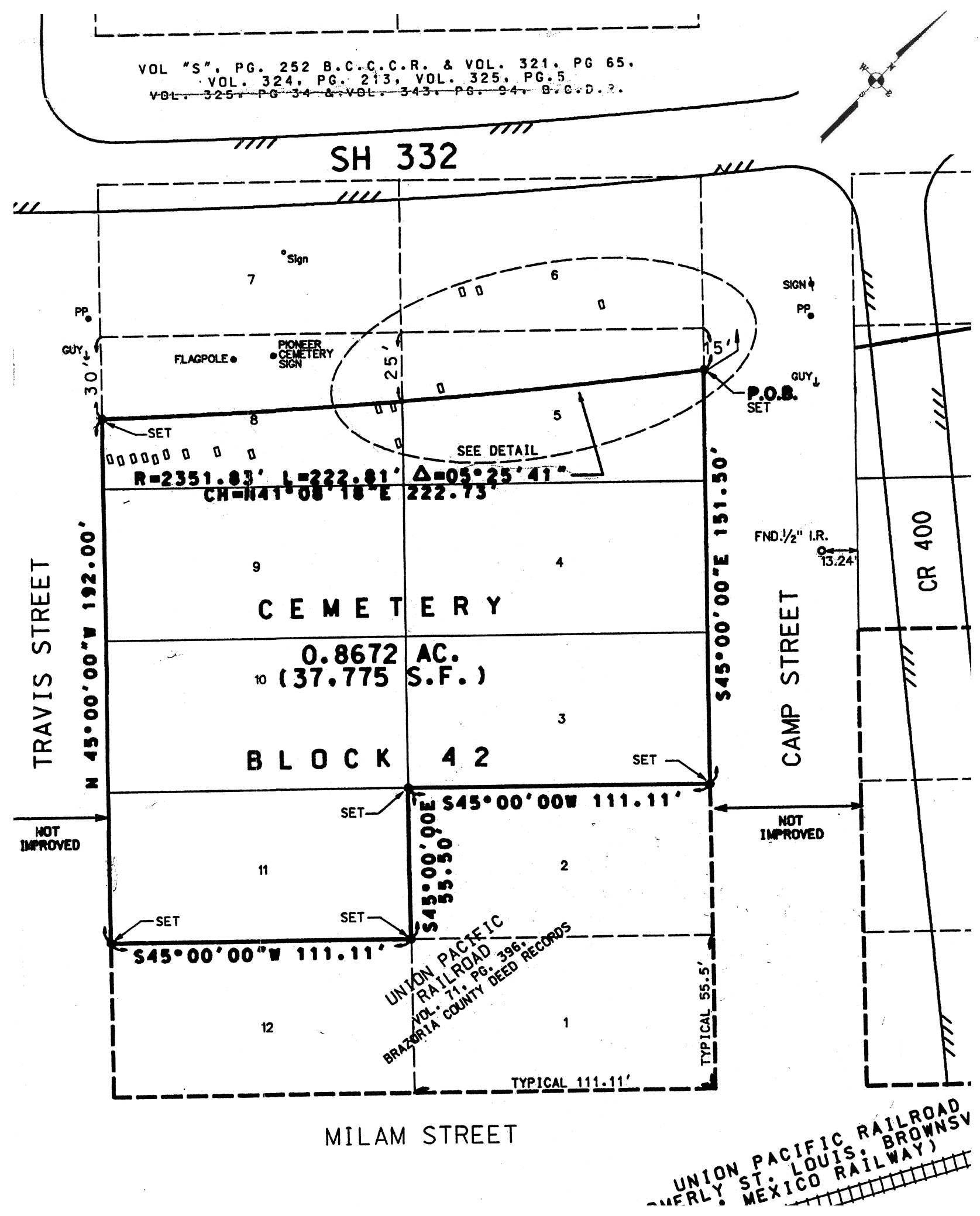

Figure 2.1. Map of Pioneer Cemetery in relation to the town lots of the "Townsite of Old Brazoria." Compiled from Dismukes and Bettis (2002:Figure 26). 
Table 2.1. Summary of lot ownership and deed transactions pertaining to Pioneer Cemetery, Block 42, of the "Townsite of Old Brazoria"

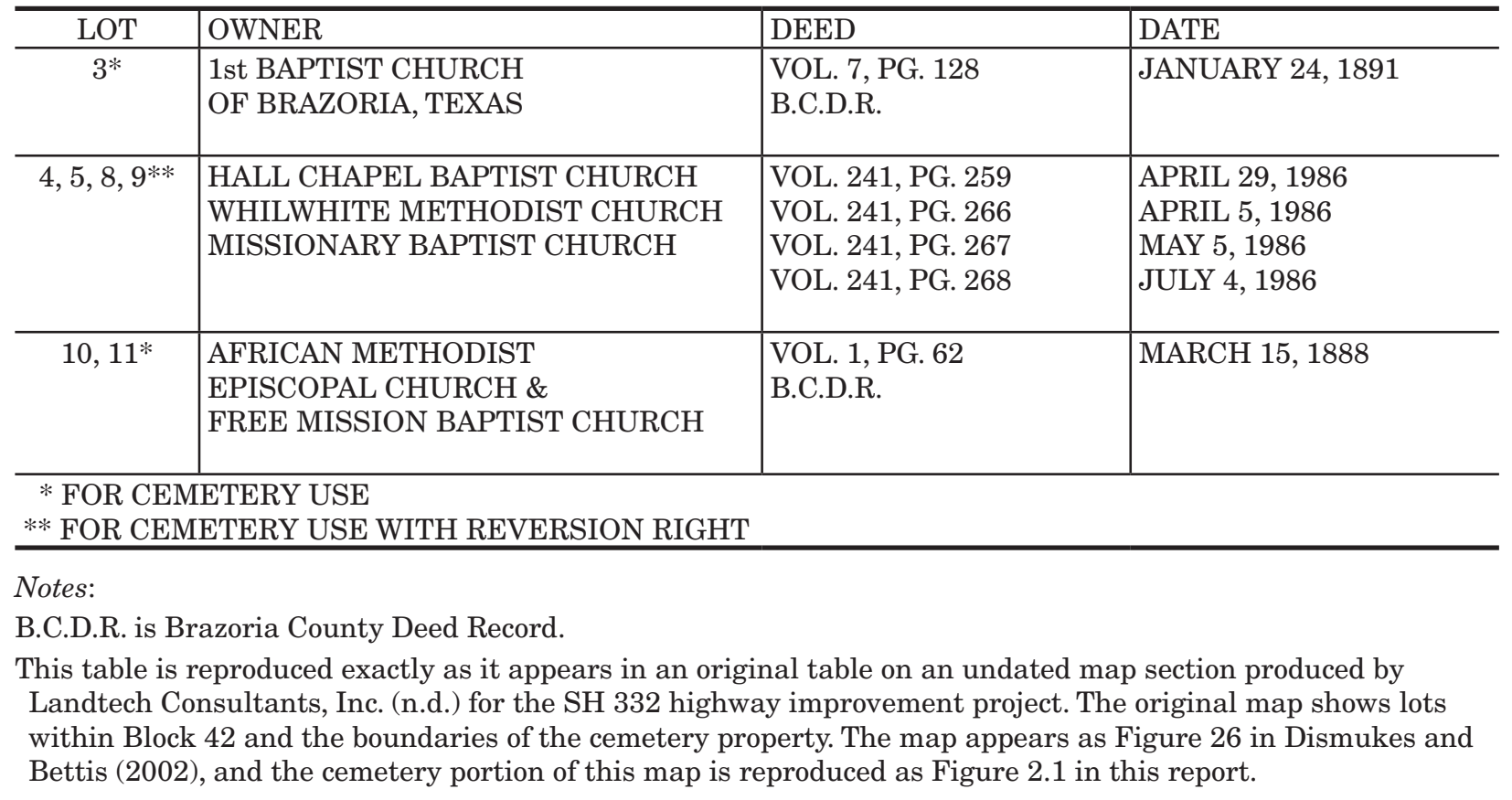

As depicted in Figure 2.1, Pioneer Cemetery encompasses 0.8672 acres $\left(37,775 \mathrm{ft}^{2}\right)$ within Block 42 of the "Old Townsite of Brazoria" in the "Stephen F. Austin League, A-20" (Dismukes and Bettis 2002:Figure 26). Within Block 42, the cemetery includes all of Lots 3, 4, 9, 10, and 11 and parts of Lots 5 and 8. According to the deed records, the cemetery originally included all of Lots 5 and 8, but the western portions of these lots were presumably acquired by the State of Texas in the 1940s as part of the SH 332 road right of way. Lots 6 and 7 are the two westernmost lots of Block 42, but they were never part of the official cemetery lands as recorded in these deed records. This is notable because many of the unmarked graves found and exhumed during the 2003 and 2008-2009 archeological investigations are located in Lot 6.

TxDOT historians located the original 1888 deed record in which the first two city lots were acquired as a cemetery for three local African American churches (this deed record is illustrated by Dismukes and Bettis [2002:Appendix B, Figure 28]). This 1888 transaction, as well as the deed records for additional 1891 and 1986 transactions, are cited on the TxDOT land acquisition map for the SH 332 roadway (see Figure 2.1 and Table 2.1). Unfortunately, the cited deed records reflect only the acquisition of individual lots at the time they became part of the cemetery. No full chain of title has ever been established for any of the lots comprising the Pioneer Cemetery property, so there is no information on the ownership or use of these properties prior to their acquisition by African American churches.

A 2003 survey by the Cemetery Committee of the Brazoria County Historical Museum documented 59 graves that were marked with some type of tombstone (see Appendix F), and a 1987 cemetery survey stated that at least 50 unmarked 
graves were thought to be within the cemetery (Burkholder and Benefiel 1991). There is no way of knowing just how many individuals were laid to rest in Pioneer Cemetery since no formal records were kept in the beginning. Given the history of this cemetery, there are still many unknown facts. Questions of how big Pioneer Cemetery might be, where its boundaries are and how they changed through time, how many graves are present, and how old the burials may be are discussed later in this report (see Chapter 8).

The route of State Highway 332 through Brazoria was established in 1939 after construction was completed for the three-span Parker truss bridge spanning the Brazos River. Replacing the aging structure and widening lanes to accommodate increasing traffic became a TxDOT priority in the late 1990s and early 2000s. However, the project called for the old historic three-span bridge to remain in place due to its historic significance.

Known as the Brazoria Bridge, the structure was built during the Great Depression by the Keliher Construction Company. In 1991 it was listed on the National Register and received a Texas Historical Marker (Texas Historical Commission 2015a, 2015b). The bridge was completed in 1939, but it was called the "bridge that goes to nowhere" because it was some time before the approaches were finished and vehicles could actually use the bridge. Even then, money was scarce, and the approach roads were not paved until after World War II (Texas Historical Commission 1991:9).

A 1930 aerial photograph (Dismukes and Bettis 2003:Figure 5) shows that the northern and southern boundaries of the cemetery were roughly defined by linear vegetation patterns following little-used roads and property borders. The western boundary was not well defined, with the cemetery area generally being grass-covered while the areas to the west were wooded. It is notable that there was no vehicular bridge over the Brazos River and no road adjacent to Pioneer Cemetery where SH 332 would later be constructed. However, the Union Pacific Railroad and the railroad bridge over the Brazos were already in place. Originally called the St. Louis, Brownsville, and Mexico Railroad, this line was constructed about 1906 (Dismukes and Bettis 2002:5) and the tracks and railroad right of way form the eastern boundary of the cemetery.

By 1944 the cemetery boundaries had changed little and were still poorly defined (Dismukes and Bettis 2002:Figure 7). The Brazoria Bridge was in place, but the road that became known as SH 332 extended only as far south as Camp Street. The 1944 aerial photo shows that the cemetery had only two firm boundaries at that time: the railroad tracks on the east, and Camp Street (also called County Road 400) on the north. The southern boundary appears as an ephemeral tree line along a fence or property border. But sometime after 1944, the SH 332 section south of the river was paved, and it ran along the west side of Pioneer Cemetery. As shown in Figure 2.1, the road was built along the western edges of cemetery Lots 6 and 7, and the right of way encroached onto cemetery Lots 5 and 8. Local informants recalled that graves were exhumed from the $\mathrm{SH} 332$ roadway and relocated to another cemetery (Dismukes and Bettis 2002:40,53). The primary informant believed this occurred 
in 1939, but since the road was not built for several more years, it could have been sometime in the early 1940 s.

TxDOT archeologists were well aware of the potential for unmarked graves at Pioneer in 1997 and 1998, quite early in the planning stages for the SH 332 project. Dismukes and Bettis (2002:39-40) stated (as of 1997):

However, interviews of the cemetery caretakers by Houston District personnel and observations by ENV personnel suggest that the cemetery is considerably larger than these six lots. According to the local informants, Pioneer Cemetery now legally includes lots 4 and 9 of Block 42, which were deeded to the cemetery at the culmination of a land use dispute in 1985, and also includes lots 5, 6, 7, and 8 of Block 42 and possibly lots 1 and 12 of Block 43, as well as the intervening section of the block divider named Peach Street on the old plats. Reportedly, a number of burials were moved during the original construction of SH 332 in approximately 1939, including burials from lots $5,6,7$, and 8 , Block 42 . The informants believe that more burials are present under the existing road, and ENV staff members (Nancy Kenmotsu and Lain Ellis) have reported seeing the apparent outlines of grave shafts in the borrow ditch fronting SH 332.

Adding to the confusing history of unmarked graves at Pioneer Cemetery are many rumors about graves beyond its current borders, but they are all unsubstantiated. When the highway was built sometime after 1944, graves were reportedly removed from the TxDOT right of way and reburied elsewhere. One story states that the graves were relocated just west of the cemetery across the street on the back of a city lot (Dismukes and Bettis 2002:11-12). Another story states that the graves were relocated to White Oak Cemetery in 1939 (Dismukes and Bettis 2002:53). This story has not been verified, and it is not clear where White Oak Cemetery is located. ${ }^{2}$

Prefield research conducted by John Clark (TxDOT, see Dismukes and Bettis 2002:Sub-Appendix A) states:

When the present road alignment was selected in 1939, Peach Street was obviously utilized in the design since it overlies the original street. However, the new alignment appears to have encroached into the cemetery such that graves are in the roadside drainage ditch and the shafts are exposed when the ditch is maintained, according to Nancy Kenmotsu and Sterling Hays who have visited the site.

Additionally, longtime caretakers at the cemetery suggest that graves extended well beyond the fenced portion of the cemetery and raised many questions as to the horizontal extent of the cemetery (Dismukes and Bettis 2002:53). After a 1977 interview with Mr. Traversia Viola, the youngest of three generations of caretakers for the cemetery, it was clear that "Mr. Viola Sr. and Ms. Kennedy believe there are still graves under the roadway" (Dismukes and Bettis 2002:53). To confuse matters further, Dismukes learned additional information during fieldwork

2 No research has been undertaken to try to find records pertaining to the reported relocation of Pioneer Cemetery burials. As of March 2015, the online Find A Grave website lists a White Oak Cemetery in nearby Angleton, but it contains only 5 recorded grave markers. This may or may not be the cemetery where the Pioneer graves were relocated. 
in January 1999. At that time Mr. "Tuff” Williams, an elderly neighbor, informed Dismukes that "the graves behind the house that he owns, on the property across the street from the cemetery, were not put there in 1939. Rather, they were moved from there to Pioneer Cemetery at some point in time" (Dismukes and Bettis 2002:11).

While some facts in these statements are questionable, the information provided by Mr. Viola and Ms. Kennedy led archeologists to suspect that unmarked burials were probably present under the existing SH 332 road and right of way.

During the course of the PAI fieldwork, other Brazoria locals shared additional rumors that suggest that graves likely extended into the Union Pacific Railroad right of way as well. When the railroad was constructed in 1907, the cemetery had already been in use for at least 19 years, and according to city plat maps, the railroad truncates the eastern boundary of cemetery Block 42 (see Figure 2.1; Dismukes and Bettis 2002:Figure 26). If any burials were in that corner of the cemetery at the time, they would have likely been left in place because the railroad tracks were placed on top of a high artificial berm to raise the tracks well above the floodplain.

As the previous discussion makes clear, many of the details of the history of Pioneer Cemetery are not known. It is quite possible that Pioneer was already a resting place for African Americans well before 1888. This often-cited date for the establishment of Pioneer Cemetery is based on the assumption that no burials occurred there until after the first land transaction. This topic is considered carefully later in this report.

\section{PREVIOUS HISTORICAL AND ARCHEOLOGICAL INVESTIGATIONS AT PIONEER CEMETERY}

The first attempt to understand the history of Pioneer Cemetery occurred in 1997 in conjunction with planned road improvements to $\mathrm{SH} 332$. John Clark (1997) conducted a background investigation and compiled extensive notes on the project area, and TxDOT archeologists conducted interviews with local Brazoria residents and people connected to Pioneer Cemetery. Many historic and archeological investigations of Pioneer Cemetery occurred in the years that followed (see Table 1.1). Dismukes and Bettis (2002) provide a summary of all of the TxDOT research and field investigations conducted for Pioneer Cemetery between 1997 and 2002.

Beginning in 1999, historical and archeological investigations became more intensive as TxDOT planned to expand SH 332 and replace the bridge crossing the Brazos River. TxDOT archeologists conducted a variety of onsite investigations, consisting of deep backhoe trenching in the floodplain, shovel testing in wooded areas, and shallow trenching in selected areas to search for historic features. They also conducted a magnetometer and side-scan sonar survey in the Brazos River and searched for unmarked graves in the vicinity of Pioneer Cemetery using mechanical scraping (Dismukes and Bettis 2002:6, 7). In March 1999, Pioneer Cemetery was designated an archeological site and was assigned the site number 41BO202. In May 2002 TxDOT archeologists recommended that Pioneer Cemetery was eligible 
for listing in the National Register of Historical Places and for designation as a State Antiquities Landmark (Dismukes and Bettis 2002:13-14).

Prewitt and Associates, Inc., (PAI) became involved with the Pioneer Cemetery project beginning in 2003. Following up on the 1999 mechanical scraping, TxDOT asked PAI to investigate seven soil anomalies, five of which were confirmed to be rectangular grave shafts. The goal was to re-locate and investigate the soil anomalies and to exhume, analyze, and rebury any graves or human remains that were identified. PAI identified five unmarked grave shafts within or near the SH 332 right of way, while one feature turned out to be a tree root disturbance rather than a grave (Burial 2), and the seventh possible feature was never found. Remains of three individuals were excavated and analyzed (Burials 1,3, and 4), and two other graves (Burials 5 and 6 ) were left in place because they fell on the highway/cemetery boundary and would not be disturbed. In April 2003 the three exhumed burials were reinterred in Pioneer Cemetery. Tiné and Boyd (2003) present the full details of PAI's 2003 bioarcheological investigations.

Archeological work for the SH 332 project was put on hold from 2003 to 2008. As construction planning progressed for the new roadway and bridge, PAI was once again contracted to conduct archeological investigations. In September 2008, PAI archeologists resumed fieldwork at Pioneer Cemetery, scraping and searching for unmarked graves within the SH 332 right of way. This work is fully described in the following chapter. 


\title{
CHAPTER 3: PROJECT SUMMARY AND METHODS OF INVESTIGATION
}

\author{
Douglas K. Boyd, Aaron R. Norment, and Jennifer K. McWilliams
}

Preliminary project planning research by archeologists and historians with the Texas Department of Transportation's (TxDOT) Archeological Studies Program revealed a high likelihood that unmarked graves were present under the paved SH 332 roadway that would be impacted by the new road construction (see Chapter 2 ). Therefore, in compliance with state laws protecting cemeteries and graves in Texas, TxDOT and Prewitt and Associates, Inc., (PAI) collaborated to ensure that every reasonable measure was taken to discover and remove unmarked graves from the SH 332 right of way. The first two sections of this chapter summarize the legal requirements for protection of graves, the history of State Highway 332 as it pertains to Pioneer Cemetery, and the chronology of the current road improvement project coordination efforts. The remaining sections focus on the archeological work that was completed from 2008 to 2010, including the mechanical search for unmarked graves and the archeological excavation of 11 historic burials.

\section{LEGAL MANDATE FOR PROTECTION OF GRAVES}

When the SH 332 roadway was built in the late 1930s and early 1940s it was common to remove marked graves from proposed road construction areas. At Pioneer Cemetery, some marked graves were reportedly exhumed from the roadway and moved elsewhere. Although some laws existed to protect graves at the time, the road was built long before there were legal mandates to search for and remove unmarked graves prior to construction projects. It is clear in this case that some graves were missed and were eventually paved over beneath SH 332. Any graves that were left behind would presumably have been unmarked graves.

When the PAI burial excavations occurred in 2008-2009, Texas' state laws did provide strong protection for historic graves and cemeteries. ${ }^{3}$ For these investigations, the burials that were found and exhumed from the SH 332 right of way were considered to be part of Pioneer Cemetery, a fact that is well supported by multiple lines of evidence, including historical documents and oral testimonies. Therefore, no permission was required from plot owners or descendants for the exhumation and relocation of the burials to a new location within the cemetery. Had the identity of any of the deceased been known, an attempt would have been made to identify and notify their next of kin

3 In September 2009, after the Pioneer Cemetery graves were exhumed, the Texas Health and Safety Code was amended to protect unmarked graves, regardless of their age or cultural affiliation. These new requirements would not have applied to Pioneer Cemetery because these graves were exhumed and reinterred within the same cemetery. The history of HB 2927, enacted on September 1, 2009, is available on Texas Legislature Online, at http://www.legis.state.tx.us/ billlookup/text.aspx?LegSess=81R\&Bill=HB2927\#. 
before the grave excavation was done, but this is not a legal requirement in cases in which a grave is moved from one location to another within the same cemetery. All of the grave exhumations and reinterments were done with the approval and permission of the Pioneer Cemetery Association.

The pertinent legal points for the Pioneer Cemetery archeological project, as defined in the state's Health and Safety Code (HSC) and the Texas Administrative Code (TAC), are:

1. Cemeteries include all areas where one or more human burials occur, and a cemetery does not have to be formally dedicated in deed records or contain marked graves (HSC, Title 8, Section 711.035(g)(1)).

2. Prior notification of plot owners, descendants, or other relations in advance of relocation of burials is not necessary if the relocation will occur from one plot to another within the same cemetery (HSC, Title 8, Section 711.004(e)(1)).

3. Relocation of burials within a cemetery does not require a disinterment permit from the State Registrar (Vital Statistics Unit, Texas Department of State Health Services) as stipulated in the Texas Administrative Code (TAC, Title 25, Part 1, Section 181.6(d)).

4. The relocation of burials from the TxDOT right of way to the portion of Pioneer Cemetery beyond the right of way was conducted in accordance with all the provisions of Health and Safety Code pertaining to Removal of Remains (HSC, Title 8, Section 711.004).

The Texas Historical Commission (THC) (2015c) includes a list of the laws, statutes, and court decisions relating to historic cemeteries and graves in Texas.

\section{STATE HIGHWAY 332 PROJECT HISTORY AND COORDINATION}

As discussed in Chapter 2, the previous historical and archeological investigations at Pioneer Cemetery set the stage for the current project (see Table 1.1). Following the 2003 work, the road improvement work did not progress much for several years, and then the project came back online in 2008 (Table 3.1). In September 2008, TxDOT archeologist Alan Bettis monitored scraping of a portion of the area under the northbound (eastern) lane and identified three stains indicative of grave shafts. Bettis did not intend to remove the graves at that time, and covered the shaft stains with plywood and a large wooden sign board, then marked the locations of the graves by placing vertical $2 \times 4$-inch boards marked with brightly colored flagging tape. The area was then backfilled, and the tops of the $2 \times 4$ s were exposed above the ground surface level.

PAI was contracted again by TxDOT under Work Authorization No. 57728SA001 to remove these three graves inside the state-owned right of way of SH 332. Under this work authorization, PAI created a work plan (dated October 1,2008 ) and a permit application that was submitted to THC. THC issued Texas Antiquities Permit No. 5058 to PAI on October 10, 2008. PAI then conducted the 
Table 3.1. Summary of historical and bioarcheological investigations at Pioneer Cemetery by the Texas Department of Transportation (TxDOT) and Prewitt and Associates, Inc. (PAI)

\begin{tabular}{|c|c|c|c|}
\hline $\begin{array}{l}\text { PAI Project No. } \\
\text { and TxDOT } \\
\text { WA No. }\end{array}$ & Date & $\begin{array}{c}\text { Project } \\
\text { Description }\end{array}$ & References \\
\hline$\overline{-}$ & 1997 & $\begin{array}{l}\text { TxDOT historian John W. Clark, Jr. conducted baseline } \\
\text { historical research for the SH } 332 \text { road improvement } \\
\text { project. He recommended that deed and/or plat } \\
\text { research was needed for the Pioneer Cemetery property. }\end{array}$ & $\begin{array}{l}\text { Clark (1997); Dismukes } \\
\text { and Bettis (2002) }\end{array}$ \\
\hline- & July 1997 & $\begin{array}{l}\text { Charles MacHart (TxDOT Brazoria Area Office) and } \\
\text { Ellen Stephenson (TxDOT Houston District) conducted } \\
\text { an interview with Mr. Traversia Viola, Sr. (Viola } \\
\text { Funeral Homes, West Columbia) and Ms. Ora Kennedy } \\
\text { on July } 2,1997 \text {. These interviews highlighted the high } \\
\text { potential for unmarked graves in the SH } 332 \text { right of } \\
\text { way. }\end{array}$ & $\begin{array}{l}\text { MacHart and Stephenson } \\
\text { (1997); Dismukes and } \\
\text { Bettis (2002) }\end{array}$ \\
\hline- & $\begin{array}{l}\text { September- } \\
\text { October } 1998 ; \\
\text { January } 1999\end{array}$ & $\begin{array}{l}\text { As part of the larger SH } 332 \text { project, TxDOT historians } \\
\text { and archeologists conducted work pertaining to Pioneer } \\
\text { Cemetery (called Area C), including archival research, } \\
\text { oral history interviews, and a mechanical search for } \\
\text { unmarked graves. This work identified seven possible } \\
\text { unmarked graves east of SH } 332 \text {. }\end{array}$ & $\begin{array}{l}\text { Dismukes and Bettis } \\
(2002: 10-11,50,53)\end{array}$ \\
\hline- & $\begin{array}{l}\text { Late January } \\
1999\end{array}$ & $\begin{array}{l}\text { TxDOT archeologists scraped with a backhoe in an area } \\
\text { west of SH } 332 \text { (within Lots } 1 \text { and } 12 \text { of Block 43). No } \\
\text { unmarked graves were found. }\end{array}$ & $\begin{array}{l}\text { Dismukes and Bettis } \\
(2002: 11)\end{array}$ \\
\hline- & March 1999 & $\begin{array}{l}\text { TxDOT archeologists recorded Pioneer Cemetery as } \\
\text { an archeological site, and it was assigned site number } \\
\text { 41BO202. }\end{array}$ & $\begin{array}{l}\text { 41BO202 site form (Texas } \\
\text { Archeological Sites Atlas) }\end{array}$ \\
\hline- & $\begin{array}{l}\text { Unknown, ca. } \\
\text { 1999-2001 }\end{array}$ & $\begin{array}{l}\text { Deed record search by TxDOT staff located the earliest } \\
\text { deed record pertaining to Pioneer Cemetery. The deed } \\
\text { record is dated March 15, 1888, and it refers to the } \\
\text { purchase of Lots } 10,11 \text {, and } 12 \text { of Block } 42 \text { by the } \\
\text { African Methodist Episcopal Church and Free Mission } \\
\text { Baptist Church of Brazoria. }\end{array}$ & $\begin{array}{l}\text { Texas Department of } \\
\text { Transportation Staff } \\
\text { (n.d.); Dismukes and } \\
\text { Bettis (2002) }\end{array}$ \\
\hline- & $\begin{array}{l}\text { Unknown, ca. } \\
\text { 1999-2001 }\end{array}$ & $\begin{array}{l}\text { TxDOT consultants prepare a map showing the } \\
\text { locations of unmarked graves found in January } 1999 \\
\text { in relation to the current property boundaries of } \\
\text { Pioneer Cemetery. The map has a table listing the deed } \\
\text { transactions in } 1888,1891 \text {, and } 1986 \text {. }\end{array}$ & $\begin{array}{l}\text { Landtech Consultants, } \\
\text { Inc. (n.d.); map } \\
\text { reproduced in Dismukes } \\
\text { and Bettis (2002:Figure } \\
26) \text {. } \\
\end{array}$ \\
\hline- & May 2002 & $\begin{array}{l}\text { TxDOT archeologists recommend Pioneer Cemetery } \\
\text { (41BO202) as eligible for listing in the National } \\
\text { Register of Historic Places and for designation as } \\
\text { a State Archeological Landmark (now called State } \\
\text { Antiquities Landmark). }\end{array}$ & $\begin{array}{l}\text { Dismukes and Bettis } \\
(2002: 14)\end{array}$ \\
\hline $\begin{array}{l}\text { 203011, } \\
\text { 57304SA001 }\end{array}$ & $\begin{array}{l}\text { March and } \\
\text { April } 2003\end{array}$ & $\begin{array}{l}\text { PAI conducted machine excavations to re-locate and } \\
\text { investigate seven possible burial features previously } \\
\text { found by TxDOT. PAI could not re-locate one feature, } \\
\text { and one was determined to be a tree root disturbance. } \\
\text { Two graves were re-located but left in place. PAI } \\
\text { conducted hand excavations to exhume three unmarked } \\
\text { graves: Burials } 1,3 \text {, and } 4 \text {. This was followed by the } \\
\text { reburial of the interments inside the Pioneer Cemetery } \\
\text { fence. }\end{array}$ & Tiné and Boyd (2003) \\
\hline
\end{tabular}

initial archeological investigations for Phase 1 of the project between October 13 and October 22. However, a fourth grave was identified, spurring an additional search, resulting in the identification of a total of seven unmarked graves. This discovery prompted additional consultation and correspondence between THC and TxDOT regarding level of effort and coverage of the search area. In December 2008, the agencies arrived at an agreement regarding an appropriate level of effort and 
Table 3.1, continued

\begin{tabular}{|c|c|c|c|}
\hline $\begin{array}{l}\text { PAI Project No. } \\
\text { and TxDOT } \\
\text { WA No. }\end{array}$ & Date & $\begin{array}{c}\text { Project } \\
\text { Description }\end{array}$ & References \\
\hline \multirow[t]{6}{*}{$\begin{array}{l}\text { 208024, } \\
\text { 57728SA001 }\end{array}$} & May 8, 2007 & $\begin{array}{l}\text { TxDOT issued a work authorization to allow for } \\
\text { PAI to begin planning the search, exhumation, and } \\
\text { reinterment of multiple historic graves at Pioneer } \\
\text { Cemetery. }\end{array}$ & - \\
\hline & $\begin{array}{l}\text { September } \\
2008\end{array}$ & $\begin{array}{l}\text { TxDOT archeologists conducted mechanical scraping } \\
\text { under the northbound lanes (east of centerline) of } \\
\text { SH } 332 \text { and discovered three unmarked graves (later } \\
\text { designated as Burials 7, } 8 \text { and 9). The grave shafts } \\
\text { were left intact, covered with protective layers and fill. } \\
\text { TxDOT contacted PAI about excavating these graves } \\
\text { and continuing the search for unmarked graves. }\end{array}$ & - \\
\hline & \begin{tabular}{|l|} 
October 10, \\
2008 \\
\end{tabular} & $\begin{array}{l}\text { The Texas Historical Commission (THC) issued Texas } \\
\text { Antiquities Permit No. } 5058 \text { to PAI. }\end{array}$ & - \\
\hline & $\begin{array}{l}\text { October } 13- \\
22,2008\end{array}$ & $\begin{array}{l}\text { PAI excavated the three graves found by TxDOT and } \\
\text { continued the search for unmarked graves under the } \\
\text { northbound traffic lanes of SH } 332 \text {. PAI excavated } \\
\text { Burials } 7,8 \text {, and } 9 \text { and discovered more unmarked } \\
\text { graves under the northbound traffic lanes. } \\
\text { PAI found and excavated Burial 10, then exposed grave } \\
\text { shafts for seven more unmarked graves designated } \\
\text { Burials } 11-18 \text {. The excavation was left open but the } \\
\text { graves were covered with protective material while } \\
\text { TxDOT and PAI coordinated the next phase of work. }\end{array}$ & - \\
\hline & $\begin{array}{l}\text { Late October } \\
2008 \text { to } \\
\text { January } 2009\end{array}$ & $\begin{array}{l}\text { The project was put on hold while TxDOT and THC } \\
\text { conferred about the Area of Potential Effects, the } \\
\text { project impacts, and the appropriate level of effort for } \\
\text { the grave search. } \\
\text { After negotiations were concluded, the scope of the } \\
\text { fieldwork for Permit No. } 5058 \text { was changed. }\end{array}$ & - \\
\hline & $\begin{array}{l}\text { January- } \\
\text { February } \\
2009\end{array}$ & $\begin{array}{l}\text { PAI returned to Pioneer Cemetery to continue } \\
\text { fieldwork. Burials } 11-17 \text { were excavated and removed. } \\
\text { Burial } 18 \text { was investigated but found to be the } \\
\text { remnants of Burial } 3 \text { (previously excavated in 2003). } \\
\text { PAI also completed extensive and deep scraping of } \\
\text { the remainder of the area under the northbound } \\
\text { traffic lanes of SH } 332 \text { (east of the road centerline). No } \\
\text { additional unmarked graves were found. }\end{array}$ & - \\
\hline $\begin{array}{l}\text { 210033, } \\
\text { 57913SA002 }\end{array}$ & $\begin{array}{l}\text { September- } \\
\text { October } 2010\end{array}$ & $\begin{array}{l}\text { On September 17, 2010, a work authorization } \\
\text { was signed to allow PAI to summarize the field } \\
\text { investigations and prepare a work plan for the next } \\
\text { phase of work. } \\
\text { PAI reviewed the status of the Pioneer Cemetery } \\
\text { project and prepared a work plan describing the } \\
\text { mechanical search for unmarked graves in the } \\
\text { western half of the project area (west of the current } \\
\text { SH } 332 \text { centerline), and the excavation and removal of } \\
\text { unmarked graves that might be found. The work plan } \\
\text { also outlined the data analyses of the excavated burials } \\
\text { and plan for the reinterment of all excavated burials. }\end{array}$ & $\begin{array}{l}\text { Unpublished work } \\
\text { plan, October } 2010 . \\
\text { This document was } \\
\text { incorporated into the } \\
\text { next work authorization. }\end{array}$ \\
\hline
\end{tabular}

an investigation strategy for the project area. TxDOT modified the terms of Texas Antiquities Permit to reflect this revised effort and strategy. 
Table 3.1, continued

\begin{tabular}{|c|c|c|c|}
\hline $\begin{array}{c}\text { PAI Project No. } \\
\text { and TxDOT } \\
\text { WA No. } \\
\end{array}$ & Date & $\begin{array}{c}\text { Project } \\
\text { Description }\end{array}$ & References \\
\hline \multirow[t]{3}{*}{$\begin{array}{l}\text { 210039, } \\
\text { 57914SA002 }\end{array}$} & $\begin{array}{l}\text { October- } \\
\text { November } \\
2010\end{array}$ & $\begin{array}{l}\text { After TxDOT removed the pavement of the southbound } \\
\text { lanes of SH 332, PAI conducted an extensive grave } \\
\text { search using mechanical scraping over the western half } \\
\text { of the project area (from the SH } 332 \text { centerline to the } \\
\text { west edge of the state-owned right of way). No more } \\
\text { unmarked graves were found. }\end{array}$ & - \\
\hline & $\begin{array}{l}\text { November } \\
2010- \\
\text { July } 2011\end{array}$ & $\begin{array}{l}\text { PAI wrote the burial descriptions and conducted the } \\
\text { preliminary analyses and descriptions of the burial } \\
\text { containers, burial container hardware, and personal } \\
\text { items associated with all } 14 \text { excavated burials } \\
\text { (including } 3 \text { from } 2003 \text { ). PAI compiled four draft } \\
\text { chapters comprising the majority of the technical } \\
\text { report. }\end{array}$ & $\begin{array}{l}\text { Four draft chapters were } \\
\text { completed. They were } \\
\text { later incorporated into } \\
\text { this report. }\end{array}$ \\
\hline & $\begin{array}{l}\text { October } \\
2011- \\
\text { September } \\
2012\end{array}$ & $\begin{array}{l}\text { PAI arranged for and assisted in the reburial planning. } \\
\text { On September } 12,2012 \text {, the } 11 \text { burials excavated } \\
\text { from Pioneer Cemetery in } 2008-2009 \text { were reinterred } \\
\text { inside the cemetery fence (near the } 2003 \text { reinterment } \\
\text { gravesite). }\end{array}$ & - \\
\hline $\begin{array}{l}\text { 215004, } \\
57501 \mathrm{SA} 004\end{array}$ & 2015 & $\begin{array}{l}\text { The final report was completed and archeological } \\
\text { records from all PAI investigations since } 2008 \text { were } \\
\text { curated. }\end{array}$ & This report \\
\hline
\end{tabular}

PAI and TxDOT then signed Supplemental No. 1 (for Work Authorization No. 57728SA001) on December 30, 2008, and a Revised Work Plan was prepared (dated January 2, 2009). PAI conducted Phase 2 of the archeological investigations in January and February 2009. But work was stopped again in February 2009 as TxDOT constructed the bridge over the Brazos River and prepared the northbound lane for traffic. The bridge and northbound lane were completed in October 2010, and PAI was contracted under Work Authorization No. 57913SA002 to conduct the third phase of scraping, covering the southbound lane and western right of way of SH 332, thus completing the mechanical exploration of the project area. The third phase of fieldwork was conducted from October 25 through November 19, 2010.

The discussions below describe the details of the phased investigations that occurred at Pioneer Cemetery from 2008 through 2010. Table 3.2 summarizes all of the burial features excavated in 2003 and 2008-2009 at Pioneer Cemetery.

\section{PHASE I: INVESTIGATIONS EAST OF SH 332 CENTERLINE}

PAI's first phase of work spanned from October 13 to 22, 2008. A two-person crew monitored Gradall work to reexpose the three previously identified graves (Figure 3.1). Graves 7-9, previously identified by Bettis, were re-located using the $2 \times 4$ s and flagging tape as a guide. The protective fill was removed by careful machine digging and hand excavations until the large plywood and wooden signboards were exposed and removed. When the work began, the area was very wet, having been inundated with rain from Hurricane Ike a month earlier. Water had accumulated in the excavated trench. After the grave shafts were exposed, Gradall work focused on digging sumps and drainage ditches to relieve the area of water. A fourth grave, 


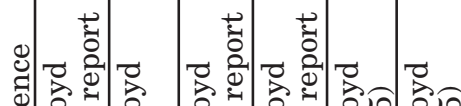

ڤึ.

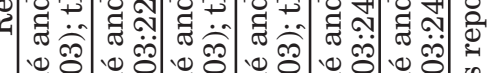

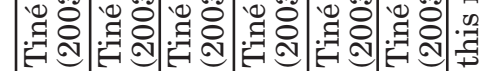

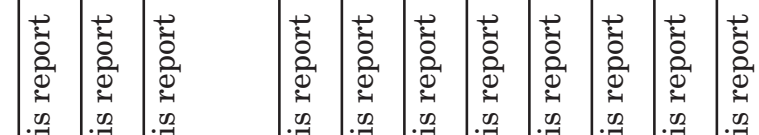

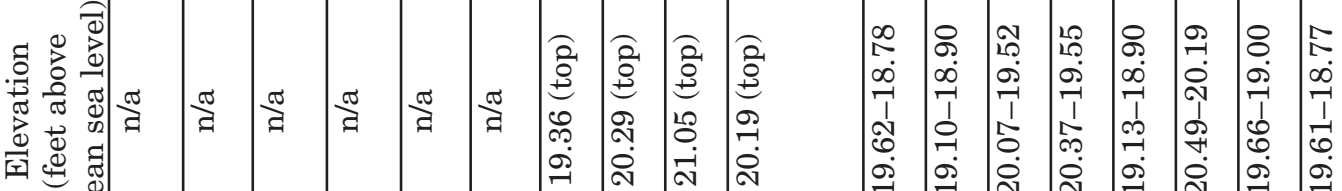

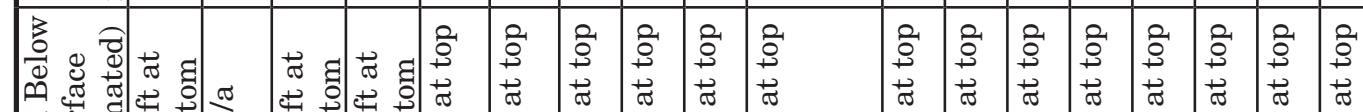

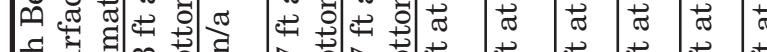

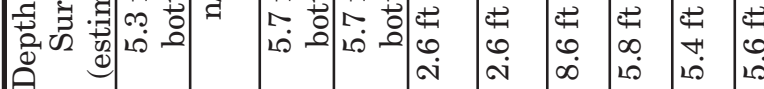

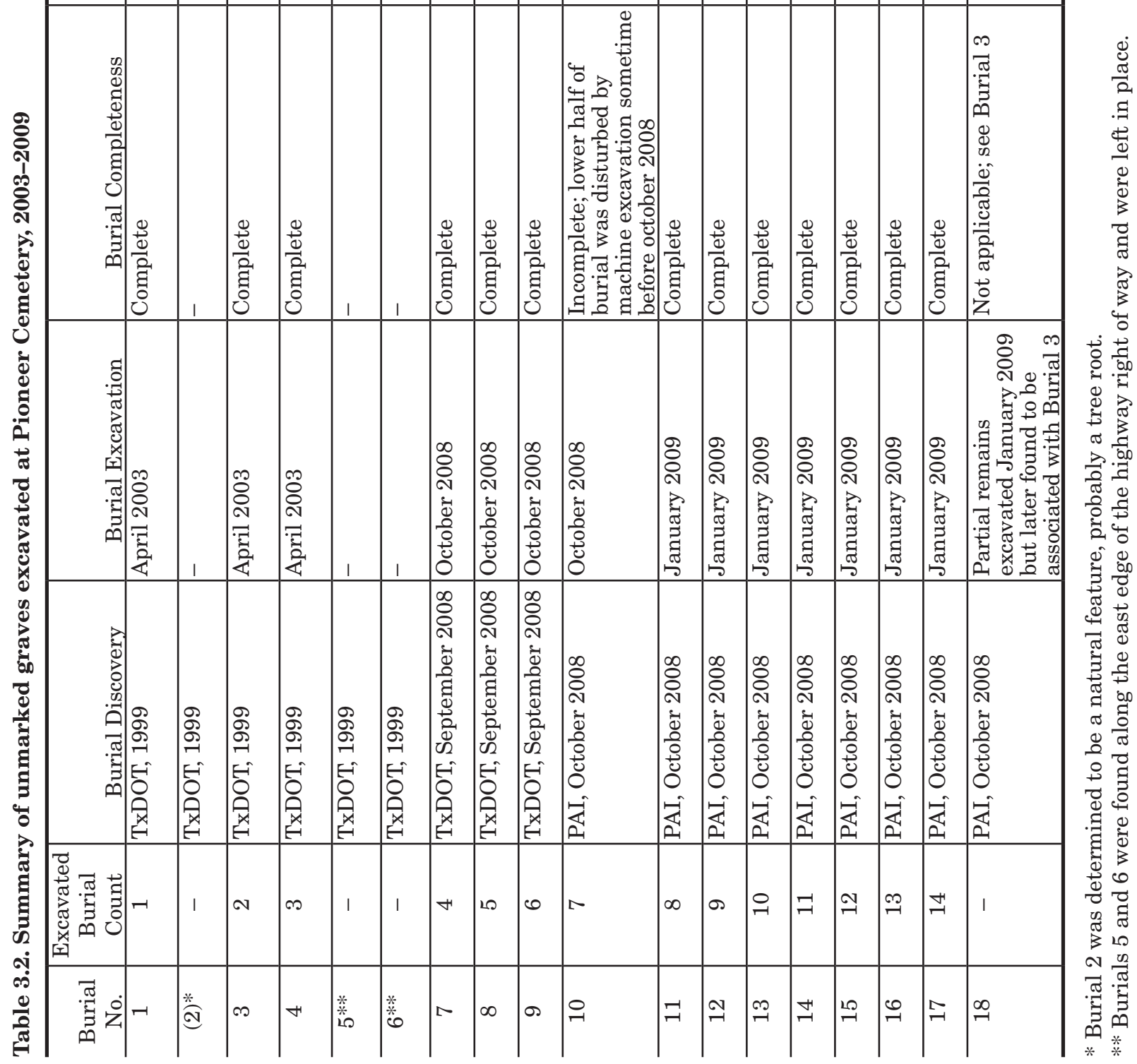


Grave 10, was discovered and exposed during the cutting of a drainage ditch. Only a portion of Grave 10 was found to be intact at the time of its discovery. After minimal inspection, it was determined that previous highway-related work had removed the remainder of the grave. This may have resulted from road improvements such as the installation of highway lighting or signage, or perhaps only a portion of the grave was removed during the 1940s grave relocation.

After the graves were exposed, PAI archeologists excavated Burials 7-10. A two-person team excavated each grave, and each team exposed, documented, and removed one grave per day. Burial excavation procedures are described below.

The following week, two archeologists returned to the field to monitor the scraping of the remaining area. More graves were identified and designated as Burials 11-18. The finding of additional unmarked graves, some in an area that had been scraped before, highlighted the difficulty of identifying grave shafts in the homogenous clay sediments at Pioneer Cemetery.

\section{THC AND TxDOT CONSULTATION}

After the discovery of additional graves, THC and TxDOT went through a round of correspondence and consultation ${ }^{4}$ regarding the appropriate level of effort for the mechanical grave search at Pioneer Cemetery.

The concern for doing a comprehensive grave search at Pioneer Cemetery was heightened by the accidental discovery of unmarked graves after a new building was constructed at the Texas Ranger Hall of Fame and Museum in Waco, Texas. The proposed improvements were located in a section of Waco's First Street Cemetery where many historic graves were known to have been but had reportedly been exhumed and moved following a court order in 1968. An archeological survey of the museum expansion area conducted and reported in 2006 found that there were no unmarked graves in the project area and recommended that the project construction could proceed (Bradle et al. 2006). A new museum annex building was built, and the excavation of exterior utility lines was underway in 2007 when local citizens found human bones in the piles of dirt removed from the trenches. The project was halted, and several years of negotiations, accusations, lawsuits, and confusion ensued (Anonymous 2014; Jervis 2009; Smith 2008, 2015). The City of Waco ended up hiring another archeological firm that conducted an extensive grave search and exhumed more than 200 unmarked graves from around the new building. Most of the graves are from the African American burial section of the Waco First Street Cemetery, and the analysis and reporting of the burials is still underway (Nesta Anderson, personal communication 2015).

The unfortunate events at the Waco First Street Cemetery were covered by the local, state, and national news, and they highlighted the need for archeological due diligence when historic cemeteries are involved. The Waco incident ultimately resulted in the proposal and passage of legislative changes to the cemetery provisions in the Texas Health and Safety Code. Spurred by District 48 Representative Donna Howard, House

4 Letter from F. Lawerence Oaks to Diana [sic] Noble, December 2, 2008; letter from Dianna F. Noble to F. Lawerence Oaks, December 15, 2008, with concurrence signed by Oaks; email from Mark Denton to Scott Pletka, December 23, 2008 (Denton 2008). 


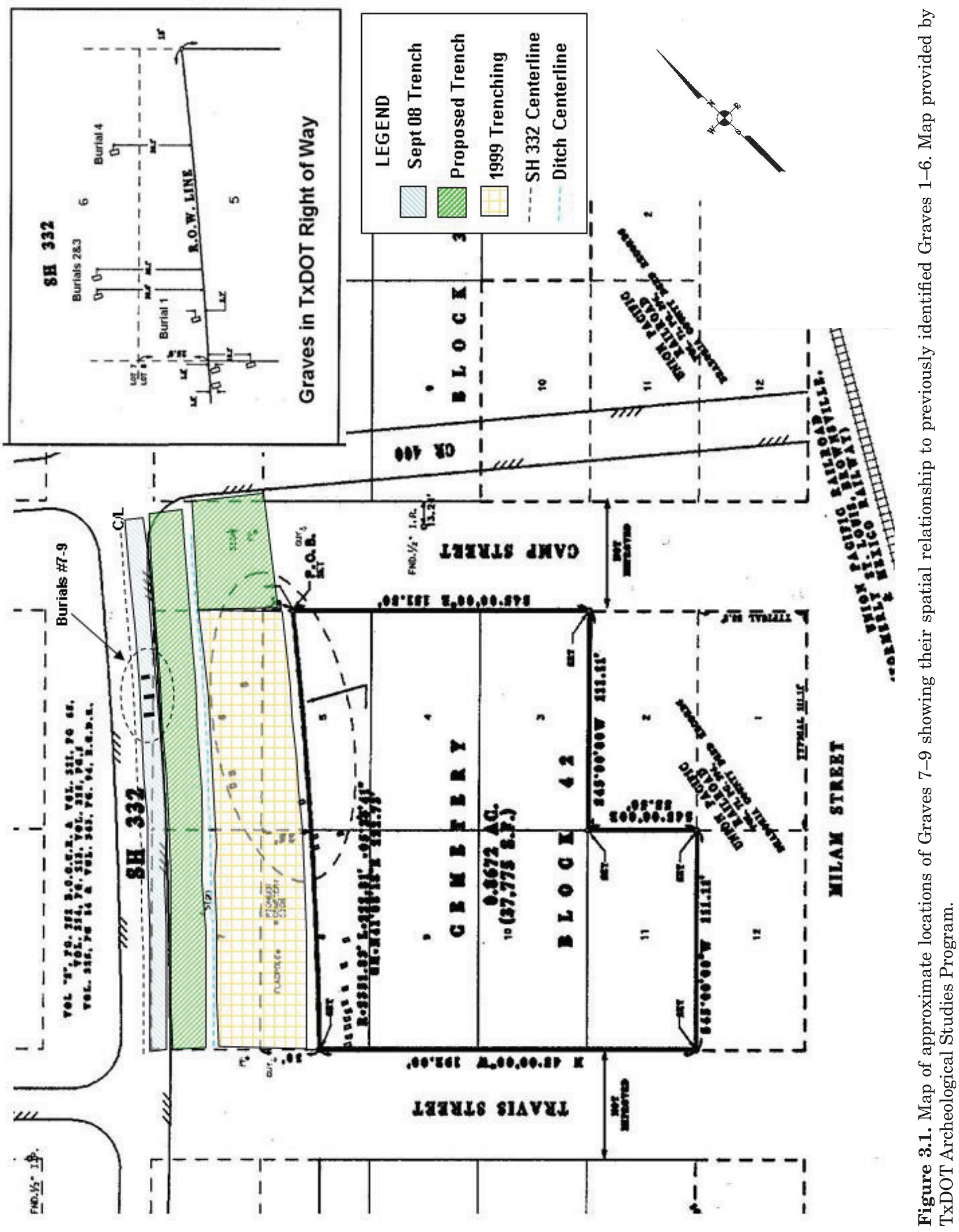


Bill 2927 was passed and became effective September 1, 2009 (Howard 2009; Smith 2008). This bill was working its way through the legislative process and being debated in the State Capitol as the Pioneer Cemetery work was in progress in $2008 .{ }^{5}$ The Waco First Street Cemetery problems were fresh on everyone's minds as unmarked graves kept showing up at Pioneer Cemetery. Consequently, both state agencies involved with the Pioneer project wanted to make sure the search for unmarked graves was done properlyespecially in the light of difficulty of identifying grave shafts in the homogenous clay sediments at Pioneer Cemetery. These events also reinforced the idea that mechanical scraping to search for unmarked graves should be deeper and horizontally extensive (i.e., large open blocks rather than narrow trenches).

The final agreement between the agencies on how to proceed at Pioneer Cemetery was outlined in a letter from Dianna Noble, TxDOT Director of Environmental Affairs, to Mr. F. Lawerence Oaks, THC Director, dated December 15, 2008, with a concurrence signature by Oaks (Noble 2008). The stipulations of this agreement were as follows:

- First, TxDOT intends to remove the graves that have already been identified and inter them within the modern boundaries of Pioneer Cemetery, as originally agreed.

- Second, TxDOT plans to continue scraping in previously-unexamined areas adjacent to the existing pavement along the southbound land of $\mathrm{SH} 332$ from the pavement edge to the flow line of the original ditch (Area B on the attached map).

- Third, TxDOT will reexamine an area constituting one-third of the previously investigated area adjacent to the cemetery (the crosshatched areas on the attached map).

- Fourth, TxDOT will examine the area under and adjacent to the pavement of the northbound lane when this area becomes accessible during phased construction (Area $\mathrm{C}$ on the attached map).

- Fifth, TxDOT will extend all scraping for graves at least one foot into subsoil.

- Finally, any additional graves that are discovered during this work will be excavated and re-interred in accordance with the 2002 plan. This work will be done as soon as practical. To allow for construction work to proceed as close to the original schedule as possible, any identified burial that would not otherwise be disturbed during construction may be recorded, temporarily left in place and moved following construction in the area.

This THC/TxDOT agreement letter included a revised map of the Pioneer Cemetery project area that defined new excavation boundaries as well as new area assignments as Areas A, B, C, and D (Figure 3.2).

Based on these stipulations, PAI prepared a revised work plan, dated January 2, 2009. It was approved by TxDOT and submitted to THC to modify the terms of Antiquities Permit No. 5058. Once the revised permit was issued, the new

5 The events that transpired for this development project are chronicled on the FirstStreetCemetery. org website. 


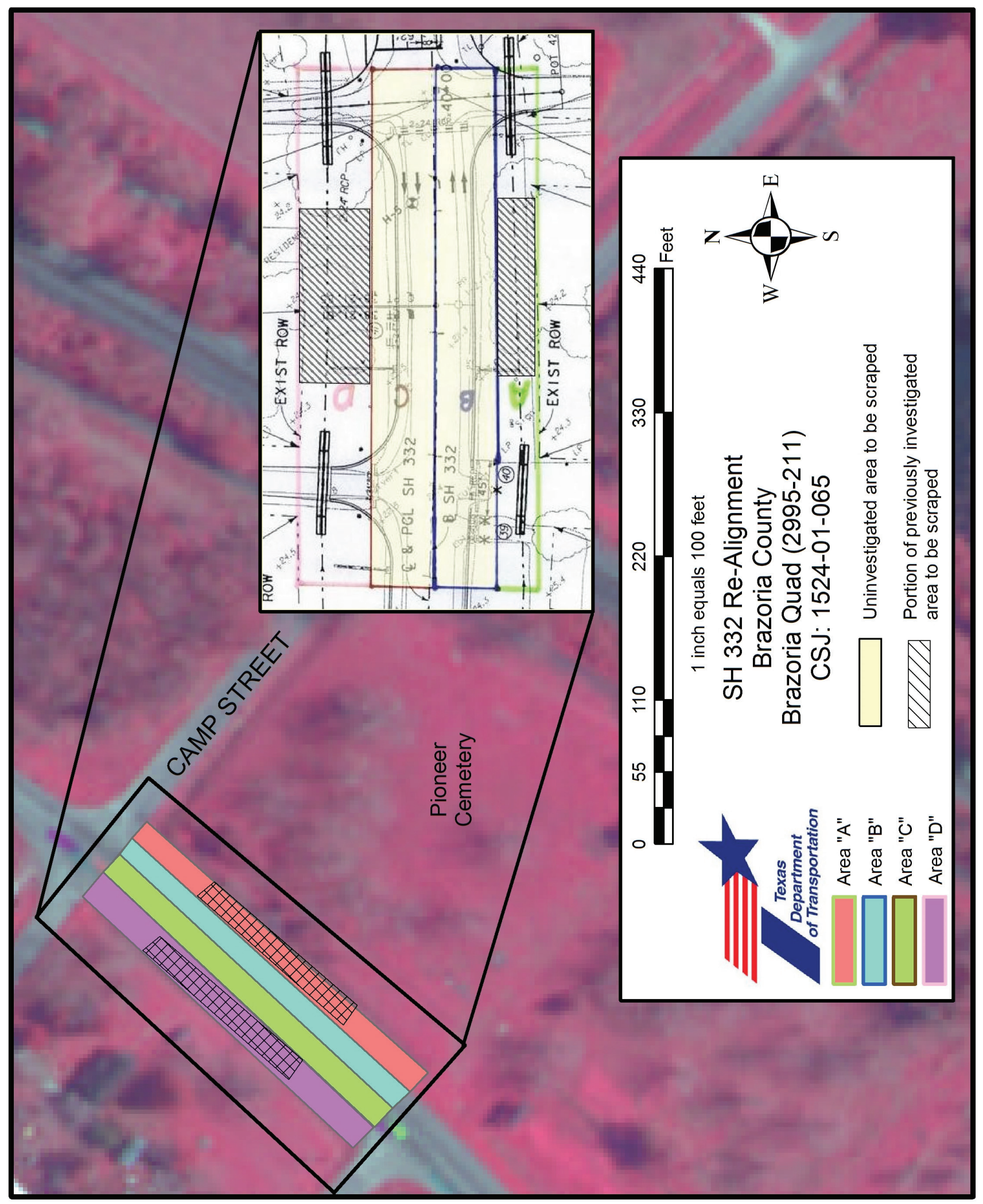

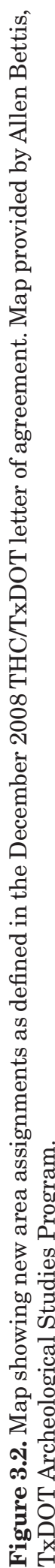


plan and revised project area map were incorporated into Phases II and III of the archeological investigations (see Figure 3.2).

Area A was a 100-ft-long segment in the middle of the cemetery's eastern fenceline, bounded by two telephone poles that were left in place with a balk left in place for support. The 38-ft-wide swath was bordered by the cemetery fence to the east and a ditch on the west. A gas line running along the middle of the old ditch remained in place throughout the investigations and conveniently defined this boundary. The gas line veered to the east near the north end of the project area and this had to be avoided while trenching. The agreement stipulated that one-third of Area A, which had already been investigated by TxDOT personnel, was to be reexamined.

At the time of the December 2008 agreement, no archeological investigations had been conducted in Areas B, C, or D. Area B was the area underneath the northbound SH 332 lanes that spanned $38 \mathrm{ft}$ wide and stretched the entire 300-ft length of the newly assigned project area. Area $\mathrm{C}$ was underneath the southbound SH 332 lanes, a corridor ca. $30 \mathrm{ft}$ wide and $285 \mathrm{ft}$ long. Area D was the SH 332 right of way west of the southbound lanes, and it was ca. $80 \mathrm{ft}$ wide and $285 \mathrm{ft}$ long.

\section{PHASE II: INVESTIGATIONS EAST OF SH 332 CENTERLINE}

When PAI archeologists returned to the field for Phase II, they followed the procedures established in the December 2008 THC/TxDOT agreement and the January 2009 revised work plan. These investigations were conducted in January and February of 2009. The work included extensive mechanical excavations to search for unmarked graves and the excavation, documentation, and removal of seven historic burials.

At the start of Phase II, the area around the large excavation block containing Burials 11-18 received priority for scraping to ensure that no additional graves remained around the perimeter of the known burial cluster. After the mechanical search near the main burial block, two two-person teams began excavating Burials 11-17 while the mechanical search and monitoring continued to the north and south. Burial 18 was also investigated, but this feature turned out to be the bottom remnant of Burial 3, which had been excavated by PAI in 2003. At that time, standing water and mud had prevented the complete removal of the lowest portion of western end of the grave, and some portions of the outer burial box had been left in situ.

After the removal of Burials 11-17, Area B, underneath the northbound SH 332 lane, was mechanically scraped. Area B's east-west boundaries were clearly defined in the field, delineated by the cut in the asphalt road on the west and the gas pipe (conveniently delineated the center of the old ditch line) on the east. The ends of Area B were delineated by Camp Street on the north and Travis Street on the south.

At the conclusion of these investigations, the entire Area $\mathrm{B}$ had been trenched to a depth of at least $3 \mathrm{~m}$ below the original ground surface ( $4-5 \mathrm{~m}$ below the paved $\mathrm{SH} 332$ roadway). The total scraped area was approximately $11,400 \mathrm{ft}^{2}$, with the volume of mechanically excavated fill estimated at ca. $112,203 \mathrm{ft}^{3}$. 


\section{INTERIM CONSTRUCTION PERIOD}

PAI work at Pioneer Cemetery was put on hold for almost two years, from early 2009 through October 2010, while the new bridge over the Brazos River was constructed, the northbound lanes were repaved, and all the traffic was diverted to a new northbound lanes. Once this work was completed, the pavement and overburden were removed from the old southbound lane of SH 332. At that point, the third and final phase of PAI's archeological work could begin.

\section{PHASE III: INVESTIGATIONS WEST OF SH 332 CENTERLINE}

TxDOT issued a work authorization for the Phase III work in October 2010 (WA No. 57914SA002). This four-week phase occurred in late October and early November 2010. This work concentrated on the western side of SH 332, from the centerline to the west edge of the TxDOT right of way, with Areas $\mathrm{C}$ and $\mathrm{D}$ extending southwest from Camp Street and westward from the centerline of SH 332.

PAI archeologists closely monitored the mechanical scraping and search for unmarked graves, with the aid of heavy equipment provided by TxDOT, within Areas C and D (see Figure 3.2). For both Areas C and D, two or three archeologists monitored the excavations of one or two machines, and dump trucks removed the excavated fill from the work area. Area $\mathrm{C}$ was ca. $285 \mathrm{ft}$ long by $30 \mathrm{ft}$ wide and consisted of all the deposits underneath the pavement of the southbound lane of SH 332. Area D was ca. $285 \mathrm{ft}$ long by $75-77 \mathrm{ft}$ wide, and it encompassed the area from western edge of the paved road to the western edge of the road right of way.

A few small areas could not be excavated. A house is just beyond the western edge of the right of way so a 30x90-ft buffer was left in place and not investigated. An area of buried utilities in the northeast corner of Area D (ca. 35x50 ft) and two concrete culvert drainages at the northwest (ca. $25 \times 45 \mathrm{ft}$ ) and southwest (ca. 20x40 ft) corners of Area D, remained unexcavated. In addition, a 3-4 ft gap along the line between Area B and C was left unexcavated. This occurred because concrete safety barriers had to be left in place all along the centerline of the roadway. However, PAI archeologists were aware of this, and paid special attention to the vertical exposures along both sides of this strip. Hence, it is unlikely that any unmarked adult grave shafts could have been missed.

At the conclusion of the Phase III work, all of Areas C and D had been mechanically scraped at least $3.0 \mathrm{~m}$ deep below the old ground surface $(4.0-5.0 \mathrm{~m}$ below the old roadway surface). No additional graves were identified, and this work completed the search for unmarked graves for the SH 332 project.

\section{ARCHEOLOGICAL FIELD METHODS}

The field methods described in this section pertain to PAI's efforts to re-locate previously discovered unmarked graves, the machine-search for additional unmarked graves, and burial investigation procedures. The latter includes establishing elevation controls and mapping of the grave locations. 


\section{Re-location of Previously Discovered Unmarked Graves}

Re-location of previously identified graves occurred twice during this project, both times using excavation machines to facilitate the work. Phase I began with machine digging to find the three unmarked graves (Graves 7-9) originally found by TxDOT-ENV personnel in late 2008. These graves had been covered with plywood and marked with flagging tape and $2 \times 4$-inch boards before backfilling. Re-location of these graves was relatively easy, since their locations were clearly marked above the ground surface. A Gradall was used to carefully pull back the backfill until the protective wood covering was encountered. At that point, shovels were used to remove overburden until the burial container was exposed. Trowels and smaller digging tools were then used to expose the burial remains.

During Phase II, archeologists re-located Graves 11-17, which had been identified during the Phase I scraping. After these grave shaft outlines were identified, each grave had been temporarily covered with sheets of plywood. The relocation was conducted in a similar method to that described above.

\section{Elevation Control and Burial Mapping}

During the mechanical trenching, basic elevation control was maintained in two ways. While mechanical excavations were in progress, a tape measure was used to track the depth of the trenching. A laser level was used to control the depth of the machine excavations.

Two types of mapping was done. Daily sketch maps were maintained in the field notes. These were generally comprised of previously printed aerial photographs annotated with areas of mechanical trenching to show daily progress and locations of any unusual feature or burial discoveries. A TxDOT-subcontracted survey crew followed up by doing high-resolution mapping. When new graves were found, the survey crew was called and usually arrived at the project area in a few hours. The crew also mapped the corners of our excavation blocks, edges of scraped areas, sign posts, utility lines, and any other landmarks. The survey crew finalized the site mapping on the final day of fieldwork.

\section{Burial Excavation Procedures}

The Gradall was used to remove overburden until either a graveshaft stain or wooden burial container fragment was exposed. If a graveshaft was identified, which was rarely the case, it was cleaned and photographed and an elevation was taken. The area was then hand-trowelled or shovel-skimmed until wood was encountered. In several cases, wood was only exposed on one end and sufficient overburden (over a foot or more) was present to utilize the Gradall to save time. Once wood was exposed, a two-person team was assigned to each burial. A preliminary plan map was created, and elevations of the uppermost wood were recorded.

For the most part, burial container wood was in fairly good condition, although it was often very wet. Wood usually came out in planks or sections and, with the exception of one burial, it appeared to be soft wood (such as pine) or softer, 
porous varieties of hardwood. When the wood was wet and partially decomposed, the horizontal wood planks often blended together, and it was hard to differentiate between the outer shipping box, if in fact there was one, and the inner burial container. When possible, the crew attempted to determine if the uppermost sections of wood represented the remains of the coffin or casket lid, an outer box lid, or planks representing the top of a burial vault (running transverse to the burial container wood planks). Sometimes this distinction was not possible until sufficient wood was removed to reveal if an outer box was present beyond the vertical sides of the burial container. A complete understanding of the degradation of the wood and the nature of the burial boxes was often not possible until all of the wood was removed.

For each grave excavation, the upper wood was photographed and an initial outline of the grave was mapped. A wood sample was collected and labeled. After appropriate documentation, the upper wood was removed from the grave. Usually bone was found immediately below these upper layers of wood, and often some portion of the skull or dense bone was embedded within some of the partially decayed wood. The two-person crew excavated from the head and foot ends toward the middle, working together until the entire skeleton was exposed. Bone was generally in good condition, with the exception of skeletal elements from younger individuals.

The skeletons appeared in situ in some burials, while others had been clearly disarticulated by the rising and falling water table and the collapse of the decayed wood from the top and sides of the burial containers. In some cases it appeared that the bottom wood had even been pushed upward due to the fluctuating water table. Several graves contained many bones that were jumbled together or had been crushed into ca. 1-inch fragments. Whatever the condition of the bone, excavators exposed the skeletal remains and, when present, all of the coffin hardware and personal items buried with the deceased. Mapping continued throughout the process, and it was sometimes necessary to remove some upper bones and artifacts to expose contents of the lower burial (this was especially true for disarticulated remains). Photographs were taken at various stages to document the spatial relationships and the excavation process. After all the skeletal materials and artifacts were exposed, final photographs were taken of each burial to document the locations, condition, and overall layout of all the burial remains.

The final removal of the skeletal remains and artifacts began after the documentation was complete. The bones and artifacts were removed and separated by prescribed areas: Area A, the head and upper vertebrae; Area B, the right arm and torso to the hip region; Area C, the left arm and torso; Area D, the right leg; and Area E, the left leg. Laboratory trays were used to separate the bones, bone fragments, and artifacts (including fabric, when present) by burial area as they were pulled from the grave. Bones were then wrapped in newspaper, and aluminum foil was wrapped around the newspaper for stability. If bones were easily identifiable, they were labeled on the outside of the packaging with the name of the element(s); otherwise, the packages were labeled with area designations.

Artifacts were placed in plastic bags that were then placed inside paper bags labeled with provenience information. Delicate objects were wrapped carefully and 
labeled "Fragile" to ensure care during transportation and to alert the laboratory staff for processing. All bone packages, artifact bags, wood, and fabric samples were carefully packed in a cardboard burial box for safe transport to the PAI laboratory for further processing and analysis.

After the bones were removed from the grave, the fieldwork focused on ensuring that all burial-related materials were removed from the grave and surrounding area. At this time, the base of the container was scraped, and the container sideboards (vertical walls) were removed to search for additional decorative hardware and nails. A final elevation reading was taken at the base of each burial container. Wood from the bottom of the container was removed, often allowing for a better look at the configuration between the burial container and outer box (if one was present). After the last wood was removed, the excavation was continued $1 \mathrm{ft}$ deeper to ensure no additional coffin hardware, skeletal materials, or personal items were missed. The elevation of the bottom of the final excavation was recorded.

\section{Analyses of Pioneer Cemetery Burials}

Following completion of the field investigations, all of the human skeletal remains and materials associated with Burials 7-17 were returned to PAI's laboratory in Austin. The analyses of these materials took place from 2009 through 2012 and included detailed studies by several knowledgeable experts in human osteology, historic burial archeology and mortuary material culture, and identification of wood and fabric samples. The descriptions of the burials and detailed analyses of all the burial remains are discussed within this report as follows:

- Descriptions of all 14 excavated burials in 2003 and 2008-2009—Chapter 4

- Analysis of the burial container hardware-Chapter 5, Appendixes A and B

- Analysis of personal items-Chapter 6

- Analysis of human skeletal remains-Chapter 7, Appendix C

- Identification of wood samples-Appendix D

- Identification of textile samples-Appendix E 



\section{CHAPTER 4: BURIAL DESCRIPTIONS}

Aaron R. Norment, Cory J. Broehm, and Douglas K. Boyd

(with contribution by Angela L. Tiné)

This chapter describes the 14 burials excavated from Pioneer Cemetery in 2003 and 2008-2009 (Table 4.1). The descriptions of the three burial features excavated in 2003 (Burials 1, 3, and 4) are reproduced from Tiné and Boyd (2003:2125 ) with only minor changes. Burial features 2,5 , and 6 are also described here but are not excavated burials. ${ }^{6}$

\section{TERMINOLOGY}

For Burials 1-6, burial depth refers to the depth below the ground surface as measured from a level string line to the bottom of the burial container. For Burials 7-17, actual elevations (below sea level) were mapped with a total data station, and the elevations are presented along with the depth below ground surface to the top of the burial (i.e., the highest point where the wooden burial container was encountered). Skeletal preservation is defined:

- Excellent: skeleton complete and fully intact

- Good: skeleton more than 75 percent complete, with most bones, particularly long bone shafts, intact

- Fair: skeleton 25-75 percent complete or fragmented or deteriorated

- Poor: less than 25 percent of skeleton present or skeleton highly fragmented or deteriorated

Dental abbreviations used to describe specific teeth are:

- C: canine; I: incisor: M: molar; P: premolar

- Capital letters: permanent teeth

- Lowercase letters: deciduous teeth

- Superscripted numbers: upper (maxillary) tooth number

- Subscripted numbers: lower (mandibular) tooth number

- $\mathrm{C}^{\mathrm{x}}$ or $\mathrm{C}_{\mathrm{x}}$ : upper or lower canine

6 In 2003, Burial 2 was determined to be a natural feature, and Burials 5 and 6 were left in place. Another possible burial feature found in 2003 was never re-located and was not assigned a burial number. 


\begin{tabular}{|c|c|c|c|c|c|c|c|c|c|c|c|c|c|c|}
\hline تص & $\underset{\nu}{\infty}$ & $\stackrel{\infty}{\infty}$ & 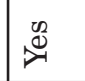 & $\stackrel{\infty}{\infty}$ & $\overbrace{\nu}^{\infty}$ & $\sum_{\nu}^{\infty}$ & $\stackrel{\infty}{\infty}$ & $\stackrel{\square}{0}$ & $\overbrace{\approx}^{\infty}$ & $\stackrel{\infty}{\approx}$ & $\stackrel{\infty}{\approx}$ & $\stackrel{\infty}{\infty}$ & $\overbrace{\nu}^{\infty}$ & $\stackrel{\infty}{\infty}$ \\
\hline 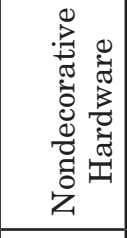 & $\stackrel{\infty}{\infty}$ & $\stackrel{\substack{0 \\
\nu}}{2}$ & $\stackrel{\varpi}{\approx}$ & $\underset{\nu}{\infty}$ & 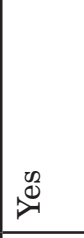 & $\stackrel{\infty}{\infty}$ & 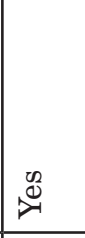 & 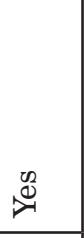 & $\stackrel{0}{\infty}$ & $\stackrel{\infty}{2}$ & 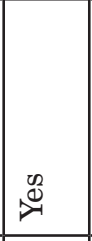 & $\underset{\nu}{\infty}$ & 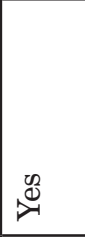 & $\stackrel{\infty}{\Perp}$ \\
\hline 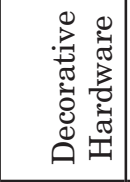 & $\stackrel{\infty}{\infty}$ & $\stackrel{\infty}{\infty}$ & $\stackrel{\infty}{2}$ & $\underset{\nu 1}{\infty}$ & $\stackrel{\infty}{\infty}$ & $\ddot{z}$ & ż & 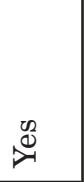 & 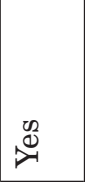 & 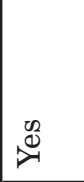 & $\underset{\gamma}{\varpi}$ & $\underset{\nu}{\infty}$ & 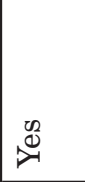 & $\underset{\gamma}{\infty}$ \\
\hline 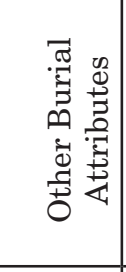 & 1 & 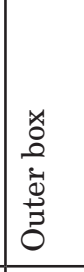 & 1 & 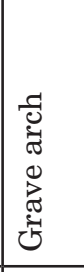 & 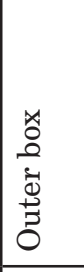 & 1 & 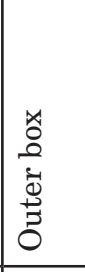 & 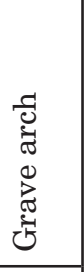 & 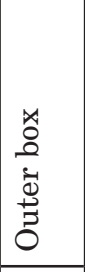 & 1 & 1 & 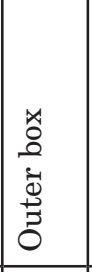 & 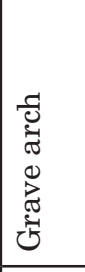 & 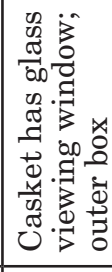 \\
\hline 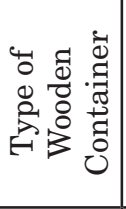 & 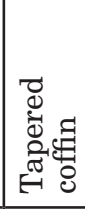 & 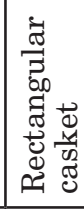 & 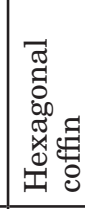 & 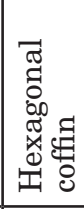 & 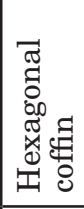 & 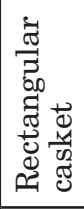 & 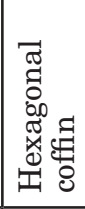 & 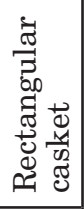 & 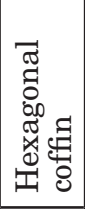 & 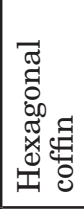 & 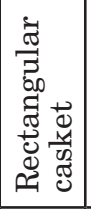 & 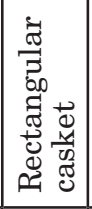 & 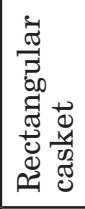 & 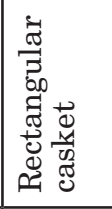 \\
\hline 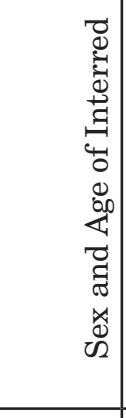 & 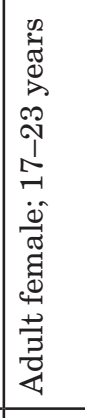 & 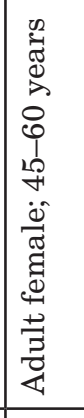 & 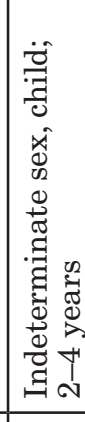 & 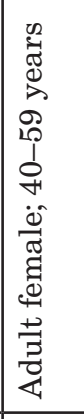 & 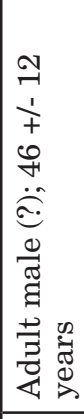 & 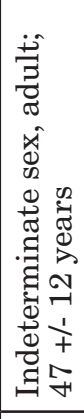 & 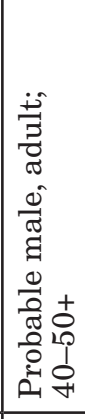 & 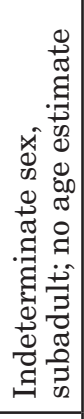 & 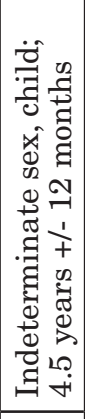 & 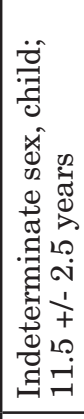 & 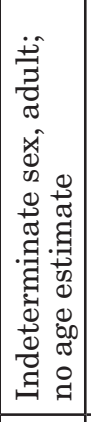 & 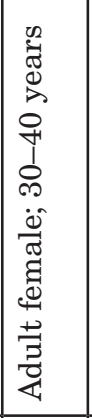 & 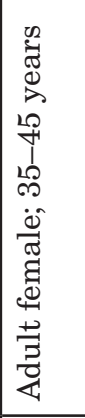 & 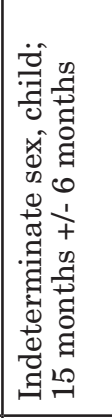 \\
\hline 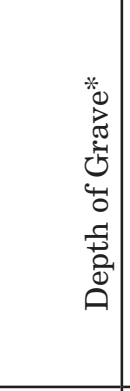 & 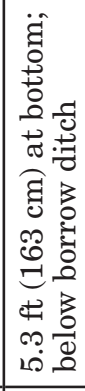 & 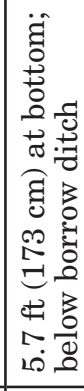 & 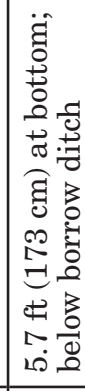 & 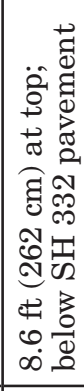 & 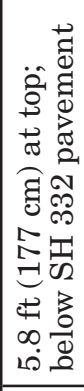 & 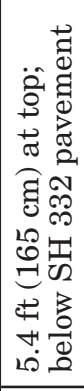 & 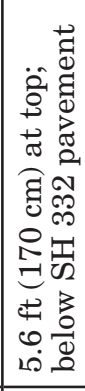 & 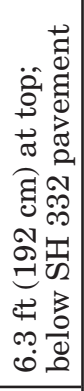 & 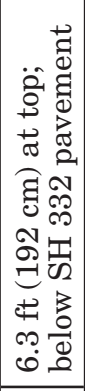 & 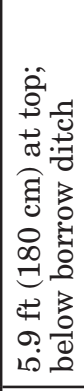 & 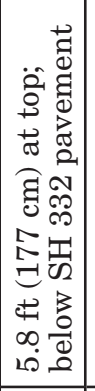 & 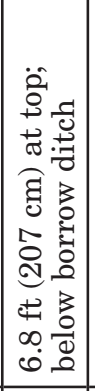 & 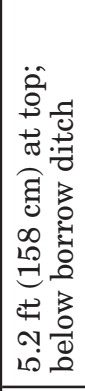 & 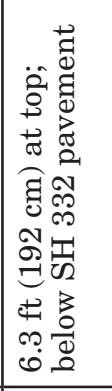 \\
\hline 离 & 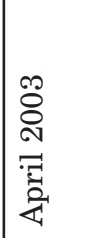 & 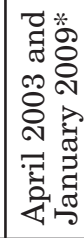 & 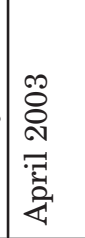 & 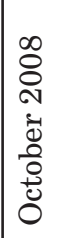 & 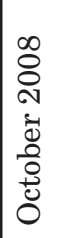 & 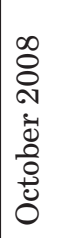 & 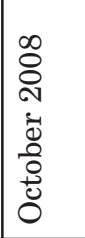 & 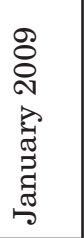 & 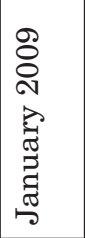 & 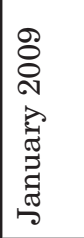 & 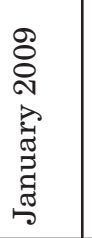 & 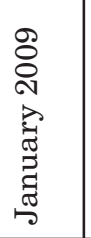 & 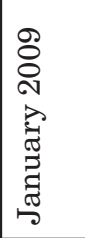 & 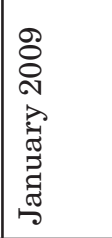 \\
\hline 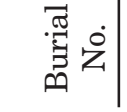 & $1-1$ & $\infty$ & $\mid+$ & 15 & $\infty$ & ar & $1 \stackrel{-1}{-1}$ & -1 & ㄱ & $\stackrel{\infty}{\sim}$ & - & $\stackrel{20}{-1}$ & $\stackrel{0}{-1}$ & 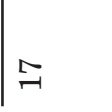 \\
\hline
\end{tabular}


Additional abbreviations used in the burial descriptions are:

- L: left

- $\quad$ R: right

- MC: metacarpal

- MT: metatarsal

\section{BURIAL DESCRIPTIONS}

\section{Burial 1}

Burial Discovery, Excavation, and Reinterment: Burial 1 was found in 1999 by TxDOT archeologists and excavated in April 2003 by PAI archeologists. These remains were reinterred at Pioneer Cemetery on April 4, 2003.

Burial Shaft Size and Depth:The grave shaft measured 197x56 cm (77.6x22.0 inches), and the bottom was $163 \mathrm{~cm}$ ( $5.3 \mathrm{ft}$ ) below the ground surface in the east borrow ditch of SH 332 (ground surface as modified in 2003; not the original ground surface).

Burial Orientation: E-W; head to west

Coffin / Casket Description: The coffin was a wooden, 4-sided burial container with the long sides tapered toward the feet. It measured $194 \mathrm{~cm}$ (76.4 inches) in length, and its width ranged from $55 \mathrm{~cm}$ (21.7 inches) at the head end to $35 \mathrm{~cm}$ (13.8 inches) at the foot end. The coffin wood was identified by Phil Dering (personal communication 2003) as hard pine.

Coffin/Casket Hardware: 4 white metal coffin screws, 2 white metal ornamental dummy tacks, 6 iron tacks, 89 machine-cut nails and nail fragments

Personal Items: One white porcelain button was recovered from the left side of the individual at the level of the pelvis.

Other Artifacts: An iron lid from a hinged metal toolbox was at the west end of the grave above the coffin. The rectangular lid measured 66x22 cm (26.0x8.7 inches) and is $1.5 \mathrm{~cm}$ (0.6 inches) thick. It was found in January 1999, when Burial 1 was initially discovered. The investigators (Dismukes and Bettis 2002:Figure 25) state that the toolbox lid "was perfectly aligned with the grave and may have served at one time as a marker for the grave..."

Burial Position / Taphonomy: The individual was probably originally in an extended position; however, much of the skeleton was disarticulated. Fluctuations in the water table caused the grave shaft to fill with water overnight during excavation, and this appears to have occurred within the grave and coffin many times in the past. As a result, various bones had floated from their original positions and settled elsewhere. Most elements had shifted to the north side of the grave, except the right arm bones and right tibia and fibula, which remained on the south side. However, the arm bones were scattered, and the distal ends of the lower leg were oriented proximally. Several elements from the left side of the body were embedded in the north wall of the grave. The skull was lodged in the northwest corner with the 
mandible and maxilla in the north wall. Several vertebrae were piled in the lumbar region, although others were isolated in various parts of the upper body. The arm and hand bones were scattered in the chest region, making determination of the original arm positions impossible.

\section{Skeletal Preservation: Good}

Sex: Female

Age: $17-23$ years

Biological Affinity: No formal assessment was made due to the poor condition of the skeleton, but morphological features were consistent with African American ancestry (Tiné and Boyd 2003:41).

Skeletal Inventory: Nearly complete skull and mandible; both clavicles; partial scapulae; manubrium; sternal body; nearly complete vertebral column and ribs; partial left and right ilia, auricular surfaces present but eroded; left and right ischia; right pubis; diaphysis, distal epiphysis, and partial proximal epiphysis of left humerus; diaphysis and partial proximal epiphysis of right humerus; left radius, missing distal epiphysis; right radius; left ulna, missing distal epiphysis; right ulna; left femur with distal epiphysis fragments; right femur, missing distal epiphysis; both patellae; left tibia, missing distal epiphysis; right tibial diaphysis; left and right fibulae, missing proximal epiphyses; most hand and foot elements.

Pathology: None observed

Dental Inventory: Complete permanent dentition except for postmortem loss of right $\mathrm{P}_{2}$.

Dental Pathology: One carious lesion each on the occlusal surfaces of right $\mathrm{M}^{1}$ and left $\mathrm{M}^{2}$; three hypoplastic lines on each $\mathrm{I}^{1}$; one hypoplastic line on each mandibular incisor.

Dental Anomalies / Modifications: None observed

\section{Burial 2}

Burial 2 was identified as a soil stain in 1999 but was later determined to be a natural feature. Dismukes and Bettis (2002:11) reported that, "An additional disturbance, recorded as Grave \#2, may or may not ultimately be shown to be a grave. Only the smallest soil disturbance was seen in the side-wall as the trench was excavated." The feature was not further excavated at that time because it was close to a buried gas line. Careful monitoring of backhoe excavations in this area in 2003 , along with hand excavations in the immediate vicinity of the buried gas line, failed to reveal any further evidence of a grave shaft. The feature observed in 1999 was in all likelihood a tree root disturbance. Similar features were observed in several areas during the backhoe trenching in 2003.

\section{Burial 3}

Burial Discovery, Excavation, and Reinterment: Burial 3 was found in 1999 by TxDOT archeologists and excavated in April 2003 by PAI archeologists. These 
remains were reinterred in Pioneer Cemetery on April 4, 2003. In January 2009, wood remnants, several small bones, and three artifacts found by PAI archeologists were designated as Burial 18, but these remains were later determined to be in the same location as Burial 3. These materials are now assigned to Burial 3 and are described here. These additional remains were reinterred in Pioneer Cemetery on September 12, 2012.

Burial Shaft Size and Depth: The grave shaft measured 213x80 cm $(83.9 \times 31.5$ inches), and the bottom was $173 \mathrm{~cm}(5.7 \mathrm{ft})$ below the ground surface in the east borrow ditch of SH 332 (ground surface as modified in 2003; not the original ground surface).

Burial Orientation: E-W; head to west

Coffin/Casket Description: A rectangular wooden casket was within a rectangular wooden outer box. The wood from the outer box and inner casket were melded together, and it was not possible to give accurate measurements of the casket. The outer box measured $211 \times 78 \mathrm{~cm}$ ( $83.1 \times 30.7$ inches). The wood was identified by Phil Dering (personal communication 2003) as hard pine.

Addendum to Coffin / Casket Description: The January 2009 investigation uncovered the walls and bottom of the outer box that had been left in place in 2003. A wood sample from the bottom layer of outer box wood is identified as southern yellow pine (see Appendix D).

Coffin / Casket Hardware: 17 white metal ornamental dummy tacks, 4 iron screws, 11 machine-cut nails

Addendum to Coffin / Casket Hardware: The 2009 investigations recovered 1 white metal ornamental coffin screw.

Personal Items: Three celluloid or Bakelite hairpins were recovered from the head and neck region. One gold-plated metal hair barrette with an ornate floral design was beneath the occipital. Two small gold metal hoop earrings were present in the cranial area. Twelve identical medium-sized white porcelain buttons and one large white porcelain button were recovered from the torso. The matching buttons appear to have originally been arranged in two vertical rows. A gold ring was recovered from a cluster of hand elements over the abdominal region. Because these small bones were jumbled, it is not certain on which hand the ring was worn.

Addendum to Personal Items: The 2009 investigation recovered one celluloid or Bakelite hairpin that is identical to the three found in 2003. It was found in the upper half of the burial.

Other Artifacts: Two pieces of oyster shell were recovered from burial shaft fill but these may have been placed on top of, rather than inside, the casket.

Addendum to Other Artifacts: The 2009 investigation recovered one complete seashell from the upper half of the burial. The seashell is a single valve and most closely matches the bivalve called a Ponderosa Ark, or Noetia (Eontia) ponderosa. It is a common type on the Texas gulf coast (Andrews 1981:87). 
Burial Position/Taphonomy: The individual was supine, in an extended position with the head to the west. The arms were folded over the abdomen. Although the top of the skull is facing west, the cranial area was slightly disturbed. The mandible was to the left of the skull with the mental eminence facing west, and face position was indeterminate. Most of the bones were stained black.

Skeletal Preservation: Fair

Sex: Female

Age: $45-60$ years

Biological Affinity: No formal assessment was made due to the poor condition of the skeleton, but morphological features were consistent with African American (Tiné and Boyd 2003:41).

Skeletal Inventory: Nearly complete calvarium and mandible; both zygomatics; partial maxillae; left clavicle; partial scapulae; iliac fragments, including partial left and right auricular surfaces; miscellaneous rib and vertebral fragments, including atlas and centra from axis and seventh cervical vertebra; left humerus; right humerus with partial proximal epiphysis; left radius; fragments of proximal 1/2 of right radius; proximal 2/3 of left ulna; fragments of distal 1/2 of right ulna; proximal $2 / 3$ of left femur with fragments of distal epiphysis; right femur, missing most of distal epiphysis; distal 1/2 of left tibia; both patellae; partial proximal epiphysis and distal 1/2 of right tibial diaphysis; proximal 2/3 of left fibular diaphysis; distal $2 / 3$ of right fibular diaphysis and partial distal epiphysis; incomplete hand and foot elements.

Addendum to Skeletal Inventory: Distal half of unsided MC II or III and many very small, unidentified bone fragments. No pathology/anomalies observed.

Degenerative Pathology: Mild to moderate osteophytosis of superior and inferior margins of $\mathrm{C} 7$ centrum with compression evident; mild ridging along medial margin of distal articular surface of left femur; thick elevated bony ridge along all of visible medial margin of posterior right patella, articular surfaces of both patellae are granular and becoming porous; pronounced, thick bony ridging along entire lateral margin of distal left tibia with pinpoint porosity along less than $1 / 4$ of the medial margin; mild bony ridging on posterior superior left talus.

Metabolic / Hematological Pathology: Bony apposition along endocranial surface of frontal squamous with striated, undulating appearance and bony nodules, consistent with hyperostosis frontalis interna (HFI).

Dental Inventory: Left $\mathrm{I}^{1}, \mathrm{I}^{2}, \mathrm{M}^{1}$, and $\mathrm{M}^{2}$; Right $\mathrm{I}^{1}, \mathrm{C}^{\mathrm{x}}, \mathrm{P}^{1}$, and $\mathrm{M}^{2}$; Left $\mathrm{P}_{2}-\mathrm{M}_{3}$; Right $\mathrm{P}_{2}-\mathrm{M}_{2}$

Dental Pathology: Antemortem loss of left $\mathrm{P}^{1}$; carious lesion on mesial right $\mathrm{P}^{1}$ and distal right $\mathrm{C}^{\mathrm{x}}$; one carious lesion each on lingual and distal surfaces of left $\mathrm{I}^{1}$; large carious lesion has destroyed most of mesial $\mathrm{I}^{2}$ crown; cervical carious lesion on distal left $\mathrm{M}_{1}$; hypoplastic line on right $\mathrm{P}^{1}$. 
Dental Anomalies / Modifications: Left $\mathrm{M}_{3}$ impacted, all other $\mathrm{M}_{3} \mathrm{~s}$ and sockets not observable; rounded horizontal grooves worn into the lingual surfaces of left and right maxillary central incisors; lateral incisors not observable.

\section{Burial 4}

Burial Discovery, Excavation, and Reinterment: Burial 4 was found in 1999 by TxDOT archeologists and excavated in April 2003 by PAI archeologists. These remains were reinterred in Pioneer Cemetery on April 4, 2003.

Burial Shaft Size and Depth: The grave shaft measured $113 \times 50 \mathrm{~cm}$ (44.5x19.7 inches), and the bottom was $173 \mathrm{~cm}(5.7 \mathrm{ft})$ below the ground surface in the east borrow ditch of SH 332 (ground surface as modified in 2003; not the original ground surface).

Burial Orientation: SE-NW; head to NW

Coffin/Casket Description: Burial container was a hexagonal wooden coffin. It measured $98 \mathrm{~cm}$ (38.6 inches) in length, and its maximum width was $30 \mathrm{~cm}(11.8$ inches) at the shoulder. The head end was $10 \mathrm{~cm}$ (4.0 inches) wide, while the foot end was $20 \mathrm{~cm}$ ( 7.9 inches) wide. The wood was identified by Phil Dering (personal communication 2003) as hard pine.

Coffin/Casket Hardware: 5 white metal ornamental dummy tacks, 6 small iron tacks, 79 machine-cut nails and nail fragments

Personal Items: Three white porcelain buttons of different sizes were present in the neck and torso areas. A small triangular fragment of gray slate was recovered from the left torso region. It is uncertain whether this item was an intentional inclusion.

Other Artifacts: None observed

Burial Position / Taphonomy: The skeletal remains were extremely poorly preserved and very little bone was visible. The burial appears to have been extended with the head to the west, but any other body positioning could not be determined.

Skeletal Preservation: Poor

Sex: Indeterminate

Age: $2-4$ years

Biological Affinity: Indeterminate

Skeletal Inventory: The petrous portions of both temporals were present, as well as some miscellaneous bone fragments. Most skeletal elements were completely deteriorated. Dust outlines of a few long bones, probably the left humerus and tibiae, were observable in situ.

Pathology: Not observable

Dental Inventory: Left $\mathrm{I}^{1}-\mathrm{C}^{\mathrm{x}}, \mathrm{M}^{1}$; Right $\mathrm{I}^{1}, \mathrm{M}^{1} ;$ Left $\mathrm{I}_{1}-\mathrm{C}_{\mathrm{x}}, \mathrm{M}_{1}$; Right $\mathrm{M}_{1} ;$ Left $^{1}{ }^{1} \mathrm{c}^{\mathrm{x}}-\mathrm{m}^{2}$; Right $\mathrm{i}^{2}-\mathrm{m}^{2} ;$ Left $\mathrm{i}_{2}, \mathrm{~m}_{2}$; Right $\mathrm{i}_{2}, \mathrm{c}_{\mathrm{x}}, \mathrm{m}_{2}$

Dental Pathology/Anomalies / Modifications: None observed 


\section{Burials 5 and 6}

The grave shafts for Burials 5 and 6 were discovered in 1999, but Dismukes and Bettis (2002) do not provide any detailed descriptions of these features. The west ends of both grave shafts were re-located in a north-south backhoe trench in 2003. Once the precise TxDOT right of way was determined, the backhoe trench was expanded eastward so that its eastern edge was exactly on the right of way line. The trench exposed about $40 \mathrm{~cm}$ (15.7 inches) of the head ends of both graves at a depth of approximately $80 \mathrm{~cm}$ (31.5 inches) below the ground surface (which may be close to the original ground surface at the time of burial). A decision was made to leave these graves in place, and the west ends of both were covered with a protective slab of concrete that measures $3.0 \mathrm{~m}$ long (north-south) by $1.6 \mathrm{~m}$ wide (east-west) and is 15 to $30 \mathrm{~cm}$ thick (9.8x5.2 ft; 5.9 to 11.8 inches thick).

\section{Burial 7}

Burial Discovery, Excavation, and Reinterment: Burial 7 was discovered in September 2008 by TxDOT archeologists and excavated in October 2008 by PAI archeologists. These remains were reinterred in Pioneer Cemetery on September 12, 2012.

Burial Shaft Size and Depth: The grave shaft measured ca. 190x75 cm (74.8x29.5 inches), with the top elevation of the burial container located at $20.04 \mathrm{ft}$ above sea level and the bottom of the container located at $19.04 \mathrm{ft}$ above sea level. The top of Burial 7 was at $262 \mathrm{~cm}(8.6 \mathrm{ft})$ below the $\mathrm{SH} 332$ pavement.

Burial Orientation: E-W; head to west

Coffin/Casket Description: A hexagonal wooden coffin was present just below the planks that made up the grave arch over the coffin. The coffin tapered toward both the head and feet and measured ca. $160 \mathrm{~cm}$ (63 inches) long. It was widest at the shoulders and measured only ca. $46 \mathrm{~cm}$ (18 inches). This is likely due to compression of the coffin sides from the surrounding soil. Accurate measurements could not be made due to the condition of the burial container. Three wood samples were identified as southern yellow pine (see Appendix D). All three samples were recorded as coffin wood, but one of the samples may have been grave arch wood because the grave arch was not recognized until the end of the excavation.

Coffin/Casket Hardware: 4 white metal screw heads, 17 machine-cut nails

Personal Items: The only personal items recovered were two identical white prosser buttons, both found within the torso region.

Other Artifacts: None observed

Burial Position/Taphonomy: The individual was likely supine, in an extended position with the head to the west. Overall, the remains were quite disturbed, and it could not be determined where the arms and hands were positioned. The zone of saturation was at the same level as the burial container resulting in a high level of disturbance, and likely caused the remains to migrate to the southern half of the coffin. 
Skeletal Preservation: Fair

Sex: Female

Age: 40-59 years

Biological Affinity: Possible African American

Skeletal Inventory: Up to 3/4 complete calvarium; L and R zygomatics; L mandible missing anterior alveolar region; $\mathrm{L}$ and $\mathrm{R}$ clavicles; $\mathrm{R}$ glenoid fossa; scapula body fragments; fragments of the manubrium and body of the sternum; $L$ and $R$ first ribs; $20+$ rib fragments; atlas superior and inferior articular facet fragments; odontoid and L superior facet of axis; complete T12; fragments of the centra and neural arches of the remaining cervical and thoracic vertebrae; four largely complete lumbar vertebrae; part of sacral promontory; fragment of the $L$ pubis; most of the $R$ os coxae including ilium (crest missing), ischium, pubis, acetabulum, and auricular surface; portions of $\mathrm{L}$ and $\mathrm{R}$ humeri; $\mathrm{L}$ radius; $\mathrm{R}$ ulna; $\mathrm{L}$ capitate and scaphoid; $\mathrm{R}$ capitate, scaphoid, lunate, triquetral, and trapezoid; L MC II, III, IV, and V; R MC I, II, III, IV, and V; nine manual phalanges; L and R femora, tibiae, and fibulae; L and $\mathrm{R}$ patellae; $\mathrm{L}$ talus, calcaneus fragment, navicular, medial, intermediate, and lateral cuneiforms; $\mathrm{R}$ talus and lateral cuneiform; L MT I, II, III, and IV, and an unsided MT head; R MT I; three pedal phalanges.

Degenerative Pathology: DJD throughout skeleton, primarily marginal osteophytic lipping, with centrum compression in the cervical column and Schmorl's nodes throughout the vertebral column. Notable changes include:

Progressive degeneration in lumbar spine: L4 and L5 are the most severely affected with osteophytic formation, porosity, eburnation, and surface alteration of the facets. The lamina of the neural arch of L4 on the left side is collapsing into the vertebral foramen, although there is no evidence of fracture.

The L capitate and proximal MC II and III have porosity and overall irregular and degenerative morphology of both articular and nonarticular surfaces. The scaphoid is porous on nonarticular surfaces. These features are suggestive of osteochrondrosis, likely secondary to repetitive microtrauma and blood flow compromise from occupational activities. Circulatory disorders and ligamental collapse may also lead to this disorder (Aufderheide and Rodríguez-Martín 1998:88).

Enthesopathy: None observed.

Flexor ridges of the manual phalanges and insertions for interossei muscles on proximal pedal phalanges are well developed.

Robust upper extremity muscle attachments.

Skeletal Anomalies: Biparietal diploic expansion without associated ectocranial porosity on posterior parietals. The sagittal suture starting at bregma is thinned and has lost all diploic bone, and appears as a $4 \mathrm{~cm}$ trench cutting through the parietal expansion, deepening as it runs posteriorly. This extends onto the left lambdoidal suture (right not preserved). There is an enlarged right parietal foramen, $3 \mathrm{~mm}$ in diameter. A thin layer of sclerotic bone is present on the endocranial surface along 
the sagittal suture. This extends onto the frontal in the distribution of the anterior fontanelle and along the midline. On the frontal, the bone has a more flowing appearance. There is no evidence of cranial deformation. Though the exact etiology is unclear, a metabolic or nutritional problem such as anemia is most likely.

Dental Inventory: $\mathrm{LC}^{\mathrm{x}} ; \mathrm{LP}_{2}$

Dental Pathology: All six mandibular molars were lost antemortem. LP ${ }^{1}$ was lost postmortem. Other dental loss could not be assessed. Minor dental wear. Possible carious lesions and minor calculus formation on both teeth.

Dental Anomalies / Modifications: None observed

\section{Burial 8}

Burial Discovery, Excavation, and Reinterment: Burial 8 was discovered in September 2008 by TxDOT archeologists and excavated in October 2008 by PAI archeologists. These remains were reinterred in Pioneer Cemetery on September 12, 2012.

Burial Shaft Size and Depth: The grave shaft measured ca. 200x85 cm (78.7x33.5 inches), and the top of the coffin was exposed at $20.9 \mathrm{ft}$ above sea level. The top of Burial 8 was found at $177 \mathrm{~cm}(5.8 \mathrm{ft})$ below the $\mathrm{SH} 332$ pavement.

Burial Orientation: E-W; head to west

Coffin/Casket Description: The burial container was a wooden, hexagonal coffin that tapered toward the feet of the individual. It measured 190.5 (75 inches) $\mathrm{cm}$ long, and was $55.8 \mathrm{~cm}$ (22 inches) wide at its widest point. This coffin was inside of a wooden outer box that measured ca. $200 \times 61 \mathrm{~cm}$ (79x24 inches). Four samples of coffin wood and two samples of outer box wood were all identified as southern yellow pine (see Appendix D).

Coffin / Casket Hardware: 6 swing bail coffin handles (2 types), 14 white metal screw heads, 34 machine-cut nails

Personal Items: A white, milk glass bottle was recovered from the left arm area of the individual. It had a woven pattern on the surface with a small area for an attached label. The bottle was blown in mold with an applied lip and bead finish and may have the letters "OC" marked on the base. In addition, three white prosser buttons were recovered near the pelvic area. Four fabric samples were recovered and may represent clothing or a coffin liner (see Appendix E).

Other Artifacts: None observed

Burial Position/Taphonomy: The individual was supine, in an extended position with both arms folded at the waist and laid over the abdominal area. The cranium was at the western end of the coffin, but was crushed under the pressure of the soil, as were several other bones; therefore, it could not be determined which direction the head was facing.

Skeletal Preservation: Good

Sex: Probable male 
Age: 46 years +/- 12 years, based on one ectocranial suture

Biological Affinity: African American

Skeletal Inventory: With the exception of the small, delicate bones of the internal face and the base, the cranium is largely complete; $\mathrm{L}$ zygomatic; $\mathrm{L}$ and $\mathrm{R}$ maxillae; mandible complete except L condyle; parts of diaphyses of both clavicles; portion of glenoid fossa and body fragments of both scapulae; large number of rib fragments; atlas and axis; centra and neural arch fragments from parts of the cervical, thoracic, and lumbar spine; sacral promontory fragment; os coxae fragments, including portions of both acetabula; portions of $L$ and $R$ humeri, radii, and ulnae; $L$ capitate, lunate, scaphoid, trapezoid; $R$ capitate, lunate, and triquetral; unsided pisiform and hamate fragment; L MC II shaft; R MC V; 3 unsided metacarpal fragments; 15 manual phalanges; $\mathrm{L}$ and $\mathrm{R}$ femora, tibiae, and fibulae; $\mathrm{L}$ and $\mathrm{R}$ patellae; all $\mathrm{L}$ and $\mathrm{R}$ tarsals; all $\mathrm{L}$ and $\mathrm{R}$ metatarsals; six pedal phalanges.

\section{Infection/Inflammation:}

- Multiple foci of compact bone growth with lattice-like morphology in L and R maxillary sinuses, suggesting sinusitis.

- Continuous, well-remodeled/healed sclerotic bone across all three compartments of distal $15 \mathrm{~cm}$ of $\mathrm{R}$ tibia. No medullary involvement and does not involve tibiotalar joint. Similar noncontiguous growth foci on the R fibula, distributed across entire shaft. Periosteal lesions such as these are due to direct (usually from trauma) or blood born infection, subperiosteal bleeding from trauma, or occasionally overlying ulcers. The distribution in this individual suggests one of the former two, particularly secondary to trauma.

Degenerative Pathology: DJD, especially marginal and surface osteophyte formation and porosity, evident mainly in the hands, feet, and vertebral column (cervical region affected most severely with compression, porosity, facet eburnation), but also on TMJ, elbow, hip, and knee, as well as:

- Focal approximating eburnation on the L scaphoid and trapezoid, L lunate and capitate, and $\mathrm{R}$ capitate and lunate.

- Focal eburnation on the L talar tibial facet and distal L MT I.

Enthesopathy:

- Enthesophytic development of lateral ridges of proximal 2/3 of L and R MT IV, which also have curved proximal ends.

- Major muscle markings are moderately robust.

Dental Inventory: Left $\mathrm{I}^{1}$ - $\mathrm{P}^{2}$; Right $\mathrm{I}^{1}, \mathrm{C}^{\mathrm{x}}$, probable $\mathrm{M}^{3}$ (two radicals only). Left $\mathrm{C}_{\mathrm{x}}$; Right $\mathrm{I}_{1}-\mathrm{P}_{2}, \mathrm{M}_{3}$

Dental Pathology:

- $\mathrm{RI}^{2}, \mathrm{LI}_{1}$, and $\mathrm{LI}_{2}$ appear to have been lost postmortem. $\mathrm{RP}^{2}, \mathrm{RM}^{1}$, and $\mathrm{RM}^{2}$ loss could not be assessed due to alveolar damage. All other teeth lost antemortem 
and the alveolar regions have been almost completely resorbed, with the exception of $\mathrm{RP}^{1}$, whose crypt is present but enlarged and has evidence of active bone resorption and abscess formation.

- The crypt of $\mathrm{LI}^{2}$, which has not been lost, is also enlarged with a possible abscess.

- Heavy dental wear, with at most a remnant enamel rim. $\mathrm{LP}^{2}$ is an exception, lacking even dentin exposure.

- Possible caries in $\mathrm{LC}^{\mathrm{x}}$ and caries in $\mathrm{LC}_{\mathrm{x}}$. Minor to moderate calculus formation on $\mathrm{LP}^{2}, \mathrm{RP}_{1}, \mathrm{RP}_{2}$, and $\mathrm{RM}_{3}$

- Focal hypercementosis on proximal lingual surface of root of $\mathrm{LP}^{2}$

Dental Anomalies / Modifications: Pipesmoker's type facet, or patterned wear from other tool use, in the left anterior maxillary dentition. A large half circle defect has been worn into the crowns of the left central and lateral incisors and left canine down to their roots, with some corresponding wear in the left mandibular dentition. Polish is pronounced on these surfaces, but there is no gross evidence of striations, grooves, or pitting on the polish.

\section{Burial 9}

Burial Discovery, Excavation, and Reinterment: Burial 9 was discovered in September 2008 by TxDOT archeologists and excavated in October 2008 by PAI archeologists. These remains were reinterred in Pioneer Cemetery on September 12, 2012.

Burial Shaft Size and Depth: The grave shaft measured ca. 177.8x61 cm (70x24 inches). The top of the burial container was located at $20.63 \mathrm{ft}$ above sea level. The top of Burial 9 was found at $165 \mathrm{~cm}(5.4 \mathrm{ft})$ below the SH 332 pavement.

Burial Orientation: ESE-WSW; head toward the west/southwest

Coffin/Casket Description: This burial did not contain an outer box; only a rectangular wooden casket. The casket measured 163x46 cm (64.1x18.1 inches). One sample (two pieces) of casket wood was identified as southern yellow pine (see Appendix D).

Coffin / Casket Hardware: 7 machine-cut nails

Personal Items: Four white prosser buttons were recovered from the head and torso area, and likely were from a shirt. Three of the buttons were identical, and the fourth was slightly larger. Also, a single collar stud with a red glass insert was found around the head area. Several articulated pieces of a prosthetic leg were found in the foot end of the burial, and evidence indicates that this was a right leg prosthesis. The prosthesis parts were iron plates connected with bolts or pins. A remnant of wood adhering to the iron frame was identified as southern yellow pine (see Appendix D). An iron center-bar buckle found in the lower pelvic area may have been a strap buckle for attaching the prosthetic to the leg. One fabric sample was recovered and may represent clothing or a coffin liner (see Appendix E).

Other Artifacts: None observed 
Burial Position/Taphonomy: The individual was supine, in an extended position, but it could not be determined where the arms and hands were positioned. Much of the cranium was intact and the maxillary was pointed toward the south, indicating a south-facing position.

\section{Skeletal Preservation: Fair}

Sex: Indeterminate

Age: 47 years +/- 12 years, based on limited ectocranial suture closure observations

\section{Biological Affinity: African American}

Skeletal Inventory: Much of the calvarium (except glabella) and the right maxilla are present but fragmented; L maxilla anterior alveolar region; L zygomatic; $\mathrm{R}$ zygomatic fragment; mandible missing much of alveolar region; shafts of $L$ and $R$ clavicles and sternal end of L clavicle; portion of glenoid fossa of L scapula; parts of acromion and body fragments of $L$ and $R$ scapulae; $R$ first rib fragment; unsided second rib fragment; 47 rib fragments; 2 articular facets of atlas, 2 articular facets and odontoid of axis; portions of the cervical, thoracic, and lumbar vertebral column; bases of the greater sciatic notches of both ilia; unsided acetabulum fragment; $L$ and $\mathrm{R}$ humeri, radii, and ulnae; $\mathrm{L}$ lunate and capitate; $\mathrm{R}$ triquetral; unsided hamate; $\mathrm{L}$ MC I, III, and V; unsided MC II shaft; two unidentified metacarpal shafts; six manual phalanges; $L$ and $R$ femora; $L$ patella fragment; most of $L$ tibia and fibula diaphyses; unsided tibial plateau fragments; unsided intermediate or lateral cuneiform.

\section{Infection/Inflammation:}

- Well-healed, smooth compact bone growth engulfing the entire left tibia, with more growth present on the anterior crest and medial compartment. It is more undulating to spiculated in the lateral and proximal posterior compartments and seems most prominent in areas of muscle attachment. The distal medial compartment exhibits fusiform woven bone formation in a ca. $5 \times 4 \mathrm{~cm}$ area. Its extent could not be determined because the distal tibia was broken across the lesion and the distal tibia is missing. L fibula is also engulfed in well-healed compact bone growth. It is spiculated on its medial border and distally the fibula has fused with the tibia. There is no medullary space narrowing in either bone. This may be the result of infection or massive subperiosteal hemorrhage.

Degenerative Pathology: Some DJD, with assessment limited by poor preservation:

- Porosity in the R TMJ and L patella.

- Minor to moderate osteophytic lipping on the proximal $\mathrm{L}$ and $\mathrm{R}$ radii.

- Porosity, marginal and surface osteophytes, and Schmorl's nodes are found in the cervical, thoracic and lumbar spine, with eburnation also in the cervical spine and surface alteration in cervical and thoracic spine.

Trauma: Bones of the right leg below the knee are absent and a prosthetic leg is present, evidence most likely of trauma prior to death, although the nature of this trauma is not directly evident on the skeleton. The distal femur on the right side 
is incomplete, despite an attempt at reconstruction. Several fragments of proximal tibia were recovered with the prosthetic leg in situ, suggesting a below-the-knee amputation. Whether infection or trauma led to the loss of the right leg and lesions on the left, or the left became secondarily infected after amputation, or less likely they are not related, is unclear, as is how long prior to death the loss of the lower leg occurred. The left distal tibia lesion suggests ongoing infection, or additional trauma.

Enthesopathy: Marked enthesopathic growth on the midshaft linea aspera of the L femur, and slightly less marked growth on the right. Femora are equal in size and are normal in shape. Radial tuberosities are marked and have enthesophytic growth. Ulnar tuberosities are marked but with no enthesophytic growth. The flexor ridges of the manual phalanges are well developed. The two distal manual phalanges also have significant bone growth on their volar surfaces, mainly on the lateral aspects of the bases and on the tufts.

Dental Inventory: Left $\mathrm{I}^{2}-\mathrm{M}^{2}$; Right $\mathrm{I}^{1}-\mathrm{C}^{\mathrm{x}}, \mathrm{P}^{2}-\mathrm{M}^{2} ;$ Left $\mathrm{P}_{1}$ or $\mathrm{P}_{2}, \mathrm{M}_{1} ;$ Right $\mathrm{C}_{\mathrm{x}}, \mathrm{M}_{2}$ Dental Pathology:

- $\mathrm{LM}^{3}$ and $\mathrm{RM}^{3}$ were lost antemortem and the alveolar regions have been completely resorbed. Time of loss of $\mathrm{LI}^{1}$ and $\mathrm{RP}^{1}$ and all mandibular teeth not present could not be assessed.

- Minor to moderate dentin exposure/wear on the crowns of all teeth.

- Caries on $\mathrm{RC}^{\mathrm{x}}$ and $\mathrm{LP}^{1}$ and possible caries on $\mathrm{LC}^{\mathrm{x}}, \mathrm{LP}^{2}, \mathrm{LM}^{1}, \mathrm{LM}^{2}, \mathrm{RP}^{2}, \mathrm{RM}^{1}, \mathrm{LM}_{1}$, and $\mathrm{RM}_{2}$. Minor to moderate calculus formation is present on all teeth. Because of periodontal disease and subsequent root exposure evident throughout alveolar regions, much of the calculus formation is on the roots of the teeth.

- Chip of enamel of anterior occlusal/labial surface of $\mathrm{RI}^{1}, \mathrm{~L}$ and $\mathrm{R} \mathrm{C}^{\mathrm{x}}, \mathrm{RC}_{\mathrm{x}}$.

Dental Anomalies / Modifications:

- Enamel wear on $\mathrm{RI}^{1}$ is on the mesial side of the crown only, forming an acute angle that slopes distally, suggesting activity-related wear. $\mathrm{LI}^{1}$ is missing, so this could not be further investigated.

- Significant interproximal wear flattening surfaces between $\mathrm{P}^{2}$ and $\mathrm{M}^{1}$, and $\mathrm{M}^{1}$ and $\mathrm{M}^{2}$ on the left and between $\mathrm{P}^{2}$ and $\mathrm{M}^{1}$ on the right. The distal crown of $\mathrm{LM}_{1}$ shows similar wear, exposing dentin on the interproximal surface.

- $\mathrm{LP}_{2}$ has a kinked root with fusiform expansion at the kink.

\section{Burial 10}

Burial Discovery, Excavation, and Reinterment: Burial 10 was found and excavated in October 2008 by PAI archeologists. These remains were reinterred in Pioneer Cemetery on September 12, 2012.

Burial Shaft Size and Depth:Accurate measurements for the grave shaft dimensions could not be fully obtained because the Gradall removed the lower portions of the burial. What remained of the grave shaft measured ca. 140x55 cm (55.1x51.6 inches). 
The top of the burial was $20.42 \mathrm{ft}$ above sea level, and excavations stopped at the bottom of the burial, which was $19.3 \mathrm{ft}$ above sea level. The top of Burial 10 was found at $170 \mathrm{~cm}(5.6 \mathrm{ft})$ below the $\mathrm{SH} 332$ pavement.

Burial Orientation: E-W; head to west

Coffin/Casket Description: The burial container was a hexagonal wooden coffin, and what remained of the coffin measured $140 \times 53 \mathrm{~cm}(55.1 \times 20.9$ inches $)$. The coffin sat inside of a larger wooden box that was deteriorated and could not be accurately measured, but it was probably similar in size to the estimated burial shaft size. One sample of coffin wood was identified as southern yellow pine (see Appendix D).

Coffin / Casket Hardware: 27 machine-cut nails

Personal Items: Seven buttons were recovered from the torso region. Four were white prosser buttons of the same size; 2 were celluloid or Bakelite buttons of two different sizes, and 1 was bone. It is unclear if these buttons belonged to the same garment. Three fabric samples were recovered and may represent clothing or a coffin liner (see Appendix E).

Other Artifacts: None observed

Burial Position/Taphonomy: The individual was supine, in an extended position, but the position of the hands and arms could not be determined. The cranium was too fragmented to determine the direction in which the face was facing. A large portion of the grave was disturbed by a Gradall cut. Much of the lower extremities, as well as the entire east end of the burial shaft and coffin were removed by mechanical scraping.

Skeletal Preservation: Fair

Sex: Probable male

Age: 40-50 years +/- based on limited ectocranial suture observation

Biological Affinity: African American

Skeletal Inventory: Cranium is about 75 percent complete with the exception of some of the small, delicate bones of the face and the cranial base and some fragments of the vault; mandible missing posterior ascending ramus; lateral $3 / 4$ of $\mathrm{L}$ clavicle; $\mathrm{L}$ glenoid fossa and acromion pieces from both scapulae; several rib fragments; atlas; axis; neural arch fragments from much of cervical, thoracic, and lumbar spine; five cervical or upper thoracic centra fragments; base of unsided greater sciatic notch; fragment of unsided acetabulum; L and $\mathrm{R}$ humeri, radii, and ulnae; L capitate, lunate, scaphoid, trapezoid, hamate; $R$ capitate, lunate, trapezium, and hamate; base of L MC II; base and shaft of L MC III; unidentified metacarpal shaft; one manual phalanx; L lateral cuneiform.

Degenerative Pathology: DJD, mainly osteophytic lipping and porosity, throughout the skeleton, but especially marked in the vertebral column. Other notable changes:

- Atrophy of L mandibular coronoid. 
- Surface osteophytes present on both TMJ (and surface alteration), both humeral heads, the $\mathrm{R}$ elbow, and an unsided acetabulum.

- Eburnation present on the $\mathrm{R}$ occipital condyle, $\mathrm{L}$ shoulder, trapezium and radial facets of $L$ scaphoid, lunate facets of $R$ capitate and hamate, MC I and scaphoid facets of $\mathrm{R}$ trapezium.

- Severe DJD of the vertebral column, affecting the region equally. Joint surface alteration, eburnation of facets and centra surfaces, surface osteophytes, compression, and Schmorl's nodes are common. A thoracic lamina and spine has collapsed on the right side onto the neural arch below it, creating a pseudoarthrosis with irregular osteophytic growth and eburnation. Two fragments, one in the thoracic region and the other in either the thoracic or lower cervical region, show fusion of an inferior facet with the superior facet of the vertebra below. There is no evidence of fracture, although the bones are heavily fragmented.

Trauma: A 4.5-cm-long rib fragment has a healing to healed oblique fracture. The significant DJD and fusion of the thoracic spine is also likely secondary to trauma.

Enthesopathy: None observed. Major muscle origins/insertions are pronounced.

Dental Inventory: $\mathrm{LP}_{1}$ or $\mathrm{P}_{2}$

Dental Pathology: All teeth not recovered were lost antemortem. The tooth immediately mesial to $\mathrm{L} \mathrm{P}_{1}$ or $\mathrm{P}_{2}$ was lost relatively recently before death, as the alveolus is resorbing. There is some evidence of buccal abscess with this tooth as well. The remaining teeth appeared to have been lost well before death. The recovered tooth has minimal wear (not even dentin exposure) and calculus formation.

\section{Burial 11}

Burial Discovery, Excavation, and Reinterment: Burial 11 was found in October 2008 by PAI archeologists and excavated in January 2009 by PAI archeologists. These remains were reinterred in Pioneer Cemetery on September 12, 2012.

Burial Shaft Size and Depth: The dimensions of the grave shaft could not be identified. The top elevation where the burial container was first encountered measured $19.62 \mathrm{ft}$ above sea level with the bottom measuring at $18.78 \mathrm{ft}$ above sea level. The top of Burial 11 was found at $192 \mathrm{~cm}(6.3 \mathrm{ft})$ below the east edge of the SH 332 pavement.

Burial Orientation: E-W; head to west

Coffin/Casket Description: Burial container was a rectangular wooden casket measuring $207 \mathrm{~cm}$ ( 81.5 inches) in length, with its width being $60 \mathrm{~cm}$ ( 23.6 inches). Measurements across the head, shoulders, and feet were each near $60 \mathrm{~cm}$. Initially, the first wood encountered was thought to be an outer box for the casket, but it was realized that only one wooden casket was present. It is likely that wooden planks 
had been placed across the top of the casket to form a grave arch. One sample of coffin wood was identified as southern yellow pine (see Appendix D), but no samples of the grave arch wood were taken.

Coffin / Casket Hardware: 4 swing bail handles, 6 escutcheon and thumbscrew sets, 33 machine-cut nails

Personal Items: A total of four white prosser buttons were recovered from within the casket. Two of the buttons were located near the head and upper torso, while the remaining two were found on the lower right side of the torso. Three of the buttons were identical, resembling shirt buttons, while one was slightly larger. Additionally, a single piece of pencil graphite was also recovered near the head and upper torso.

Other Artifacts: None observed

Burial Position/Taphonomy: The individual was supine, in an extended position with the head to the west. It is possible that the arms were crossed at the wrist and rested over the abdominal area. Although the cranium was very fragmented, the position of the mandible just below the cranium suggests the head eventually tilted and faced north. Most of the post crania were poorly preserved, and additional body positioning could not be determined.

Skeletal Preservation: Poor. Analysis is partly based on field notes.

Sex: Indeterminate

Age: Subadult, likely at least 4 years. There is an unfused proximal or distal femoral epiphysis and additional fragments of unfused long bone epiphyses that could not be identified.

\section{Biological Affinity: Indeterminate}

Skeletal Inventory: Fragments of frontal, L and R parietals, and occipital; shaft of unsided clavicle; few fragments of diaphyses of L humerus, radius, and ulna; one manual phalanx; fragments of diaphyses of $\mathrm{R}$ femur, $\mathrm{L}$ tibia, and $\mathrm{L}$ fibula; $\mathrm{L}$ patella; part of tibial facet of $\mathrm{L}$ talus.

Pathology: None observed

Skeletal Anomalies: On the left posterior parietal,just lateral to the sagittal suture, there is an irregularly shaped defect of the outer table, measuring ca. $1.13 \times 2.29 \mathrm{~cm}$. The outer table of bone is missing, and the floor of the lesion, in the diploic bone, has remodeled into compact bone. The margins are generally sharp and steeply dropping, but sometimes overhanging, and there is no associated reactive bone formation outside the defect. Its etiology and relationship to cause of death are unclear. It may be due to trauma, resolved local infection, or, most likely, neoplasm (especially a form of histiocytosis X) or congenital condition, (e.g. aplasia cutis).

Dental Inventory: Fragment of crown of a permanent incisor, possibly $\mathrm{I}_{2}$ Dental Pathology/Anomalies / Modifications: None observed 


\section{Burial 12}

Burial Discovery, Excavation, and Reinterment: Burial 12 was found in October 2008 by PAI archeologists and excavated in January 2009 by PAI archeologists. These remains were reinterred in Pioneer Cemetery on September 12, 2012.

Burial Shaft Size and Depth: The dimensions of the grave shaft could not be identified. The top elevation where the burial container was first encountered measured $19.1 \mathrm{ft}$ above sea level with the bottom measuring at $18.9 \mathrm{ft}$ above sea level. The top of Burial 12 was found at $192 \mathrm{~cm}(6.3 \mathrm{ft})$ below the ground surface in the east borrow ditch of $\mathrm{SH} 332$.

Burial Orientation: E-W; head to west

Coffin/Casket Description: A small, hexagonal coffin was present within a rectangular wooden box. The collapse of both wooden containers created some confusion as to what was the actual coffin and what was the outer box. With the upper wood removed, the diamond-shaped coffin walls became more pronounced. The coffin measured $121 \mathrm{~cm}$ (47.75 inches) in length, and its maximum width was 26.5 (10.5 inches) $\mathrm{cm}$ at the shoulder. The head measured $15.2 \mathrm{~cm}$ (6 in) wide, while the foot end was $11.4 \mathrm{~cm}$ ( 4.5 inches) wide. Three samples of coffin wood were identified as southern yellow pine, and one sample of outer box wood was identified as white oak (see Appendix D).

Coffin / Casket Hardware: 2 white metal coffin screws, 25 machine-cut nails

Person Items: Five white prosser buttons of four different sizes were recovered from the torso area. It is likely that these were shirt buttons.

Other Artifacts: None observed

Burial Position / Taphonomy: The skeletal remains were extremely poorly preserved, with very little bone visible. The individual appears to have been supine, in an extended position with the head to the west. Any additional body positioning could not be determined.

Skeletal Preservation: Poor

Sex: Indeterminate

Age: 4.5 years +/- 12 months

Biological Affinity: Indeterminate

Skeletal Inventory: Unidentifiable fragments of the cranial vault, including L and $R$ petrous portion of temporals; $R$ mandible; unidentified long bone fragments

Pathology: None observed

Dental Inventory: Left $\mathrm{c}^{\mathrm{x}}, \mathrm{m}^{2} ;$ Right $\mathrm{i}^{2}, \mathrm{c}^{\mathrm{x}}, \mathrm{m}^{2} ;$ Left $\mathrm{i}_{1}, \mathrm{i}_{2}, \mathrm{~m}_{1}, \mathrm{~m}_{2} ;$ Right $\mathrm{i}_{1}, \mathrm{i}_{2}, \mathrm{~m}_{1}, \mathrm{~m}_{2}$; Left I ${ }^{1}-\mathrm{M}^{2} ;$ Right I ${ }^{1}-\mathrm{M}^{1}$; Left $\mathrm{I}_{1}-\mathrm{M}_{2}$; Right $\mathrm{I}_{1}-\mathrm{M}_{2}$

Dental Pathology: Calculus formation on both $\mathrm{m}^{2}$ 
Dental Anomalies/Modifications: Polish on lingual surface of $\mathrm{R}^{2}$, and wear on the same surface of this tooth and $\mathrm{R}_{1}, \mathrm{~L}_{1}$ and $\mathrm{L} \mathrm{i}_{2}$. Well-circumscribed, $2.69 \times 2.29$ mm lack of enamel formation on surface of distolingual cusp of $\mathrm{L} \mathrm{M}^{1}$, exposing the underlying dentine.

\section{Burial 13}

Burial Discovery, Excavation, and Reinterment: Burial 13 was found in October 2008 by PAI archeologists and excavated in January 2009 by PAI archeologists. These remains were reinterred in Pioneer Cemetery on September 12, 2012.

Burial Shaft Size and Depth: The grave shaft measured $169 \mathrm{~cm}$ (66.5 inches) long, with the width ranging from $48 \mathrm{~cm}$ (18.9 inches) to $64(25.2$ inches) $\mathrm{cm}$. The top of the burial was located at $19.1 \mathrm{ft}$ above sea level and the bottom at $18.9 \mathrm{ft}$ above sea level. The top of Burial 13 was found at $180 \mathrm{~cm}(5.9 \mathrm{ft})$ below the ground surface in the east borrow ditch of $\mathrm{SH} 332$.

Burial Orientation: E-W; head to W

Coffin/Casket Description: Burial container was a hexagonal wooden coffin. It measured $151 \mathrm{~cm}$ (59.4 inches) in length, and its maximum width was $39 \mathrm{~cm}(15.3$ inches) at the shoulder. The head end measured $22 \mathrm{~cm}$ ( 8.6 inches) wide, and the foot end was $13 \mathrm{~cm}$ (5.1 in) wide. Two samples of coffin wood were identified as southern yellow pine (see Appendix D).

Coffin / Casket Hardware: 6 white metal screw heads, 19 machine-cut nails

Personal Items: Five white prosser buttons were recovered from the torso area. Four of the buttons were identical, and the fifth had slight ridgelines around the button edge. Also from the torso region was a small thin-metal label from a child's bib pin (clothes fastener). It is made from cuprous metal with the word "BABY" inscribed on its surface. Since the interred individual was ca. 11.5 years old, it is likely that the bib had represents an heirloom item of special importance to the parents of the deceased. Four fabric samples were recovered and may represent clothing or a coffin liner (see Appendix E).

Other Artifacts: None observed

Burial Position/Taphonomy: Overall, the skeletal remains were in fair to good condition. The burial appears to have been supine, in an extended position with both arms and hands extended along their respective sides. Much of the cranium was fragmented, but overall the skeleton appeared to be in the correct anatomical position.

Skeletal Preservation: Fair to good

Sex: Indeterminate

Age: 11.5 years +/- 2.5 years

Biological Affinity: Indeterminate 
Skeletal Inventory: 50-75 percent complete calvarium; L and R zygomatics; portions of ascending rami of mandible; sternal half of $L$ clavicle; $R$ clavicle; $L$ and $R$ glenoid fossae and scapula body fragments; 40+ rib fragments; atlas; axis; mostly complete vertebral column; promontory and three segments of sacrum; fragment of $L$ ilium and $\mathrm{R}$ ischial tuberosity; $\mathrm{L}$ and $\mathrm{R}$ acetabula; $\mathrm{L}$ auricular surface; $\mathrm{L}$ and $\mathrm{R}$ humeri, radii, and ulnae; L capitate, trapezoid, and scaphoid; 5 unsided and unidentified MC shafts; 4 manual phalanges; $L$ and $R$ femora; $L$ and $R$ patellae; $L$ and $R$ tibiae diaphysis; $L$ and $R$ fibulae diaphyses; $L$ calcaneus (cuboidal facet) and navicular; $R$ calcaneus (talar facet), talus, and navicular; unidentified tarsal fragments; R MT III and IV; two proximal pedal phalanges.

Pathology: None observed

Dental Inventory: Left $\mathrm{I}^{1}-\mathrm{M}^{3} ;$ Right $\mathrm{I}^{1}-\mathrm{M}^{3} ;$ Left $\mathrm{I}_{1}-\mathrm{M}_{3} ;$ Right $\mathrm{I}_{1}-\mathrm{M}_{2}$

Dental Pathology: Chipping of enamel of occlusal surfaces of L and $\mathrm{R} \mathrm{I}^{2}$. There is minimal to no wear.

\section{Burial 14}

Burial Discovery, Excavation, and Reinterment: Burial 14 was found in October 2008 by PAI archeologists and excavated in January 2009 by PAI archeologists. These remains were reinterred in Pioneer Cemetery on September 12, 2012.

Burial Shaft Size and Depth: The grave shaft measured 215.9x81.3 cm (85x32 inches). The top of the burial was located at $20.37 \mathrm{ft}$ above sea level and the bottom was at $19.55 \mathrm{ft}$ above sea level. The top of Burial 14 was found at $177 \mathrm{~cm}(5.8 \mathrm{ft})$ below the ground surface in the east borrow ditch of SH 332.

Burial Orientation: E-W; head to W

Coffin / Casket Description: The burial container was a rectangular wooden casket with no outer box. The casket was $192 \times 61 \mathrm{~cm}$ (75.6x24 inches). One sample of casket wood was identified as southern yellow pine (see Appendix D).

Coffin / Casket Hardware: 11 white metal screw heads, 42 machine-cut nails, 6 screws

Personal Items: A single white prosser button was recovered near the torso.

Other Artifacts: None observed

Burial Position/Taphonomy: The individual was in an extended position, and was likely supine. The arms may have been crossed. A small disturbance extends across the west end of the burial where a small trench was excavated. The disturbance does not extend through the bottom of the casket. Much of the cranium was disturbed by this trench.

Skeletal Preservation: Poor

Sex: Indeterminate

Age: Adult

Biological Affinity: Indeterminate 
Skeletal Inventory: Fragments of frontal, parietals, occipital, and temporals; $\mathrm{R}$ zygomatic; most of mandible; $L$ and $R$ clavicle shafts; $L$ and $R$ acromia of scapulae; six rib fragments; superior facet of atlas; axis; upper lumbar neural arch; parts of two thoracic or lumbar centra; sacral fragment; fragments of unsided ilium and ischium; part of $\mathrm{R}$ auricular surface; $\mathrm{L}$ proximal and distal humerus; $\mathrm{R}$ humerus diaphysis; part of shafts of $L$ and $R$ radii; proximal epiphysis of $L$ and $R$ ulnae; $R$ scaphoid; L and R shafts of MC II; two unsided metacarpal shafts; three manual phalanges; proximal half of $\mathrm{L}$ femur; proximal epiphysis and diaphysis of $\mathrm{R}$ femur; $\mathrm{L}$ patella; fragments of diaphyses of $\mathrm{L}$ and $\mathrm{R}$ tibiae; diaphyses of $\mathrm{L}$ and $\mathrm{R}$ fibulae; $\mathrm{R}$ talus; one pedal phalanx.

Degenerative Pathology: Osteophytic lipping on left superior facet and body of the axis.

Enthesopathy: None observed. Major muscle insertions are gracile.

Dental Inventory: Left $\mathrm{I}^{2}-\mathrm{P}^{1}$; Right $\mathrm{I}^{1}-\mathrm{P}^{2}$; unidentified maxillary premolar root; Left $\mathrm{I}_{1}$ (crown only), $\mathrm{I}_{2}-\mathrm{P}_{2}$; Right $\mathrm{I}_{1}, \mathrm{C}_{\mathrm{x}}, \mathrm{P}_{1}$ (crown only), $\mathrm{P}_{2}$

Dental Pathology:

- $\quad \mathrm{R} \mathrm{M}_{1}, \mathrm{M}_{2}$, and $\mathrm{M}_{3}$ were lost antemortem, but other missing teeth could not be assessed due to missing alveolar bone.

- Minor to moderate wear/dentine exposure.

- Caries on $\mathrm{LI}^{2}, \mathrm{LC}^{\mathrm{x}}, \mathrm{LP}^{1}, \mathrm{RI}^{1}, \mathrm{LP}_{1}$, and $\mathrm{RP}_{2}$. Possible caries on $\mathrm{LI}_{1}, \mathrm{LP}_{2}, \mathrm{RI}_{1}$, and $\mathrm{RC}_{\mathrm{x}}$. Minimal to moderate calculus deposits in the maxillary and mandibular anterior dentition and premolars.

- Chipping of occlusal surfaces of crowns of $\mathrm{LI}^{2}$ and $\mathrm{RI}^{1}$

Dental Anomalies / Modifications: $\mathrm{RM}_{3}$ appears to have erupted on, or drifted onto, the ascending ramus of the mandible, based on the presence of resorbing alveolar bone. The wear on $\mathrm{LI}_{2}$ and $\mathrm{LC}_{\mathrm{x}}$ forms a shallow, continuous concavity, suggesting a pipesmoker's facet or other patterned use of the teeth.

\section{Burial 15}

Burial Discovery, Excavation, and Reinterment: Burial 15 was found in October 2008 by PAI archeologists and excavated in January 2009 by PAI archeologists. These remains were reinterred in Pioneer Cemetery on September 12, 2012.

Burial Shaft Size and Depth: The grave shaft measured 205x82 cm (80.7x32.3 inches), with the top of the casket measured at $19.13 \mathrm{ft}$ above sea level and the bottom at $18.9 \mathrm{ft}$ above sea level. The top of Burial 15 was found at $207 \mathrm{~cm}(6.8 \mathrm{ft})$ below the ground surface in the east borrow ditch of SH 332 .

Burial Orientation: E-W; head to west

Coffin/Casket Description: A rectangular wooden casket was present within a rectangular wooden box. The outer box measured 190x61 cm (74.8x24 inches), with the casket fitting inside. Much of the wood from the casket had collapsed. Because of 
the poor condition of the wood, it was not possible to obtain an accurate measurement of the casket. One sample of casket wood and one sample of outer box wood were identified as southern yellow pine (see Appendix D).

Coffin / Casket Hardware: 7 white metal screw heads, 42 machine-cut nails, 5 screws

Personal Items: A whiteware saucer was recovered near the head. It has a diagnostic maker's mark-“WOOD \& HAWTHORN"- that was used only from 1882 to 1887 (Godden 1991:687). A bird talon/toe bone with remnants of gold plating also was found near the head and may have been worn as a necklace. Two white prosser buttons were also recovered; one near the neck and one to the left of the left shoulder area. A white metal alloy finger ring and a celluloid or Bakelite finger ring were recovered near the right femur, and due to this position they were likely worn on the right hand. A single silver plated cuprous finger ring was found on a phalanx in the torso region, but it is unclear on which hand this ring was worn.

Other Artifacts: None observed

Burial Position/Taphonomy: The skeletal remains were well preserved, with most of the long bones intact. The individual was supine, in an extended position with the head to the west. It is fairly obvious that the right arm was extended down the right side due to the placement of carpals and finger rings recovered during excavation. Despite a ring found on a single phalanx, just above the pelvis it is not possible to accurately determine whether a hand was placed in this area. The cranium was very fragmentary, therefore, the face position was indeterminate.

Skeletal Preservation: Good

Sex: Female

Age: $30-40$ years

Biological Affinity: Possible African American

Skeletal Inventory: Mostly complete calvarium; L and R zygomatics; L and R maxilla around nasal aperture; mandible incomplete on $\mathrm{R}$ side; $\mathrm{L}$ and $\mathrm{R}$ clavicles; $\mathrm{L}$ and $\mathrm{R}$ glenoid fossae and scapula body fragments; $\mathrm{R}$ first rib; 47+ rib fragments; atlas; axis; most of the cervical, thoracic, and lumbar vertebrae; fragmented sacrum; L ilium, ischium, acetabulum, and auricular surface; $\mathrm{R}$ ilium, ischium, and acetabulum; $\mathrm{L}$ and $\mathrm{R}$ humeri, radii, and ulnae; $\mathrm{L}$ scaphoid, $\mathrm{R}$ triquetral, unsided lunate; L MC II and III; R MC II, III, and IV; unsided MC I; 15 manual phalanges; L and R femur; distal femur epiphysis fragments; $L$ and $R$ patellae; $L$ and $R$ tibia; $L$ and $R$ fibula; unsided proximal fibula epiphysis; L talus fragment; L intermediate cuneiform; R lateral cuneiform; L MT I, III or IV, and V; R MT III and IV; 4 pedal phalanges; $7.6 \mathrm{~g}$, ca. $4 \mathrm{~cm}^{3}$, of hardened, dense, lightweight, unidentified material from the region of the skull. It is black and homogenous in texture, with a convoluted and fissured surface. Histological examination revealed occasional fungal elements, but no preserved tissue.

Degenerative Pathology: Sporadic, minor osteophytic lipping throughout the vertebral column and on the R glenoid fossa and R proximal ulna. Eburnation on the trapezoid 
facet of the $\mathrm{R}$ scaphoid and the lateral or medial side of the volar distal articular surface of an unsided proximal fourth phalanx. Schmorl's nodes in the thoracic spine and a partially remodeled cortical and trabecular defect in a posterior lumbar centrum that likely resulted from posterior disc herniation or cyst formation.

Enthesopathy: None observed. Major muscle insertions are gracile, though flexor ridges of manual phalanges are marked.

Skeletal Anomalies: Moderate bony spicule formation on the neural arches of thoracic and lumbar column, located at the midline of the neural arch superiorly and between the inferior facets. There is also spicule formation not associated with DJD adjacent to some inferior facets in the lumbar region. These are in the distributions of the ligamentum flavum and the facet capsular ligaments, and suggest partial ossification of these ligaments, which may be associated with degenerative disease in the vertebral column, DISH, ankylosing spondylitis, or metabolic disease, though a genetic component may be present (Okuda et al. 2004; Pantazis et al. 1998; Santiago et al. 1997).

Dental Inventory: $\mathrm{L}\left(\mathrm{R}\right.$ ?) $\mathrm{P}^{1}$ or $\mathrm{P}^{2} ; \mathrm{RM}^{3} ; \mathrm{RM}_{3}$; unidentified mandibular molar root

Dental Pathology:

- Left $\mathrm{I}^{1}, \mathrm{I}^{2}, \mathrm{C}^{\mathrm{x}}$ and Right $\mathrm{I}^{1}, \mathrm{I}^{2}, \mathrm{C}^{\mathrm{x}}, \mathrm{P}^{1}$ were lost antemortem, as were the entire left mandibular dentition and Right $\mathrm{I}_{1}, \mathrm{I}_{2}, \mathrm{C}_{\mathrm{x}}$, and $\mathrm{M}_{2}$. All other missing teeth could not be assessed for time of loss.

- Minor to moderate dental wear/dentine on $\mathrm{LP}^{1}$, which also has hypercementosis at root tip.

- There are multiple confluent carious lesions on the $\mathrm{RM}_{3}$ that have significantly eroded its occlusal surface, which is polished. The adjacent buccal surface of the crown is also polished. $\mathrm{RM}^{3}$ has an occlusal surface carious lesion that has obliterated most of the crown and the dentin core. The lingual wall of the crown is entirely missing due to this, and the superior part of the root is worn flat on its side and polished. This area appears to approximate with the polished buccal surface of the $\mathrm{RM}_{3}$.

\section{Burial 16}

Burial Discovery, Excavation, and Reinterment: Burial 16 was found in October 2008 by PAI archeologists and excavated in January 2009 by PAI archeologists. These remains were reinterred in Pioneer Cemetery on September 12, 2012.

Burial Shaft Size and Depth: The dimensions of the burial shaft could not be determined, but the casket was first encountered at $19.69 \mathrm{ft}$ above sea level and the base of the casket was recorded at $18.81 \mathrm{ft}$ above sea level. The top of Burial 16 was found at $158 \mathrm{~cm}$ ( $5.2 \mathrm{ft}$ ) below the ground surface in the east borrow ditch of SH 332 .

Burial Orientation: E-W; head to west

Coffin / Casket Description: Several planks of wood located just above the rectangular casket likely represent a grave arch that covered the casket, which measured 
$175 \times 60 \mathrm{~cm}(68.9 \times 23.6$ inches). Measurements taken indicate a gradual narrowing of the casket toward the feet, but this apparent tapering may be due to the melding and admixture of the casket wood with the outer box. The tapering is slight enough (only about 2 inches) that this is not likely to have been a tapered coffin. One sample of casket wood and one sample of grave arch wood were identified as southern yellow pine (see Appendix D).

Coffin / Casket Hardware: 4 double lug swing bar casket handle sets, 5 escutcheon and thumbscrew sets, 53 machine-cut nails, 1 screw

Personal Items: Two identical white prosser buttons were recovered from the torso region, along with a safety pin. They were likely shirt buttons. A single celluloid/ Bakelite hairpin was recovered near the left foot.

Other Artifacts: None observed

Burial Position/Taphonomy: The individual was supine, in an extended position with the head to the west. It appears the arms were folded across the chest, but it was indeterminate as to where the hands were positioned. The head looks to have rotated upward, leaving the face positioned toward the west/northwest.

Skeletal Preservation: Fair

Sex: Female

Age: $35-45$ years

\section{Biological Affinity: Indeterminate}

Skeletal Inventory: Mostly complete calvarium; L and R zygomatics; L and R maxilla around alveolar region; mandible (condyles missing); $\mathrm{L}$ and $\mathrm{R}$ clavicles; $\mathrm{R}$ glenoid fossa; $L$ and $R$ scapula body fragments; $L$ first rib; 40+ ribs and rib fragments; atlas; axis; most of the cervical, thoracic, and lumbar vertebral column; fragments of the sacrum; L ilium, acetabulum, and auricular surface; R ilium, ischium, acetabulum, and auricular surface; $\mathrm{L}$ and $\mathrm{R}$ humeri, radii, ulnae; $\mathrm{L}$ capitate, scaphoid, lunate, trapezoid, hamate; $\mathrm{R}$ capitate, scaphoid, lunate, trapezoid, trapezium; L and $\mathrm{R}$ MC I, II, and III; 3 unidentified metacarpal shafts; 13 manual phalanges; L and R femora, tibiae, and fibulae; $L$ and $R$ patellae; $L$ and $R$ talus; $L$ calcaneus (anterior and posterior talar facets); L intermediate cuneiform and navicular; $R$ intermediate and medial cuneiforms, navicular, and cuboid; L and R MT I, II, III, and V; 2 unidentified tarsals (likely lateral cuneiforms); 2 pedal phalanges.

Infection / Inflammation: Fusiform expansion of anterior medial compartment of $\mathrm{R}$ tibia beginning at approximately midshaft and extending superiorly for ca. $12 \mathrm{~cm}$, where it has been cut off by a bone break. Compact, well-remodeled bone with no loss of medullary space.

Degenerative Pathology: Mainly minor to moderate osteophyte formation along the centra margins of C4-C6 and several thoracic centra, and on two lumbar facets. Schmorl's node on $\mathrm{C} 4$.

Enthesopathy: None observed. Muscle insertions of average robusticity. 
Dental Inventory: Left $\mathrm{I}^{1}-\mathrm{M}^{3}$; Right $\mathrm{I}^{1}-\mathrm{M}^{1}$; Left $\mathrm{I}_{1}-\mathrm{P}_{2}, \mathrm{M}_{2}, \mathrm{M}_{3}$; Right $\mathrm{I}_{1}-\mathrm{P}_{2}, \mathrm{M}_{2}$

Dental Pathology:

- Crowded anterior dentition.

- $\mathrm{LM}_{1}, \mathrm{RM}_{1}$, and $\mathrm{RM}_{3}$ were lost antemortem. The remaining missing teeth could not be similarly assessed.

- Minor to moderate wear except in the mandibular incisors, which show more extensive dentine exposure.

- Interproximal carious lesions on $\mathrm{R}^{1}$ and $\mathrm{I}^{2}$ and interproximal and occlusal surface carious lesions on $\mathrm{RM}_{2}$ leading to obliteration of one cusp. This last tooth is less worn than its antimere and the person may have avoided using it due to pain. Minor calculus formation on $\mathrm{LM}^{3}, \mathrm{RM}^{1}, \mathrm{RP}_{2}$, and $\mathrm{RM}_{2}$.

- Alveolar bone recession in the anterior and premolar regions of the maxilla.

- Chipping of anterior occlusal enamel of $\mathrm{L} \mathrm{I}^{1}$ and $\mathrm{L} \mathrm{I}_{2}$

- Linear enamel hypoplasias in the following teeth (count in parentheses): $\mathrm{L}$ and $R I_{1}$ (2 each), L (2) and $R I_{2}$ (1), L and R C (2 each), $L_{3} M_{3}$ (1), and $R M_{2}$ (1).

\section{Burial 17}

Burial Discovery, Excavation, and Reinterment: Burial 17 was found in October 2008 by PAI archeologists and excavated in January 2009 by PAI archeologists. These remains were reinterred in Pioneer Cemetery on September 12, 2012.

Burial Shaft Size and Depth: The dimensions of the burial shaft could not be determined, but the top of the coffin was measured at $19.66 \mathrm{ft}$ above sea level, with the base of the excavations ending at $19 \mathrm{ft}$ above sea level. The top of Burial 17 was found at $192 \mathrm{~cm}(6.3 \mathrm{ft})$ below the ground surface in the east borrow ditch of SH 332 .

Burial Orientation: E-W; head to west

Coffin/Casket Description: A rectangular wooden casket with a glass-viewing window was present within a rectangular wooden box. The outer box measured $134 \times 50 \mathrm{~cm}$ long (52.3x19.7 inches). The casket measured $130 \times 42 \mathrm{~cm}(51.2 \times 16.5$ inches). A teardrop-shaped glass viewing window that was part of the original casket lid was rotated out of place. The glass measured $45.7 \mathrm{~cm}$ long (18 inches) by 21.6 (8.5 inches) $\mathrm{cm}$ at its widest point. One sample of casket wood was identified as southern yellow pine (see Appendix D).

Coffin/Casket Hardware: 4 swing bail casket handles (2 different types), 1 white metal coffin screw, 73 machine-cut nails

Personal Items: Three identical white prosser buttons were recovered; two were found near the head and one was found in the torso region. Additionally, two very small white metal shoe buckles were found around the feet of the individual. These shoe buckles are a matching pair.

Other Artifacts: None observed 
Burial Position/Taphonomy: Because the remains were so poorly preserved, the position of the individual was indeterminate. The only certain observation is that the head was at the west end of the casket and the feet were at the east.

Skeletal Preservation: Poor

Sex: Indeterminate

Age: 15 months +/- 6 months

Biological Affinity: Indeterminate

Skeletal Inventory: Unidentified fragments of cranium, including $\mathrm{L}$ and $\mathrm{R}$ petrous portions of temporals; rib fragments; four neural arch halves; partial $\mathrm{R}$ auricular surface; unidentified long bone fragments

Pathology: Not observable

Dental Inventory: Left or Right $\mathrm{I}^{2}, \mathrm{C}^{\mathrm{x}} ;$ Left $^{1}$; Right $\mathrm{i}^{1}$-c $^{\mathrm{x}} ;$ Left $\mathrm{i}_{1}, \mathrm{c}_{\mathrm{x}}$; Right $\mathrm{i}_{1}, \mathrm{~m}_{1}$ Dental Pathology/Anomalies / Modifications: None observed

\section{DISCUSSION OF BURIAL CONTAINERS}

This section provides a brief summary of the wooden burial containers associated with the burials just described. As shown in Table 4.1, all of the burial containers had some type of plain (undecorated) iron hardware used in their construction. Machine-made cut (square) nails made up the bulk of the plain hardware. A few burials also had iron screws or tacks. The number of iron specimens may be quite misleading, however, because it is certain that a great many iron nails, screws, and tacks were simply too deteriorated to be recognized and recovered. In almost all of the burials, the small iron artifacts were highly corroded, and no attempt was made to measure or classify them.

Twelve of the 14 excavated burials had some type of decorative hardware. Jeremy Pye's analysis this hardware (including handles, escutcheons and thumbscrews, and ornamental screws and tacks) is presented in Chapter 5. Although the manufacturer and/or period of manufacture could be identified for several types of decorative hardware and for at least one of the personal items (i.e., a whiteware saucer with a maker's mark), the wooden burial containers from Pioneer Cemetery are less diagnostic but informative nonetheless. The types and styles of burial containers allow for general chronological inferences, but more importantly the burial containers encompass some social information regarding the late-nineteenth- and early-twentieth-century burial population.

All of the burials had a wooden container (a coffin or casket) associated and Table 4.2 summarizes all of the attributes for these containers, and Figure 4.1 illustrates the shapes of the common nineteenth-century burial receptacles. The primary wooden containers are all identified as coffins ( 1 tapered and 6 hexagonal) or rectangular caskets (7). Crow (2004:65) cites several sources indicating that hexagonal containers were the most common form of burial container prior to 1850. During the later half of the nineteenth century, rectangular forms increased 
in popularity, and by 1927 the hexagonal container was considered obsolete. The hexagonal coffin form was gradually phased out during the late nineteenth century, although they were still used more commonly during this period in rural areas Crow (2004:65). Because the coffin hardware indicates that most of these burials date to the late nineteenth century, the even mix of hexagonal coffins and rectangular caskets is not surprising since Brazoria was a small rural town.

The single example of a tapered coffin shape is Burial 1. Some researchers have suggested that tapered receptacles were a transitional form between hexagonal coffins and rectangular caskets, but Crow (2004:66-67) argues that this is not the case. He suggests that the tapered form, while certainly rare, appeared in the seventeenth century and was still used into the twentieth century.

Three of the 14 burials had evidence of a prepared grave arch with protective wood over the main container (Figure 4.2). In this case, a burial shaft was dug but the bottom portion ( 1 to $2 \mathrm{ft}$ ) was stepped inward with the coffin or casket set inside this smaller shaft. A series of wooden planks was then laid over the coffin or casket, with the planks resting on the earthen benches on either side of the smaller shaft. This formed a solid wood layer at the bottom of the larger shaft and immediately above the coffin or casket. Crow (2004:Figure 5) presents a good illustration of how a grave arch were constructed.

Six of the 14 burials had evidence of an outer box that enclosed the main container. These outer boxes are rough wooden containers that were just larger than the coffin or casket. Often times, these boxes were the shipping crates use to protect mass-produced burial containers during transport from the place of manufacture. Crow (2004:70) states that these rough outer containers were likely in use during the early nineteenth century, but they appear more frequently after 1850 . Crow (2004:70-71) also notes that shipping containers appear more commonly in urban cemeteries than in rural cemeteries, while the grave arches were more common in rural cemeteries in the late nineteenth century. This appears to reflect the more common use of mass-produced coffins and caskets in cities, while rural burials were more likely to contain locally made coffins or caskets. The mix of both burial styles in Pioneer Cemetery is consistent with a late nineteenth- and early-twentieth century burial dates as evidenced by the decorative hardware and personal items (see Chapters 5 and 6).

Given the deteriorated state of the wood, it was not possible to identify if the containers had any exterior paint or other decorative treatment. Wood samples were taken from the burial containers, and whenever possible a wood sample was obtained from the outer boxes or wooden planks of the grave arches. In some cases, multiple wood samples were taken from one coffin or casket to determine if two or more wood types were being used. The 2003 wood samples were examined by Dr. Phil Dering, and the 2009 wood samples were submitted to Dr. Leslie Bush for identification (see Appendix D). At least one wood sample from each of the 14 main burial containers was identified, and in all cases the coffins and caskets were made of pine. Wood samples taken from four of the six outer boxes were identified, and three of these were identified as pine. The fourth sample, from the outer box of 


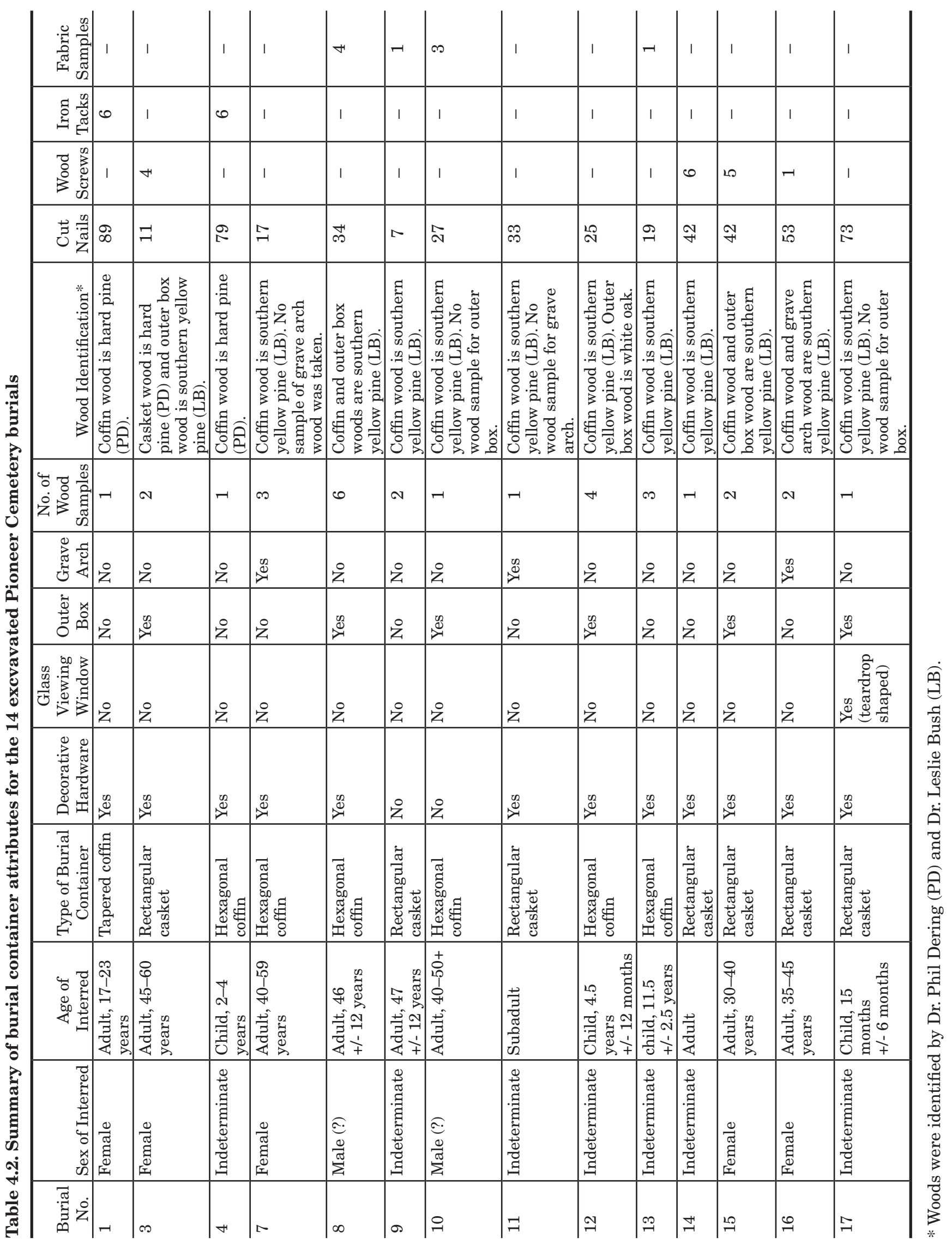



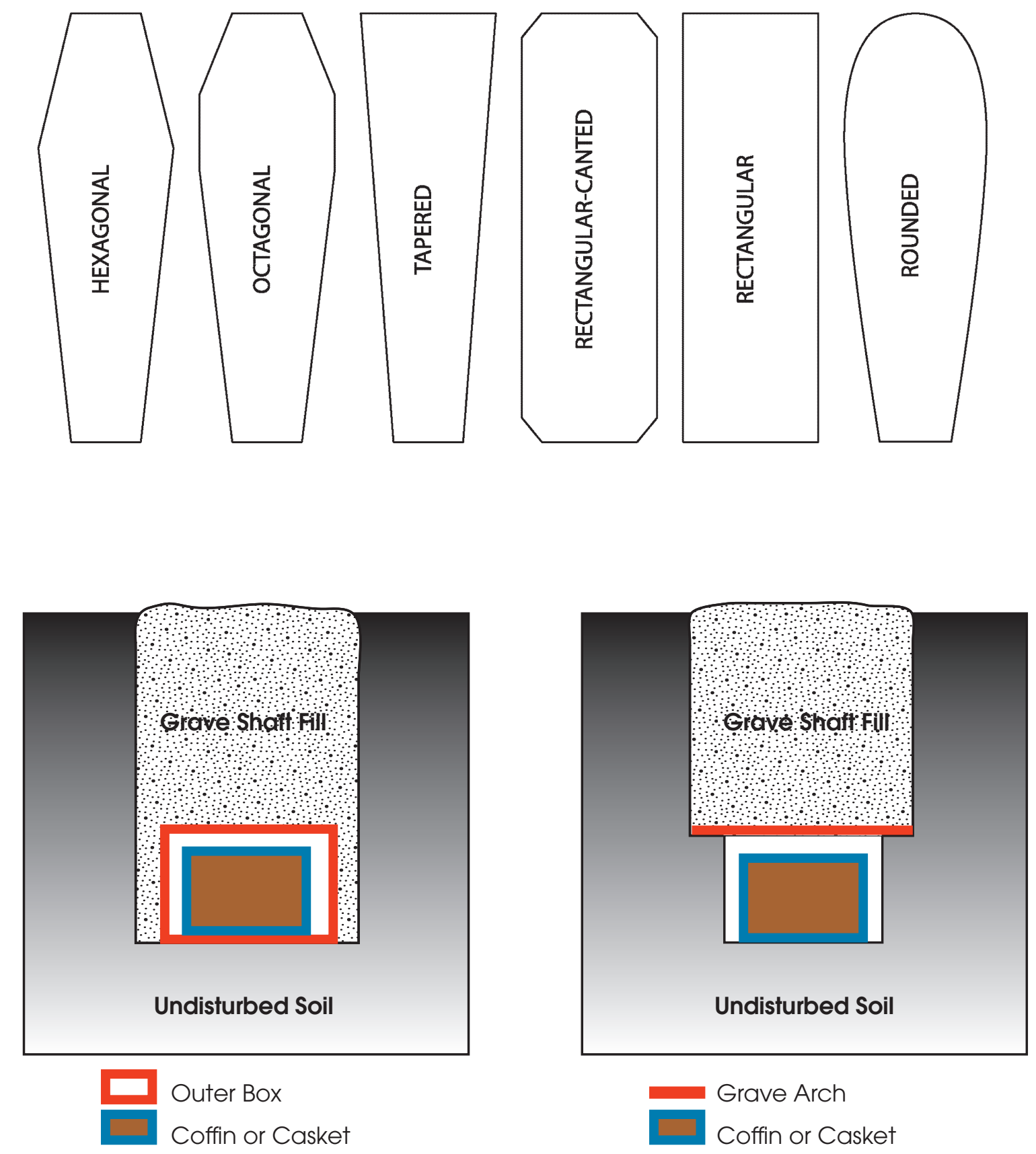

Figure 4.1. Shapes of common nineteenth-century burial receptacles (from Crow 2004:Figure 4) and schematic cross sections of outer boxes and grave arches (after Crow 2004:Figure 5).

Burial 12, was identified as white oak. Only one grave arch wood sample was taken. This wood, from the grave arch of Burial 16, was identified as pine.

Only one of the 14 excavated burials, Burial 17, had a glass viewing window (Figure 4.3). This teardrop shaped glass oval measured 18.0 inches long by 8.5 in wide and ranged in thickness from 0.10 to 0.13 inches. An attempt was made to date this glass using Moir's (1987) equation for dating the manufacture of window 

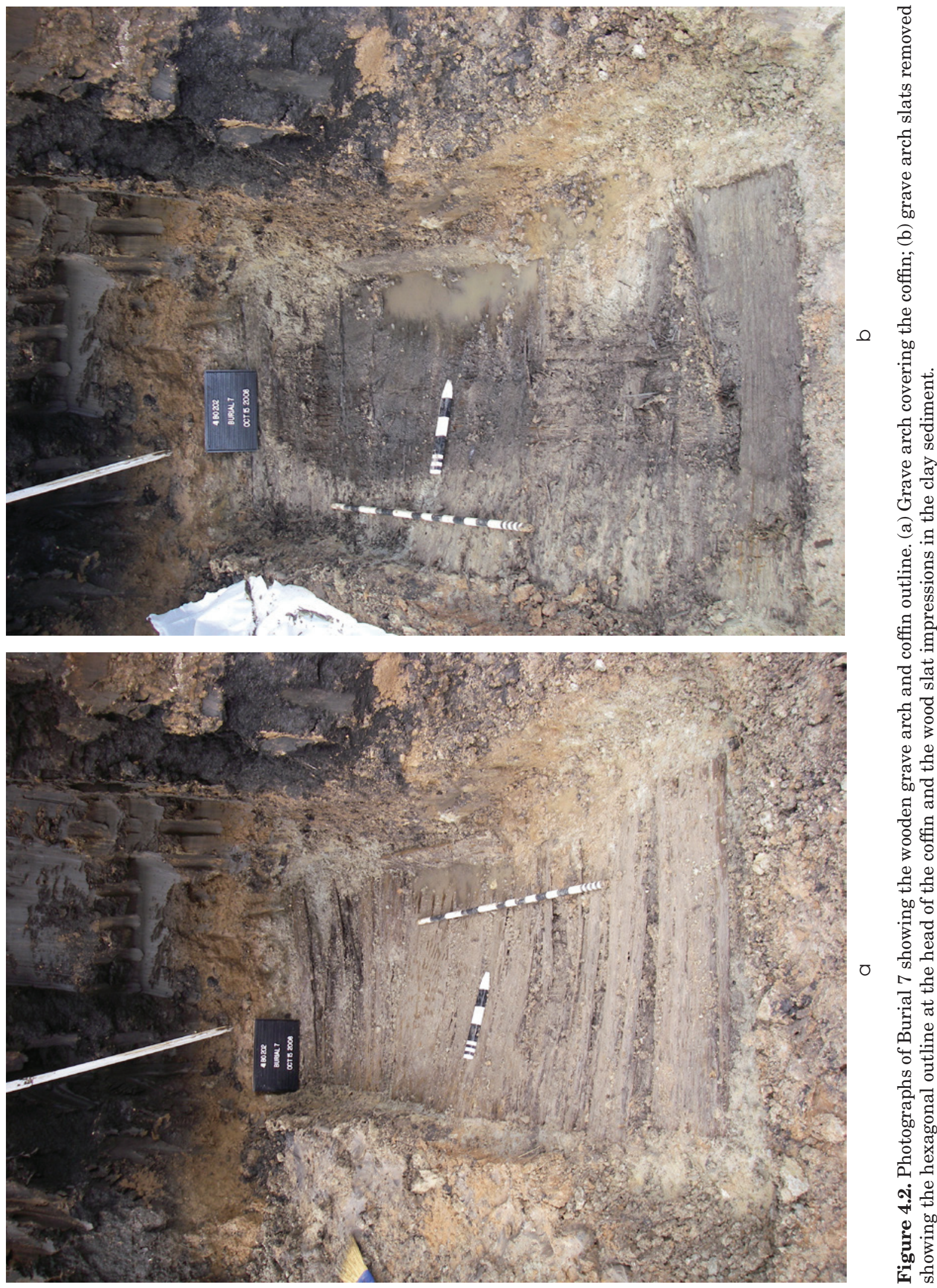
glass based on its thickness. This equation gives a date range for this window as 1926-1990, which is much later than the age estimate of late nineteenth century based on the casket hardware. Obviously, Moir's dating method does not work well in this instance, probably because the casket makers chose to use a thicker glass for the viewing window than was standard for structural window glass at the time. Pye (2007:140-146) discusses the many difficulties with dating viewing windows and notes that viewing glass was typically thicker than standard window glass. Viewing windows were often marketed in catalogs as single or double thickness. It is likely that the viewing glass in the Burial 17 casket was one of the heavier glasses available. One notable attribute of this viewing window is that it is rough cut, especially around the tighter curves at the top and the bottom. This indicates that this piece was cut from a larger plate of glass specifically to fit into the casket. Thus, it is likely that the Burial 17 casket and glass viewing window were made locally rather than being mass-produced.

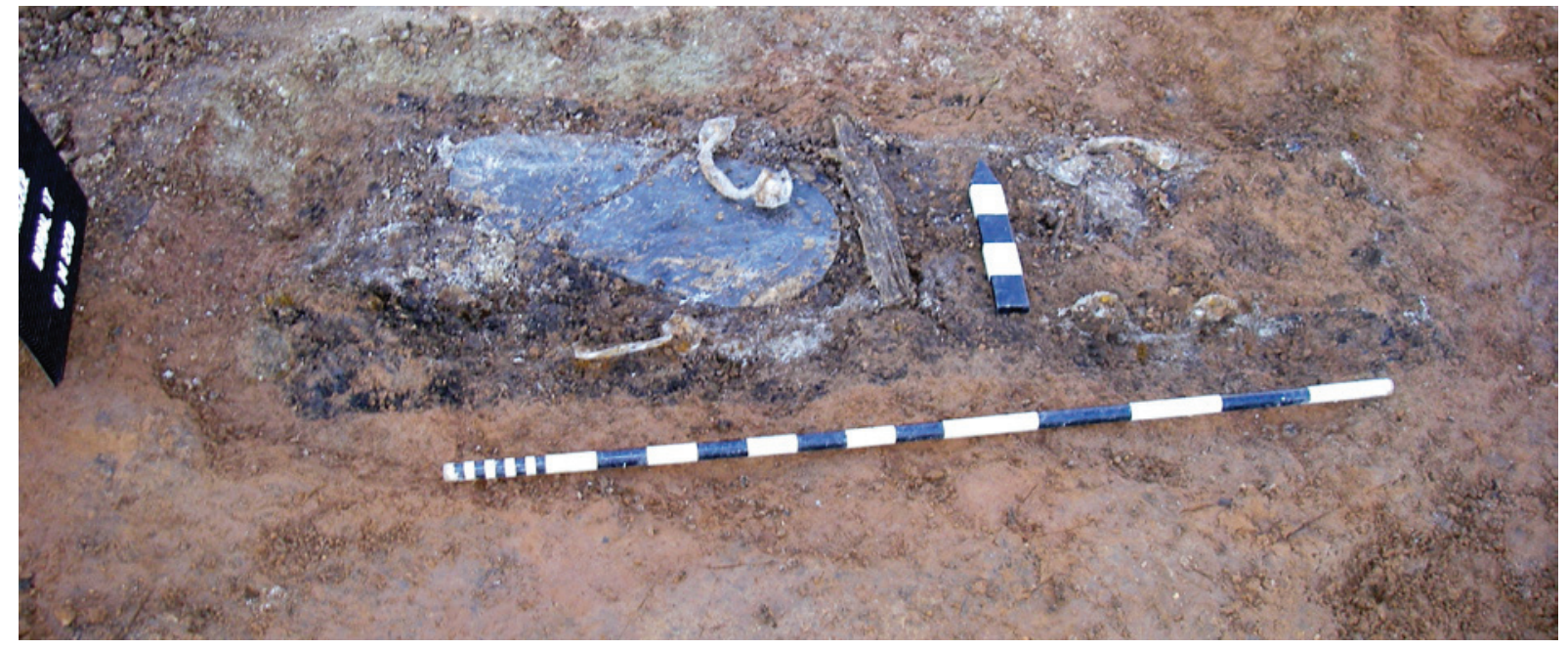

Figure 4.3. Photograph of Burial 17 showing the glass viewing window.

Fabric samples were taken from four of the burials and submitted to the Conservation Research Laboratory at Texas A\&M University (see Appendix E). These samples could represent coffin linings, but it is likely that most of them are from clothing worn by the deceased. Consequently, the fabric samples are discussed with the personal items in Chapter 6 and in Appendix E. 



\section{CHAPTER 5: ANALYSIS OF BURIAL CONTAINER HARDWARE}

Jeremy W. Pye

In February 2011, Prewitt and Associates, Inc. contracted with the author to analyze historic burial container hardware recovered from the 2008-2009 excavations at Pioneer Cemetery. Twelve of the 14 excavated burials contained some type of burial container hardware, consisting of four primary handle types, two sets of thumbscrews and escutcheons, three types of coffin screws, and four types of ornamental tacks. Through analysis and comparison of this hardware collection to United States patent records ( $\mathrm{n}=1,438)$, period manufacturers' trade catalogs $(\mathrm{n}=218)$, and archeological cemetery excavation literature $(\mathrm{n}=155)$, these 12 interments can be dated to sometime between 1853 and 1910 .

The analysis and historical study of burial container hardware is crucial in establishing a useful discourse between multiple lines of evidence recorded and recovered in historical cemetery investigations. Burial container hardware imbibes multiple social and aesthetic meanings. For some affluent members of society, ornate and expensive burial container hardware was used as a marker of social status (Burgess et al. 2007). Others used ornate hardware as a means of masking social realities and presenting the illusion of wealth (Little et al. 1992). Various types of hardware held religious and ideological symbolic value in the development of the outward expression of the Victorian Beautification of Death movement (Bell 1987, 1990). The nineteenth and early twentieth century perspectives viewed the ornamentation of the funeral and the coffin or casket as an extremely important part in the expression of sentiment and community re-structuring.

Burial container hardware holds great interpretive value for archeologists, and precise identification of types and styles of burial container hardware is vital in defining the chronology of a burial, particularly in the absence of dated grave markers. Moreover, variations in styles, hardware forms, and materials speak volumes about economic expenditure and therefore indirectly reflect aspects of socioeconomic class, status, and community involvement in the funeral process (Bell 1987, 1990; Davidson 1999, 2004; Little et al. 1992; Pye 2007). Nearly all of the archeological cemetery excavation reports reviewed for this project (see Appendix A) have used burial container hardware as a means to place undated burials within a temporal context. However, as Buchner (1999:28), Davidson (1999), and Mainfort and Davidson (2006) note, there are serious dangers and limitations in the uncritical application of past hardware analyses to newly excavated materials.

7 At the time Jeremy Pye conducted this analysis in 2011, he was an independent consultant and was working on his doctoral research on historic cemetery archeology at the University of Florida, Gainesville. As of 2015, Pye is a staff archeologist with Cultural Resource Analysts, Inc., in Shreveport, Louisiana. 
Prior to the work by Mainfort and Davidson (2006) and Davidson (1999), the most widely used "authoritative manuals" on dating coffin hardware were Hacker-Norton and Trinkley (1984) and Trinkley and Hacker-Norton (1984). These reports were among the first to employ period hardware catalogs to establish their chronologies. While this approach was innovative for the time, the numbers of hardware catalogs used for comparison were few. These works did succeed in illustrating one very important point-that various types of coffin hardware were stocked by stores throughout the country, and may have sat on the shelf for some time before being used. Therefore, just because one hardware type appears and then disappears from the hardware catalogs very early does not mean that it cannot be introduced into the archeological record at a later time period. Buchner (1999:28) equates this type of lag to the demonstration of local cultural sequences, which should be independently researched in each region independent of possibly inaccurate dates from other areas of the country. Because of the problem of lag time, coffin hardware may provide a maximum age for a burial (especially if a specific item has an associated patent date), but it cannot provide a reliable minimum age for a burial.

\section{METHODOLOGY}

This analysis was conducted using the methods established by Davidson (1999) for the classification of hardware from the Freedman's Cemetery project in Dallas, Texas. Essentially, a new type was designated whenever a different artifact form/style (or combination of elements) was encountered. Davidson (2006:120121) gives the example, "the first thumbscrew...was given the type designation Thumbscrew Type I....[I]f the next burial excavated contained a thumbscrew with an even slightly different design motif, [then] it was assigned a new type number (e.g., Thumbscrew Type 2).”

Following Davidson (1999, 2006:121), these artifacts were dated and contextualized through three lines of evidence: patent dates, dates derived from period hardware catalogs, and known dates of cemetery use. A fourth line of evidence-the estimated interment ranges of burials from previously excavated cemeteries - can be included, but it must be critically analyzed based on the previous lines of evidence.

\section{United States Patent Records: Utility Patents (1839-1907)}

There were 1,069 utility patents related to coffins, coffin hardware and other types of mortuary goods that dated between 1839 and 1907 on record at the United States Patent Office during primary research conducted by Davidson on the Freedman's Cemetery project. A full series of photocopies were made for comparison purposes and were available for examination during this analysis.

\section{United States Patent Records: Design Patents (1843-1907)}

There were 369 design patents related to coffins, coffin hardware and other

types of mortuary goods that dated between 1843 and 1907 on record at the United 
States Patent Office during primary research conducted by Davidson for this project. A full series of photocopies were made for comparison purposes and were available for examination during this analysis.

\section{Manufacturers' Trade Catalogs}

For this analysis, 218 mortuary hardware trade catalogs, dating between 1797 and 1965, were examined for comparative purposes (see Appendix B). These catalogs were either viewed at a number of different libraries and museums throughout the country or are in the collections of the author or James Davidson. Exact and similar matches to recovered hardware from the Pioneer Cemetery burial excavations are presented in the tables in this chapter.

\section{Previous Historic Cemetery/Burial Excavation Reports}

Also consulted were 155 reports of excavated historical period cemeteries (see Appendix A). In the following tables, when possible, identical matches to each hardware type are listed. In some instances, similar matches may be mentioned, and it should be noted that even though they are not listed, most pieces of hardware have contemporary similar forms. Care should be taken in future studies to identify exact stylistic matches and not matches of simple form similarity.

\section{HARDWARE DESCRIPTIONS AND TYPOLOGY}

No attempt is made here to describe the complete history and various iterations of all hardware classes. For more descriptive information about each hardware class, see Davidson (1999, 2004) and Mainfort and Davidson (2006). However, for general purposes, a brief contextual discussion of each hardware form found at Pioneer Cemetery will be presented followed by descriptive discussions of each hardware type as constructed within the current typology. The burial container hardware types associated with the Pioneer Cemetery burials and described in this chapter are summarized in Table 5.1.

\section{Burial Container Handles}

\section{Double-Lug, Swing-Bail Handles}

The double-lug, swing-bail handle is one variant of the general swing-bail form. It is comprised of three elements: two lugs, which are affixed via screws to the side of the coffin, and the bail, which forms the gripping portion of the handle. The bail is mounted into the lugs by the insertion of two metal pins (of iron or steel wire) at either end. Davidson $(1999,2004: 407)$ reports that swing-bail handles have been in production from the eighteenth into the twentieth century, when the short-bar and later the extended bar handles became more popular.

\section{HANDLE TYPE A}

Handle Type A (Figure 5.1a) is a double-lug, swing-bail handle represented by 11 total artifacts distributed between Burials 8, 11, and 17 at Pioneer Cemetery 


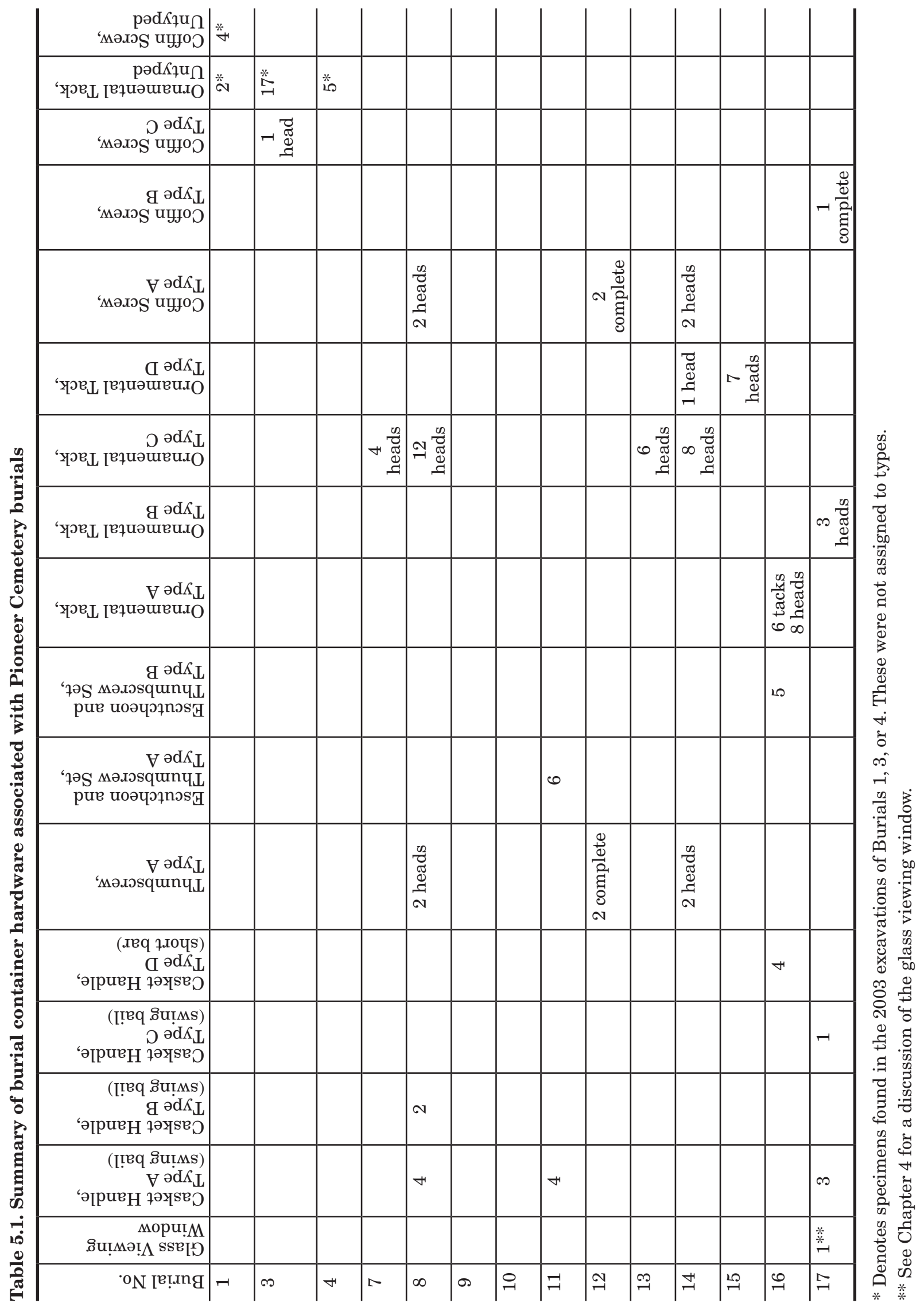




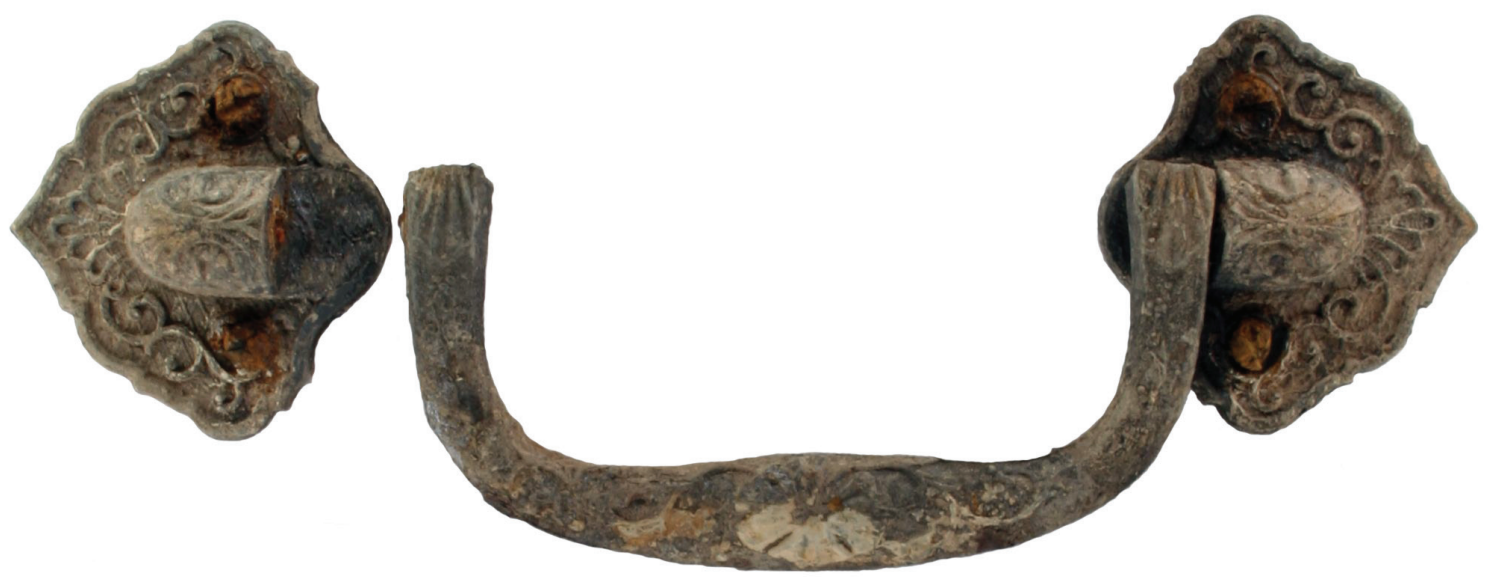

a

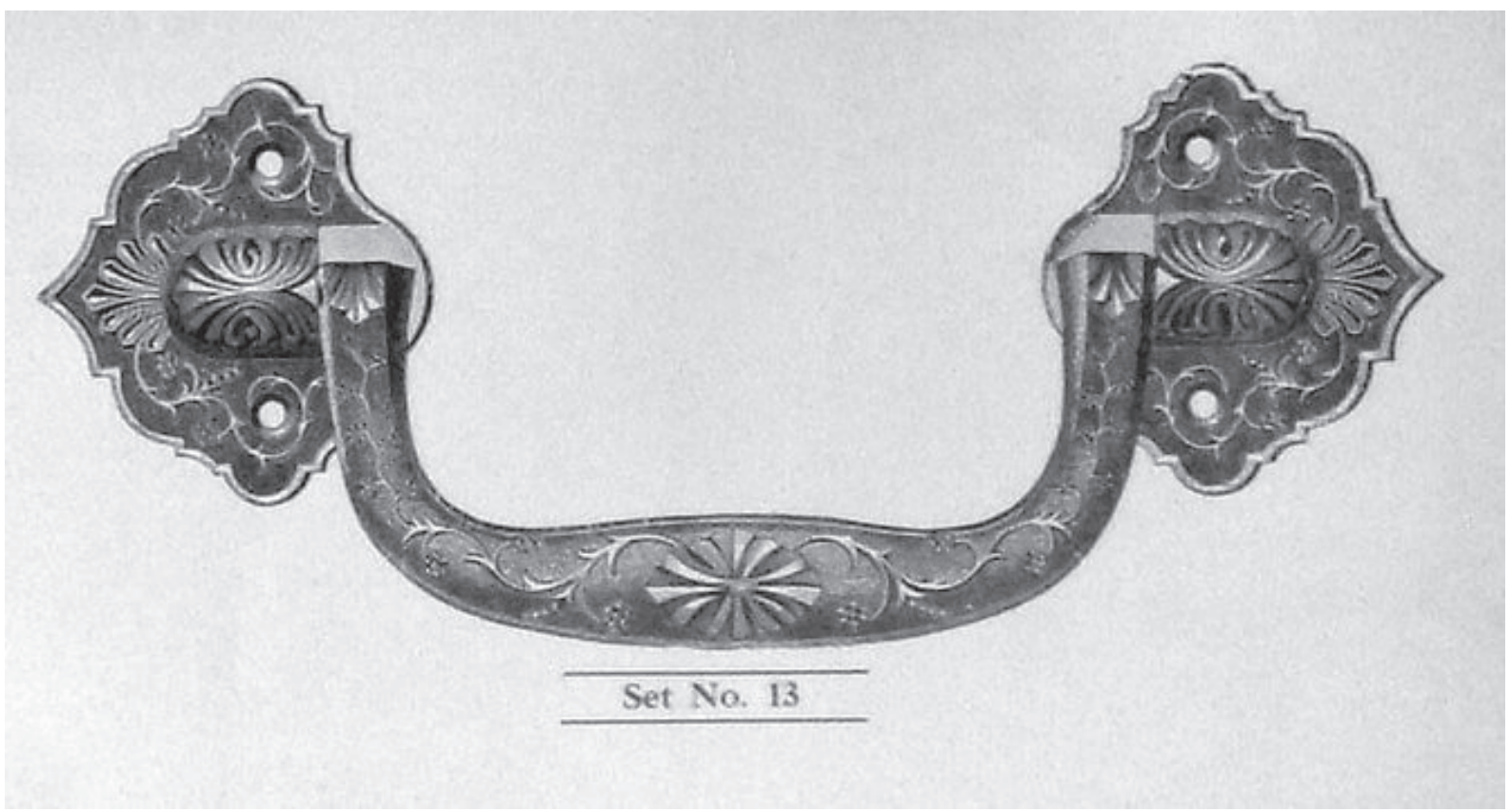

b

Figure 5.1. Handle Type A. (a) Specimen from Pioneer Cemetery; (b) illustration from page 114 in the circa 1904 Illustrated Catalog of Gate City Coffin Company.

(Table 5.2). These items were made of a high-quality, nonferrous white metal and were possibly silver plated. The handle consists of two decorative lugs with a floral design on the apex of the pin housing. A series of intricately woven vines and floral patterns appears on the lug face. The lug is roughly shaped like a shield with a sharp point on the outer terminus and gentle curved points and the three other sides reaching the widest point midway along the pin housing. The reverse face of many of the lugs contains the mold mark "1206." A central floral or sunburst disk appears on the middle front face of the bail. Within the central disc is another floral pattern similar to what appears on the pin housing. From this central disc extends a vine with numerous small floral blooms along the vine. The reverse of the bail is bare except for the central mold recess. 
Table 5.2. Description of Handle Type A

\begin{tabular}{|c|c|c|c|c|}
\hline Type No. & \multicolumn{4}{|c|}{ Handle Type A (Size Grades A.1 and A.2) } \\
\hline Form & \multicolumn{4}{|l|}{ Double-lug, swing-bail } \\
\hline Material & \multicolumn{4}{|c|}{ Nonferrous white metal (possibly silver-plated?) } \\
\hline \multirow[t]{3}{*}{ Burial(s) } & \multicolumn{4}{|l|}{ Burial $8(n=4$ A.1) } \\
\hline & \multicolumn{4}{|l|}{ Burial $11(\mathrm{n}=4$ A.2) } \\
\hline & \multicolumn{4}{|l|}{ Burial $17(\mathrm{n}=3$ A.2) } \\
\hline Internal Date & \multicolumn{4}{|l|}{ N/A } \\
\hline Weight & \multicolumn{4}{|l|}{$?$} \\
\hline Dimensions & \multicolumn{4}{|c|}{$\begin{array}{l}\text { A.1) Total handle width ( } 6.2 \text { inches }) \text {; total height ( } 2.81 \text { inches }) \text {; } \\
\text { A.2) Total handle width ( } 7.19 \text { inches); total height ( } 2.87 \text { inches }) \\
\end{array}$} \\
\hline Mold Markings & \multicolumn{4}{|l|}{ “1206” on lug of smaller size grade } \\
\hline Matches & Cemetery & No. of Burials & Dating & Citation \\
\hline 1 (possible) & Neal (Big Cove) Cemetery, AL & 3 & $1880-1920$ & Trudeau 2005:86, 102, 117 \\
\hline 2 (similar) & Howard Cemetery (39MN7), SD & 1 & $1850 \mathrm{~s}-1920 \mathrm{~s}$ & Boen and Taft 1999 \\
\hline 2 & Redfield Cemetery, GA & 1 & $1875-1930$ & Braley and Moffat 1995:63 \\
\hline 3 & Thurston Cemetery, IL & 1 & $1848-1900$ & $\begin{array}{l}\text { Bird et al. 2003:Appendix } \\
\text { G:16 }\end{array}$ \\
\hline $4(\mathrm{~A} .2)$ & Venable Lane Cemetery, VA & 1 & post 1870 & Grey et al. 1993:15 \\
\hline $5(\mathrm{~A} .1)$ & $\begin{array}{l}\text { Third New City Cemetery, TX, } \\
\text { Type } 6\end{array}$ & 1 & 1879-1895 & $\begin{array}{l}\text { Foster and Nance 2002: } \\
\text { F-138 }\end{array}$ \\
\hline 6 (A.2) & $\begin{array}{l}\text { Third New City Cemetery, TX, } \\
\text { Type Type } 20\end{array}$ & 9 & 1879-1905 & $\begin{array}{l}\text { Foster and Nance 2002: } \\
\text { F-153 }\end{array}$ \\
\hline 7 (A.1) & $\begin{array}{l}\text { Freedman's Cemetery, TX, } \\
\text { Handle Type } 44\end{array}$ & 5 & $1885-1899$ & Davidson 1999:301 \\
\hline $8(\mathrm{~A} .2)$ & $\begin{array}{l}\text { Freedman's Cemetery, TX, } \\
\text { Handle Type } 75\end{array}$ & 23 & $1885-1899$ & Davidson 1999:301 \\
\hline Matches & Catalogue & Page (Item No.) & Dating & Source \\
\hline 1 (A.1) & Zanesville Coffin Co. & 7 (No. 25) & circa 1880 & Library of Congress \\
\hline $2(\mathrm{~A} .2)$ & Zanesville Coffin Co. & 7 (No. 26) & circa 1880 & Library of Congress \\
\hline $3(\mathrm{~A} .1)$ & Stolts, Russell \& Co. & 6 (No. 621) & 1880 & $\begin{array}{l}\text { Strong National Museum } \\
\text { of Play }\end{array}$ \\
\hline $4(\mathrm{~A} .2)$ & Stolts, Russell \& Co. & 6 (No. 121) & 1880 & $\begin{array}{l}\text { Strong National Museum } \\
\text { of Play }\end{array}$ \\
\hline $5(\mathrm{~A} .1)$ & Harrisburg Burial Case Co. & 17 (No. 1206) & circa 1885 & Hagley Museum, DE \\
\hline $6(\mathrm{~A} .2)$ & Harrisburg Burial Case Co. & 17 (No. 1210) & circa 1885 & Hagley Museum, DE \\
\hline 7 & Gate City Coffin Co. & $114($ Set No. 13) & circa 1904 & Davidson Collection \\
\hline
\end{tabular}

*Note: There are no known design patent matches.

No design patents were located for this handle type, though this style appears in four known merchandise catalogs dating between 1880 and 1904 (Figure 5.1b; see Table 5.2). It is typically offered in three sizes as shown in the 1885 illustrated catalog of the Harrisburg Burial Case Company (Figure 5.2). Two of these size grades, the medium and larger varieties, are present in the Pioneer Cemetery sample; they have been labeled Handle Type A.1 and A.2. Size grades would have varied in price, though no prices were located for this handle type.

Handles of similar styles have been recorded in seven archeological cemetery excavations from Alabama, Georgia, Illinois, South Dakota, and Texas. Cemeteries reporting matching styles have population date ranges from the 1850 s to the $1930 \mathrm{~s}$. 


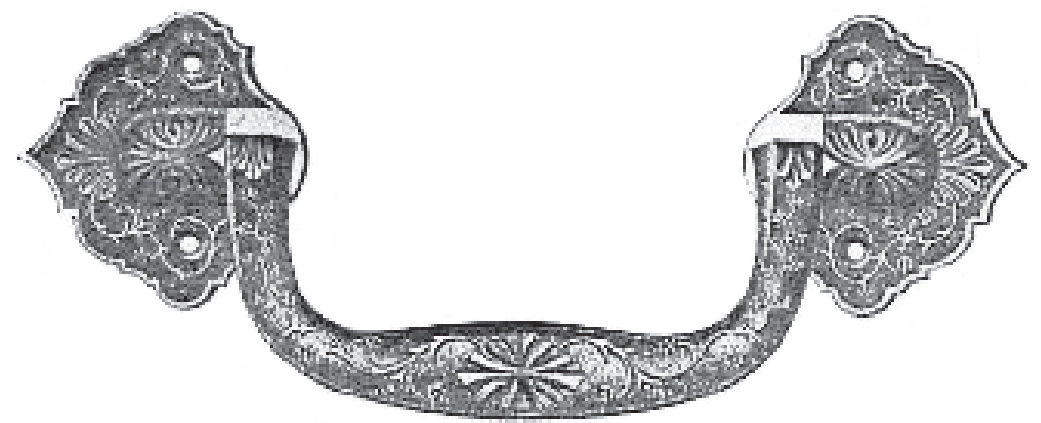

No. 1204
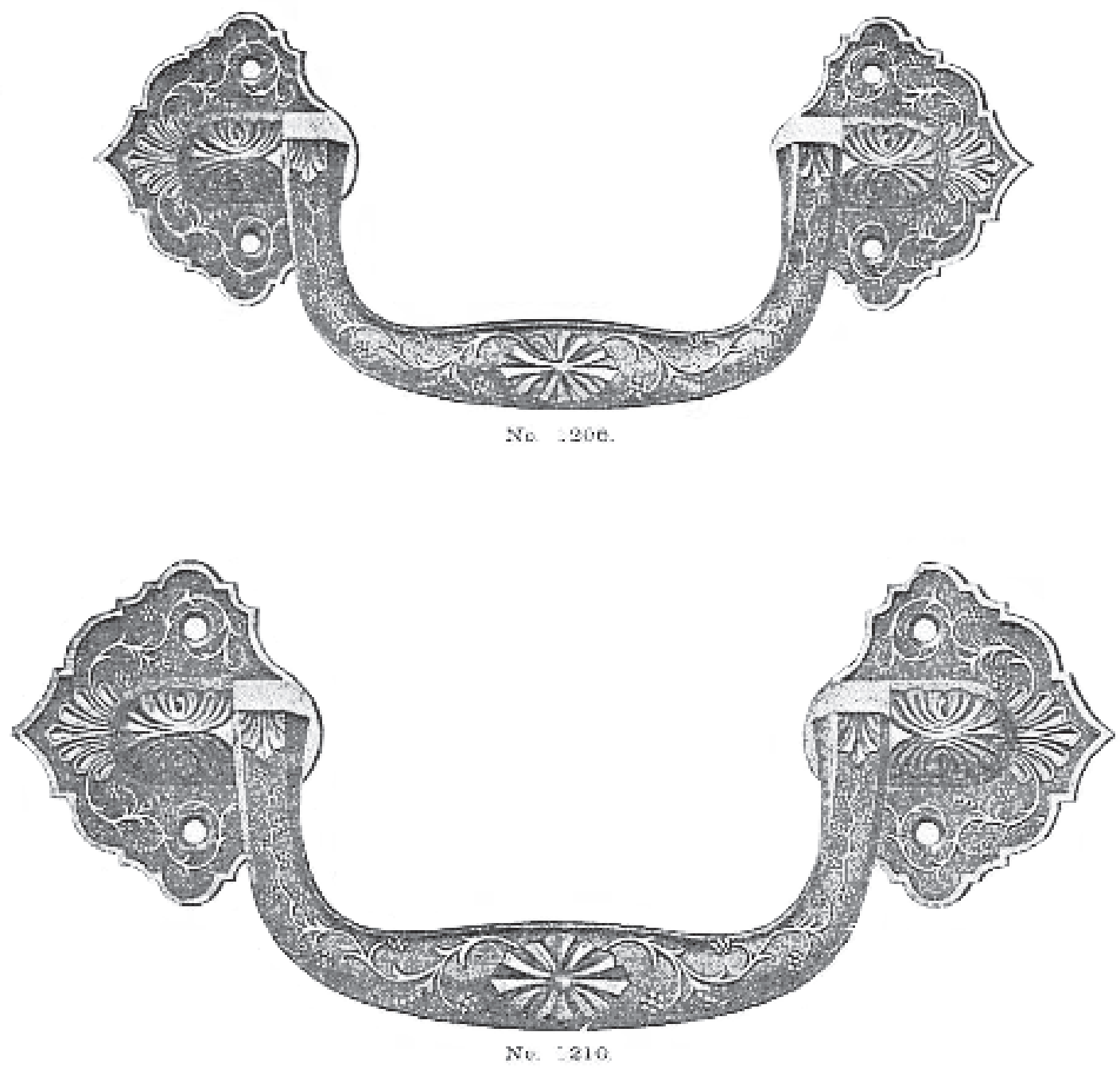

Figure 5.2. Handle Type A size grades as illustrated on page 17 in the circa 1885 Illustrated Catalog of Harrisburg Burial Case Company. 
This date range is very broad, however; it is more likely that this handle was on the market sometime between the 1870s and early 1900s.

\section{HANDLE TYPE B}

Handle Type B (Figure 5.3a) consists of double-lug, swing-bail handles represented by only two artifacts from Burial 8 at Pioneer Cemetery (Table 5.3). These items were made of a nonferrous white metal and were likely silver plated. The mold number " 1200 " is evident on the reverse faces of the lugs. The bail is smooth, while the lugs are decorated with floral and vine motifs accenting small oval elements at the terminal arcs of the lugs. This exact bail and lug combination appears as a "silver-plated" coffin handle in the 1869 James M. Shanahan illustrated catalog (Figure 5.3b).

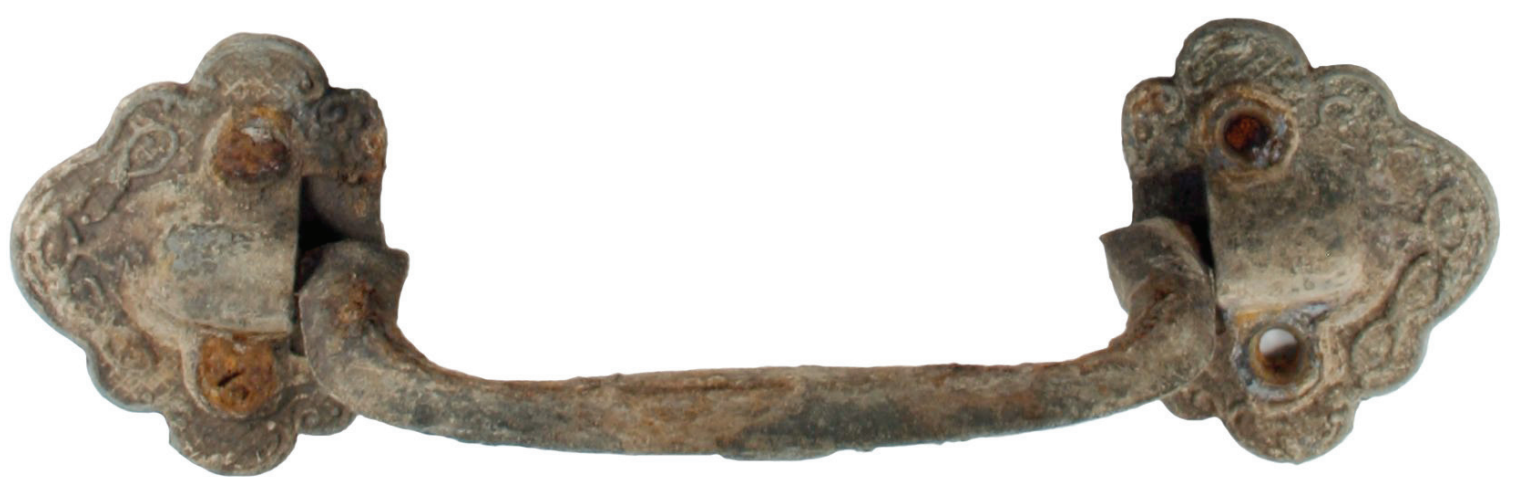

a

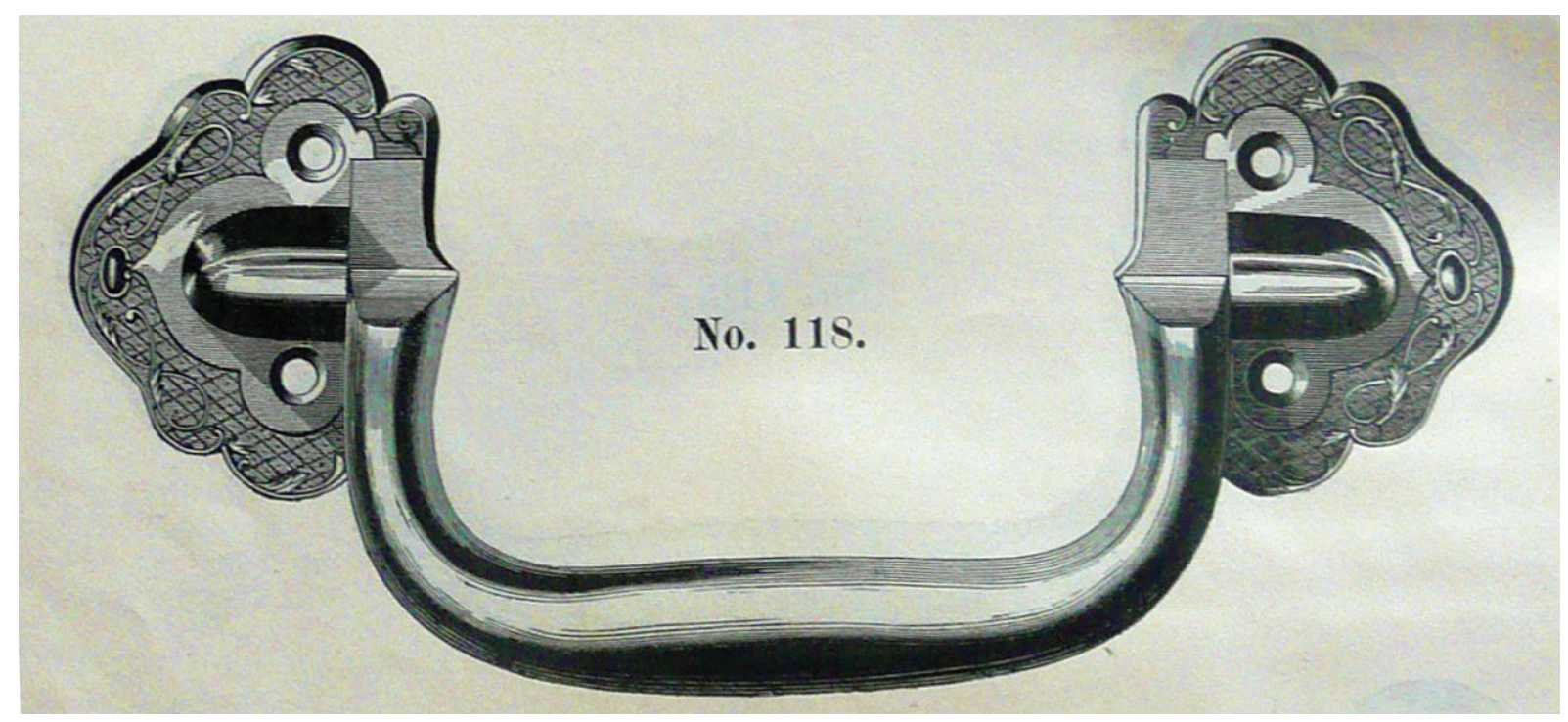

b

Figure 5.3. Handle Type B. (a) Specimen from Burial 8 at Pioneer Cemetery; (b) illustration from page 4 in the circa 1869 Illustrated Catalog of the Firm of James M. Shanahan. 
Table 5.3. Description of Handle Type B

\begin{tabular}{|c|c|c|c|c|}
\hline Type No. & \multicolumn{4}{|l|}{ Handle Type B } \\
\hline Form & \multicolumn{4}{|l|}{ Double-lug, swing-bail } \\
\hline Material & \multicolumn{4}{|c|}{ Nonferrous white metal (possibly silverplated?) } \\
\hline $\operatorname{Burial}(\mathrm{s})$ & \multicolumn{4}{|l|}{ Burial $8(\mathrm{n}=2)$} \\
\hline Internal Date & \multicolumn{4}{|l|}{ N/A } \\
\hline Weight & \multicolumn{4}{|l|}{$?$} \\
\hline Dimensions & \multicolumn{4}{|c|}{ Total handle width (7.26 inches); total height (3.22 inches) } \\
\hline Mold Markings & \multicolumn{4}{|l|}{ "1200" on lug } \\
\hline Matches & Cemetery & No. of Burials & Dating & Citation \\
\hline 1 (similar lug) & Grafton Cemetery, IL & 1 & $1834-1873$ & Buikstra et al. 2000:66 \\
\hline 2 (similar lug) & $\begin{array}{l}\text { Quaker Burying Ground, VA, } \\
\text { Type D }\end{array}$ & 1 & $1784-1890 \mathrm{~s}$ & $\begin{array}{l}\text { Bromberg et al. } 2000 \text { : } \\
\text { Figure } 87\end{array}$ \\
\hline 3 (similar lug) & Nancy Creek Cemetery, GA & 1 & 1884 & Garrow et al. 1985:19 \\
\hline 4 (similar lug) & $\begin{array}{l}\text { Freedman's Cemetery, TX, } \\
\text { Handle Type } 134 \\
\end{array}$ & 1 & $1885-1899$ & Davidson 2004:512 \\
\hline 5 (similar lug) & $\begin{array}{l}\text { Elmbank Cemetery, Ontario, } \\
\text { Canada }\end{array}$ & 3 & $1832-1933$ & Lipovitch et al. 2003 \\
\hline 6 & Alameda-Stone Cemetery, AZ & 2 & $1860-1882$ & $\begin{array}{l}\text { Heilen and Gray 2010; } \\
\text { Pye 2010a }\end{array}$ \\
\hline 7 & Williams Green Cemetery, VA & 1 & circa $1800-1880$ & $\begin{array}{l}\text { Ezell and Huston } \\
\text { 2006a:174 }\end{array}$ \\
\hline Matches & Catalogue & Page (Item No.) & Dating & Source \\
\hline 1 (similar lug) & $\begin{array}{l}\begin{array}{l}\text { Sargent \& Co. }(\$ 7.00 \text { per dozen } \\
\text { pairs })\end{array} \\
\end{array}$ & 119 (No. 1200) & 1866 & Library of Congress \\
\hline 2 & $\begin{array}{l}\begin{array}{l}\text { Sargent \& Co. }(\$ 7.50 \text { per dozen } \\
\text { pairs })\end{array} \\
\end{array}$ & 119 (No. 1411) & 1866 & Library of Congress \\
\hline 3 & James M. Shanahan & 4 (No. 121) & circa 1869 & \begin{tabular}{|l|} 
Smithsonian \\
Institution \\
\end{tabular} \\
\hline 4 (similar lug) & $\begin{array}{l}\begin{array}{l}\text { Sargent \& Co. }(\$ 6.00 \text { per dozen } \\
\text { pairs })\end{array} \\
\end{array}$ & 274 (No. 1200) & 1871 & Library of Congress \\
\hline 5 & $\begin{array}{l}\begin{array}{l}\text { Sargent \& Co. }(\$ 7.50 \text { per dozen } \\
\text { pairs })\end{array} \\
\end{array}$ & 274 (No. 1411) & 1871 & Library of Congress \\
\hline 6 & $\begin{array}{l}\text { Sargent \& Co. }(\$ 8.40 \text { per dozen } \\
\text { pairs })\end{array}$ & 416 (No. 1411) & 1874 & Library of Congress \\
\hline 7 & J.L. Wayne \& Sons & 17 (No. 644) & 1874 & Ohio Historical Society \\
\hline 8 (similar lug) & Cincinnati Coffin Co. & 4 (No. 1200) & 1877 & \begin{tabular}{|l|} 
Smithsonian \\
Institution \\
\end{tabular} \\
\hline 9 (similar) & Crane, Breed, and Co. & 38 (No. 51) & 1877 & $\begin{array}{l}\text { Smithsonian } \\
\text { Institution }\end{array}$ \\
\hline 10 (similar) & C. Sidney Norris & 32 (No. 69) & circa 1880 & $\begin{array}{l}\text { University of Delaware } \\
\text { Libraries }\end{array}$ \\
\hline 11 (similar) & \begin{tabular}{|l|} 
C. Sidney Norris [Price List] \\
$(\$ 4.25$ per dozen pairs $)$ \\
\end{tabular} & 4 (No. 69) & circa 1880 & $\begin{array}{l}\text { University of Delaware } \\
\text { Libraries }\end{array}$ \\
\hline 12 (similar) & Harrisburg Burial Case Co. & 17 (No. 1411) & circa 1885 & Hagley Museum, DE \\
\hline 13 (similar lug) & W.B. Belknap \& Co. & 968 (No. 116) & 1895 & Davidson Collection \\
\hline 14 (similar lug) & W.B. Belknap \& Co. & 1090 (No. 116) & 1901 & Library of Congress \\
\hline
\end{tabular}

Note: There are no known design patent matches.

Just as with Handle Type A, this style of handle came in three size grades as shown in the 1885 illustrated catalog of the Harrisburg Burial Case Company (Figure 5.4). The two handles found at Pioneer Cemetery represent the larger of the 
three size variants. Five exact bail/lug combination matches were encountered in the period catalogs. There are four additional similar matches where it is unclear whether small differences in stylistic elements reflect real differences in style or minor differences in illustration. Finally, there are five cases where lug matches were found. It is noteworthy that the lugs from Pioneer Cemetery have the mold mark "1200," though this lug is officially associated with the bail of a similar style, and not the plain bail. This highlights the fact that lugs and bails were interchangeable and could be mixed and matched. The 14 total mortuary catalogs in which this handle
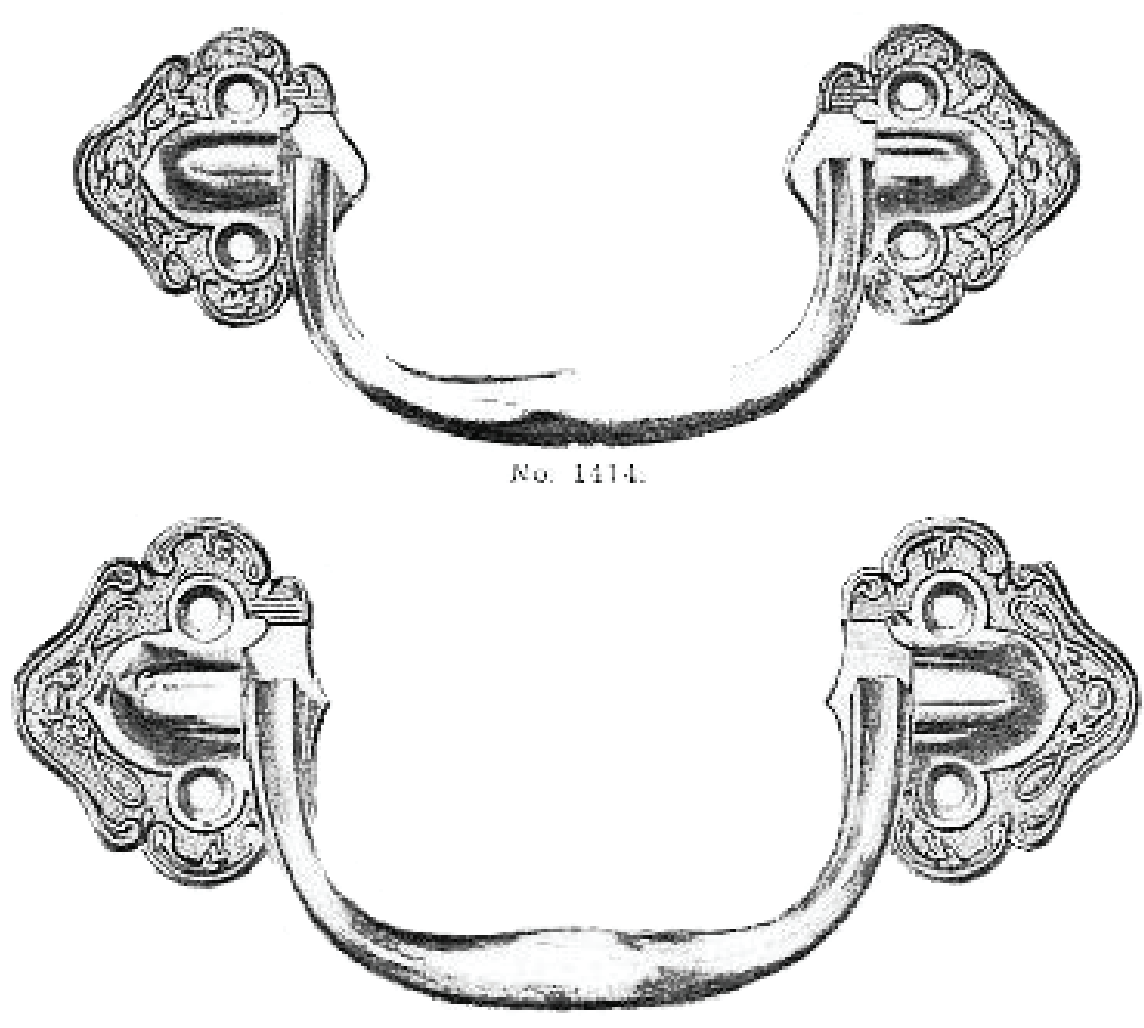

Nu. L.2:3

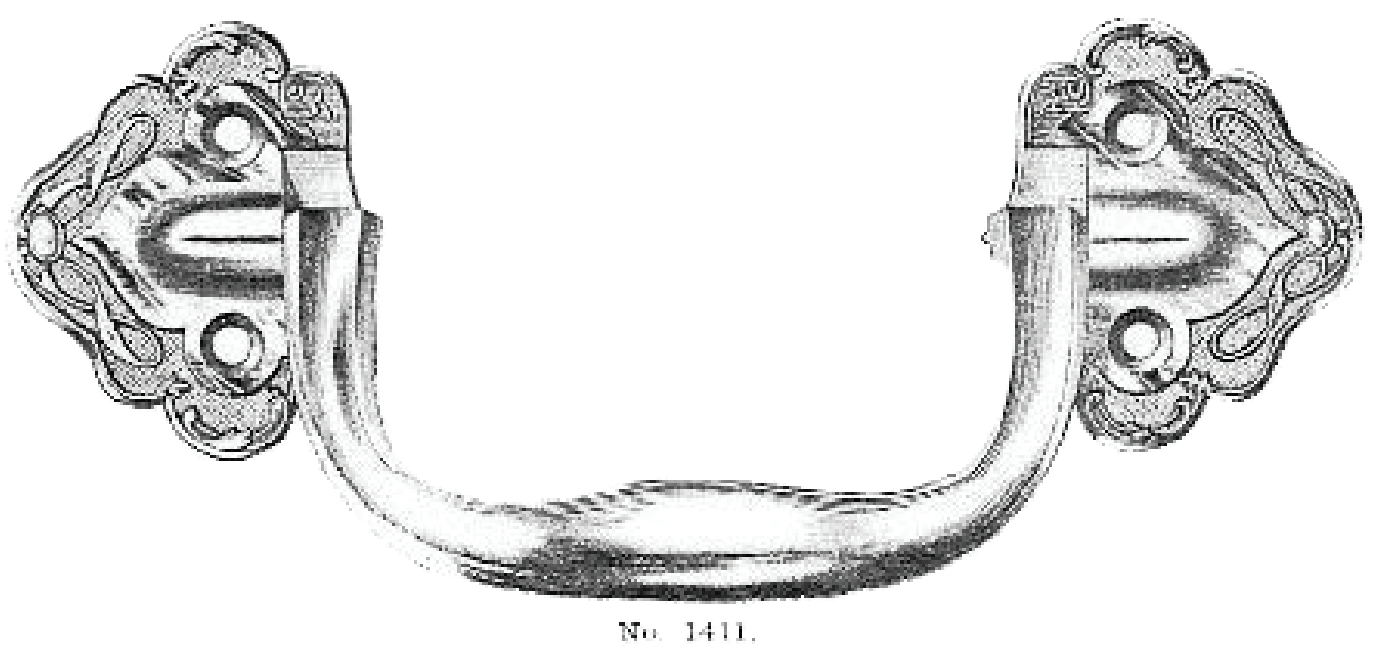

Figure 5.4. Handle Type B size grades as illustrated on page 17 in the circa 1885 Illustrated Catalog of the Harrisburg Burial Case Company. 
or lug type is illustrated date from 1866 to 1901 (see Table 5.3). Retailers would have been charged $\$ 7.50$ for one dozen pairs of these handles in 1866 , and $\$ 8.40$ in 1874. It is unclear how much of a markup would have been placed on these items when sold to the consumer.

Exact matches of Handle Type B were encountered in two cemetery excavations from Arizona and Virginia. Lug matches were found in five cemetery excavations from Georgia, Texas, Illinois, Virginia, and Ontario, Canada (see Table 5.3). There are no known patent records for this particular handle type, therefore it is not clear when this style entered the market. However, it is clear from the dates associated with the hardware catalogs and dates attributed to the comparison cemeteries consulted that this type of handle was in use between the late 1860s and the early 1900s.

\section{HANDLE TYPE C}

Handle Type C (Figure 5.5) consists of a double-lug, swing-bail handle recovered from Burial 17 at Pioneer Cemetery (Table 5.4). This item was made of a nonferrous, white metal, and was likely silver plated. The design pattern on the bail begins with a raised ring in the middle of the bail from which raised ripples travel out along the bail. The perimeter of the pin housing also has ridges. Small fans on the roughly shield-shaped lug extend diagonally outward from the four corners of the pin housing. A honeycomb pattern is present in the areas below and above the pin housing between the diagonal fans. No mold number is evident on either the lug or the bail.

Exact matches of Handle Type $\mathrm{C}$ were encountered in two cemetery excavations in Texas, which through other hardware associations yielded a date range of 1893-1905 and 1900-1907 (see Table 5.4). There are no known patent records for this particular handle type, nor have catalog matches been located. Therefore, it is not clear when this style entered the market. Based on the dates associated with the comparison cemetery, this handle was certainly on the market in the 1890s through the very early 1900s. Nevertheless, the double-lug, swing-bail form has a much broader age range, and this handle could have been introduced anywhere from the 1860 s through the 1900 s.

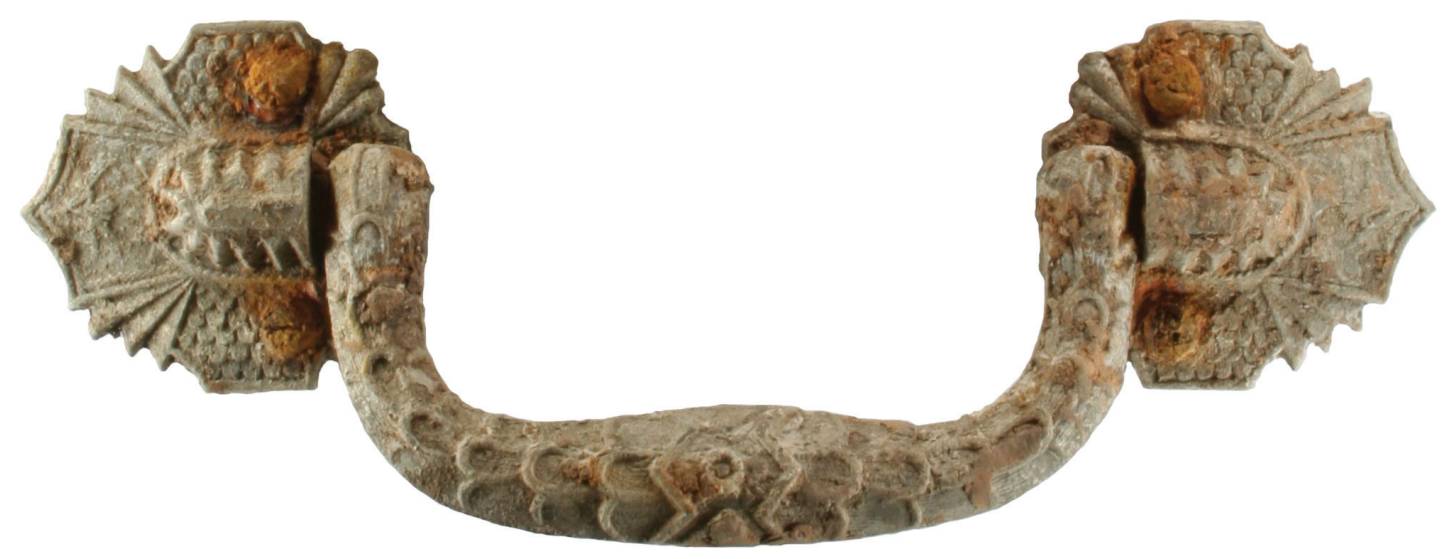

Figure 5.5. Handle Type C from Burial 17 at Pioneer Cemetery. 
Table 5.4. Description of Handle Type C

\begin{tabular}{|c|c|c|c|c|}
\hline Type No. & \multicolumn{4}{|l|}{ Handle Type C } \\
\hline Form & \multicolumn{4}{|l|}{ Double-lug, swing-bail } \\
\hline Material & \multicolumn{4}{|c|}{ Nonferrous white metal (possibly silverplated?) } \\
\hline Burial(s) & \multicolumn{4}{|l|}{ Burial $17(\mathrm{n}=1)$} \\
\hline Internal Date & \multicolumn{4}{|l|}{ N/A } \\
\hline Weight & \multicolumn{4}{|l|}{$?$} \\
\hline Dimensions & \multicolumn{4}{|c|}{ Total handle width (7.625 inches); total height (2.875 inches) } \\
\hline Mold Markings & \multicolumn{4}{|l|}{ none } \\
\hline Matches & Cemetery & No. of Burials & Dating & Citation \\
\hline 1 (similar lug) & $\begin{array}{l}\text { Third New City } \\
\text { Cemetery, TX, Type } 25\end{array}$ & 6 & $1893-1905$ & Foster and Nance 2002:F-159 \\
\hline 2 & $\begin{array}{l}\text { Third New City } \\
\text { Cemetery, TX, Type } 46\end{array}$ & 1 & $1893-1905$ & Foster and Nance 2002:F-183 \\
\hline 3 & $\begin{array}{l}\text { Freedman's Cemetery, } \\
\text { TX, Type } 4\end{array}$ & 4 & $1900-1907$ & Davidson 1999 \\
\hline
\end{tabular}

Note: There are no known catalog or design patent matches.

\section{Double-Lug, Short-Bar Handles}

The double-lug short-bar handle is a variant of the short bar concept. This variety is more complex than earlier swing-bail forms and can consist of up to nine parts: two lugs, two arms, two pins, a bar/tube, and two tips. The earliest patent dates for elements of the short bar handle appears in 1866, with numerous stylistic variants (e.g., C. Strong's Coffin Handle, U.S. Patent No. 97,827, Figure 5.6) being patented continuing through the 1870s and 1880s (Mainfort and Davidson 2006:125-126). Based on period trade catalogs, it is evident that early form, short bar handles were for sale in 1871, as advertised in the $1871 \mathrm{H}$. E. Taylor \& Co. illustrated catalog. These handles grew in popularity in the $1880 \mathrm{~s}$ and dominate the available catalogs through the early twentieth century.

\section{HANDLE TYPE D}

Handle Type D (Figure 5.7) is represented by a minimum of four handles recovered in Burial 16 (Table 5.5). The lugs of this handle are roughly rectangular with gently rounded corners. Abutting the sides of the pin housing and extending to each side is what could possibly be interpreted as acanthus leaves or at least something floral in nature. A fan extends outward toward the top and bottom, terminating in a gently curved scalloped design. The same fan pattern appears on the top of the arms. A set of circumscribed circles appears one above the other toward the bottom of the arm. A mold mark of "76" can be seen on the small upper face on the reverse of the arm. Within the clutches of the arms appear remnants of wood suggesting a wooden bar. ${ }^{8}$ The white metal tips begin with a metal band moving into a restricted neck, a bulbous midsection, a narrower restriction band, and terminate in a

8 A remnant of wood in one lug was identified as pine. 

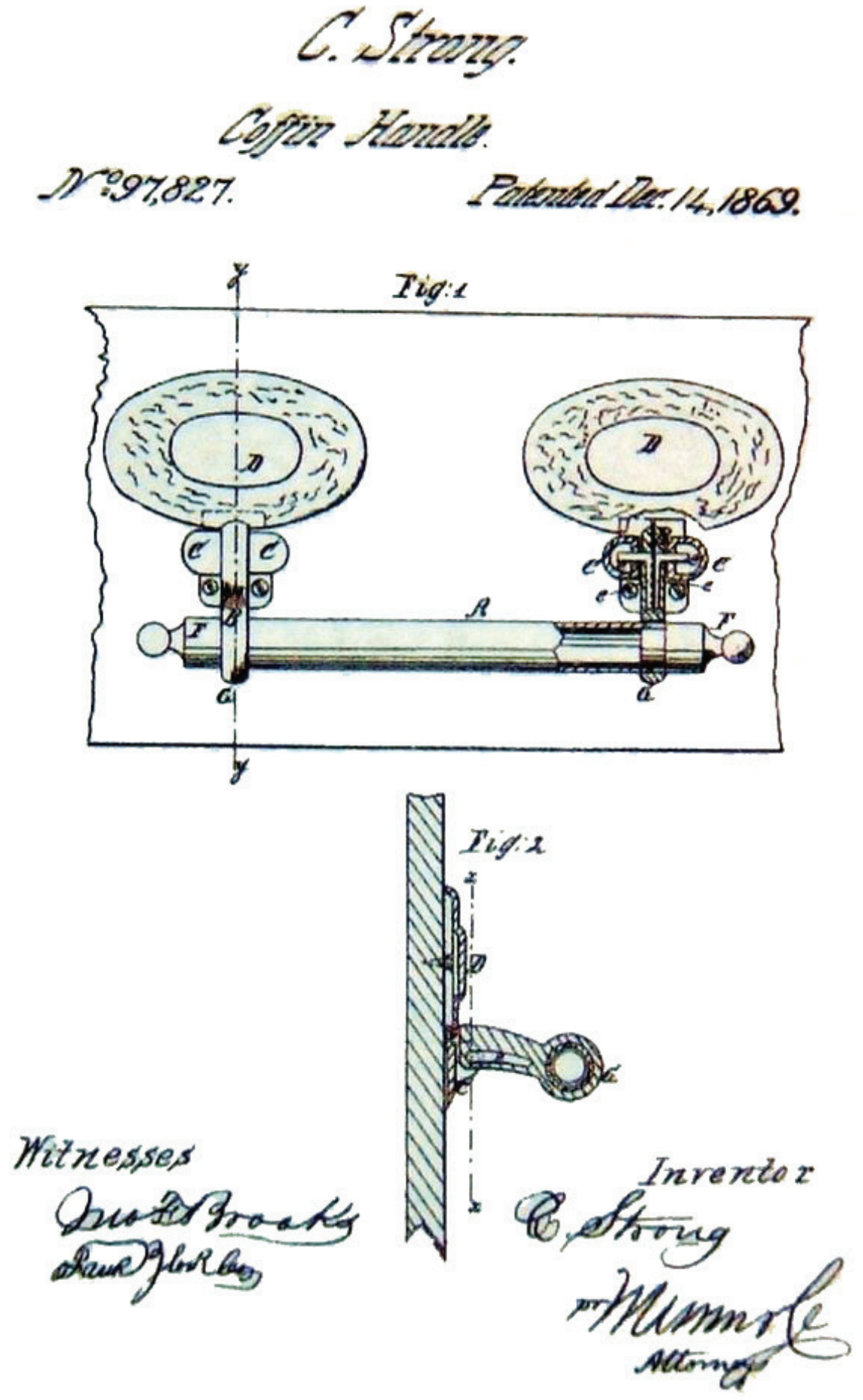

Figure 5.6. C. Strong 1869 Patent No. 97,827 for coffin handle showing early short bar. 
gentle dome. A floral bouquet crest is etched into the front face of the tips. This handle is a classic double-lug short bar handle, which likely dates between 1880 and the early twentieth century. No patent, catalog, or archeological matches were located.

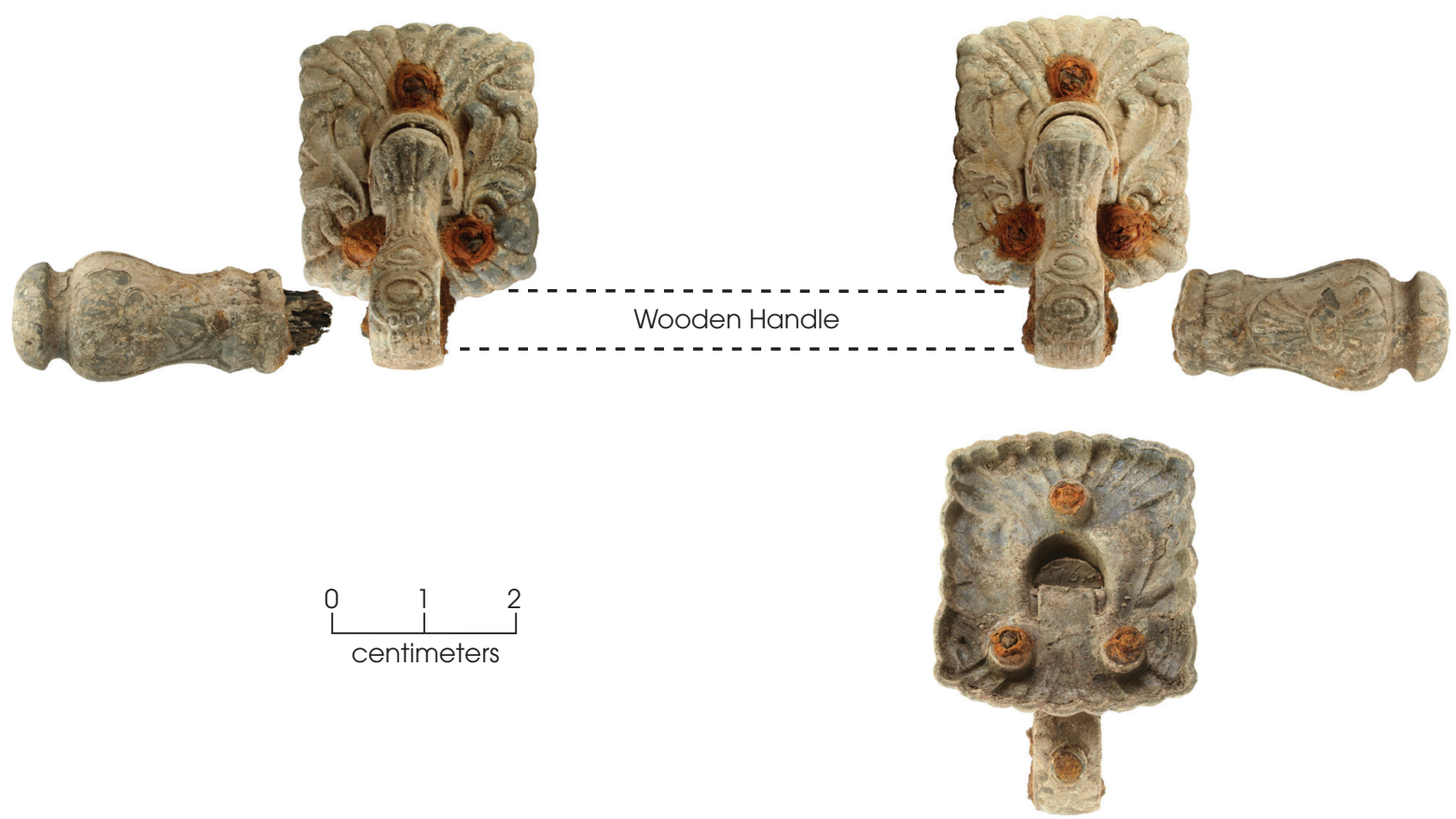

Figure 5.7. Handle Type D from Burial 16 at Pioneer Cemetery. Illustration shows how the handle tips and lug and arm assembly would have fit together with a wooden handle. The upper back arm plate has a mold mark of " 76 ".

Table 5.5. Description of Handle Type D

\begin{tabular}{l|l}
\hline Type No. & Handle Type D \\
\hline Form & Double-lug, short-bar handle \\
\hline Material & White metal lugs, tips, and arms (silverplated), wooden/wood core bar \\
\hline Burial(s) & Burial $16(\mathrm{n}=4)$ \\
\hline Internal Date & N/A \\
\hline Weight & $?$ \\
\hline Dimensions & $\begin{array}{l}\text { Total handle width (frag.); total bar width (frag.); bar diameter (0.750 inches); lug width } \\
\text { (2.54 inches); lug height (3.02 inches); arm length (2.56 inches); finial length (2.72 inches); } \\
\text { finial diameter (0.87 inches) }\end{array}$ \\
\hline Mold Markings & "76" on top back panel of arm \\
\hline
\end{tabular}

Notes: There are no known catalog or design patent matches.

There are no known examples of this type recovered from other cemetery excavations. 


\section{Thumbscrews}

Thumbscrews evolved out of earlier forms of coffin screws with the first identified iteration appearing in a 1859 patent issued to $\mathrm{Mr}$. H. Marshall for an innovative type of rectangular metal casket (U.S. Utility Patent No. 25,659). The flat-bodied forms, like those recovered from the Pioneer Cemetery excavations, first appear with an 1874 patent issued to W. M. Smith (U.S. Utility Patent 7,797) for a flat-bodied, urn-shaped design. These new types of thumbscrews quickly became available, appearing in catalogs in 1875 . Thumbscrews are great temporal diagnostics due to the fact that continued advancements and variations in designs yielded further registered patents up to 1884. Moreover, companies and individuals continued to produce new forms, for which patents applications were not filed, even into the twentieth century (Mainfort and Davidson 2006:133-134).

\section{Thumbscrew Type A}

Thumbscrew Type A (Figure 5.8a and d) is associated with Escutcheon Type A (Figure 5.8b and c) and is represented by six artifacts from Burial 11 at Pioneer Cemetery (Table 5.6). This thumbscrew form has a cylindrical base consisting of a lower band, a constricted band, and an upper band. The main body of the screw head is a stylized cross with the arms angled slightly upward with a string of spheres around the margins. Just within this line of spheres on each face is a wide raised line along the sides and top of the cross bar. Hanging down from the vertical segment of the cross is a ribbon with a circular disc, resembling a medal. The vertical arm exhibits a Maltese cross. The line of spheres that exists on the margins of the cross bar do not continue up the vertical arm.

No matches to this screw have been located in patent records or period catalogs, but this thumbscrew type has been recovered in three archeological cemetery excavations, all from Texas (see Table 5.6). The cemeteries have dates ranging from 1878 to 1907 , with most of the items being attributed to the later end of this period.

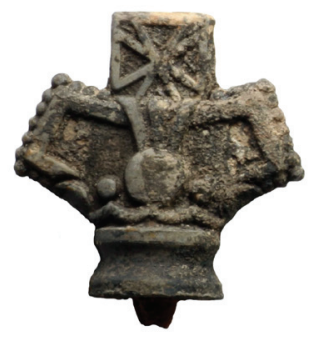

a

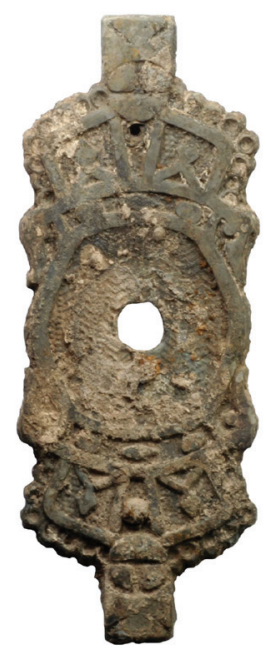

b

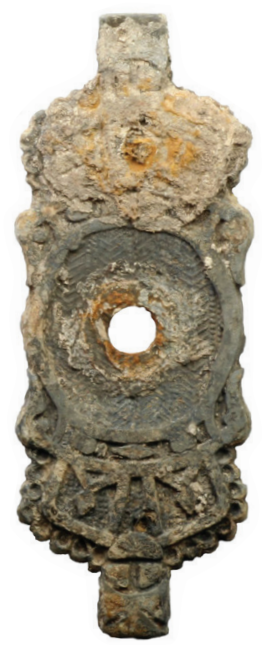

C

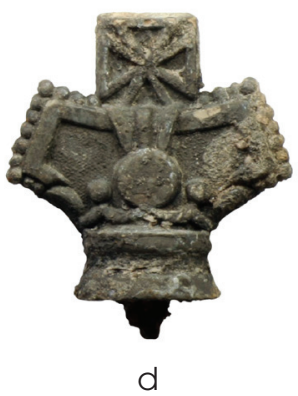

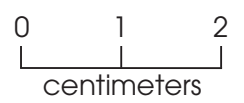

Figure 5.8. Thumbscrew and Escutcheon Set Type A from Burial 11 at Pioneer Cemetery. 
Table 5.6. Description of Thumbscrew Type A

\begin{tabular}{|c|c|c|c|c|c|}
\hline \multicolumn{2}{|l|}{ Type No. } & \multicolumn{4}{|l|}{ Thumbscrew Type A } \\
\hline \multicolumn{2}{|l|}{ Form } & \multicolumn{4}{|l|}{ Flat-bodied, cylindrical base } \\
\hline \multicolumn{2}{|l|}{ Material } & \multicolumn{4}{|l|}{ White metal } \\
\hline \multicolumn{2}{|l|}{$\operatorname{Burial}(\mathrm{s})$} & \multicolumn{4}{|l|}{ Burial $11(n=6)$} \\
\hline \multicolumn{2}{|c|}{ Associated Hardware } & \multicolumn{4}{|l|}{ Escutcheon Type A } \\
\hline \multicolumn{2}{|c|}{ Internal Date } & \multicolumn{4}{|l|}{ N/A } \\
\hline \multicolumn{2}{|l|}{ Weight } & \multicolumn{4}{|l|}{$?$} \\
\hline \multicolumn{2}{|c|}{ Dimensions } & \multicolumn{4}{|c|}{ Total screw length (with shaft) (?); head height (1.13 inches); head width (1.13 inches) } \\
\hline \multicolumn{2}{|c|}{ Mold Markings } & \multicolumn{4}{|l|}{ None evident } \\
\hline Matches & & Cemetery & $\begin{array}{c}\text { No. of } \\
\text { Burials }\end{array}$ & Dating & Citation \\
\hline 1 & \multicolumn{2}{|c|}{ Anderson Cemetery, TX } & 1 & 1886 & Turpin and Bement 2002:24 \\
\hline 2 & \multicolumn{2}{|c|}{ Potter's Field Greenwood Cemetery, TX } & 1 & 1878-1911 & Tiné et al. 2002:64-65 \\
\hline 3 & \multicolumn{2}{|c|}{ Freedman's Cemetery, TX, Coffin Screw Type 19} & 14 & 1900-1907 & Davidson 1999:294 \\
\hline 4 & \multicolumn{2}{|c|}{ Freedman's Cemetery, TX, Coffin Screw Type 19} & 11 & 1885-1899 & Davidson 1999:294 \\
\hline
\end{tabular}

Note: There are no known catalog or design patent matches.

\section{Thumbscrew Type B}

Thumbscrew Type B (Figure 5.9) is associated with Escutcheon Type B and is represented by five artifacts from Burial 16 (Table 5.7). It consists of a flatbodied head with a stylized pentagon form with concave facets. The design looks like a curtain pulled back revealing four upward-pointing triangles in the void.

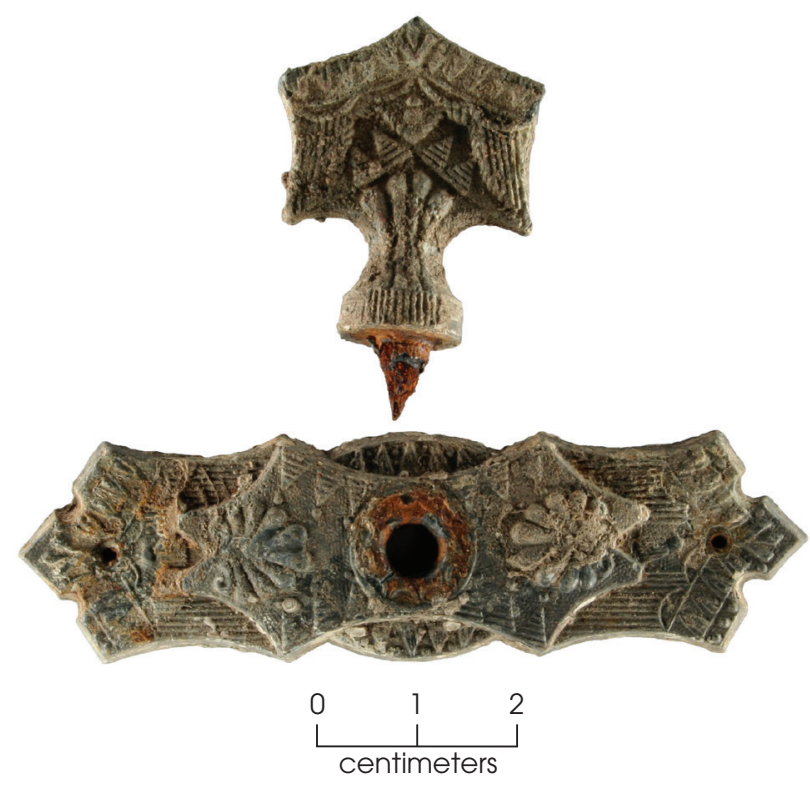

Figure 5.9. Thumbscrew and Escutcheon Set Type B from Burial 16 at Pioneer Cemetery.
These triangles are sitting atop a fan with four fingers that run down a constricted neck to a cylindrical, filigreed band serving as the base.

Exact matches have been not been located in any patent records or period trade catalogs. However, this screw has been identified in excavations at four historic cemeteries in Georgia, Arkansas, and Texas. Archeological interpretations date burials with this type of thumbscrew between 1870 and 1910 (see Table 5.7).

\section{Escutcheons}

The term escutcheon refers to decorative screw plates with a central hole through which a thumbscrew or coffin screw can pass for mounting. These accessories did 
Table 5.7. Description of Thumbscrew Type B

\begin{tabular}{|c|c|c|c|c|c|}
\hline \multicolumn{2}{|l|}{ Type No. } & \multicolumn{4}{|l|}{ Thumbscrew Type B } \\
\hline \multicolumn{2}{|l|}{ Form } & \multicolumn{4}{|c|}{ Flat-bodied, cylindrical base } \\
\hline \multicolumn{2}{|l|}{ Material } & \multicolumn{4}{|l|}{ White metal } \\
\hline \multicolumn{2}{|l|}{ Burial(s) } & \multicolumn{4}{|l|}{ Burial $16(\mathrm{n}=5)$} \\
\hline \multicolumn{2}{|c|}{ Associated Hardware } & \multicolumn{4}{|l|}{ Escutcheon Type B } \\
\hline \multicolumn{2}{|c|}{ Internal Date } & \multicolumn{4}{|l|}{ N/A } \\
\hline \multicolumn{2}{|l|}{ Weight } & \multicolumn{4}{|l|}{$?$} \\
\hline \multicolumn{2}{|c|}{ Dimensions } & \multicolumn{4}{|c|}{$\begin{array}{l}\text { Total screw length (with shaft) (?); head height (1.32 inches); head width (1.05 } \\
\text { inches) }\end{array}$} \\
\hline \multicolumn{2}{|c|}{ Mold Markings } & \multicolumn{4}{|l|}{ None evident } \\
\hline Matches & & Cemetery & $\begin{array}{l}\text { No. of } \\
\text { Burials }\end{array}$ & Dating & Citation \\
\hline 1 & Eddy $\mathrm{Ce}$ & etery, AR, Type 1 & 1 & 1870-1900 & Mainfort and Davidson 2006 \\
\hline 2 & Redfield & emetery, GA & 1 & 1890-1910? & Braley and Moffat 1995 \\
\hline 3 & Freedms & s Cemetery, TX, Type 26 & 28 & 1902-1906 & Davidson 1999 \\
\hline 4 & Third N & City Cemetery, TX & 21 & 1880-1905 & Foster and Nance 2002:F-88 \\
\hline
\end{tabular}

Note: There are no known catalog or design patent matches.

not develop at the same time as the earliest coffin screws, but are first observed in the 1865 Russell \& Erwin Mfg. Co. hardware catalog. These early varieties consisted largely of simple diamond-shaped forms. It was not until the widespread introduction of thumbscrews in the 1870s that escutcheon designs began to evolve so that they could be sold with thumbscrews as matched sets. This type of artifact has a broad temporal range of approximately 1865-1920s (Mainfort and Davidson 2006:147).

\section{Escutcheon Type A}

Escutcheon Type A (see Figure 5.8) is represented by six artifacts from Burial 11 at Pioneer Cemetery (Table 5.8). This escutcheon is associated with Thumbscrew Type A and shares stylistic elements with this thumbscrew. The plate has a central hole with a wide raised gentle octagonal line. On each end is a crownshaped formation terminating with a small square with a Maltese cross. A line of small spheres runs around the body margin of the crown area, but not the square termination. This artifact type does not appear in any patent records or period trade catalogs. It has, however, been recovered in one burial from a Texas cemetery dated between 1878 and 1911.

\section{Escutcheon Type B}

Escutcheon Type B (see Figure 5.9) is represented by five artifacts recovered from Burial 16 (Table 5.9), and is associated with Thumbscrew Type B. It shares some stylistic elements with Thumbscrew Type B, but it is not clear whether these

originally came in a set. This escutcheon is made up of two plates. The larger base 
Table 5.8. Description of Escutcheon Type A

\begin{tabular}{|c|c|c|c|c|c|}
\hline \multicolumn{2}{|l|}{ Type No. } & \multicolumn{4}{|l|}{ Escutcheon Type A } \\
\hline \multicolumn{2}{|l|}{ Form } & \multicolumn{4}{|l|}{ Flat-bodied, rectangular } \\
\hline \multicolumn{2}{|l|}{ Material } & \multicolumn{4}{|l|}{ White metal } \\
\hline \multicolumn{2}{|l|}{$\operatorname{Burial}(\mathrm{s})$} & \multicolumn{4}{|l|}{ Burial $11(n=6)$} \\
\hline \multicolumn{2}{|c|}{$\begin{array}{l}\text { Associated } \\
\text { Hardware }\end{array}$} & \multicolumn{4}{|l|}{ Thumbscrew Type A } \\
\hline \multicolumn{2}{|c|}{ Internal Date } & \multicolumn{4}{|l|}{ N/A } \\
\hline \multicolumn{2}{|l|}{ Weight } & \multicolumn{4}{|l|}{$?$} \\
\hline \multicolumn{2}{|c|}{ Dimensions } & \multicolumn{4}{|c|}{ Total length (2.46 inches); total width (0.94 inches) } \\
\hline \multicolumn{2}{|c|}{ Mold Markings } & \multicolumn{4}{|l|}{ None evident } \\
\hline Matches & & Cemetery & $\begin{array}{c}\text { No. of } \\
\text { Burials }\end{array}$ & Dating & Citation \\
\hline 1 & Pott & eld Greenwood Cemetery, TX & 1 & $1878-1911$ & Tiné et al. 2002:64-65 \\
\hline
\end{tabular}

Note: There are no known catalog or design patent matches.

Table 5.9. Description of Escutcheon Type B

\begin{tabular}{|c|c|c|c|c|c|}
\hline \multicolumn{2}{|l|}{ Type No. } & \multicolumn{4}{|l|}{ Escutcheon Type B } \\
\hline \multicolumn{2}{|l|}{ Form } & \multicolumn{4}{|l|}{ Flat-bodied, rectangular } \\
\hline \multicolumn{2}{|l|}{ Material } & \multicolumn{4}{|l|}{ White metal } \\
\hline \multicolumn{2}{|l|}{$\operatorname{Burial}(\mathrm{s})$} & \multicolumn{4}{|l|}{ Burial $16(n=5)$} \\
\hline \multicolumn{2}{|c|}{ Associated Hardware } & \multicolumn{4}{|l|}{ Thumbscrew Type B } \\
\hline \multicolumn{2}{|c|}{ Internal Date } & \multicolumn{4}{|l|}{ N/A } \\
\hline \multicolumn{2}{|l|}{ Weight } & \multicolumn{4}{|l|}{$?$} \\
\hline \multicolumn{2}{|c|}{ Dimensions } & \multicolumn{4}{|c|}{ Total length (3.82 inches); total width (0.9 inches) } \\
\hline \multicolumn{2}{|c|}{ Mold Markings } & \multicolumn{4}{|l|}{ None evident } \\
\hline Matches & & Cemetery & $\begin{array}{c}\text { No. of } \\
\text { Burials }\end{array}$ & Dating & Citation \\
\hline 1 & \multicolumn{2}{|c|}{ Eddy Cemetery, AR, Type 1} & 2 & $1870-1900$ & Mainfort and Davidson 2006:146-147 \\
\hline 2 & \multicolumn{2}{|c|}{ Third New City Cemetery, TX, Type 4} & 9 & 1880-1905 & Foster and Nance 2002:F-63 \\
\hline 3 & \multicolumn{2}{|c|}{ Freedman's Cemetery, TX, Type 20} & 31 & $1902-1906$ & Davidson 1999 \\
\hline
\end{tabular}

Note: There are no known catalog or design patent matches.

plate has a central disc bounded by outward-facing triangles around the center screw hole. After the disc it slightly constricts before curving back out to triangular points on the sides and the terminal point. A series of floral blooms sit between the outer margin and a thin raised line mirroring the general pointed shape of the ends. An area of narrowly spaced, thin, horizontal, parallel lines lay between this terminal design, and the central disc consists of a simple diamond form with a border of raised half diamonds. A raised, smooth diamond lies within the border. Settled within the 
widest part of the inner diamond is a central disc. Sitting atop the base plate is a smaller upper plate, which is roughly rectangular with a constricted midsection similar to a spool. Inward-facing triangles mark the upper and lower margins of the top face. A raised circular platform surrounds the screw hole. This upper plate ends with double peaks between which are floral fans facing toward the screw hole.

No matches have been located in period trade catalogs or patent records. However, exact matches have been located in three archeological cemetery excavations in Arkansas and Texas. Based on additional contextual data, the associated burials in these cemeteries have been dated between 1870 and 1906 (see Table 5.9). This date range is consistent with the known general time frame for the manufacture of associated thumbscrews.

\section{Ornamental Tacks}

As a general class of artifact, "Ornamental Tack" includes a number of different forms, some of which exhibit geometric floral patterns, and others that imitate objects (i.e., bow, lamb, or anchor). The more substantial coffin tacks (dummy screws) are made of a white metal, while the stud forms are most often comprised of thin, lightweight, pressed cupric metal. In all instances, a ferrous tack shaft is affixed to the underside of the main body. These ornamental tacks are usually placed along the perimeter of the coffin lid, or on the sides of the coffin itself. As a general artifact class, the ornamental tack is commonly found in catalogs from the 1850s to the 1920s (Davidson 1999, 2004:419-420; Mainfort and Davidson 2006:153).

\section{Decorative Studs}

Decorative studs are a specific type of ornamental tack, which include geometric forms, such as diamond and star-shaped studs, as well as representational forms, many of which (i.e., lambs, crosses, cherubs, etc.) convey religious symbolism (Davidson 1999, 2004:420). Decorative studs, like the larger ornamental tack category, are commonly found in catalogs from the 1850s to the $1920 \mathrm{~s}$; however, many of these forms occur in the latter portion of this time range (Davidson 1999, 2004:419-420; Mainfort and Davidson 2006:153).

\section{ORNAMENTAL TACK TYPE A}

Ornamental Tack Type A (Figure 5.10) is represented by six tack fragments and eight fragmentary heads from Burial 16 at Pioneer Cemetery (Table 5.10). Because there are no complete artifacts present, it is very difficult to firmly identify whether stylistic variation is present. The items shown in Figure 5.10 suggest they have a gentle domed apex, but with all of the bottom margins broken, little else can be noted. Figure 5.11 shows a wide selection of studs available for sale in the ca. 1904 Gate City Coffin Company illustrated catalog. On this one page, there are 16 stud styles that have a smooth domed top but have great stylistic variation below the dome. Close inspection of the Pioneer Cemetery artifacts suggest that what is present are bell-shaped studs with four tiers, like that depicted in the $1894 \mathrm{~W}$. D. Wilmarth \& Company illustrated catalog (Figure 5.12). 

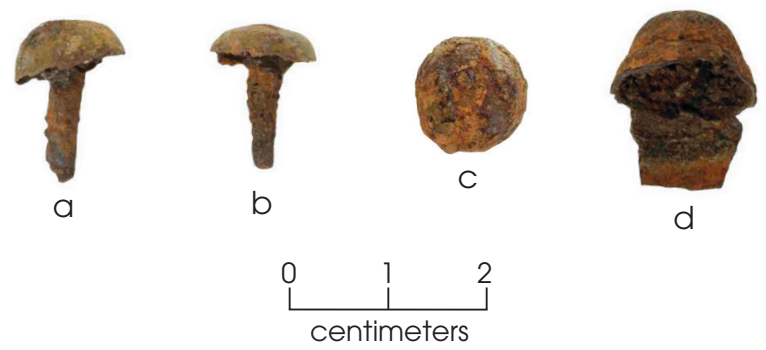

Figure 5.10. Ornamental Tack Type A from Burial 16 at Pioneer Cemetery.

Table 5.10. Description of Ornamental Tack Type A

\begin{tabular}{|c|c|c|c|c|c|}
\hline \multicolumn{2}{|l|}{ Type No. } & \multicolumn{4}{|l|}{ Ornamental Tack Type A } \\
\hline \multicolumn{2}{|l|}{ Form } & \multicolumn{4}{|l|}{ Bell-shaped stud } \\
\hline \multicolumn{2}{|l|}{ Material } & \multicolumn{4}{|l|}{ Cupric alloy, burnished } \\
\hline \multicolumn{2}{|l|}{ Burial(s) } & \multicolumn{4}{|l|}{ Burial $16(\mathrm{n}=6$ tacks, 8 heads $)$} \\
\hline \multicolumn{2}{|c|}{ Internal Date } & \multicolumn{4}{|l|}{ N/A } \\
\hline \multicolumn{2}{|l|}{ Weight } & \multicolumn{4}{|l|}{$?$} \\
\hline \multicolumn{2}{|c|}{ Dimensions } & \multicolumn{4}{|c|}{ *Height $(0.61$ inches $) ;{ }^{*}$ Diameter $(0.86$ inches $)$} \\
\hline \multicolumn{2}{|c|}{ Mold Markings } & \multicolumn{4}{|l|}{ None evident } \\
\hline Matches & & Cemetery & No. of Burials & Dating & Citation \\
\hline 1 & Ridle & y Cemetery, TN & 2 & $1905-1910$ & \begin{tabular}{|l} 
Buchner et al. \\
1999:176
\end{tabular} \\
\hline 2 & Nanc & y Creek Cemetery, GA & 1 & 1879 & Garrow et al. 1985 \\
\hline 3 & Prov & dence Baptist Church Cemetery, TN & 2 & 1899-1933 & Oster et al. 2005:214 \\
\hline 4 & Texa & State Cemetery, TX & 5 & $1884-1951$ & $\begin{array}{l}\text { Dockall, Powell, and } \\
\text { Steele 1996:148 }\end{array}$ \\
\hline Matches & & Catalogue & Page (Item No.) & Dating & Source \\
\hline 1 & Stolt & , Russell \& Co & 34 (No. 14, 2) & 1880 & $\begin{array}{l}\text { Strong National } \\
\text { Museum of Play }\end{array}$ \\
\hline 2 & Zane & sville Coffin Co. & 24 (No. 37) & 1880 & $\begin{array}{l}\text { Smithsonian } \\
\text { Institution (NMAH) }\end{array}$ \\
\hline 3 & F.H. & Gill \& Co. [Price list] (\$1.30 per gross) & (No. 217) & circa 1880 & Pye Collection \\
\hline 4 & F.H. & Hill \& Co. & 63 (No. 217) & 1881 & Pye Collection \\
\hline 5 & Colu & nbus Coffin Co. & 31 (No. 37) & 1882 & Winterthur Museum \\
\hline 6 & Warf & eld \& Rohr & 60 (No. 13) & circa 1890 & Davidson Collection \\
\hline 7 & W.D. & Wilmarth \& Co. & $8,14$ (No. 45,84$)$ & 1894 & Library of Congress \\
\hline 8 & Kreg & al Case Co. & 315 (No. 105) & 1895 & $\begin{array}{l}\text { Strong National } \\
\text { Museum of Play }\end{array}$ \\
\hline 9 & Loui & J. Lamb & $3,6$ (No. 13,45$)$ & circa 1895 & Davidson Collection \\
\hline 10 & $\begin{array}{l}\text { Loui } \\
45-6\end{array}$ & $\begin{array}{l}\text { J. Lamb [Price list] (No. } 13 \text { - } \$ 1.25 \text {, No. } \\
1.15 \text { ) }\end{array}$ & (No. 13, 45) & circa 1895 & Davidson Collection \\
\hline 11 & Chic & go Coffin Co. & 117 & 1896 & Library of Congress \\
\hline 12 & John & Murphy \& Co. & 66 (No. 13) & circa 1900 & Davidson Collection \\
\hline 13 & Cran & fordsville Casket Co. & 226 & circa 1900 & Davidson Collection \\
\hline 14 & Gate & City Coffin Co. & 185 (No. 84) & circa 1904 & Davidson Collection \\
\hline 15 & Chat & anooga Coffin Co. & 162 (No. 84, 45) & 1905 & Library of Congress \\
\hline 16 & $\begin{array}{l}\text { Chat } \\
\text { large }\end{array}$ & $\begin{array}{l}\text { anooga Coffin Co. [Price list] (No. } 84 \text { - } \\
-\$ 1.50, \text { No. } 45 \text { - small - } \$ 1.40 \text { per gross) }\end{array}$ & 14 (No. 84, 45) & 1905 & Library of Congress \\
\hline 17 & Cinc & nnati Coffin Co. & (No. 12) & 1906 & Davidson Collection \\
\hline
\end{tabular}

Notes: There are no known design patent matches.

All of these artifacts are fragmentary; the majority of brass has deteriorated, leaving just part of the the stud.

They could represent a number of types or multiple similar types. 


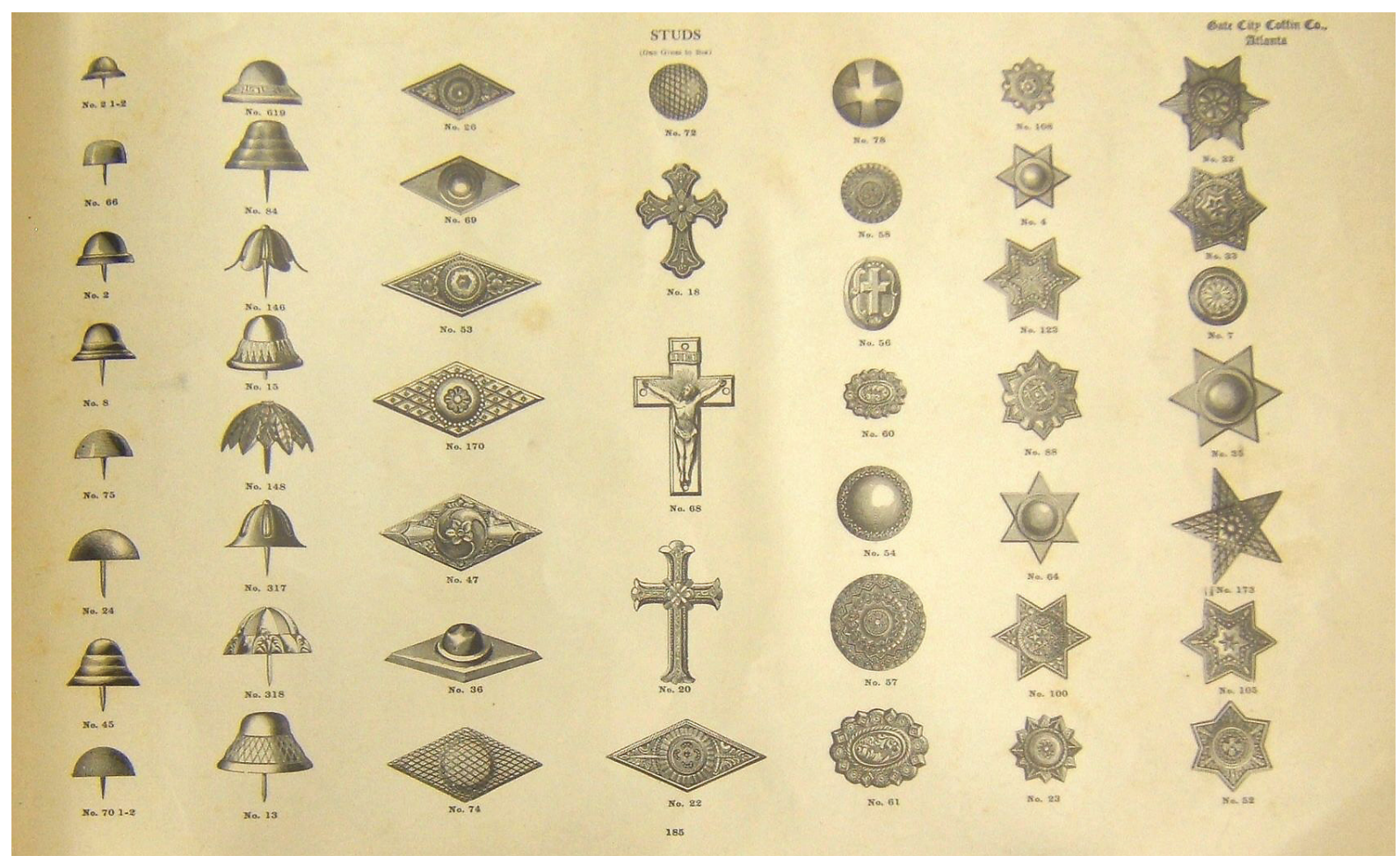

Figure 5.11. Examples of studs illustrated on page 185 of the circa 1904 Gate City Coffin Company Illustrated Catalog.

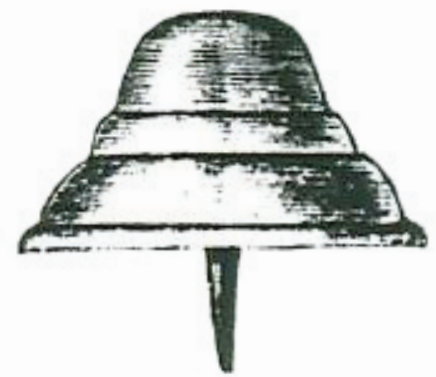

\section{No. 45. SMALL BELL S'TUD. \\ I'lain liurnshel.}

Figure 5.12. Possible match for Ornamental Tack Type A as illustrated on page 8 of the $1894 \mathrm{~W}$. D. Wilmarth \& Company Catalog.

If it is assumed that all of the fragmentary studs in this burial were bellshaped studs, it becomes easier to trace their temporal and geographic distribution. This type of bell-shaped stud was advertised in at least 17 mortuary merchandise catalogs between 1880 and 1906 and ranged in cost between $\$ 1.30$ per gross in 1880 to $\$ 1.50$ per gross in 1905 (see Table 5.10). These studs have been noted in four 
archeological cemetery excavations in Texas, Tennessee, and Georgia, with inferred dates ranging from 1879 until possibly as late as 1951, though this later date is the terminal date for one of the cemeteries and not for a specific burial with this type of hardware. A general span of use between the late 1870s and 1910 is likely.

\section{Lining Tacks}

Lining tacks were used to affix a cloth lining to the interior of the burial container, to affix a cloth covering to the exterior of the container, or they were arranged on the surface of the container to provide personal information of the deceased or to create a decorative pattern. These tacks are typically small, with an iron shank and head (flat iron, domed iron, domed, brass, domed china, or domed lead/white metal). Often the iron shank deteriorates or becomes detached, and only the heads remain (Davidson 1999).

Because the presence or absence of lining or cloth covering is a basic economic indicator, the ability to identify lining tacks is important. Linings do not typically preserve except when lying in association with cuprous hardware, and even then it is difficult to distinguish a cloth lining from clothing remnants; therefore, the recovery of lining tacks provides a more concrete indicator as to whether or not the burial container was lined (Davidson 2004:418).

\section{ORNAMENTAL TACK TYPE B}

Ornamental Tack Type B (Figure 5.13a) is represented by three artifacts from Burial 17 at Pioneer Cemetery (Table 5.11) and is made of white metal formed into a dome and affixed to an iron shank. This is a ubiquitous form of lining tack and is present in 22 trade catalogs dating between 1865 and 1906. It is likely that these lining tacks were first marketed in the 1850s alongside white metal coffin screws and white metal coffin tacks, though no design patents have been located to corroborate this assumption. In contrast to other types of hardware, it is noteworthy that the price of these lining tacks actually decreased through time from $\$ 0.15$ per gross in the 1866 Sargent and Company price list to $\$ 0.08$ per gross in the 1905 Chattanooga Coffin Company illustrated catalog and associated price list (Figure 5.13b; see Table 5.11).

In most archeological cemetery excavation reports, not much attention is given to lining tacks. Consequently, it is very difficult to determine with certainty how often this type of tack appears in the archeological record. Mainfort and Davidson (2006:170) note that this domed, white metal tack was the most common lining tack utilized in burials at the Freedman's Cemetery (dated 1869-1907) in Dallas, Texas, but Davidson (1999, 2004) and Peter et al. (2000) do not give frequencies for or discuss lining tacks in any great detail. Similarly, an examination

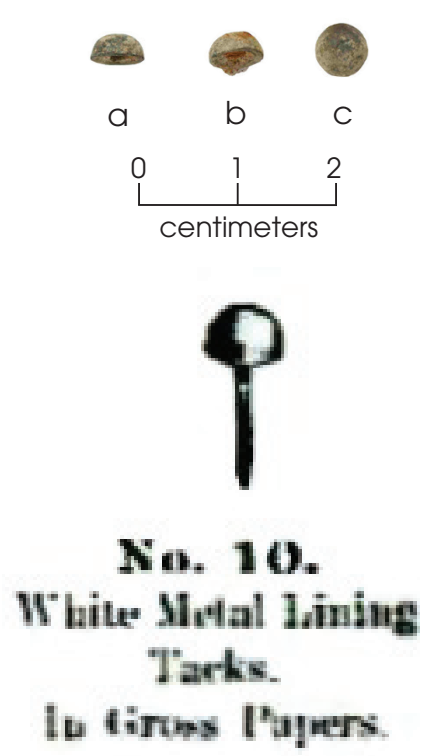

Figure 5.13. Ornamental Tack Type B. (a) Specimens from Pioneer Cemetery; (b) example of "White Metal Headed Lining Tack" as illustrated on page 177 of the 1905 Chattanooga Coffin \& Casket Company Illustrated Catalog. 
Table 5.11. Description of Ornamental Tack Type B

\begin{tabular}{|c|c|c|c|c|c|}
\hline \multicolumn{2}{|l|}{ Type No. } & \multicolumn{4}{|l|}{ Ornamental Tack Type B } \\
\hline \multicolumn{2}{|l|}{ Form } & \multicolumn{4}{|l|}{ Domed head lining tack } \\
\hline \multicolumn{2}{|l|}{ Material } & \multicolumn{4}{|l|}{ White metal head } \\
\hline \multicolumn{2}{|l|}{ Burial(s) } & \multicolumn{4}{|l|}{ Burial $17(\mathrm{n}=3)$} \\
\hline \multicolumn{2}{|c|}{ Internal Date } & \multicolumn{4}{|l|}{ N/A } \\
\hline \multicolumn{2}{|l|}{ Weight } & \multicolumn{4}{|l|}{$?$} \\
\hline \multicolumn{2}{|c|}{ Dimensions } & \multicolumn{4}{|c|}{ Head height (0.10 inches); head diameter (0.20 inches) } \\
\hline \multicolumn{2}{|c|}{ Mold Markings } & \multicolumn{4}{|c|}{ None evident } \\
\hline Matches & & Cemetery & No. of Burials & Dating & Citation \\
\hline 1 & \multicolumn{2}{|c|}{$\begin{array}{l}\text { Elmbank Cemetery, Ontario, } \\
\text { Canada }\end{array}$} & 3 & $1832-1933$ & Lipovitch et al. 2003 \\
\hline 2 & \multicolumn{2}{|c|}{ Freedman's Cemetery, TX } & $?$ & $1869-1907$ & Davidson 1999 \\
\hline \multicolumn{2}{|l|}{ Matches } & Catalogue & Page (Item No.) & Dating & Source \\
\hline \multirow{2}{*}{$\frac{1}{2}$} & \multicolumn{2}{|c|}{ Russell \& Erwin Mfg. Co. } & 331 & 1865 & Library of Congress \\
\hline & \multicolumn{2}{|c|}{ Sargent and Co. $(\$ 0.15$ per gross $)$} & 128 (No. 10) & 1866 & Connecticut State Library \\
\hline 3 & \multicolumn{2}{|c|}{ Sargent and Co. $(\$ 0.12$ per paper $)$} & 154 (No. 10) & 1869 & Connecticut Historical Society \\
\hline 4 & \multicolumn{2}{|c|}{ J.M. Shanahan (firm) } & 20 (No. 28) & circa 1869 & Smithsonian Institution (NMAH) \\
\hline 5 & \multicolumn{2}{|c|}{$\begin{array}{l}\text { J.M. Shanahan (firm) [Price list] } \\
(\$ 0.10 \text { per gross, } \$ 1.80 \text { per } 1,000)\end{array}$} & 2 (No. 28) & 1869 & Smithsonian Institution (NMAH) \\
\hline 6 & \multicolumn{2}{|c|}{ Sargent and Co. $(\$ 0.125$ per paper $)$} & 282 (No. 10) & 1871 & Library of Congress \\
\hline 7 & \multicolumn{2}{|c|}{ Cleveland Burial Case Co. } & 68 & circa 1872 & Smithsonian Institution (NMAH) \\
\hline 8 & \multicolumn{2}{|c|}{ Cincinnati Coffin Co. } & 39 (No. 10) & 1877 & Newberry Library \\
\hline 9 & Stolt & Russell \& Co & 32 & 1880 & Strong National Museum of Play \\
\hline 10 & Cinc & nati Coffin Co. & (No. 10) & circa 1880 & Strong National Museum of Play \\
\hline 11 & Zane & ville Coffin Co. & 25 (No. 10) & 1880 & Smithsonian Institution (NMAH) \\
\hline 12 & Colu & bus Coffin Co. & 34 & 1882 & Winterthur Museum \\
\hline 13 & Harr & burg Burial Case Co. & 51 (No. 10) & circa 1885 & Hagley Museum \\
\hline 14 & Warf & ld \& Rohr & 61 (No. 10) & circa 1890 & Davidson Collection \\
\hline 15 & Kreg & 1 Case Co. & 318 (No. 10) & 1895 & Strong National Museum of Play \\
\hline 16 & Chic & go Coffin Co. & 117 & 1896 & Library of Congress \\
\hline 17 & Crav & ordsville Casket Co. & 226 & circa 1900 & Davidson Collection \\
\hline 18 & Gate & City Coffin Co. & 204 (No. 10) & circa 1904 & Davidson Collection \\
\hline 19 & Chat & anooga Coffin Co. & 177 (No. 10) & 1905 & Library of Congress \\
\hline 20 & $\begin{array}{l}\text { Chat } \\
(\$ 0.0\end{array}$ & $\begin{array}{l}\text { anooga Coffin Co. [Price list] } \\
\text { per gross) }\end{array}$ & 19 (No. 10) & 1905 & Library of Congress \\
\hline 21 & Cinc & nati Coffin Co. & (No. 10) & 1906 & Davidson Collection \\
\hline
\end{tabular}

Note: There are no known design patent matches.

of artifact photographs from the Elmbank Cemetery (dated 1832-1933) in Ontario, Canada, reveals that three burials had these types of tacks, though the report makes scant mention of them.

\section{Coffin Tacks (Dummy Screws)}

The term "coffin tack" refers to a specific kind of ornamental tack with a white metal screw head affixed to a small ferrous tack shaft. They are commonly used in conjunction with true coffin screws to give the illusion that more screws were used in the construction of the burial container. For this reason, coffin tacks 
are often referred to as "dummy screws" (Davidson 1999, 2004:402-403). Coffin tacks were available for sale in some locations from the 1850 s well into the 1900 s but were most popular between the 1850 s and the 1880 s. While the exact introduction date of this type of artifact is unclear, W. H. Nichols was granted a U.S. patent for a coffin tack on July 26, 1859 (U.S. Letter Patent No. 24911; Figure 5.14). Identification of stylistic variation in this artifact class is problematic both from a historical and an archeological perspective. Illustrations in period catalogs are often poor, thus confusing variation. Additionally, with few exceptions, the size ranges of coffin tacks are not given in catalogs. Similarly, many archeological reports do not give measurements or show profile views of coffin tacks, further inhibiting identification. Future analyses of these artifacts will depend on careful comparison of measurements with other well-documented archeological materials and useful trade catalogs.

\section{ORNAMENTAL TACK TYPE C}

Ornamental Tack Type C (Figure 5.15a) is represented by 30 artifacts from Burials 7, 8, 13, and 14 at Pioneer Cemetery (Table 5.12). This tack type consists of a domed, cylindrical, slotted, nonferrous, white metal head with a ferrous tack shaft. It had a double filigree decorative form, with the sides of the dome being slightly slanted and the lower filigree collar mirroring the very slight slant of the side. This type of tack, or at least a similar version (based on examinations of photographs), has been recovered in two cemetery excavations in Virginia and Ontario, Canada. An exact type match from the Alameda-Stone Cemetery, Tucson, Arizona, was identified based on measurements and stylistic comparison (Pye 2010a).

While no specific design patent is known to exist for this ornamental tack type, it possibly appears in at least six period trade catalogs dating from 1853 to 1903, which shows that these items were still for sale into the twentieth century even though their popularity had waned (Figure 5.15b). The two earliest catalogs, the 1853 Peck \& Walter price list, and the 1857 Peck \& Walter \& Sargent Bros. catalog (see Table 5.12), provide measurement classifications to item number, and therefore form the basis of the current coffin tack typology. The other four catalog matches were determined by stylistic similarities observed in illustrations.

\section{ORNAMENTAL TACK TYPE D}

Ornamental Tack Type D (Figure 5.16a) is represented by eight artifacts from Burials 14 and 15 at Pioneer Cemetery (Table 5.13). This tack type consists of a domed, cylindrical, slotted, nonferrous, white metal head with a flanged, filigreed brim and a ferrous tack shaft. This type has a brim with a filigreed decorative band along the outer one half of the brim. The sides of the dome are relatively straight, curving slightly at the interface with the brim, with the dome being gently curved. It, or at least a similar tack, has been recovered in three cemetery excavations in South Carolina, Texas, and Illinois dating between 1848 and 1910.

The first definite appearance of this coffin tack, with identical measurements, was in the 1857 Peck \& Walter \& Sargent Bros. catalog, and it is well illustrated in the 


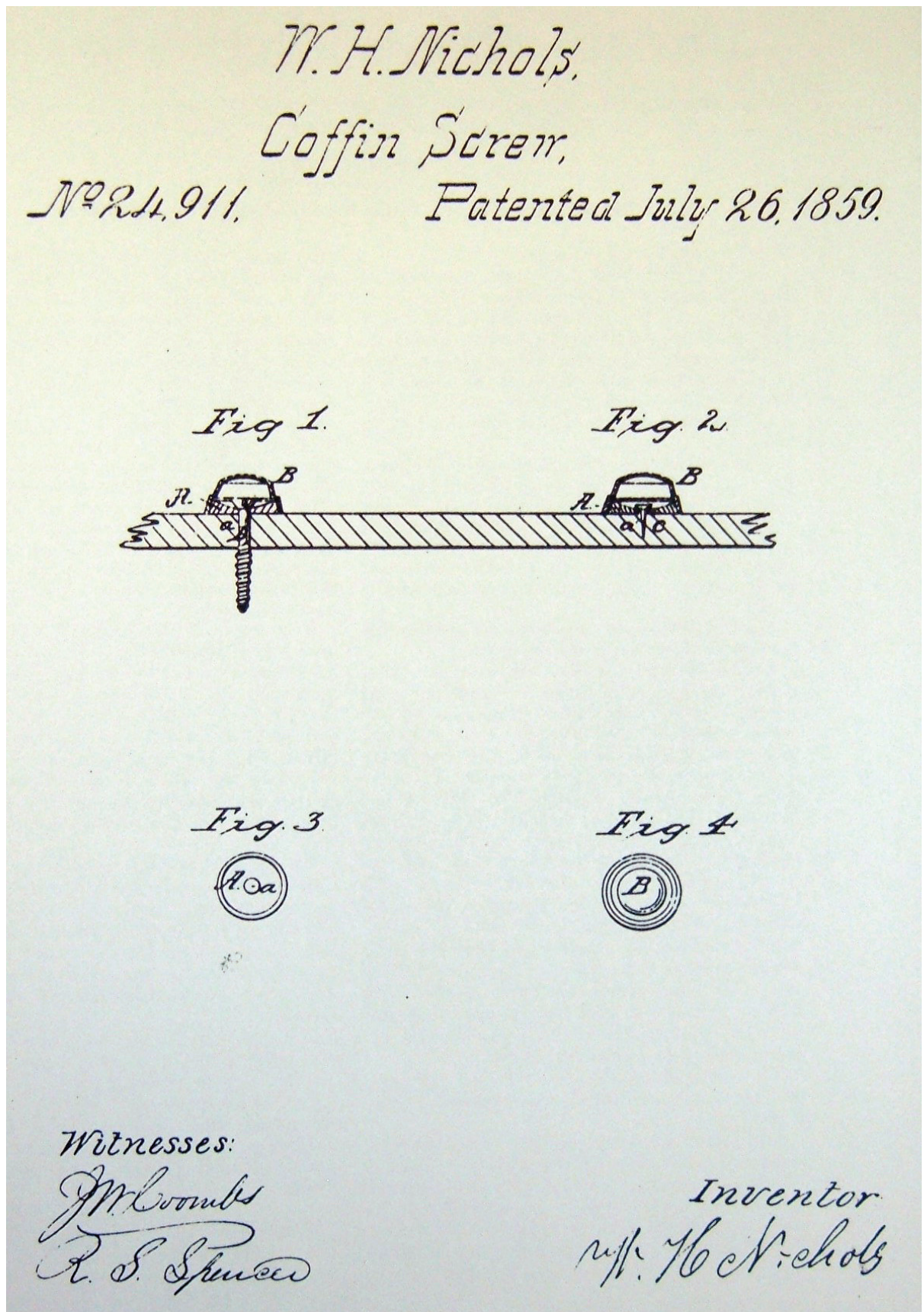

Figure 5.14. W. H. Nichols 1859 Patent No. 24,911 for coffin screw and tack.

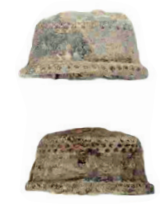

a

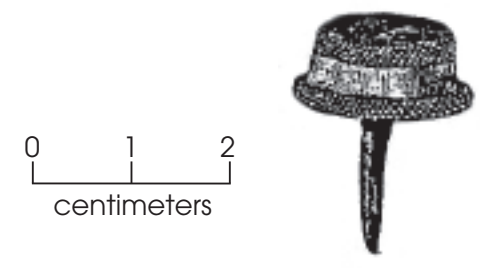

b

Figure 5.15. Ornamental Tack Type C. (a) Specimens from Pioneer Cemetery; (b) probable match as illustrated on page 109 of the 1861 Sargent \& Company Catalog and Price List. 
Table 5.12. Description of Ornamental Tack Type C

\begin{tabular}{l|l}
\hline Type No. & Ornamental Tack Type C \\
\hline Form & Double filigree, cylindrical, slotted \\
\hline Material & White metal \\
\hline \multirow{2}{*}{ Burial(s) } & Burial 7 $(\mathrm{n}=4)$ \\
\cline { 2 - 2 } & Burial 8 $(\mathrm{n}=12)$ \\
\cline { 2 - 2 } & Burial 13 $(\mathrm{n}=6)$ \\
\cline { 2 - 2 } & Burial 14 $(\mathrm{n}=8)$ \\
\hline Internal Date & N/A \\
\hline Weight & $?$ \\
\hline Dimensions & Head height $(0.262$ inches $) ;$ head diameter $(0.516$ inches $)$ \\
\hline Mold Markings & None evident \\
\hline
\end{tabular}

\begin{tabular}{l|l|l|l|l}
\hline Matches & \multicolumn{1}{|c|}{ Cemetery } & No. of Burials & \multicolumn{1}{c|}{ Dating } & \multicolumn{1}{c}{ Citation } \\
\hline 1 & Alameda-Stone Cemetery, AZ, Type 4 & 2 & $1860-1882$ & $\begin{array}{l}\text { Heilen and Grey 2010; Pye } \\
2010 \mathrm{a}\end{array}$ \\
\hline 2 & & & $2000: 468$ \\
\hline 3 & Quaker Burying Ground, VA, Type C-1 & 2 & $1784-1890 \mathrm{~s}$ & Bromberg et al. 2000 \\
\hline
\end{tabular}

\begin{tabular}{l|l|l|l|l}
\hline Matches & \multicolumn{1}{|c|}{ Catalogue } & Page (Item No.) & \multicolumn{1}{c}{ Dating } & \multicolumn{1}{c}{ Source } \\
\hline $1^{*}$ & $\begin{array}{l}\text { Peck \& Walter price list }(\$ 0.72 \text { per } \\
\text { gross) }\end{array}$ & $31($ No. 11) & 1853 & Davidson Collection \\
\hline $2^{*}$ & $\begin{array}{l}\text { Peck \& Walter \& Sargent Bros. }(\$ 0.72 \\
\text { per gross) }\end{array}$ & $52($ No. 11$)$ & 1857 & Davidson Collection \\
\hline $3^{* *}$ & Sargent and Co. & $109($ No. 26$)$ & 1861 & Yale University Libraries \\
\hline $4^{* *}$ & Warfield \& Rohr & $69($ No. 30) & circa 1880 & University of Delaware \\
\hline $5^{* *}$ & W.B. Belknap \& Co. $(\$ 0.48$ per gross) & $969($ No. 16) & 1895 & Davidson Collection \\
\hline $6^{* *}$ & Simmons Hardware Co. & $1172($ No. 16) & 1903 & Library of Congress \\
\hline
\end{tabular}

Notes: There are no known design patent matches.

Due to the fact that subtle similarities exist among this artifact class, it is difficult to precisely match types from archaeological contexts with poor preservation. Matches presented are those which are most positively correlated.

*Best match located.

**Similar item.
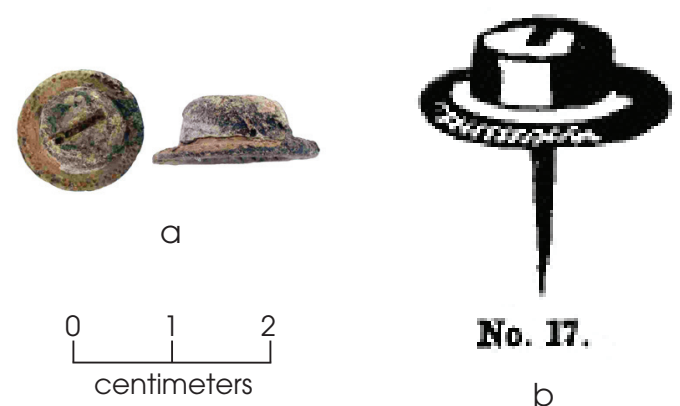

No. 17.

b

Figure 5.16. Ornamental Tack Type D. (a) Specimen from Pioneer Cemetery; (b) possible match illustrated on page 331 of the 1865 Illustrated Catalog of the Russell \& Erwin Company. 
Table 5.13. Description of Ornamental Tack Type D

\begin{tabular}{|c|c|c|c|c|c|}
\hline \multicolumn{2}{|l|}{ Type No. } & \multicolumn{4}{|l|}{ Ornamental Tack Type D } \\
\hline \multicolumn{2}{|l|}{ Form } & \multicolumn{4}{|c|}{ Flanged-filigree brim, cylindrical, slotted } \\
\hline \multicolumn{2}{|l|}{ Material } & \multicolumn{4}{|l|}{ White metal } \\
\hline \multirow{2}{*}{\multicolumn{2}{|c|}{ Burial(s) }} & \multicolumn{4}{|l|}{ Burial $14(\mathrm{n}=1)$} \\
\hline & & \multicolumn{4}{|l|}{ Burial $15(\mathrm{n}=7)$} \\
\hline \multicolumn{2}{|c|}{ Internal Date } & \multicolumn{4}{|l|}{ N/A } \\
\hline \multicolumn{2}{|c|}{ Weight } & \multicolumn{4}{|l|}{$?$} \\
\hline \multicolumn{2}{|c|}{ Dimensions } & \multicolumn{4}{|c|}{ Head height (0.24 inches); head diameter (0.682 inches) } \\
\hline \multicolumn{2}{|c|}{ Mold Markings } & \multicolumn{4}{|l|}{ None evident } \\
\hline \multicolumn{2}{|c|}{ Matches } & Cemetery & No. of Burials & \multicolumn{2}{|r|}{ Citation } \\
\hline 1 & $\begin{array}{l}\text { Mou } \\
\text { Type }\end{array}$ & asant Cemetery, SC, & 2 & $1850-1910$ & \begin{tabular}{|l} 
Trinkley and Hacker-Norton \\
1984:8
\end{tabular} \\
\hline 2 & $\begin{array}{l}\text { Free } \\
33 \\
\end{array}$ & s Cemetery, TX, Type & 4 & $1869-1884$ & Davidson 1999 \\
\hline 3 & Thur & Cemetery, IL & 1 & $1848-1900$ & Bird et al. 2003:Appendix G:13 \\
\hline Matches & & Catalogue & Page (Item No.) & Dating & Source \\
\hline $1^{*}$ & $\begin{array}{l}\text { Peck } \\
(\$ 0.9 \\
\end{array}$ & $\begin{array}{l}\text { lter, \& Sargent Bros. } \\
\text { gross) }\end{array}$ & $52($ No. 30) & 1857 & Davidson Collection \\
\hline $2^{*}$ & Russ & Erwin Mfg. Co. & 331 (No. 17) & 1865 & Library of Congress \\
\hline $3 * *$ & $\begin{array}{l}\text { Marl } \\
\text { gros: }\end{array}$ & \& Strong $(\$ 0.62$ per & 6 (No. 34) & 1865 & Davidson Collection \\
\hline $4 * *$ & Cran & ed, and Co. & 169 (No. 34) & 1877 & Library of Congress \\
\hline $5^{* *}$ & Cinc & Coffin Co. & \begin{tabular}{|l} 
broadside (No. \\
$34)$
\end{tabular} & circa 1880 & Strong National Museum of Play \\
\hline $6^{* *}$ & C. $\mathrm{Si}$ & Norris \& Co. & $9($ No. 34$)$ & circa 1880 & University of Delaware \\
\hline $7 * *$ & $\begin{array}{l}\text { C. } \mathrm{Si} \\
(\$ 0.5 \\
\end{array}$ & $\begin{array}{l}\text { Norris \& Co. [Price list] } \\
\text { gross) }\end{array}$ & 2 (No. 34) & circa 1880 & University of Delaware \\
\hline $7 * *$ & Warf & Rohr & 6 (No. 34) & circa 1880 & University of Delaware \\
\hline $8 * *$ & F.H. & 30.70 per gross) & 58 (No. 34) & 1881 & Pye Collection \\
\hline $9 * *$ & $\begin{array}{l}\text { W.B. } \\
\text { gross }\end{array}$ & lap \& Co. $(\$ 1.25$ per & 969 (No. 34) & 1895 & Davidson Collection \\
\hline $10 * *$ & Simr & Hardware Co. & 1172 (No. 34) & 1903 & Library of Congress \\
\hline
\end{tabular}

Notes: There are no known design patent matches.

Due to the fact that subtle similarities exist among this artifact class, it is difficult to precisely match types from archaeological contexts with poor preservation. Matches presented are those which are most positively correlated.

*Best match located.

**Similar item.

1865 Russell \& Erwin Mfg. Co. catalog (Figure 5.16b). Visually similar forms appear in eight other trade catalogs between these early catalogs and 1903. No specific design patent is known to exist for this ornamental tack type, but as mentioned previously, they were popular in the early 1850 s through the 1880 s and were still sold into the twentieth century.

\section{Coffin Screws}

The general hardware category of coffin screws consists of a form of hardware with a white metal screw cap affixed to a ferrous screw shaft. The top 
of the white metal cap typically has a slot to accept a screwdriver for mounting (Davidson 1999, 2004:400). Mainfort and Davidson (2006:141) suggests that coffin screws were commonly used in sets of four or six, with one screw placed at each corner of the burial container, with the possibility of an extra set being mounted at either the shoulder or waist of the container. It should be noted that in cases where only two are present, these screws are often mounted at the head and the foot ends of the container.

Coffin screws were in common usage by the $1850 \mathrm{~s}$; they make their first known appearance in the 1853 Peck and Walter Manufacturing Company price list. A U.S. patent was granted to W. H. Nichols for this type of screw on July 26, 1859 (U.S. Letter Patent No. 24911; see Figure 5.14). Coffin screws were replaced by thumbscrew forms in large part in the 1870s and 1880s and by the late 1880s were carried only by general hardware suppliers and jobbers (Mainfort and Davidson 2006:141). However, the overall temporal range of coffin screws runs from about 1850 to 1910 . The problems associated with the identification and analysis of coffin tacks mentioned above apply to coffin screws as well.

\section{Coffin Screw Type A}

Coffin Screw Type A (Figure 5.17a) is represented by six artifacts, two each from Burials 8, 12, and 15 at Pioneer Cemetery (Table 5.14). This screw type consists of a double filigreed, domed, cylindrical, slotted, non-ferrous, white metal head with a ferrous screw shaft. The sides of the dome are slanted slightly and the dome is gently

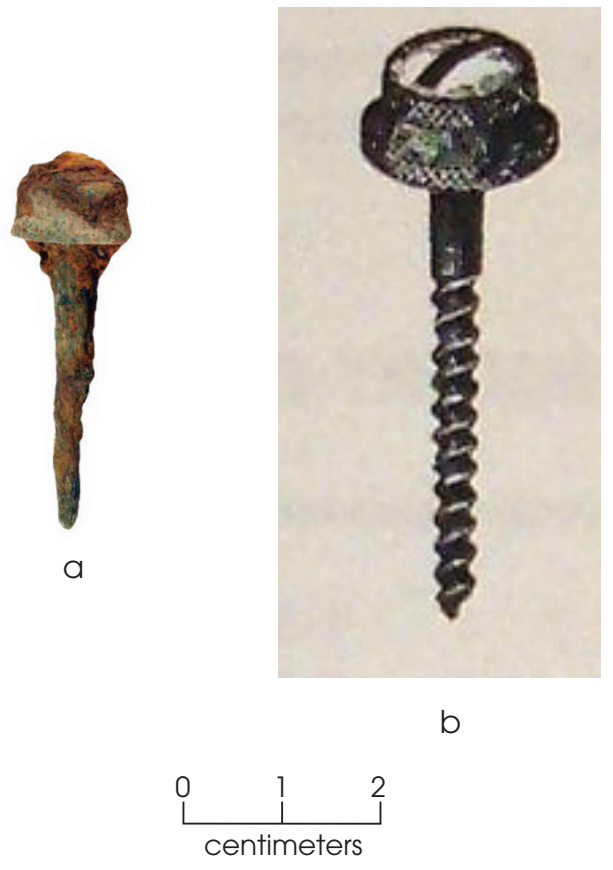

Figure 5.17. Coffin Screw Type A. (a) Specimen from Pioneer Cemetery; (b) possible match as illustrated on page 417 of the 1874 Sargent \& Company Price List and Illustrated Catalog. curved. The filigreed collar is relatively short and is not especially prominent (as observed in the digital artifact images from Pioneer Cemetery). Coffin Screw Type A, or at least a similar type of screw, has been recovered in four cemetery excavations in Arkansas, Texas, Kentucky, and Indiana. Based on measurements, the Pioneer Cemetery Coffin Screw Type A matches the Eddy Cemetery Coffin Screw Type 1 (Mainfort and Davidson 2006). All other matches are based only on visual similarity.

The first definite appearances of this screw were in the 1853 Peck \& Walter price list and the 1857 Peck \& Walter \& Sargent Bros. catalog. Both 11/4-in. and 11/2-in. coffin screws were recovered from the excavations at Pioneer Cemetery. In these two early catalogs, prices were $\$ 0.85$ and $\$ 0.90$ per gross, respectively, for these sizes of screw. Similar matches (Figure 5.17b) based on visual comparison appear in six other trade catalogs dating from 1866 to 1877 (see Table 5.14). No specific design patent is known to exist for this ornamental tack type, but as mentioned previously, they were popular generally from the early 1850 s through to the 1880 s but were still sold into the twentieth century. 
Table 5.14. Description of Coffin Screw Type A

\begin{tabular}{|c|c|c|c|c|c|}
\hline \multicolumn{2}{|l|}{ Type No. } & \multicolumn{4}{|l|}{ Coffin Screw Type A } \\
\hline \multicolumn{2}{|l|}{ Form } & \multicolumn{4}{|l|}{ Double filigree, cylindrical, slotted } \\
\hline \multicolumn{2}{|l|}{ Material } & \multicolumn{4}{|l|}{ White metal } \\
\hline \multirow{3}{*}{\multicolumn{2}{|c|}{$\operatorname{Burial}(\mathrm{s})$}} & \multicolumn{4}{|l|}{ Burial $8(n=2)$} \\
\hline & & \multicolumn{4}{|l|}{ Burial $12(\mathrm{n}=2)$} \\
\hline & & \multicolumn{4}{|l|}{ Burial $15(\mathrm{n}=2)$} \\
\hline \multicolumn{2}{|c|}{ Internal Date } & \multicolumn{4}{|l|}{ N/A } \\
\hline \multicolumn{2}{|l|}{ Weight } & \multicolumn{4}{|l|}{$?$} \\
\hline \multicolumn{2}{|c|}{ Dimensions } & \multicolumn{4}{|c|}{$\begin{array}{l}\text { Total screw length (with shaft) (1.2 inches-1.5 inches); head height ( } 0.262 \text { inches); head } \\
\text { diameter ( } 0.516 \text { inches) }\end{array}$} \\
\hline \multicolumn{2}{|c|}{ Mold Markings } & \multicolumn{4}{|l|}{ None evident } \\
\hline Matches & & Cemetery & No. of Burials & Dating & Citation \\
\hline 1 & \multicolumn{2}{|c|}{ Eddy Cemetery, AR, Coffin Screw Type 1} & 1 & $1880-1900$ & $\begin{array}{l}\text { Mainfort and } \\
\text { Davidson (2006) }\end{array}$ \\
\hline 2 & \multicolumn{2}{|c|}{ Freedman's Cemetery, TX, Coffin Screw Type 5} & 15 & $1869-1884$ & Davidson (1999) \\
\hline 3 & \multicolumn{2}{|c|}{ Vardeman Cemetery, KY, Coffin Screw Type 1} & 1 & 1861 & Davidson (n.d.) \\
\hline 4 & \multicolumn{2}{|c|}{ Michigan City Old Graveyard, IN } & 1 & $1835-1864$ & Strezewski 2003:22 \\
\hline Matches & \multicolumn{2}{|r|}{ Catalogue } & $\begin{array}{c}\text { Page } \\
\text { (Item No.) }\end{array}$ & Dating & Source \\
\hline $1^{*}$ & \multicolumn{2}{|c|}{$\begin{array}{l}\text { Peck \& Walter price list (1 1/4 inches - } \$ 0.85 \text { per } \\
\text { gross; } 1 \text { 1/2 inches - } \$ 0.90 \text { per gross })\end{array}$} & 31 (No. 7) & 1853 & Davidson Collection \\
\hline $2^{*}$ & \multicolumn{2}{|c|}{$\begin{array}{l}\text { Peck \& Walter, \& Sargent Bros. }(11 / 4 \text { inches } \\
\text { - } \$ 0.85 \text { per gross; } 11 / 2 \text { inches - } \$ 0.90 \text { per gross) }\end{array}$} & 51 (No. 7) & 1857 & Davidson Collection \\
\hline $3 * *$ & \multicolumn{2}{|c|}{ Markham \& Strong } & 6 & 1875 & Davidson Collection \\
\hline $4^{* *}$ & \multicolumn{2}{|c|}{ Sargent \& Co. } & 125 & 1866 & Davidson Collection \\
\hline $5^{* *}$ & \multicolumn{2}{|c|}{ Sargent \& Co. } & $152($ No. 16,18$)$ & 1869 & Davidson Collection \\
\hline $6^{* *}$ & \multicolumn{2}{|c|}{ Sargent \& Co. } & 281 (No. 16, 18) & 1871 & Library of Congress \\
\hline $7 * *$ & \multicolumn{2}{|c|}{ Sargent \& Co. } & 417 (No. 16, 18) & 1874 & Library of Congress \\
\hline $8 * *$ & \multicolumn{2}{|c|}{ Crane, Breed, and Co. } & 168 (No. 16) & 1877 & Library of Congress \\
\hline
\end{tabular}

Notes: There are no known design patent matches.

Due to the fact that subtle similarities exist among this artifact class, it is difficult to precisely match types from archaeological contexts with poor preservation. Matches presented are those which are most positively correlated.

*Best match located.

***Possible match.

\section{Coffin Screw Type B}

Coffin Screw Type B (Figure 5.18) is represented by one artifact from Burial 17 at Pioneer Cemetery (Table 5.15). Stylistically, this screw is similar to Coffin Screw Type A, but the head dimensions vary slightly. Due to the lack of measurements reported in most archeological contexts, it is difficult to identify definitive matches. The first and only concrete catalog appearances of this screw 


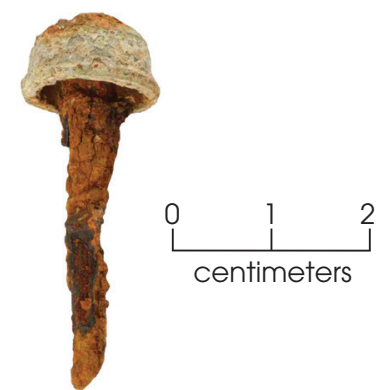

Figure 5.18. Coffin Screw Type B from Burial 17 at Pioneer Cemetery. based on measurements of the white meta 1 head were in the 1853 Peck \& Water price list and the 1857 Peck \& Walter \& Sargent Bros. catalog. The coffin screw from Pioneer Cemetery measures roughly $1 \frac{1 / 2}{2}$ inch long and would have cost $\$ 1.00$ per gross at the time these catalogs were printed. No specific design patent is known to exist for this coffin screw type. As mentioned previously, coffin screws were popular from the early 1850s through the 1880s but were still sold well into the twentieth century.

Table 5.15. Description of Coffin Screw Type B

\begin{tabular}{|c|c|c|c|c|c|}
\hline \multicolumn{2}{|l|}{ Type No. } & \multicolumn{4}{|l|}{ Coffin Screw Type B } \\
\hline \multicolumn{2}{|l|}{ Form } & \multicolumn{4}{|l|}{ Double filigree, cylindrical, slotted } \\
\hline \multicolumn{2}{|l|}{ Material } & \multicolumn{4}{|l|}{ White metal } \\
\hline \multicolumn{2}{|l|}{ Burial(s) } & \multicolumn{4}{|l|}{ Burial $17(n=1)$} \\
\hline \multicolumn{2}{|c|}{ Internal Date } & \multicolumn{4}{|l|}{ N/A } \\
\hline \multicolumn{2}{|l|}{ Weight } & \multicolumn{4}{|l|}{$?$} \\
\hline \multicolumn{2}{|c|}{ Dimensions } & \multicolumn{4}{|c|}{$\begin{array}{l}\text { Total screw length (with shaft) (1.45 inches); head height (0.28 inches); head diameter (0.54 } \\
\text { inches) }\end{array}$} \\
\hline \multicolumn{2}{|c|}{ Mold Markings } & \multicolumn{4}{|c|}{ None evident } \\
\hline Matches & & Catalogue & Page (Item No.) & Dating & Source \\
\hline $1^{*}$ & $\begin{array}{l}\text { Peck } \\
\text { gross }\end{array}$ & \& Walter price list (1 1/2 inches - $\$ 1.00$ per & $31($ No. 12) & 1853 & Davidson Collection \\
\hline $2 *$ & $\begin{array}{l}\text { Peck } \\
\text { per g1 }\end{array}$ & $\begin{array}{l}\text { \& Walter, \& Sargent Bros. (1 1/2 inches - } \$ 1.00 \\
\text { oss) }\end{array}$ & 51 (No. 12) & 1857 & Davidson Collection \\
\hline
\end{tabular}

Notes: There are no definitive matches from archaeological excavations.

There are no known design patent matches.

Due to the fact that subtle similarities exist among this artifact class, it is difficult to precisely match types from archaeological contexts with poor preservation. Matches presented are those which are most positively correlated.

*Best match located.

\section{COFFIN SCREW TYPE C}

Coffin Screw Type C (Figure 5.19a) is represented by one artifact from Burial 3 at Pioneer Cemetery (Table 5.16). This artifact type is a domed, cylindrical, slotted, non-ferrous, white metal head with a ferrous screw shaft. The sides of the dome are slanted slightly and the dome is gently curved. The filigreed collar is slanted slightly mirroring the slant of the sides. This type of screw, or at least a similar version of it, was found in four cemetery excavations, two of which, Meadowlark Cemetery in Kansas (Pye 2007), and the Alameda-Stone Cemetery in Arizona (Pye 2010a) were based on measurement comparisons and visual similarity. These cemeteries ranged in date from 1850 to 1900, which reflects the general time range for the popularity of coffin screws. 
Coffin Screw Type C appears in three period trade catalogs between 1857 and 1895 . The first definite appearance of this screw based on measurements was in the 1857 Peck \& Walter \& Sargent Bros. catalog. This screw is well illustrated in the 1895 catalog of the W. B. Belknap \& Company (Figure 5.19b). Since the artifact from Pioneer Cemetery no longer has its screw shaft, it is not possible to determine its length. In 1857, the $1 \frac{1}{2}$ inch version of this screw cost $\$ 1.00$ per gross. Prices increased over time, and the $1 \frac{1}{2}$ inch screw cost $\$ 1.52$ per gross in 1865 (see Table 5.16). No specific design patent is known to exist for this screw type, but as mentioned previously, coffin screws were generally popular from the early 1850 s through the 1880 s but were still sold into the twentieth century.
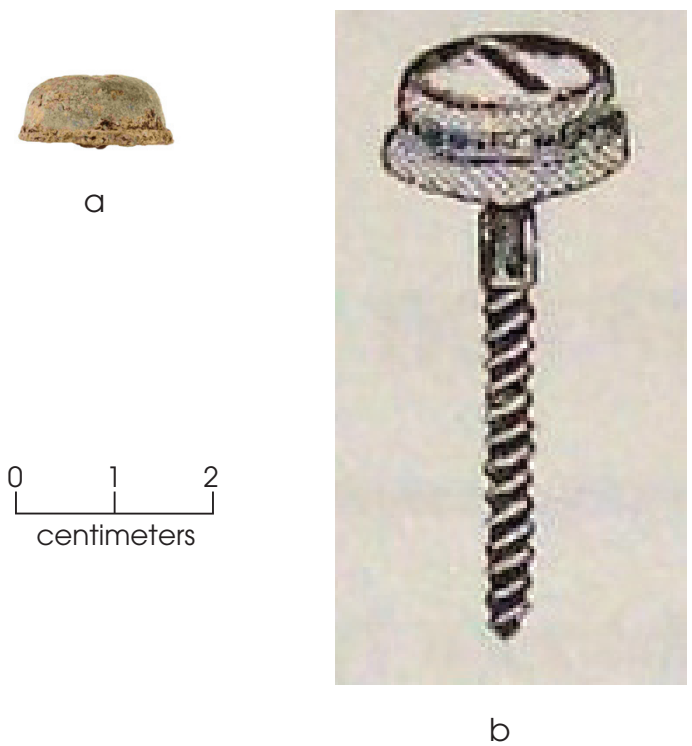

Figure 5.19. Coffin Screw Type C. (a) Specimen from Burial 3 at Pioneer Cemetery; (b) probable match as illustrated on page 969 in the $1895 \mathrm{~W}$. B. Belknap \& Company Illustrated Catalog.

Table 5.16. Description of Coffin Screw Type C

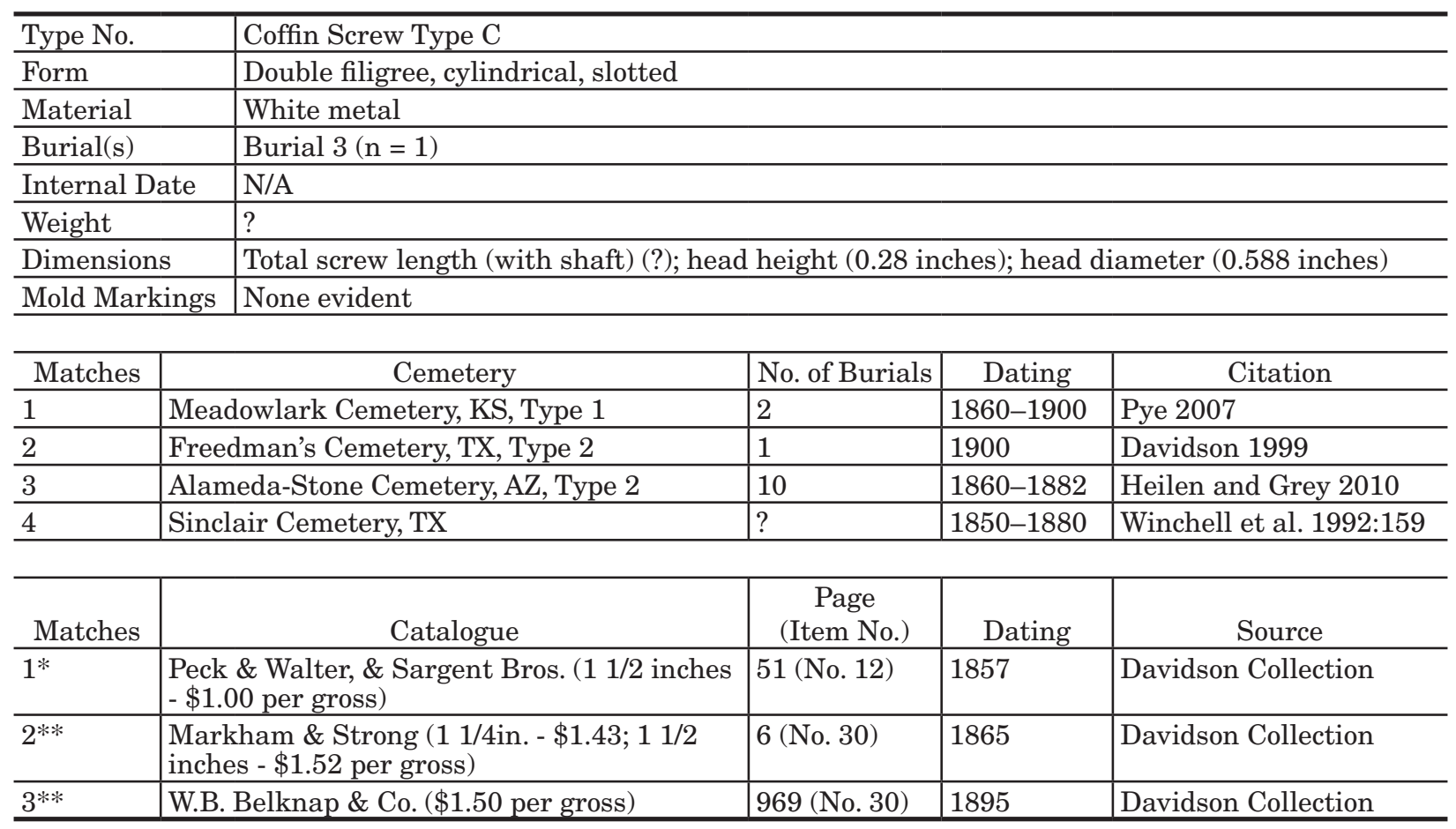

Notes: There are no known design patent matches.

Due to the fact that subtle similarities exist among this artifact class, it is difficult to precisely match types from archaeological contexts with poor preservation. Matches presented are those which are most positively correlated.

*Best match located.

**Similar item. 


\section{BURIAL CHRONOLOGY AND SOCIOECONOMIC IMPLICATIONS}

Twelve of the 14 burials excavated from Pioneer Cemetery revealed a small sample of burial container hardware, consisting of four handle types, two sets of thumbscrews and escutcheons, three types of coffin screws, and four types of ornamental tacks, including one stud type, two coffin tacks, and one type of lining tack. Tables 5.17 and 5.18 show the associations of hardware types with all of the Pioneer Cemetery burials, as well as provide specific artifact counts, measurements, and analyst observations. Six of the burials (Burials $3,7,12,13,14,15$ ) contained only coffin screws or other types of ornamental tacks and no other decorative hardware types. Three (Burials 8, 16,17) contained coffin screws or ornamental tacks as well as other types of hardware such as handles or thumbscrews/escutcheons. One burial (Burial 11) contained handles and a set of thumbscrews and escutcheons but no other forms of hardware. Based purely on the date ranges of the recovered burial container hardware (see individual hardware tables), the investigated burials can be dated to sometime between the early 1850 s and the 1910 s. It is necessary, however, to consider the historical context of the cemetery in reference to the material culture.

Deed records indicate that the Pioneer Cemetery property was acquired in 1888 (Tiné and Boyd 2003; see Chapter 2). However, it is likely that interments occurred on the property prior to this time. It is generally accepted that coffin screws and coffin tacks were most popular between 1850 and the late 1870 s to early 1880 s, when they were phased out of mainstream mortuary catalogs (Mainfort and Davidson 2006:141). Therefore, the burials containing only these types of artifacts likely occurred prior to the formal establishment of Pioneer Cemetery. It is not uncommon, however, for outmoded hardware to appear in later burials.

Mainfort and Davidson (2006:142) note that coffin screws were associated with marked graves dated to 1882 and 1890 at Eddy Cemetery, Arkansas. Late use of coffin screws was also recorded in Freedman's Cemetery, Dallas, Texas, where two burials containing coffin screws were dated to ca. 1900 (Davidson 1999, cited in Mainfort and Davidson 2006:142). Finally, two burials, one dating to 1894, recovered during the Choke Canyon Reservoir project in McMullen County, Texas, contained coffin screws (Fox 1984).

There are a number of interrelated explanations for this phenomenon. Tiné and Boyd (2003:31) attempt to understand the presence of coffin screws in the three prior burials excavated from the Pioneer Cemetery in terms of a rural versus urban context. Coffin screws, tacks, and other forms of outmoded hardware could have been used for longer periods of time because they would have been available through local general stores or undertakers who had accumulated a back stock of merchandise over the years they were in business. This idea was proposed by Hacker-Norton and Trinkley (1984) in their study of the A. L. Calhoun collection, which consisted of mortuary hardware that had been curated in a rural South Carolina general store and would have potentially been available for sale as late as the 1920s. This notion could be further supported in the Pioneer Cemetery context by the fact that 


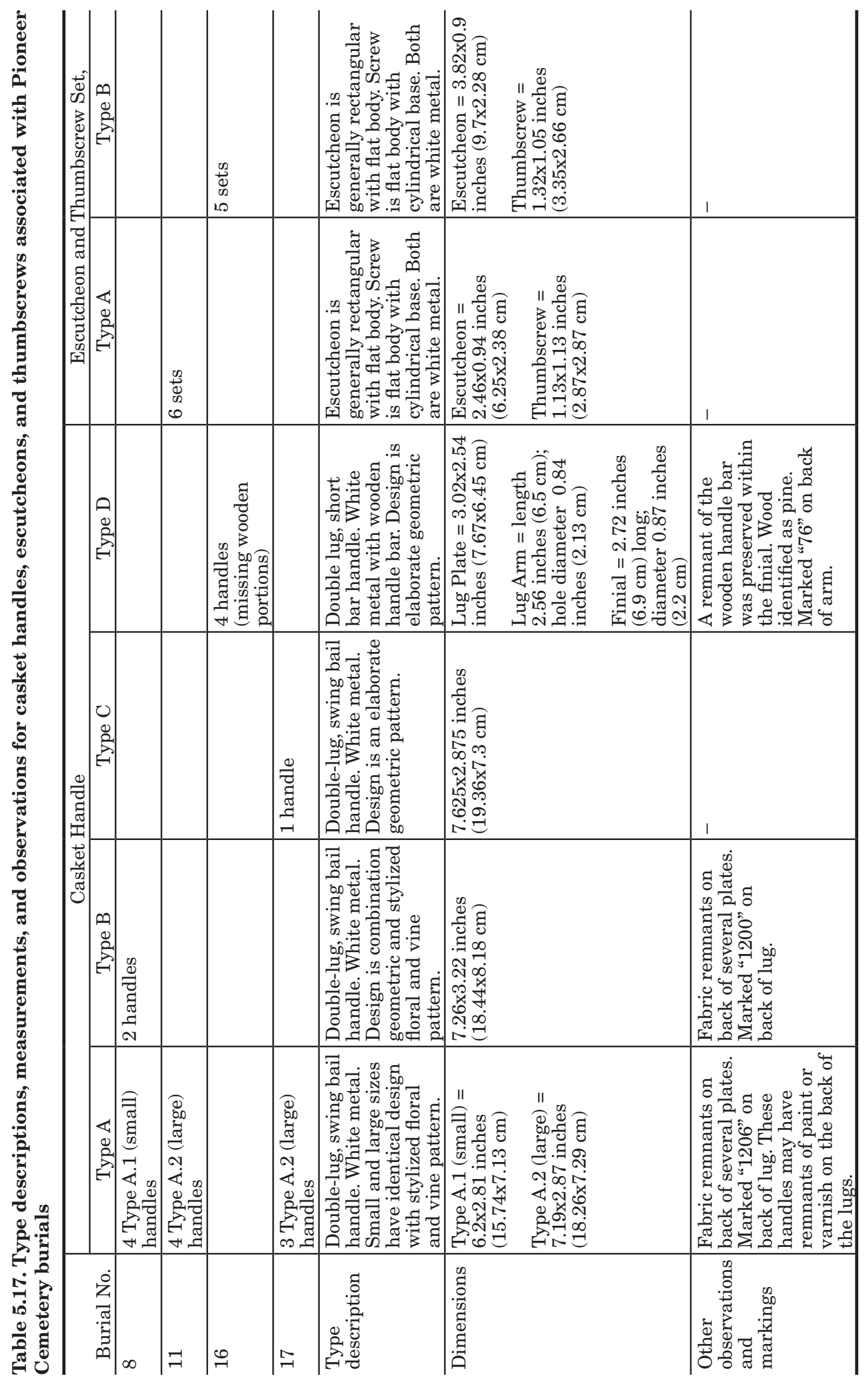




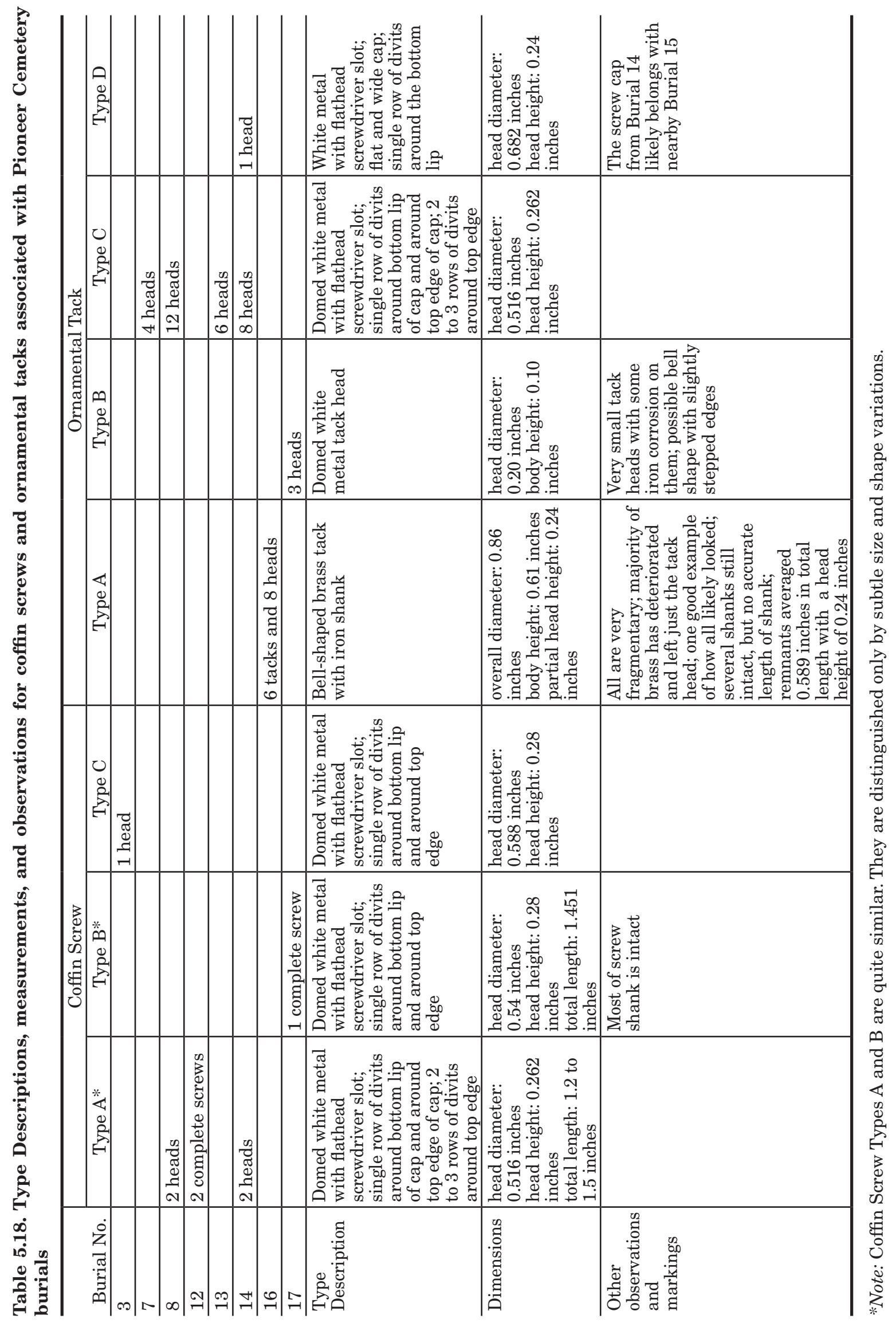


handles are mix and matched in two burials (Burials 8 and 17) in order to make an even set of four or six (see Table 5.17).

It is very reasonable to assume that rural shopkeepers and undertakers would have accumulated back stocks, but it is also possible that these individuals were purchasing already outmoded merchandise from regional catalogs, traveling company salesman, jobbers, or general hardware catalogs, which continued to carry earlier forms of hardware, like coffin screws and tacks, well into the twentieth century (Mainfort and Davidson 2006:141; Tiné and Boyd 2003:31). From an economic standpoint, it is important to recognize that if hardware was being purchased from back stock in both rural and urban contexts, the total costs would likely be reduced. If people were purchasing mismatched sets of handles or other types of hardware, as has already been discussed in the Pioneer cemetery hardware collection, costs would also have been lower. The majority of burials in this sample contained either coffin screws or coffin tacks or both. As noted in period trade catalogs, the costs associated with these items actually decreased as time passed, so if the Pioneer Cemetery burials occurred in the early end of the temporal range (ca. 1850-1870), costs would have been more significant compared with income, whereas elaboration of the burial container would have been more accessible to low-income African Americans in a later temporal context (ca. 1870-1910).

\section{CONCLUSION}

This chapter has described several general classes of mortuary hardware and specific descriptions of those represented in the burial excavations in Pioneer Cemetery, Brazoria County, Texas. The analyzed artifacts suggest that the 12 interments with burial container hardware occurred between 1853 and 1910. Given the general popularity of certain hardware types, however, most burials probably occurred between 1860 and the 1880s, with one burial (Burial 16, which contained the short bar handle) taking place between the 1880s and 1900 . 



\section{CHAPTER 6: ANALYSIS OF PERSONAL ITEMS}

Aaron R. Norment and Douglas K. Boyd

Each of the 14 burials excavated at Pioneer Cemetery contained personal artifacts other than coffin/casket hardware. Most of these objects are typically found with individuals who are laid to rest: clothing-related items, objects of adornment, and various other personal items. Also recovered were several unique items not associated with clothing or funerary hardware. The personal items recovered from the Pioneer Cemetery burials are described here and summarized in Table 6.1.

Many of the coffins and/or caskets were excavated from at or below the water table, and periodic fluctuating water levels disturbed many of the burials. Most of the human remains were disarticulated and scattered within the coffin/casket, as were most artifacts within the burial. Due to these conditions, some of the smaller objects may have been missed. Figure 6.1 is a photograph of Burial 15 showing the disturbed nature of the remains within the casket. Notably, many small bones had been moved by the fluctuating water table, and some were found inside the whiteware saucer at the head end of the grave.

\section{CLOTHING AND ADORNMENT}

Buttons were the most common personal artifact recovered. Fifty-five buttons were found, and 52 are white Prosser buttons of various sizes (ranging from 0.33 to 0.69 inches). Each burial had at least one white Prosser button present. Of those, 35 measure between 0.39 and 0.49 inches, and 13 measure 0.49 in. One of the Prosser buttons recovered during the 2003 excavations was not measured. Prosser buttons date after 1840, following the patent of the Prosser process issued to Richard Prosser of London June 17, 1840 (Sprague 2002:113). France quickly cornered the market for these buttons, eventually driving English manufacturers out of business (Sprague 2002). Prosser buttons soon became mass produced and readily available (Sprague 2002:124). There is not a specific ending date for the manufacture of Prosser buttons, but production continued into the 1950s and 1960s, when plastic buttons delivered the fatal blow to the Prosser button industry (Sprague 2002:115).

At Pioneer Cemetery, three common types of Prosser buttons were recovered (Figure 6.2a-c): the four-hole dish; the two-hole pantywaist; and the piecrust (Sprague 2002:112). The breakdown of buttons recovered is as follows: 37 four-hole dish type; 12 two-hole pantywaist type (Tiné and Boyd 2003:Figure 5.7), and 2 four-hole piecrust type. The majority were recovered from the torso and head/neck region, suggesting they were likely shirt or blouse buttons. A few were recovered 


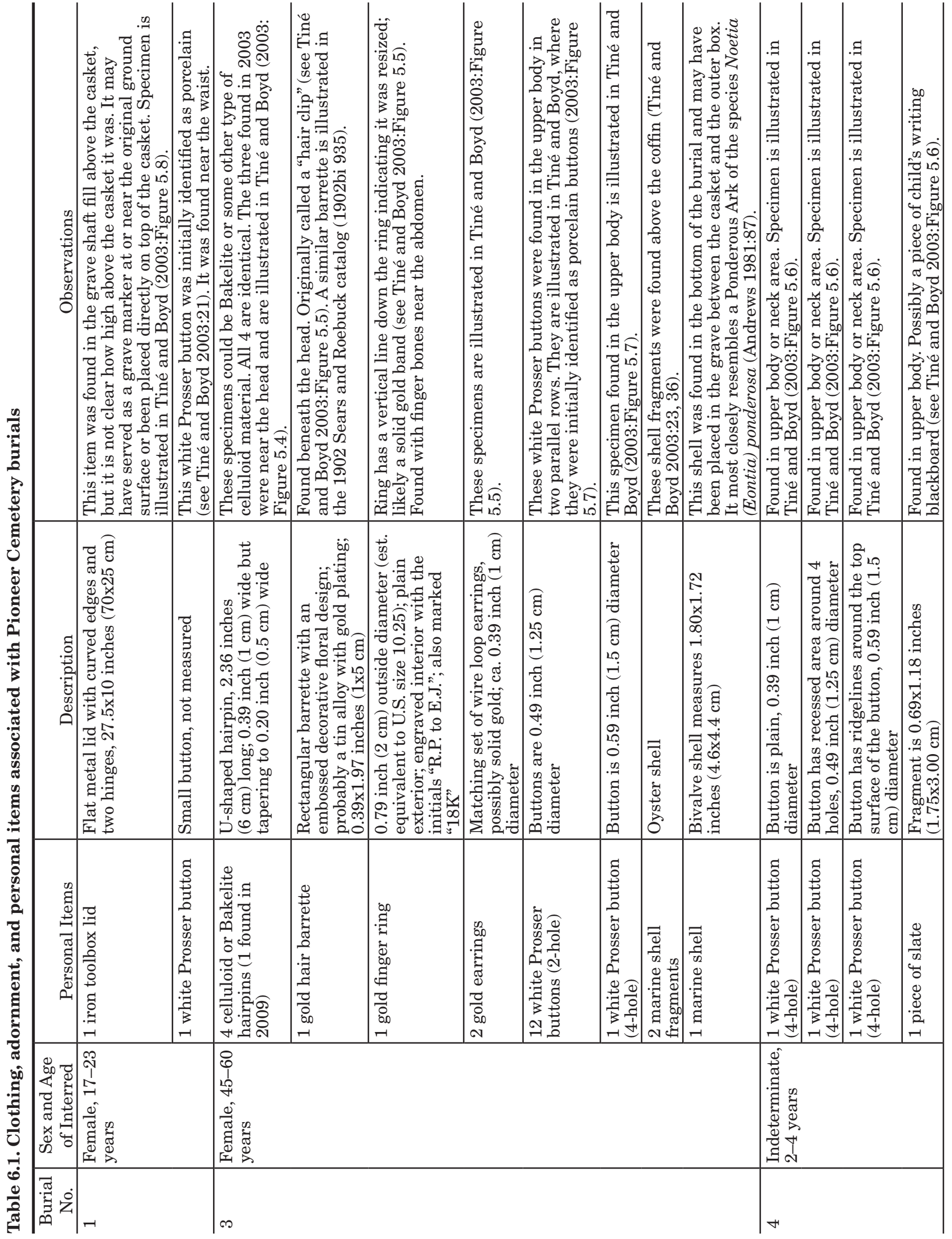




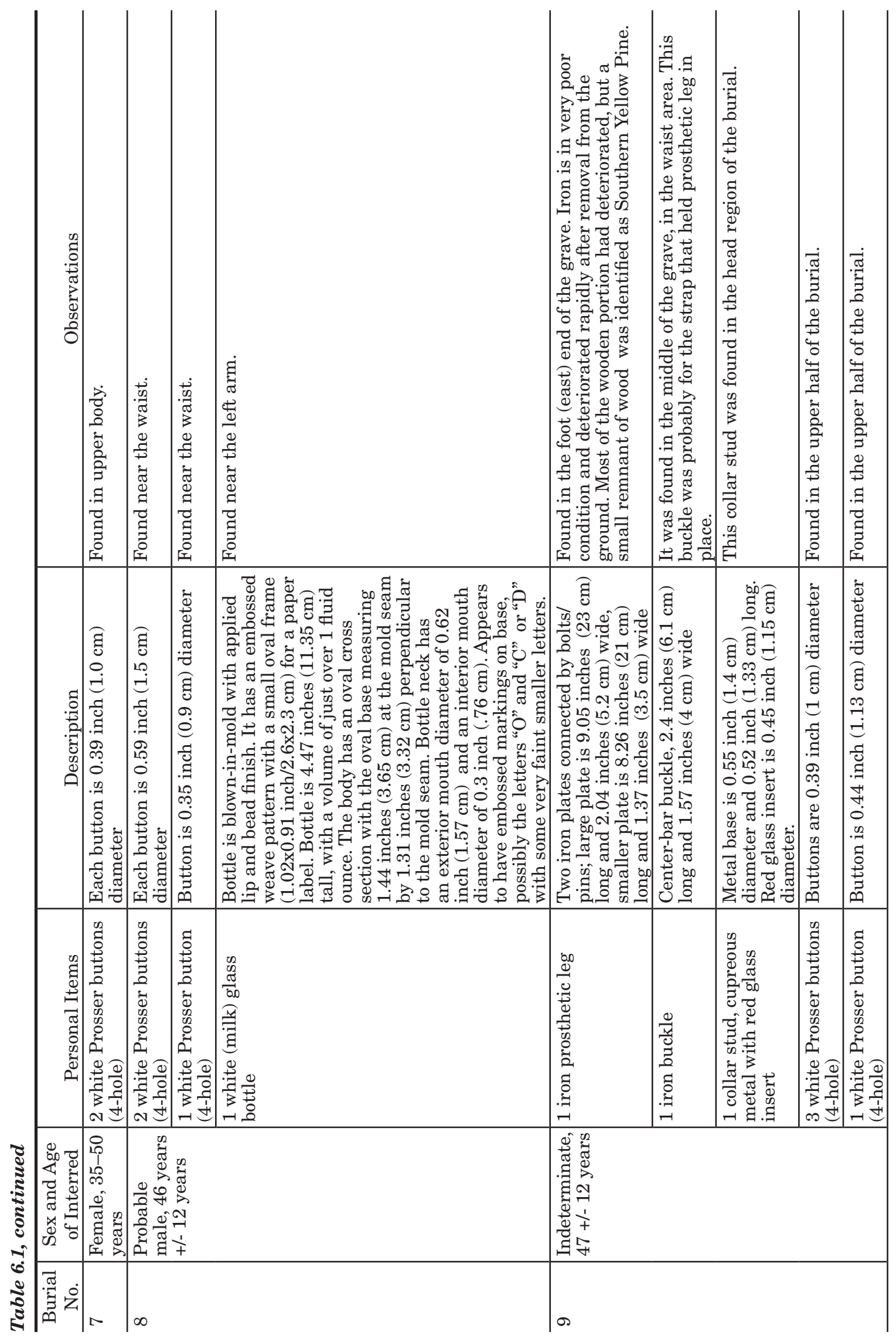




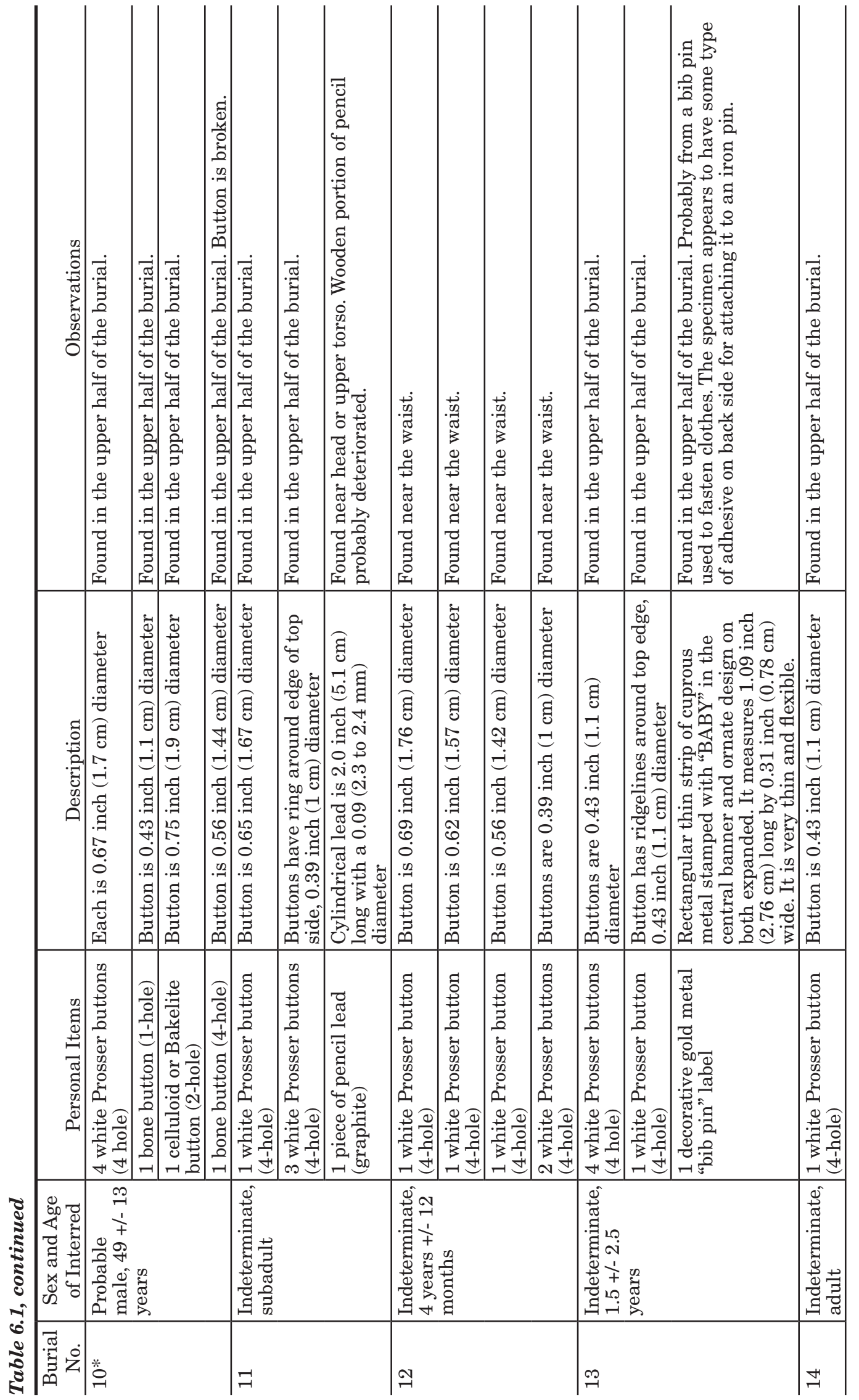




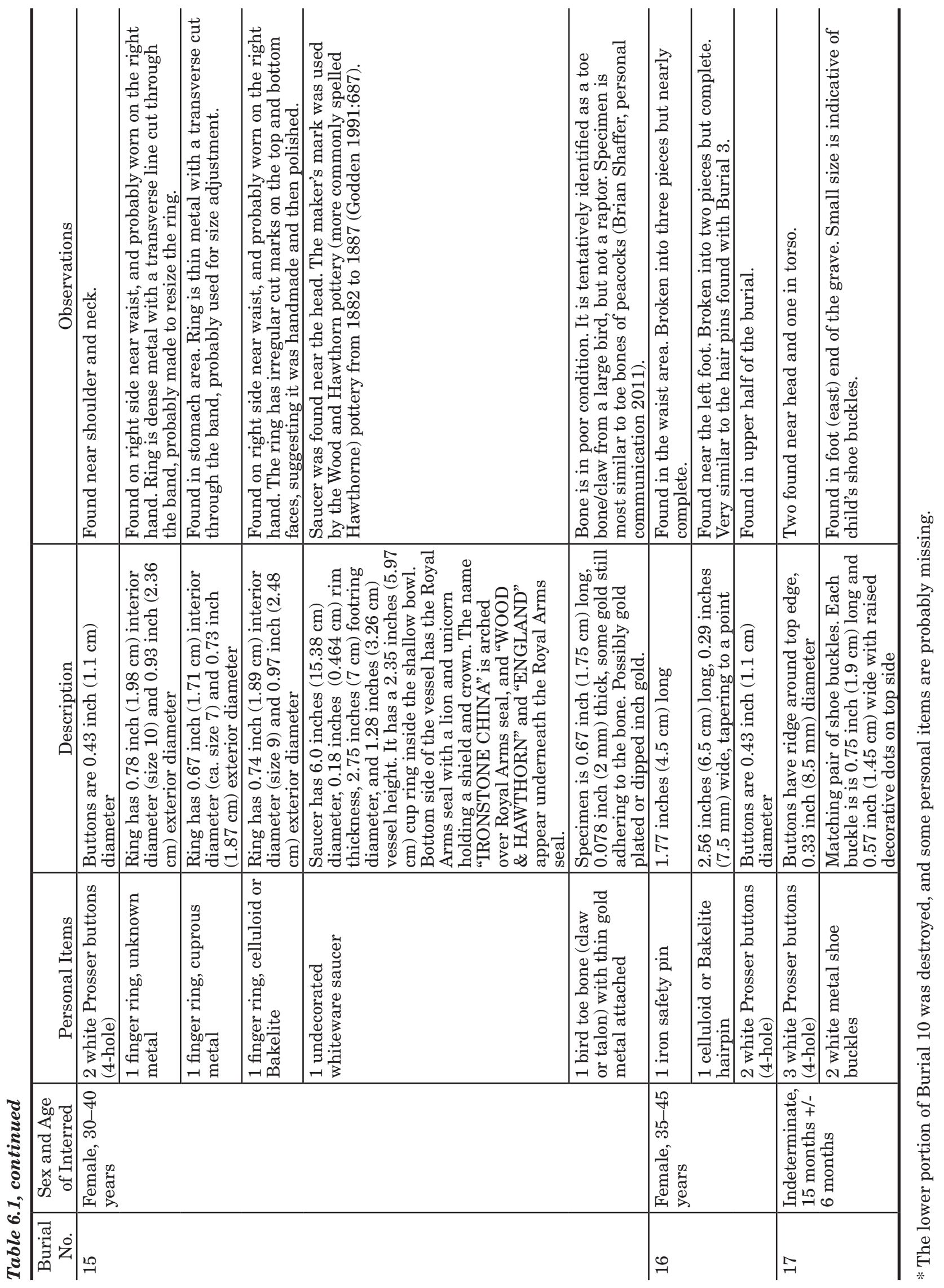




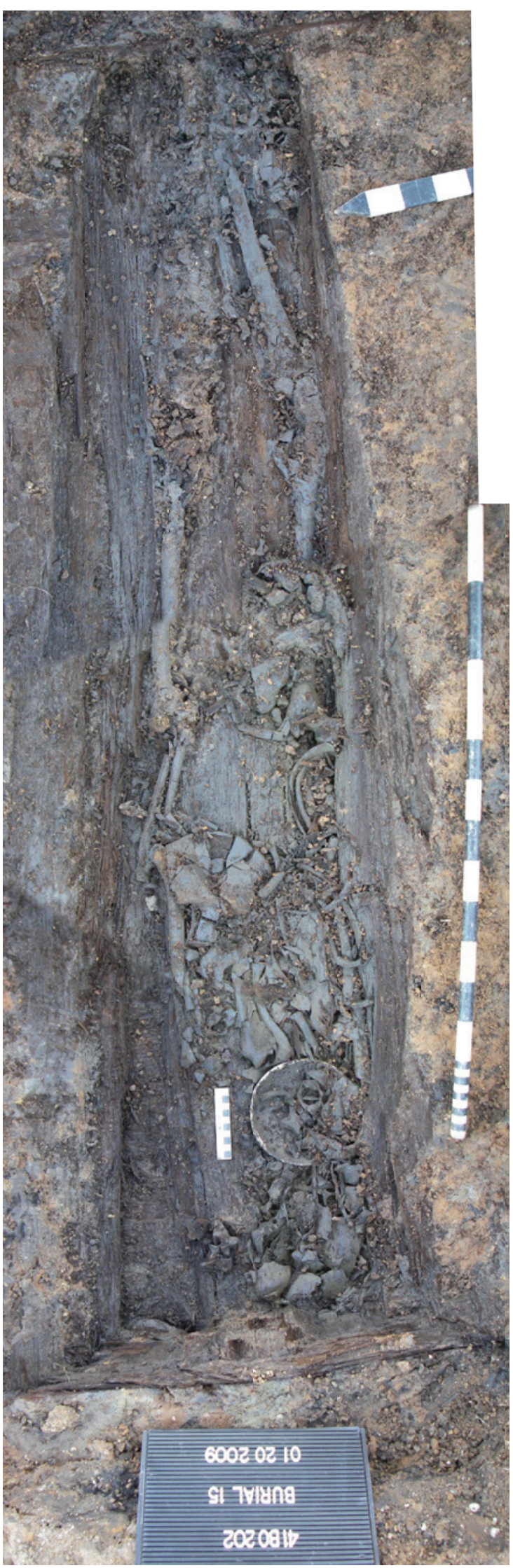



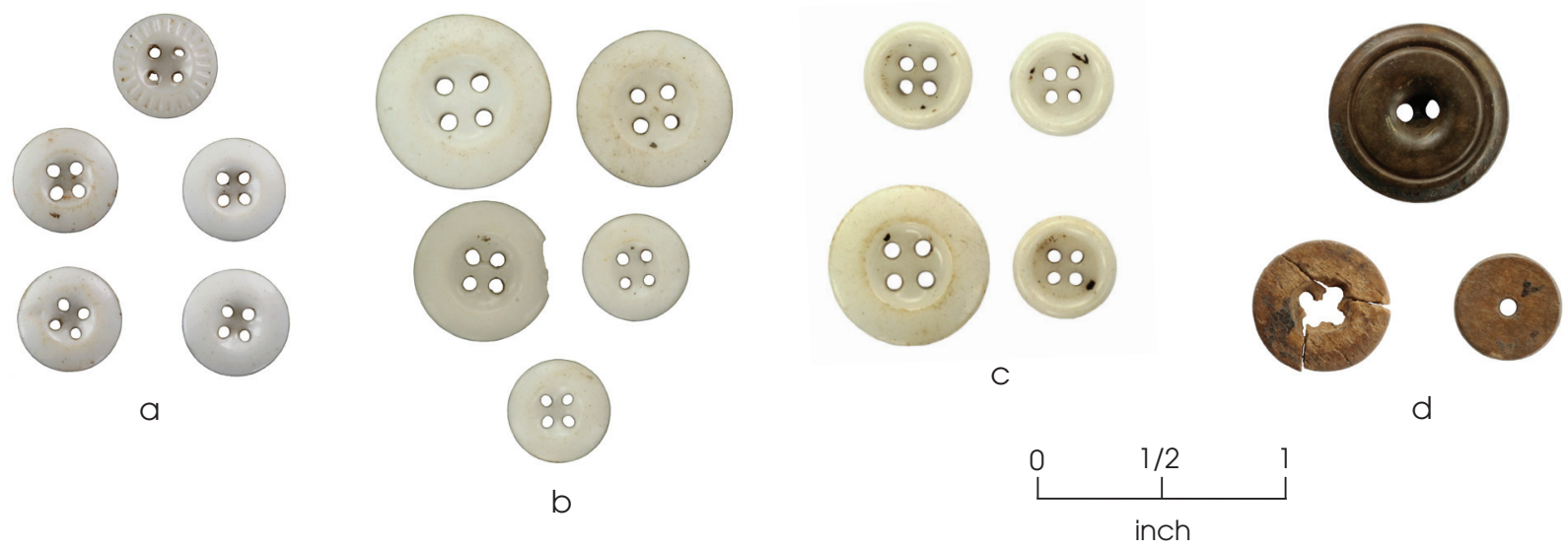

Figure 6.2. Buttons from Pioneer Cemetery burials. (a-c) Selection of Prosser four-hole buttons from various burials; (d) celluloid plastic and bone buttons from Burial 10.

from the waist region. This could indicate additional shirt or blouse buttons or possible undergarment buttons. Burial 3, a 45-60-year-old woman, was the only burial to contain two-hole pantywaist buttons, all of which were located around the torso. Based on their size and location, they are likely shirt or blouse buttons, from both the cuff and the torso. All other burials contained the four-hole dish or piecrust Prosser types, a testament to their popularity.

In addition to the Prosser buttons, three buttons of different materials were recovered. One appears to be a celluloid plastic, and the other two are bone (Figure $6.2 \mathrm{~d}$ ). These three buttons were the only non-Prosser buttons recovered, and all three were found in Burial 10. The celluloid button has a diameter of 0.75 inches and has two holes. The term "Bakelite" is often used to describe these types of buttons, but due to the amount of variation in the process of manufacturing and labeling of these buttons, the general term "celluloid" is used to refer to the material. The bone buttons measure 0.56 and 0.43 inches in diameter, with the larger having four holes and the smaller having a single hole. On one side of the smaller bone button, there appears to be a pilot hole where the button was placed so the thread hole would be centered and straight. There was no identification made as to what animal the bone came from, but Owens (2000:410) mentions that cattle bones were often used to make bone buttons due to their constant availability. Bone buttons were used primarily for utilitarian purposes, such as undergarments (typically men's) and suspender attachments (Owens 2000:410). It is likely that the single-hole bone button is actually a "mold" for a cloth-covered button, but only the bone core has survived (Hinks 1995).

Various other artifacts related to personal adornment were recovered. Five hairpins were found (Figure 6.3a). Four of the pins were found in Burial 3 (Tiné and Boyd 2003:31, Figure 5.4) and one was recovered from Burial 16; both of which were identified as female. The material is difficult to identify, and the Montgomery Ward \& Co. catalog from 1895 has several examples of hard rubber hairpins (Montgomery Ward \& Co. 1895:87), but none are celluloid plastic or Bakelite. 

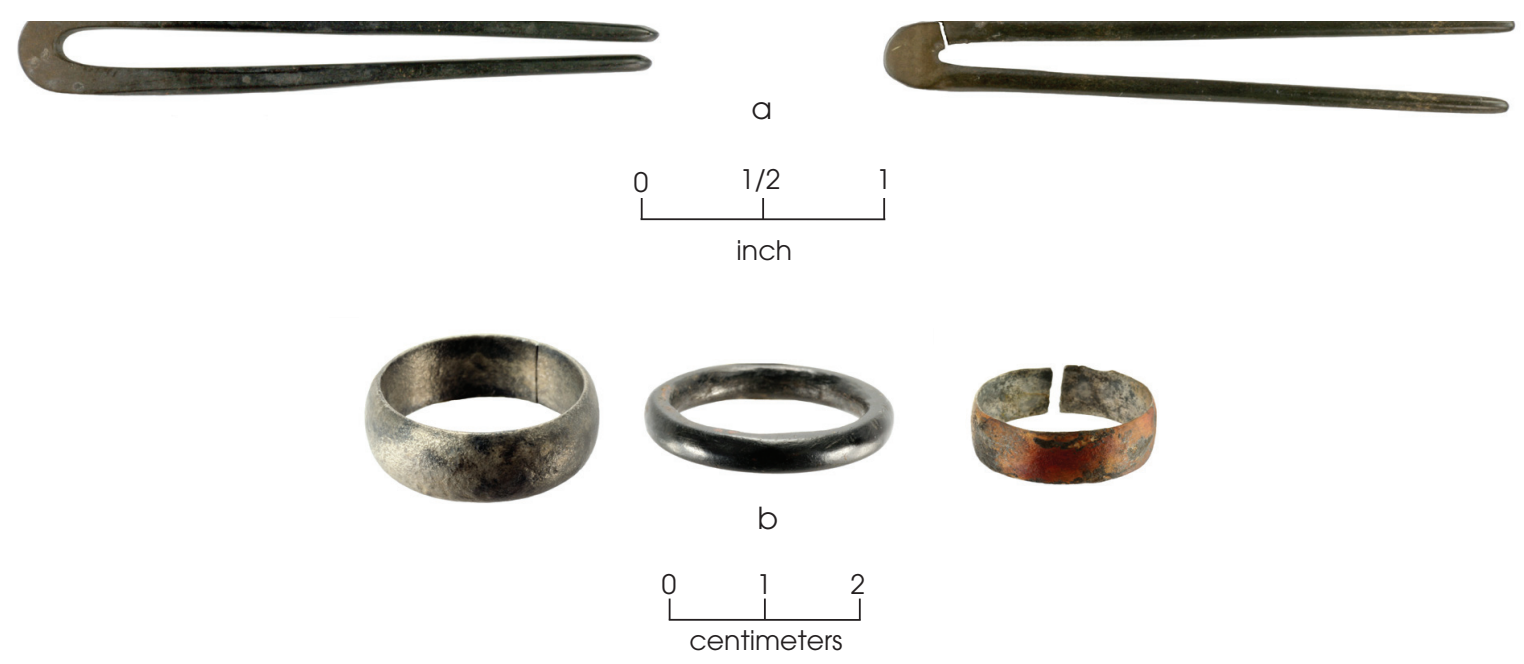

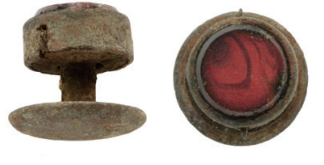

C

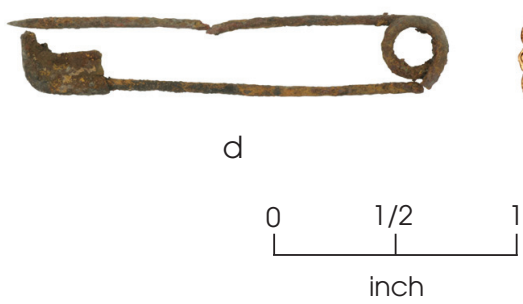

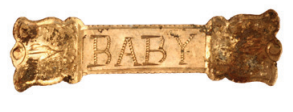

e

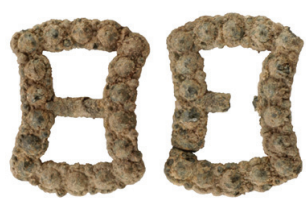

f

Figure 6.3. Jewelry and clothing items from Pioneer Cemetery burials. (a) Hard rubber hair pins from Burials 3 and 16; (b) finger rings from Burial 15; (c) collar stud from Burial 9; (d) safety pin from Burial 16; (e) "BABY" bib pin from Burial 13; (f) child's shoe buckles from Burial 17.

Four finger rings were recovered from the excavations (Figure 6.3b). One found in Burial 3 (Tiné and Boyd 2003:Figure 5.5), an adult female, appears to be a wedding band based on its size, and the inscription on the inside of the band reads "R.P. to E.J." The ring is also marked as "18K" on the inside of the band. The other three finger rings were found with Burial 15, also a female. One of these also appears to have been a wedding band made of an unknown metal. It was put through an acid test to see if the metal was precious and the results came back as the ring being a nonprecious metal, most likely a white metal alloy or "pot" metal. One of the other rings is a plain, cuprous ring of a simple design. The third appears to be a celluloid plastic material that has various cut marks that appear to be from the making of the ring. Based on the cut marks, it is possible the ring was handmade. The Montgomery Ward \& Co. 1895 catalog (pages 165, 166) depicts several styles of plain bands, both solid gold and plated.

Also in Burial 3 were two gold earrings and a single gold hair barrette (Tiné and Boyd 2003:Figure 5.5). The earrings are small, plain hoops, and the barrette is embossed with an elaborate floral design and is likely plated tin or tin alloy. The pre- 1900 catalogs did not offer this item for sale, but that does not necessarily mean that the article was not available from other sources. The 1902 Sears, Roebuck \& Co. catalog (1902a:1093) advertises five varieties of similar items called "Ladies hair 
lock retainers" or "new hair barrettes." Burial 3 yielded many clothing and personal adornment items, which could be a reflection of this woman's social status.

One collar stud was recovered from Burial 9 (see Figure 6.3c), an adult of indeterminate sex. It is thought to be a collar stud because only one item like this was recovered. The 1895 Montgomery Ward \& Co. catalog (p. 173) has 16 examples of "collar buttons." The collar stud from Burial 9 closely resembles item number "20102, separable stone inset," and has a red swirled glass or stone inset.

A single safety pin was recovered from Burial 16 (Figure 6.3d). An attempt was made to identify the fragments based on the types identified from Freedman's Cemetery in Dallas, but the Burial 16 pin was too fragmentary to make an accurate comparison. However, based on similarities to Types A, 1GI, and 1HI styles defined at the Freedman's Cemetery, the safety pin from Pioneer Cemetery could date to after 1878 (Owens 2000:424-427). It is not one of the early designs with only a wire frame and closure.

A single bib pin (Figure 6.3e) was recovered from Burial 13. Owens (2000:430) describes the common bib pin as a "gold bar, rectangular in form, with a decorative outline, usually with engraved decorations or set stones." The specimen from Pioneer Cemetery has the word "BABY" engraved on its front. It is a very thin, gold foil-like piece that once adhered to another surface, but the gold label is all that remains. The 1895 Montgomery Ward \& Co. catalog (p. 176) illustrates several examples described as "Baby Pins."

The only other clothing-related items recovered are two small shoe buckles (Figure 6.3f) found in Burial 17, a toddler of indeterminate sex. They are made of a white metal alloy and have decorative raised dots around the edge.

\section{PROSTHETIC LEG HARDWARE}

Excavation of Burial 9 yielded a prosthetic leg, similar to what would be recognized as a "peg" leg (Figure 6.4). What remains of the prosthetic is the iron brace parts that made up the load-bearing portion of the lower leg. The main portion of the prosthesis consists of two parallel iron straps secured with two large screws (Figure 6.4a), one near the base (distal end) and one near the top (proximal end). These large iron straps would have been on either side of a wooden shank that served as the actual support, and several smaller iron strap braces and screws also were found (Figure 6.4b). The main section of the prosthesis measures ca. 10 inches long, and is ca 3.5 inches at its widest point, tapering to ca. 2 inches wide at its distal end. Some small fragments of wood found within the iron straps were identified as southern yellow pine (see Appendix D). Also recovered was a single buckle, probably the strap buckle for keeping the prosthetic in place (Figure 6.4c). It is an iron, center-bar buckle that measures ca. 2.5 inches long. The buckle was found along the center right edge of the casket wall and was probably moved by fluctuating water levels, which disturbed the contents of the casket (perhaps because it was still attached to a leather strap). The brace was in the lower portion of the grave, and the absence of lower right leg bones indicates that the prosthetic was for the right leg. 


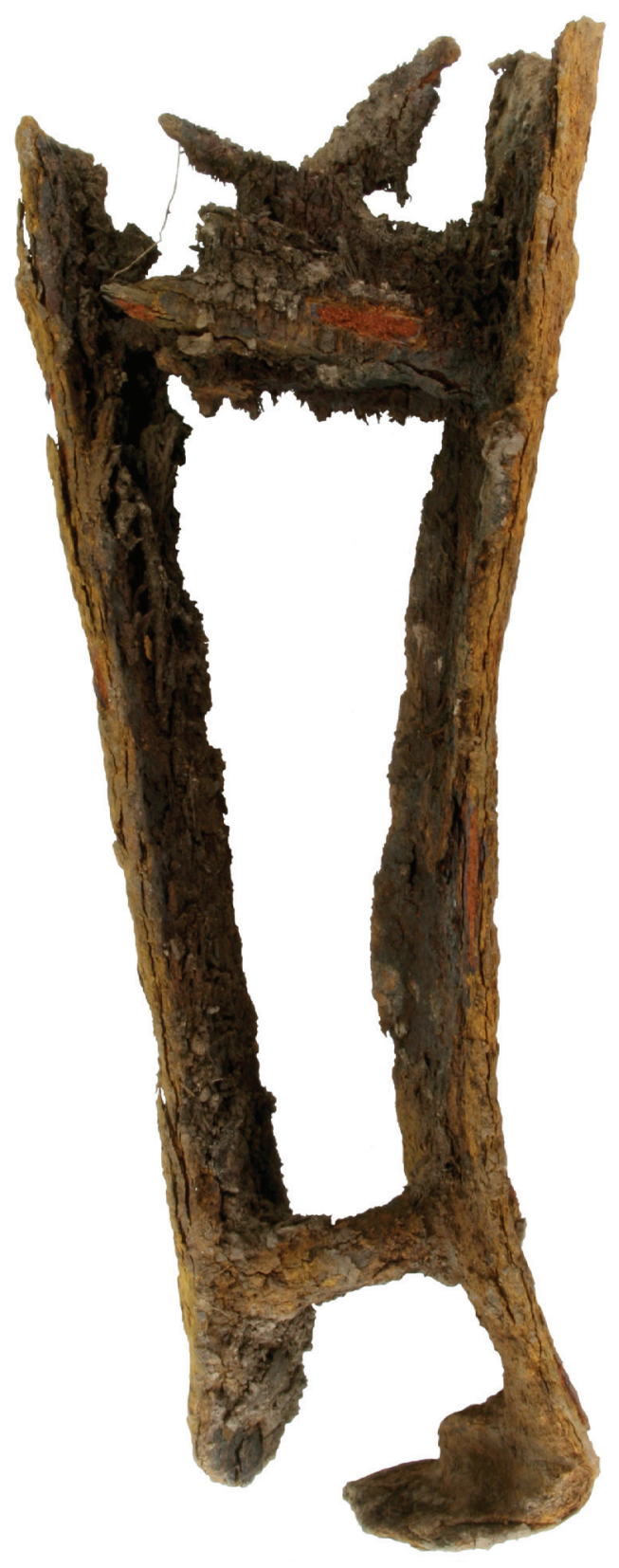

a
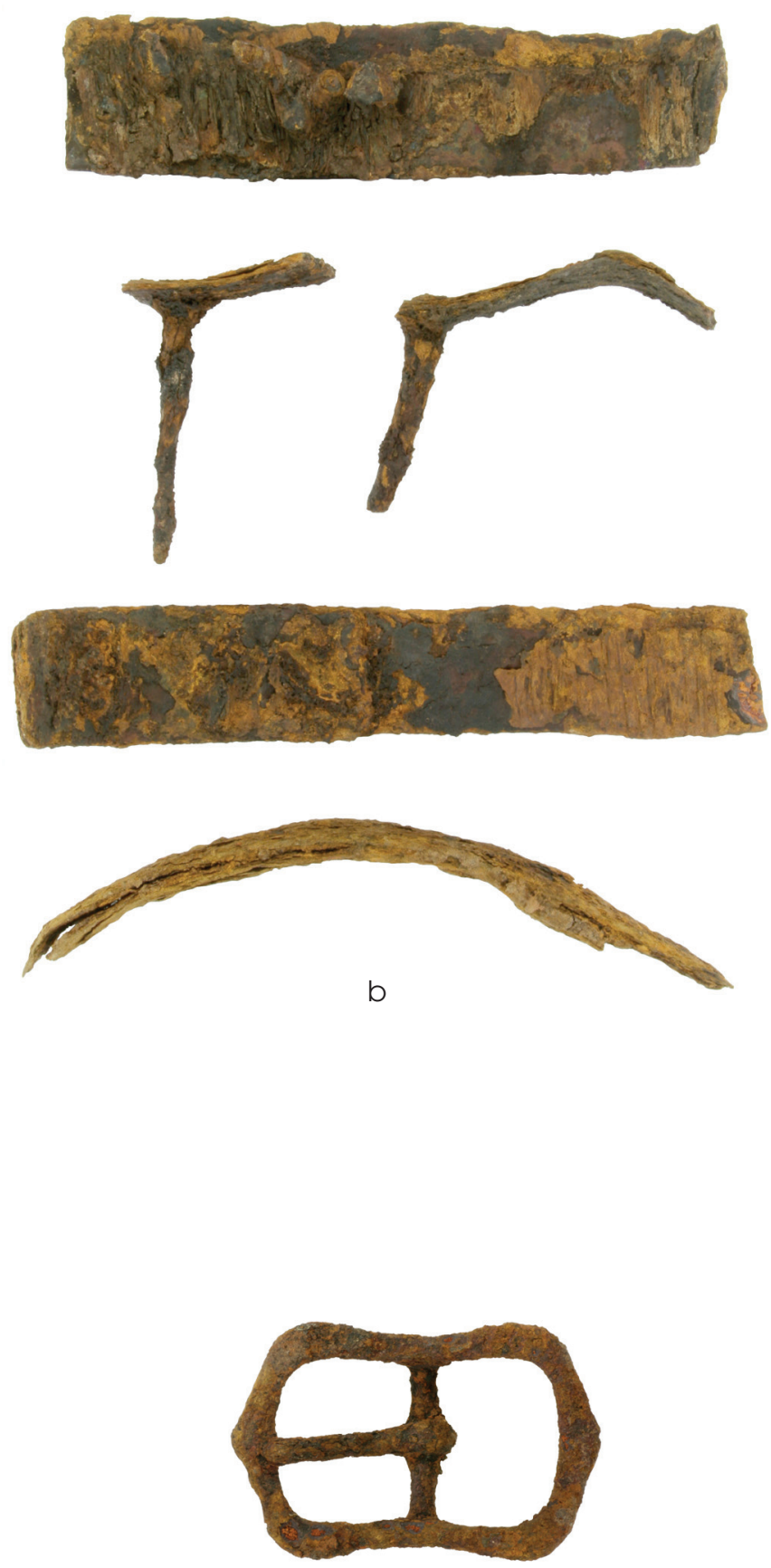

C

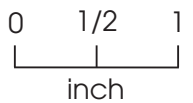

Figure 6.4. Iron pieces and buckle of prosthetic leg from Burial 9. (a) Main straps and screws; (b) smaller straps and screws ; (c) probable strap buckle for securing the prosthesis. 
Based on evidence from historic cemetery archeological investigations, Owsley (1995) examined nineteenth-century surgical practices and noted that "evidence of autopsy, amputation, and surgical experimentation in historic North American skeletal samples is rare" (p. 126). The iron and wood prosthesis associated with Burial 9 is an interesting find, then, especially for what it reveals about healthcare practices in the late nineteenth century. In this case, this man's (probable male) right distal femur was too poorly preserved to estimate how long he lived after the amputation, but he certainly lived long enough to have been fitted with a prosthesis. Not all amputations during that ere were so successful. An amputation in 1873 failed to save the life of Wilson S. Keith, who was wounded in an Indian attack while on a cattle drive. He died quickly and was buried, along with his freshly amputated left lower leg, in the Seven Rivers Cemetery in Eddy County, New Mexico (Ferguson 1993:IV-51 to IV-53).

\section{GRAVE OFFERINGS}

Traditional African American burial practices commonly involve placing many types of offerings on graves.

Black graves are made distinct by the placement of a wide variety of offerings on top of the burial mound....Most of these items are pottery or pressed-glass containers, but many different objects are encountered, including cups, saucers, bowls, clocks, salt and pepper shakers, medicine bottles, spoons, pitchers, oyster shells, conch shells, white pebbles, toys, dolls' heads, bric-a-brac statues, light bulbs, tureens, flashlights, soap dishes, false teeth, syrup jugs, spectacles, cigar boxes, piggy banks, gun locks, razors, knives, tomato cans, flower pots, marbles, bits of plaster, toilet tanks. These objects, when arranged on a group of graves, constitute a visual environment which in Afro-American tradition is seen as the world of the spirits, often the spirits of ancestors. Grave-yard goods are a statement of homage; their function is to keep a tempestuous soul at rest. Far from being heaps of junk, funeral offerings are sanctified testimonies; material messages of the living to placate the potential fury of the deceased (Vlach 1978:139).

Several unique items recovered during excavations at Pioneer Cemetery are possible grave offerings. A lid from a hinged metal toolbox was encountered in the upper shaft fill at the west end of Burial 1 during the 1999 TxDOT investigations (Tiné and Boyd 2003:Figure 5.8). The toolbox may have been a cherished item buried with the deceased, or it may have served as a marker for the grave because a commercial headstone was unaffordable or unavailable.

In association with Burial 3, two fragments of oyster shell were present in the grave shaft fill above the outer box lid, and one marine shell found in the bottom of the grave (Figure 6.5) is identified as a bivalve of the species Ponderous Ark, or Noetia (Eontia) ponderosa (Andrews 1981:87). Although these shells could be accidental inclusions from previous scraping activity, they are likely burial offerings. In the South, burials were often decorated with various kinds of objects, including shells placed on top of the grave. Shells were a particularly common offering on 


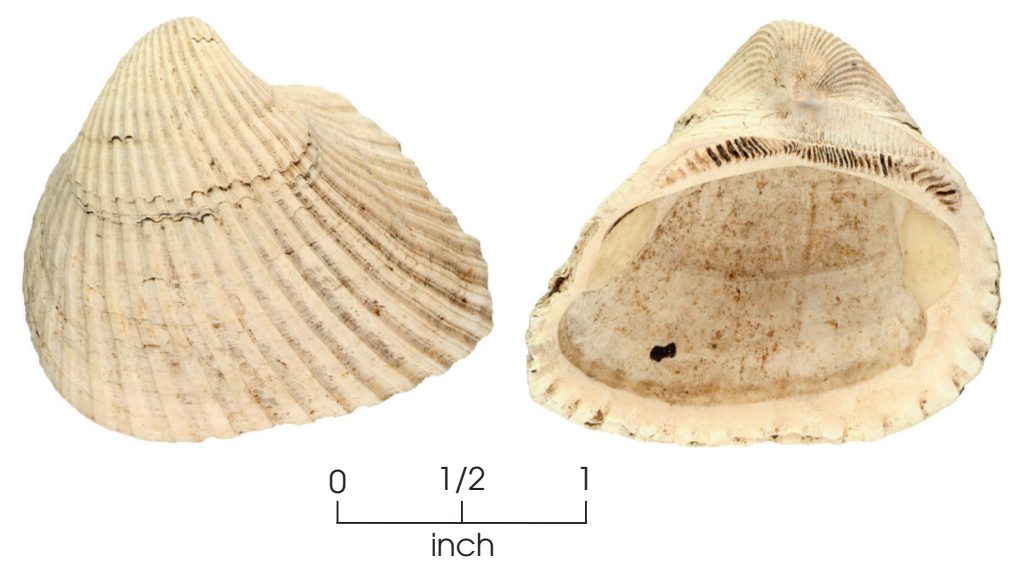

Figure 6.5. Marine shell from Burial 3. The shell is identified as Ponderosa Ark, or Noetia (Eontia) ponderosa.

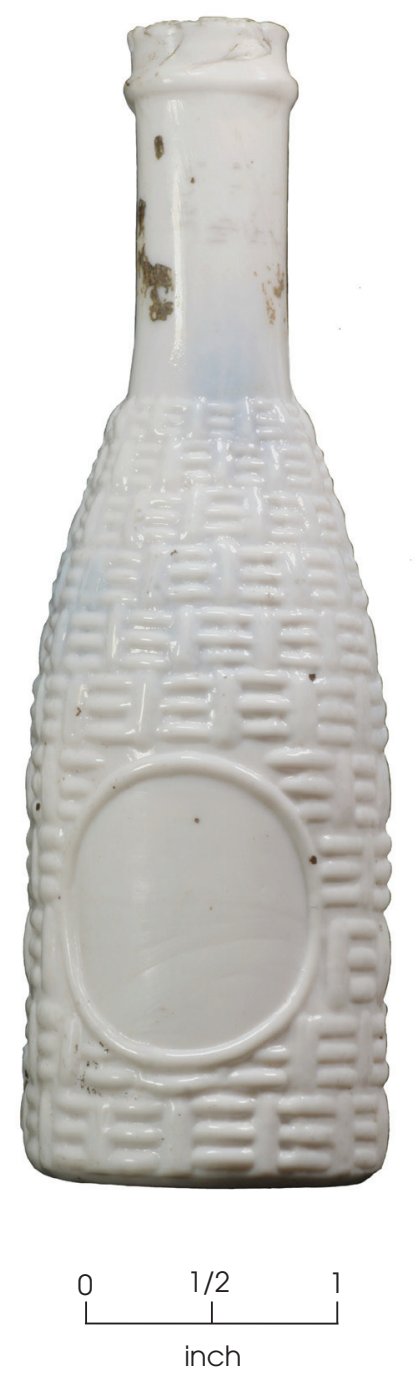

Figure 6.6. White milk glass bottle from Burial 8. all times, even in death. the surface of African American graves (Jordan 1982:21). According to various theories, seashells (1) symbolize water and death and represent the world of the dead; (2) enclose the soul's immortal presence; (3) represent the ocean voyage from Africa; and (4) were symbolic of a return to Africa by sea (Afrolumens 2003; Chicora Foundation Inc. 1996; Clow and Green 2000:457; Peter, Prior, Green, and Clow 2000:551-552). Shells were found in several graves excavated at Freedman's Cemetery in Dallas, along with glass and ceramic objects (Clow and Green 2000). Marine shells would have been readily available from the nearby gulf coast.

Burial 4 contained a small slate fragment. The burial is that of a 2-4-year-old child, and Clow and Green (2000:460) state that items often placed in children's graves would have a connection to being a child, such as a favorite toy or activity. It is possible that this child was in school and learning to write, and the slate could have served as a connection to the child.

Burial 8 contained an intact white glass bottle that was blown-in-mold with an applied lip and bead finish (Figure 6.6). This small "milk" glass bottle measures ca. 4.5 inches tall with a volume of just over one fluid ounce. The body has a slight oval shape (in transverse cross section) and measures 1.44 inches wide at the mold seam and 1.31 inches wide perpendicular to the mold seam. The bottle has an embossed design with a woven pattern resembling a basket; a smooth, plain oval area on one side is where a paper label was likely located. The bottle's original contents are unknown. Clow and Green (2000:456) state that cosmetic items were plentiful in excavations at the Freedman's Cemetery in Dallas. Perfume bottles, compacts, and milk-glass makeup containers were among the most frequently recovered. If this bottle is a perfume or cosmetic bottle, it suggests how important it was to present oneself at one's best at

A small segment of graphite pencil lead was recovered from Burial 11. The segment measures 2 inches long with a diameter of 0.09 inches. The pencil lead fragment was recovered near the head/ upper torso of the grave. It is possible that a pencil was placed in the deceased's pocket when they were laid to rest. 
The final two unique objects were recovered from Burial 15, an adult female. One is a gilded bird claw/toe bone (Figure 6.7). The bone is in poor condition but has been tentatively identified as a peacock toe bone (Brian Shaffer, personal communication 2011). It was recovered near the woman's head and could have been a necklace, an earring, or decorative hair ornament, but this is not certain. The second unique item is a whiteware saucer (Figure 6.8) that was also found near the woman's head (see Figure 6.1). The saucer measures six inches in diameter, and its base bears the maker's mark "WOOD \& HAWTHORN" from England. The royal arms seal of a lion and unicorn holding a shield and crown sits above the manufacturer's name, with "IRONSTONE CHINA" arched above the seal. This is the mark used by the British firm Wood \& Hawthorn (also Hawthorne) from 1882 to 1887 (Godden 1991:687). Although both Godden (1991:687) and Jewitt (1883:478) show the company name spelled Hawthorne, the mark on this saucer has the name without the "e." It is not clear if this difference has any temporal significance.

Clow and Green (2000:454) discuss the common occurrence of broken whiteware among the graves excavated at Freedman's Cemetery, and how this was and still is a common practice among African Americans. One interpretation offered as to why broken ceramics were left as a grave offering is that broken items were less likely to be stolen (Clow and Green 2000:454). Other reasons for ceramics left as grave offerings are explained as being a constant reminder of the feeling of home to the deceased (Clow and Green 2000:454-455). Ceramic fragments are often found above or on the surface of the grave. The unique case of the saucer being intact likely has multiple interpretations. The location of the saucer from Pioneer Cemetery and its completeness suggest that the saucer likely held something of significance that was placed in the coffin.

\section{FABRIC SAMPLES}

Nine fabric samples from four different burials were submitted to the Conservation Research Laboratory at Texas A\&M University. Fabric cleaning and analysis was conducted by Haley Streuding and Helen Dewolf. The details are presented in Appendix E and summarized in Table 6.2. ${ }^{9}$
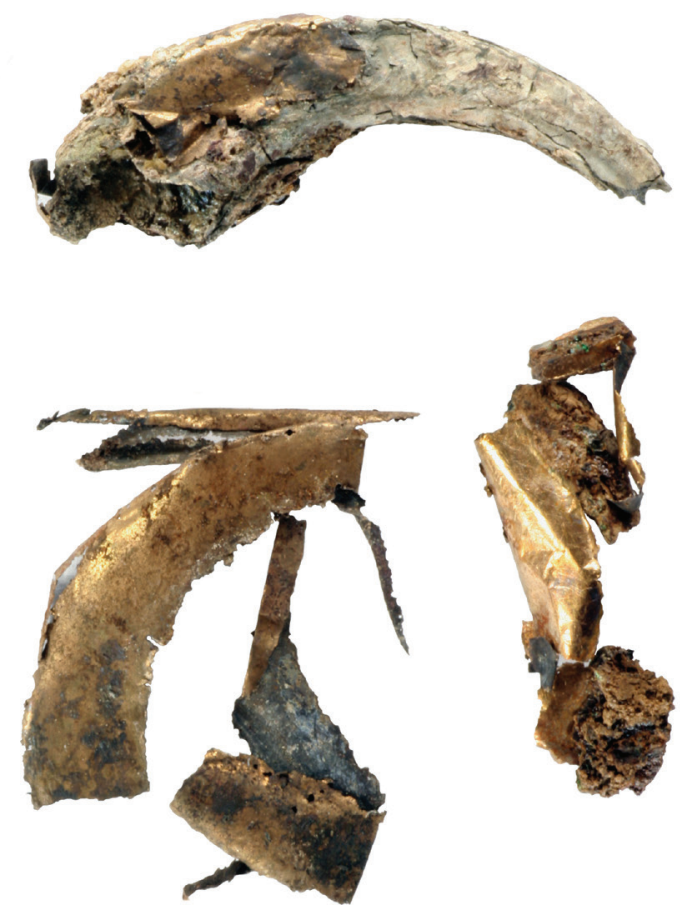

9 In the field, fabric samples were assigned sequential numbers (e.g., 8-1, 8-2) to designate individual fabrics observed from different locations within a burial. The letters were added to the sample numbers by the CRL during the fabric analysis to distinguish different fabric types within one sample. 


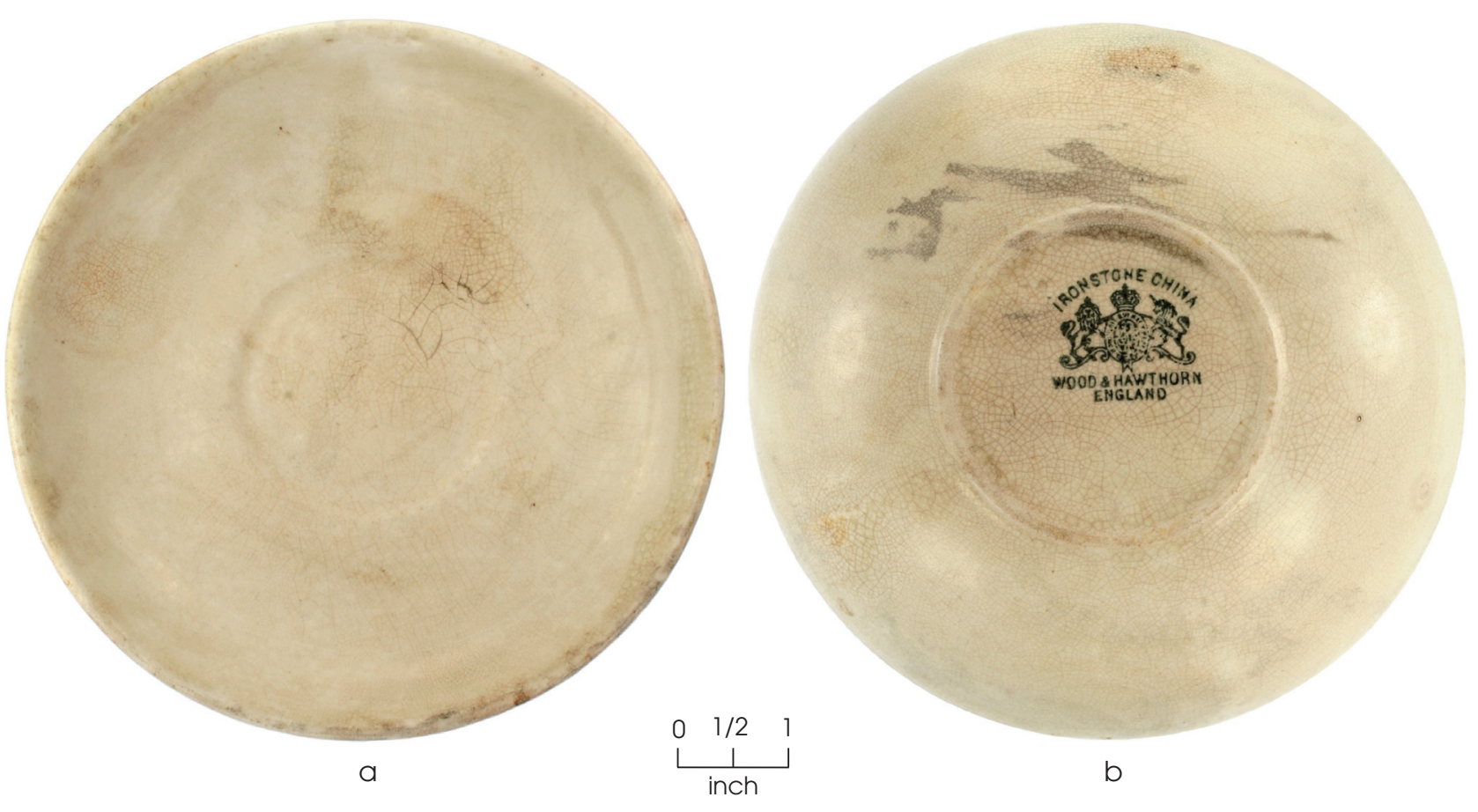

Figure 6.8. Undecorated whiteware saucer from Burial 15.

The fabric samples are all quite similar in appearance. Many exhibit attributes indicating that they were probably sewn on a sewing machine. The burn test indicates that these samples are protein-based fabric such as animal hair. The CRL textile analysis suggest that in most, if not all, of the samples were likely wool (see Appendix E).

Based on their context, it is impossible to determine whether the recovered fabric samples are from clothing or coffin liners. Most of the samples came from obviously disturbed contexts due to the fluctuating water table and movement of materials within the graves. Sample 10-3 was found pressed onto a fragment of wood. This could indicate that this Burial 10 fabric sample was a remnant of a coffin lining, but there is not enough evidence to say definitively. Fabric was recovered from all zones in the burials, which further adds to the confusion regarding the fabric's function. Fabric found in Zone A (the head area) could represent a coffin liner, a head bonnet, or even a pillow placed under the head of the deceased. Fabric found in Zones B and C (the upper body) could represent coffin lining, shirt or blouse, the upper part of a dress or undergarment, or a coat. Fabric found in Zones D and E (the lower body) could represent coffin lining, the lower portion of a dress, pants, or undergarments.

Because of the diversity of textile types within individual graves, it is likely that some of the fabric samples represent clothing. At least two or more different types of fabric were found in Burials 8, 9, and 10, and a coffin liner would 
presumably be a single fabric. Sample 9-1A, a knitted textile, is particularly likely to represent clothing.

Some of the fabric samples could have been associated with fraternal or religious organizations. Many of the extant headstones in Pioneer Cemetery display emblems of various organizations that had chapters for African Americans (such as the Masons and the International Order of Oddfellows) or that were exclusively African American (such as the Order of the Eastern Star and the Sisters of the Mysterious Ten) (see Appendix F). The regalia associated with many of these groups was quite ornate.

Table 6.2. Fabric samples from Pioneer Cemetery burials*

\begin{tabular}{|c|c|c|c|c|c|}
\hline $\begin{array}{c}\text { Burial } \\
\text { No. }\end{array}$ & Sex and Age & $\begin{array}{c}\text { Sample } \\
\text { No. }\end{array}$ & $\begin{array}{c}\text { Burial } \\
\text { Context }\end{array}$ & $\begin{array}{c}\text { Sample } \\
\text { size }\end{array}$ & Fabric Description** \\
\hline \multirow[t]{7}{*}{8} & \multirow{7}{*}{$\begin{array}{l}\text { Probable male, } \\
\text { adult, } \\
\text { age } 46 \\
(+/-12 \text { years })\end{array}$} & $8-1 \mathrm{~A}$ & Zone C/D & Medium & Twill, single weave, single ply yarn. \\
\hline & & $8-1 \mathrm{~B}$ & Zone C/D & Medium & $\begin{array}{l}\text { A } 2 / 1 \text { weft-faced, loose twill weave. Probably machine } \\
\text { made. Warp yarn appears to be finer than weft yarn. }\end{array}$ \\
\hline & & $8-2$ & Zone D & Large & Twill weave, single-ply yarn. Probably machine made. \\
\hline & & $8-3 \mathrm{~A}$ & Zone D/E & Large & Twill weave, single-ply yarn. Similar to sample 8-1A. \\
\hline & & $8-3 \mathrm{~B}$ & Zone D/E & Large & $\begin{array}{l}\text { Loose twill weave, fine warp, heavier weft. Similar to } \\
\text { sample 8-1B. }\end{array}$ \\
\hline & & $8-4 \mathrm{~A}$ & Zone $\mathrm{E}$ & Medium & $\begin{array}{l}\text { Twill weave, possibly single or double weave. Similar to } \\
\text { samples 8-1A and 8-3A. }\end{array}$ \\
\hline & & $8-4 \mathrm{~B}$ & Zone E & Medium & Loose twill weave. Similar to samples 8-1B and 8-3B. \\
\hline \multirow[t]{3}{*}{9} & \multirow{3}{*}{$\begin{array}{l}\text { Indeterminate } \\
\text { sex, adult, } \\
\text { age } 47 \\
(+/-12 \text { years })\end{array}$} & $9-1 \mathrm{~A}$ & Zone A & Medium & Fine, 2-ply yarn. Knitted. \\
\hline & & $9-1 \mathrm{~B}$ & Zone A & Medium & $\begin{array}{l}\text { A } 2 / 1 \text { weft-faced twill weave. Probably machine made. } \\
\text { Warp and weft are single ply. Sewing thread appears to } \\
\text { be } 3 \text { ply. }\end{array}$ \\
\hline & & $9-1 \mathrm{C}$ & Zone A & Medium & $\begin{array}{l}\text { Plain or tabby weave with single-ply yarn forming } \\
\text { both warp and weft. Probably machine made. Fulled or } \\
\text { brushed on one side. }\end{array}$ \\
\hline \multirow[t]{3}{*}{10} & \multirow{3}{*}{$\begin{array}{l}\text { Probable male, } \\
\text { adult, } \\
\text { age } 40-50+\end{array}$} & $10-1$ & Zone A & Medium & $\begin{array}{l}\text { Loose, } 2 / 1 \text { weft-faced twill weave. Warp and weft are } \\
\text { single-ply. Fabric looks to be seamed. }\end{array}$ \\
\hline & & $10-2$ & Zone A & Medium & $\begin{array}{l}\text { Loose, plain weave with single-ply yarn for warp and } \\
\text { weft. Portions appear rolled and hemmed, but no } \\
\text { stitching holes visible. }\end{array}$ \\
\hline & & $10-3$ & Zone A & Small & $\begin{array}{l}\text { Single-ply, loose twill weave with some finished edges, } \\
\text { meaning they were rolled and hemmed. Probably } \\
\text { machine made. Secondary } 2 \text { - or } 3 \text {-ply sewing thread } \\
\text { present. }\end{array}$ \\
\hline 13 & $\begin{array}{l}\text { Indeterminate } \\
\text { sex, child, } \\
\text { age } 11.5 \\
(+/-2.5 \text { years })\end{array}$ & $13-1$ & Zone $\mathrm{C}$ & Medium & $\begin{array}{l}\text { Single-ply twill weave with a fine warp and heavier } \\
\text { weft. Probably machine sewn. Similar to Samples 8-1B, } \\
\text { 8-3B, 8-4B, and 10-1. }\end{array}$ \\
\hline
\end{tabular}

* Fabric sample analysis was conducted by the Conservation Research Laboratory at Texas A\&M University (see Appendix E).

** All fabric samples were subjected to a burn test, and results indicate that all samples are protein-based fabrics such as animal hair, most likely wool. 



\title{
CHAPTER 7: OSTEOLOGICAL ANALYSIS OF HUMAN REMAINS
}

\author{
Cory J. Broehm ${ }^{10}$
}

The basic osteological descriptions of the 14 burials excavated in 2003 and 2008-2009 were presented in Chapter 4. This chapter summarizes the methods used in the acquisition and analysis of the osteological data and presents some interpretations for the small burial population from Pioneer Cemetery.

\section{METHODOLOGY}

As much as possible, the methods of osteological analysis employed for the 2008-2009 burial sample followed that used for the burial excavation and analysis work at Pioneer Cemetery in 2003 (Tiné and Boyd 2003:17-18). The main difference is that the three burials excavated in 2003 were analyzed in the field just prior to the reburial on April 4, 2003. In contrast, the remains for the 11 burials excavated in 2008-2009 were taken to the PAI laboratory, where the osteological examinations and data analyses were done over a period of time.

The methods used for both phases of work generally followed the guidelines established in the Standards for Data Collection from Human Skeletal Remains (Buikstra and Ubelaker 1994), except where noted below. The osteological analysis included an inventory of skeletal and dental elements, sex assessment, age estimation, biological affinity, skeletal and dental metrics, skeletal and dental nonmetrics, and pathological observations. The detailed osteology data for all 14 burials are presented in Appendix C. To complete the documentation of the burials excavated in 2008-2009, laboratory photographs were taken of representative examples of age, sex, biological affinity, anomalies, and pathology.

The inventory of skeletal remains was recorded in numerical code according to the completeness of the bone. This was supplemented by a description, which also documented any taphonomic alterations. A detailed inventory of joint surfaces of adults was also completed to document the pattern and severity of degenerative joint disease.

\section{Age and Sex}

Sex was estimated only for adults and was determined on the basis of pelvic and cranial morphology (Bass 1995; Krogman and Iscan 1986; Phenice 1969; Schwartz 1995; Stewart 1979), although only limited characters could typically be observed. Metric indicators of sex were generally used as a supplement to

10 Broehm was employed at Prewitt and Associates when he conducted this analysis. He is currently a pathology resident at the University of New Mexico's School of Medicine. 
the morphological indicators. Poor skeletal preservation at Pioneer Cemetery limited metrical analysis to two univariate discriminant functions: the maximum diameter of the femoral head (Stewart 1979:120) and circumference of the tibia at the nutrient foramen (Symes and Jantz 1983). Data from both were derived from skeletal collections composed of individuals from roughly the same time period as the recovered burials, many of whom were poor or indigent. The Symes and Jantz standards are based on American Blacks, whereas Stewart's results were derived from a mixed racial sample.

Difficulties in using overall skeletal robusticity and univariate metric analysis have been documented at Third New City Cemetery in Houston (Foster and Nance 2002) and at Albert J. Phillips Memorial Cemetery in Galveston County (Dockall, Powell, and Steele 1996), both late-nineteenth to early-twentieth-century African American cemeteries along the upper Texas coast. At Third New City Cemetery, skeletal elements of both males and females were large and had prominent muscle origins and insertions (Foster and Nance 2002:118). The data from Phillips Memorial Cemetery are biased due to the small sample size but are suggestive nonetheless. Measures of the tibia circumference at the nutrient foramen for two of three females were above the mean and the sectioning point, suggesting they would be interpreted as males using the Symes and Jantz (1983) data.

Ectocranial suture closure (Meindl and Lovejoy 1985) and auricular surface morphology (Lovejoy et al. 1985) served as the most commonly used indicators of adult age at death. The former method was often limited to only one or a few observations per individual, with resulting age ranges pooled into a single range, which decreased the accuracy of the method. Pubic symphysis morphology (Brooks and Suchey 1990; Suchey and Katz 1986; Todd 1920,1921) could only be used in one instance. Dental wear was not assessed because commonly used standards of dental wear to estimate age (Brothwell 1981; Miles 1962) seemed to either underage the individuals or place their ages beyond the accuracy range of the method. No age-specific standard of dental wear for this population exists, and some variation was observed in burials of similar age. For example, Burials 15 and 16 are roughly the same age based on auricular surface morphology, but the former had no teeth while the latter had a full dentition. Analysis was also hampered by the extent of ante- and postmortem tooth loss. Epiphyseal union (Scheuer and Black 2000) and stages of dental development and eruption (Moorrees et al. 1963a; 1963b; Ubelaker 1989) permitted age assessment for subadults and young adults.

\section{Biological Affinity}

Definitive identification of biological affinity was largely obviated by the fragmented condition of the skeletons. Neither cranial measurements nor postcranial indices were possible. Biological affinity was assessed from 27 morphological observations of the cranium, mandible, and teeth, mostly presented in Rhine (1990; see also Bass 1995; Gill and Rhine [eds] 1990; Stewart 1979; Ubelaker 1989). Some of these traits are age- and sex-related and of less value in assessing biological affinity. 


\section{Pathology}

Pathological conditions were generally described in narrative form rather than numerically as prescribed in Buikstra and Ubelaker's (1994) Standards. Pathology was categorized as infection/inflammation, degenerative, trauma, metabolic/hematologic, neoplasm, enthesopathy, or skeletal anomalies.

Due to its prevalence and in many cases severity, degenerative joint disease (DJD) in adults was numerically coded following Buikstra and Ubelaker (1994) on a form created for this project. Each synovial joint surface was scored for overall completeness and completeness of its margin, and for presence, extent, and severity of osteophytic lipping, porosity, eburnation, surface osteophytes, and joint surface alteration. Vertebral bodies were assessed as above (except surface alteration) as well as for compression and Schmorl's nodes, which were scored as present/absent. Porosity was initially scored for vertebral bodies, but review of the recorded data showed that the scoring was inconsistent and thus is not considered further in this report. The skeletal and joint inventories in a few instances do not match, due to a combination of slightly differing scoring units, scoring methods, and different analysts.

\section{Dental Data}

Dental data were also collected mostly according to the guidelines of Buikstra and Ubelaker (1994). Data were collected mainly through gross observation. Dental inventory, including premortem and postmortem tooth loss, development/eruption, location and degree of calculus deposits, presence and location of all observable caries and abscesses, degree of attrition, and the presence, type, and location of enamel hypoplasias were documented both numerically and visually. Where possible, measurements of teeth were taken.

Deciduous and permanent dental development was assessed following Moorrees et al. (1963a, 1963b). Dental attrition was assessed following Smith (1984) for the anterior dentition and premolars and Scott (1979) for the molars. Dental wear was not recorded on Burials 4, 11, and 17 due to their young ages at death. Some carious lesions were scored as "\#?" which means possible caries. These sometimes large defects at the cemento-enamel junction may represent caries, taphonomic damage, or both. Some may be obscuring caries. Antemortem damage or modification was described in narrative form and plotted on a diagram. Dental nonmetric traits were assessed and scored using the methods outlined in Scott and Turner (1997) and Turner et al. (1991).

\section{DISCUSSION OF THE PIONEER BURIAL POPULATION}

The demographic and pathological data gleaned from the analysis of the 14 skeletons found at Pioneer Cemetery are summarized in Table 7.1. Although only a handful could positively be identified as African American based on the skeletal remains, all are presumed so based on the history of the cemetery, thus providing a coherent population for study in at least one respect. 


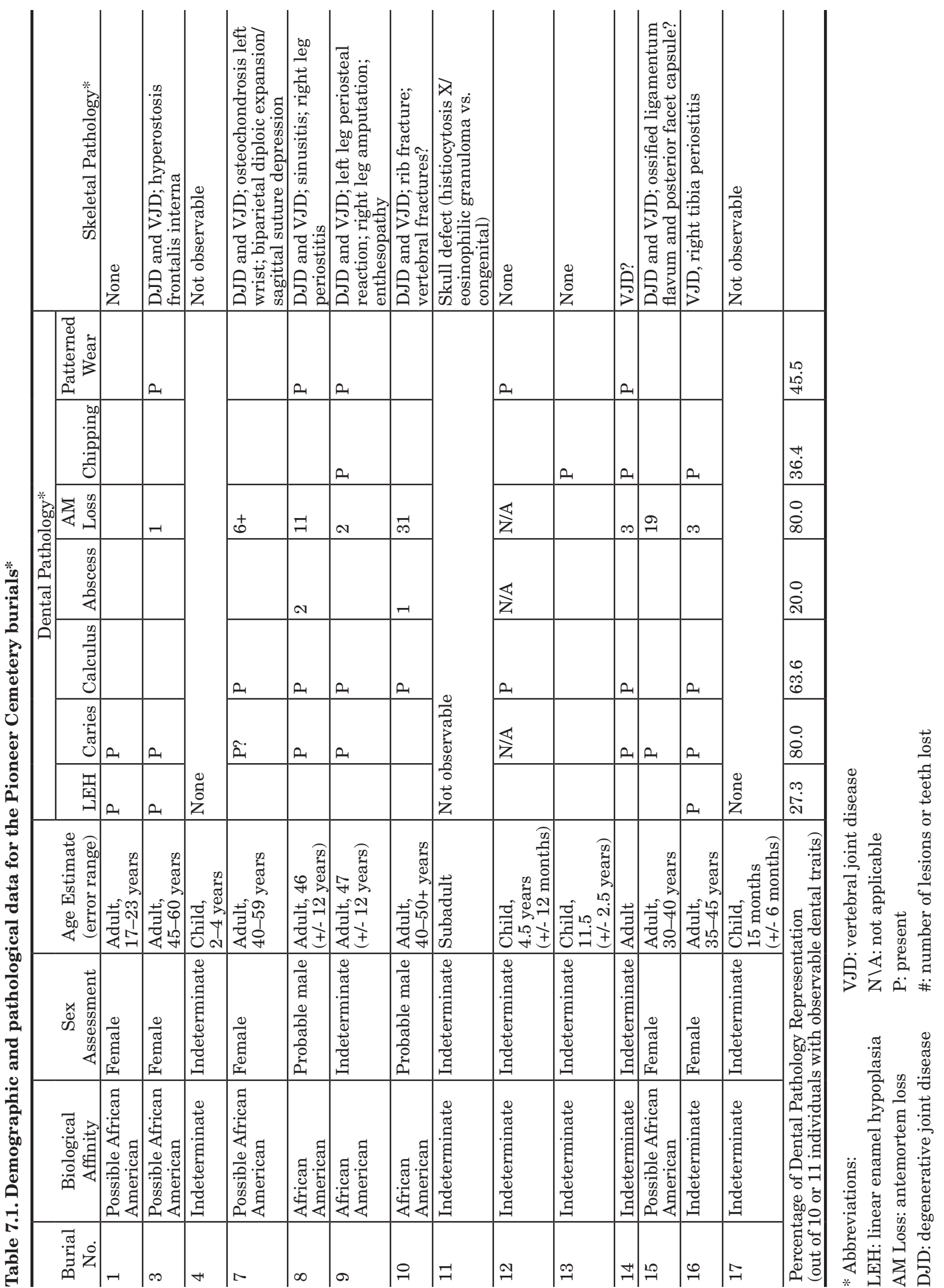


It is difficult to discern what additional meaningful conclusions may be drawn from the skeletons as a group, or what they can tell us about the late nineteenthto early twentieth-century African American community the deceased belonged to. Though most age categories are represented, the sample is too small for any meaningful age-at-death data. Likewise, there are too few infants and children to make any inferences about infant and childhood mortality. The 2.5:1 adult female to male ratio is clearly skewed, though this cannot be summarily dismissed as sampling error. Some males could have been incorrectly labeled females. Higher mortality in women, typically due to the risks associated with pregnancy and childbirth, can also alter the sex ratio. However, the females at Pioneer Cemetery were generally beyond childbearing years. Most likely the ratio is the result of sampling bias. Males outnumbered females in Brazoria County in every U.S. census from 1880 through 1920. Limited data on numbers of males and females by age category suggest adult and subadult males outnumbered adult and subadult females (Historical Census Browser 2004), though U.S. census data during this period was notoriously inaccurate (Farley 1970: 23-25) and females may have been consistently undercounted.

In light of the small sample (and in some cases poor preservation), only a few general comments about health will be made here. Degenerative joint disease (DJD) placed a significant burden on the older individuals in this Pioneer Cemetery group, who exhibited both high frequencies and severity of DJD. Osteoarthritis, or DJD of synovial joints, is a progressive condition characterized by chronic remodeling of joint cartilage leading ultimately to loss of cartilage, bone on bone approximation and movement, and compensatory bony joint remodeling (Aufderheide and Rodríguez-Martín 1998:93; Ortner 2003:545-546). The process of vertebral body and disk degeneration (vertebral joint disease; VJD) is functionally and etiologically the same as for synovial joints (Larsen 1997:162) and is considered with them in this discussion under the umbrella term DJD. Multiple factors contribute to the development of DJD, including age, injury or activity mechanically stressing the joint, female sex, obesity, as well as individual susceptibilities to the disease (Rogers and Waldron 1995:33), though mechanical stress and physical activity remain the primary factors (Larsen 1997:163).

Considering all forms of expression of DJD, all the major joints (shoulder, elbow, wrist, hand, hip, knee, foot, vertebral column) are affected at roughly similar rates. Aside from the older individuals in Burials 7-10, osteophytosis is the most common expression of DJD in both the appendicular skeleton and vertebral column (which is also the most common site of osteophytosis). However, the osteophytosis is limited in severity and extent, both across the skeleton and in any given joint. Causes of osteophytes include aging, DJD, intervertebral disk disease, diffuse idiopathic skeletal hyperostosis (DISH), trauma, and other conditions, and caution must be used in interpreting them as DJD in the absence of other indications (Rogers and Waldron 1995:26), as is the case in many of the Pioneer Cemetery individuals. Notable exceptions include Burials 15 and 16, which show eburnation in the hand/ wrist, and Burial 3, which has limited DJD in the knees, ankle, and cervical column.

In the older individuals, Burials 7-10, osteophytes is also the most common expression of DJD throughout the skeleton, but there is significant expression 
of other forms of DJD as well, and more of their joint surfaces are severely and extensively affected. The most affected areas are: Burial 7, the left wrist and cervical and lower lumbar column; Burial 8, the wrists, feet, and cervical column; Burial 9, the vertebral column. Burial 10 has the most severe and extensive DJD recorded in this entire sample, affecting every joint region preserved: shoulder, elbow, hands, hip, feet, vertebral column, and even the occipital condyle. In all of these burials, the hands, feet, and vertebral column are most commonly and severely affected. Vertebral column DJD suggests chronic, repetitive heavy lifting and carrying. Cervical degeneration and compression may be linked with carrying items on the head, which is more commonly observed in women (Larsen 1997:176). There are other indications of heavy manual labor in this group, including overall robust muscle attachments (Burials 8-10), well-developed muscles in the arms and hands (Burial 7) and feet (Burial 8), and osteochondrosis of the left wrist (Burial 7). Trauma, which may be due to violence as well as work accidents, was also only observed in this subgroup, including rib fracture, vertebral fracture(s), and belowthe-knee amputation.

That these individuals have degenerative joint disease is not surprising, given their age, but the extent and severity is striking. Without doubt, it is problematic to compare osteoarthritis in younger and older persons, such as comparing Burials 7-10 with Burials 14, 15, and 16, who are younger. Although Burial 15 exhibits some vertebral column degenerative disease (and ossified ligamentum flavum and posterior facet capsules) and upper extremity osteoarthritis, the others have minimal evidence of DJD anywhere in the skeleton. Burials 14 and 15 are also remarkably gracile, though the latter has well-developed flexor ridges in the fingers (which correlates with DJD in the hand). Burial 16 is average in size and muscle attachments. Burials 7-10 also stand in contrast to Burial 3, another older female, who shows relatively little DJD, though the thoracic and lumbar columns are poorly preserved. The fact that the hands and vertebral column are most noticeably affected by DJD in this subgroup, like they are in the older individuals, suggests these two groups may have engaged in similar activities, although the sample is too small to draw any real conclusions.

These pathological data suggest hard labor for at least some of the Pioneer Cemetery dead. Slavery certainly fits this bill, though the vast majority of blacks in Brazoria County continued to work as manual laborers after emancipation. The osteological and archeological data indicate that the individuals in Burials 7-10 were old enough to have spent part of their lives as slaves, especially if they died before 1885 or 1890 . If any of them died before 1875 , they would have spent a substantial part of their lives laboring as slaves. Burial 10 is likely under aged, and Burial 7 is at least at the latter end of the age range (see Table 7.1). The more severe osteoarthritis in these older adults may be due to aging alone, but in some, the evidence suggests that some degree of the osteoarthritis may be related in part to slavery and heavy labor. If so, the evidence seems to indicate that the physical demands of slave labor were heavier than those of physical labor after emancipation. Unfortunately, comparison of the Pioneer skeletons with those of known slaves is not very illuminating in this respect. As expected, the prevalence of osteoarthritis at the 
selected sites is high (e.g., Kelley and Angel 1983; 1987; Rathbun 1987; Wilczak et al. 2006), with the possible exception of an urban sample from New Orleans (Owsley et al. 1987). However, occurrence rates among slave populations and post-Civil War non-slave populations (black and white) cannot be clearly differentiated (see summary table in Tiné 2000:499).

Complementary indicators of general health, nutrition, and stress (of which hard labor would certainly be an example) and susceptibility to stress and infection, come from dental linear enamel hypoplasias $(\mathrm{LEH})$ and periosteal reactions. Though caution must be used in directly correlating the prevalence or absence of skeletal lesions with the overall health of a population (Wood et al. 1992), the presence of lesions at least indicates the presence of some insult or disease. Enamel hypoplasias provide evidence of insult during childhood. Malnutrition, infectious disease, diarrhea, weaning, as well as stress in general can all contribute to their formation. Hypoplasias were observed in three individuals, all adults, but none in the older individuals that might have been slaves. Dental attrition and antemortem tooth loss may have affected these results, however. There is no certain evidence of specific nutritional deficiencies such as rickets, pellagra, or metabolic disease. The cranial expansion of Burial 7 may be well-healed porotic hyperostosis, evidence of anemia, though it would be an unusual presentation. Porotic hyperostosis is traditionally linked with iron deficiency anemia (especially due to dietary deficiency or parasite load) during childhood. Walker et al. (2009), however, convincingly argue that porotic hyperostosis is caused by vitamin B12 deficiency during childhood, most likely due to a combination of maternal deficit and diarrheal disease, which was ever-present in young children. The related lesion, cribra orbitalia, may be the result of vitamin B12 and C deficiencies. Whether due to a lack of iron or vitamin B12/C, the lesions suggest a childhood spent under some stress.

Periosteal reactions, or nonspecific infections, provide some indication of sanitation and the infectious load in the environment, the exposure to those infections (often through trauma), the susceptibilities of individuals and populations to resulting disease due to malnutrition, existing predispositions or diseases, and a host of other factors. They thus provide a reasonable measure of general health and the ability to buffer against insult (Ortner 2003:209). These lesions were also found in three individuals, two of which are older individuals. With the exception of the lesion in Burial 9, which is related to significant trauma to the leg, lesions are focal, unilateral, well-remodeled/healed, and located on the tibiae/fibulae-bones vulnerable to trauma due to lack of soft tissue protection. The pattern suggests that these individuals suffered not widespread infection but some trauma that may have become secondarily infected. There is in fact no evidence at Pioneer Cemetery of systemic infection, or of specific infections like tuberculosis or syphilis.

The individuals at Pioneer Cemetery also suffered from significant dental disease, manifesting in various forms. Calculus is mineralized plaque, which is an accumulation of microorganisms, especially bacteria that have colonized the tooth surface in a protein, sugar, and lipid matrix. Caries is a disease characterized by enamel, dentine, and cement demineralization from acid production by plaque bacteria. If left untreated, demineralization leads to cavity formation, tooth death, 
and loss. Diets sticky and high in carbohydrates are strongly linked to calculus and caries (Hillson 1996:276-278; Ortner 2003:590). Corn and sugar, both cariogenic foods, are thought to have been a large part of the African American diet during the period the burials were interred. This diet, coupled with a lack of dental care, is predictive of high rates of dental disease. The prevalence of caries and calculus in permanent teeth in occlusion is presented in Table 7.2. These percentages are diluted somewhat by antemortem loss, postmortem loss of alveolar regions, and Burials 13 and 16, both of which have fairly complete dentitions and few cavities. The large proportion of cavities and calculus at or below the cemento-enamel junction indicates significant periodontal disease as well.

Table 7.2. Rates of dental caries and calculus in the Pioneer Cemetery burials*

\begin{tabular}{l|c|c|c|c|c|c}
\hline $\begin{array}{c}\text { Dental } \\
\text { Anomaly }\end{array}$ & $\begin{array}{c}\text { No. of Individuals } \\
\text { with Teeth }\end{array}$ & $\begin{array}{c}\text { No. of Affected } \\
\text { People }\end{array}$ & $\begin{array}{c}\text { Percent } \\
\text { Affected People }\end{array}$ & $\begin{array}{c}\text { Total No. of } \\
\text { Teeth }\end{array}$ & $\begin{array}{c}\text { No. of Affected } \\
\text { Teeth** }\end{array}$ & $\begin{array}{c}\text { Percent Affected } \\
\text { Teeth** }\end{array}$ \\
\hline Caries & 10 & 8 & $80 \%$ & 154 & $21(36)$ & $13.6 \%(23.4 \%)$ \\
\hline Calculus & 10 & 6 & $60 \%$ & 154 & 38 & $24.7 \%$ \\
\hline
\end{tabular}

* Applies only to individuals with permanent teeth in occlusion.

** Numbers of positive caries and possible caries (in parentheses).

The rate of caries in adults is remarkably similar across four African American skeletal samples from the South (described below): Pioneer Cemetery (80 percent); Cedar Grove in southwest Arkansas (83 percent); Phillips Memorial in Galveston County, Texas (83 percent); and Freedmen's Cemetery in Dallas, Texas (80.4 percent). The caries rate is lower at a fifth site, Third New City Cemetery in Houston. Although the rate per individual was not available, the rate per permanent adult tooth was just 16.6 percent, compared with 23.4 to 36 percent at Pioneer, 21.8 percent at Cedar Grove, and 25 percent at Phillips Memorial. (25 percent). The relatively low Third New City Cemetery rate may be explained by overall good dental hygiene in this community, based on low caries and calculus rates and minimal dental wear, even in older individuals, as well as some professional dental care (fillings and dentures/partials). In contrast, there is no evidence of dental care at Pioneer or Phillips Memorial, and about 4 percent of burials at Freedmen's and Cedar Grove populations had some care. Further, all the adults at Cedar Grove and 10 of 11 adults at Phillips Memorial had calculus. No data from Freedmen's are available (Dockall and Powell 1996; Foster and Nance 2002; Rose 1985; Tiné 2000).

Calculus, caries, and periodontal disease can explain, at least in part, the high rates of antemortem tooth loss at Pioneer Cemetery. Out of a maximum of 288 total permanent teeth that would have been in occlusion in the nine adults, at least 76 (26 percent) were lost antemortem. Four individuals had lost more than five teeth. Comparable data are only available from Cedar Grove, where an estimated 23 percent of permanent adult teeth were lost antemortem due to dental disease (Rose and Santeford 1985). In Pioneer Cemetery Burials 7 to 10, antemortem loss is also associated with temporomandibular joint disease (Langsjoen 1998), although 
the significant tooth loss in Burial 15 is not. Antemortem loss cannot necessarily be attributed to diet and caries alone, however. Significant dental attrition and dental trauma, both in evidence at Pioneer Cemetery, undoubtedly contributed. Burials 3, 8, 9, and 14, all adults, display patterned wear in their anterior teeth suggesting their use as tools, or possibly in the smoking of pipes. In the latter two individuals, chipping of the anterior dentition is also present, while Burial 9 had interproximal flattening of the molars. Anterior tooth chipping was also observed in Burials 13 and 16. Even a young child, Burial 12, has some unusual lingual surface wear of the anterior teeth. In light of the patterned wear in the anterior dentition, the chipping is likely due to use of the teeth as tools or in processing food should be explored. Foreign matter in processed food during this period was a well known occurrence, including grit and fragments of lead and iron in flour (from the millstone and metal from the stone and packing for the wheat sheaves) and dirt and sand in sugar, milk, and molasses (Swearingen 1884:15). Another possibility is pica, the practice of eating nonnutritive substances such as paper, clay, and sand, which was a well-documented practice among rural blacks during this period (Kiple and King 1981:119-122).

\section{COMPARATIVE ANALYSIS OF LATE-NINETEENTH- AND EARLY-TWENTIETH-CENTURY AFRICAN AMERICAN LIFE IN TEXAS}

The Pioneer Cemetery burial population does provides some insights into the lives of African Americans during the latter nineteenth and early-twentieth centuries, especially when comparisons are made with other historic cemetery burial samples in conjunction with published historical sources on black life in Brazoria County and the southern United States. This section presents a relatively superficial overview of African American life in Brazoria from ca. 1850 through 1920. It would certainly benefit from more exhaustive research into Brazoria County history as it pertains to African Americans, but examining the local lifestyle and conditions during slavery is largely beyond the scope of this work.

In this section, four historic cemetery burial populations, three in Texas and one in Arkansas, are compared with the Pioneer Cemetery data. In this comparative sample of five, three are rural populations and two are urban. All are predominantly, if not entirely, African American cemeteries used during roughly the same time, ca. 1865 to 1920 . Unfortunately, it is not exactly clear when within this time frame the Pioneer burials were interred, and this confounds the comparison to some degree.

The five historic cemeteries for this comparative analysis are:

\section{Pioneer Cemetery, Brazoria County, Texas (ca. 1865 to present)}

As described in this report, Pioneer is a predominantly African American cemetery in the town of Brazoria, Texas. It is unclear exactly when the cemetery began, but burials there almost certainly predate the official 1888 date when the land was dedicated as a cemetery in deed records. This burial sample is limited to 14 graves, and most (perhaps all) were freedmen who died between 1865 and 1900. Brazoria was a small rural agricultural community during the last half of the nineteenth century. 


\section{Phillips Memorial Cemetery, Galveston County, Texas (ca. 1884-1927)}

Phillips Memorial Cemetery served as the only African American cemetery for rural Galveston County in the vicinity of La Marque and Texas City until the 1940s. In 1927, many of the graves were at least partially exhumed and removed. Apparently this was done by opening the coffins/caskets and lifting the remains out by their clothing (Dockall, Powell, and Steele 1996:iv). Smaller and loose elements were left behind. Of the 53 graves recorded and excavated, only 43 still contained human skeletal remains, typically vertebrae, hand, and foot elements. A few skeletons were relatively complete. Twelve burials were likely interred before 1900, including a child and infant, and 31 were interred after 1900, likely all adults. Only about half the adults could be assigned a sex (Dockall, Powell, and Steele 1996).

\section{Third New City Cemetery, Houston, Texas (ca. 1875-1905)}

The Third New City Cemetery officially opened in 1879 in Houston's Freedmen's Town, also known as the "Fourth Ward." It served one of Houston's earliest and most prominent African American communities. Historical and osteological data suggest that the Third New City Cemetery was used primarily, but not exclusively, by African Americans. This large urban cemetery took interments as early as the 1850 s, when a portion of the tract was used as a hospital and graveyard by the city. Public burials decreased from 1905 to 1910 . After ca. 1910, the cemetery may have primarily been used as a pauper and hospital cemetery. Skeletal remains of 355 individuals were recovered and analyzed (Foster and Nance 2002).

\section{Cedar Grove Cemetery, Southwestern Arkansas (ca. 1890-1927)}

The Cedar Grove Cemetery in southwest Arkansas served the African American community's Cedar Grove Baptist Church from 1881 to 1927. It is unclear when the first graves were interred, but the cemetery may predate the establishment of the church. The individuals interred in this rural cemetery are believed to have been emancipated slaves turned sharecroppers, along with some of their descendants. Skeletal remains of 80 individuals were recovered, representing about 40 percent of all interments (Rose 1985). These 80 individuals likely were interred between 1900 and 1915 (Davidson et al. 2002).

\section{Freedmen's Cemetery, Dallas, Texas (ca.1869-1907)}

The Freedmen's Cemetery was founded in 1869 as a burial ground for former slaves living in Freedmen's Town in the Dallas area. It served as the only burial ground for Dallas's burgeoning African American population until 1902. The interments thus represent all socioeconomic levels in the community. The archeological project recovered remains of 1,157 individuals, representing about 25 percent of all graves at the site. Of these, 269 were interred before 1900 and 887 date after 1900 (Peter et al. 2000).

Admittedly, the limited information from five cemetery sites can hardly give due justice to the complexities of African American life during this period, and several limitations must be kept in mind when comparing and interpreting data derived from these burial populations. For this discussion, burials are categorized based 
on whether they were interred before or after 1900. This is a somewhat arbitrary distinction based on archeological convenience and is not necessarily relevant for epidemiological study. A more accurate analytical approach would be to divide the burials by cohort based on age and date of interment, though this level of analysis is well beyond the scope of this study. Small sample size and poor condition of skeletal remains also hinders population-level conclusions and comparisons for some sites. Furthermore, investigators have used differing methodologies to analyze, interpret, and report remains, often obviating direct comparison of statistics from different sites. In addition, several publications discuss both Freedmen's and Cedar Grove Cemeteries, and these different publications sometimes present differing results.

Even within one cemetery burial population, evaluating health patterns is less than straightforward. For example, the presence of a given lesion may be agerelated, so an older burial sample can make a population appear to be less healthy. In fact, as Wood et al. (1992) postulate, an increase in a particular lesion in a population may actually suggest overall better health because individuals better suited to fight disease survive longer, long enough to develop skeletal lesions. Alternatively, they argue, skeletons with disease represent the sickest or weakest in a population, and may artificially inflate the prevalence of disease within a burial population.

The historical sources, too, are not without their problems. The 1870, 1890, and 1920 U.S. censuses did not accurately count blacks, especially those living in rural regions (Farley 1970:23-25). Further, many statistics on disease and mortality during this period are from the federal Death Registration Areas, which at this time only encompassed 10 northern cities and the District of Columbia. It is believed that urban blacks suffered more often from disease and were generally less healthy than rural blacks. But even by 1910, 77 percent of African Americans were still living in rural areas (Farley 1970:61-62), and the epidemiology of these regions-including the populations of Pioneer, Phillips Memorial, and Cedar Grove Cemeteries-is cloudy at best.

\section{African American Life in Texas: Emancipation to 1900}

At the last U.S. census before the end of slavery, 5,116 enslaved blacks and 6 free colored people lived in Brazoria County, making up 71.6 percent of the total population. The importance of the slave economy in Brazoria County is further illustrated by comparing these statistics to those of the entire state of Texas in 1860, when blacks made up about 30 percent of the total population statewide (Historical Census Browser 2004). Slave labor at the sugar and cotton plantations that dominated the region helped make Brazoria County the richest in Texas by 1860 (Kleiner 2010; Strobel 1926). As discussed above, it is possible that several individuals recovered from Pioneer Cemetery worked as slaves on one of the 46 plantations and were included in the 1860 slave census.

After emancipation, the African American population of Brazoria County increased. But as whites moved into the county as well, the percentage of blacks as a portion of the overall population remained fairly steady until about 1900 (Historical Census Browser 2004; see Chapter 8). Prior to 1900, more blacks were 
moving into Texas than leaving. In fact, until the 1880 s, blacks from other states were recruited to work in Texas (Rice 1971:162). A considerable number colonized Brazoria County in the 1870s and 1880s as part of land ownership and tenancy schemes (Rice 1971:207). Exodus movements to Kansas, Oklahoma, Mexico, and Liberia did not have a net negative effect on the numbers of blacks in Texas or Brazoria County (Rice 1971:198-206). As discussed in more detail below, the black population in Brazoria County declined after 1900 as blacks sought better lives in cities and in the North.

Limited data are available on the impact of birth rates and aging on the size of the black population. In 1887, 149 births were formally recorded in Brazoria County, 98 of blacks (crude rate of 10.9 births/1,000) and 51 of whites (crude rate of 15.5 births/1,000) (Foster 2001). These figures, if accurate, suggest a higher birth rate among whites. However, it seems more likely blacks were not properly counted in this survey. Fertility among blacks did decline in the latter part of the nineteenth century, as did population growth (Farley 1970:51-58). In fact, Farley (1970:3) estimates that black fertility was cut in half between the Civil War and the Great Depression. However, black fertility remained higher than white fertility and was higher among southern and rural blacks than northern and urban blacks (Farley 1970:104-109). The reasons for this shift are not completely understood. In perhaps the most complete study of this trend, Farley (1970:11-12, 120-123, and 215-226) suggests that venereal disease (especially syphilis) and malnutrition, as well as increasing education of women, played major roles in the decline. Notably, just over half of all blacks in school in Brazoria County in 1890 were girls (Historical Census Browser 2004). However, life expectancy may have increased in the late 1800s and early 1900s in Texas (Davidson et al. 2002), and this would have contributed somewhat to population growth, partially countering declining fertility.

Reconstruction, which lasted from 1865 to 1873, promised great change for the former slaves. By 1870, blacks in Texas had been given the right to vote, held state level offices, and were members of the military and police (Barr 1996:42; Rice 1971:8). In 1869, free public schools were guaranteed (Barr 1996:47), and illiteracy among blacks in Texas dropped from 95 percent in 1865 to 75 percent in 1880, though school attendance dropped after 1873 (Barr 1996:64; Rice 1971:209). By 1900 , illiteracy was 38.2 percent statewide (Rice 1971:209). This trend appears to be mirrored in Brazoria County. According to the 1870 U.S. census, 2,667 blacks over the age of 21 (47 percent) were illiterate, compared with just 44 whites. In 1900, 1,061 black males over 21 (13 percent) were illiterate, compared with 20 whites. In 1870 in Brazoria County, only 37 blacks attended school, while 62 whites attended. By 1890, 2,026 blacks were in school, and 607 whites attended (Historical Census Browser 2004).

But the progress of Reconstruction rapidly faltered after emancipation, and Brazoria County saw a significant decline in agricultural production when the slaves were freed. Most of the old plantations were deserted or portioned into smaller farms or pastures (Kleiner 2010; Rogers 1958). Whites resented, and were often incredulous of, the new order, which eliminated the enslaved backbone of their economy and made blacks nominally equal to their former superiors, putting 
them in positions of authority and responsibility. The Black Codes passed during this period sought to remedy white concerns, restricting black rights and trying to force them back into agriculture. The white reaction was often violent as well. In Texas between 1865 and 1868, whites committed more than 1500 violent acts against blacks, and more than 350-400 blacks were murdered by whites (Barr 1996:43; Dulaney 2010).

Prejudice and violence by whites against blacks in Texas persisted long beyond Reconstruction. Between 1870 and 1900, more than 500 lynchings of African Americans were officially recorded in the state of Texas (Rice 1971:250), but data on the number of lynching in Brazoria County are not available. This statewide total is likely incomplete and certainly does not include the large number of nonfatal incidents of violence. There is no evidence of lynching in the skeletal remains at any of the comparative cemetery sites. There is, in fact, only limited osteological evidence that may represent interpersonal violence during this period, whether white on black, black on black, or self inflicted.

For purposes of this discussion, trauma is classified as accidental unless it is from a weapon or a fracture of a classic type that results from assault, such as parry wound or facial fractures. Cranial and rib fractures are perhaps more likely than others to be due to interpersonal violence and are mentioned as possibilities in the relevant sections. Neither Pioneer nor Phillips Memorial Cemeteries had clear evidence of such violence, except a rib fracture at the former. In Houston, where recorded causes of traumatic deaths in 1900 included gunshot, burns, beatings, exposure, shock, and tetanus (Foster and Nance 2002:127), just five instances of possible interpersonal violence were found at the Third New City Cemetery. These include a nose fracture in a woman, rib and distal ulna fractures in two men, and two bullet wounds that likely caused death (Foster and Nance 2002:144). The authors speculate that the higher death rate among young males in 1900 evident in the city death records may be the result of occupational trauma or interpersonal violence (p. 127). At Freedmen's Cemetery in Dallas, possible weapon injuries (gunshot or stab wounds) were present in 22 individuals, 14 of them male (Tiné 2000:506), but only one of these was a person interred before 1900 (Tiné 2000:510). Tiné (2000:506) estimates 80 percent died from their wounds, so most of the people buried after 1900 were actually injured after 1900 as well. There are no reliable data on cranial and rib fracture patterns (Tiné 2000:509).

After the Civil War, the regional economy began to recover but blacks found that the vast majority of jobs available to them in Brazoria County continued to be as agricultural laborers. Farming remained the mainstay of the postwar economy, but agriculture diversified during these years. Farmers in Brazoria County, both black and white, raised cotton, corn, sugar (the top three in acreage and revenue) as they had before the war, as well as grains, sweet and Irish potatoes, and fruit, including wild grapes. Livestock, especially cattle and hogs, was an increasingly important part of the farm economy (Foster 2001; Kleiner 2010). Persistent racism, inequality, and a lack of land available from the Freedmen's Bureau (Barr 1996:54) meant most blacks ended up as tenant farmers or sharecroppers (Barr 1996:57-58; Rice 1971:165), if not simply field laborers (Donald 1971:27). These jobs provided less 
chance of economic and social stability, particularly since blacks earned less than their white counterparts in the same jobs. Further, unemployment and poverty were generally higher for blacks than whites. For example, of the 30 paupers recorded in Brazoria County in 1887, 29 were black (Foster 2001). In Brazoria County in 1900, the U.S. census lists 971 black-operated farms and 750 white-operated farms. This figure is misleading, however, because only 33 percent of black farms at this time were owned or part-owned, compared with 73 percent of white farms. (Historical Census Browser 2004).

The skeletons of blacks in rural coastal Texas attest to lives spent toiling in manual labor. As discussed above, three-quarters of the adults at Pioneer Cemetery had evidence of degenerative joint disease, and most had evidence other than osteophytosis. If the significant osteoarthritis in these individuals is not related to hard labor during slavery, it suggests that postwar work also involved heavy labor that took a toll on the joints. Of the 10 adults and possible adults at Phillips Memorial Cemetery (most of whom had few analyzable elements), about half showed some evidence of DJD, and this number likely underestimates the true prevalence. The DJD evidence is mostly in the form of osteophytic lipping in the lower limb and some vertebral degenerative disease, and it is widespread in only one instance (a man in his late 40s to early 50s). Unfortunately, the severity of DJD was not recorded. Enthesophytes, mainly of the upper limbs, was observed on three individuals (Dockall and Powell 1996) who could have started life as slaves. If so, the apparent mildness of the lesions is noteworthy. However, age ranges are generally not available to help clarify whether these individuals might have worked as slaves or engaged in hard labor after emancipation.

Farmwork was not only physically demanding but posed an ever-present risk of accidents. During slavery, "falls, overturned carts, runaway wagons, drownings, limbs caught in farm machines, kicks from animals, and cuts from axes and scythes blades" were common dangers (Savitt 1978:106). It seems likely these same threats continued after emancipation. The lack of medical care and frequent solo work in rural areas made these accidents even more dangerous. At Pioneer Cemetery, the rib fracture, vertebral trauma, and a leg amputation (and perhaps osteochondrosis of the wrist) are all consistent with work-related accidents, though nonwork-related trauma or interpersonal violence cannot be excluded. The lower leg amputation (Burial 9 at Pioneer) provides some evidence of medical care in the area. At Phillips Memorial, only one adult had any injury, an aligned upper limb fracture and joint dislocation. No specifics are given, and it is unclear if this man received medical care for these injuries.

Some manufacturing enterprises operated in Brazoria County, but it is unclear how many blacks they employed, if any. Hide and tallow factories opened in the late 1860s (Kleiner 2010), and by 1884, the county had cotton gins and grist and sugar mills (Hallstein 2010). The U.S. census lists only one manufacturing in 1880 U.S. census and four in 1890, but these employed only a handful of people (Historical Census Browser 2004). In rural areas, the growing black professional class was limited to teachers and ministers (Rice 1971:194) and indeed, 42 black teachers are listed in the 1890 Census in Brazoria County (Historical Census Browser 2004). 
The 1887 Agricultural Census shows that teacher's salaries in Brazoria County averaged $\$ 52.50$ for white males and $\$ 35$ for white females in contrast to $\$ 48.15$ for black males and $\$ 45$ for black females (Foster 2001). This hierarchy in salaries held true across the state at the time, with black females earning the lowest pay (Rice 1971:224). It is likely that Brazoria County, in comparison with larger cities like Dallas and Houston, had a limited variety of jobs, a smaller class of business owners, and fewer physicians, lawyers, and other professionals among the black community (Prior and Schulte 2000:96; Rice 1971:194).

Even in urban settings, most African Americans worked in some form of manual labor in the late-nineteenth and early-twentieth centuries. The Dallas City Directories suggest that at least 60 percent of jobs held by black men were as porters, teamsters, or general laborers. More than 90 percent of women worked as cooks, laundresses, or domestics (Davidson et al. 2002:260). In Dallas, of the individuals interred in Freedmen's Cemetery prior to 1900, over two-thirds of men and women showed peripheral DJD or osteophytosis of the vertebrae. Most cases were mild. No significant patterning in the joints could be discerned, but the wrist and hand was least affected, and the knee was most affected (Tiné 2000:498, Table III-105). Significantly, just over two-thirds of all individuals under 30 years of age had evidence of DJD as well (Tiné 2000:503, Table III-110), suggesting this was not strictly age- or cohort-related.

Men are slightly but consistently higher in all categories of DJD expression (Tiné 2000:497-502) and tend to have more joints affected (Tiné 2000:498, Table III-105). Women have more severe cervical osteophytosis, men more severe cervical and lumbar osteophytosis (Tiné 2000:499-502). The former finding fits a recurring pattern observed partially at Pioneer Cemetery as well. Enthesopathy, particularly of the upper body/arm, is also common and, like DJD, more common in men. Nearly one-third of females and just over half of all males have upper body enthesopathy/ muscle attachment hypertrophy, while 3 percent of women and 13 percent of men have lower body enthesopathy/hypertrophy (Tiné 2000:503, Table III-112). A more detailed analysis by Davidson et al. (2002:261-262) suggests that degenerative joint disease increased in women and decreased in men toward the later part of the 1800 s, a shift they linked to increasing employment among women and increasing unemployment among men.

The data from Pioneer, Phillips Memorial, and Freedmen's contrast with those from Houston in some ways. While U.S. census data show most blacks in Houston also worked in manual labor jobs (Foster and Nance 2002:146), and older adults certainly would have worked as slaves, there is remarkably little evidence of DJD. However, this may be skewed by the poor condition of skeletal remains, which often lacked articular surfaces. In the Third New City Cemetery sample of 288 adults, a total of 33 adults (just over 10 percent) have evidence of DJD (especially foot, then wrist and hands) and 14 have VJD. Not surprisingly, this was observed mostly in older adults and men, who were affected twice as often affected as women, a pattern matching that seen in Dallas. Only 10 cases of enthesophytes were recorded at Third New City, 7 of which were in men. A small number of muscle pulls and shoulder injuries also were recorded. It should be noted that while women displayed less 
direct evidence of heavy labor, the osteologists also observed that the females were generally robust (Foster and Nance 2002:145-146).

Osteological data suggests the risk of accidents and trauma in the city was no less than in the country. At Freedmen's Cemetery, nearly one third of all individuals (just three of whom were subadults) buried before 1900 have a fracture, dislocation, or other evidence of trauma (atypical arthritis, burns, soft tissue ossification) not likely from interpersonal violence. This is roughly the same proportion as seen at Pioneer Cemetery. Males at Freedmen's were affected generally twice as often as females. For both men and women, the leg was most often affected, though the skull (which may more likely be the result of violence), hands, feet, and arm were also affected significantly, and a small number of vertebral fractures were also recorded (Tiné 2000:504-510). The fact that the legs, hands, and feet are particularly affected supports an activity- or work-related etiology. Of the 18 or 19 fractures with evidence of possible care (i.e., realignment), only two individuals were buried prior to 1900 . For the remainder buried after 1900, it is unclear when the injury and care for those individuals occurred (Tiné 2000:513-514). Like the evidence for DJD, there is less evidence for trauma in Houston compared to Dallas, though the patterning had some similarity. Only 17 individuals with 22 fractures (5 percent of all adults) were observed, mainly vertebra, femora, hands, and feet. Men were affected three times as often as women in the Houston population (Foster and Nance 2002:135, 144, Table 19).

Beside the stresses of physical labor, rural life in Texas posed additional difficulties for blacks that affected their health and susceptibility to disease. Housing was typically a one- or two-room shanty with a shed for a kitchen. Living space was often cramped due to large families (Barr 1996:104; Rice 1971:259). In the US, the unsanitary conditions and lack of proper ventilation in black homes were often commented upon (e.g., Conrad 1887; Rice and Jones 1990), and as late as 1915, less than half of rural black homes had a privy (Fort 1915). Drinking water was also of poor quality (Farley 1970:70). Sharecropping and tenant farming often left farmers in perpetual debt or eking out a marginal existence, and they faced the risk of crop failure, droughts, and floods, such as the one in 1885 one left hundreds homeless in Brazoria County (Rice 1971:259). Such natural disasters posed a constant threat of financial ruin and starvation. In 1887, one quarter of the cotton crop in Brazoria county was lost to worms (Foster 2001). The pervasive problem of malnutrition affecting blacks was underscored by the often discussed "new" problems of pellagra and rickets that were recognized after the war (Kiple and King 1981:189).

The stresses of physical labor and poor living conditions and nutrition left their mark in the form of higher death rates and increased susceptibility to disease among African Americans. While the 1887 Agricultural Census for Brazoria County lists the crude death rate per 1,000 as 4.7 for blacks and 8.2 for whites, deaths among black were almost certainly underreported. Other numbers in this survey are more plausible. Twice as many black women died as black men, and black women died at a rate three times that of white women. This may be due to the risks involved in childbirth. As discussed below, maternal mortality estimates for black women at 
the turn of the century are very high, while black men died significantly more often due to homicide (Foster 2001).

Infectious diseases, including tuberculosis, pneumonia, diarrheal diseases (including cholera), typhoid, malaria, yellow fever, smallpox, and syphilis, were the most common causes of death. The prevalence of syphilis is often tied to lower economic status and standard of living, while some other diseases, such as malaria and yellow fever, were particularly prevalent in coastal areas. All of these diseases generally took a higher toll on blacks than whites (Farley 1970:70; Kiple and King 1981). ${ }^{11}$ In fact, tuberculosis was the number-one killer of blacks during this period, often killing more than twice as many blacks as whites, along with other pulmonary diseases (Donald 1971:161-162; Farley 1970:70; Kiple and King 1981:188; Rice and Jones 1990). Medical and public health journals of the late 1800s and early 1900s commonly discuss the problems of tuberculosis and syphilis among blacks (see Rice and Jones 1990).

Infectious diseases especially affected city dwellers, who lived in crowded communities plagued with roaming livestock, standing water, backyard privies, and a lack of waste treatment facilities (Anonymous 1941 in Davidson et al. 2002:251; Rice and Jones 1990:xiii;). Reported death rates were higher in urban areas than in rural areas (Farley 1970:61-62). The role of poor sanitation is frequently cited in medical journals as a major factor contributing to the prevalence of tuberculosis and other diseases among blacks (see abstracts in Rice and Jones 1990).

The problem of disease among blacks piqued considerable interest from whites in the health professions. The overall white concept of black health was multifaceted, varying somewhat in emphasis, but certain themes emerge in the literature. Blacks were often viewed as an essentially unsanitary people living in unsanitary conditions (particularly in relation to tuberculosis), inferior to whites, and lacking a moral compass and self-discipline. without their white masters' guidance. Critics claimed that tuberculosis and venereal disease were unheard of before emancipation (Farley 1970:59). "There was no more healthy race of people to be found anywhere in the world than the slaves of the South before the Civil War" (Allen 1915:195). The lack of morality and self-control was especially invoked to explain the high rates of syphilis and other venereal diseases among blacks (Allen 1915; Donald 1971:67, 157; Rice and Jones 1990:xii-xiii). The literature also reveals a tendency among white authorities to claim the prevalence of diseases among African Americans was exacerbated by their practice of seeking treatment from healers who relied on folk remedies of often dubious efficacy, though they may have often only had access to such healers (Donald 1971:158; Rice and Jones 1990:xii). It is unclear if healers were any less effective than mainstream medicine in the treatment of diseases at the time, before the widespread adoption and enforcement of public sanitation and health laws_-particularly in black sections of the city-and the use of antibiotics.

11 "The colored race in life assurance," an 1898 article in the Journal of the American Medical Association (Anonymous 1898), provides some interesting statistics on diseases and how the data affected life insurance policies for blacks. 
There is in fact no evidence for specific diseases at either Pioneer or Phillips Memorial Cemetery, though this should not be taken as a sign they were not present. Skeletons from Dallas and Houston do, however, show evidence of some of the diseases known to plague blacks, particularly city dwellers, including tuberculosis and other pulmonary diseases, syphilis (congenital and acquired), neurocysticerosis, sinusitis, and mastoiditis (Foster and Nance 2002; Tiné 2000).

The rate of nonspecific infections is high, however, at both Pioneer and Phillips Memorial Cemeteries. As described earlier, these lesions give some indication of infectious load and sanitary conditions in the environment, the general health of those afflicted, and their exposure to trauma, particularly for those lesions on the vulnerable tibiae. At Pioneer Cemetery, one third of adults have some evidence of nonspecific infection. All are unilateral lower-leg lesions, supporting a partial trauma etiology (one is the amputee). At Phillips Memorial, nonspecific infection was recorded on 40 percent of adults, all affecting the tibiae and/or fibulae, and half of adults with any long bone present. One is bilateral and one unilateral, but the extent could not be determined for two cases (Dockall and Powell 1996). At the Third New City Cemetery, there were 79 total cases of nonspecific infection, 66 of which were periosteal type reactions in adults (just less than one quarter affected), mostly occurring on the tibiae. Only one child had evidence of infection (Foster and Nance 2002:140). Poor preservation may have played a role in the seemingly low prevalence of infections in both children and adults.

In contrast to these numbers, nearly 70 percent of all adults buried in Freedmen's Cemetery before 1900 had some periosteal reactions, more than half of which were "systemic" (at least three bones affected) (Tiné 2000:491, Table III-103). Sixty percent of subadults suffered from nonspecific infection, 80 percent of which were systemic (Tiné 2000: 490-491, Tables III-102 and III-103). Adult lesions tended to be healing to healed, while subadult infections were active at the time of death. Davidson et al. (2002) describe the temporal trend in tibial periosteal reactions in more detail, and these numbers differ slightly from those of Tiné (2000). Subadults have increasing evidence of infection through the latter $1800 \mathrm{~s}$, from 40 percent in the cemetery's early group (1869-1884) to 70 percent by the end of the century (1885-1899). Men had an overall slight decrease in infection rates during this same period, from 70 percent to 60 percent, while women had stable rates at 40-46 percent. More subadult and adult lesions are considered "severe" during the later 1800s period than in any other at Freedmen's (Davidson 2002:253). The higher incidence among men may suggest greater exposure to trauma, while the reverse trends in men and women may suggest increasing employment among women and the concomitant dangers associated with women's labor, much like the trend reversal seen in DJD.

Like the historical data, the osteological data provide evidence of high infectious load in the environment (and likely poor sanitation) in Dallas in the late 1800 s coupled with an inability to acutely fight infection possibly due to malnutrition. This was particularly true for infants and children. The large number of infants less than one year at death buried at Freedmen's suggests high infant mortality (Tiné 2000:478, Table III-97), as diarrheal disease and malnutrition took their toll (e.g. Foster and Nance 2002:146-147; Tiné 2000:471). Infants are underrepresented at the 
Third New City Cemetery, though high infant mortality was the norm, based on city death records (Foster and Nance 2002:120-123). Linear enamel hypoplasias (LEH) are strongly linked to malnutrition. Hypoplasias of deciduous teeth at Freedmen's only occur between 1885 and 1900 (Davidson et al. 2002:244). In Dallas, there was no adequate pre-1900 sample of permanent teeth (Tiné 2000:484). Pooled temporal data, most from individuals buried after 1900, showed very high rates of LEH: 72 percent of adults and 58 percent of subadults (Tiné 2000:484, Table III-100).

Perhaps the higher rates of LEH among adults in the post-1900 Dallas sample can be explained in this light. These people would have grown up mainly during the later 1800 s, with some possibly having labored in their younger years during slavery. Indeed, though no exact numbers are given, older individuals who may have been slaves or lived a substantial part of their lives prior to 1900 had a slightly higher prevalence (Tiné 2000:484). Rates of LEH on permanent teeth increased from 1885 to 1900 , over the pre-1885 rate (Davidson et al.:2002). At Third New City rates are high as well. About half of individuals with permanent teeth observable had LEH, females (64 percent) more often than males (46 percent), though a considerable number of those affected could not be sexed (Foster and Nance 2002:138). No data on subadults are available. More than nonspecific infection rates, these data may accurately reflect post-epositional conditions in Houston during this time, as teeth likely preserved better than all other bony elements.

Lastly, the pattern of the other two childhood lesions linked to malnutritioncribra orbitalia and porotic hyperostosis-is notable and seemed to increase in Dallas during the end of the nineteenth century. From 1869 to 1884, no skeletons were affected. Between 1885 and 1899, 15 percent of subadults had cribra orbitalia and 4.3 percent of subadults and 3.4 percent of women had porotic hyperostosis. No men were affected. Cribra orbitalia makes it first appearance in adults buried at the site after 1900, with just over 10 percent affected. As was the case with LEH in adults at Freedmen's Cemetery, these individuals would have spent their childhoods in the later half of the 1800s. Porotic hyperostosis increased in women (11 percent), and made it first appearance in men (5 percent) after 1900 (Davidson et al. 2002:250). All adult lesions were healed and all subadult lesions were active at death (Tiné 2000:487-488). In contrast, at the Third New City Cemetery the population prevalence is only 3 percent for cribra orbitalia and 4 percent for porotic hyperostosis (Foster and Nance 2002:143). As was observed for rates of nonspecific infection, these low frequencies of occurrence may also be biased by poor preservation.

There is overall less evidence from rural sites for childhood malnutrition and stress. This could reflects the often-stated idea that rural life offered overall better health conditions, or it may simply mean that rural children tended to die more quickly before malnutrition and stress were manifested in their skeletons. At Pioneer Cemetery, about one quarter of skeletons with teeth had LEH (3/11, all adults). At Phillips Memorial, one LEH was present in an adult buried prior to 1900 and one in an adult buried post-1900 (but likely raised in the latter 1800s), though only 12 interments had any teeth preserved (Dockall, Powell, and Steele 1996). Using unpublished data from Cedar Grove in Arkansas, Tiné (2000:484, Table III-100) estimates that 95 percent of adults with teeth had at least one LEH. The 
numbers provided by Davidson et al. (2002:244) are comparably high for the Dallas Freedmen's Cemetery, both in deciduous and permanent teeth, in sharp contrast to their rural counterparts in Texas and even to the urban population at Freedmen's.

There is significant variability in the presence of cribra orbitalia and porotic hyperostosis. Only one possible case of porotic hyperostosis was observed at Pioneer Cemetery. Of 12 individuals from Phillips Memorial Cemetery, 4 adults out of 6 with frontal and/or parietal bones preserved had some evidence of cranial thickening or porotic hyperostosis (Dockall and Powell 1996). Three are cranial thickening and may not represent a true pathologic process. The Cedar Grove Cemetery again stands in contrast to its counterparts in Texas, rural and urban. Twenty-seven percent of adults at Cedar Grove had cribra orbitalia or porotic hyperstosis (Rose and Santeford 1985).

\section{African-American Life in Texas, 1900 to 1920}

By the turn of the century, the limited gains made by blacks during Reconstruction were quickly eroding. A decline in state offices held by blacks went hand in hand with a steady decline in black voting during the late 1800s. The latter was due to a combination of disappointment in effective change, intimidation, and legal measures. In 1895, the Taxpayer's Union began to enforce white primaries in Brazoria County to keep blacks from voting and holding office (Kleiner 2010), a trend occurring statewide. This may be viewed, perhaps, as a subset of the continued violence and intimidation directed at African Americans. The poll tax of 1902 and white primary law of 1903 further shut blacks out of political life. During the 1890s, 100,000 blacks voted, but by 1906 only 5,000 did so (Barr 1996:80). Further legislation in the early 1900s institutionalized segregation in public transportation, schools, accommodations, and neighborhoods (Dulaney 2010). Nationwide, black ownership of land declined (Farley 1970:22).

The Antilynch Law of 1897 did have some of its desired effect. In Texas, there were 71 lynching victims from $1889-1893$ and 72 victims from 1894-1898, but that number fell to only 39 from 1899-1903 (Rice 1971:153-154). Despite this decline, Texas was still ranked third in the nation in lynchings between 1900 and 1910, recording over 100 (Barr 1996:136). Again, it is unclear how comprehensive or accurate even these numbers are, or what the overall trend in violence toward blacks was.

There is osteological evidence of increased interpersonal violence during the early 1900 s, particularly gunshots, among both urban and rural blacks. Phillips Memorial had two instances out of 31 adults: a gunshot or other metal wound in a young woman, and a parry fracture (Dockall and Powell 1996). At Cedar Grove, two individuals had been shot (one man and one woman), and 20 percent of men had cranial fractures (Davidson et al. 2002:266; Rose and Santeford 1985). As described above, osteological evidence suggests that interpersonal violence increased in Dallas, possibly due to the increasing population in the city, though there is no way to say if this was from white on black or black on black incidents. Of the 22 possible cases (gunshot or stab wounds), all but one was interred after 1900. Considering that 887 burials were recovered from the post-1900 component at Freedmen's, the overall 
percentage of cases is still quite low. Considering the small sample size of the two rural sites, there would seem to be more risk of violence there than in the city.

There is some evidence that the overall health of African Americans may have been improving. Data gathered by the state of Texas at that time suggest that blacks and whites were dying at a rate that mirrored their proportions in the population. This conclusion has been challenged by researchers who believe it is highly suspect (Brumby 1911; Collins 1917; Steiner 1913, 1915). Specific data on Brazoria County are lacking. Nationwide the mortality rate of blacks was 2.7 times the white average (Kiple and King 1981:188), though that statistic, too, is based on flawed U.S. census data. Life expectancy increased but still lagged behind that of whites (though see Farley [1970:207-208], who states that life expectancy based on census data does not show any increase until the Great Depression). According to estimates by Davidson et al. (2002:235), life expectancy in 1900 Texas was 49 years for whites and 38 for blacks. By 1910, it had improved to 54 years for whites and 45 for blacks. There are no particular historical or environmental reasons to think that mortality and life expectancy in Brazoria was any better than the national average.

Infant mortality is a strong correlate of the overall level of health of a population. In 1900, the estimated nonwhite infant death rate in the United States was 275/1,000 (Farley 1970:212), which exceeds by a considerable margin the 175.9/1,000 mortality rate of Angola, the modern country with the worst mortality rate of infants less than one year (CIA World Factbook 2009). In Texas, the estimated infant mortality was 114/1,000 births for whites and 176/1,000 for blacks. By 1910, it had improved to 97/1,000 for whites and 148/1,000 for blacks (Davidson et al. 2002), which would still place black Texans at third worst in the modern world, behind Afghanistan (CIA World Factbook 2009). Estimated infant mortality at Freedmen's (based on proportion of infants interred) began to drop after 1900, from 52.6 percent to 33.4 percent, perhaps mirroring the national trend. At rural Cedar Grove, however, infant mortality remained very high, possibly related to congenital syphilis in this population (Rose 1989). Farley (1970:222-226) tracks the rise in mortality from syphilis among blacks during this period, though it was more common among city dwellers than rural populations. In 1920, the nonwhite infant mortality rate due to syphilis was 2.7/1,000 (Farley 1970:216).

Blacks also had higher stillbirth rates-two to three times the white average (Kiple and King 1981:188). Limited data suggest that this was true in Texas as well. Though the accuracy of the numbers is questionable, perhaps the trend is less so. The ratio of live to stillborn births in 1910-1912 was 40:1 for whites and 15:1 for blacks. By 1913-1914, it had improved to 48:1 white and 20:1 black. In 1914-1916, it declined again, 40:1 white and 11.5:1 black (Collins 1919; Steiner 1913; 1915). By 1920, the black stillbirth rate in the United States was 72/1,000 (Farley 1970:210 212 ), close to the rate of 62/1,000 at Cedar Grove by Rose's calculation (1989). The maternal mortality rate in 1920 was 13/1,000 (Farley 1970:209). This places African American maternal mortality, a proxy measure of access to medical care, at a tie with Rwanda, the seventh worst in the world in 2005, according to a joint report by the WHO, UNICEF, UNFPA, and the World Bank (2007). The increased number of younger females dying at Cedar Grove may suggest childbirth related mortality. The 
excess of women dying before age 40 at Freedmen's both before and after 1900 (Tiné 2000:474), and the fewer women reaching old age at the Third New City Cemetery in Houston (Foster and Nance 2002:123), may suggest that maternal mortality took its toll in those cities as well.

The osteological data suggest that poor health and vulnerability to disease persisted in black children born after the turn of the century. None of the few children buried at Pioneer Cemetery or Phillips Memorial had LEH, cribra orbitalia, or porotic hyperostosis, and the adults with these lesions would have developed them before 1900. On the other hand, the children at Cedar Grove seem in remarkably poor health. Half (13 of 28) of the subadults had cribra orbitalia/porotic hyperostosis (Rose and Santeford 1985), and two thirds of all children with teeth had LEH (Tiné 2000:484, Table III-100). Thirty-four of 44 subadults at Cedar Grove had some evidence of infection at death, including all but 1 of the 11 who died at birth and all 5 who died in utero (Rose and Santeford 1985). Four subadults also had evidence of rickets, accounting for 24 percent of all children between 3 and 20 months (Rose 1989).

The pooled temporal data on LEH from Freedmen's, discussed above, were remarkable for overall high rates. Little change occurred between the middle and late periods. ${ }^{12}$ It is worth noting that no deciduous teeth of children buried after 1900 had LEH (Davidson et al. 2002:244). Further, while porotic hyperostosis decreased by nearly half from the middle period in subadults (from 4.3 to 2.5 percent), cribra orbitalia more than doubled (from 15 to 34 percent) (Davidson et al. 2002:250). Nonspecific infection of all types among subadults buried after 1900 increased from about 60 to 75 percent (Tiné 2000). Tibial infections may be stable and are overall less severe than those observed prior to 1900, but they remain at the high rate of ca. 70 percent (Davidson et al. 2002).

Major causes of death across the board continued to be infectious diseases. In 1908, the first morbidity and mortality tables were published for the state of Texas, though admittedly blacks were underrepresented (Brumby 1908:12-13). Infectious causes predominated, but no clear, consistent patterns emerge for black health. However, malaria, smallpox, syphilis, gonorrhea, pellagra, rickets, and homicide clearly were disproportionately reported in African Americans (Brumby 1908, 1911; Collins 1917, 1919; Steiner 1913, 1915). A smallpox epidemic spread across Texas starting in 1898 and lasted through 1904 (Tabor 1904), but its impact on blacks is not clear. Of the top six causes of disease in 1890 and 1900 in the United States, pneumonia, heart disease, and cancer all increased between these years, while diarrheal disease, diseases of the nervous system, and typhoid decreased among blacks and whites (Donald 1971:162). In 1900 tuberculosis and pneumonia still killed more than 450 and about 350 blacks per 100,000, respectively (Kiple and King 1981:191). In 1904, tuberculosis was first recognized by the Texas State Health Officer as "the most serious of all communicable diseases, with which we have to contend" (Tabor 1904:5) and funeral home records from La Marque, Galveston County, Texas, in the early twentieth century show that tuberculosis

12 For the Dallas Freedman Cemetery, the middle period burials date 1885-1899 and the late period burials date 1900-1907. 
continued to be a major cause of death (Dockall and Powell 1996:102-103). By 1930, tuberculosis and pneumonia were finally decreasing, but they, like essentially all diseases besides cancer, remained significantly higher in blacks than whites (Kiple and King 1981:191).

Rural health may have actually declined during this period, due to overpopulation, unsafe drinking water, poor diet, poverty, and lack of public health knowledge (Farley 1971:7, 72). An increase in pellagra deaths by the 1920s suggests worsening of the diet (Farley 1970:217-222). This problem was recognized in Texas as early as 1911, though no particular mention was made in relation to African Americans (Brumby 1911). By 1911 state health officials expressed concern about food and water quality, sewage disposal, and sanitation issues (Brumby 1911), although it is unclear if these concerns had any impact on health policies or practices. Urban blacks would not benefit from public health initiatives until after 1920 (Farley 1971:72), and rural areas likely lagged behind.

Nonspecific infection data do not provide any clear evidence for either an improvement or decline in adult health overall during this period. At Phillips Memorial, perisoteal reactions are decreased slightly from pre-1900 levels. Seven of 31 adults ( 7 of 19 with any long bone present, and 3 of 8 with a tibia present) had some form of nonspecific infection in the skeleton. At Cedar Grove, the rates of infection in adults were very high. Fourteen of 15 males and 13 of 21 females were afflicted (Rose and Santeford 1985). Additional data from Rose (1989) suggest all men and over 80 percent of women had some bony infection. Half the men and all the women had bilateral involvement. Almost all of these infections were healed (Rose and Santeford 1985). Ten men and 9 women had the tibia affected (Davidson 2002:252). These data provide yet more osteological evidence that this population had very high exposure to infection and trauma and little resistance to these stressors (Davidson 2002; Rose 1985, 1989).

The osteological data from Dallas are complicated, but prevalence of infection among adults remained high, with little change from pre-1900 levels, though there are some hints at improving health. Overall, rates of nonspecific infection in adults decreased slightly (from 67 to 62 percent), but rates of systemic infection increased slightly (from 60 to 67 percent) (Tiné 2000:491, Table III-103). Tibial lesions in men appeared to continue a decreasing trend (from 60 to 50 percent) and increased slightly in women (from 46 to 52 percent) (Davidson et al. 2002). Most cases were milder than those that occurred prior to 1900 (Davidson et al. 2002:253). As noted above, infection among children appears to worsen during this period. It is unclear, however, whether these data reflect real changes in disease rates, changes in mortality, or changes in the population (due to immigration of large numbers of blacks and changes or differences in disease susceptibility) are impossible to discern with the available information. It is perhaps significant in this light that the evidence of limited medical care at this site (two leg amputations, aligned fractures) also occurred mainly in burials interred after 1900 (Tiné 2000:513-514).

Overall, agricultural and domestic work for blacks in Texas decreased during the early 1900s, and African Americans continued to struggle with economic 
inequality. By the early twentieth century, lower wages and lack of jobs led black women in Texas to work outside the home at a higher rate than white women, usually as domestics, seamstresses, and teachers (Barr 1996:150-151). In Brazoria County, an unsystematic review of census records from 1900 to 1920 suggests that most black men continued to work in agriculture (Historical Census Browser 2004). Not until the 1940s would there be much manufacturing work in Brazoria County (Kleiner 2010). Thirty-seven manufacturing establishments are listed there in the 1900 U.S. census and 22 in the 1920 census (Historical Census Browser 2004). In the north Galveston Bay and La Marque areas in the first two decades of the century, most blacks also worked as laborers, a large percentage in agriculture, but an increasing number worked as railroad men and longshoremen, as well as general laborers (Dockall, Powell, and Steele 1996:31).

Indications of labor such as DJD is relatively high at Phillips Memorial Cemetery, and remains unchanged from pre-1900 levels. Altogether, 15 of the 31 adults have some DJD in evidence, including 13 with peripheral osteoarthritis (all manifested as osteophytic lipping), and 5 with vertebral joint disease. There is a predilection for the feet and hands, but this may be biased by the fact that most recovered elements were from these regions. Five have some well-developed muscle attachments, 3 in the arm, 1 femur, and 1 unknown. Of the 5 trauma cases, (foot, parry, hand, and fibula fractures and a joint dislocation at the elbow), only the parry fracture is not consistent with work- or activity-related causes. The rates of DJD at Cedar Grove are similar to those observed at Phillips Memorial. About half of adults have some form of the condition. Again, males are higher than females: 2/3 males have any form of DJD, and half are affected if osteophytosis or Schmorl's nodes are excluded. Just under half of the females have any type of DJD, and about a third excluding osteophytosis or Schmorl's nodes. There is no joint predilection. Non-weapons trauma (including cranial and rib fractures) was high, similar to that in Pioneer Cemetery and was observed in 9 of 15 males (including 3 head and 2 rib) and 4 of 21 females (hands, upper limb, feet, 2 ribs). One right femur amputation was also recorded (Rose and Santeford 1985).

At Freedmen's, rates of DJD are generally higher than for their rural cousins (except Pioneer Cemetery). Almost 60 percent of women had DJD, essentially unchanged from women interred prior to 1900 , but males increased slightly (to 77 percent). Again, most cases were mild (Tiné 2000:497-98). Osteophytosis of vertebral column decreased however, in women, but only slightly in men. Most are moderate in severity. Schmorl's increased in women and decreased in men, but they were still more common in men (Tiné 2000:501, Table III-108). Davidson et al. (2002:255) link an increase in DJD of the elbow and shoulder in women to increasing work as laundresses and an increase in severity of cervical disease in men to increased employment as porters in Dallas. Enthesopathy does not clearly support this as upper limb enthesopathy decreases slightly in both sexes while lower limb increases slightly, though men are still twice as often affected as women (Tiné 2000: 503, Table III-112). Overall fractures and dislocations increased after 1900 , though stress fractures decreased. "Other" forms of trauma decreased by half (Tiné 2000:510). 


\section{SUMMARY}

By the early 1900s, the lack of progress, if not downright loss of already held gains, by African Americans in the South led large numbers to emigrate to the cities and the northern United States (Farley 1970:41-46). Black southerners fled to escape Jim Crow laws, racial violence, and the rigid social order of the South. This phenomenon lasted for decades, from about 1915 to the 1970s, and it had a great impact on America. Wilkerson (2010:9) states:

Historians would come to call it the Great Migration. It would become perhaps the biggest underreported story of the twentieth century. It was vast. It was leaderless. It crept along so many thousands of currents over so long a stretch of time as to be difficult for the press truly to capture while it was underway. Over the course of six decades, some six million black southerners left the land of their forefathers and fanned out across the country for an uncertain existence in nearly every other corner of America. The Great Migration would become a turning point in history. It would transform urban America and recast the social and political order of every city it touched. It would force the South to search its soul and finally to lay aside a feudal caste system. It grew out of the unmet promises made after the Civil War and, through the sheer weight of it, helped push the country toward the civil rights revolutions of the 1960s.

In Texas, the percentage of African Americans dropped from 20 percent of the population in 1900 to 15.9 percent in 1920, though their overall numbers increased by about 120,000 . By 2008 , blacks made up just 11.9 percent of the population (Historical Census Browser 2004). In Dallas from 1900 to 1910, the population doubled, but the percentage of blacks stayed the same as other groups moved to the city at a higher rate (Davidson 2000:315, Table III-43). In Brazoria County, the percentage of blacks dropped from 74 to 55 percent between 1890 and 1900. By 1920 , black numbers dropped from 8,219 to 6,547 , or 31.9 percent of the county's total population. The overall population increased from 14,861 to 20,614 , and the numbers then held steady until 1950, though percentages continued to decline. After 1950 , the black population began to grow again. By 2000, just over 20,000 blacks lived in Brazoria County, making up just 8.5 percent of the population (Historical Census Browser 2004).

Conditions did improve slowly, particularly after World War I, and then again after World War II (Farley 1970). But even at the beginning of the twenty-first century, African Americans lagged behind whites in most of the same socioeconomic and epidemiological indicators as they did in the decades after the Civil War. Long after the sharecropping days and segregation, economic inequality persisted. In the first decade of the twenty-first century, black unemployment in the United States was almost twice the white average. Weekly wages of full-time black workers were also over one hundred dollars less than those of their white co-workers during this same time (U.S. Bureau of Labor Statistics n.d.). Not surprisingly, one quarter of all blacks—nearly three times the percentage of whites-lived below the poverty line, including a third of all black children (U.S. Census Bureau 2010). 
Infant and maternal health also lagged. By 2006 black infant mortality in the United States was 12.9/1,000 live births, more than twice the non-Hispanic white mortality. In Texas, it was $11.88 / 1,000$, about twice the rate of white Texans. All of the top four causes of death in infants-low birth weight, congenital malformations, sudden infant death syndrome, and maternal complications-took a greater toll on black babies (Mathews and MacDorman 2010). In 2008, when infant mortality for whites in Texas was 5.9/1,000, infant mortality for blacks was 9.9/1,000, and black mothers in Brazoria County were less likely than their white counterparts to get prenatal care in the first trimester. Black mothers are also twice as likely to be 17 years or under when they become pregnant and more likely to have low-birthweight babies (Texas Department of State Health Services 2011). Black mothers still suffer two to three times the white average in deaths associated with pregnancy. The nationwide maternal mortality in 2008 was $10.5 / 100,000$ births for whites and 28.4/100,000 for blacks (U.S. Department of Health and Human Services 2010). In Texas, the overall numbers of maternal deaths are fortunately low. In 2007, white maternal mortality was 21.6/100,000 births, while among blacks it was 26/100,000. In 2008, it was 25.4 and 41.5, respectively (Texas Department of State Health Services 2011).

Blacks continue to die at a higher rate than whites and live shorter lives. Life expectancy for blacks in Texas, though it is now well above what is was 100 years ago, continues to lag several years behind that of whites. In 2008, life expectancy was 77.4 years for whites and 74.6 years for African Americans. In 2008, the age-adjusted mortality was $979.3 / 100,000$, compared to $844.1 / 100,000$ for whites. Among the top causes of death that year (unadjusted for age), whites were more impacted by heart disease, cancer, cerebral vascular accident, and flu/pneumonia. African Americans were more affected by diabetes and kidney disease, and they were far more likely to have died of HIV and sepsis. Although the number of cases has vastly diminished, the old scourge of tuberculosis continues to kill blacks disproportionately. Of the 67 tuberculosis deaths in 2008, 19 were white and 14 were black. African Americans are also affected by a myriad of other infectious disease more often than whites, including whooping cough, viral hepatitis, and syphilis. Black males are also especially at risk for death by homicide (Texas Department of State Health Services 2011).

The investigation of the individuals buried at the Pioneer Cemetery helps put in perspective these barometers of social and health status among contemporary African Americans, as well as the great gains made over the last 100 years. This study also illuminates the fact that many of the health problems faced by latenineteenth-century African Americans in Brazoria still persist today, though they are less frequent. Further, the root causes of these health challenges remain and were established long before the people buried in Pioneer Cemetery were born. Perhaps the ultimate value in the study of the nineteenth-century skeletal remains from Pioneer Cemetery is to help economic and public health policymakers better understand the historical context of the racial and social inequalities they are trying to redress. 


\title{
CHAPTER 8: AFRICAN AMERICAN GRAVEYARDS, PIONEER CEMETERY, AND THE AFRICAN DIASPORA
}

\author{
Douglas K. Boyd and Aaron R. Norment
}

Back in them times they didn't put anything on 'em for the memory. No sign on it to show who it is. There's many a grave out here... Most of them aren't marked... There's graves all along in here. You don't know who it is. They marked the grave with a stick or something like a particular design. But eventually that will fail. Twenty years go by and nobody knows who's buried there.

-African American informant Brazoria County, Texas

(Wright 1994:91)

The statement above was made by an African American interviewed by Cheryl Wright in her oral history of the African American community near the Levi Jordan Plantation in Brazoria County. ${ }^{13}$ The informant was speaking about African American burial practices of the late-nineteenth and early-twentieth centuries (Wright 1994, 1998). This person's recollection speaks volumes about why it is common for older African American cemeteries to have so few graves marked with headstones and large areas with only subtle hints of unmarked graves. While the informant was speaking specifically about the Jordan (or Juden) Cemetery in southern Brazoria County, the statement "There's many a grave out here... Most of them aren't marked" seems to apply equally well to Pioneer Cemetery and many other African American graveyards scattered across the South. [avoid rep]

How does one relatively small, predominantly African American cemetery with many unmarked graves fit into the bigger picture of history of Texas history? The short answer is that story of Pioneer Cemetery is, in many ways, representative of a broader pattern of African American history that characterized the entire eastern half of Texas in the nineteenth and early twentieth centuries. Like many such cemeteries, Pioneer Cemetery began as a graveyard for enslaved peoples and later became the primary burial ground for the local freedmen community. Other traits it shared with many old African American graveyards include a paucity of formal grave markers and the loss of ephemeral grave markers over time, a lack of written burial records, the loss of knowledge of grave locations with each passing generation, and the encroachment of modern development onto cemetery land. The result is a relatively large graveyard with few known graves

13 The unidentified informant is one of 17 African Americans (10 men and 7 women) from the Levi Jordan Plantation area that Wright interviewed between January and June 1993. 
and a twentieth-century roadway built over some portion of the old burial ground. This situation is not unique to Pioneer Cemetery. What happened there over more than a century and a half has undoubtedly happened at many black cemeteries across eastern Texas and the southern United States.

The identities of the 14 individuals whose remains were exhumed and moved are unknown. It is likely that each of these graves was marked in some way at the time of death. Some grave markers may have been ephemeral wooden crosses that decayed over time, and others may have been consisted of only a cluster of fieldstones or brica-brac that became scattered and lost. Some of the graves could have originally had substantial molded concrete or carved stone monuments that identified the deceased, but these, too, could have been broken and lost over time. For whatever reasons, these graves probably ended up unmarked and unrecognizable by the late 1930 s, when the SH 332 bridge over the Brazos River was being constructed. After World War II ended, the SH 332 roadway south of the Brazos River was completed, and this paved road went over many of these lost graves.

The 14 exhumed burials all appear to date between 1850 and 1911 (Table 8.1). The osteological analysis of the skeletal remains identified the exhumed individuals as:

ADULTS

Male, older $(>40)$

Female, young $(<30)$

Female, older $(>30)$

Indeterminate sex, unknown age

Indeterminate sex, older $(>40)$

\section{SUBADULTS AND CHILDREN}

Indeterminate sex, young child $(<6)$

Indeterminate sex, older child (6-12)

Indeterminate sex, subadult
2

1

4

1

1

3

1

1

Not unexpectedly, 7 of these 14 individuals exhibit biological traits indicative of African ancestry.

Identifications of age, sex, and biological affinity are an essential part of osteological analyses and studies of burial populations. But these are impersonal data that belie the fact that all of these people, while living, had separate identities and were important within their families and community. To their families they were sons and daughters, brothers and sisters, aunts and uncles, mothers and fathers. To their community they were known by their occupations and economic status, their individual personalities, and their broader social roles. Whether perceived as a respectable businessman, a wise old grandmother and healer, a leader in the church choir, a happy and loving child, or a ne'er-do-well drifter, each person had his or her own identity.

It is unfortunate that the individual identities of these Brazoria citizens have been lost to time and historical circumstance, but this, too, was and is a common occurrence among African Americans. In lieu of individual histories, the remainder 


\begin{tabular}{|c|c|c|c|c|c|c|c|c|c|c|c|c|c|c|c|c|c|c|c|c|c|c|}
\hline & 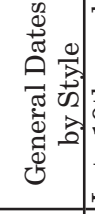 & 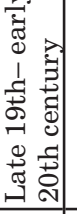 & & 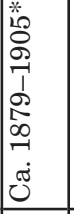 & & & & & & & & 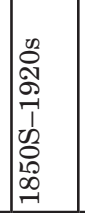 & & & & 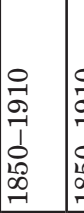 & 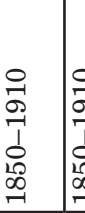 & $\begin{array}{l}0 \\
-1 \\
9 \\
-1 \\
1 \\
0 \\
\infty \\
0 \\
-1 \\
\end{array}$ & $\mid \begin{array}{l}0 \\
-1 \\
9 \\
-1 \\
1 \\
0 \\
0 \\
0 \\
-1 \\
\end{array}$ & $\begin{array}{l}0 \\
-1 \\
\sigma \\
-1 \\
1 \\
0 \\
\infty \\
-1 \\
-1\end{array}$ & & 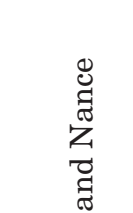 \\
\hline & 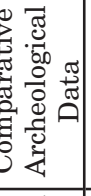 & & & & & & 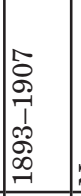 & 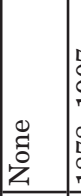 & $\begin{array}{l}\infty \\
\infty \\
\infty \\
-1 \\
\infty \\
\infty \\
\infty \\
-1 \\
-1\end{array}$ & $\begin{array}{l}\overrightarrow{1} \\
\overrightarrow{9} \\
\overrightarrow{2} \\
0 \\
0 \\
0 \\
0 \\
-1 \\
\end{array}$ & 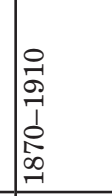 & 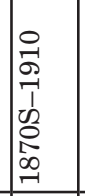 & 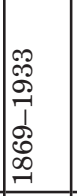 & & $\begin{array}{l}0 \\
-1 \\
- \\
1 \\
1 \\
\infty \\
+1 \\
0 \\
-1 \\
\end{array}$ & & & $\begin{array}{l}8 \\
8 \\
0 \\
1 \\
1 \\
10 \\
\infty \\
-1 \\
-1\end{array}$ & & & & 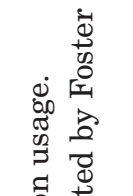 \\
\hline & 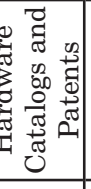 & & 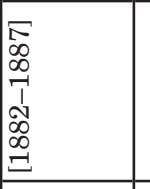 & & 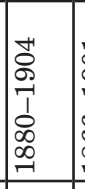 & $\begin{array}{l}-\overrightarrow{0} \\
0 \\
\\
0 \\
0 \\
0 \\
0 \\
-1 \\
\end{array}$ & \begin{tabular}{|l|} 
\\
\\
$z$ \\
$z$
\end{tabular} & 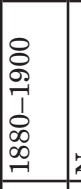 & 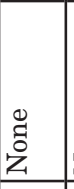 & $\begin{array}{l}0 \\
\\
0 \\
z\end{array}$ & 茴 & \begin{tabular}{|l|}
0 \\
0 \\
0 \\
-1 \\
1 \\
0 \\
$\infty$ \\
0 \\
-1 \\
\end{tabular} & $\mid \begin{array}{l}0 \\
0 \\
\infty \\
1 \\
1 \\
1 \\
0 \\
0 \\
-1 \\
-1 \\
\end{array}$ & 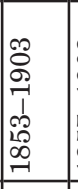 & $\begin{array}{l}2 \\
0 \\
0 \\
-1 \\
1 \\
1 \\
18 \\
0 \\
-1 \\
\end{array}$ & 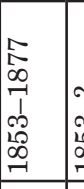 & 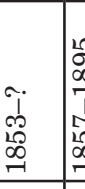 & $\begin{array}{l}20 \\
2 \\
\infty \\
1 \\
1 \\
12 \\
10 \\
0 \\
-1 \\
\end{array}$ & & & & 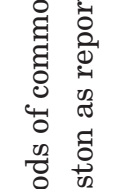 \\
\hline & $\stackrel{-}{\rightarrow}$ & & & -1 & $\infty$ & & -1 & & & & & & $\infty$ & & & & $\neg$ & & & & 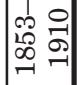 & 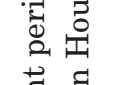 \\
\hline & 9 & & & & & & & H & & & 10 & $\nexists$ & & & & & & & & & 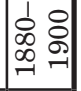 & 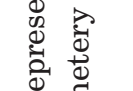 \\
\hline & 190 & & $\neg$ & & & & & & & & & & & & $\ltimes$ & & & & & & 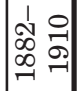 & $\begin{array}{ll}\pi \\
0 \\
0 \\
0 \\
0 \\
0\end{array}$ \\
\hline & $\underset{刂}{ \pm}$ & & & & & & & & $\curvearrowright$ & & & & & $\infty$ & $\neg$ & N & & & & & 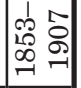 & 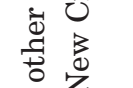 \\
\hline & 9 & & & & & & & & & & & & & 0 & & & & & & & 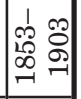 & 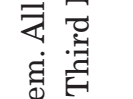 \\
\hline & I & & & & & & & & ค & & & & & & & N & & & & & {$\left[\begin{array}{ll}1 & \\
0 \\
0 \\
0 \\
0\end{array}\right.$} & 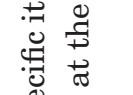 \\
\hline & $\Rightarrow$ & & & & + & & & & & 0 & & & & & & & & & & & 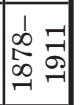 & 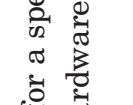 \\
\hline & 의 & & & & & & & & & & & & & & & & & & & & r. & $\underbrace{0}_{\infty})$ \\
\hline & o. & $\dashv$ & & & & & & & & & & & & & & & & & & & a. & \\
\hline & $\infty$ & & & & + & N & & & N & & & & & $\stackrel{\Im}{\nexists}$ & & N & & & & & 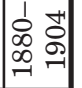 & 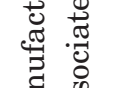 \\
\hline & $\checkmark$ & & & & & & & & & & & & & + & & & & & & & 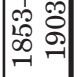 & \\
\hline & $\nabla$ & & & & & & & & & & & & & & & & & & 10 & & {$\left[\begin{array}{ll}1 & 9 \\
0 & 0 \\
0 & 0 \\
\hdashline & 9\end{array}\right.$} & 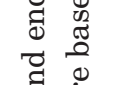 \\
\hline & $\infty$ & & & & & & & & & & & & & & & & & $\neg$ & 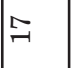 & & 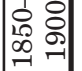 & ${ }_{0}^{20}$ \\
\hline & -1 & & & & & & & & & & & & & & & & & & $\sim$ & +r & 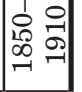 & 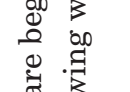 \\
\hline & 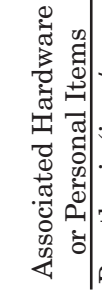 & 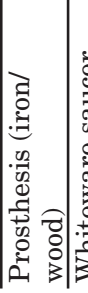 & 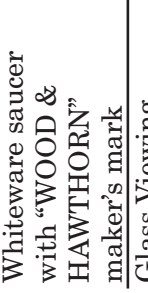 & 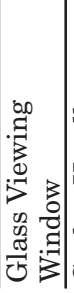 & 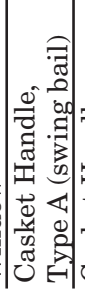 & 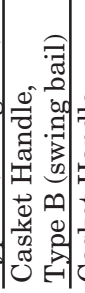 & 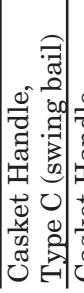 & 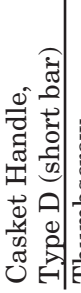 & 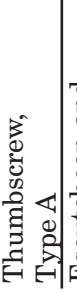 & 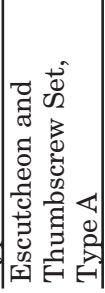 & 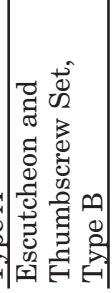 & 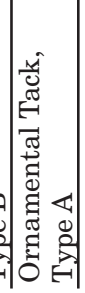 & 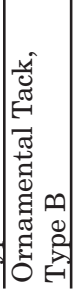 & 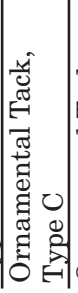 & 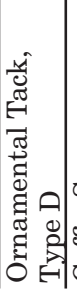 & 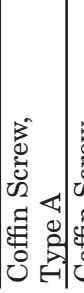 & 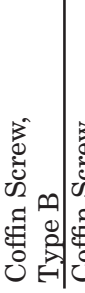 & 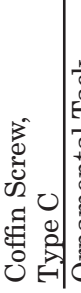 & 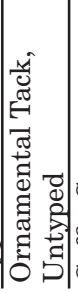 & 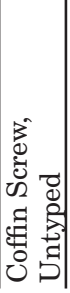 & 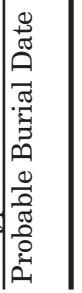 & 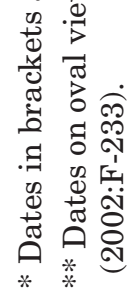 \\
\hline
\end{tabular}


of this chapter looks at the African American community of Brazoria and examines the unique characteristics of the Pioneer Cemetery burials to place these unknown people within the broader historical contexts of African Diaspora studies.

\section{AFRICAN AMERICANS IN TEXAS AND BRAZORIA}

Many histories have been written about Brazoria and Brazoria County, but they are, by and large, histories of white people written by white people. Except for noting that the regional agricultural economy depended upon the labor of slaves and freedmen, many of these histories seldom recognize the contributions of blacks in the development of the town or the county. In this section, we look at the history of African Americans in Texas and Brazoria County to provide some historical context for understanding the African American community of Brazoria and its burial ground called Pioneer Cemetery.

Historically, blacks comprised a large portion of the population in eastern Texas in the second half of the nineteenth century, and Brazoria County was among those with a large percentage of enslaved blacks. Table 8.2 summarizes the enslaved population of Texas and Brazoria County from 1836 through 1864 based primarily on tax data, with census figures added for 1840, 1850, and 1860 . One may note that there are significant discrepancies in the population figures for 1850 and 1860, with the U.S. census population data being much higher than the tax roll data (21 percent higher in 1850 and 14 percent higher in 1860). The census data are probably more accurate because there was certainly an incentive for plantation owners to underestimate one's slaveholdings when the taxman came. But several important facts may be gleaned from these data. First, the population data show that enslaved Africans and African Americans comprised a sizable population in Texas during the Republic of Texas, early Statehood, and Confederate States periods. Second, Brazoria County accounted for a significant portion of all the slaves during the Republic of Texas period and into statehood. And third, as Brazoria County's general population increased, its slave population dropped in proportion to Texas's overall slave population. While the dominant trend for Brazoria County was a rapid increase in the slave population from 1837 through the end of the Civil War, the growth in the county slowed down somewhat relative to the rest of the state.

Table 8.3 shows and increase in the enslaved population of Brazoria County in the Republic of Texas, early Statehood, and Confederacy periods, from 1837 through 1864. Slaveholdings grew in the early Republic of Texas years from 1837 through 1840, followed by lower annual increases in the latter years of the Republic of Texas, from 1840 to 1845 . This decline may reflect plantation owners' concerns about potential loss of slaveholdings when Texas was considering annexation into the United States. They may also reflect other historical factors, such as the yellow fever epidemic that hit Galveston and the Texas coast in 1844 (Hogan 1969:229-230). Kleiner (2010:n.p.) notes that population growth in Brazoria County was slower in 1843 and 1844 due to yellow fever and flooding.

The slave population in Texas experienced its largest single-year increase in 1845-1846, perhaps spurred by euphoric growth once Brazoria County plantation 
Table 8.2. Comparison of the enslaved populations of Texas and Brazoria County from 1836 through 1864. Data from Campbell (1989)

\begin{tabular}{|c|c|c|c|c|c|c|}
\hline \multirow[b]{3}{*}{ Year } & \multicolumn{3}{|c|}{$\begin{array}{c}\text { Tax Roll Data } \\
\text { (from Campbell 1989)* }\end{array}$} & \multicolumn{3}{|c|}{ Census Data } \\
\hline & \multirow[b]{2}{*}{ No. of Slaves in Texas } & \multicolumn{2}{|c|}{ Slaves in Brazoria County } & \multirow[b]{2}{*}{ No. of Slaves in Texas*** } & \multicolumn{2}{|c|}{ Slaves in Brazoria County } \\
\hline & & No. & Percent & & No. $* * *$ & Percent \\
\hline 1836 & ca. 5000 & 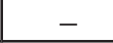 & 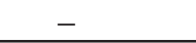 & 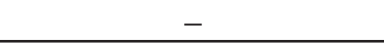 & $\begin{array}{cccc}- \\
\end{array}$ & 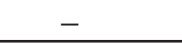 \\
\hline 1837 & $4212(+)$ & 892 & - & - & - & - \\
\hline 1838 & - & - & - & - & - & - \\
\hline 1839 & $\begin{array}{c}- \\
\end{array}$ & $\overline{-}$ & $\begin{array}{c}- \\
\end{array}$ & $\begin{array}{cc}- & \\
\end{array}$ & $\begin{array}{cc}- \\
\end{array}$ & $\overline{-}$ \\
\hline 1840 & 12,570 & 1,665 & $13.2 \%$ & 11,323 & 1,316 & $11.6 \%$ \\
\hline 1841 & - & - & - & - & - & - \\
\hline 1842 & $\begin{array}{llll}- & \\
\end{array}$ & - & 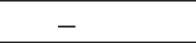 & - & - & - \\
\hline 1843 & - & - & - & - & - & - \\
\hline 1844 & - & - & - & - & - & - \\
\hline 1845 & 27,555 & 2,094 & 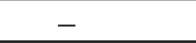 & - & - & - \\
\hline 1846 & 30,505 & 2,520 & $8.3 \%$ & - & - & - \\
\hline 1847 & 39,056 & $\begin{array}{c}- \\
\end{array}$ & $\begin{array}{c}- \\
\end{array}$ & 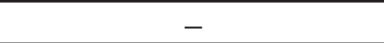 & 3,013 & $\overline{-}$ \\
\hline 1848 & 40,308 & - & - & - & - & - \\
\hline 1849 & 42,759 & - & - & - & - & - \\
\hline 1850 & 48,145 & 3,161 & $6.6 \%$ & 58,161 & $3507(5)$ & $6.0 \%$ \\
\hline 1851 & 58,740 & 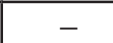 & $\begin{array}{cc}- & \\
\end{array}$ & 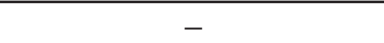 & $\begin{array}{cc}- \\
\end{array}$ & $\begin{array}{c}- \\
\end{array}$ \\
\hline 1852 & 68,584 & $\begin{array}{cc}- \\
\end{array}$ & $\begin{array}{c}- \\
-\end{array}$ & $\begin{array}{cc}- \\
-\end{array}$ & $\begin{array}{c}- \\
-\end{array}$ & $\overline{-}$ \\
\hline 1853 & 78,306 & - & - & - & - & - \\
\hline 1854 & 90,003 & - & - & - & - & - \\
\hline 1855 & 105,186 & 4,292 & $4.1 \%$ & - & - & - \\
\hline 1856 & 113,139 & - & - & - & - & - \\
\hline 1857 & 124,782 & - & - & - & - & - \\
\hline 1858 & 133,737 & - & - & - & - & - \\
\hline 1859 & 146,370 & - & - & - & - & - \\
\hline 1860 & 160,467 & 4,782 & $3.0 \%$ & 182,566 & $5110(6)$ & $2.8 \%$ \\
\hline 1861 & 169,166 & - & - & - & - & - \\
\hline 1862 & - & - & - & - & - & - \\
\hline 1863 & - & - & - & - & - & - \\
\hline 1864 & - & 5,125 & - & - & - & - \\
\hline
\end{tabular}

*Slave population data for Texas are based on tax roll data compiled by Campbell (1989:Table 1, 54-58).

**The 1840 population figure is for the Republic of Texas from Barr (1996:17). The 1850 and 1860 figures are U.S. census data as stated by Campbell (1989:Table 1) and in the U.S. Historical Census Browser (University of Virginia 2004).

***The population figures for Brazoria County are from Kleiner (2010) and University of Virginia (2004). There were 5 and 6 free blacks listed in the 1850 and 1860 censuses, respectively.

owners knew that Texas would enter the United States as a slaveholding state. This was then followed by a decade of sustained growth of the county's slave population up through 1855 . This growth trend slowed considerably in the years prior to and during the Civil War. It is notable that in 1860, 1,772 slaves in Brazoria County were owned by only 10 people - the largest slaveholders in the county, owning 102-344 slaves each (Campbell 1989:Appendix 4). Their combined slaveholdings accounted for between 35 and 37 percent of all the slaves in Brazoria County, although they only owned 4.5 percent of the land (Campbell 1989:Appendix 4, 274; Kleiner 2010:n.p.). 
Table 8.3. Increase in enslaved population of Brazoria County from 1837 through 1864. Data from Forstall (1995), Campbell (1989), and University of Virginia (2004)

\begin{tabular}{c|c|c|c|c|c}
\hline Year & No. of Slaves* & $\begin{array}{c}\text { Increase in } \\
\text { No. of Slaves }\end{array}$ & No. of Years & $\begin{array}{c}\text { Per Annum Increase in } \\
\text { No. of Slaves }\end{array}$ & $\begin{array}{c}\text { Slave Population Listed in } \\
\text { Census** }\end{array}$ \\
\hline 1837 & 892 & - & - & - & - \\
\hline 1840 & 1,665 & 773 & 3 & 257.7 & 1,316 \\
\hline 1845 & 2,094 & 429 & 5 & 85.8 & - \\
\hline 1846 & 2,520 & 426 & 1 & 426.0 & 3,507 \\
\hline 1850 & 3,161 & 641 & 4 & 160.3 & - \\
\hline 1855 & 4,292 & 1,131 & 5 & 226.2 & 5,116 \\
\hline 1860 & 4,782 & 490 & 5 & 98.0 & - \\
\hline 1864 & 5,125 & 343 & 4 & 85.8 & \\
\hline
\end{tabular}

*Slave population data from tax rolls as compiled by Campbell (1989:Appendix 2)

**The 1840 census figure is from Kleiner (2010). U.S. census slave population data from Forstall (1995) and University of Virginia (2004).

Using the data from Tables 8.2 and 8.3, Figure 8.1 compares populations if Texas and Brazoria County during the 45 years from 1825 through 1870. The overall trends are essentially the same, depicting a steady and substantial growth in the black population across Texas, with a closely corresponding growth trend for the black population of Brazoria County. The rapid growth in the enslaved black population is attributable to two main factors-the continued importation of slaves into Texas and the encouragement of "slave breeding" to increase one's slave holdings and as a business enterprise.

Focusing more closely on the post-emancipation period, Figure 8.2 includes graphs of historical black population data from 1850 to 1930, with emancipation occurring in 1865 . The top graph shows a steady and fairly rapid increase in the overall Texas population for this entire period. Relatively speaking, the black population grew slowly for nine decades following Statehood in 1845, while the white population increased at a much higher rate. In Brazoria County, enslaved blacks made up 72.4 percent of the population in 1850 and 71.6 percent in 1860 , which was significantly higher proportion than in the whole state (at 27.5 and 30.3 percent). Over the next seven decades, the numbers of blacks fluctuated somewhat but the overall growth trend was relatively flat. During this same time, the white population of Brazoria County increased much more rapidly. When the same data are shown as a line graph of percentages, as in Figure 8.3, the fundamental population trend is clear. The proportion of blacks in Texas decreased slowly over nine decades, while the proportion of blacks in Brazoria County leveled off from 1870 through 1890, and then dropped radically up until 1920. It is likely this pattern represents an exodus of blacks from Brazoria County during the Jim Crow era. Often called "the great migration," the mass movement of blacks from rural areas to urban cities, and from the South to the North, was a means of escaping from the poverty associated with being a farm laborer or tenant farmer and from the threat of racial violence that was prevalent in the rural South (Gilbert and Eli 2000:65; Gregory 2005; Kyriakoudes 1998; Wilkerson 2010). 

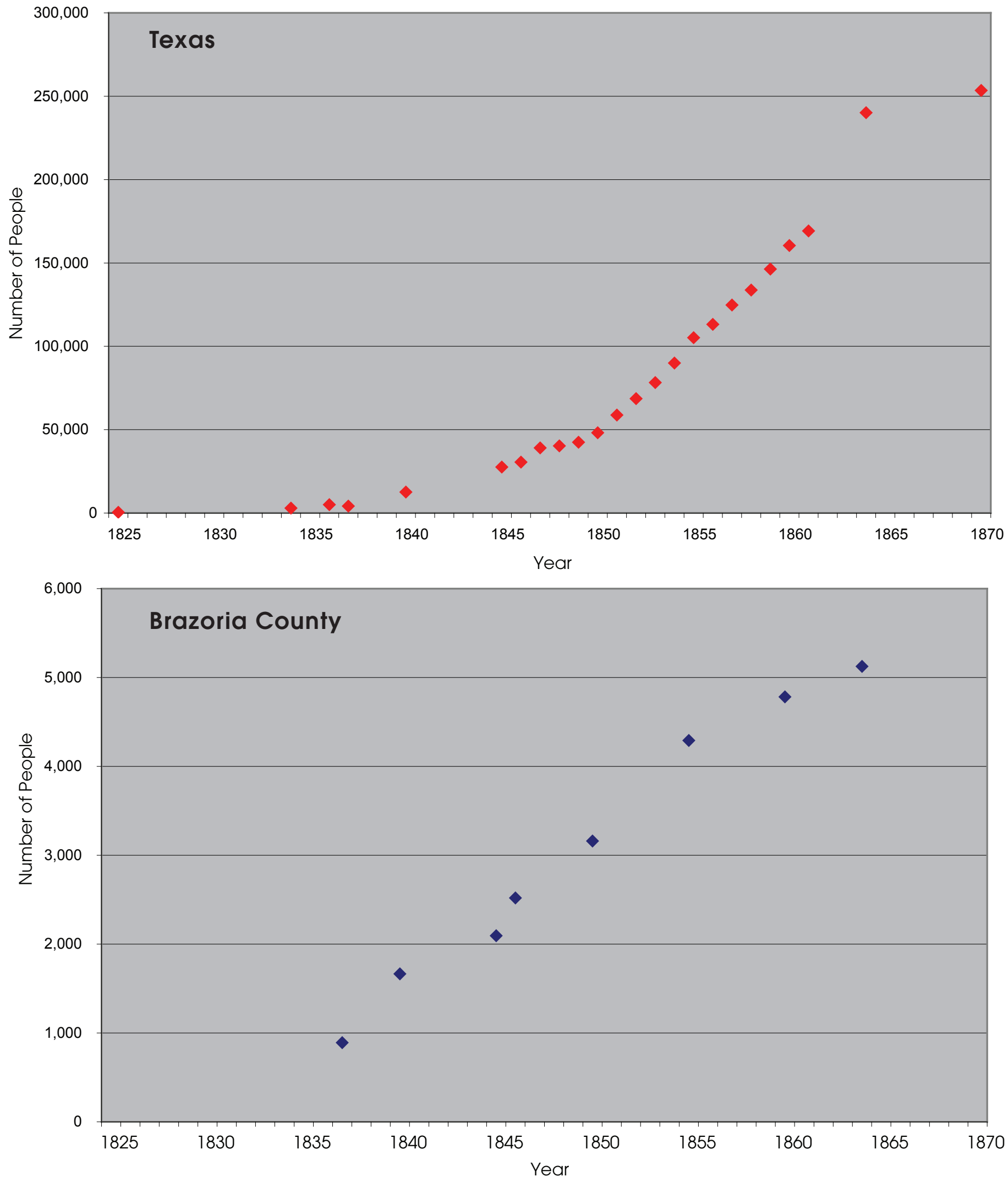

Figure 8.1. Graphs comparing the black population of Texas and Brazoria County from 1825 through 1870. Data from Tables 8.2 and 8.3 . 

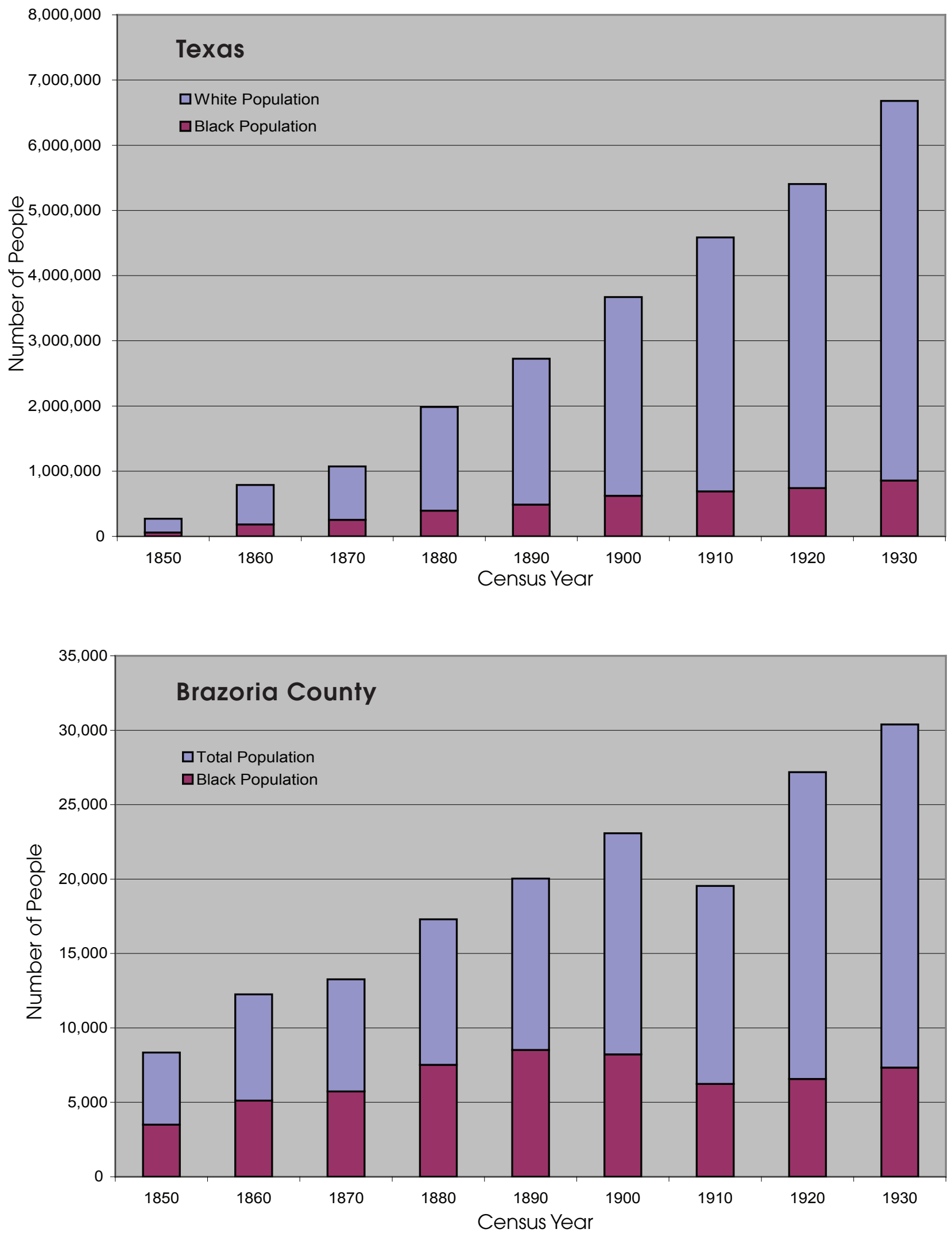

Figure 8.2. Bar graphs of historical U.S. census data from 1850-1930 comparing the black populations of Texas (top) and Brazoria County (bottom). Data from Forstall (1995) and University of Virginia (2004). 


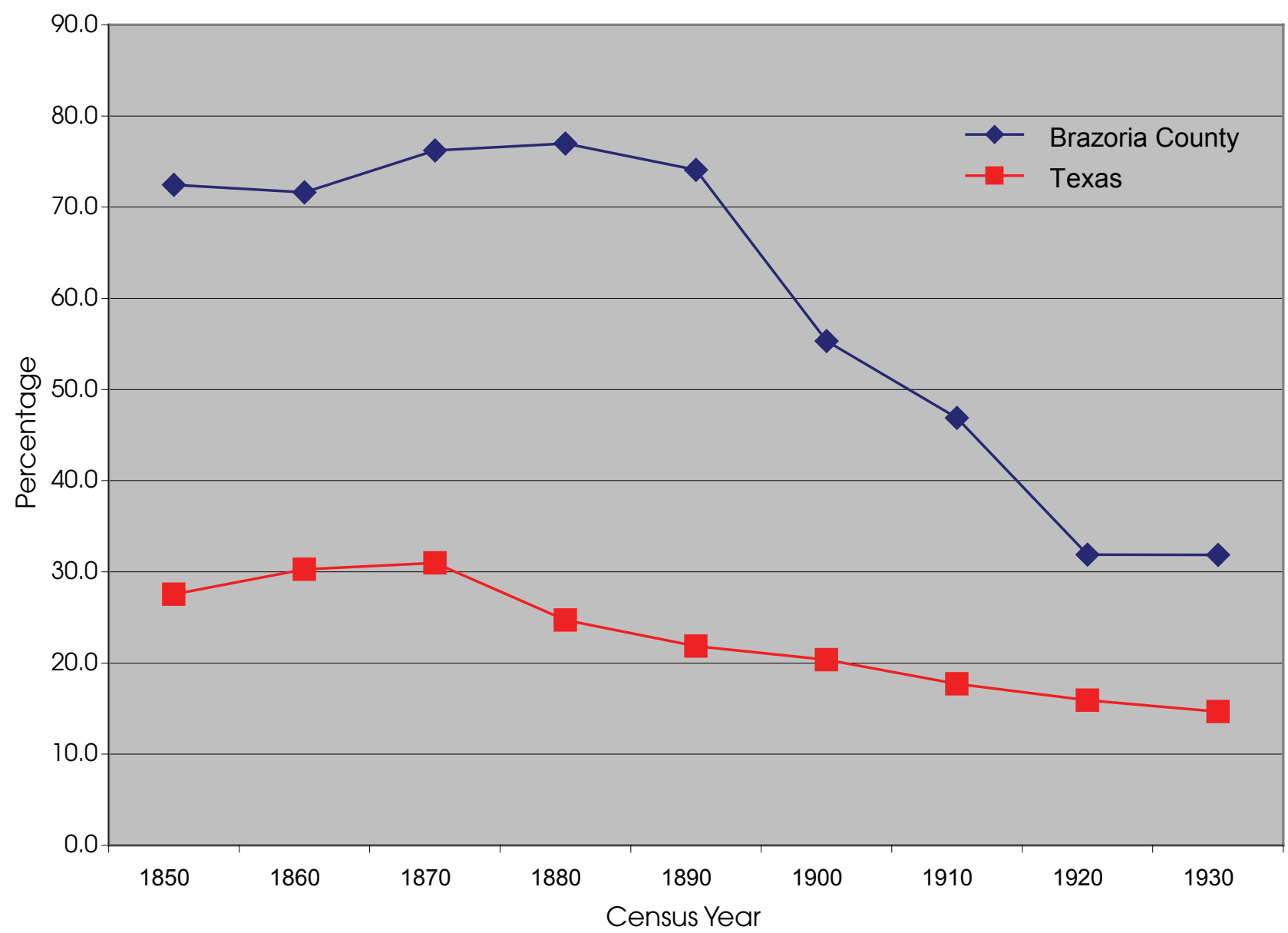

Figure 8.3. Line graph of U.S. census data from 1850-1930 illustrating the percentage of blacks within the total populations of Texas and Brazoria County. Data from Forstall (1995) and University of Virginia (2004).

The 1870 and 1880 U.S. census records were examined to better understand the population of the town of Brazoria during the late nineteenth century (the 1890 U.S. Census records burned). These are the first two censuses made after emancipation, and both made the subtle distinction between black and mulatto (an offspring of one white and one black parent). Population data for the Brazoria townsite extrapolated from these census records and are presented in Table 8.4. This census enumeration pages listed individuals by their "color" with the five options listed as: $\mathrm{W}=$ White, $\mathrm{B}=$ Black, $\mathrm{m}=$ Mulatto, $\mathrm{C}=$ Chinese, or $\mathrm{I}=$ Indian. A summary statistic was written at the bottom of each page, and mulattos were included within the total number of "colored" individuals. The figures in Table 8.4 were derived by going through the original handwritten enumeration pages, line by line, and counting the number of individuals in each classification. In 1870, the Brazoria townsite population of 720 was 47 percent black, 17 percent mulatto, and 36 percent white. The 1880 U.S. census showed similar numbers for 677 residents: 45 percent black, 16 percent mulatto, and 39 percent white. Interestingly, the 1880 census listed only one "Mexican" in Brazoria, a disabled individual living under the care of another family. 
Table 8.4. Summary of U.S. census population data by "Color" for the "Town of Brazoria" in 1870 and 1880*

\begin{tabular}{l|c|c|c|c}
\hline \multirow{2}{*}{\multicolumn{1}{c|}{ Recorded "Color" }} & \multicolumn{2}{c|}{ 1870 U.S. Census } & \multicolumn{2}{c}{ 1880 U.S. Census } \\
\cline { 2 - 5 } & No. & Percentage & No. & Percentage \\
\hline "Black" & 338 & $46.94 \%$ & 304 & $44.90 \%$ \\
\hline "Mulatto" & 122 & $16.94 \%$ & 108 & $15.95 \%$ \\
\hline "White" & 260 & $36.11 \%$ & 264 & $39.00 \%$ \\
\hline Mexican & 0 & $0.00 \%$ & 1 & $0.15 \%$ \\
\hline Total population & 720 & $100.00 \%$ & 677 & $100.00 \%$ \\
\hline \multicolumn{4}{|c}{} \\
\hline African American data summary & No. & Ratio of Black to White & No. & Ratio of Black to White \\
\hline Total "black" and "mulatto" & 460 & 1.8 to 1 & 412 & 1.6 to 1
\end{tabular}

*Data from the U.S. Bureau of the Census, Brazoria County 1870, Town of Brazoria and the U.S. Bureau of the Census, Brazoria County 1880, Enumeration District 1, Election Precinct 1.

By 1890, the town of Brazoria was the county seat and had 900 residents, but when the railroad bypassed Brazoria, Angleton became the county seat in 1897. Brazoria's population dropped to 633 in 1904 but had risen back to 1,050 by 1929 (Hallstein 2010). Without knowing the racial makeup of the county residents during these years, we can only guess that African Americans constituted some 40 to 50 percent of Brazoria's population (based on the Table 8.4 data).

What is notable in Table 8.4 is that the African American community comprised the majority of Brazoria residents in 1870 (65 percent) and 1880 (61 percent). Unfortunately, there is no easy way to find the exact number of enslaved blacks living in Brazoria from its inception in 1828 until emancipation in $1865 .{ }^{14}$ Circumstantial evidence, however, suggests that slaves would have made up a substantial part of the Old Brazoria population, perhaps even the majority, during the Republic, early Statehood, and Civil War periods.

\section{What Are the Origins of African Americans in Texas and Brazoria County?}

Many of the enslaved people in Texas were African Americans several generations removed from Africa that were brought from other southern states. This is especially true for the Mexican and Republic of Texas periods, when many wealthy men came to Texas and brought their slaves with them. But it is also true that some plantation owners continued to import more slaves into Texas to increase their labor forces, while slave traders (including independent operators and plantation owners) imported slaves to sell in Texas or transported slaves through Texas to sell in other states. Importing slaves into Texas was illegal during the Mexican period but it went on nonetheless. The slavery issue was one of the underlying causes of the Texas revolution, and once Texas gained its independence, the Republic quickly enacted laws to protect the institution of slavery and allow all new landowners to bring their slaves with them as they settled in the Republic. At the same time, Republic

14 Compiling these numbers would be a slow process involving extensive examination of tax rolls or, for the 1850 and 1860 census, identifying the white slaveowners living in Brazoria in the population schedules and then searching for these names in the corresponding slave census to find the number of slaves each person owned. 
of Texas laws forbid the direct importation of African slaves and declared such acts to be piracy (Campbell 1989:39, 46-48; Campbell 2013). This move may have been largely political, with the Republic catering to world opinion rather than a true desire to stop the African slave trade (Campbell 1989:48). The evidence does show that illegal importation of African slaves into Texas did occur with some regularity, and some Texian citizens were active participants in this slave trade. Slave traders sought to do business in Texas and other southern states for one simple reason: they could sell African slaves in the United States for at least twice the price that they would receive in Cuba (Barker 1902:156).

Brazoria County, via the Brazos River, was a primary entry point for imported slaves, and the slave trade in Texas included bringing blacks in from other southern states, directly from Africa, and from Africa via Cuba and other Caribbean islands. While the sale of slaves between southern states was legal, records document the illegal importation of African slaves into Texas as early as 1816 and as late as 1856 (Barker 1902:146-147, 157; Campbell 1989:39, 46-47; McGhee 2000:156). Diplomatic correspondence from the Republic of Texas leaves no doubt that some Texas officials were trying to stop the illegal trade in African slaves, especially the shipment of African slaves through the Caribbean, Cuba in particular, into Texas (Torget 2015).

Exactly how significant the African slave trade was in Texas is open to debate. Barker (1902) and Campbell (1989), for example, both argue that the slave trade played a minimal role. Campbell (1989) acknowledges that "the African trade, although outlawed by the constitution of the republic, supplied a few of the slaves who arrived between 1836 and 1861" (p. 53), but he concludes that "only a tiny fraction of the state's bondsmen were brought in by the illegal African trade" (p. 54). In a summary of slavery in Texas, Campbell (2013:n.p.) states that "A few slaves, perhaps as many as 2,000 between 1835 and 1865, came through the illegal African trade." Barker (1902:156-157) believes there were only three or four illegal shipments of slaves into the Republic of Texas and that the total number of imported Africans was "not more than six or seven hundred" and certainly "did not exceed a thousand." In contrast, other researches argue that the slave trade was much more significant but was virtually undocumented and impossible to track (McGhee 2000; Robbins 1972; Tadman 1996). Robbins (1972:139-140,148) gives varying estimates, including 5,000 to 6,000 African slaves brought to Texas between 1816 and 1860. At the other end of the scale is Tadman's (1996) assessment that the slave trade, both domestic and illegal, was far more significant. He estimates that: (1) "fully up to 70 percent of blacks in Texas in 1860 had been traded into the state" and (2) "Texas imported approximately 127,812 slaves" in the two decades from 1840 to 1859 (as cited by McGhee 2000:x, 126).

McGhee's dissertation titled The Black Crop: Slavery and Slave Trading in Nineteenth Century Texas is one of the more comprehensive studies, but McGhee (2000:119) admits that:

Estimating the precise extent of the African slave trade into Texas is a daunting task, primarily for two reasons: 1. Many of the illegal Africans imported into Texas were smuggled through the state into nearby states such as Louisiana and Mississippi (although direct 
importations into Texas gradually increased and peaked prior to the Civil War), and 2. Because the importations from Africa were illegal, the forged paperwork and counterfeit manifests or bills of sale are difficult to distinguish from regular (legal) slave sales. Thus, any attempt to fix a figure is bound to be a rough estimate.

Some interesting details regarding the extent of the African slave trade come from the diplomatic correspondence of the Republic of Texas (Torget 2015), including the text of the African Slave Trade Treaty between the Republic of Texas and Great Britain. Signed on November 16, 1840, and described in a proclamation by president Sam Houston on September 16, 1842, the African Slave Trade Treaty was a mutual cooperation agreement "for the suppression of the African Slave Trade" (Houston 1842). This treaty allowed British and Republic of Texas naval vessels to search and seize suspected slave trading vessels along the Texas coast. On January 4, 1841, James Hamilton (a financial agent for the Republic of Texas) wrote a letter to Abner Lipscomb (Secretary of State for the Republic of Texas), in which he described some of the details of the African Slave Trade Treaty that had been signed with Great Britain. In this letter, Hamilton mentions that he had tried but failed to expand the area where British ships could search suspected slave trader's vessels from the Texas coast to the whole Gulf of Mexico. He specifically stated: “... but in consequence of the enormous traffic in Africans from the coast carried on in and from the Island of Cuba, I could not secure this object and finally agreed on the compromise contained in the Treaty" (Hamilton 1841:924). His statement indicates that the African slave trade was not a minor problem within the Republic of Texas.

Although importing African slaves into Texas was illegal during the Mexican period, new settlers and slave traders often used a common ploy to make their business appear legitimate. Rather than importing slaves, the traders would have their subjects sign papers testifying that they were indentured servants for a specified number of years. Bugbee (1989b:667) summarized the loophole as follows: "In 1828, the government of Coahuila and Texas provided means for evading the [slave trade] law by legalizing contracts made in foreign countries, and the American settlers continued to come with their slaves, now called indented servants." Long periods of indenture in such contracts, sometimes 99 years, effectively kept indentured servants in bondage for life (Campbell 1989:24). The Mexican government allowed for the importation of slaves under the guise of indentured servants, and the Republic of Texas later kept this loophole in place (Barker 1902:150; Bugbee 1898a:408-409, 1898b:667-668; Campbell 1989:23-24, 29-32).

Acknowledging the uncertainty in the numbers, it is clear that the African slave trade was thriving in Texas from the 1830s through the 1850s, and that Africanborn slaves were regularly being brought into Texas. Many of these Africans were being brought into Brazoria County through the port of Velasco. In 1836, Monroe Miller, a slave trader and owner of the Chenango Plantation in Brazoria County, is reported to have "landed a cargo of 171 Africans along the Brazos River" on the same day that the Texas Declaration of Independence was signed at Washington-on-theBrazos (McGhee 2000:156; Silverthorne 1986:29). In the 1830s, James W. Fannin ${ }^{15}$

15 This is the same James Fannin who was executed by the Mexicans at Goliad (Smith n.d.c). 
and Joseph Mims were slave traders and plantation owners in Brazoria County, and they made regular trips to Cuba, bringing back African slaves they purchased at the Havana slave market (McGhee 2000:157).

Although historian Eugene Barker (1902:157) believed there was no documentary evidence that African slave trade continued in Texas after annexation, he cites the recollections of some older men who witnessed African slaves brought into Texas ports. The latest incident that Barker thought was "authenticated" was a slave ship that came into Indianola in 1856. Barker had "talked with several men who claim to have seen some of the negroes that were purchased from this vessel" (p. 157).

Kelley (2010:55-56) discusses the presence of African slaves in Texas, noting that they were most concentrated in Brazoria County. He states that (p. 56):

Of the approximately fifty plantations in the county, there is documented evidence of at least one African-born slave on fourteen of them. Moreover, African-born slaves seem to have been geographically concentrated in just a few areas: Monroe Edwards's Chenango Plantation on Oyster Creek; the Mims plantation on the west bank of the San Bernard River; and most of all, the Gulf Prairie $^{16}$ neighborhood, where there is evidence of Africans on all of the plantations except the Westall place and Joel Bryan's Durazno. Lastly, accounts from the 1830s of groups of slaves conversing in at least two different African languages leave no doubt that many of the Africans could communicate with each other, which in turn raises the likelihood that African speech communities existed in Brazoria County. Together these factors would have maximized - though not in all cases guaranteed-the opportunity to form families and preserve knowledge and lifeways from Africa...

The Fannin-Mims Plantation, located about 4 miles west of Brazoria, had many African slaves, a fact supported by detailed slave inventories in probate records. Kelley (2010:78) notes that in 1845 at least 7 of 13 slave households included one or more Africans. There were 6 such families in 1862, and 8 in 1870. The 1870 U.S. census also documents that Brazoria County had 33 married or partnered Africanborn women, 28 of whom appear to have been married to African-born men, while 6 African-born men. Noting this pattern, Kelley (2010:78) speculated that there was:

...a strong desire on the part of both men and women to pair with someone of like background. In fact, the high consistency with which Africans sought out African marriage partners suggests not merely that "African" constituted a distinct identity among Brazos slaves, but that African-born men and women of specific linguistic, religious, and cultural backgrounds sought—and in many cases found-marriage partners with similar backgrounds... and given that the structure of the Atlantic trade to Cuba drew heavily on a few areas of Africa, resulting in the transference of specific local cultures and identities to the Brazos. With clusters of people of probable common origin dotting the Lower Country, it is not unreasonable to assume that coherent language and spiritual communities may have formed, with family constituting the anchor of these communities...

$\overline{16}$ The Gulf Prairie area was only a few miles southeast of Brazoria. 
At various times in the 1830 s, there were as many as 200 African-born slaves at the Chenango Plantation, which made Chenango one of the more distinctive slave communities in Brazoria County (Kelley 2008:406). But the diversity of slave communities was only one part of the picture. Kelley (2010:2-3, 132-133) describes antebellem Texas plantations on the Brazos River not as a classic southern-style plantation system, but rather as a system of distinct plantation communities complicated by Anglo and Euro-American ethnic diversity and heavily influenced by their origins under Mexican political sovereignty. In short, the slave communities on many Brazoria County plantations were very different from the slave communities at most other southern plantations.

In 1902, when his article titled "The African Slave Trade in Texas" was published, Barker (1902:158) noted: "Some of the Africans who were brought in during the period of the republic are still living -in fact, along the coast from Matagorda to Velasco and along the banks of the Brazos and Colorado rivers they are not at all uncommon." That there were still quite a few Africans living along the Texas coast-people who had survived the transatlantic journey, been shipped through Cuba or directly into Texas, and labored as slaves in Texas-is a testament to the realities of the illegal slave trade in Texas. Despite these facts and all of the evidence mentioned above, we know very little about where these peoples came from in Africa or how they managed to coalesce and survive as distinct enslaved and freedmen communities in Texas.

\section{A Snapshot of Brazoria County in 1887}

Pioneer Cemetery officially began with the deed transfer of lands in 1888, and it is unfortunate that the 1890 census burned and left a significant gap in the data. However, a report published by the Texas Bureau of Agriculture in 1889 (Foster 2001:247-248) provides an excellent snapshot of Brazoria County in 1887. This report cited the population of Brazoria County as 9,774 in 1880 and 12,291 in 1887, of which 6,120 were male and 6,171 were female. The Bureau of Agriculture report (Foster 2001:247-248) listed the 1887 residents of Brazoria County by "color and nationality" as follows:

$\begin{array}{lrr}\text { Americans } & 2,895 & 23.55 \% \\ \text { Colored } & 8,998 & 73.21 \% \\ \text { English } & 8 & 0.07 \% \\ \text { German } & 242 & 1.97 \% \\ \text { French } & 52 & 0.42 \% \\ \text { Hebrew } & 12 & 0.10 \% \\ \text { Irish } & 11 & 0.09 \% \\ \text { Italians } & 3 & 0.02 \% \\ \text { Mexican } & 13 & 0.11 \% \\ \text { Spanish } & 9 & 0.07 \% \\ \text { Swedes } & 31 & 0.25 \% \\ \text { Poles } & 17 & 0.14 \% \\ \text { Total } & 12,291 & 100.00 \%\end{array}$


The Europeans were mostly likely recent immigrants who had come to Texas after 1880. But the majority of Brazoria County residents were "Colored" freedmen or descendants of freedmen. Among this group, there would certainly have been a number of people who had been born in Africa or whose parents had been born there.

\section{Washington Edwards: Portrait of an African Slave}

A rare photograph in the collection of the Texas State Library and Archives provides verifiable visual evidence of a person who was brought as a slave directly from Africa to Brazoria County. An unknown photographer took a picture of Mr. Washington Edwards in 1889 (Figure 8.4), and annotations on the image show that Edwards was a former slave who lived in Brazoria County. The photograph (Unknown 1889) has handwritten notes that provide details about the subject and perhaps about the photographer:

- Washington Edwards was 103 years old when the photograph was taken in 1889 .

- He died in 1905.

- Edwards was born in Africa and was brought to Brazoria County in the "early thirties" (1830s) by Monroe Edwards, and he "landed on the Bernard River a few miles west of Columbia."

- He arrived in Texas "prior to the Mexican War" (the Texas Revolution) and lived near Columbia, Texas.

- He still spoke his native African language.

- When Edwards was taken from Africa, he left behind a wife and a son.

- Notations in two places are difficult to read but suggest that Edwards may have been sold to "Col. Hill" and "Wm. Hill."17

- A notation suggests that Edwards died in March 1905.

- The photograph was annotated by a man named Bartlett, who signed it "Compliments of / John S. Bartlett / Columbia Texas / 7/17/05."

Although it is not absolutely certain, circumstantial evidence suggests that John S. Bartlett, who donated the image to the State Archives, was also probably the photographer. An online search discovered one published source that confirms that Bartlett was indeed taking photographs of historic places in Brazoria County around the turn of the century. Two of his photographs appear in a 1901 almanac that was published in 1902 (Hicks 1902:46-47). Both photographs are historic places in Columbia (now West Columbia) that were severely damaged by the infamous 1900 hurricane. One was of the Independence Tree, and the other was of the ruins of the

$\overline{17}$ This most likely refers to William Green Hill, who fought in the Texas Revolution was known as "Colonel" although he was not of that rank. Hill was came to Brazoria County in 1830 and lived there until his death on June 30,1860. He was a senator for the Republic of Texas in 1836, and he lived on the Waverly Plantation and then founded the Osceola Plantation. He was a freemason and a very wealthy man at the time of his death (Green 2010; Smith n.d.a). 

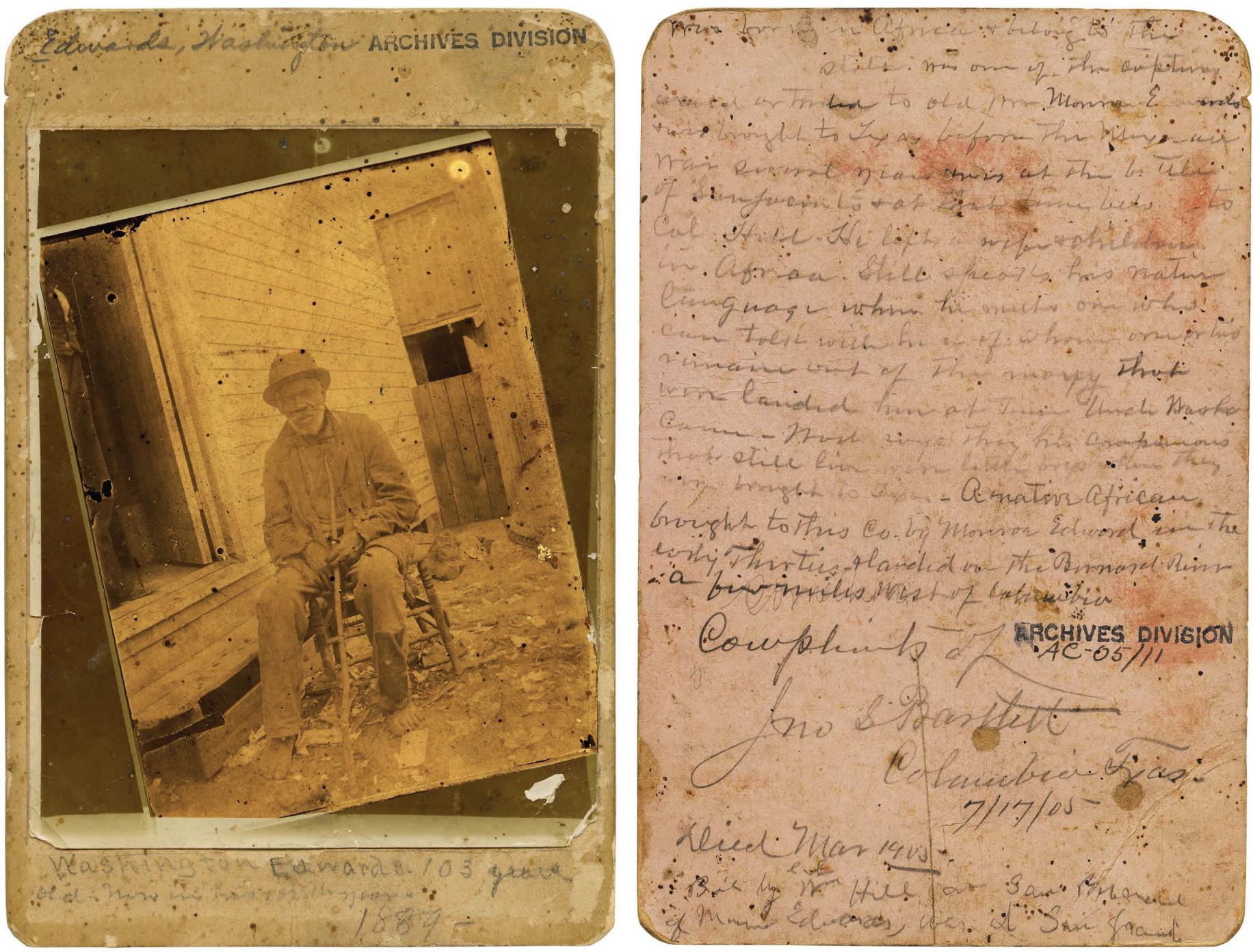

Figure 8.4. Photograph taken in 1889 of Washington Edwards, an African man who was brought into Texas as a slave. (Top) Photograph with stamped and handwritten notations. (Bottom) Back side of Photograph with stamped and handwritten notations. Photo is from the Prints and Photographs Division of the Texas State Library and Archives (Unknown 1889).

First Capitol of the Republic of Texas. Both images bear the caption "Photographed by John S. Bartlett, Columbia, Texas."18

Online genealogy records (Ancestry.com) confirm John S. Bartlett lived in Brazoria County for many decades. U.S. census records for 1880, 1900, and 1910, Brazoria County Tax Records for 1900 and 1901, and a 1930 death certificate all reveal that John Sox Bartlett was born in 1851 in Waverly, Tennessee, and died in East Columbia

\footnotetext{
$\overline{18}$ A handwritten note on the latter photo says "Old Capitol after Storm Sept. 1899" and the almanac text (Hicks 1902:49) also states that the storm was on September 8, 1899. These dates are incorrect, and there is no doubt that these photographs were taken after the great hurricane of September 1900. The almanac text states that "The two pictures from John S. Bartlett, given with this chapter, have a historic value. The first shows the famous 'Independence Trees' and the second one the 'First Capitol of Texas' as they appeared the morning after the great cyclone that destroyed much of Galveston and the surrounding country" (Hicks 1902:48-47). Other people took photographs of the damage to the First Capitol building (Boyd 2008:3), and there is no doubt that Bartlett's photograph is of the same structure that was destroyed by the 1900 storm.
} 
in January 1930. In the 1880 census, "J. S. Bartlett" was listed as a 28-year-old farmer from Tennessee, and he was married Carrie Bartlett from Tennessee. Their 3-year-old son, Harry, had been born in Texas, which suggests that they were living in the state by 1877 . Consequently, Bartlett could have taken the picture in 1889. He was living in Brazoria County when he donated the photograph to the State Archives in 1905. His occupation was listed as a "Druggist" on his 1930 death certificate and in the 1900 and 1910 census records.

Washington Edwards' age, as written on the photograph, is questionable. If the notations on the front of the photograph are true, Washington Edwards was 103 years old in 1889. This means that he would have been born around 1786 and that he would have been between 44 and 50 years old when he was captured in Africa and brought to Texas in the early 1830s (sometime between 1830 and 1836). While this is possible, it seems somewhat unlikely that he would have been enslaved when he was 44 to 50 years old. In his slave importing business, Monroe Edwards sought to bring in young slaves because they were worth considerably more than old slaves. An entry in the diary of William F. Gray on April 30, 1836, notes that Gray was staying at the home of Ashmore Edwards, who was the brother of Monroe Edwards. While there, Gray observed a group of "Guinea Negros from Cuba" imported a month before. Gray observed: "About fifty of those poor wretches are now here, living out of doors, like cattle. They are all young, the oldest not 25 , the youngest, perhaps, not more than 10; boys and girls huddled together... One girl sat apart and held no converse with the crowd. She is said to belong to a different tribe from any of the rest..." (as cited by Smith n.d.b:6).

If the notations on the photograph are taken at face value, it also would indicate that Washington Edwards was 119 years old when he died in 1905. It seems rather unlikely that Washington Edwards would have lived to be 119 years old, or that he would have known his exact age. A search for Washington Edwards on Ancestry. com (census and death records) found no documents that come close to matching this man. Edwards was a common name in Brazoria County, and the 1870 census lists 22 African Americans with that surname, four of whom were born in Africa between 1814 and 1825. The 1900 census shows that a man named Wash Edwards was living in Brazoria County that year and was from Africa, but he was born in 1828. This could not be the same man.

Other possible explanations must be considered. Edwards could have lied about or exaggerated his age, or some informant could have lied about or exaggerated about his age. It is also possible that Bartlett misunderstood Washington Edward's age or wrote down incorrect information. Edwards may not have known how old he was, and Bartlett may have simply guessed. Another possibility is that the number "1889" written on the front of the photograph does not refer to the year when the picture was taken. If this were some type of photograph index number, then the front and back captions may have meant that Washington Edwards was 103 years old when he died in 1905. If so, then Washington Edwards would have been much younger when he was captured in Africa and brought to Texas in the 1830s. In this case, he would have been born about 1802 and would have been between 28 and 34 years old when he was brought to Texas (between 1830 and 1836). 
Regardless of his age or the exact date when the photograph was taken, Washington Edwards was apparently one of the Africans brought to Texas by Monroe Edwards in the 1830s. Monroe Edwards had come to Texas in 1825 and gotten deeply involved in the African slave trade before purchasing the Chenango Plantation in September 1836 (Smith n.d.b). He apparently brought several shipments of African slaves into Texas, but in one incident in 1836 he purchased African slaves from Cuba and brought them up the Brazos River and then overland to his Chenango Plantation (Jones 2010). Washington was probably among the "92 Negroes" owned by Monroe Edwards in 1837 and 1837 (Smith n.d.b:8), and he may have lived on the Waverly Plantation and Osceola Plantations and been owned by William Green Hill for a time. When Washington Edwards died in 1905, he had been a slave for at least three decades of his life and had lived in Brazoria County for at least 70 years. He was probably buried somewhere in Brazoria County, but location of his grave is not known. Like the graves of many black pioneers in Brazoria County, Washington Edwards' final resting place may be lost to history. If it were not for his chance encounter with a photographer sometime around the turn of the century, we would not know of his existence at all.

\section{HISTORIC BLACK CEMETERIES IN BRAZORIA}

\section{Old Brazoria Cemetery}

The oldest cemetery in the town of Brazoria is, not surprisingly, called the Old Brazoria Cemetery. It is six blocks northwest of Pioneer Cemetery in one of the older parts of town. The Old Brazoria Cemetery dates to 1827, when the town of Brazoria was just beginning to be settled. A Texas Historical Marker provides this summary:

Site given to Brazoria in 1827 by government of Mexico as cemetery for Catholics; thus was open to all residents, as all Austin Colony settlers were legally Catholics. By 1930, this was full, and new cemetery opened. Most pioneer families have members buried here. (THC Marker No. 9532, erected 1967)

It is unlikely that many of the enslaved blacks that had lived in or near Brazoria were buried in the Old Brazoria Cemetery. Slaves were not considered citizens, and during the Mexican period they were probably not considered Catholics, as all of the first Texian residents would have been. It was much more common in antebellum Texas for slaves to be buried in their own segregated cemeteries. And it was common for freedmen cemeteries to spring up at or near the locations of slave cemeteries.

\section{Origins of Pioneer Cemetery}

Pioneer Cemetery is usually reported to have been started in 1888 and is the only African American cemetery known to have exited in the nineteenth century. Dismukes and Bettis (2002:52) summarize the official beginnings of Pioneer Cemetery as follows:

Deed record searches by Texas Department of Transportation staff resulted in the finding of the original deed for the Pioneer Cemetery. Ownership of Lots 10, 11, and 12 of Block 42 in Brazoria, Texas (known 
today as Old Brazoria or Old Town) was transferred to the trustees, and their successors, of the African Methodist Episcopal Church and the Free Mission Baptist Church of Brazoria on March 15, 1888, "to be used as a burial ground for members of the said churches and such others persons as the trustees at the time in office shall permit."

As is often the case with old cemeteries, however, the date of the land transaction does not tell the whole story. It is likely that there were already African American burials on the property when this initial land purchase occurred, and the official transaction was simply acknowledging a land use that was already well established. While there are no known burials that date prior to 1888, circumstantial evidence suggests that Pioneer Cemetery was probably used as a burial ground many years earlier.

There is no hard evidence that burials occurred at Pioneer Cemetery before 1888 , but this seems quite likely given the history of the town's black population. By 1888, the African American population in Brazoria County was already quite large and still increasing. At the end of that decade, the black population reached its peak. Census data show that 1890 had the highest black population for the 100-year period from 1850 to 1950. But the town of Brazoria was platted in 1828 (Dismukes and Bettis 2002:4, 22,45), and its population grew along consistently with that of Brazoria County (see Tables 8.1 through 8.4 ). All of this evidence suggests that there were large numbers of enslaved blacks and freedmen who lived and died in and near Brazoria in the period from 1828 through 1887, and one must wonder: Where were all these people buried?

\section{Estimating Death Rates for Brazoria}

Going from population data to estimates of numbers of people who died and may have been buried at Pioneer Cemetery is difficult. Data on death rates were extracted from the 1850 U.S. census using the online Historical Census Browser (University of Virginia 2004). In 1850, there were 1,334 whites living in Brazoria County, and there were 30 deaths recorded for the year ending June 1, 1850. At the same time, there were 3,507 enslaved blacks living in Brazoria County, and 110 slaves who died during that year. These data translate to an annual death rate of 2.2 percent for whites and 3.1 percent for enslaved blacks. Unfortunately, comparable vital statistics data were not recorded in any other census years.

However, statistics are available for the year 1887 in a Texas Bureau of Agriculture report for 1887-1888 (Foster 2001:Tables 20 and 21, 296-301). Table 8.5 presents the 1887 death data for Texas and Brazoria County, including 17 causes of death recorded for both white and colored citizens. Table 8.6 is a summary of the population and number of deaths for Texas and Brazoria County, with a calculation of the annual death rates. A few patterns in the data are interesting. First, the 1887 annual death rates were virtually identical for blacks and whites in Texas, at 1.1 percent. Second, the death rates were slightly lower for people living in Brazoria County than for the whole state. And third, the annual death rate for blacks living in Brazoria County was slightly lower than it was for whites living in the county (0.5 percent vs. 0.8 percent). 
Table 8.5. Comparison of the numbers and causes of death for Texas and Brazoria County in 1887*

\begin{tabular}{|c|c|c|c|c|c|c|c|c|}
\hline \multicolumn{9}{|c|}{ DATA FOR TEXAS } \\
\hline \multirow[b]{2}{*}{ Cause of Death } & \multicolumn{7}{|c|}{ Total Deaths } & \multirow[b]{2}{*}{$\begin{array}{l}\text { Colored Deaths } \\
\text { (percent) }\end{array}$} \\
\hline & $\begin{array}{l}\text { White } \\
\text { Males }\end{array}$ & $\begin{array}{c}\text { White } \\
\text { Females }\end{array}$ & White & \begin{tabular}{|c|} 
Colored \\
Males
\end{tabular} & $\begin{array}{l}\text { Colored } \\
\text { Females }\end{array}$ & Colored & Total & \\
\hline Consumption & 454 & 527 & 981 & 114 & 206 & 320 & 1,301 & $24.6 \%$ \\
\hline Diarrhea (infantile) & 374 & 249 & 623 & 94 & 56 & 150 & 773 & $19.4 \%$ \\
\hline Dysentery & 208 & 184 & 392 & 48 & 59 & 107 & 499 & $21.4 \%$ \\
\hline Pneumonia & 626 & 467 & 1,093 & 211 & 120 & 331 & 1,424 & $23.2 \%$ \\
\hline Typhoid fever & 623 & 594 & 1,217 & 96 & 102 & 198 & 1,415 & $14.0 \%$ \\
\hline Congestive chills & 407 & 295 & 702 & 63 & 62 & 125 & 827 & $15.1 \%$ \\
\hline Black jaundice & 79 & 53 & 132 & 10 & 13 & 23 & 155 & $14.8 \%$ \\
\hline Bright's disease & 85 & 46 & 131 & 11 & 7 & 18 & 149 & $12.1 \%$ \\
\hline Chills and fevers & 101 & 101 & 202 & 58 & 37 & 95 & 297 & $32.0 \%$ \\
\hline Scarlet fever & 80 & 81 & 161 & 7 & 7 & 14 & 175 & $8.0 \%$ \\
\hline Measles & 234 & 238 & 472 & 51 & 46 & 97 & 569 & $17.0 \%$ \\
\hline Malaria & 205 & 180 & 385 & 60 & 62 & 122 & 507 & $24.1 \%$ \\
\hline Sunstroke & 13 & 21 & 34 & 2 & 2 & 4 & 38 & $10.5 \%$ \\
\hline Suicide & 34 & 22 & 56 & 4 & 5 & 9 & 65 & $13.8 \%$ \\
\hline Accident & 240 & 66 & 306 & 62 & 16 & 78 & 384 & $20.3 \%$ \\
\hline Murder & 124 & 16 & 140 & 52 & 14 & 66 & 206 & $32.0 \%$ \\
\hline All other diseases & 5,136 & 4,884 & 10,020 & 1,236 & 1,431 & 2,667 & 12,687 & $21.0 \%$ \\
\hline Total Deaths & 9,023 & 8,024 & 17,047 & 2,179 & 2,245 & 4,424 & 21,471 & $20.6 \%$ \\
\hline \multicolumn{9}{|c|}{ DATA FOR BRAZORIA COUNTY } \\
\hline & \multicolumn{7}{|c|}{ Total Deaths } & \multirow[b]{2}{*}{$\begin{array}{c}\text { Colored Deaths } \\
\text { (percent) }\end{array}$} \\
\hline Cause of Death & $\begin{array}{l}\text { White } \\
\text { Males }\end{array}$ & $\begin{array}{c}\text { White } \\
\text { Females }\end{array}$ & White & \begin{tabular}{|c|} 
Colored \\
Males \\
\end{tabular} & $\begin{array}{l}\text { Colored } \\
\text { Females }\end{array}$ & Colored & Total & \\
\hline Consumption & & 1 & 1 & & 4 & 4 & 5 & $80.0 \%$ \\
\hline Diarrhea (infantile) & & & 0 & 6 & 3 & 9 & 9 & $100.0 \%$ \\
\hline Dysentery & 5 & & 5 & & 1 & 1 & 6 & $16.7 \%$ \\
\hline Pneumonia & & & 0 & & 1 & 1 & 1 & $100.0 \%$ \\
\hline Typhoid fever & & & 0 & & & 0 & & \\
\hline Congestive chills & 3 & & 3 & & & 0 & 3 & $0.0 \%$ \\
\hline Black jaundice & & & 0 & & & 0 & & \\
\hline Bright's disease & & & 0 & & & 0 & & \\
\hline Chills and fevers & & & 0 & & & 0 & & \\
\hline Scarlet fever & & & 0 & & & 0 & & \\
\hline Measles & & & 0 & & & 0 & & \\
\hline Malaria & & & 0 & & & 0 & & \\
\hline Sunstroke & & & 0 & & & 0 & & \\
\hline Suicide & & & 0 & & & 0 & & \\
\hline Accident & & & 0 & & & 0 & & \\
\hline Murder & 2 & & 2 & 5 & & 5 & 7 & $71.4 \%$ \\
\hline All other diseases & 8 & 8 & 16 & 3 & 19 & 22 & 38 & $57.9 \%$ \\
\hline Total Deaths & 18 & 9 & 27 & 14 & 28 & 42 & 69 & $60.9 \%$ \\
\hline
\end{tabular}

* Data reproduced from Table No. 20 and Table No. 21 in an 1887 Texas Bureau of Agriculture report by Foster (2001). Shaded columns are calculated statistics not in the original tables.

The Brazoria County data are interesting when compared with mortality data for the United States and all of Texas as summarized by Davidson et al. (2002:231-241, Tables 9.3 and 9.4). Two general trends are evident—overall life 
Table 8.6. Summary of population, deaths, and death rates for Texas and Brazoria County in $1887^{*}$

\begin{tabular}{l|c|c|c|c}
\hline \multicolumn{5}{c}{ DATA FOR TEXAS } \\
\hline & White & Colored & Total & Colored (percent) \\
\hline Population** & $1,539,930$ & 395,576 & $1,935,506$ & $20.4 \%$ \\
\hline Deaths & 17,047 & 4,424 & 21,471 & $20.6 \%$ \\
\hline Annual death rate & $1.11 \%$ & $1.12 \%$ & $1.11 \%$ & \\
\hline \multicolumn{5}{c}{ DATA FOR BRAZORIA COUNTY } \\
\hline Population*** & White & Colored & Total & Colored (percent) \\
\hline Deaths & 3,280 & 8,998 & 12,278 & $73.3 \%$ \\
\hline Annual death rate & 27 & 42 & 69 & $60.9 \%$ \\
\hline
\end{tabular}

*Death data from Foster (2001:Tables 20 and 21).

** The total population of Texas in the 1887 agricultural census was 2,015,032. This included 78,878 Mexicans and 648 Chinese, who are excluded from the white and black totals.

*** The 1887 population data for Brazoria County are from Foster (2001:247), as summarized in Table 8.4.

expectancy was lower for blacks than it was for whites, and infant mortality was higher for blacks that it was for whites. The following data (taken from Davidson's Tables 9.3 and 9.4) compares the life expectancy:

\begin{tabular}{lcc} 
Location and Year & White Life Expectancy & Black Life Expectancy \\
\hline United States, 1900 & 51.8 & 41.8 \\
United States, 1910 & 54.6 & 46.8 \\
United States, 1920 & 57.4 & 47.0 \\
United States, 1930 & 60.9 & 48.5 \\
& & \\
Texas, 1900 & 49.0 & 38.6 \\
Texas, 1910 & 54.0 & 45.6
\end{tabular}

The following data (also taken from Davidson's Tables 9.3 and 9.4) compares infant mortality (the number of deaths per 1,000 live births per annum):

$\begin{array}{lrc}\text { Location and Year } & \text { White Infant Mortality } & \text { Black Infant Mortality } \\ \text { United States, 1900 } & 110.8 & 170.3 \\ \text { United States, 1910 } & 96.5 & 142.6 \\ \text { United States, 1920 } & 82.1 & 131.7 \\ \text { United States, 1930 } & 60.1 & 99.9 \\ & & \\ \text { Texas, 1900 } & 114.8 & 176.9 \\ \text { Texas, } 1910 & 97.0 & 148.5\end{array}$

Given these data, it seems odd that the 1887 mortality data show very little difference in the mortality rates for whites and blacks in Texas and, in Brazoria County, a slightly higher mortality rate for whites than blacks.

Table 8.7 compares the census population data for Brazoria County and the town of Brazoria for the years 1870 and 1880, and then uses the known 1887 Brazoria County population data as a proxy to estimate the 1887 population for the 
town of Brazoria. Based on the 8,998 black residents living in Brazoria County in 1887, it is estimated that between 495 and 720 people lived in the town of Brazoria that year. Assuming an annual death rate of 0.5 to 0.8 percent (as was calculated in Table 8.6), this means that between 3 and 7 people black Brazoria residents probably died that year.

Going one step further in this purely theoretical exercise, Table 8.8 uses population data and average death rates to calculate an estimated number of deaths that probably occurred among the black residents of Brazoria each year from 1837 to 1940 . The gray cells in the table represent actual data, while the white cells represent extrapolated data or calculations. First, the actual population data for Brazoria County in various years were used to extrapolate the town's population for each year in between, and the 5.5 to 8.0 percent figures were used to estimate the probable population range (high and low estimates) for the town of Brazoria. Then the annual death rate figures of 0.5 to 0.8 percent were used to calculate the probable number of deaths, with high and low estimates, that occurred each year among the black community. The estimated deaths for all the years were then totaled, resulting in the estimate that between 1,759 and 4,061 deaths occurred among Brazoria's black residents in just over a century. Again, the obvious question is: Where were all these people buried?

It is clear that many African Americans lived, worked, and died in Brazoria from 1837 to 1940 . It is also likely that many of these people were buried at Pioneer Cemetery. Thus, circumstantial evidence strongly suggests that Pioneer Cemetery dates much earlier than 1888, and that it probably served as the main cemetery for the enslaved black community in antebellum times.

Table 8.7. Comparison of population data for Brazoria and Brazoria County in 1870, 1880, and 1887*

\begin{tabular}{|c|c|c|c|c|c|c|c|c|}
\hline \multirow[b]{2}{*}{$\begin{array}{c}\text { Recorded } \\
\text { Color }\end{array}$} & \multicolumn{3}{|c|}{$\begin{array}{c}1870 \\
\text { U.S. Census* }\end{array}$} & \multicolumn{3}{|c|}{$\begin{array}{c}1880 \\
\text { U.S. Census* }\end{array}$} & \multirow{2}{*}{$\begin{array}{c}1887 \\
\text { Bureau of } \\
\text { Agriculture } \\
\text { Census** } \\
\text { Brazoria } \\
\text { County }\end{array}$} & \multirow{2}{*}{$\begin{array}{c}1887 \\
\text { Estimated } \\
\text { Population**** } \\
\text { Brazoria }\end{array}$} \\
\hline & $\begin{array}{l}\text { Brazoria } \\
\text { County }\end{array}$ & Brazoria & $\begin{array}{l}\text { Percentage } \\
\text { in Brazoria }\end{array}$ & $\begin{array}{c}\text { Brazoria } \\
\text { County }\end{array}$ & Brazoria & $\begin{array}{l}\text { Percentage } \\
\text { in Brazoria }\end{array}$ & & \\
\hline Black **** & 5,736 & 460 & $8.0 \%$ & 7,524 & 412 & $5.5 \%$ & 8,998 & $495-720$ \\
\hline White & 1,791 & 260 & $14.5 \%$ & 2,250 & 264 & $11.7 \%$ & 3,280 & $339-420$ \\
\hline Other & 0 & 0 & $\mathrm{n} / \mathrm{a}$ & 0 & 1 & $\mathrm{n} / \mathrm{a}$ & 13 & $?$ \\
\hline Total & 7,527 & 720 & $9.6 \%$ & 9,774 & 677 & $12.0 \%$ & 12,291 & $1180-1475$ \\
\hline
\end{tabular}

* U.S. census data from Table 8.3.

** 1887 data from The First Annual Report of Agricultural Bureau of the Department of Agriculture, Insurance, Statistics, and History, 1887-88 (Foster 2001:247-248). The "Other" category is 13 persons designated as "Mexican." All other European immigrants are included with White. The 1887 data are close to the population data from an 1890-1891 Agricultural Bureau report, stated as: Black 8,566; White 2,938; Indian 1 (Hollingsworth 1892:Table 28).

*** The estimate range for 1887 is based on the percentages of blacks in Brazoria in 1870 and 1880.

**** Black includes mulatto. 
Table 8.8. Estimated black population of Brazoria and hypothesized number of deaths, 1837 through 1940*

\begin{tabular}{|c|c|c|c|c|c|c|}
\hline Year & $\begin{array}{c}\text { Slave } \\
\text { Population } \\
\text { in Brazoria } \\
\text { County* } \\
\end{array}$ & $\begin{array}{c}\text { Black } \\
\text { Freedmen } \\
\text { Population } \\
\text { in Brazoria } \\
\text { County } \\
\end{array}$ & $\begin{array}{l}\text { Low Estimate } \\
\text { of Black } \\
\text { Population of } \\
\text { Brazoria** }\end{array}$ & $\begin{array}{c}\text { High Estimate } \\
\text { of Black } \\
\text { Population of } \\
\text { Brazoria** } \\
\end{array}$ & $\begin{array}{l}\text { Low Estimate } \\
\text { of No. of Black } \\
\text { Deaths in } \\
\text { Brazoria*** }\end{array}$ & $\begin{array}{l}\text { High Estimate } \\
\text { of Black } \\
\text { Deaths in } \\
\text { Brazoria*** }\end{array}$ \\
\hline 1837 & 892 & \multirow{28}{*}{$\begin{array}{c}\text { not } \\
\text { applicable }\end{array}$} & 49 & 71 & 2.5 & 5.7 \\
\hline 1838 & 1,149 & & 63 & 92 & 3.2 & 7.4 \\
\hline 1839 & 1,406 & & 77 & 112 & 3.9 & 9.0 \\
\hline 1840 & 1,665 & & 92 & 133 & 4.6 & 10.7 \\
\hline 1841 & 1,750 & & 96 & 140 & 4.8 & 11.2 \\
\hline 1842 & 1,835 & & 101 & 147 & 5.0 & 11.7 \\
\hline 1843 & 1,920 & & 106 & 154 & 5.3 & 12.3 \\
\hline 1844 & 2,005 & & 110 & 160 & 5.5 & 12.8 \\
\hline 1845 & 2,094 & & 115 & 168 & 5.8 & 13.4 \\
\hline 1846 & 2,520 & & 139 & 202 & 6.9 & 16.1 \\
\hline 1847 & 2,680 & & 147 & 214 & 7.4 & 17.2 \\
\hline 1848 & 2,840 & & 156 & 227 & 7.8 & 18.2 \\
\hline 1849 & 3,000 & & 165 & 240 & 8.3 & 19.2 \\
\hline 1850 & 3,161 & & 174 & 253 & 8.7 & 20.2 \\
\hline 1851 & 3,387 & & 186 & 271 & 9.3 & 21.7 \\
\hline 1852 & 3,613 & & 199 & 289 & 9.9 & 23.1 \\
\hline 1853 & 3,839 & & 211 & 307 & 10.6 & 24.6 \\
\hline 1854 & 4,065 & & 224 & 325 & 11.2 & 26.0 \\
\hline 1855 & 4,292 & & 236 & 343 & 11.8 & 27.5 \\
\hline 1856 & 4,390 & & 241 & 351 & 12.1 & 28.1 \\
\hline 1857 & 4,488 & & 247 & 359 & 12.3 & 28.7 \\
\hline 1858 & 4,586 & & 252 & 367 & 12.6 & 29.4 \\
\hline 1859 & 4,684 & & 258 & 375 & 12.9 & 30.0 \\
\hline 1860 & 4,782 & & 263 & 383 & 13.2 & 30.6 \\
\hline 1861 & 4,867 & & 268 & 389 & 13.4 & 31.1 \\
\hline 1862 & 4,952 & & 272 & 396 & 13.6 & $\begin{array}{l}31.7 \\
\end{array}$ \\
\hline 1863 & 5,037 & & 277 & 403 & 13.9 & 32.2 \\
\hline 1864 & 5,125 & & 282 & 410 & 14.1 & 32.8 \\
\hline 1865 & \multirow[t]{15}{*}{$\begin{array}{c}\text { not } \\
\text { applicable }\end{array}$} & 5,226 & 287 & 418 & 14.4 & 33.4 \\
\hline 1866 & & 5,327 & 293 & 426 & 14.6 & 34.1 \\
\hline 1867 & & 5,428 & 299 & 434 & 14.9 & 34.7 \\
\hline 1868 & & 5,529 & 304 & 442 & 15.2 & 35.4 \\
\hline 1869 & & 5,630 & 310 & 450 & 15.5 & 36.0 \\
\hline 1870 & & 5,736 & 460 & 460 & 23.0 & 36.8 \\
\hline 1871 & & 5,914 & 325 & 473 & 16.3 & 37.8 \\
\hline 1872 & & 6,092 & 335 & 487 & 16.8 & 39.0 \\
\hline 1873 & & 6,270 & 345 & 502 & 17.2 & 40.1 \\
\hline 1874 & & 6,448 & 355 & 516 & 17.7 & 41.3 \\
\hline 1875 & & 6,626 & 364 & 530 & 18.2 & 42.4 \\
\hline 1876 & & 6,804 & 374 & 544 & 18.7 & 43.5 \\
\hline 1877 & & 6,982 & 384 & 559 & 19.2 & 44.7 \\
\hline 1878 & & 7,160 & 394 & 573 & 19.7 & 45.8 \\
\hline 1879 & & 7,338 & 404 & 587 & 20.2 & 47.0 \\
\hline
\end{tabular}


Table 8.8, continued

\begin{tabular}{|c|c|c|c|c|c|c|}
\hline Year & $\begin{array}{c}\text { Slave } \\
\text { Population } \\
\text { in Brazoria } \\
\text { County* } \\
\end{array}$ & $\begin{array}{c}\text { Black } \\
\text { Freedmen } \\
\text { Population } \\
\text { in Brazoria } \\
\text { County }\end{array}$ & $\begin{array}{c}\text { Low Estimate } \\
\text { of Black } \\
\text { Population of } \\
\text { Brazoria** }\end{array}$ & $\begin{array}{c}\text { High Estimate } \\
\text { of Black } \\
\text { Population of } \\
\text { Brazoria** }\end{array}$ & $\begin{array}{l}\text { Low Estimate } \\
\text { of No. of Black } \\
\text { Deaths in } \\
\text { Brazoria*** } \\
\end{array}$ & $\begin{array}{l}\text { High Estimate } \\
\text { of Black } \\
\text { Deaths in } \\
\text { Brazoria*** }\end{array}$ \\
\hline 1880 & & 7,524 & 412 & 412 & 20.6 & 33.0 \\
\hline 1881 & & 7,734 & 425 & 619 & 21.3 & 49.5 \\
\hline 1882 & & 7,944 & 437 & 636 & 21.8 & 50.8 \\
\hline 1883 & & 8,154 & 448 & 652 & 22.4 & 52.2 \\
\hline 1884 & & 8,364 & 460 & 669 & 23.0 & 53.5 \\
\hline 1885 & & 8,574 & 472 & 686 & 23.6 & 54.9 \\
\hline 1886 & & 8,784 & 483 & 703 & 24.2 & 56.2 \\
\hline 1887 & & 8,998 & 495 & 720 & 24.7 & 57.6 \\
\hline 1888 & & 8,840 & 486 & 707 & 24.3 & 56.6 \\
\hline 1889 & & 8,682 & 478 & 695 & 23.9 & 55.6 \\
\hline 1890 & & 8,523 & 469 & 682 & 23.4 & 54.5 \\
\hline 1891 & & 8,493 & 467 & 679 & 23.4 & 54.4 \\
\hline 1892 & & 8,463 & 465 & 677 & 23.3 & 54.2 \\
\hline 1893 & & 8,433 & 464 & 675 & 23.2 & 54.0 \\
\hline 1894 & & 8,403 & 462 & 672 & 23.1 & 53.8 \\
\hline 1895 & & 8,373 & 461 & 670 & 23.0 & 53.6 \\
\hline 1896 & & 8,343 & 459 & 667 & 22.9 & 53.4 \\
\hline 1897 & & 8,313 & 457 & 665 & 22.9 & 53.2 \\
\hline 1898 & & 8,283 & 456 & 663 & 22.8 & 53.0 \\
\hline 1899 & & 8,253 & 454 & 660 & 22.7 & 52.8 \\
\hline 1900 & & 8,219 & 452 & 658 & 22.6 & 52.6 \\
\hline 1901 & & 8,021 & 441 & 642 & 22.1 & 51.3 \\
\hline 1902 & & 7,823 & 430 & 626 & 21.5 & 50.1 \\
\hline 1903 & & 7,625 & 419 & 610 & 21.0 & 48.8 \\
\hline 1904 & & 7,427 & 408 & 594 & 20.4 & 47.5 \\
\hline 1905 & & 7,229 & 398 & 578 & 19.9 & 46.3 \\
\hline 1906 & & 7,031 & 387 & 562 & 19.3 & 45.0 \\
\hline 1907 & & 6,833 & 376 & 547 & 18.8 & 43.7 \\
\hline 1908 & & 6,635 & 365 & 531 & 18.2 & 42.5 \\
\hline 1909 & & 6,437 & 354 & 515 & 17.7 & 41.2 \\
\hline 1910 & & 6,237 & 343 & 499 & 17.2 & 39.9 \\
\hline 1911 & & 6,270 & 345 & 502 & 17.2 & 40.1 \\
\hline 1912 & & 6,303 & 347 & 504 & 17.3 & 40.3 \\
\hline 1913 & & 6,336 & 348 & 507 & 17.4 & 40.6 \\
\hline 1914 & & 6,369 & 350 & 510 & 17.5 & 40.8 \\
\hline 1915 & & 6,402 & 352 & 512 & 17.6 & 41.0 \\
\hline 1916 & & 6,435 & 354 & 515 & 17.7 & 41.2 \\
\hline 1917 & & 6,468 & 356 & 517 & 17.8 & 41.4 \\
\hline 1918 & & 6,501 & 358 & 520 & 17.9 & 41.6 \\
\hline 1919 & & 6,534 & 359 & 523 & 18.0 & 41.8 \\
\hline 1920 & & 6,574 & 362 & 526 & 18.1 & 42.1 \\
\hline 1921 & & 6,650 & 366 & 532 & 18.3 & 42.6 \\
\hline 1922 & & 6,726 & 370 & 538 & 18.5 & 43.0 \\
\hline 1923 & & 6,802 & 374 & 544 & 18.7 & 43.5 \\
\hline 1924 & & 6,878 & 378 & 550 & 18.9 & 44.0 \\
\hline 1925 & & 6,954 & 382 & 556 & 19.1 & 44.5 \\
\hline
\end{tabular}




\begin{tabular}{|c|c|c|c|c|c|c|}
\hline Year & $\begin{array}{c}\text { Slave } \\
\text { Population } \\
\text { in Brazoria } \\
\text { County* } \\
\end{array}$ & $\begin{array}{c}\text { Black } \\
\text { Freedmen } \\
\text { Population } \\
\text { in Brazoria } \\
\text { County }\end{array}$ & $\begin{array}{c}\text { Low Estimate } \\
\text { of Black } \\
\text { Population of } \\
\text { Brazoria** } \\
\end{array}$ & $\begin{array}{l}\text { High Estimate } \\
\text { of Black } \\
\text { Population of } \\
\text { Brazoria** } \\
\end{array}$ & $\begin{array}{c}\text { Low Estimate } \\
\text { of No. of Black } \\
\text { Deaths in } \\
\text { Brazoria*** }\end{array}$ & $\begin{array}{l}\text { High Estimate } \\
\text { of Black } \\
\text { Deaths in } \\
\text { Brazoria*** }\end{array}$ \\
\hline 1926 & & 7,030 & 387 & 562 & 19.3 & 45.0 \\
\hline 1927 & & 7,106 & 391 & 568 & 19.5 & 45.5 \\
\hline 1928 & & 7,182 & 395 & 575 & 19.8 & 46.0 \\
\hline 1929 & & 7,258 & 399 & 581 & 20.0 & 46.5 \\
\hline 1930 & & 7,341 & 404 & 587 & 20.2 & 47.0 \\
\hline 1931 & & 7,321 & 403 & 586 & 20.1 & 46.9 \\
\hline 1932 & & 7,301 & 402 & 584 & 20.1 & 46.7 \\
\hline 1933 & & 7,281 & 400 & 582 & 20.0 & 46.6 \\
\hline 1934 & & 7,261 & 399 & 581 & 20.0 & 46.5 \\
\hline 1935 & & 7,241 & 398 & 579 & 19.9 & 46.3 \\
\hline 1936 & & 7,221 & 397 & 578 & 19.9 & 46.2 \\
\hline 1937 & & 7,201 & 396 & 576 & 19.8 & 46.1 \\
\hline 1938 & & 7,181 & 395 & 574 & 19.7 & 46.0 \\
\hline 1939 & & 7,161 & 394 & 573 & 19.7 & 45.8 \\
\hline 1940 & & 7,135 & 392 & 571 & 19.6 & 45.7 \\
\hline \multicolumn{5}{|c|}{ Total Estimated Deaths } & 1,759 & 4,061 \\
\hline \multicolumn{7}{|c|}{$\begin{array}{l}\text { * Gray cells are actual data taken from Tables } 8.2,8.3 \text {, and } 8.4 \text {, with U.S. census data as used in Figure 8.2. } \\
\text { Unshaded cells are estimates extrapolated from actual data. }\end{array}$} \\
\hline
\end{tabular}

The 1880 U.S. census provides definitive evidence that Pioneer Cemetery was the burial ground for African Americans who lived in Brazoria, including former slaves. A comparison of the names in the 1880 U.S. census for Brazoria with the list of names of people buried at Pioneer Cemetery (see Appendix F) discovered three matches. To confirm the headstone data (see Table F.1), the Find A Grave online database was consulted, and photographs of the individual headstones were examined. The three individuals who lived in Brazoria in 1880 and are known to have been buried at Pioneer Cemetery are:

- Denie Davis, listed as a 24-year-old black woman in 1880 census. Headstone data shows that she was born on September 15, 1855, and died on December 24, 1912 (note the 1-year discrepancy in age).

- Douglas Dwire, listed as a 35-year-old mulatto man in 1880 census. He was born in Texas, and his father was born in Mexico. Headstone data shows that he was born in 1840 and died in 1923 (note the 4- to 5-year discrepancy in age).

- Lizzie Higgins, listed as 4-year-old mulatto woman in 1880 census. Headstone data shows that she was born on September 11, 1878, and died on May 17, 1925 (note the 1- to 2-year discrepancy in age). 
Of these three people, one woman was born about 13 years after emancipation, and the other woman and man were older and almost certainly had been enslaved. A fourth connection between the 1880 census and the Pioneer grave markers was found in the Johnican family. The Brazoria census lists Ben Johnican, an 18-yearold black male. One of the Pioneer grave markers is for Darcus Johnican, who died on April 18, 1909, and was the wife of A. B. Johnican. Her stone is broken and her age at death is missing, but Darcus was likely married to the Ben Johnican who appeared in the 1880 census. Ben Johnican was probably born into slavery in about 1862 , but he would have been emancipated when he was about 3 years old.

\section{How Big Is Pioneer Cemetery and Where Are All the Graves?}

Figure 8.5 is a compilation map showing the locations of 16 unmarked graves (14 exhumed and 2 left in place) relative to the cemetery lots as shown on an earlier TxDOT plat map of Pioneer Cemetery (see Figure 2.1). A notation on the margin of the TxDOT plat map contains the following text:

BOUNDARY SURVEY OF PIONEER CEMETERY
BEING LOTS 3, 4, 9, 10,11, AND PART
OF LOTS 5, AND 8, BLOCK 42, OLD
TOWNSITE OF BRAZORIA, TEXAS IN THE
STEPHEN F. AUSTIN LEAGUE, ABSTRACT
NO. 20 BRAZORIA COUNTY, TEXAS

According to this statement and the deed records cited on the map (see Table 2.2), Lots 6 and 7, at the western end of the Block 42, were never officially part of Pioneer Cemetery. Of the 14 unmarked graves that were discovered, exhumed, and moved, 13 of them were located on Lot 6 . This provides clear evidence that the boundaries of Pioneer Cemetery were fluid and changed over time. Jordan (1982:38) notes that while fences enclose most southern folk cemeteries, this is not necessarily true for most older African American cemeteries. For a variety of reasons, "African American cemeteries became much more visible after the Civil War" (Baugher and Veit 2014:175). The locations of the slave burial grounds are unknown at most antebellum plantation sites across Texas. There are many cases in Texas where old African American cemeteries had very few marked graves, no fences at all, or fences in the wrong places, resulting in poorly defined boundaries by the latter half of the twentieth century. ${ }^{19}$

Lots 1, 2, and 12 of Block 42 belong to the Union Pacific Railroad, which was originally called the St. Louis, Brownsville, and Mexico Railroad when it was constructed around 1906 along the southern edge of Old Brazoria (Dismukes and Bettis 2002:5, Figure 26). Based on the evidence described above, it is certainly possible that black residents of Brazoria were buried in the railroad right of way when the tracks were laid down.

\footnotetext{
19 Examples of this in Texas include the Phillips Memorial Cemetery on Galveston Island (Dockall and Powell 1996; Dockall et al. 1996), the Dallas Freedman's Cemetery (Davidson 2004; Peter et al. 2000), the Montgomery Hill Cemetery in Navarro County (Feit and Trask 2013), Houston's Third City Cemetery (Foster and Nance 2002), the African American section of the Waco First Street Cemetery, and an isolated grave in Hill County at 41HI294 (Freeman et al. 2006).
} 


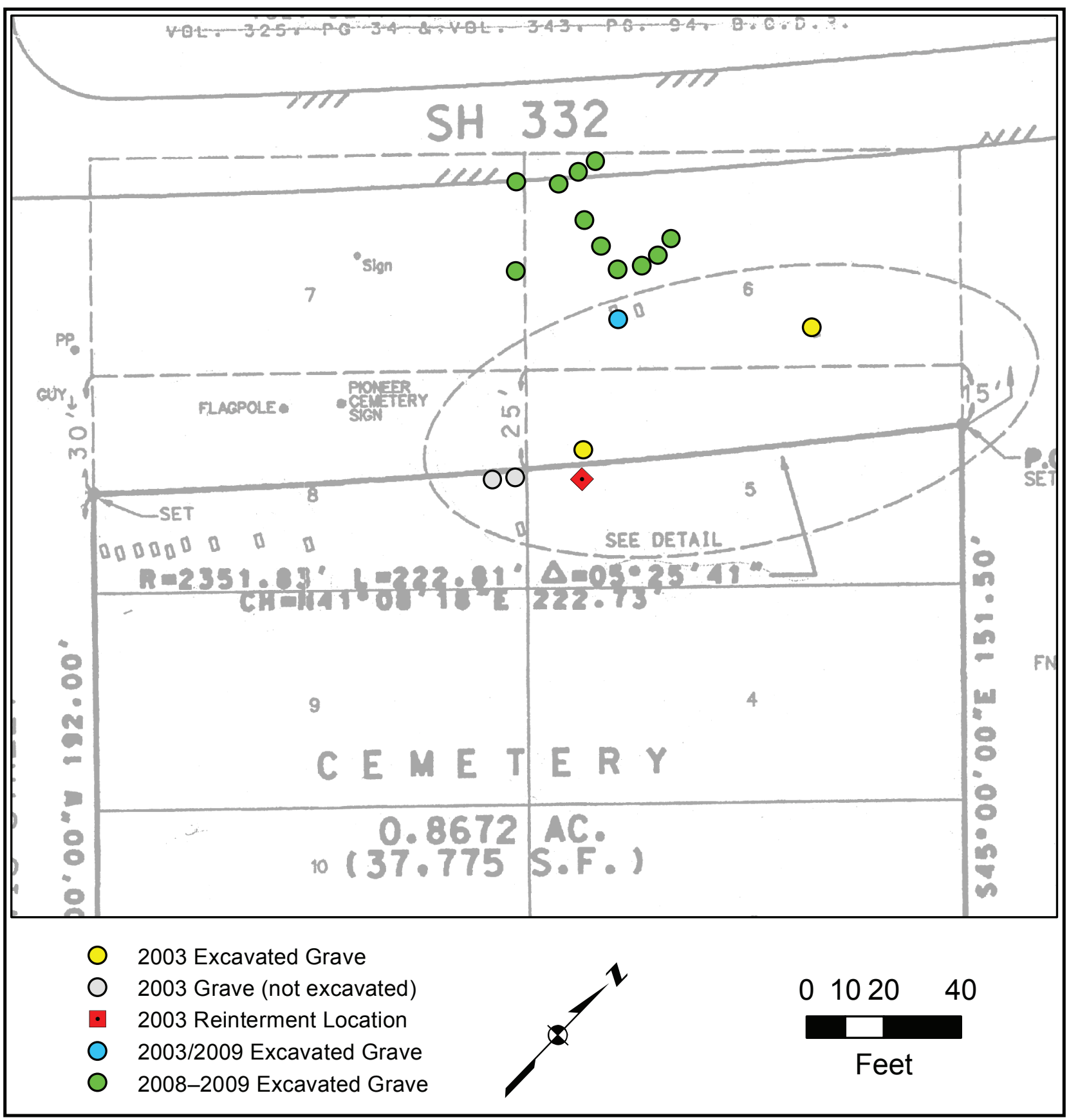

Figure 8.5. Map of Pioneer Cemetery showing the locations of 16 unmarked graves in relation to the city lots within Block 42 .

In 2003, the Cemetery Committee of the Brazoria County Historical Museum compiled a listing of all the marked graves in the Pioneer Cemetery (see Appendix F). At that time, there were only 59 graves with tombstones of any kind. Only 56 of these graves have headstones that include death year, and only 50 of those contain information enabling us to identify the person's age at death the sex of the deceased. Although three of the more recent graves (from 1991, 
1992, and 2000) are of Hispanics, Pioneer Cemetery was used predominately by the African American community throughout its history. Figure 8.6 is a graph comparing the year and age at death for all 56 Pioneer Cemetery grave makers. What is immediately obvious is that these data do not represent a realistic burial population that one would expect for a community cemetery such as Pioneer. The cemetery is currently 0.87 acres in size, and it was obviously somewhat larger in the past, perhaps much larger. And it was in use continuous use for at least six decades-from 1888 through 1948—and probably for a century or more. Yet only 59 graves are known to exist there, and only 56 have a known death year. Again, we must wonder: Where are all the graves?

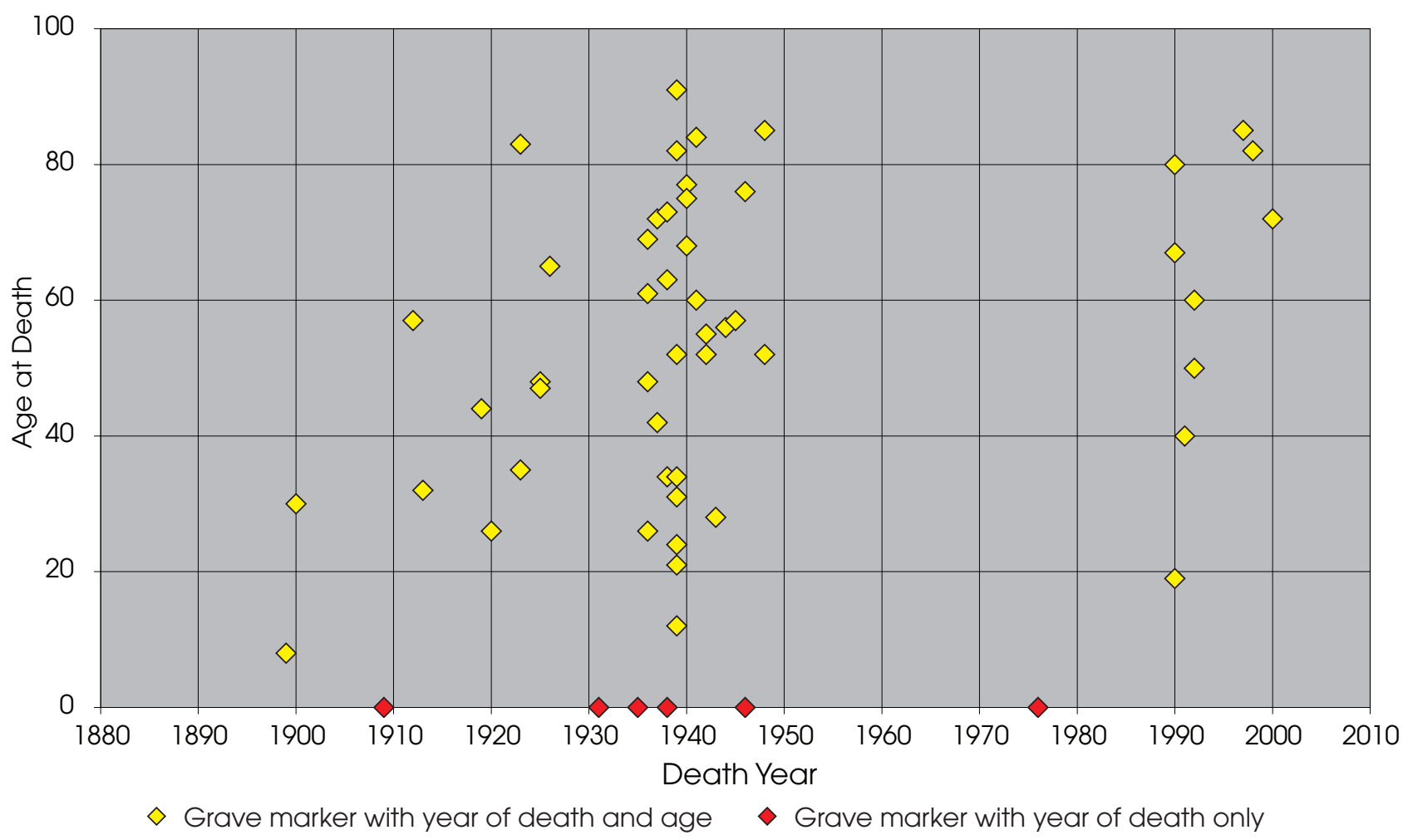

Figure 8.6. Graph of chronology and age at death for 56 marked graves at Pioneer Cemetery.

There are several odd discrepancies between the tombstone data and the history of the cemetery that are noteworthy and warrant discussion.

- The earliest death date on a documented Pioneer tombstone is 1899, which is more than a decade after the 1888 land transaction that formally acknowledged official creation of the cemetery. Does this mean that no burials occurred at Pioneer Cemetery in this 11-year period? This is highly unlikely, and it is reasonable to assume that quite a few burials would have occurred during this time. 
- Only 12 of the 53 burials date prior to 1930 , and there are several multiyear gaps with no burials occurring in the years 1901 to 1908,1914 to 1918, and 1927 to 1930. It is quite unlikely that no African Americans were buried at Pioneer Cemetery during these years.

- There is a significant gap in the burial dates during the latter half of the twentieth century. Only one burial, in 1976, occurred during the 40-year period from 1949 to 1989 . An oral history interview with the former cemetery caretaker, Traversia Viola, suggests that part of this gap does reflect a real phenomenon, being a period when few or no burials occurred. Mr. Viola noted that the community stopped burying people at Pioneer Cemetery around the time that SH 332 was constructed [ca. 1946 for the paved road on west side of cemetery] because the lots were full (MacHart and Stephenson 1997:53). Dismukes and Bettis (2002:11) also note that: "The newest graves are lined up just outside the edge of TxDOT right of way on the south end of the cemetery property. When asked how this happened Mr. Viola stated that after the Law Suit in 1985 they found out they had more land, and since the cemetery had been considered full, this additional land gave them the opportunity to again inter in the cemetery."

- The tombstone inscriptions indicate that the graves represent 25 males and 23 females, with 8 people of unknown sex. This nearly 1:1 ratio is a reasonable expectation for a normal community population, whether burial or living. In contrast, the age at death data from the tombstones certainly does not reflect a normal burial population. The group has only two children below the age of 18 ; one is a 12-year-old boy and the other is an 8-year-old of unknown sex. A normal burial population for a late nineteenth- and early twentieth-century community is expected to have a fairly high percentage of infants and young children. The paucity of infant and child graves is probably due, at least in part, to the fact that their graves would have had less substantial headstones than adult graves, and in some cases no formal grave markers at all. This means that infant and child graves were much more likely to become lost over time. Another possible explanation comes from Houston's Third New City Cemetery, where a relative paucity of infant and child burials also was observed in the exhumed burial population. Foster and Nance (2002:123) speculate that it was common for infants and young children to be buried at home in their own backyards rather than in expensive cemetery plots.

We can only guess at how many unmarked graves may be present at Pioneer Cemetery, but the archeological and circumstantial evidence suggests there may be many hundreds. The archeological investigations in 2003 and 2008-2009 discovered and exhumed 14 unmarked graves from the road right of way, and all of them were located outside the legal boundaries of the cemetery (i.e., the lots purchased as part of the cemetery). There are also unsubstantiated rumors that the cemetery was once much larger and that unmarked graves are located farther west beyond the current SH 332 right of way and to the east near and under the raised bed of the railroad tracks (see Chapter 2). 


\section{Where Did the Graves Exhumed in 1939 Get Relocated?}

Brazoria County reportedly "moved the graves from the Pioneer Cemetery to a 'White Oak Cemetery' in approximately 1939, when SH 332 was built. Bodies were removed from Lots 5, 6, 7, and 8 when the road was constructed" (MacHart and Stephenson 2002:53). This information came from Traversia Viola and Ora Kennedy. Unfortunately, no substantive archival or oral history research has been done to find out if and when the burials were removed from Pioneer Cemetery, or where any of the exhumed remains were sent for reburial. Since no empty grave shafts were found within the SH 332 right of way, it means that if any graves in the path of the roadway were exhumed in 1939, they must have been shallow graves and the subsequent road construction obliterated all evidence of their existence. Since 14 unmarked but fully intact graves were exhumed from the SH 332 right of way in 2003 and 2008-2009, the archeological evidence would suggest that these graves either had no headstones and were not moved in 1930s or 1940s. It is also possible that only the grave markers were moved at that time but the actual graves were not. Without a serious research effort to determine what happened at Pioneer Cemetery when SH 332 bridge and road were originally constructed, these questions will remain unanswered.

\section{WHY ARE SO MANY AFRICAN AMERICAN CEMETERIES LOST?}

It is a fact that quite a few African American cemeteries in Texas have been involved in development projects that led to archeological excavations and relocations of many unmarked graves. Is this due to some modern racial bias or is it the result of historical circumstances?

In general, it would be difficult to argue that there are any modern racial motivations in which African American graveyards are being somehow singled out and targeted by development projects. There might be some rare individual cases where an argument of racial bias can be made, but this certainly does not apply across the board to cemetery projects in Texas. In contrast, however, a great deal of evidence points to a harsh historical reality that factors into this equation and no doubt had its roots in antebellum racism. It is undeniable that many old African American cemeteries are lost in time and in space. This is true across the entire eastern half of Texas where the enslaved and freedmen populations were substantial in the nineteenth and early twentieth centuries. This phenomenon is a direct result of the historical racial discrimination associated with slavery and post-emancipation oppression.

In Texas, we know where large numbers of nineteenth-century AngloEuropean community cemeteries are located. In contrast, we have only a vague or no idea where most antebellum slave cemeteries are located, and the number of marked graves (i.e., marked with headstones) at most post-emancipation freedmen community cemeteries is probably a small percentage of the graves that actually exist. It is usually up to local communities to document and protect such cemeteries. As Michelle Mears (2009:161) observed about freedmen cemeteries in the Austin 
area: "Although a great many of the earlier burial sites do not have grave markers, Austinites are working to maintain these cemeteries and erect historical markers."

The one question that needs to be answered-Why have so many older African American cemeteries become lost?-must be addressed from a broad historical perspective. There are, of course, many reasons why nineteenth- and early twentieth-century African American cemeteries in Texas have become lost. But before this topic is discussed, some important misconceptions about African American graves and cemeteries that must be considered.

\section{Misconceptions About "Marking" of African American Graves and Cemeteries}

Prior to emancipation, blacks had little or no control over their own lives and very little control over how they were allowed to mourn deaths. Roediger (1981:165) notes that in the Southern United States, "the legal response to the slave's desire for a decent burial was equivocal at best and hostile at worst. Nowhere was the slave funeral legally protected as a human right and only rarely was it protected in limited ways." Consequently, slave funerals were often held at night and hidden from view or they were carefully controlled by white owners and overseers. Slave masters were "particularly anxious to discourage 'heathenish' African funeral rites" primarily because they were fearful of things they did not understand (Roediger 1981:168).

Despite the systematic attempts to discourage African beliefs, African funerary rituals and beliefs did survive, as Roediger (1981) describes in his treatise on funerals, death, and heaven among Southern slave communities. "Merely to point out the continuation of African burial customs, in various degrees, among American slaves seriously understates the African aspect of slave behavior concerning death and funerals. What is involved is not only the practice of African rituals in an American context, but the continuation, albeit in a changed form, of basically a West African understanding of the meaning of death" (p. 174). Many specific customs that are documented as integral components of slave funerals have West African origins, and these customs represent "an adaptable complex of West African religious values regarding death" (p. 174). These beliefs were manifest in all aspects of funerals and death, including slave burial grounds. Roediger (1981:174-175) notes that the "artistic grave decorations of slaves can be understood only with reference to such a complex of values."

African Diaspora folklorist John Michael Vlach (1990:139) summed up one of the main misconceptions about black cemeteries rather succinctly: "The common expectation for a cemetery is neat rows of stones and markers on a well-mowed green lawn.” Rather, Vlach (1990:139) notes:

Black graves are made distinct by the placement of a wide variety of offerings on the top of the burial mound. Most of these items are pottery or pressed-glass containers, but many different objects are encountered, including cups, saucers, bowls, clocks, salt and pepper shakers, medicine bottles, spoons, pitchers, oyster shells, conch shells, 
white pebbles, toys, dolls' heads, bric-a-brac statues, light bulbs, tureens, flashlights, soap dishes, false teeth, syrup jugs, spectacles, cigar boxes, piggy banks, gun locks, razors, knives, tomato cans, flower pots, marbles, bits of plaster, toilet tanks. These objects, when arranged on a group of graves, constitute a visual environment which in Afro-American tradition is seen as the world of the spirits, often the spirits of ancestors. Graveyard goods are a statement of homage; their function is to keep a tempestuous soul at rest. Far from being heaps of junk, funeral offerings are sanctified testimonies; material messages of the living intended to placate the potential fury of the deceased.

Vlach (1990:139) even mentions an archeological survey in which the field archeologists failed to recognize a black graveyard, thinking that the late-nineteenthand early-twentieth-century artifacts dispersed across a wide area was simply a historic trash scatter. Based on his experiences in South Carolina, Combes (1974:59, 61) similarly cautions archeologists to be aware that "nineteenth and twentieth century 'junk' found scattered in the woods may be an indication of a burial location."

When visiting historic African American graveyards, or African American sections in mixed-race cemeteries, the distinctions are clear if one pays attention. The use of traditional headstones, made of concrete or natural stones engraved or painted with names and dates, did not become prevalent for African Americans until after emancipation. The general paucity of traditional tombstones, and sometimes the total absence of formal grave markers, is a notable characteristic of older African American graveyards. It is especially true that commercially manufactured monuments, particularly of marble or granite, are exceedingly rare at many nineteenth- and early-twentieth-century black graveyards. As a general rule, the older the cemetery, the fewer headstones there will be and the simpler they will be. Cast-concrete headstones are quite common, whether they are neatly stamped with uniform letters or engraved by hand, and whether they are plain or ornately decorated. Among rural blacks in the early twentieth century, it was common for one black man to make cast-concrete headstones for many people within his community, and these local craftsmen often had their own artistic styles that are quite distinctive and recognizable (Little 1989; Rotundo 1997).

Indeed, the use of vernacular or handmade grave markers in lieu of formal inscribed tombstones is a common trait in older African American cemeteries. Chandler (2010:n.p.), a cemetery researcher in Atlanta Georgia, made the following observations:

When visiting an African-American Cemetery, it is noticeable how few grave markers are visible. This is a common feature, and is not conducive to the income or social status of the interred. Instead, it has to do with the African burial tradition which places less emphasis on the singular plot and more emphasis towards the burial ground as a whole...Hand-made grave markers are an expression of the deceased's family, just like the grave offerings...

Whether headstones are present or not, older African American graves were often marked with many types of surface evidence, such as borders made of 
common items and odd arrangements of diverse everyday objects added onto the grave mound. These types of markings were quite meaningful to those who shared and understood the culture, but they would appear to be haphazard and cluttered collections of trash to outsiders. Far from being random, "there is a discernable pattern in the types of objects left on graves" and these offerings have a strong link to African heritage (Vlach 1990:141, 142-147). Unfortunately, it is not uncommon for well-intentioned people to actually destroy the surface evidence of grave locations in efforts to "clean up" the debris from historic black graveyards.

At African American cemeteries, the use of ephemeral grave markings and simple vernacular markers, and the frequent lack of formal headstones altogether, are sometimes interpreted as evidence of the abject poverty of the people involved. This is unfortunate because it is simply not true. This interpretation is a biased view that imposes modern white beliefs regarding death and burial on the historic communities of enslaved blacks and freedmen, who had varied and complex Africanbased beliefs blended with Christian traditions. The reality is that older African American graves were indeed "marked" in many ways, but they were not marked in ways that the dominant white society would think of as appropriate. The use of simple folk-made headstones or bric-a-brac grave markings is a reflection of traditional African American culture and heritage, not poverty. Davidson (2004:ix-x, 34-36) notes that retention of vernacular belief systems and folk traditions relating to death and funerals was an important way for African American communities to maintain their sense of identity.

Puckett (1926:105) observes that "broken crockery is used as the chief decoration for Negro graves. This seems to be a direct African survival." ${ }^{20} \mathrm{He}$ also notes that in parts of the Congo, "the natives mark the final resting place of their friends by ornamenting their graves with crockery, empty bottles, old cooking-pots, etc., all of which articles are rendered useless by being cracked or perforated with holes" (Puckett 1926:105). It is important to consider that many white Americans, today and in the past, would not recognize these burials. Isolated graves marked in this manner are particularly likely to be mistaken for historic scatter.

In the 1990s, David Bruner conducted a study of the African American community in Brazoria County, focusing on oral history and an analysis of the "Juden Cemetery" graveyard associated with the Levi Jordan Plantation. In his thesis "Hidden Power: Burial Practices of an African-American Slave and Tenant Community" (Bruner 1996:120), he notes that African American community had a "system of 'hidden' symbols" used to mark graves. He also notes that their burial practices changed through time, and that a significant shift in how graves were marked occurred soon after emancipation. During slavery times, the hidden symbols had specific cultural and spiritual meanings that their white overseers did not understand. This symbolism was ultimately of African origin, but with many modifications over generations. The cultural and spiritual symbols included how graves were clustered and oriented within their graveyards and how graves were adorned with a wide variety of everyday objects (with glass bottles and glass and ceramic vessels fragments being most common at Juden). After emancipation, freedmen

${ }^{20}$ Puckett cites another researcher who believed this might have been an American Indian practice that was adopted by African Americans. 
communities were less constrained by a desire to hide their traditional beliefs, and the patterns of marking cemeteries and graves evolved and became more open.

The scarcity of commercial tombstones and formal grave markers in historic African American cemeteries is not a phenomenon restricted to the southern states, as is demonstrated by research at cemeteries in Pennsylvania and Illinois. Researchers at the Midland Cemetery in Dauphin County, Pennsylvania, noted the following:

After grave orientation, perhaps the most noticeable aspect of the cemetery is the relative scarcity of grave markers for the number is interments known to be here. Although the cemetery is believed to hold burials from the late eighteenth century, and was in regular use throughout the nineteenth century, grave markers from the decades preceding the Civil War have either vanished, or never existed. This is a common aspect of African American burial grounds across the country and has little to do with income or social status. Traditional African burial traditions place less emphasis on the precise spot of burial, and much importance on the place, or burial ground as a whole. Spirits of the dead are believed to linger in the general area of the burial ground, and are not tied to a specific gravesite (Afrolumens 2003).

A similar set of observations were made by King (2010:127) while researching an African American Cemetery in New Philadelphia, Illinois:

Formal landscaping was not typical of 19th- and 20th-century African American cemeteries. Graves were often randomly placed, and to maintain tranquility and avoid disturbing the spirits, no attempt was made to control the growth of vegetation. Graves were often unmarked or indicated by handmade markers or stones, while more ornate markers became increasingly common in the 20th century. In the early 20 th century, flowers, such as lilies, were introduced as grave decorations.

From all of the statements above, one may conclude that older African American communities did not consider formal grave markers to be all that important. The graves were certainly marked, but they were marked in more ephemeral ways that Euro-Americans did not understand. The offerings placed at a grave by friends and family or simple cast-concrete markers made by local craftsmen were far more personal and meaningful for the black community than massproduced engraved headstones. We may also conclude that older African American cemeteries usually look quite different from contemporary white cemeteries. The lack of ornate landscaping and vegetation maintenance are not signs of neglect or disrespect, as is often believed by outsiders. These traits simply reflect traditional African-derived beliefs regarding appropriate treatment of graves and burial grounds. One unintended but significant consequence of these beliefs is that older African American burial grounds are often difficult to find and recognize by people who are not aware of the traditions behind them. Chandler (2010:n.p.) summed up this phenomenon:

Unfortunately, because of the lack of formal landscaping and permanent markers, older African American cemeteries are 
overlooked as vacant land, and these important historical sites are forgotten. In African American cemeteries in the south, a clear African aesthetic remains. Comparisons between African American graves adorned with offerings and those in the Congo with the same offerings are nearly identical.

Even in urban areas, vegetation growth may obscure old cemeteries associated with freedman communities. Mears (2009:111-112) notes that: "Recent rediscovery of the old Sneed Plantation slave cemetery, called Williamson Creek Cemetery, points out that there may be more such hidden and overgrown cemeteries in Travis County...Very few grave markers are found in the cemetery. Preservationists estimate that there could be as many as five hundred graves but have only been able to identify 139 people buried there." The Williamson Creek Cemetery, located in south Austin less than $500 \mathrm{ft}$ from Interstate Highway 35 and across the street from a large movie theater and restaurant complex, was unknown to all but few people until recently. This cemetery was never really lost, however: its location was simply obscured by dense vegetation growth and its historical significance was overlooked until the Travis County Historical Commission began a concerted effort to document freedman communities and cemeteries.

\section{Case Studies of Forgotten African American Cemeteries in Texas}

The discussion below summarizes six case studies of forgotten African American cemeteries in Texas, focusing on selected cemeteries that have been investigated more extensively than most. As the reader will see, five of the six case studies involve the discovery and bioarcheological excavations of unmarked graves in conjunction with development projects, including state-funded road improvements, as was the case for Pioneer Cemetery. The sixth case study involves a small rural cemetery (Bull Hill Cemetery) that was investigated through archival and oral history research.

\section{Freedman's Cemetery, Dallas}

Soon after emancipation, several freedmen communities began to develop in and around Dallas. One of the larger ones was just north of Dallas, and it was called Freedman's Town. In 1869, an acre of land was purchased as a burial ground, and it became known as the Freedmen's Cemetery. Three more acres were added to expand the cemetery in 1879, and the property was annexed by the City of Dallas in 1887. Although multiple attempts were made to close Freedman's Cemetery over the years, it remained a viable burial ground for black Dallas residents until 1907, when a new city cemetery opened. Oral history suggests that burials occurred there as late as 1925. Many of the graves were never marked, and the locations of the marked graves were lost over time. By 1965, there were few grave markers left, and more than three quarters of the property had been sold off for road and railroad development. The remaining quarter became an open space called "Freedman's Memorial Park (Davidson 2000; Peter et al. 2000). A large portion of Freedman's Cemetery was paved over in the 1940 s by the construction of the North Central 
Expressway, and it appears that no attempt was made to exhume and move any of the graves at that time. This roadway bisected the black community in north Dallas, creating a barrier that effectively started the decline and demise of the old neighborhood (Davidson 2000:49).

Fast forward to 1986, when TxDOT was in the planning stages for a highway expansion of the North Central Expressway (U.S. Highway 75) in the middle of one of the nation's largest cities. The project spurred an archeological investigation to search for unmarked graves that would be impacted by the road construction. They found far more graves than anyone anticipated. What was envisioned as a relatively small project that might involve several dozen graves turned into a four-year field investigation, with research, analysis, reporting, and community outreach efforts lasting for another decade. The archeological investigations involved an estimated 25 percent of the cemetery, and several thousand more unmarked graves are located in the remainder of the cemetery that is now protected. James Davidson (2000 and 2004) and Duane Peter et al. (2000) discuss the complex history of Freedmen's Cemetery, and the bulk of the bioarcheological investigations are reported by Davidson (2004) and Peter et al. (2000).

The Texas Historical Commission declared Freedman's Cemetery to be a State Archeological Landmark in 1990, just as the first exploratory archeological investigations began. In 1992, the site was declared a Dallas Historic Landmark. From 1991 to 1994, archeologists excavated the remains of 1,150 burials containing 1,157 individuals. The exhumed burials were dated to the following periods:

$\begin{array}{lcc}\text { Period of Interment } & \text { No. of Individuals } & \text { Percent of Burial Population } \\ \text { Early Period, 1869-1884 } & 64 & 5.5 \\ \text { Middle Period, 1885-1899 } & 171 & 14.8 \\ \text { Late Period, 1900-1907 } & 884 & 76.4 \\ \text { Unknown but Pre 1900 } & 37 & 3.2 \\ \text { Unknown } & 1 & 0.1\end{array}$

Freedman's Cemetery constitutes one of the most important burial populations relevant to African American history in the post-emancipation period, and it is one of the most intensively studied comparative cemetery data sets in the United States (e.g., Davidson et al. 2002). "For the African American community today, Freedman's Cemetery is symbolic of its sense of place in the history of Dallas" (Peter et al. 2000:3).

The Freedman's Cemetery project is also a case study in the emotional politics of cemetery archeology, and the early days of the project were fraught with mistakes that could have been avoided. Davidson and Brandon (2012) discuss the complex political history of the bioarcheological project, which involved an ongoing power struggle between the road engineers, bioarcheologists, and the black descendant community. After the burial excavations were completed in 1994, the project was stalled for about three years before starting up again. Ultimately, the Freedman's Cemetery project did get on the right track by honest and direct communication 
with the descendant community and listening to what they had to say. Davidson and Brandon (2012:608) conclude that:

Freedman's Cemetery is a vastly important site; it is a priceless archaeological treasure that engendered contentious, polarizing politics, as well as a commensurate 'community making' experience. It was emotionally difficult, because it opened up a window that exposed hidden wrongs, perpetrated against the Black community, but Freedman's also opened up invaluable insights into their combined pasts.

The Freedman's Cemetery bioarcheological project spawned several longterm benefits for the African American community of Dallas. Among these are:

- The project helped solidify the local African American community, bringing together various factions with the common goal of protecting the remainder of the cemetery.

- The project allowed the local descendant community a voice in the treatment of the human remains, in the planning of the bioarcheological analyses, and in the direction of the public outreach efforts.

- The project helped to better define the Freedman's Cemetery, both historically and geographically, so that the remainder of the cemetery could be preserved and memorialized.

- The community collaboration ultimately led to the construction of a permanent memorial at the cemetery. The Freedman's Cemetery Memorial, located at Lemmon Avenue and the North Central Expressway (U.S. Highway 75), is now an important public memorial to educate the public and commemorate the black community of north Dallas.

- The community collaboration also led to the creation of a permanent museum exhibit at the African American Museum of Dallas. Called "Facing the Rising Sun: Freedman's Cemetery," this exhibit tells the story of the historically significant Freedman Town community and graveyard through objects, photographs, and multimedia displays.

In retrospect, it is quite amazing that a large cemetery of several thousand graves in the middle of one of the largest cities in the United States could simply vanish in less than a century. But that is exactly what happened. Freedman's Cemetery was officially in use up through 1907, and may have been used for burials as late as 1925. But by the time the mechanical grave searches began in the 1980s, no marked graves remained. Fragments of gravestones were found during the archeological excavations, but they were all displaced and out of context. Only two complete inscribed gravestones were discovered, and these had been intentionally removed from their original locations and dumped along a roadway. Davidson (2004:98) summarized the situation as follows:

What the destruction of essentially all the standing tombstones at Freedman's Cemetery did was alter the cultural landscape of Dallas's cemeteries on a fundamental level. This desecration attempted to 
erase Freedman's from view, to transform Freedman's 4 acres from a burial ground containing the remains of an estimated 5000 AfricanAmericans into a blank canvas and potential commercial real estate, available for whatever purpose.

The Freedman Cemetery story should serve as a cautionary tale for all of us-developers, engineers, city planners, and archeologists.

\section{Phillips Memorial Cemetery, Galveston}

Phillips Memorial Cemetery (41GV125) is a historic African American cemetery in La Marque, Galveston County, Texas. It was the scene of intensive historical and bioarcheological research in the 1990s, triggered by a TxDOT road expansion project. In May 1991, expansion of State Highway 3 (SH 3) was underway in La Marque, and 53 shaft outlines of unmarked graves were discovered on the east side of and adjacent to the Phillips Memorial Cemetery. This discovery led to a series of archeological investigations within the road right of way, first by TxDOT archeologists and later by Texas A\&M University archeologists. In June 1991, a TxDOT archeologist found records indicating that 51 graves had been removed from the roadway in 1927, just prior to the original construction of $\mathrm{SH} 3$, and began machine scraping in the road expansion area. This search identified 47 unmarked graves and it was assumed that some or all of these graves had not been moved. Texas A\&M archeologists were contracted to conduct excavations of these grave locations, and their first field investigation was carried out from late July through early August 1991. This work examined 44 burial locations and discovered that many of these graves had been partially or completely removed, while some were completely intact. Texas A\&M archeologists returned for a second season of work at Phillips Memorial Cemetery in summer of 1992, and they found and excavated nine more unmarked graves that had been underneath the SH 3 pavement. This brought the total number of archeologically investigated burials to 53 . Following the burial excavations, the Texas A\&M researchers conducted bioarcheological analyses of the burial remains, and completed oral history interviews with local community members to define the history of the cemetery and the black community. The results of these investigations are reported by Dockall, Powell, and Steele (1996).

The history of the cemetery, and of the 1927 burial relocation, is a convoluted story (as described by Dockall, Powell, and Steele 1996:1-2, 42-45, 203). Although there are no deed records that illuminate its early history as a graveyard, the Phillips Memorial Cemetery was reportedly established around 1884, when it was apparently associated with the Campbellville Missionary Baptist Church. Early funeral home records show that the cemetery was in use by 1914, when it was called the La Marque Negro Cemetery. These records document 47 burials that occurred there from 1914 through 1929. A second African American burial ground, called the Rising Star Cemetery, was started in 1929, reportedly because the older La Marque Negro Cemetery was full. Local funeral home records indicate that only one burial occurred at the Phillips Memorial Cemetery from 1938 to 1946.

When the State of Texas decided to expand Highway 6 (now SH 3) in the 1920s, Galveston County Commissioners were aware that the road work would 
impact the east side of the cemetery. In July 1927, the Commissioners Court approved a motion that would allow "for the purchase by the county of 50 or more lots in the La Marque Colored Cemetery, at a cost not exceeding $\$ 5.00$ per lot, these lots being needed for the removal of bodies on the new right of way of Highway No. 6..." (Dockall, Powell, and Steele 1996:43). On August 16, 1927, the Commissioners Court ordered the Road and Bridge Committee and the County Health Officer to supervise the relocation of graves from the roadway and the purchase of land in the adjacent cemetery for the new graves. On October 25, 1927, the Commissioners Court granted final approval for $\$ 300$ for the new grave plots. It appears that the actual relocation of the graves took place between August 16 and October 25, 1927, and the remains were reinterred in a new location in Phillips Memorial Cemetery (Dockall, Powell, and Steele 1996:43-45).

The archeological investigations revealed as much about the 1927 grave relocation effort as the historical records do. Dockall, Powell, and Steele (1996:45) state that:

It is not clear from the records how the actual removal of the bodies was accomplished. It was not until archeological investigations at the site were completed that the manner in which burials were moved became known. In 1927, coffins were opened and most of the human remains were removed and relocated to an undefined area of the cemetery. However, coffin boxes, coffins, and some portions of the skeletons were left behind.

The bioarcheological investigations revealed that 10 of the 53 exhumed burials contained no skeletal remains, while 37 burials contained between 3.1 and 49 percent of the skeletal remains. Three graves had skeletons that were 50 to 90 percent complete, two were 94 percent complete, and one was 100 percent complete (Dockall, Powell, and Steele 1996:203, Table 50). Based on this archeological evidence, it was concluded that the 1927 burial excavations had impacted almost all of the burials, but that exhumation process was not rigorous, and significant portions of the skeletal remains were left behind in many of the burials. Almost all of the coffin and casket remains were left behind. In one of the graves moved in 1927, an unusual concrete cone had been thrown into the empty casket (Burial 11). The object was identified as a molded slump test cone, designed to determine the correct amount of water to be added to the concrete aggregate, that was created during the 1927 highway construction (Dockall, Powell, and Steele 1996:55, 124, 206, Figure 33).

Despite the fact that most of the graves exhumed in 1991 and 1992 had been partially disinterred in 1927, the burial remains that were left behind were very informative. All 53 of the exhumed burials had been buried in coffins or caskets, and most of these were left behind. Although the earliest historically documented grave is from 1914, the coffin hardware indicates that a number of burials might have occurred at Phillips Memorial in the last two decades of the nineteenth century (Dockall, Powell, and Steele 1996:42, 129-139, Figure 34). Not surprisingly, the burials were all oriented west to east (head to toe), but unlike burials at some other African American cemeteries, they were all neatly arranged in rows (Dockall, Powell, and Steele 1996:Figure 4). The archeologists speculate that "It is possible 
that he influence of the church resulted in a more formal, rigid burial pattern" (Dockall, Powell, and Steele 1996:23). All of the burials exhumed in 1991 and 1992 were reinterred at the Mainland Memorial Cemetery located a few miles away in Hitchcock, Texas.

The relatively low number of marked graves at Phillips Memorial Cemetery is notable. From all the official burial records, researchers compiled a list of 67 people known to have been buried in the cemetery from 1914 through 1946 . But only one of the exhumed graves had a marker identifying the deceased (John Edwards, Burial 38), and as of ca. 1994 there was only six extant grave markers (for seven individuals) in the rest of the cemetery (Dockall, Powell, and Steele 1996:42-47, 124-127, Tables 19 and 20). The only other surface evidence of graves in the remainder of the cemetery was limited to two graves marked by concrete "gravestone pedestals" (i.e., plinths that once held a marker) and three graves marked by low concrete curbing (Dockall, Powell, and Steele 1996:126).

Several facts argue for a large number of unmarked graves at Phillips Memorial Cemetery and indicate that most interments were never marked with formal gravestones or that the formal grave markers deteriorated or were removed many years ago. (1) Only one of the 53 graves exhumed in 1991 and 1992 had a formal tombstone (although other gravestones may have been removed prior to the 1927 relocation effort). (2) The paucity of marked graves throughout the rest of the cemetery (i.e., the area not impacted by the road project) suggests that many graves are unmarked. (3) The 67 burials documented in official burial records are all from one local funeral home. It is likely that people were buried there by other funeral homes and independent of any funeral home. And finally (4), the earliest documented burial at Phillips Memorial is 1914, but the archeological evidence suggests that a number of the burials occurred prior to this time, with some probably dating to the $1890 \mathrm{~s}$.

\section{Third New City Cemetery, Houston}

Allen Parkway Village (APV) is a housing redevelopment that occurred in the 1990s just west of downtown in Houston's historically black Fourth Ward. The APV is within the area that was known as Freedman's Town, which was Houston's most prominent African American community in the late-nineteenth and early-twentieth centuries. The project, which was undertaken by the U.S. Department of Housing and Urban Development, included a 36-acre parcel that had undergone a previous housing redevelopment in 1939-1941. This original housing project had removed a large section of the old African American neighborhood, and it had impacted a portion (approximately 4.5 acres) of Houston's Third New City Cemetery. But all of the graves were reportedly exhumed and relocated.

The Third New City Cemetery reportedly dates between 1879 and 1904 (Foster and Nance 2002:115). An early Houston city hospital was built on the property in 1859 , and "it is possible that the city could have used the hospital grounds for burials as early as 1859" (Foster and Nance 2002:107). After the cemetery officially closed, some burials were still occurring there as late as 1910 (p. 115). Historically, 
this large cemetery was an important place for Houston's Fourth Ward residents. Like many other large African American cemeteries in the post-emancipation era, burial records are virtually nonexistent, and there is no way to know how many people were interred there during the 31- to 51-year period when it was active.

The recent redevelopment included a search for unmarked graves in the area of the old cemetery, which covered approximately 4.5 acres (p. 115). This effort discovered hundreds of burial features, which led to an intensive bioarcheological investigation, reported by Foster and Nance (2002). These investigations were conducted from 1996 to 1998, and the archeologists ultimately excavated 446 burial features, of which 335 contained human remains (p. 119). The burials were predominately African American, but they represented "a mixture of people from different ethnic and socioeconomic backgrounds" (p. 148). The exhumed remains were reburied in a "specially dedicated memorial cemetery park located in the northeastern corner of the project area" but within the area of the original cemetery (p. 177).

Records indicate that in 1941 more than 900 graves were exhumed and turned over to a local funeral home, the Brookside Mortuary Company, for reburial (Foster and Nance 2002:107, 115). At the time this work was done, only one grave had a marker that identified the name of the deceased. It is clear that many parts of the cemetery had been impacted over the years by the expansion of city hospital facilities and other improvements. Foster and Nance 2002:107) state that by 1939, "The old cemetery area had been developed with additional city buildings, including a partially constructed 'Veteran's Building,' a repair shop, a mule barn, two car sheds, and various other storage sheds.” All of these improvements were removed during the 1939-1941 redevelopment project.

Despite the fact that a substantial effort was reportedly made to exhume the burials in 1941, Foster and Nance (2002:115) note that "a large number of grave features apparently were overlooked." Since more than 900 graves were relocated in 1941 , one would expect that the 1990s investigations would have found hundreds of exhumed burials, such as empty coffins with no human remains, but this is not the case. Poor bone preservation and extensive construction-related disturbances were noted as significant factors in the excavated burials (Foster and Nance 2002:115117). Only around 100 burial features contained no human remains, and many of these probably represent exhumed graves. Foster and Nance (2002:117) lists the completeness of 355 excavated graves with skeletal remains as follows:

$\begin{array}{lr}\text { Skeletons }>75 \text { percent complete } & 10 \\ \text { Skeletons 50-75 percent complete } & 14 \\ \text { Skeletons } 25-50 \text { percent complete } & 32 \\ \text { Skeletons }<25 \text { percent complete } & 299\end{array}$

Some of these burials, especially those with less than 50 percent of the skeletal remains present, most likely represent partially exhumed graves.

The extensive disturbances observed in some of the graves excavated in the 1990s are explained, at least in part, by the "cutting and filling" (i.e., removal of 
sediment from high areas and filling in of low areas) that accompanied the 1939-1941 housing construction project (p. 17, Figure 4). It is clear that some burials had been relatively intact but were disturbed by these construction activities. It is also likely that the remnants of many of the graves that were exhumed in 1941 were completely destroyed by the widespread cut and fill activities.

Unfortunately, the bioarcheological research project in the 1990s included only minimal historical research on the history of the Third New City Cemetery, so the full story of what happened there is not known. However, the broad outline of what happened at the Houston's Third New City Cemetery in the twentieth century is not unusual. Even before the cemetery was officially abandoned, the lack of formal gravestones and the lack of city maintenance would have made the property appear more like an abandoned tract of land rather than a large cemetery. After it was formally abandoned, the city and local businessmen viewed this large property near downtown as a development opportunity, and the fact that there was a cemetery was of little consequence. City officials knew that the African American community was in decline, and that even if they protested, they were powerless to stop the development.

\section{New Home Cemetery, Fort Bend County}

In conjunction with an expansion of FM 1464 near Sugar Land, Texas, GeoMarine archeologists conducted a search for unmarked graves within the road right of way adjacent to the large New Home Cemetery (41FB334). In spring 2010, PBS\&J archeologists conducted trenching in the FM 1464 right of way and found human remains and evidence of in situ graves along the west side of the cemetery (Cordova and Anderson 2010). In November and December 2010, Geo-Marine archeologists found and exhumed 24 unmarked graves (11 complete and 13 with partial skeletal remains) in the road right of way. In May 2011, they scraped an area underneath the pavement of FM 1464, but no additional unmarked graves were found. All of the disinterred remains were reburied in the New Home Cemetery on May 9, 2011.

Hill and Pye (2012) report the details of the bioarcheological investigations. Based on the mortuary evidence (mainly coffin hardware styles) and associated remains, they infer that the exhumed burials date from 1895 through the 1960s. Historic deed research indicates that the property was purchased in 1895 to serve as "a place of worship and a place of rest for the African Americans of the Sugar Land community" (Hill and Pye 2012:3). Of the 24 exhumed burials, only one was identified to name (the 1954 burial of Leah Simpson).

New Home is typical of many African American cemeteries in that there are few graves relative to its large size. Hill and Pye (2012:15) state:

There are few formal markers or gravestones. All are modest in appearance, ranging from simple crosses fashioned from small pieces of white PVC pipe, to handmade concrete markers with hand lettering, to commercial-grade gray granite headstones with commercial engraving (Figure 7). The markers/graves in the southwestern aspect of the cemetery are in rows oriented east/west 
with the heads west (Figure 8), but those in the northwestern aspect are randomly arranged in small clusters with differing orientations per cluster. There are no markers in the majority of open space within the cemetery.

This appears to be a classic case in which a road construction encroached into a portion of an African American cemetery where there were many unmarked graves. The New Home Mission Baptist Church purchased 2.19 acres of land in December 1895. A church was built soon after, and they began to use the remaining land for burials. In 1950, the New Home Mission Baptist Church sold a parcel of land along the west side of the cemetery to the State of Texas for the construction of FM 1464. This tract was removed from the original 2.19-acre cemetery property. The state apparently did not make any attempt to move the graves for this road project in the 1950s. The cemetery continued to be used by the local African American community into the 1980s (Hill and Pye 2012:11-12).

When TxDOT began planning for the widening of FM 1464 in 2006, locals knew that there were still graves in the road right of way. In 2006, a local black community leader and landowner of the New Home Cemetery, Mr. Woodrow M. Jones:

"personally hired the McWilliams Funeral Home of Hempstead, Texas, to undertake the task of exhuming the bodies from the ROW. This was done so that grave contents could be removed from the area to be affected and reburied within the current cemetery boundary. During this process, Denise Adams, a reporter for the Fort Bend Herald, authored an article that appeared in the paper on July 16, 2006 , that discussed some points of the project. According to Adams, the funeral home was responsible for the removal of a total of 26 "sets of remains" (Adams 2006) over a period of nearly two years. Adams stated in the article that a funeral home tag that contained the name of the Fort Bend Fraternal Undertaking Company...was recovered from one of the excavated graves (Hill and Pye 2012:11-12).

Unfortunately, it appears that the actual exhumation and removal of graves was not done properly, and many graves were partially exhumed or missed completely. Hill and Pye (2012:15) state that:

Mr. Jones negotiated with a local commercial funeral home to disinter graves that were in the portion of the cemetery sold to TxDOT for the expanded ROW. In addition the relocation of those graves, Mr. Jones paid for new grave markers. As reported by PBS\&J and confirmed by Geo-Marine, the removal and relocation of those graves was neither complete for the ones that were disinterred, nor comprehensive for the area as a whole. In other words, skeletal elements and funerary containers were left in situ (but greatly disturbed), and there were other graves that were still intact despite the assurance to Mr. Jones that relocation was complete.

\section{Montgomery Hill Cemetery, Navarro County}

In 2011, AmaTerra archeologists excavated 25 burials from the Montgomery Hill Cemetery (41NV716) in Navarro County, Texas. The work is reported by Feit 
and Trask (2013), who inferred that the burials all date between 1865 and 1885 . The burial ground was associated with the freedmen community in the Montgomery Hill/Eureka area, and most graves were of former slaves associated with various plantations. The black community was fairly stable from the 1870s through the 1940s, but it was largely gone by the time the Richland-Chambers Reservoir was built in 1986. At that time, the cemetery had been essentially forgotten. The cemetery was rediscovered in 2009, when human remains were found along a beach at the lake. The high knoll that had once been Montgomery Hill had become an island inside the lake (Chambers Creek Island), and the normally inundated cemetery was exposed to shoreline erosion by drought conditions.

The excavations revealed some interesting African American mortuary traits at Montgomery Hill. The burial population consisted of 21 juveniles and just 4 adults. Burial 1, a 9- to 12-month old infant, had a pierced coin pendant worn around the neck along with a beaded necklace. Five other graves (Burials 13, 15, 16,17 , and 24) contained beads or beaded necklaces found in the upper torso areas, with most being small glass beads. Burial 21, a 6- to 9-month-old infant, had a modified animal incisor (probably from a pig) worn as a pendant. While these could simply be ornamental jewelry, Feit and Trask $(2013: 140-148,192)$ believed they were more likely charms that had significance to their owners and were related to African-spiritual beliefs. It is notable that grave vaulting was identified for at least 11 of the 25 interments exhumed from Montgomery Hill Cemetery (Feit and Trask 2013:185). Feit and Trask (2013:34) state that cemeteries can contribute to the studies of "how various ethnic groups and communities lived and died in America" and can "further illuminate the lost stories of nineteenth century African Americans along the Texas frontier."

When the reservoir was built in the $1980 \mathrm{~s}$, most people knew nothing of the abandoned Montgomery Hill community or its cemetery. But the cemetery was not truly forgotten; it was simply overlooked. During the 2011 AmaTerra investigations, archeologists interviewed several African Americans who lived in the area and remembered the community and cemetery. Jennings and his sister Ola Mae Calloway had lived at Montgomery Hill and remembered the "old slave cemetery" that was located 50 yards from their home (Feit and Trask 2013:26). They did not know the names of any individuals buried there, and they did not think their grandmother or great-grandmother knew of anyone who was buried there. From the oral history work, Feit and Trask (2013:26) inferred that the Montgomery Hill Cemetery was no longer active by about 1875 . One white man who lived in the area remembered seeing the old cemetery in the 1960s, recalling that there were no tombstones but that the graves were marked with rocks (Feit and Trask 2013:26). A 1940 aerial photograph shows that the cemetery was a wooded area surrounded by houses and plowed fields. The locals recall that everyone knew where the cemetery was and left it alone.

\section{Bull Hill Cemetery, Falls County}

Unlike the other case studies, this example is not bioarcheological investigation done in conjunction with a development project. It was a cemetery 
research project conducted primarily by Nedra Lee, a Preservation Fellow working for the Texas Historical Commission. In 2007-2008, Lee conducted archival research and field investigations at the Bull Hill Cemetery (41FA86) in Falls County, Texas, along with oral history interviews with the descendant community (Lee 2009; Lee and Bruseth 2008; Styles and Lee 2010a, 2010b). The Bull Hill Cemetery, a slightly trapezoidal fenced area measuring approximately $125 \mathrm{~m}$ east-west by $110 \mathrm{~m}$ north-south, may have been used as early as the 1830s and up through $1961 .{ }^{21} \mathrm{It}$ reportedly contains at least 100 graves of enslaved workers from the Churchill Jones Plantation along with later freedmen from the nearby China Grove community and their descendants. After 1961, the local African American community stopped using the Bull Hill Cemetery and began burying people in the cemetery at the nearby China Grove African (Baptist) Church. A local man and his wife maintained the old cemetery for a few years, but this ceased in the 1970s (Lee and Bruseth 2008:11). When the Texas Historical Commission began its investigations at the Bull Hill Cemetery in 2007, brush clearing and mowing were necessary to find the grave markers. ${ }^{22}$

The onsite investigation at Bull Hill identified 101 features, of which 90 were thought to be graves that were marked in various ways (Lee 2009; Lee and Bruseth 2008). They also conducted remote sensing surveys of portions of the cemetery using a cesium magnetometer and a ground-penetrating radar; these surveys were contained mostly within the cemetery fence (Lee 2009:Figure 8; Lee and Bruseth 2008:Figure 7). The magnetometer survey covered ca. 85 percent of the cemetery and identified numerous anomalies roughly aligned northeast-to-southwest rows, and these anomalies appear to represent both marked and unmarked graves. The GPR survey blocks covered smaller areas (one 20x20 m and the other approximately 40×22 m) and revealed many anomalies, including a dozen that probably represent grave shafts. Following the remote sensing, some limited mechanical scraping was conducted outside the current cemetery fence, but no grave shafts were found.

Based on surficial evidence and the remote sensing results, the researchers defined four areas at Bull Hill as: (1) the probable location of the oldest burials; (2) the probable location of unmarked pre-19th century burials; (3) the location of the known marked graves; and (4) an area that has no remote sensing anomalies or surface indications of graves (Lee 2009:Figure 12). The descendant community believes that there are about 100 burials at the cemetery, and the collective surface evidence and remote sensing data suggest that there is at least that many. However, no testing of the magnetic anomalies and nonanomaly areas was done, and no mechanical scraping was done inside the fenced cemetery area. Consequently, it should not be assumed that the lack of magnetometer anomalies over large areas indicates an absence of graves.

\footnotetext{
$\overline{21}$ The earliest grave at Bull Hill was believed to be that of James Coryell, a Texas Ranger who was killed by Native Americans in May 1837. Texas Historical Commission archeologists excavated the grave in February 2011 (Mercado-Allinger and Bruseth 2011). The last known burial there occurred in 1961 (Lee 2009:29).

${ }_{22}$ In contrast to Bull Hill, a substantial handmade brick fence encloses marked graves within the Jones Family Cemetery. Located about 1.7 miles southwest of Bull Hill, the Jones Family Cemetery is about 1 acre and is within the Jones Plantation site (41FA87). It contains the graves of the white plantation owners and their descendants.
} 
Lee conducted an analysis of the grave markers and surface evidence for 90 mapped grave locations (Lee and Bruseth 2008:Table 1 and Appendix I; Lee 2009:Table 1), which resulted in the following typological classification:

$\begin{array}{lr}\text { Commercial marble or granite markers } & 9 \\ \text { Concrete markers with cast or stamped lettering } & 5 \\ \text { Carved flat stones } & 6 \\ \text { Unmodified field or flat stones } & 26 \\ \text { Temporary metal (funeral home) markers } & 27 \\ \text { Brick, machine-made } & 8 \\ \text { Brick, handmade } & 1 \\ \text { Wood post } & 2 \\ \text { Bent iron bar } & 1 \\ \text { Iron right with shaft } & 1 \\ \text { Iron pipe in concrete with brick } & 1 \\ \text { Metal bucket } & 1 \\ \text { Metal pipe } & 1 \\ \text { Stoneware jar } & 1\end{array}$

The commercial marble and granite markers all dated between 1911 and 1953. There were no readable dates on the concrete markers and or the carved flat stone. The temporary metal markers had stamped patent dates of 1911, 1918, and 1925, but only two had burial dates from 1944 (associated with a permanent granite marker) and 1955.

Circumstantial historical evidence indicates that many burials probably occurred at Bull Hill well before the earliest grave marker was placed there in 1911. Although the cemetery was never really lost or abandoned, the knowledge of its time depth and history, as well as the evidence of ephemerally marked and unmarked interments, were essentially unknown until the Texas Historical Commission conducted its research project from 2007-2009. Lee (2009:30) notes that the "unexpected closing of Bull Hill resulted in the decreased visibility of the cemetery, and with it, its near loss in local memory. While some local knowledge about the cemetery persisted during the time of our fieldwork [in 2007], the memory of the China Grove Church and community seemed to figure more prominently among interviewed individuals." Although there are only 90 known and suspected graves, the research reveals that Bull Hill Cemetery is probably the final resting place for many enslaved African Americans and freedmen whose graves are unmarked and whose stories are unknown. Taking from African Diaspora theory, Lee (2009:33) views "the significance of black cemeteries as repositories of silenced histories and "monumentalized spaces with political agendas" (quote from Meskell 2002:288).

Since its rediscovery, the Bull Hill Cemetery has become a significant place once again for the African American community. The Texas Historical Commission created a historical marker to commemorate "the long forgotten African American Cemetery" at Bull Hill, and it was unveiled in a well-attended ceremony on July 
10, 2010 (Styles and Lee 2010a:n.p.). The event was attended by descendants of the black slaves and descendants of the white slave owners, many of whom still live in the area. Because of these initial efforts, the work has blossomed into an ongoing oral history project pertaining to the Bull Hill Cemetery, China Grove, and other African American communities in Falls County (Styles and Lee 2010a, 2010b).

\section{Understanding Lost and Forgotten Black Cemeteries}

Collectively, these case studies reveal a pattern of how old African American cemeteries are forgotten and lost over time. While the particular circumstances are different in each case, the historical events have a common thread. Each of these cemeteries was once an important part of an active and vibrant local black community, but the location of the graves became forgotten as the population dwindled and community residents dispersed. Younger generations moved away, and the older generations passed on, leaving behind only a few people who had intimate knowledge of the cemetery and the grave locations within it. In each case, there were still some people who remembered knew many of the details, even if their information was spotty and incomplete. Another common thread is that a relatively small number of graves were originally marked with formal tombstones, and it is likely that most graves originally had ephemeral (e.g., wooden) markers or surface indications that were not easily recognizable as grave markers.

In the case of Montgomery Hill Cemetery at the Richland-Chambers Reservoir, the cemetery was not truly forgotten at the time the lake was built. Many local residents, black and white, knew of its existence, and the cemetery was never really "abandoned." Unfortunately, no one involved with the reservoir construction project in the 1980s thought to seek out and interview the locals to find out where the old cemeteries were located. When the cemetery was "rediscovered" some 25 years later, there were still black people living in the area who had memories of, and historical connections to, the Montgomery Hill Cemetery. Someone just had to look for them.

It was a housing development project that led to the removal of African American burials at Houston's Third New City Cemetery, first in 1939-1941 and then again in the 1990s. The latter work included archeological investigations that found graves that had reportedly been exhumed in the first development phase, but the reality is that most of graves had been only partially exhumed and some were largely intact. Road development projects led to the discoveries of unmarked graves at the Dallas Freedman's, Phillips Memorial Cemetery, and New Home Cemeteries. At the Freedman's Cemetery, Texas Department of Transportation project planners were shocked by the number of unmarked graves that were discovered and had to be relocated. In hindsight, a thorough historical investigation of the Dallas freedman community and the Freedman Cemetery should have been done long before the bioarcheological investigations began and the road construction contract was let. And an honest effort to involve the descendant community early in the project planning stages would have been beneficial in many ways. As was noted for the Third New City Cemetery project, previous grave relocations were reported for the 
Phillips Memorial Cemetery and New Home Cemetery. At Phillips Memorial, the 1927 grave relocation effort proved to be inadequate, with most graves being only partially exhumed. At the New Home Cemetery, graves were reportedly moved in 2006 but this effort was inadequate at best. The latter case is rather disturbing because it was done so recently. One might expect a grave relocation effort in 2006 to have been more thorough and respectful than a grave relocation done in 1927 . Apparently, it was not.

The five case studies involving development projects that led to bioarcheological studies share two common themes: poorly defined cemetery histories and a high potential for unmarked graves. Even though the cemeteries were known to exist, almost nothing was known about them until archival and oral history research were completed, and this usually did not happen until late in the archeological project. In all five of these cases, the cemeteries proved to have many unmarked graves that were discovered through mechanical grave searches and were subsequently exhumed and analyzed using bioarcheological methods. The lesson from the sixth case study, the Bull Hill Cemetery, is that historic African American cemeteries can be rediscovered and revitalized through archival and oral history research involving the descendant community, without having to wait until the cemetery is threatened by development.

Based on the case studies described above, as well as knowledge of other cemetery projects and black mortuary customs, we can begin to develop a list of some of the most common reasons why older African American cemeteries became lost and forgotten. These reasons include:

- Older African American cemeteries may look like vacant land, and natural vegetation growth may easily consume a cemetery and hide its grave markers and surface evidence. Given enough time, uncontrolled vegetation will eventually damage and destroy fences, grave borders, and other surface evidence. Vegetation growth and sediment buildup will eventually topple, break, and bury even substantial grave markers. Anglo and European traditions dictate that cemetery areas must be maintained, and they tend to view uncontrolled vegetation growth as neglect. But African Americans did not share these views until rather recently. In the late-nineteenth and earlytwentieth centuries, and even into the latter half of the twentieth century in some areas, a common belief among African Americans was that overgrown vegetation in a cemetery was acceptable and that constant removal of vegetation would in fact disturb the dead (Lee 2009:27-28). The concept of the neatly manicured Victorian-style cemetery was not prevalent among African Americans (Baugher and Veit 2014:169), and this is undoubtedly a major factor that has contributed to the disappearance of historic African American cemeteries across the landscape.

- Older African American cemeteries may contain lots of seemingly unrelated items that may appear to be nothing more than a surface scatter of historic 
artifacts. Such material remains can be easily misinterpreted, even by trained archeologists, as disturbed house sites or debris dumped on a vacant lot. Since many of the artifacts may date to the twentieth century, such locations are often given little consideration and dismissed as unimportant. The difficulty in recognizing material remains as grave offerings is another factor that has contributed to the disappearance of historic African American cemeteries across the landscape.

- African American communities were commonly displaced, both in antebellum times and after emancipation. Entire communities were sometimes forced to move away, and other communities simply declined until they vanished as people moved from rural areas to cities. There were many factors that caused "freedom colonies" to decline and be abandoned (Sitton and Conrad 2005:140-143, 172-175, 181-185), but anytime a community was displaced or disappeared, it effectively severed the ties between the people and their cemeteries. The disappearance of an associated community may accelerate the deterioration of a cemetery and increase the perception that the land is abandoned.

- Cemetery and burial records were not generally kept by or for enslaved blacks, and freedmen continued this tradition for many decades after emancipation. The locations of individual graves were kept in people's memories, but this information was lost as older members of the community passed on.

- By the latter part of the nineteenth century, local black churches, and funeral homes, and communities usually began to keep some type of cemetery records documenting burials, but it is not uncommon for such records to have been destroyed or lost over time. An unidentified informant who lived near the Levi Jordan Plantation commented on the relationship between the Juden Cemetery and the local Jerusalem Church, stating: "Jerusalem has their own, but the cemetery doesn't belong to the church. It's for the community. It belongs to the people. Now if you were a member of Jerusalem, they kept records. When you died and stuff like that. They had one book and it was destroyed. I'm looking for information. It's just lost. Nobody knows" (unidentified informant in Wright 1994:93).

- In many situations, it is the local African American community that possesses the most intimate knowledge of local cemeteries and graves. Unfortunately, it is these very people who are often ignored in the planning and completion of development projects involving their historic communities and cemeteries. This was certainly the case for the Freeman's Cemetery in Dallas (as described by Davidson and Brandon 2012).

- Historically, racism has been a factor in the disappearance of graves and cemeteries. The Dallas Freedman's Cemetery appears to be a case in which large numbers of grave markers were intentionally removed and the presence of graves was simply ignored. 


\section{THE PIONEER CEMETERY BURIALS AND THE AFRICAN DIASPORA}

As discussed earlier in this chapter, the 14 burials excavated from Pioneer Cemetery are an admittedly small sample. They are not representative of the whole African American burial population in Pioneer Cemetery, and they are certainly not representative of the African American community of Brazoria or Brazoria County at any given time. But they are an interesting group of historic burials nonetheless, and the bioarcheological evidence they provided does indeed contribute to the larger study of the African diaspora.

Before discussing the diaspora-related burial evidence, it is important to understand why African American archeology and the bioarcheology of historic black cemeteries are so relevant to modern African Americans. What can we hope to learn from these types of investigations, and to whom does it matter?

Many archeologists have noted the importance of archeological evidence in bridging the gap between modern African Americans with their enslaved ancestors. This is a wide gap indeed, and relatively little is known about the transitions from slavery to freedom given the large numbers of people who were forced into bondage. Reconstructing the reality of African and African American experiences, from slavery through the Jim Crow era, is difficult for many reasons. Chief among these is the fact that historical documents providing meaningful details are sparse, and most documents usually present only the perspective of the dominant white society. Consequently, archeological remains are extremely important, and they provide one of the best forms of evidence for researching the social identities of enslaved Africans and African Americans in the New World.

Archeological work at African American burial grounds is especially important because it provides unique kinds of evidence that may help "African descendants...rediscover their past and reconnect with their ancestry" (Elliott 2011:5). Such investigations often provide evidence of African-derived belief systems-ideas that were brought to the Americas from various parts of Africa, evolved over time, and eventually became too diluted to recognize as African beliefs. In short, archeological investigations of African American burial grounds are extremely relevant to modern African American communities because the physical evidence is important in tracing the African diaspora through time and across space. In our modern world, development activities often impact historic cemeteries and graves, leading to excavations and burial relocations in which archeologists try to learn new facts about the people and cultures involved. But when those graves are of people of African descent, the remains of the dead may speak volumes for people who had little or no voice in life.

\section{Health and Pathology Issues}

The overall assessment of the burial population, consisting of 9 adults and 4 children, is that the people were generally in good health (see Chapter 7). The cause of death could not be identified for any of the individuals. Dental anomalies were reflected at rates that are not unexpected for the late-nineteenth and early- 
twentieth centuries: Of the 10 individuals with permanent teeth, 80 percent ( 8 adults) had caries and 60 percent ( 6 adults and 1 child) had some degree of calculus buildup. Not unexpectedly, antemortem tooth loss was high among the older adults.

Some degree of degenerative joint disease (DJD) and vertebral joint disease (VJD) was present in 8 of the 9 adults, being absent only in 1 younger female. Within this population, these joint disorders appear to be the result of severe mechanical stress from hard physical activity. The four oldest people (Burials 7-10) all suffered from multiple types of DJD and VJD, with severely affected joint surfaces on the spine, shoulder, elbow, wrists, hands, hip, and feet. In short, their bones reveal that these individuals spent their entire lives doing hard physical labor, including repetitive heavy lifting and carrying. One of the older men (Burial 10) also had fractured ribs and possible trauma-related vertebral damage suggesting some type of work-related injury.

Linear enamel hypoplasia (LEH) was observed on the teeth of 3 of 11 individuals. This dental anomaly is often considered to be indicative of poor nutrition or severe mental- or disease-related stress leading to metabolic disruption in normal dental development. But the 27.3 percent LEH rate observed for the Pioneer burials is considerably lower than the LEH rate seen in many black cemetery populations. The urban Dallas Freedman's Cemetery population, for example, had an LEH rate of 68.5 percent (Clow and Green 2000:Table III-100); Davidson et al. 2002:244).

Cranial defects were observed on one subadult (at least 4 years old) of indeterminate sex (Burial 11), but the exact nature and cause of the defects could not be positively identified. While the bone anomaly could be the result of trauma, a healed local infection, or a congenital condition, it most likely represents a neoplasm (abnormal tissue or tumor growth) and could have been caused by some type of cancer or autoimmune disorder.

One adult male (Burial 9), who died between 35 and 59 years of age, had an amputated right leg (removed at the knee) that had been replaced with a prosthetic leg. It appears to have been a simple prosthesis made with wood (remnants of yellow pine were found) held in place by an iron frame. It is likely that there had been leather socket and straps for attaching the prosthesis, but these perishable materials did not survive. A cursory attempt was made to identify and date this prosthetic leg, but this was not possible due to the extensive corrosion of the iron frame parts. It does seem to be consistent with the less expensive types of artificial legs available in the late-nineteenth century and into the early-twentieth century. It may have been something like the simple peg legs illustrated (Nos. 144 and 145) in an 1888 catalog of artificial limbs (Marks 1988:49). The presence of this artificial leg attests to the fact that this middle-aged man had some reliable medical care after sustaining a severe injury or disease that required a leg amputation.

Four adult individuals had evidence of patterned tooth wear suggesting the use of their teeth as tools in repetitive tasks or perhaps wear from pipe smoking. These include one female (Burial 3), one male (Burial 8), and two of indeterminate sex (Burials 9 and 14). Such tooth wear is not uncommon among late-nineteenthcentury burial populations, and some of it is attributed to probable pipe smoking 
among both men and women (Graham 2014:101-102). It is often assumed that tobacco use was primarily by men, but there is considerable evidence otherwise. Pipe smoking and snuff consumption in the southern United States, were both common in the latter half of the nineteenth century by blacks and whites, and many southern women also used both forms of tobacco (Betts 1993:n.p.).

\section{Mortuary Remains and Economic Status}

All 14 of the individuals were buried in wooden coffins or caskets. Twelve of the burial containers ( 86 percent) had some type of decorative hardware (see Tables 4.1 and 4.2). None of these coffins or caskets may be considered top of the line, but without knowing individual death dates it is impossible to know if the casket hardware represented current styles or perhaps older styles that were less expensive. Another unknown factor is whether individual families were paying all the burial expenses on their own, or whether they had some type of burial insurance to help with funeral costs. Regardless, the use of no hardware and different types of decorative hardware indicates that these burials probably represent a broad range of economic circumstances for the families of the deceased. Some of the families made a conscious choice to pay for moderately expensive burials for their loved ones, whether directly at the time of death or over long periods through the purchase of burial insurance or fraternal group memberships. One young child (Burial 17) was interred in a fairly elaborate casket with a glass viewing window (see Tables 4.1 and 4.2). This was probably an expensive casket at the time, suggesting that this child was from a relatively affluent family.

By comparing coffin hardware recovered from excavated burials at the Dallas Freedman's Cemetery with prices listed in mortuary hardware catalogs, Davidson (2004:230-279) was able to look at variability in individual economic status as reflected in the costs of burial hardware. This fascinating study supported several main conclusions, five of which are mentioned here.

(1) There is definite evidence for social stratification within the historic Dallas freedman's community, with the estimated cost of burial hardware (low [average] high) varying as follows (low [average] high cost data from Tables 4-18, 4-19, and 4-20):

\begin{tabular}{llll} 
Period/Dates & Adult Male Cost $(\$)$ & Adult Female Cost $(\$)$ & Subadult Cost $(\$)$ \\
\hline $\begin{array}{c}\text { Early Period, } \\
\text { 1869-1884 }\end{array}$ & $0.01[0.16] 0.42$ & $0.01[0.15] 0.42$ & $0.01[0.05] 0.08$ \\
$\begin{array}{c}\text { Middle Period, } \\
\quad 1885-1899\end{array}$ & $0.00[0.76] 4.32$ & $0.00[1.32] 4.95$ & $0.00[0.98] 3.16$ \\
$\begin{array}{c}\text { Late Period, } \\
\text { 1900-1907 }\end{array}$ & $0.00[3.09] 13.38$ & $0.00[3.61] 11.41$ & $0.80[2.35] 6.97$
\end{tabular}

This study acknowledged that the cost of hardware represents proxy data for the total cost of the burial, which of course could not be calculated because there is no information on other funeral expenses. Historic funeral home records show that the 
cost of the "above ground mortuary displays" (Davidson 2004:275) was significant, especially when commercially manufactured headstones were purchased. ${ }^{23}$

(2) This study also took the burial dates into account as much as possible, and concluded that the degree of social stratification increased through time. There was little or no social stratification during the Early Period, 1869-1884, but the level of social stratification increased significantly in the Middle Period, 1885-1899. The average and high-end costs of burial hardware were, not surprisingly, highest in the Late Period, 1900-1907.

(3) The most expensive burials were those of women, and children's burials were the least expensive. During the Middle Period, the average cost of women's burial hardware was nearly twice as much as the men's. In the Late Period, women's burial hardware cost was still 15 percent higher than the men's.

(4) Most of the Freedman's Cemetery burial hardware was comparable, in style and cost, with the hardware from contemporary white burials at the Dallas Pioneer Cemetery (although no direct cost data could be derived for the Pioneer burials). This suggests that many of the freedman were on an equal economic footing with their white neighbors.

And finally (5), one can argue, the Dallas's freedman community was "resisting" white dominance in two different ways with respect to mortuary rites. Some individuals had traditional burials with little or no expenses incurred in casket hardware, tombstones, and other funeral trappings considered important to the white community. While this austerity may have been an economic necessity for some families, others were probably making a conscious decision to maintain their traditional African American beliefs and identities even when they could afford more elaborate burials. At the same time, other freedman families chose fairly elaborate burials and mainstream mortuary practices for their departed loved ones specifically to demonstrate their economic parity with the white community.

Because of racial discrimination within the American insurance industry, African Americans in the southern United States banded together to create their own mutual aid groups in the form of fraternal and sororital societies. Within the Dallas freedman community, benevolent fraternal and sororital organizations were of great importance, particularly because of the burial insurance and death benefits they offered. While freedmen could sometimes get burial insurance through a state or national life insurance company, this option offered none of the social and other benefits of membership in a fraternal or sororital group. Davidson (2004:171-209) amply illustrates these facts in his analysis of historical records pertaining to mutual aid societies in Dallas (Davidson's study is discussed in more detail later in this chapter).

In his 1907 classic study titled Economic Co-operation among Negro Americans, W. E. B. Du Bois (1907:92-128) argued that the true importance of beneficial, insurance, and secret societies to the negro community could not be known because these groups

23 Some of the exhumed burials once had headstones, but they were removed long ago. Davidson (2004:277) states: "Whatever the total number of tombstones were originally, we know that in the early 1920s all of the gravestones were dragged from their former locations marking individual graves, broken up, and used as fill to form the road bed during the initial construction of old Lemmon (later called Calvary) Avenue in a deliberate and racist act." 
were so numerous and widespread. Du Bois made a distinction between "beneficial and insurance societies" that operated transparently following legitimate insurance business practices and the "secret societies." ${ }^{24}$ However, almost all of these societies functioned by charging their members a monthly or annual fee, so that membership in these groups was limited to freedmen in the middle to upper economic classes. The secret societies mentioned by Du Bois (1907:109-128) as having lodges and members in Texas are:

Masons

In 1904, Texas had 48 lodges and 1,048 members

Odd Fellows

First Negro lodge in America established in 1843

In 1906, Texas had 180 lodges and 5,200 members

Knights of Pythias

Organized in 1864 with Negro lodges starting in 1880

In 1905, Texas had 5,075 members

United Brothers of Friendship

Organized in 1861 for Colored people

In 1905, Texas had 11,000 members

Improved Benevolent and Protective Order of Elks of the World

Organized in 1899; "Improved" referred to the Colored Elks

Lodges in 30 states (Texas not specifically mentioned but likely)

Du Bois (1907:113) presents some interesting data on death rates and death benefits among Masons. He lists (p. 113) the 1904 death rates for black Masons and all Americans as follows:

$\begin{array}{lll}\text { Alabama } & \text { 14 deaths per } 1,000 & 1.4 \text { percent } \\ \text { Arkansas } & 20 \text { deaths per } 1,000 & 2.0 \text { percent } \\ \text { Mississippi } & 24 \text { deaths per } 1,000 & 2.4 \text { percent } \\ \text { Missouri } & 20 \text { deaths per } 1,000 & 2.0 \text { percent }\end{array}$

Normal Death Rate 12 deaths per $1,000 \quad 1.2$ percent

(all Americans)

The overall 1904 American death rate of 1.2 percent is quite close to the 1897 Texas death rate of 1.1 percent (see Table 8.6), but it is notable that the death rates among black Freemasons in four southern states are all higher. This may be due to the fact that the freemason members were generally older men, so a death rate slightly higher than the general population should perhaps be expected. Regardless, these data suggest that the annual death rate for Freemasons in Texas would has probably around 2 percent, and if there were 1,048 colored Masons in

24 Du Bois (1907:128-134) listed asylums, orphan's homes, old folks homes, hospitals, and cemeteries for Negroes as "Co-operative Benevolence" organizations. These were often run as separate businesses under the umbrella of a larger benevolent society. 
Texas in 1904, it is likely that 21 of the Masons would have died that year. Du Bois (1907:112) notes that for 1906 Texas Masons brought in $\$ 11,370.60$ in income and paid out $\$ 4,123.50$ in claims. If there were approximately 21 deaths that year, the payment to the family of each deceased member was about $\$ 196.3 .^{25}$ This money was essentially a life insurance policy, payable to the member's family, and it would provide enough income to insure a proper burial. The Masons were only one of many similar organizations that offered such benefits.

\section{Importance of African American Fraternal Organizations in Texas and Brazoria}

Regardless of one's economic status, funeral rites and proper burial of the dead were very important to the African American community. After emancipation, fraternal organizations and benevolent societies became an important part of southern African American society (Skocpol et al. 2006), and the town of Brazoria was no exception. Within the black community during the Jim Crow era, membership in such groups was equated with the middle and upper class and signaled a certain level of social status. Typically, it was a community's business and church leaders who played prominent roles in the founding and operations of fraternal groups and benevolent societies.

Archeologically, none of burials exhumed from Pioneer Cemetery yielded any material culture evidence that would link any of the 14 individuals with a fraternal or benevolent organization. The main form of evidence, however, would have been on gravestones, and those had all disappeared from the exhumed burials at Pioneer Cemetery (with one possible exception, discussed below).

There are several archeological examples of unmarked African American burials linked to fraternal and sororital group in Texas. Feit and Trask (2013:153154, Figure 6-18) report that a small segment of glass chain was found with Burial 12, a 7-10-year old child, at the Montgomery Hill Cemetery in Navarro County, Texas. They suggest that it could represent the three-chain links symbolic of the Grand United Order of Odd Fellows (the African American branch of the International Order of Odd Fellows). They question why a child's burial would have a fraternal organization symbol, and suggest that the chain segment may have signified the breaking of the chains that bound the spirit to earth (as per Thompson 1983). But it is also possible that it symbolized an interment paid for with burial insurance obtained through the GUOOF.

A large number of burials have been excavated from the Waco First Street Cemetery, and most are believed to have been African Americans. The archeological reporting on the Waco First Street Cemetery burials has not been completed, but African American fraternal organizations are represented by ribbon badges found with four or five of the exhumed burials (Nesta Anderson, personal communication 2015). Ribbon badges are identified for the Court of Calanthe (Nesta Anderson, personal communication 2015) and for the Knights of Tabor (mentioned and

25 This amount appears to be in line with death benefit payments for other states, as noted by Du Bois (1907:110-111). In Alabama, the benefit was $\$ 100.00$ for persons dying in the first year, $\$ 200$ in the second year, $\$ 300$ in the third year, and \$500 thereafter. In Louisiana, each member's death benefit was $\$ 200$ or $\$ 300$, and the variance was probably linked to the amount of monthly dues a member paid. 
illustrated in letter posted on the FirstStreetCemetery.org website by Griggs 2008). At Houston's Third City Cemetery, Foster and Nance (2002:F-39) illustrate a coffin ornament with a probable fraternal symbol buried with a 25 - to $50+$-year-old adult male (Burial Feature 110). Membership in these organizations was clearly an important part of these people's lives.

The largest number of African American burials with archeological evidence of a fraternal or sororital affiliation is found at the Dallas Freedman's Cemetery. Davidson (2004:200-203, Table 4-9) reported 17 graves containing personal items and coffin hardware with group names or symbols, and Peter et al. (2000:432-435, 551) lists 18 burials. The diagnostic items include cuff links, lapel pins, ribbon badges, a small box, coffin plaques, and coffin handles from burials thought to date from ca. 1885 through 1907. The fraternal or union groups represented in these burials are: Ancient Order of United Workmen; Benevolent Independent Band of Kindred, Building Laborers International Protective Union; Grand United Order of Odd Fellows; Colored Knights of Pythias; Knights of Tabor and Daughters of the Tabernacle; Free and Accepted Masons, and unidentified ("I. O. N. I. C") (Davidson 2004:Table 4-9; Peter et al. 2000:432-435).

The archeological evidence of fraternity and sorority association found with exhumed historic graves in Texas includes markings on the burial containers (i.e., coffin hardware) and as personal items buried with the deceased. However, the most common way to identify prominent blacks who were members of specific groups was the outward display of the diagnostic organization symbols, initials, or names directly on a person's headstone. These symbols were intended to be visible to cemetery visitors long after the person was interred.

In his book Trouble in Mind: Black Southerners in the Age of Jim Crow, Litwack (1998:374) notes that forced segregation of African Americans in the Jim Crow era had one unintended benefit in that it presented new economic opportunities and allowed for the emergence of a strong middle class. Fraternal groups and benevolent aid societies were a direct outgrowth of this economic success. Litwack (1998:375) describes the significance of fraternal groups in African American society:

The social and organizational life of the black community revolved around the emerging middle class. Emulating white society but always exhibiting their own distinctiveness, fraternal, benevolent, and social clubs and organizations fostered race pride and provided the camaraderie and social interaction denied black men and women in the larger society. The rituals, titles, and uniforms that characterized the fraternal orders gave members a welcome respite from their daily routines and made them feel like somebody in a society that insisted they were nobody. Of practical value, the orders and benevolent societies put into practice a mutual self-help ideology that enabled their members to set aside modest savings that would cover the cost of burials and hospitalization and provide some support in hard times.

In a discussion of the importance of fraternal organizations and burial insurance in Dallas, Davidson (2004:171) notes that "Historically, the huge 
popularity of fraternal lodges among African-Americans was at least in part, due to the funeral benefits available upon the death of a member." Ever since Prince Hall formed Masonic African Lodge No. 459 in Boston in 1784, "beneficial" or "mutual aid" societies have been an important part of African American life. Those societies blossomed across the South after emancipation, and a big part of the motivation was to demonstrate "competence to a hostile white world, using their own symbols and customs" to gain acceptance and eventual equality (Davidson 2004:173). One of the most important benefits offered to members by most fraternal groups and benevolent societies was providing money to help the family when a key income earner died and to help to cover the cost of the funeral. This occurred in large part because national life insurance companies discriminated against African Americans by denying them coverage. This was justified, in part, by insurance company claims that the mortality rate of African Americans was higher than that of whites and that blacks lapsed in their premium payments more often, so insuring them was much riskier. When insurance companies did insure blacks, their policies cost the same as policies for whites, but their benefits were frequently less. For example, the Prudential Life Insurance company in 1881 "paid, on the death of the insured, exactly 1/3 less than for a white policy holder" (Davidson 2004:174). Insurance companies also used the budding fields of anthropology and statistics to argue that the "Negro race" was mentally and physically inferior, and that their overall health had been declining since emancipation.

In his classic book The Myth of the Negro Past, Herskovits (1941:200) describes the importance of burial insurance and mutual aid societies that offered burial insurance:

Burial insurance is usually the first to be taken out and the last to be relinquished when times grow hard. It is consider more important by the very poor than sickness or accident insurance, although the latter is becoming more popular. No Negro in Cottonville [pseudonym] can live content unless he is assured of a fine funeral when he dies. Fifteen cents a week and five cents extra for each member of the family will guarantee a hundred-dollar funeral, in which the company agent plays an active part. (Powdermaker 1939:122, quoted in Herskovits 1941)

There are certain expenses besides taxes which must be paid in cash. One of these is insurance. In the dilapidated shacks of undernourished families, whose very subsistence depends upon government relief, the insurance envelope is almost invariably to be seen hanging on the wall. Even when sickness and accident insurance are allowed to lapse, the burial insurance is kept up. (Powdermaker 1939:133, quoted in Herskovits 1941)

The tradition of the burial society hangs on in the mutual organizations which, though concerned chiefly with death benefits, build up and hold their membership on the strength of the social features. In a situation under which families were loosing such insurance as they had, the burial societies were gaining in strength. (Johnson 1934:183, quoted in Herskovits 1941) 
Speaking specifically of burial societies and mutual aid societies with burial benefits, Herskovits (1941:200) also notes: "Societies of this sort are ubiquitous among New World Negroes as the most widespread and institutionalized survivals of the African desire for proper burials."

Because many types of standard insurance coverage were largely denied to African Americans, mutual aid societies and fraternal organizations flourished after emancipation, and most of these groups offered some form of burial benefit. It is not surprising then, to regularly see headstones in African American cemeteries that are adorned with symbols that designate the deceased as a member of a specific fraternal groups or mutual aid societies. Of the 59 Pioneer Cemetery burials that have some type of grave marker (54 have markers with inscriptions; see Appendix F), 12 had grave markers indicating a group affiliation (Table 8.9). One man, John Shepard, served overseas during World War I with the 816 Pioneer Infantry. The 816 was one of 27 Pioneer Infantry regiments mobilized for the war, “...non-combatant black troops [who] worked as stevedores, dug trenches, graves, and latrines, and built hospitals, roads, bridges, and railroad lines" (Lefferts 2012:2). Excluding the soldier listed in the Grafton family memorial, the other 10 adults listed in Table 8.9 were affiliated with four fraternal organizations or women's auxiliary branches: the Eastern Star, the Freemasons, the International Order of Odd Fellows, and the Sisters of the Mysterious Ten. This means that 17 percent of the identified people at Pioneer Cemetery belonged to some fraternal group or benevolent society. If we exclude the 12 more recent burials (i.e., those dating from 1976 to 2000) and look only at the 47 older burials (i.e., those dating before 1948), this number jumps to 21 percent.

Table 8.9. Group affiliations of people buried at Pioneer Cemetery

\begin{tabular}{|c|c|c|c|c|c|c|}
\hline Full Name & $\begin{array}{l}\text { Birth } \\
\text { Year }\end{array}$ & \begin{tabular}{|c|} 
Death \\
Year
\end{tabular} & $\begin{array}{l}\text { Age at } \\
\text { Death }\end{array}$ & $\begin{array}{c}\text { Probable } \\
\text { Sex }\end{array}$ & $\begin{array}{c}\text { Recorded Information on Grave } \\
\text { Markers and Organization Symbols }\end{array}$ & Group Affiliation \\
\hline Grafton, U. L. & 1891 & 1899 & 8 & $\mathrm{U}$ & \multirow{5}{*}{$\begin{array}{l}\text { Five Graftons buried together with } \\
\text { one gravestone with a star emblem } \\
\text { (simple star with no elaboration, but } \\
\text { star orientation matches Eastern } \\
\text { Star symbols) }\end{array}$} & \multirow{5}{*}{$\begin{array}{l}\text { Order of the } \\
\text { Eastern Star* }\end{array}$} \\
\hline Grafton, Ida & 1870 & 1900 & 30 & $\mathrm{~F}$ & & \\
\hline Grafton, Virginia & 1875 & 1919 & 44 & $\mathrm{~F}$ & & \\
\hline Grafton, Florance & 1894 & 1920 & 26 & $\mathrm{~F}$ & & \\
\hline Grafton, Ruth & 1888 & 1923 & 35 & $\mathrm{~F}$ & & \\
\hline Davis, W. M. & 1877 & 1925 & 48 & $\mathrm{M}$ & I.O.O.F. symbol (three chain links) & $\begin{array}{l}\text { International Order } \\
\text { of Odd Fellows* }\end{array}$ \\
\hline Shepard, John & $?$ & 1935 & - & $\mathrm{M}$ & $\begin{array}{l}\text { U.S. military marble headstone, } \\
\text { Texas Pvt } 816 \text { Pioneer Inf. }\end{array}$ & U.S. Military** \\
\hline Spenser, Esther & 1865 & 1938 & 73 & $\mathrm{~F}$ & \begin{tabular}{|l|} 
Eastern Star emblem, \\
Chapter 35 \\
\end{tabular} & $\begin{array}{l}\text { Order of the } \\
\text { Eastern Star }\end{array}$ \\
\hline $\begin{array}{l}\text { Snow, Althea } \\
\text { Darthula }\end{array}$ & 1887 & 1942 & 55 & $\mathrm{~F}$ & $\begin{array}{l}\text { Probable Eastern Star emblem } \\
\text { (matches other Eastern Star } \\
\text { symbols) }\end{array}$ & $\begin{array}{l}\text { Order of the } \\
\text { Eastern Star* }\end{array}$ \\
\hline Thomas, Josephine & 1890 & 1942 & 52 & $\mathrm{~F}$ & Eastern Star emblem & $\begin{array}{l}\text { Order of the } \\
\text { Eastern Star }\end{array}$ \\
\hline Thomas, John P. & 1915 & 1943 & 28 & $\mathrm{M}$ & $\begin{array}{l}\text { Masonic emblem (square and } \\
\text { compass) }\end{array}$ & Freemason* \\
\hline T. ? & $?$ & $?$ & - & (F?) & $\begin{array}{l}\text { Broken stone with initial only, } \\
\text { M.S.T. emblem }\end{array}$ & $\begin{array}{l}\text { Probably S.M.T. for } \\
\text { the Sisters of the } \\
\text { Mysterious Ten }\end{array}$ \\
\hline
\end{tabular}

*Symbol confirmed using gravestone photographs on Find A Grave (2015).

** The 816 Pioneer Infantry was a Negro regiment in World War I. 
Davidson (2004:Table 4.2) used newspapers and undertaker's day books to compile a list of dozens of African American fraternal and sororital orders and lodges that operated in Dallas from 1876 to 1910. It is notable that this listing includes all of the groups represented among the Pioneer Cemetery graves: the Masons, the Eastern Star, the Odd Fellows, and the Sisters of the Mysterious Ten.

\section{Women's Roles in the Brazoria Community}

Many researchers have commented on the important roles that women played in the African American community. At Pioneer Cemetery 8 of the 12 people who had ties to social or benevolent groups were women (see Table 8.9). Within the Pioneer Cemetery burial sample, at least 5 of the 14 individuals were adult women. In addition, the most unusual burial artifacts belonged to the oldest female (Burial 15, discussed below), whose age at death is estimated at 30-40 years. It is likely that many of the adult women in the unmarked graves also belonged to some kind of formal social or civic group. Speaking about the importance of such groups among African American women, Glasrud (2008:109) writes:

Other important social and civic organizations were the Lodges. Woman and men joined the lodges for social and economic reasons. The lodge organizations performed three functions critical to the black community: social relaxation, civic improvement, and provision of insurance and death benefits. Lodges organized for black women included the Heroines of Jericho, Sisters of the Mysterious Ten, and the Household of Ruth. Two of the larger and more successful of the orders were the Female Masons, the Order of the Eastern Star; and the Grand Court, Order of the Calanthe.

Women also played an important role in church life. Sharpless (2008:91) states that of all the African American churches in the rural south in 1950, "Half of the congregations traced their beginnings to the thirty-five year period starting in 1865," and notes that "Women undoubtedly played a major role in creating and sustaining church organizations." She goes on to say (pp. 91-92):

Churches served as a base for women to address community needs. In the 1880 s and $1890 \mathrm{~s}$, churchwomen founded benevolent aid societies to nurse the sick and care for orphans and the aged...The African American churches also played an active role in fostering higher education in Texas...Another method of caring for one another and for society at large was through women's clubs. Although the largest number of women's clubs were created after 1900, some had roots in the nineteenth century. By 1901, the African American Easter Star order, one of the female auxiliaries of the Masons, had thirty-three chapters in Texas.

The first blacks were made Master Masons in 1775, but the Prince Hall Freemasons was organized specifically for blacks in 1784 (Taylor 2015). The Order of the Eastern Star is an offshoot of the Masons, with membership open to Masons and women related to Masons. Like the Freemasons, the Order of the Eastern Star had separate lodges for blacks and whites. The 1874, the first lodge for black women was founded, making the Order of the Eastern Star the "oldest sorority-based black 
women's organization in America" (African American Registry 2015). Like the Prince Hall Freemasons, the Prince Hall Order of the Eastern Star was particularly strong in Texas, and it is not surprising that it was also important in Brazoria.

\section{African American Mortuary Customs and Possible Spiritual Symbolism in Pioneer Cemetery}

In his book, Cemeteries and Gravemarkers: Voices of American Culture, Richard Meyer (1989) commented that "American cemetery and gravemarker study affords fascinating opportunities to observe different aspects of ethnicity through the material records of death left by various groups." Though this statement was made about aboveground mortuary evidence, it is equally true for the mortuary remains found belowground in archeological contexts. While the aboveground remains are visible and easier to study, they are easily altered through time and are often destroyed completely. In contrast, buried mortuary remains-items placed with the deceased or directly on top of the burial container-represent a snapshot at the time of the person's death, and this type of evidence has many distinct advantages over the aboveground remains. Davidson (2004:36, 280-285) refers to the placement of unusual objects inside the coffin or in the grave shaft as the "Core Elements of Spirituality." He notes that these elements are based on African beliefs that were brought to the New World and evolved over time.

The examination of ethnicity through burial excavation and material culture analysis is nothing new, of course, but the rapidly increasing number of bioarcheological African American cemeteries studies, in Texas and across the United States, are providing a robust database for broad comparisons of African American mortuary patterns. Because of the increase in scholarly attention to African-American ethnohistory and archeology, including of all kinds and ages of sites, it has become easier to make better informed interpretations of material culture. One important aspect of this recent scholarship is a focus on recognizing material culture patterns that reflect African-derived spiritual beliefs.

For the 14 burials exhumed from Pioneer Cemetery, almost all of the evidence of aboveground markings was lost (with one exception mentioned below) and only the belowground remains have been documented. Several of the Pioneer burials are of particular interest because they exhibit traits possibly representing mortuary behaviors of African origin that were retained by nineteenth-century freedmen. In these cases, specific mortuary traits may be generally representative of, but were not exclusive to, the African American community. These traits that may have hidden spiritual meanings and possibly serve as important social identifiers for African American culture. Five of the Pioneer burials displayed mortuary traits that were particularly notable: vaulted burials, a complete milk glass bottle, and a complete whiteware saucer and bird talon that was probably part of necklace.

\section{Toolbox Lid: An Informal Grave Marker?}

None of the archeologically discovered burials had any formal tombstones that we know of. It is possible that some of the graves had tombstones that were 
accidentally removed during the mechanical scraping. It is unlikely that any large stone markers were missed, but small markers and other surface markings could have been missed. If the stories of exhuming graves in the SH 332 roadway in 1939 are true, then it is likely that anything recognizable as a grave marker was moved at that time. ${ }^{26}$ But one unusual object found at Pioneer Cemetery may be a grave marker, although many people would not have recognized it as such. A metal toolbox lid was found at the head end of Burial 1 just above the coffin. Dismukes and Bettis (2002:11, 36) found Burial 1 in 1999, and they show a photograph of the grave shaft with the tool box lid in situ. They write that it was "perfectly aligned with the grave and may have served at one time as a marker for the grave" (Dismukes and Bettis 2002:Figure 25 caption). It is likely that this item served as an informal grave marker (Tiné and Boyd 2003:Figure 5.8).

The use of homemade and vernacular grave markers is common across the southern United States in what Jeane (1992:114) calls the "Upland South Folk Cemetery Complex." Jordan (1982:48) observes the same phenomenon in historic "Southern Folk Cemeteries" and across much of Texas. The use of homemade grave markers is especially common in African American cemeteries from the late-nineteenth and earlytwentieth centuries (Little 1989; Rotundo 1997; Vlach 1990), although it is certainly not an exclusive African American tradition. Jordan (1982:14) believes "the southern folk cemetery to be a cultural conglomerate, containing contributions from each of the three main cultures-African, Amerindian, and European—responsible for the development of southern society and folkways." Yet in historic African American cemeteries, it is particularly common to find homemade grave markers, the use of natural stones, and reuse of a wide variety of nonmortuary items (i.e., things other than headstones) to mark graves. Speaking specifically of North Carolina, Little (1989:106) notes a "striking distinction between white and black graveyards is in the design of individual markers. A majority of markers in rural black graveyards are homemade."

The use of vernacular grave markers was observed at the Juden Cemetery in Brazoria County, a burial ground for enslaved blacks and the freedmen community at the Levi Jordan Plantation. After an in-depth study of this graveyard, Bruner (1996:120) noted that a common trait after emancipation was "the re-use of Anglo-European artifacts, outside of their original functions, to serve as grave markers." The following vernacular grave markers were recorded by Bruner (1996:43-74) at Juden:

"A rectangular sheet of iron" (4x3 inches) Grave 10

"Two sheets of iron metal facing each other" (head and foot) Grave 19

"A torque converter to some form of automobile" Grave 46

"A sheet of iron metal" (4x5 inches) Grave 48

"An upright iron pipe (3-inch diameter; 1 inch above ground) Grave 112

"A small iron railroad tie" Graves 115, 116, 120

"A small flat metal arch" (4 inches tall, 6 inches wide) Grave 123

"A metal bar bent into the shape of an arch" (1.7 ft tall) Graves 138, 139

26 There is no definitive evidence that any graves were actually exhumed and moved to another cemetery in 1939. Although the topic has not been researched adequately, it is possible that only the headstones were removed and relocated. 
The toolbox lid associated with Burial 1 was most likely reused as grave marker. It is possible that this lid was from a toolbox owned and used by the person while living, but this seems less likely since the deceased was an adult woman. Although it was completely rusted when it found in the excavation, it is not certain if it was left unmodified or if it might have been painted with some type of inscription that disappeared as the item rusted.

The use of vernacular grave markers is quite evident at Pioneer Cemetery. A review of photographs of 33 formal grave markers there shows that 6 are simple cast concrete or natural stones with stamped or hand-carved inscriptions. ${ }^{27}$ These were undoubtedly handmade by family members, friends, or local craftsmen. Five of these six stones are associated with pre-1950 burials and the sixth one most likely predates 1950 as well:

- Moses Calvin Alexander (1896-1948), concrete with crude stamped inscription

- Millie Campbell (1888-1944), concrete with stamped inscription

- Texana Hobbs (1865-1937), rough red sandstone with hand-carved inscription

- Willie Hobbs (1870-?), death date is gone but the marker and inscription match that of Texana Hobbs

- Francis Scoby (1875-1936), concrete cross, with stamped inscription and painted white

- Esther Spenser (1865-1938), concrete with stamped inscription and Eastern Star

\section{Marine Shells with Burial 3}

At Pioneer Cemetery, one grave had marine shells associated. Two fragments of oyster shell and one complete shell valve were found with Burial 3, a 45- to 60-year-old female. These shells were found in the lower portion of the grave shaft fill, and they were probably placed on top of the casket rather than inside. The complete shell is a single valve that most closely matches the bivalve called a Ponderosa Ark, or Noetia (Eontia) ponderosa, a common type on the Texas gulf coast (see Chapter 4).

The use of oyster shells as surface decorations on graves is a common practice in West African burial traditions and across much of the southeastern United States (Downer 2015:32, Rainville 2009:73; Vlach 1990:143). In Texas, Jordan (1982:21-25) notes that shell-decorated graves are very common in the eastern part of the state in African American, Native American, and Anglo American graves. The practice is particularly common among African Americans, and probably represents a continuation of ancient west African beliefs. In some west African cultures, sunbleached shells represent "both the whiteness and watery character of death" (Jordan 1982:21). Other researchers suggest that seashells represent water and are linked to beliefs that "the spirit world is located underwater" (Downer 2015:32).

$\overline{27}$ As seen in photographs in the online Find A Grave database for Pioneer Cemetery. 
At the New York African Burial Ground, oyster and clam shells and shell fragments were frequently found in the grave shaft fill and on top of coffin lids (Perry et al. 2009b). In at least one case, a clam shell was buried with a young child, and researchers stated that:

Perhaps the shell was placed in the coffin by mourners for its association with water, to mark the ritual transformation of the child's status via an analogy between crossing through water and crossing from life to death. The use of shells in this manner is known from Africa and the African Diaspora. (Perry, Howson, and Bianco 2009:371)

In his discussion of vernacular grave decorations, Davidson (2004:284-294) notes that seashells are among the most common items placed on graves by African Americans in the southern states, and seashells are quite common on African American graves in Texas. Both freshwater mussel shells and seashells were common in the African American graves at the Freedman's Cemetery in Dallas.

\section{Grave Vaulting in Burials 7, 11, and 16}

Among the excavated Pioneer Cemetery burials, three had grave vaults ${ }^{28}$ in which the burial container was set inside a narrow shaft at the bottom of a wider shaft, and coffin or casket was protected by a layer of wooden planks placed horizontally over the narrow shaft (see Figures 4.1 and 4.2). The three burials that exhibit this trait are:

- Burial 7, an adult female 40-59 years old in a hexagonal coffin, estimated death date $1853-1903$

- Burial 11, a subadult of indeterminate sex in a rectangular casket, estimated death date 1878-1911

- Burial 16, an adult female 35-45 years old in a rectangular casket, estimated death date 1880-1900

Grave vaulting is a mortuary practice that was widespread across the South in the nineteenth and into the early-twentieth century, but it was not restricted to any particular ethnic group. Davidson (2012) has researched this mortuary trait extensively, and he believes that grave vaulting originated in African and was introduced to the southern United States by enslaved peoples, and it subsequently spread to other groups. Whatever its origins, the practice of grave vaulting in Texas was most common among African Americans but it also was practiced by AngloEuropeans. Table 8.10 lists cemeteries in Texas where archeological evidence of grave vaulting has been found. This list, which includes nine cemeteries, is an expanded and updated version of an earlier vaulting list compiled by Crow (2004:Table 3) that included five cemeteries.

At the Freedman's Cemetery in Dallas, Davidson (2004:239, Figure 4-8) demonstrates that vaulting was very common in the Early Period (66 percent of

28 In these discussions, the term "grave vault" is used to denote the horizontal platform of wooden planks placed over the casket. This type of burial feature is also called a grave arch (Bell 1994; Crissman 1994; Crow 2004). 


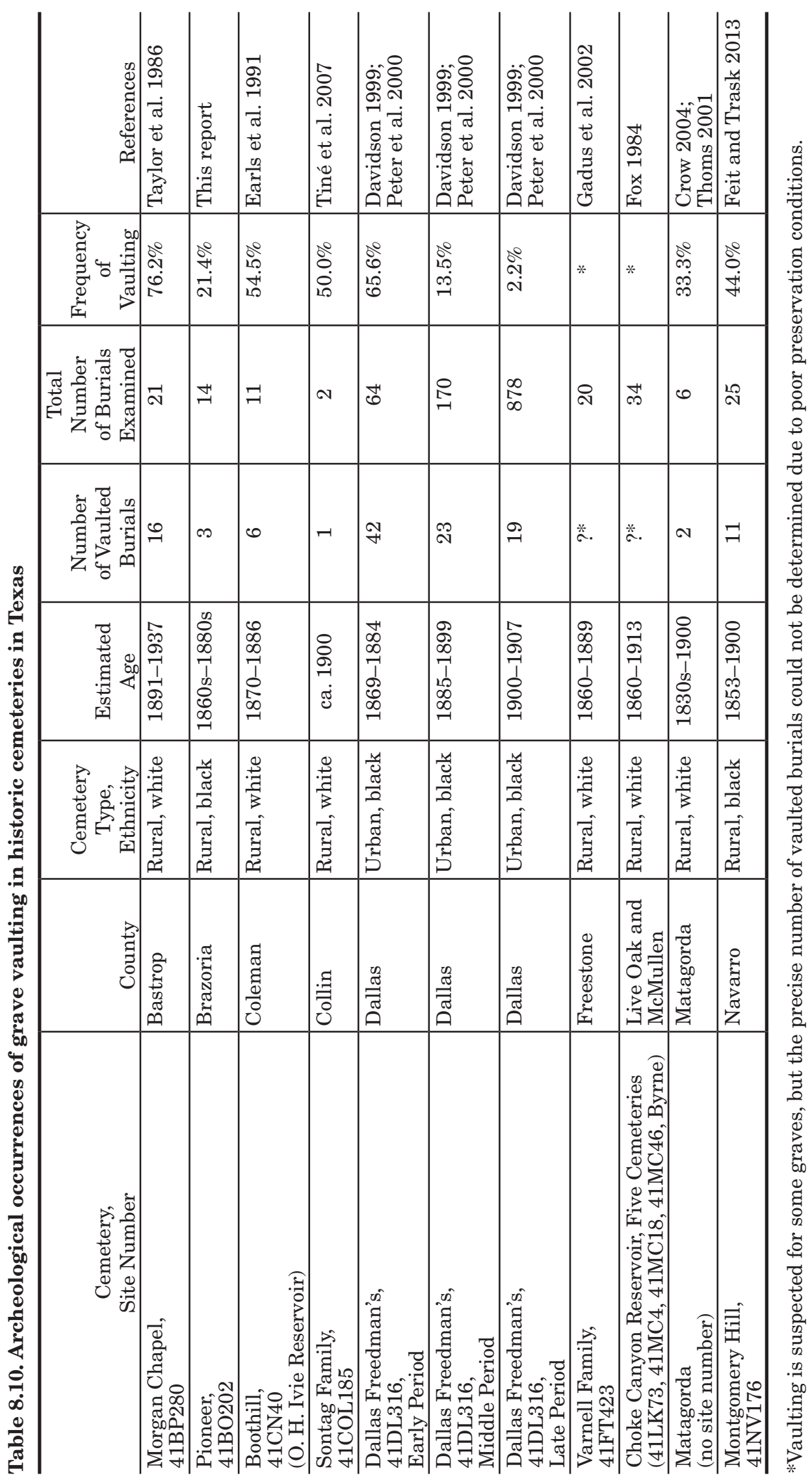


the burials dating from 1869-1884), present in the Middle Period (14 percent of the burials dating from 1885-1899), and rare in the Late Period (2 percent of the burials dating from 1900-1907). This suggests that burial vaulting declined rapidly in popularity in the last two decades of the nineteenth century.

\section{Milk Glass Bottle in Burial 8}

Burial 8 is the grave of a probable male, age 34 to 58 years old at death. A small complete glass bottle was found near the man's left arm, and was probably laying in this position when he was buried (see Chapters 4 and 6). The bottle is made white milk glass, and its body is ornately molded with a woven pattern of vertical and horizontal lines and an oval panel on one side (see Figure 6.6). It is likely that a paper label was once attached to the oval panel, and it would have identified the contents, presumably by brand name, and the company that made it. The bottle has not been identified, but it likely held some type of cosmetic product.

Exactly what significance this milk glass bottle had in this burial context is open to debate. It is assumed that the inclusion of this bottle in this man's grave was intentional, and there are many possible explanations for why it was placed in his coffin.

- The bottle belonged to the man and was an important personal item, perhaps kept and used for many years. Knowing of its importance to him in life, his family may have buried it with him purely for sentimental reasons.

- The bottle was one of the man's treasured possessions, so it was placed in the grave to keep his spirit from roaming in search of the item. In his classic treatise on Folk Beliefs of the Southern Negro, Puckett (1926:103) states that a man in Alabama told him, "Unless you bury a person's things with him he will come back after them." Thus, any objects that were placed in an African American grave, especially unusual ones, may have had special meaning in the sense that they were viewed as personal items connected to the person's spirit.

- The bottle's contents represented some cosmetic product that was important to the man, such as his favorite cologne.

- The bottle's contents may have had some symbolic or ritual significance. Perhaps it contained salt and was placed in the grave for spiritual, rather than practical, reasons. Although "salt has long been a protective agent in African American conjure" (Anderson 2002:262), this narrow-mouth bottle would not have been a good container for salt. Puckett (1926:104) notes that medicine bottles were commonly placed on African American graves, and they were often "turned upside down with the corks loosened so the medicine may soak the grave." Bruner (1996) comments on the common occurrence of complete glass bottles placed on African American graves.

- It was the milk glass itself, rather than the container or its contents, that was important. White milk containers and fragments are commonly associated with African American burials, in both aboveground and belowground contexts. This phenomenon warrants more consideration and is discussed below. 
White milk glass is often found in surface contexts at African American cemeteries. At Juden Cemetery in Brazoria County, Bruner (1996) conducted shallow test excavations specifically to look for surface grave offerings. He reports that two such grave tests yielded "milky white curved glass fragments" (Bruner 1996:81, 83), and in both cases they were found with other items, including other glass, ceramic sherds, or seashells. Aside from the object's possible significance as a container, its white color may have had ritual meaning as well (King 2010:128). In some West African traditions, the color white symbolized "purity, the world of the spirits, and the dead" (Downer 2015:32).

White milk glass objects have also been found inside African American graves. White milk glass containers were among the items recovered from on African American grave at the Freedman's Cemetery in Dallas. Davidson (2004:Tables 5.4, 5.6) lists a milk glass lid from some type of tableware, found along with pieces of broken whiteware vessels, on top of the coffin lid of Burial 358. Clow and Green (2002:456) comment on the association of cosmetic items with Freedman's Cemetery burials, and they state that recovered items include "numerous milk-glass powder or makeup containers."

\section{African Symbolism in Burial 15}

Burial 15 is the grave of a woman 30 to 40 years old at the time of her death. This individual was buried with two unusual items that warrant mention: a ceramic saucer and a decorated bird talon (see Chapters 4 and 6 and Figures 6.7 and 6.8). The saucer was found in the chest area, oriented with its top side upward (see Figure 6.1), and the bird talon was found near the woman's head. Although many of the smaller skeletal elements in Burial 15 were jumbled by repeated fluctuations of the water table, it is assumed that these items were found close to their original locations within the burial.

\section{WHITEWARE SAUCER}

The 6-inch-diameter saucer is undecorated whiteware that has a maker's mark (WOOD \& HAWTHORN, ENGLAND) indicates that it was manufactured between 1882 and 1887. As noted by cemetery archeologists, whole or partial ceramic vessels are relatively rare in historic graves (excluding Native American graves) in the Americas. Many of these finds are associated with African and African American graves.

Fremmer (1973) reports two colonial Jamaican burials that had ceramic vessels interred in the coffins. He notes that: "Extensive inquiries amongst Jamaicans have revealed that in isolated parts of the island where traditional customs survive, a dish containing a mixture of freshly ground coffee and salt is laid on the stomach of the corpse and remains there throughout the wake and burial" (p. 61). He believes the burials to be of British origin, but acknowledges that this particular trait could be related to African or British funerary rituals.

Ceramic plates were found in graves at the 8th Street First African Baptist Church Cemeteries in Philadelphia. McCarthy (1997:374) states that “...two burials 
contained ceramic plates that were placed on the stomach of the deceased..." One plate was blue-edge decorated pearlware, and the other was Chinese hand-painted porcelain. The burials were excavated from the church cemetery at 8th and Vine Streets, which contained graves dating from 1825 to 1842 . McCarthy also notes other occurrences of ceramics with an early historic English grave in Jamaica (stoneware saucer and plate), an enslaved African grave in Barbados (redware bowl), and the grave of a woman of unknown race from Alexandria, Virginia (ironstone plate). But for the First African Baptist Church Cemetery, McCarthy argues that the plates found in two graves represent mortuary beliefs that were brought to the New World from Africa.

Thompson (1983:134-135) and Jamieson (1995:50) note that items placed on African American graves could have many different meanings, and the same is undoubtedly true for items placed inside a grave. Items may have been a person's favorite possessions or the last objects used by the deceased. Other items may have had symbolic meaning (such as white milk glass representing purity and seashells representing the underwater spirit world) or practical purposes associated with a particular world cosmology (such as objects intended to placate spirits and keep them from wandering).

We can never know why the small saucer was placed in the grave with of the woman in Burial 15, but there are several possibilities. In Ireland and England, ceramic vessels containing salt were placed in graves to "control odor and/or bloating" (McCarthy 1997:375) and plates might have been placed in graves "for use in the afterlife" (p. 376) as was practiced by many cultures. However, it is quite possible that the saucer with Burial 15 had symbolic or spiritual meaning reflecting African beliefs that were retained by enslaved and freed African Americans. Jamieson (1995:51) notes that items that were pure white, especially ceramics, seashells, and pebbles, also had special meaning among African Americans. Jamieson (1995:50) also noted that "[t]he practice of placing the last article used by the deceased on the grave was recorded in Georgia in 1850" (as cited by Thompson 1983:184), and the saucer in Burial 15 could be such an item. McCarthy (1997:376) notes that "[t]he burial of the plate last used by the deceased may also have been meant to prevent the deceased spirit from harming the living in that, in parts of the South and Africa, the 'energy' or 'essence' of the dead was believed to be embodied in objects last used by the deceased. Whether accidental or deliberate, the presence of the plates on the stomach of the deceased may be associated with African-influenced or creolized practices." At the Society for Historical Archaeology meeting in 1998, McCarthy (1998) presented a short paper called "Plates in Graves: An Africanism?" which was then published in the African Diaspora Newsletter. He asks: "Is a plate in a grave an Africanism? Maybe, or maybe not." But he also notes how strongly this trait is linked to African American burials, and cites these examples, some of which are mentioned above (McCarthy 1998:n.p.):

- "Saucers have been recovered from four post-bellum African-American graves in the southern United States (Cabak and Wilson 1998)"

- "A white salt-glazed stoneware saucer and a feather-edged creamware plate 
were reported recovered from two separate eighteenth-century English graves in Jamaica (Fremmer 1973)"

- "A shallow redware bowl was found in the grave of an enslaved African at the Newton Cemetery in Barbados (Handler and Lange 1978:137)"

- “...an ironstone plate was recovered from the grave of a poorly preserved female of indeterminate race at the Quaker Cemetery in Alexandria, Virginia."

A complete decal-decorated whiteware saucer was found in a burial in rural Arkansas. As reported by Rose (1985:94-96, Figure 76), this saucer is associated with Burial 70, a female age 50 or older. It was found “under the left pelvis," (p. 96), but its true context is uncertain because many of the bones were disarticulated and jumbled, so it could have been placed on top of, rather than inside, the coffin. The vessel has no maker's mark, but a 1897 Liberty nickel was also found in the grave. The archeologists speculate that this burial dates between 1897 and 1927 . Rose (1985:96) speculates that the saucer: (1) may have held salt to "keep out evil spirits" or "keep the stomach from bloating;" or (2) may have been used during the woman's last illness, and "was placed on the grave to keep the deceased from returning" (p. 96).

Ceramic vessels have also been found inside or on top of burial containers in Texas. Whole ceramic vessels are associated with seven exhumed graves at the Dallas Freedman Cemetery, including two in the Middle Period (1885-1899) and five in the Late Period (1900-1907) (Davidson 2004:339-345, Tables 5-2, 5-4, and $5-11$. No ceramic vessels were found in Early Period (1869-1884) burials or with the broadly classified pre-1900 (1869-1899) burials. The summary information below is taken from Davidson (2004:Tables 5-2 and 5-4) with additional information on the ceramic maker's marks and dates from Peter et al. (2000:429):

\section{Middle Period}

- Burial 422, adult female and subadult. A whiteware saucer (or bowl) was found underneath the right femur. It had a "CHARLES MEAKIN" and royal crest maker's mark and dates between 1870 and 1882 .

- Burial 1034, adult, probable male. A shallow ironstone bowl with a marking of "G.P. / Co." This mark is from the Greenwood Pottery of Trenton, New Jersey, which operated between 1868 and 1933; this mark may date around 1904.

Late Period

- Burial 326, adult, probable female. A miniature ceramic teapot was found on the coffin lid.

- Burial 358, adult, indeterminate sex. Two broken whiteware vessels, a mustache cup and a vase, were found on the coffin lid.

- Burial 423, adult male. A ceramic ironstone bowl found on top of the pelvis. It bears the markings "IRONSTONE CHINA / J \& G MEAKIN / HANLEY / ENGLAND” and dates after 1851. 
- Burial 909, subadult female. A whiteware saucer was found on the coffin lid. Its markings of "DORIC" and "J. H. DAVIS" link it to an English pottery and date it from 1881 to 1891 .

- Burial 1126, adult male. A broken plate fragment was found on the coffin lid.

Of these seven examples, six appear to have been buried with complete vessels, and only one burial had a "broken" vessel.

Ceramic vessels were also found in African American burials at two other African American cemeteries in Texas: the Third New City Cemetery in Houston and the New Home Cemetery in Fort Bend County. At Third New City Cemetery (41HR886 at the Allens Parkway Village), Foster and Nance (2002:156-157, Tables 29,31 ) report that two burials had complete ceramic vessels associated with them. An adult female (Burial Feature 233) had brown transfer-printed whiteware bowl with an English maker's mark (J. H. W. \& SONS, HANLEY, ENGLAND) dating between 1891 and 1920 (illustrated on pages G-53-G-54). It was buried near the woman's left knee. Another adult female (Burial Feature 349) had a plain whiteware bowl with no markings (illustrated on p. G-66) found under the woman's right hand. The investigators speculated that these were items used by the individuals just before they died. At the New Home Cemetery (Hill and Pye 2012:43, Figure 21) a whiteware saucer was found with a young adult, probably male (Burial 8). The saucer is complete and has a base mark- "MADE IN GERMANY"- that probably indicates manufacture after the 1890 passage of the McKinley Tariff Act, which required articles of foreign manufacture be labeled with the country of their origin. Unfortunately, this burial had been badly disturbed. Although this saucer was found in close proximity to a partial set of skeletal remains, the contextual relationship between the saucer and the burial is unclear.

In his discussion of the Freedman's Cemetery, Davidson (2004:Table 5-11) mentions ceramic saucers found buried with five other African Americans in various southern states:

- A white ironstone saucer with an adolescent male (Burial 2) at the Redfield Cemetery in Georgia

- A white ironstone saucer with a young adult female (Burial 4) at Ridley Cemetery in Tennessee

- A white porcelain saucer with an older adult female (Burial 7) at Elko Switch Cemetery in Alabama

- A decal-decorated whiteware saucer with an older adult female (Burial 70) at Cedar Grove Cemetery in Arkansas

- A white ironstone saucer with an unspecified age and sex individual at the Sandy Creek Cemetery in Georgia

In a later article, Davidson (2010:615-616) states that household ceramics and medicine bottles found in African American burials are among the items he considers to be "Core Elements of Spirituality." Rather than being treasured 
personal items, he believes these objects were important because they were somehow associated with the spirit of the deceased and were most likely related to the "moment of death" (e.g., containing the last medicine used, or last meal before death).

While most documented occurrences of complete ceramic vessels in historic graves are associated with African Americans, there are well-documented cases involving Anglo or Euro-American burials. One such case is Burial 749, an adult woman, buried in the Third Street Cemetery in Dubuque, Iowa (Lillie and Mack 2013:162-163, 227, 619-620, Figures 8.23 and 10.9). This late-nineteenth-century burial included a complete whiteware plate, a British-made ware manufactured after 1851, found next to the woman's left arm (Figures 8.23 and 10.9, Table D.6). An infant in the same cemetery was buried with a silver-plated metal plate near the shoulder of the coffin. The archeologists speculate that it was a Communion paten (a plate associated with Catholic Communion rites) and that the ceramic plate buried with the woman may have functioned in a similar manner (Lillie and Mack 2013:447-448, 619, Table D.6).

From the discussions above, one may conclude that placing ceramic bowls, saucers, and plates in and on coffins is not an exclusively African American trait, but it is much more common among African Americans than any other group in America, excluding Native Americans. The trait is common across a wide geographic area and is well represented in African American cemeteries in Texas.

\section{DECORATED BIRD TALON}

The decorated bird talon from Burial 15 appears to be a unique occurrence among excavated African American graves in Texas. This item was found near the head of the deceased, an adult female, and was likely suspended on a necklace. To the author's knowledge, nothing quite like this has been found with any historic grave in Texas, and it is possible that this find represents some type of Africanderived spiritual belief.

Some ethnohistoric evidence indicates that a bird talon should not be totally unexpected in a historic African American grave. Puckett (1926:481-491, 508-511) describes the significance of various birds, domestic and wild, in African American spiritual beliefs. Birds could be messengers of good or bad omens, predict the weather, or affect people's lives in many ways. In a discussion of charms and amulets, he noted one case in which "The red foot of a jay bird kept on a person is said to achieve the same result" as a silver coin tied around the leg or worn as a necklace (Puckett 1926:314). Thus, a bird foot or a talon could have served as a charm, being suspended as necklace or contained within a charm bag worn as a necklace.

At the Montgomery Hill African American cemetery in Navarro County, Texas, Burial 21 was found with an animal (probably pig) incisor (Feit and Trask 2013:117-118, Figure 6-11). It was found near the upper right humerus, and it was had cut notches suggesting it was worn as a necklace. The individual was buried in a rectangular casket, and the grave probably had a vaulted cover. The archeologists interpreted this necklace as an African retention and noted that similar necklaces 
were found with African burials in Barbados that were 100 years older than Burial 21 (Feit and Trask 2013:146).

\section{Arrangement and Orientation of Unmarked Graves}

The orientation of the unmarked graves found at Pioneer Cemetery meets with the expectations for African American graveyards (see Figure 3.1). As is true of southern folk cemeteries, the individual graves are oriented generally east to west (head to west, feet to east), but the spatial relationships between the graves appear to be rather haphazard. Jordan (1982:30) notes that within southern folk cemeteries:

Graves are often strewn about in a rather disorderly manner, in staggered rows, separate clusters, and freestanding sites. In places, the choice of location for burial seems to have been almost purely random. Chaos is most apparent in black graveyards, but southern whites share in great measure this affinity for spatial disorder.

This trait, noted for black cemeteries across the South, faded away in first half of the twentieth century. In North Carolina, Little (1989:106) observes that “... black graves are not aligned parallel with each other or in rows as are white graves. Families are loosely grouped, but the placement of individual graves within the family grouping has no established order, so that the rhythm of the overall design is irregular and strongly individualistic." It is likely that some of the tight clusters of unmarked graves found at Pioneer Cemetery (see Figures 3.1 and 8.5) probably represent family groups, although this could only be proven with DNA evidence demonstrating blood relationships.

\section{PROTECTING LOST AFRICAN AMERICAN GRAVES}

At Pioneer Cemetery in Brazoria, unmarked graves were found where none were expected, and circumstantial evidence suggests that there may be many unmarked graves in the currently defined cemetery area and to the north, east, and south of those boundaries. This situation appears to be the norm for historic African American graveyards in Texas and throughout the South. There is little doubt that large numbers of African American graves have become forgotten over time and in many places. On occasion, entire cemeteries have become lost, though it is much more common for individual grave locations within known African American cemeteries or the African American sections of mixed-race cemeteries to be lost. These graves become lost in the physical sense when no living people know of their locations or know that they exist at all. They are also lost to communities when no one cares enough to seek out the people who remember these places. Cemeteries and graves also become lost in the documentary sense when written records of their existence disappear, if they ever existed at all. Even when such records do exist, they may be obscure and difficult to find, so no one bothers to search for, compile, or interpret them.

This loss of African American graves and cemeteries is a very real problem. Nedra Lee (2009:viii) called this phenomenon the "marginalization of African American cemeteries in the physical and social landscape of Texas." In conjunction

with her oral history research on one African American cemetery in Texas, Lee 
(2009:viii) examined "the historical processes and racial ideologies which facilitate this" and result "in the 'forgetting' of African American cemeteries in the preservation and written documentation of state and local histories." Concerted research efforts are needed to find, document, and protect the many African American burial grounds scattered across the eastern half of Texas, or they will continue to be impacted by modern development and be lost forever. Within this preservation dialogue, it is important to remember that most people care deeply about cemeteries, more than any other type of historical resource. In this book about the cultural legacy of Texas cemeteries, Terry Jordan (1982:1) states it most succinctly: "Graveyards, I have learned, are not primarily for the dead, but for the living." For African Americans, cemeteries are one of the few tangible remnants that represent their lives and undocumented contributions to the history of Texas. 


\title{
CHAPTER 9: REINTERMENT AND FINAL THOUGHTS ON PIONEER CEMETERY AND AFRICAN DIASPORA STUDIES
}

\author{
Aaron R. Norment and Douglas K. Boyd
}

The realm of the dead does truly have an impact on the living. —John Michael Vlach, 1990

In October-November 2008 and January 2009, 11 historic graves were discovered and exhumed as part of an archeological investigation in conjunction with the expansion of State Highway 332. As reported here, these unmarked graves likely contained the remains African Americans who had died in the late-nineteenth and early-twentieth centuries. Osteological analyses identified the deceased as 3 women, 2 men, 2 indeterminate adults, and 4 children. They had been buried on the western side of Pioneer Cemetery long before there was any road in this location, and their gravesites were most likely marked at the time of burial. Over time, however, the grave markers became lost and the burial locations were forgotten. These graves were then covered over when SH 332 was built in 1939 (Dismukes and Bettis 2002:Appendixes A and C; Tiné and Boyd 2003:Table 2.1).

In the late 1990s, with a growing population and expanding traffic in Brazoria County, the Texas Department of Transportation proposed to widen the road and replace the bridge. During the survey conducted for this project, archeologists discovered these graves. The 11 burials reported herein were exhumed and examined following all applicable state laws. The burial remains were reinterred to a safe place within the current borders of Pioneer Cemetery. ${ }^{29}$

\section{PIONEER CEMETERY REINTERMENT}

\section{Historic Cemetery Archeology and Burial Reinterments}

Until recently, funeral homes and morticians supervised burial relocations, which were done primarily using excavating machines and laborers. But in the early 1980s in Texas, archeologists started getting involved in historic grave excavations and cemetery relocations. The earliest archeological cemetery relocations in Texas, which occurred in the 1980s, are listed in Table 9.1. All of these investigations involved analysis and reporting of the human skeletal remains, personal items, and mortuary remains (burial containers and hardware). In these early cases, the morticians generally handled the reburials with little or no involvement of the archeologists. In the years since 1990, many more archeological cemetery

29 A few human bones were found and designated as Burial 18, but these were later determined to be displaced remains from Burial 3 that had been exhumed and reburied in 2003. These remains were reinterred with the others in September 2012, bringing the total number of reinterments to 11 complete and 1 partial. 
investigations have occurred in Texas, and archeological researchers have become increasingly involved in direct interactions with the descendant community in conjunction with cemetery relocation and preservation projects (e.g., Feit and Trask 2013; Lee 2009; Lee and Bruseth 2008; Peter et al. 2000; Powell 1998; Thoms 2001). In the past two decades, archeologists have taken over many aspects of the exhumation and relocation process, from assisting in obtaining preexcavation court orders and disinterment permits to planning and participating in reinterment ceremonies (e.g., Anderson et al. 2011; Boyd et al. 2014; Dockall, Powell, and Steele 1996; Tiné and Boyd 2003; McWilliams et al. 2014).

Table 9.1. 1980s archeological cemetery relocation projects in Texas

\begin{tabular}{l|c|l}
\hline \multicolumn{1}{c|}{ Cemetery Name, County, and Site Number } & Year of Cemetery Excavation & \multicolumn{1}{|c}{ Reference } \\
\hline $\begin{array}{l}\text { Laredo Cemetery } \\
\text { Webb County } \\
\text { (41WB22) }\end{array}$ & 1980 & McReynolds (1981) \\
\hline $\begin{array}{l}\text { Five Cemeteries at Choke Canyon Reservoir } \\
\text { Live Oak and McMullen Counties } \\
\text { (Johnson, 41KL73; Morris/Taylor, 41MC6; } \\
\text { Morgan, 41MC4; Yarbrough Bend, 41MC18; }\end{array}$ & $1981-1982$ & Fox (1984) \\
Byrne, 41MC66) & & \\
\hline $\begin{array}{l}\text { Morgan Chapel Cemetery } \\
\text { Bastrop County } \\
\text { (41BP200) }\end{array}$ & 1984 & Taylor et al. (1986) \\
\hline $\begin{array}{l}\text { Two Cemeteries at Cooper Lake } \\
\text { Delta County } \\
\text { (Tucker, 41DT104; Sinclair, 41DT105) }\end{array}$ & 1986 & Winchell et al. (1992) \\
\hline $\begin{array}{l}\text { Ferris Cemetery } \\
\text { Dallas County } \\
\text { (no site number) }\end{array}$ & Pre-1986 & $\begin{array}{l}\text { Bruseth and Lebo (1986), } \\
\text { as cited in Lebo (1988:5) }\end{array}$ \\
$\begin{array}{l}\text { Three Cemeteries at O. H. Ivie Reservoir } \\
\text { Coleman, Concho, and Runnels Counties } \\
\text { (Boothill, 41CN40; Coffee, 41CC81; Gann, } \\
\text { 41CC114) }\end{array}$ & 1989 & Earls et al. (1991) \\
\hline
\end{tabular}

Historic cemetery archeology has evolved over the years as changes have been made to the state's cemetery laws and as new and innovative bioarcheological research methods have been developed. A growing body of comparative data from excavated burials has increased our knowledge of historic mortuary material culture. In addition, modern cemetery investigations often include advanced technical studies such as DNA analysis to link historic remains with living persons (e.g., Kalter et al. 2005; McWilliams et al. 2014).

Current cemetery laws in Texas allow for exhumation and reinterment of graves to occur within the same cemetery without a court order or a disinterment permit from the Texas Department of State Health Services. This was the case for the Pioneer Cemetery Project: all of the graves were moved from one plot to another 
within the cemetery with permission of the local cemetery association. From a legal standpoint, a cemetery may move remains from one plot to another without notifying the next of kin, but common courtesy demands that such notifications be made when the identities of the deceased are known. At Pioneer, since all of the graves that were exhumed were unmarked, no next of kin could be identified. In such cases, the cemetery association speaks on behalf of the deceased.

\section{Reburial Planning and Plot Preparation}

It is important that grave excavations and burial relocation activities be handled as sensitively as possible, with public and descendant community input. Most of the people buried in Pioneer Cemetery are African Americans, including most or all of the 11 individuals recovered from under the roadway. Consequently, it was important to involve members of the local African American community in the reinterment, as was done for 3 unidentified people whose remains were exhumed from Pioneer Cemetery and reinterred there in 2003 (Tiné and Boyd 2003:9-61).

Planning for the reinterment began soon after the exhumation of the 11 burials in 2008-2009. The original plan was to conduct the reburial in March 2012 , but it was postponed due to heavy spring rains. This made it impossible for heavy machinery to enter Pioneer Cemetery to conduct excavations to find a suitable reburial plot without causing unnecessary damage to the landscape. Once the weather cleared, the reburial was rescheduled for September 2012. In the months before the event, preparations began in earnest. The effort was coordinated by TxDOT and PAI personnel, assisted by the City of Brazoria (city manager Teresa Borders and mayor Ken Corley), the Texas Historical Cemetery Guardianship Association, ${ }^{30}$ the Pioneer Cemetery Association, and local African American churches and clergy.

Following the grave excavations, all of the human remains and associated materials were placed in individual wooded reburial boxes and stored at the PAI laboratory in Austin. On September 10, 2012, PAI personnel transported the remains from Austin to Brazoria. On September 11, PAI and TxDOT personnel used a backhoe to find a suitable reburial plot inside Pioneer Cemetery. The new grave was located just east of the 2003 reburial plot, and near the rebuilt highway, but safely behind the cemetery's west fence.

\section{Reinterment Ceremony}

All of the burial remains associated with the 11 unidentified individuals were reinterred in a new location in Pioneer Cemetery during a ceremony that took place on September 12, 2012. Early that morning, the burial boxes were placed into the $6 \mathrm{x} 8$-ft excavation. The burial containers were covered with linen, and three lantanas were placed on top. People then began arriving for the ceremony.

$\overline{30}$ According to the their website, the Texas Historical Cemetery Guardianship Association (2015) is a nonprofit organization dedicated to helping "document, preserve, and maintain the cemeteries of Brazoria County." 
The memorial service began at 10 A.M. and was attended by the following people:

Clergy

Bishop Ricky Jones and wife, Jana

Reverend Lonnie Dews (St. Paul Baptist Church)

Minister Albert Thompson

Prewitt and Associates, Inc., archeologists:

Jennifer McWilliams

Aaron Norment

Texas Department of Transportation representatives

Mike Christley (retired)

Don Guidry

Mike McGuire

Eliza Paul

Grady Mapes

Michelle Milliard

Texas Historical Cemetery Guardianship Association

Bobby Koenning

Billy Koenning

Nancy Howard

Edward Wilson

Howard Gaul, president

The simple service was conducted by local African American clergymen, with opening remarks by Bishop Ricky Jones and a closing prayer by Minister Albert Thompson. Following the ceremony, two of the lantanas were planted on either side of the plaque marking the 2003 reburial. Four temporary rebar stakes were placed in the ground marking the corners of the reinterment grave.

\section{Marking the Reburial Plot}

Following the reburial, local TxDOT officials conducted the follow-up work to properly mark the reburial gravesite. First, the temporary rebar stakes at the new gravesite were replaced with a permanent galvanized steel post at each corner of the reburial plot. Second, a black granite marker was created and installed at the reinterment gravesite (Figure 9.1). Set in concrete and lying flush with the ground, the marker recognizes these 11 individuals ${ }^{31}$ with the following statement:

On September 12, 2012,
THE
TEXAS DEPARTMENT
OF TRANSPORTATION
Relocated the remains
of eleven
unidentified individuals
from the State Right-of-Way
to this location within
PIONEER CEMETERY

$\overline{31}$ Besides the 11 complete burials that were reinterred, a few remains from one other grave (Burial 3) excavated in 2003 were also reinterred at the same time. 

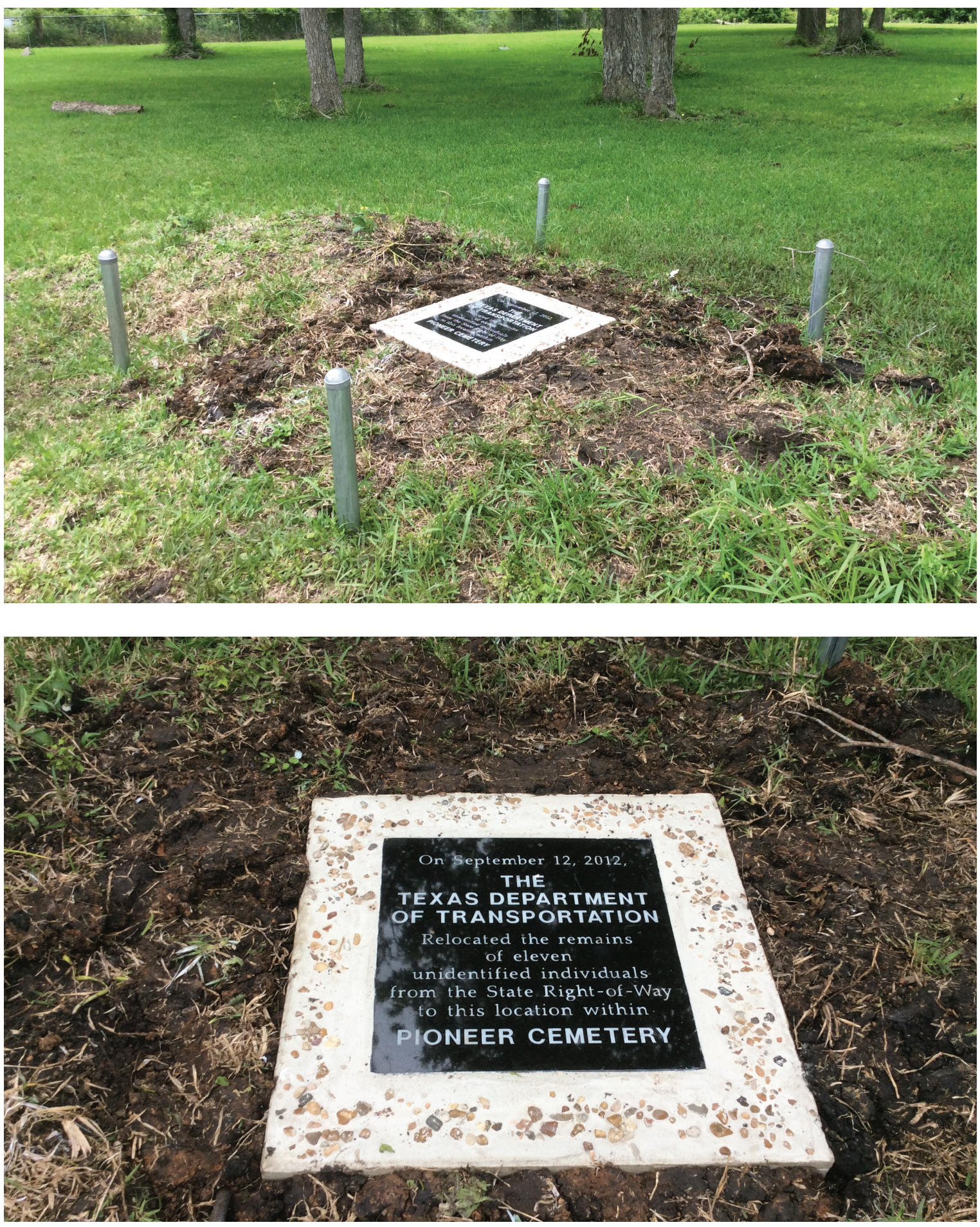

Figure 9.1. Photographs of the reinterment gravesite and newly installed marker. (a) Overview of the reinterment gravesite looking east, with Camp Street and the railroad tracks in the background; (b) closeup of the reinterment grave marker. 


\section{After the Reburial}

In conducting these grave excavations, analyses of burial remains, and the reburial ceremony, PAI and TxDOT made every effort to ensure that all the unmarked graves were found and that proper respect was given to the deceased whose remains were exhumed and reinterred. Having rested silently in unmarked graves under a roadway for over 60 years before being rediscovered, the remains of these unknown people have now been moved to their final resting place. A small portion of their story may now be told through the bioarcheological documentation of their remains.

\section{PIONEER CEMETERY AND AFRICAN AMERICAN BURIAL RESEARCH}

In his article "Some Thoughts on the Past, Present, and Future of the Archaeology of the African Diaspora," McKee (1998) argued that historical archeologists must conduct research that is relevant to modern African Americans. This was one of the stated goals of the Pioneer Cemetery investigations (Prewitt and Associates, Inc. 2011). Bioarcheological analyses of historic graves provide unique kinds of evidence that can have profound meaning to modern African Americans, as has been amply demonstrated in the New York African Burial Ground project (Perry 2009; Perry Howson, and Bianco 2009). There is no doubt that the New York African Burial Ground was a sacred place for the enslaved community at the time, but it is equally true that since its rediscovery this ancient burial ground took on a new role as a sacred place for modern African Americans. In 1993, the African Burial Ground was designated a New York City Landmark and National Historic Landmark, and the excavated portion of the burial ground was designated a National Monument in 2006 (Statistical Research, Inc. 2009:161).

In his short treatise on African American graveyard decoration, Vlach (1990:139) observed that "the values and behaviors associated with death are so strongly felt that they manage to survive the pressures of social crises and perhaps serve as a source of ethnic identity and strength. The realm of the dead does truly have an impact on the living." This statement sums up why we do historic cemetery archeology and underscores the fact that archeology can and should be relevant to living people. For the Pioneer Cemetery project, the significance is that the bioarcheological research gives voice to a group of people whose individual stories are lost. We can never know what trials and tribulations they faced in life, but it is clear that some of these people made a final expression of their culture and heritage through their individual burial rites.

For the 14 Pioneer Cemetery burials that were archeologically investigated and are reported herein, it is likely that many types of offering were placed on their grave mounds when they died and probably for years afterwards. Because the ground surface around these graves was disturbed some seven decades ago when SH 332 was first built, any offerings made by friends and relatives-and the meanings those items would have had-have been lost. But historic cemetery archeology has taught us that material remains buried with the dead have just as much cultural 
meaning and symbolism as gravestones and other surface manifestations. Our ability to interpret belowground mortuary evidence, within the historical and cultural contexts of the social groups involved, is enhanced via the rapid growth in historic cemetery bioarcheological data.

The "peculiar institution" of slavery ${ }^{32}$ left behind a legacy of racism that still lingers today, in Texas and across the United States. One aspect of that legacy is that few people cared about or bothered to document the reality of life for African Americans during slavery and after emancipation until many years after the fact. The virtual absence of meaningful contemporary documentation means that we must reconstruct historical African American life and communities as best we can using many types of evidence. The meager historical records are important, to be sure, but the material remains also must be discovered and examined archeologically. Historic cemeteries and graves represent one type of archeological resource that can contribute unique evidence to African Diaspora studies. Vlach (1991:109) noted that the African American cemetery "has long had special significance. Beyond its association with the fear and awe of death, which all humans share, the graveyard was, in the past, one of the few places in American where overt black identity could be asserted and maintained." Consequently, black graveyards are one of the best places to discover African American identity.

The Pioneer Cemetery project contributes new material culture and mortuary evidence relevant to African Diaspora research. When viewed in a broader historical context, the archeological findings, despite being based on a small burial population, increase our understanding of late-nineteenth- and early-twentieth-century African American life in Brazoria County. The bioarcheological evidence shows that these individuals were among the many hardworking African Americans who lived along the Texas Gulf Coast during the Jim Crow era. These people left behind little or no written record to document their existence, but their mortuary remains can shed light on many aspects of their lives.

It is regrettable that one research avenue could not be pursued for the Pioneer Cemetery project: DNA studies to try to identify African origins of the burial population. DNA work was suggested as a means of obtaining definitive sex determinations and as a way to look at the biological affinity and African ancestry of each individual within the burial population (Prewitt and Associates, Inc. 2011). ${ }^{33}$ One of the most comprehensive archeological DNA studies on human skeletal remains was conducted for the New York African Burial Ground project. In the 1990s, burials of over 400 seventeenth- and eighteenth-century enslaved and free African Americans were exhumed. The work resulted in many volumes of archeology, history, and skeletal biology reports and articles (e.g., Blakey 2001; Blakey and Rankin-Hill 2009a, 2009b; Medford 2009; National Park Service n.d.; New York African Burial Ground Project 2009; Perry et al. 2009a, 2009b; Statistical Research, Inc. 2009). As part of the project, the research team conducted a series of DNA genetic studies that were quite successful. They compared the historic burial DNA with the modern DNA databank for African countries (Jackson et al.

$\overline{32}$ This term was first used by historians Kenneth M. Stampp (1956) and Randolph B. Campbell (1989).

${ }_{33}$ DNA studies were recommended for the Pioneer Cemetery burials in a final analysis work plan from September 2011, but the skeletal sampling and DNA studies were later removed from the final scope of work. 
2009:85-92), and these data support many important interpretations about the burial population. The results were encouraging enough that the research team has continued the genetic studies (Jackson et al. 2009:92-93; National Park Service n.d.:52-53, 63).

The New York African Burial Ground Project raised people's awareness of the interpretive potential of DNA within African Diaspora research. It has led to more genetic research, including a recent study of three slave burials dating between 1660 and 1688 and found on the Caribbean island of Saint Martin. This effort incorporated new extraction techniques to collect minute amounts of nuclear and mitochondrial DNA from poorly preserved bones, and the ancient DNA samples were compared with genetic materials from 11 modern West African populations. The study found that one of the enslaved men probably came from a Bantu-speaking group in northern Cameroon, while another man and a woman were probably non-Bantu speakers from Nigeria or Ghana. The researchers concluded that "The idea that you can trace recent historical events by integrating ancient genomics and modern genomics is really exciting...It sets the stage for what can be done in the future" (Sarah Tishkoff as quoted in Wade 2015).

Many researchers believe that genetic studies may be one of the most significant types of work that has real relevance to modern African Americans. Leone et al. (2005:582) suggests that archeologists can study material culture along with "language, religion, dance, music, food, and mtDNA." DNA is simply another form of evidence that can help unravel the stories of the African diaspora. Leone et al. (2005:581) state:

We recognize the importance of human genetics to modern African American identities, especially regarding ties to various regions of Africa for human origins and ties to modern diasporic communities, as well as ties to an understanding of genetic components of disease inheritance.

Tracing their African origins is something that is important to many modern African Americans (Blakey 2001; Blakey et al. 2009a, 2009b; Jackson et al. 2009; Leone et al. 2005; McKee 1998; Vlach 1990), and genetic research is the most promising technique for such studies. These concepts are summarized in the concluding chapter to the New York African Burial Ground archeology report:

Characteristic of today's African American sensibility is the apparently straightforward query, "Who are your people?" This question asks both "Where did you come from?" and "How do we relate to one another?" The abhorrent circumstances under which people were separated from their families and homelands complicates the search for origins and cultural roots of African-descendant people throughout the Diaspora. The multidisciplinary African Burial Ground Project has developed new lines of data, and a host of questions, about the origins of early African New Yorkers, through historical research, preliminary genetic and craniometric data, and archaeological analysis. (Perry, Howson, and Bianco 2009:373)

Historically and geographically, Brazoria County is in a key position to make DNA studies of African American burials a worthwhile and productive endeavor. The potential to obtain genetic data to link Brazoria County blacks to their African origins is significant because relatively little is known about the African peoples brought 
as slaves to Texas. The county played a prominent role in the early history of Texas and the development of the slave-based agricultural economy. The people who were brought into Texas and forced to provide the labor had widely varying backgrounds. Some had been enslaved on other southern plantations for generations before being brought to work on plantations in Texas. These people had been acculturated in many ways, adopting the language, social norms, and Christian religion of their owners to varying degrees. Other unknown numbers of Africans were captured by slave traders, shipped across the Atlantic, and delivered directly to Texas ports or by an indirect route through the Cuban and other Caribbean slave markets. These people were not acculturated, and they came to Texas with their African beliefs and languages still intact. Consequently, many parts of Texas constitute ideal locations for conducting bioarcheological and DNA studies of community social identity, and research on African origins and the African diaspora. This is especially true for Brazoria County and the lower Brazos region since it became an odd mix of distinctive slave communities (Kelley 2010:2-3, 55-56, 78, 132-133) that survived up into the twentieth century (Barker 1902:158).

As economic development activities continue along the Texas coast, it is likely that more African American graveyards will be discovered and need to be relocated. Such occasions offer unprecedented opportunities to collaborate with the African American community and to develop DNA research strategies to look at African origins, community identity, and population dynamics. Ultimately, the skeletal remains of historic African Americans will hold the key to unraveling the most complex stories of the African diaspora in Texas. 



\section{REFERENCES CITED}

Abernathy Casket Company

ca. 1930 Casket Catalogue "H”. Abernathy Casket Company, Kansas City, Missouri.

Adams, D.

2006 "New Home Cemetery Being Restored by Group." Fort Bend Herald, July 16, 2006.

African American Registry

2015 The Order of the Eastern Star Begins. African American Registry, A Non-profit Educational Organization. Electronic document, http://www.aaregistry.org/historic events/view/order-eastern-star-begins, accessed July 26, 2015.

Afrolumens

2003 Midland Cemetery: Aspects of African American Burial Traditions at Midland. Central Pennsylvania African American History. Electronic document, http://www.afrolumens. org/rising_free/midland2.html, accessed March 24, 2011.

Allen, L. C.

1915 The Negro Health Problem. American Journal of Public Health 5:194-203. Crossref

Anderson, Jeffrey Elton

2002 Conjure in African-American Society. Ph.D. dissertation, University of Florida. Electronic document, http://archive.org/stream/conjureinafrican00ande/conjureinafrican00ande_ djvu.txt, accessed October 28, 2013.

Anderson, Nesta, Karissa Basse, Andrea Stahman, Brandy Harris, Susan Wallace, and Michael Nash 2011 Final Report Archeological Investigations at the Adams Homestead and Cemetery, 41RT367 Kosse Mine, Robertson County, Texas. PBS\&J, Austin.

Andrews, Jean

1981 Texas Shells: A Field Guide. University of Texas Press, Austin.

Anonymous

ca. 1797 [book of coffin plates, handles, ornaments, etc.] Unknown company, England.

1898 The Colored Race in Life Assurance. Journal of the American Medical Association 30(15):874.

1922 Price List (August 1, 1922). Unknown company, United States.

1941 Safeguarding the Public Health in Dallas (1873-1941). Compiled by Workers of the Dallas Unit, Writers' Program of the Works Projects Administration. Typewritten manuscript, Dallas Public Library.

2014 Editorial: First Street Cemetery Committee Hears Good Ideas for Reburial of Forgotten Early Day Wacoans. WacoTrib.com, posted July 13, 2014. Electronic document, http:// www.wacotrib.com/opinion/editorials/editorial-first-street-cemetery-committee-hearsgood-ideas-for-reburial/article_6590400d-3528-5729-8b09-4e30a994dc1d.html, accessed April 30, 2015. 
Archaeological Services, Inc.

1992 Archaeological Mitigation of the Cheyne Cemetery, Part Lot 14, Concession 1, E.H.S., Toronto Township, City of Brampton, Regional Municipality of Peel. Archaeological Services, Inc., Toronto.

ca. 2000 Archaeological Report on the Salvage Recovery of Human Remains at Trinity Anglican Church Cemetery, 79 Victoria Street, Town of Aurora, Regional Municipality of York, Ontario. Archaeological Services, Inc., Toronto.

Archaeological Services, Inc., and Gary Warrick

2005 Archaeological Investigation of the Pea Hill Site, City of Hamilton. Archaeological Services, Inc., Burlington, Ontario.

Aronow, Saul

1981 Surface Geology. In Soil Survey of Brazoria County, Texas, pp. 79-82. The U.S. Department of Agriculture, Soil Conservation Service, in cooperation with the Texas Agricultural Experiment Station.

Atkinson, J. R., and Kenneth R. Turner

1987 The Blackburn Cemetery: An Abandoned Burial Site on the Old Natchez Trace in Maury County, Tennessee. Southeast Archaeological Center, National Park Service, Tallahassee, Florida.

Atlantic Coffin \& Casket Company

1918 Catalogue "B", Wholesale dealers in coffin \& casket hardware, linings... Atlantic Coffin \& Casket Company, Rose Hill, North Carolina.

Atz, Leiellen

2005 Crawford Cemetery Relocation, Gwinnett County, Georgia. Brockington and Associates, Inc., Atlanta, Georgia.

Atz, Leiellen, and Wendy Weaver

2006 Relocation of the Roughton / Browne Cemetery, Sandersville, Washington County, Georgia. Project FLF 540(29). Brockington and Associates, Inc., Atlanta, Georgia.

Aufderheide, Arthur C., and Conrado Rodríguez-Martín

1998 The Cambridge Encyclopedia of Human Paleopathology. Cambridge University Press, Cambridge, United Kingdom.

Barker, Eugene C.

1902 The African Slave Trade in Texas. The Quarterly of the Texas State Historical Association 6(2):145-158.

Barr, Alwyn

1996 Black Texans: A History of African Americans in Texas, 1528-1995. 2nd ed. University of Oklahoma Press, Norman.

Bass, William M.

1995 Human Osteology: A Laboratory and Field Manual. 4th ed. Missouri Archaeological Society, Columbia.

Bastis, Kristen

2006 Health, Wealth, and Available Material: The Bioarchaeology of the Bulkeley Tomb in Colchester, Connecticut. Master's thesis, University of Connecticut, Storrs.

Baugher, Sherene, and Richard F. Veit

2014 The Archaeology of American Cemeteries and Gravemarkers. The American Experience in Archaeological Perspective series. University of Florida Press, Gainesville. 
Beaty, J., and Leiellen Atz

2002 Relocation of an Abandoned Cemetery in Augusta, Richmond County, Georgia. ProjectNH-117-1(114). Brockington and Associates, Inc., Atlanta, Georgia.

Belknap, W. B., \& Company

1895 Importers and Jobbers of Hardware, Louisville, Kentucky.

1901 Catalogue No. 29 (general hardware with coffin trimmings). W. B. Belknap \& Company, Louisville, Kentucky.

Bell, Edward L.

1987 The Historical Archaeology of Mortuary Behavior at a Nineteenth-Century Almshouse Burial Ground. Master's thesis, Boston University, Boston, Massachusetts.

1990 The Historical Archaeology of Mortuary Behavior: Coffin Hardware from Uxbridge, Massachusetts. Historical Archaeology 24(3):54-78.

1994 Vestiges of Mortality and Remembrance:A Bibliography On The Historical Archaeology of Cemeteries. The Scarecrow Press, Inc., Metuchen, New Jersey.

Berg, Richard E.

1990 An Investigation of Burials at the Scisson Family Cemetery in Gregory County, South Dakota. South Dakota Archaeology 14(36-92).

Betts, Vicki

1993 The "Social Dip": Tobacco Use by Mid-Nineteenth Century Southern Women. The Citizens' Companion 5(3):12-20 (August-September 1993). Electronic document, http:// www.uttyler.edu/vbetts/snuff.htm, accessed June 7, 2013.

Beynon (Landers), Diane E.

1989 Remember Me As You Pass By: Excavation of the Voegtly Cemetery. A 19th Century German-American Churchyard in Pittsburgh, Pennsylvania. 3 vols. Report to the Pennsylvania Department of Transportation, from GAI Consultants, Inc., Monroeville, Pennsylvania.

Bird, M. C.

2000 Final Report: Phase III Mitigation of the Burying Ground at Vandaworker's Corners (11-L-572), Village of Deer Park, Ela Township, Lake County, Illinois. Cultural Resource Management Report No. 811. Midwest Archaeological Research Services, Inc., Harvard, Illinois.

Bird, M. Catherine, Anne L. Grauer, and Jenna Tedrick Kuttruff

2003 Data Recovery at the Thurston Cemetery within the County Right-of-Way, York Township, DuPage County, Illinois. Midwest Archaeological Research Services, Inc., Harvard, Illinois.

Blakey, Michael L.

2001 Bioarchaeology of the African Diaspora in the Americas: Its Origins and Scope.

Annual Review of Anthropology 30:387-422. Crossref

Blakey, Michael L., and Lesley M. Rankin-Hill (editors)

2009a The New York African Burial Ground: Unearthing the African Presence in Colonial New York. Vol. 1. Skeletal Biology of the New York African Burial Ground. Part 1. Howard University Press, Washington, D.C. Electronic document, accessed http://www.gsa.gov/ largedocs/Vol1-Part1-TheSkeletalBiologyOfTheNYAGB.pdf, May 12, 2015.

2009b The New York African Burial Ground: Unearthing the African Presence in Colonial New York. Vol. 1. Skeletal Biology of the New York African Burial Ground. Part 2: Burial Descriptions and Appendices. Howard University Press, Washington, D.C. Electronic document, accessed http://www.gsa.gov/largedocs/Vol1-Part2-SkeBioOfNYABGBurialDescriptionsAndAppendices.pdf, May 12, 2015. 
Blakely, Robert L., and Lane A. Beck

1982 Bioarchaeology in the Urban Context. In Archaeology of Urban America: The Search for Pattern and Process, edited by R. S. Dickens, Jr., pp. 175-207. Academic Press, New York.

Bliss-Holbrook Company Inc.

ca. 1905 Catalogue of Coffin Studs, Plates and Ornaments Mfg. by Bliss-Holbrook Company, Inc. Bliss-Holbrook Company, Inc., Attleboro, Massachusetts.

Boen, Renee M., and Candy Taft

1999 39MN7 Howard Cemetery, Accession Number 99-103. Draft, Burial Report \#1999-11. South Dakota State Historical Society, Archaeological Research Center, Rapid City, South Dakota.

Boyd, Douglas K.

2008 Preliminary Report on Archival Research and Archeological Investigations at the First Capitol Site (41BO225), West Columbia, Texas. Letter Report No. 788. Prewitt and Associates, Inc., Austin.

Boyd, Douglas K., Amy E. Dase, Christopher W. Ringstaff, M. Katherine Spradley, and Catrina Banks Whitley

2014 Relocation of the Salvador Camarena Burial: Historical and Bioarcheological Investigations of a Mexican Migrant Worker Grave (41MV372) in Maverick County, Texas. Technical Reports No. 98, Prewitt and Associates, Inc., Austin. Archeological Studies Program Report No. 162, Environmental Affairs Division, Texas Department of Transportation, Austin.

Boyertown Casket Company

ca. 1897 [Catalogue]. Boyertown Casket Co., Boyertown, Pennsylvania.

ca. 1900 [Catalogue]. Boyertown Casket Co., Boyertown, Pennsylvania.

Boyertown Burial Casket Company

n.d. $\quad$ "The Pure Cast Iron Alloyed with Copper Casket No. 5". Boyertown Burial Casket Company, Boyertown, Pennsylvania.

n.d. $(<1910) \quad$ [Catalogue]. Boyertown Burial Casket Company, Boyertown, Pennsylvania.

1919 Catalogue “I”. Boyertown Burial Casket Company, Boyertown, Pennsylvania.

1919 Revised Price List of Pedastals Made of Brass Tubing (November 17, 1919). Boyertown Burial Casket Company, Boyertown, Pennsylvania.

ca. 1923 Catalogue “J”. Boyertown Burial Casket Company, Boyertown, Pennsylvania.

1923 Metal Catalogue, Number 4. Boyertown Burial Casket Company, Boyertown, Pennsylvania.

1927 Catalog “K”. Boyertown Burial Casket Company, Boyertown, Pennsylvania.

1936 Catalog "L" Hardwood and Covered Caskets. Boyertown Burial Casket Company, Boyertown, Pennsylvania.

1936 Catalog “LX” Supplement to Catalog “L”. Boyertown Burial Casket Company, Boyertown, Pennsylvania.

1938 Catalog “L-16”, 16-Gauge Metal Caskets. Boyertown Burial Casket Company, Boyertown, Pennsylvania. 
1940 Price List Applying to Hardwood \& Covered Caskets, Also Metal Caskets, Catalogs "L", "LX", and " $L-16$ " (effective February 19, 1940). Boyertown Burial Casket Company, Boyertown, Pennsylvania.

Bradle, Michael R., James S. Belew, and Susan Maki Wallace

2002 Archaeological Survey of the Connally I.S.D. School Tract and Cemetery Relocation, McLennan County, Texas. Prepared for Connally Independent School District, Waco, Texas. Report of Investigations Number 26. American Archaeology Group, Inc., Lampasas, Texas.

Bradle, Michael R., Gilbert T. Bernhardt, and Ron Ralph

2006 Archeological Survey and Monitoring of the Texas Ranger Hall of Fame and Museum Expansion Project for the City of Waco, McLennan County, Texas. Reports of Investigations No. 125. American Archaeology Group, LLC, Lampasas, Texas.

Braley, Chad O.

1992 Archaeological and Archival Investigations at the Deepstep A.M.E. Church Cemetery, Washington County, Georgia. Southeastern Archaeological Services, Inc., Athens, Georgia.

Braley, C. O., and William G. Moffat

1995 Archaeological and Historical Investigations of Redfield Cemetery, Jones County, Georgia. Vol. 1. Southeastern Archaeological Services, Inc., Athens, Georgia.

Brauner, David R., and Paul Christy Jenkins

1980 Archeological Recovery of Historic Burials within the Applegate Lake Project Area, Jackson County, Oregon. Department of Anthropology, Oregon State University, Corvallis.

Brock, J., and Steven J. Schwartz

1991 A Little Slice of Heaven: Investigations at Rincon Cemetery, Prado Basin, California. Historical Archaeology 25(3):78-90.

Broehm, C. J., Douglas K. Boyd, and Martha Doty Freeman

2004 Archaeological Excavation and Reburial of Historic Graves in the Oscar Abstein Cemetery (41HR976), Harris County, Texas. Texas. Archaeological Studies Program Report 64, Environmental Affairs Division, Department of Transportation, Austin, Texas. Report of Investigations No. 140, Prewitt and Associates, Inc., Austin, Texas.

Bromberg, Francine W., Steven J. Shepard, Barbara H. Magid, Pamela J. Cressey, Timothy Dennée, and Bernard K. Means

2000 "To Find Rest from All Trouble": The Archaeology of the Quaker Burying Ground, Alexandria, Virginia. Alexandria Archaeology, Office of Historic Alexandria, Alexandria, Virginia.

Brooks, S.T., and J.M. Suchey

1990 Skeletal Age Determination Based on the Os Pubis: A Comparison of the AcsádiNemeskéri and Suchey-Brooks Methods. Human Evolution 5:227-238.

Brothwell, D. R.

1981 Digging Up Bones. 3rd ed. Cornell University Press, Ithaca, New York.

Brumby, W. M.

1908 Biennial Report of the State Health Officer of Texas from September 1, 1906, to August 31, 1908. Von Boeckmann-Jones Company, Austin.

1911 Biennial Report of the Texas State Board of Health from September 1, 1908, to August 31, 1910. Austin Printing Company, Austin. 
Bruner, David E.

1996 Hidden Power: Burial Practices from an African American Slave and Tenant Community. M.A. thesis, Department of Anthropology, University of Houston, Houston, Texas.

1998 "Hidden Power: Burial Practices from an African-American Slave and Tenant Community." Excerpts from Hidden Power: Burial Practices from an African American Slave and Tenant Community, by David E. Bruner, 1996. On the Levi Jordan website by Carol McDavid. Electronic document, http://www.webarchaeology.com/html/BrunrSHA. htm, accessed July 7, 2011.

Bruseth, James E., and Susan A. Lebo

1986 Archaeoological Investigations at the Ferris Cemetery. Report submitted to the Forest Hills Park Association, Dallas, Texas.

Buchner, C. A., Emanuel Breitburg, Charles Williams, and Elizabeth A. Williams

1999 At Rest, Again: The Ridley Graveyard (40WM208) Archaeological Relocation Project, Williamson County, Tennessee. Panamerican Consultants, Inc., Memphis, Tennessee.

Bugbee, Lester G.

1898a Slavery in Early Texas. I. Political Science Quarterly 13(3):389-412.

1898b Slavery in Early Texas. II. Political Science Quarterly 13(4):648-668.

Buikstra, Jane, Jodie A. O'Gorman, and Cynthia Sutton

2000 Never Anything So Solemn: An Archeological, Biological, and Historical Investigation of the Nineteenth-Century Grafton Cemetery. Kampsville Studies in Archeology and History No. 3. Center for American Archeology, Kampsville, Illinois.

Buikstra, Jane E., and Douglas H. Ubelaker (editors)

1994 Standards for Data Collection from Human Skeletal Remains. Research Series No. 44. Arkansas Archeological Survey, Fayetteville.

Burgess, Laurie, Douglas Owsley, and John Imlay

2007 Death, Wealth and Ornament: Coffin Hardware from Congressional Cemetery. Proceedings of the Society for Historical Archaeology 40th Annual Conference on Historical and Underwater Archaeology. Williamsburg, Virginia.

Burkholder, Nanetta Key, and Lois Benefiel (editors)

1991 Tombstone Inscriptions from Some Cemeteries of Brazoria County, Texas. Brazosport Genealogical Society, Lake Jackson, Texas.

Burnston, Sharon A., and Ronald A. Thomas

1981 Archaeological Data Recovery at Catoctin Furnace Cemetery, Frederick County, Maryland. Mid-Atlantic Archaeological Research, Inc., Newark, Delaware.

Burton, Jeffery F., Jeremy D. Haines, and Mary M. Farrell

2001 "I Rei To": Archaeological Investigations at the Manzanar Relocation Center Cemetery, Manzanar National Historic Site, California. Publications in Anthropology 79. Western Archeological and Conservation Center, National Park Service, U.S. Department of the Interior.

Bybee, Alexandra D.

2002 Bioanthropological Investigations of the Reynolds Cemetery (46Ka349) in Kanawha County, West Virginia. Cultural Resource Analysts, Inc., Hurricane, West Virginia.

2003a Bioanthropological Investigations of the Burning Spring Branch Cemetery (46Ka142) in Kanawha County, West Virginia. Cultural Resource Analysts, Inc., Hurricane, West Virginia.

2003b Bioanthropological Investigations of a 19th Century Cemetery (15CP61) In Campbell County, Kentucky. Cultural Resource Analysts, Inc., Lexington, Kentucky. 
2003c Bioarchaeological Investigations of Unmarked Graves at the Samuel Robinson and Upper Prater Cemeteries (15PI190 and 15PI191), Pike County, Kentucky (Item No. 12-263.00). Cultural Resource Analysts, Inc., Lexington, Kentucky.

2004 Old Branham (15Fd94): Bioarchaeological Investigations of an Historic Cemetery, Floyd County, Kentucky (Item No. 12-301.00). Cultural Resources Analysts, Inc., Lexington, Kentucky.

2007a Bioarchaeological Investigations of the Evans Cemetery (46MD62), McDowell County, West Virginia. Contract Publication Series WV07-03. Cultural Resource Analysts, Inc., Hurricane, West Virginia.

2007b Bioarchaeological Investigations of The Alderson-Jackson Cemetery (15JS174), Jessamine County, Kentucky. Cultural Resource Analysts, Inc., Lexington, Kentucky.

2007c Bioarchaeological Investigations of an Unmarked Grave at the Rudy Cemetery (15JF675), Jefferson County, Kentucky (Item No. 5-28.10). Cultural Resource Analysts, Inc., Lexington, Kentucky.

Bybee, Alexandra D., and Michael Richmond

2003 Data Recovery at a Nineteenth Century Cemetery (15Mm137) in Montgomery County, Kentucky (Item No. 7-320.00). Cultural Resource Analysts, Inc., Lexington, Kentucky.

Cabak, Melanie, and Kristin Wilson

1998 Gender Differences among African-American Interments in the American South. Paper presented at the Annual Meeting of the Society for Historical Archaeology, Atlanta, Georgia.

Campbell, Randolph B.

2013 Handbook of Texas Online, s.v. "Slavery." Electronic document, http://www.tshaonline. org/handbook/online/articles/yps01, accessed March 25, 2015.

Cande, Kathleen

1995 The Ozarks as Destination: Phase III Archeological Investigations at the Lambert Farmstead (3CW647) and Phase II Testing at the Dement Farmstead and Cemetery (3CW685), Crawford County, Arkansas. Final Report, Project Nos. 829 and 864. Arkansas Archeological Survey, Fayetteville.

Carr, W. S., \& Company

ca. 1890 Price list of Undertakers Hardware, W. S. Carr \& Co, manufacturers. W. S. Carr \& Company, Baltimore, Maryland.

Central Burial Casket Company

n.d. (>1919) Catalogue "A" - High Grade Burial Caskets. Central Burial Casket Company, Guthrie, Oklahoma.

Chandler, K.

2010 African American Grave Traditions. On Grave Discoveries, K. Chandler blog. Posted December 27, 2010.

Chappell, Chase, Maxwell \& Company

1884 Illustrated catalogue: Cloth, velvet-covered, and wood finished Burial Caskets. Chappell, Chase, Maxwell \& Company, Oneida, New York.

Chattanooga Coffin \& Casket Company

1905 Wholesale pricelist of Undertaker's Hardware, embalming instruments and sundry supplies. Chattanooga Coffin \& Casket Company, Chattanooga, Tennessee.

1905 Catalogue No. 4. Illustrated Catalogue of Undertakers' Hardware, Embalming Instruments and Sundry Supplies. Chattanooga Coffin \& Casket Company, Chattanooga, Tennessee. 


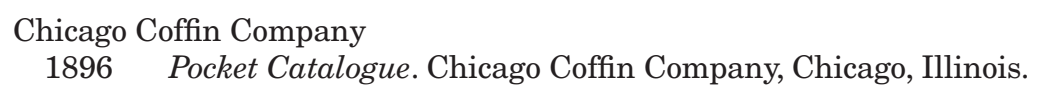

\section{Cincinnati Coffin Company}

1880 Ninth Illustrated Catalogue. Cincinnati Coffin Company, Cincinnati, Ohio.

1881 Tenth Illustrated Catalogue. Cincinnati Coffin Company, Cincinnati, Ohio.

1881 Reduced Wholesale Price List (January 1881). Cincinnati Coffin Company, Cincinnati, Ohio.

1881 Supplementary Price List (July 1881). Cincinnati Coffin Company, Cincinnati, Ohio.

1882 Eleventh Annual Illustrated Catalogue. Cincinnati Coffin Company, Cincinnati, Ohio.

1882 Wholesale Price List (January 1882). Cincinnati Coffin Company, Cincinnati, Ohio.

1883 Illustrated Catalogue. Cincinnati Coffin Company, Cincinnati, Ohio.

1883 Price List (March 1, 1883). Cincinnati Coffin Company, Cincinnati, Ohio.

ca. 1890 Illustrated Casket Catalogue "D6". Cincinnati Coffin Company, Cincinnati, Ohio.

ca. 1890 Catalogue “D7”- Paramount. Cincinnati Coffin Company, Cincinnati, Ohio.

1903 Revised Prices List of Metal Linings (June 25, 1903). Cincinnati Coffin Company, Cincinnati, Ohio.

1903 Revised Prices on Children's Caskets (June 25, 1903). Cincinnati Coffin Company, Cincinnati, Ohio.

1905 Revised Hardware Price Book, for use in connection with Casket Hardware Catalogue “F.3” and June Supplement (December 12, 1905). Cincinnati Coffin Company, Cincinnati, Ohio.

1906 Catalogue "F.4", Illustrating Casket Hardware and Sundry Undertakers' Supplies. Cincinnati Coffin Company, Cincinnati, Ohio.

1912 Casket Hardware Catalogue F5. Cincinnati Coffin Company, Cincinnati, Ohio.

Chicora Foundation, Inc.

1996 Grave Matters: The Preservation of African-American Cemeteries. Chicora Foundation document on South Carolina's Information Highway website. Electronic document, http://www.chicora.org/pdfs/Grave Matters - The Preservation of African American Cemeteries.pdf, accessed June 1, 2011.

CIA World Factbook

2009 Country Comparison: Infant Mortality Rate. Central Intelligence Agency, Washington D.C. Electronic document, https://www.cia.gov/library/publications/the-world-factbook/ rankorder/2091rank.html, accessed April 27, 2011.

Clark, John W., Jr.

1997 Notes on Old Brazoria. Background Investigation. In Historical and Archeological Investigation of the SH 332 Crossing of the Brazos River, Brazoria County, Texas, by Diane C. Dismukes and Allen C. Bettis, Jr., pp. 44-49. Texas Department of Transportation, Austin.

Cleveland Burial Case Company

1882 Illustrated Catalogue of Wood, Cloth Covered and Metallic Caskets. Cleveland Burial Case Company, Cleveland, Ohio.

ca. 1880 [hardware catalogue] Cleveland Burial Case Company, Cleveland, Ohio. 
ca. 1890 Illustrated Catalogue of Undertakers'Silver Plated Hardware, Casket and Coffin Handles, Name Plates, Thumbscrews, Thumbscrew Plated, Tack, Ornaments, Escutcheons and Hardware Sundries, Robes, Linings, and Undertakers' Dry Goods. Cleveland Burial Case Company, Cleveland, Ohio.

1920 Price List-Pedestals and Candelabras (April 1, 1920). Cleveland Burial Case Company, Cleveland, Ohio.

Clow, Charles M., and Melissa Green

2000 Grave Goods and Mortuary Practices. In Freedman's Cemetery: A Legacy of a Pioneer Black Community in Dallas, Texas, Vol. 2, edited by Duane E. Peter, Marsha Prior, Melissa M. Green, and Victoria G. Clow, pp. 449-460. Special Publications No. 6, GeoMarine, Inc., Plano, Texas. Archeology Studies Program Report No. 21, Environmental Affairs Division, Texas Department of Transportation, Austin.

Cobb, Dawn E.

1999 "Such a Lonely Place? An Archaeological and Osteological Investigation of the BrunsonSisson Cemetery (11WI874), Will County, Illinois. Illinois State Museum Society, Contract Archaeology Program. Illinois State Museum, Quaternary Studies Program, Technical Report, No. 98-1264-26.

Collins, W. B.

1917 Biennial Report of the Texas State Board of Health from September 1, 1914, to August 31, 1916. Von Boeckmann-Jones Company, Austin.

1919 Biennial Report of the Texas State Board of Health from September 1, 1916, to August 31, 1918. Von Boeckmann-Jones Company, Austin.

Columbus Coffin Company

1882 Illustrated Catalogue Wood \& Cloth Covered Coffins \& Caskets, undertakers hardware. Columbus Coffin Company, Columbus, Ohio.

Combes, John D.

1974 Ethnography, Archaeology and Burial Practices Among Coastal South Carolina Blacks. In Conference on Historic Site Archaeology Papers 1972, Vol. 7, edited by Stanley South, pp. 52-61. The Institute of Archeology and Anthropology, University of South Carolina, Columbia, South Carolina.

Condon, Cynthia G., Joy L. Becker, Heather J. Edgar, James M. Davidson, Juerena R. Hoffman, Patricia Kalima, Daniel Kysar, Susan Moorehead, Victoria M. Owens, and Keith Condon 1998 Freedman's Cemetery: Site 41DL316, Dallas, Texas, Assessments of Sex, Age at Death, Stature, and Date of Interment for Excavated Burials. Archaeology Studies Program Report No. 9. Environmental Affairs Division, Texas Department of Transportation, Austin.

Connolly, T. J., Christopher L. Ruiz, Jeanne McLaughlin, Guy L. Tasa, and Elizabeth Kallenbach 2008 Rediscovery and Recovery of the Stevens Family Pioneer Cemetery at River Bend, Springfield, Oregon. Museum Report 2008-058. Museum of Natural and Cultural History and State Museum of Anthropology, University of Oregon, Eugene.

2010 The Archaeology of a Pioneer Family Cemetery in Western Oregon, 1854-1879. Historical Archaeology 44(4):28-45.

Conrad, Horace W.

1887 The Health of the Negroes in the South: The Great Cause of Mortality among Them; the Causes and Remedies. Sanitarian 18:502-518.

Cooper, Judy H., Angela L. Tine, Marsha Prior, Charles M. Clow, David Shanabrook, and Ed Salo 2000 Cultural Resources and Bioarchaeological Investigations at the Dallas Convention Center and Pioneer Cemetery, Dallas, Texas. Miscellaneous Reports of Investigations, Number 205. Geo-Marine, Inc., Plano, Texas. 
Corbin, P. \& F.

1859 Illustrated Catalogue and price list P. \&. F. Corbin, New Britain, Connecticut.

1866 Price List, manufacturers of wrought cast brass...hinges, coffin trimmings... P. \& F. Corbin, New Britain, Connecticut.

Cordova, K. J., and N. J. Anderson

2010 FM 1464 at New Home Cemetery between Stratford Creek Drive and Oyster Creek, CSJ 1415-02-032. PBS\&J, Austin.

Costello, Julia G.

1991 Excavation of Burials from the Madam Felix/Hettick Cemetery, CA-CAL-1122H. Foothill Resource Associates, Mokelumne Hill, California.

Craig, Joseph, and Clark Spencer Larsen

1993 Life and Death on the Illinois Prairie: Archaeological and Osteological Investigations at the Cross Cemetery, Springfield, Illinois. Hanson Engineers, Inc., Springfield, Illinois.

Crane, Breed \& Company

1865 Wholesale Prices of Plain Cases, Crane's Metallic Burial Casket, etc. Crane, Breed \& Company, Cincinnati, Ohio.

1867 Wholesale pricelist of patent metallic burial cases and caskets, hearses, name plates, etc. Crane, Breed \& Company, Cincinnati, Ohio.

1877 Illustrated catalogue of undertakers' goods. Crane, Breed \& Company, Cincinnati, Ohio.

1895 Illustrated Catalogue of Hearses and Trimmings. Crane, Breed \& Company, Cincinnati, Ohio.

1910 Catalogue "D”, burial Garments, Robes, Casket Linings, Pillow and Lining Sets, Door Crapes. Crane \& Breed Mfg. Co., Cincinnati, Ohio.

Crawford, Kristine

2003 Archaeological Investigations of St. Peter's Anglican Church Property, 240 College Street, Cobourg, County of Northumberland, Ontario. Archaeological Services, Inc., Toronto.

Crawford, Kristine, Alexis Hutcheson, Eva MacDonald, Brian Nahri, David Robertson, and Ronald Williamson

2008 Ontario Cemeteries Act site Investigation, The Old Don Jail Burial Area, Proposed Draft Plan of Subdivision, Part of Lot 15, Concession 1 From the Bay, Geographic Township of York and Part of Block U, Don Improvement Plan, City of Toronto. Archaeological Services, Inc., Toronto.

Crawfordsville Casket Company

ca. 1900 Illustrated Catalogue No. 9 of Coffins, Caskets, Dry Goods, Hardware, etc. Crawfordsville Casket Company, Crawfordsville, Indiana.

Crissman, James K.

1994 Death and Dying in Central Appalachia: Changing Attitudes and Practices. University of Illinois Press, Urbana.

Crist, Thomas A. J., William H. Henry, Joe W. Joseph, Reginald H. Pitts, Wade P. Catts, Alex Caton, Arthur Washburn, and Sean Norris

2000 With Death Came Liberty: The Archaeology and History of the Sam Goode Cemetery, Mecklenburg County, Virginia. In New South Associates Technical Report, No. 747. Contract DACW21-99-D-0004, Delivery Order 0005. New South Associates, Stone Mountain, Georgia. 
Crist, Thomas A. J., Reginald H. Pitts, Arthur Washburn, John P. McCarthy, and Daniel G. Roberts 1996 "A Distinct Church of the Lord Jesus": The History, Archaeology, and Physical Anthropology of the Tenth Street First African Baptist Church Cemetery, Philadelphia, Pennsylvania. Site Number 36PH72. Vine Expressway (I-676), L.R. 67045. ER \#82-0133101-W. John Milner Associates, Inc., Philadelphia, Pennsylvania.

Crow, Michael S.

2004 Mortuary Practice in Sociohistorical and Archaeological Contexts: Texas, 1821-1870. M.A. thesis. Texas A\&M University, College Station.

Cultural Resources Inc.

2002 Results of Excavation of A Human Burial at Site 44SK481 Located at the Former Nansemond Ordnance Station, Suffolk, Virginia. Cultural Resources, Inc., Fredericksburg, Virginia.

Dallas Coffin Company

ca. 1900 Catalogue “G”. Dallas Coffin Company, Dallas, Texas.

Davidson, James M.

n.d. Holmes-Vardeman-Stephenson Cemetery Analysis: Mortuary Hardware Typology, Burial Chronology, and Socioeconomic Study. Draft manuscript. Program for Archaeological Research, University of Kentucky, Lexington.

1999 Freedman's Cemetery (1869-1907): A Chronological Reconstruction of an African American Burial Ground, Dallas, Texas. Master's thesis, University of Arkansas, Fayetteville.

2000 The Development of Freedmen's Cemetery. In Freedman's Cemetery: A Legacy of a Pioneer Black Community in Dallas, Texas, Vol. 2, edited by Duane E. Peter, Marsha Prior, Melissa M. Green, and Victoria G. Clow, pp. 233-407. Special Publications No. 6, Geo-Marine, Inc., Plano, Texas. Archeology Studies Program Report No. 21, Environmental Affairs Division, Texas Department of Transportation, Austin.

2004 Mediating Race and Class Through the Death Experience: Power Relations and Resistance Strategies of an African-American Community, Dallas, Texas (18691907). Ph.D. dissertation, Department of Anthropology, University of Texas at Austin.

2006 Material Culture, Chronology, and Socioeconomics. In Two Historic Cemeteries in Crawford County, Arkansas, edited by R. C. Mainfort, Jr., and James M. Davidson, pp. 97-218. Arkansas Archeological Research Series No. 62. Arkansas Archeological Survey, Fayetteville.

2010 Keeping the Devil at Bay: The Shoe on the Coffin Lid and Other Grave Charms in Nineteenth- and Early Twentieth-Century America. International Journal of Historical Archaeology 14:614-649.

2012 "They Laid Planks 'Crost the Coffins": The African Origin of Grave Vaulting in the United States. International Journal of Historical Archaeology 16:86-134.

Davidson, James M., and Jamie C. Brandon

2012 Descendant Community Partnering, the Politics of Time, and the Logistics of Reality: Tales from North American African Diaspora Archaeology. In The Oxford Handbook of Public Archaeology, edited by Robin Skeates, Carol McDavid, and John Carman, pp. 605-628. Oxford University Press, United Kingdom. Crossref

Davidson, James M., Jerome C. Rose, Myron P. Gutmann, Michael R. Haines, Keith Condon, and Cindy Condon

2002 The Quality of African-American Life in the Old Southwest near the Turn of the Twentieth Century. In The Backbone of History: Health and Nutrition in the Western Hemisphere, edited by Richard H. Steckel and Jerome C. Rose, pp. 226-277. Cambridge University Press, Cambridge, United Kingdom. Crossref 
Deming, J., Marion M. Almy, Janet S. Matthews, and Steven H. Koski

1993 Report on the Excavation of 8LL1758 as Contained Within the Proposed U.S. 41 Business Right-of-Way On Fowler Street Between First and Second Streets in the City of Fort Myers, Lee County, Florida. Archaeological Consultants, Inc., Sarasota, Florida.

Denton, Mark

2008 Letter from Mark Denton, Archeology Division, Texas Historical Commission, to Scott Pletka, Archeological Studies Program, Texas Department of Transportation, December 23, 2008. On file at the Archeological Studies Program, Environmental Affairs Division, Texas Department of Transportation, Austin.

Dismukes, Diane C., and Allen C. Bettis, Jr.

2002 Historical and Archeological Investigation of the SH 332 Crossing of the Brazos River, Brazoria County, Texas. Texas Department of Transportation, Austin.

Dockall, Helen Danzeiser, Douglas K. Boyd, Martha Doty Freeman, Rolando L. Garza, Kevin E. Stork, Karl W. Kibler, and Joan E. Baker

1996 Confederate Veterans At Rest:Archaeological and Bioarchaeological Investigations at the Texas State Cemetery, Travis County, Texas. Reports of Investigations No. 107. Prewitt and Associates, Inc., Austin.

Dockall, Helen Danzeiser, and Joseph F. Powell

1996 The Phillips Memorial Cemetery Population. In Home Hereafter: An Archaeological and Bioarchaeological Analysis of an Historic African-American Cemetery (41GV125), by Helen Danzeiser Dockall, Joseph F. Powell, and D. Gentry Steele, pp. 87-103. Reports of Investigations No. 5. Center for Environmental Archaeology, Texas A\&M University, College Station.

Dockall, Helen Danzeiser, Joseph F. Powell, and D. Gentry Steele

1996 Home Hereafter: An Archaeological and Bioarchaeological Analysis of an Historic African-American Cemetery (41GV125). Reports of Investigations No. 5. Center for Environmental Archaeology, Texas A\&M University, College Station.

Dominion Manufacturers, Ltd.

n.d. (post 1906) Catalogue No. 30 Illustrating Casket Hardware designed \& manufacturered by.... Dominion Manufacturers, Ltd., Toronto.

Donald, Henderson $\mathrm{H}$.

1971 The Negro Freedman. Cooper Square Publishers, New York.

Dottridge Brothers, Ltd.,

n.d. $\quad$ Price List of Finished Coffins, List No. 1058. Dottridge Brothers, Ltd., London.

n.d. Wholesale Coffin List. Dottridge Brothers, LTD., London.

n.d. Wholesale Coffin Furniture \& Drapery List [Price List]. Dottridge Brothers, Ltd., London.

n.d. Wholesale Coffin Furniture \& Drapery List. Dottridge Brothers, Ltd., London.

1965 Coffin Furniture. Dottridge Brothers, Ltd., London.

Downer, Joseph A.

2015 Hallowed Ground, Sacred Place: The Slave Cemetery at George Washington's Mount Vernon and the Cultural Landscapes of the Enslaved. M.A. thesis, Department of Anthropology, George Washington University, Washington, D.C. Electronic document, http://www.mountvernon.org/research-collections/archaeology/slave-burial-groundresearch/research-papers/hallowed-ground-sacred-place, accessed May 28, 2015. 
Du Bois, W. E. Burghardt (editor)

1907 Economic Co-operation among Negro Americans: Report of a Social Study made by Atlanta University, under the patronage of Carnegie Institution of Washington, D.C., together with the proceedings of the twelfth Conference for the Study of the Negro Problems, held at Atlanta University on Tuesday, May the 28th, 1907. The Atlanta University Press, Atlanta, Georgia. Electronic document, http://scua.library.umass.edu/ digital/dubois/dubois12.pdf, accessed June 1, 2015.

Dulaney, W. Marvin

2010 Handbook of Texas Online, s.v. "African Americans.” Electronic document, http://www. tshaonline.org/handbook/online/articles/pkaan, accessed April 26, 2011.

Earls, Amy C., Christopher R. Lintz, George W. Gill, Patrick L. O’Neill, and W. Nicholas Trierweiler 1991 Investigations of Historic Cemeteries at O. H. Ivie Reservoir, Coleman, Concho, and Runnels Counties, Texas. Mariah Technical Report No. 103. Mariah Associates, Inc., Austin, Texas.

Edwards, Douglas M., Lori Hager, and Robert Jackson

2005 Former Sacramento County Hospital Burial Ground Excavation, University of California Davis Medical Center, Radiation Oncology Expansion Project. Pacific Legacy, Inc., Cameron Park, California.

Elia, Ricardo J., and Al B. Wesolowsky (editor)

1991 Archaeological Excavations at the Uxbridge Almshouse Burial Ground in Uxbridge, Massachusetts. BAR International Series 564. Tempus Reparatum: Archaeological and Historical Associates Limited, Oxford, United Kingdom.

Elliott, Brendan

2011 African American Burial Grounds: Rediscovering the Past, A Template for the Future. Richmond's Historic Cemeteries: A Virginia Commonwealth University Project. Electronic document, http://wp.vcu.edu/richmondcemeteries/files/2012/09/ Elliott_AfricanAmBurialGrounds.pdf, accessed March 16, 2015.

Elliott, D. T., and Rita F. Elliott

1989 Bethany Cemetery, Effingham County, Georgia. Ebenzer Archaeological Report Series No. 2. Elliott and Elliott, Athens, Georgia.

Espenshade, C. T.

2004 Historic Grave Removal and Reinterment: Final Report-Clarion County, Pennsylvania, Shippenville Borough, S.R. 0322, Section 370, Shippenville Intersection Improvement Project. Skelly and Loy, Inc., Monroeville, Pennsylvania.

Ezell, Raymond, and Clifton A. Huston

2006a Archaeological Removal of Historic Burials at the Williams-Green Cemetery (44CU134) on the Continental 181 Fund, LLC Tract in Culpeper County, Virginia. ECS Mid-Atlantic, LCC, Fredericksburg, Virginia.

2006b Archaeological Removal of Five Historic Burials from Site 44ST00613 At the Quantico Corporate Center Tract, Stafford County, Virginia. ECS Mid-Atlantic, LLC, Fredericksburg, Virginia.

Farley, Reynolds

1970 Growth of the Black Population: A Study in Demographic Trends. Markham Publishing Company, Chicago, Illinois.

Farrell, James J.

1980 Inventing the American Way of Death, 1830-1920. Temple University Press, Philadelphia, Pennsylvania. 
Feit, Rachel, and Willa R. Trask

2013 Into the Afterlife: Archaeological Excavations and Analysis of Human Remains at the Montgomery Hill Cemetery (41NV716), Navarro County, Texas. Technical Report No. 52. AmaTerr Environmental, Inc., Austin.

Feldstone, A. J.

1986 Excavations Conducted at the Hundred Mile Inn Cemetery Site (33Cn105) Near the Town of Pikeville in Candell County, Ohio. Occasional Papers Series, No. 314. Department of Anthropology, Hartman College, Ashford, Ohio.

Ferguson, Bobbie

1983 Final Report on the McGee Creek Cemetery Relocations, Atoka County, Oklahoma. Bureau of Reclamation, McGee Creek Project, Farris, Oklahoma.

1993 "... and they laid them to rest in the little plot beside the Pecos": Final Report on the Relocation of old Seven Rivers Cemetery, Eddy County, New Mexico. 2 vols. U.S. Bureau of Reclamation, Denver, Colorado.

Forstall, Richard L. (compiler and editor)

1995 Population of Counties by Decennial Census: 1900 to 1990. Compiled and edited by Richard L. Forstall, Population Division, U.S. Bureau of the Census, Washington, D.C. Electronic document, http://www.census.gov/population/cencounts/tx190090.txt, accessed April 1, 2015.

Fort, A. G.

1915 The Negro Health Problem in Rural Communities. American Journal of Public Health 5:191-193. Crossref

Foster, Eugene, and Linda A. Nance (editors)

2002 Archaeological Investigation Report:Allen Parkway Village, 41HR886, Houston, Harris County, Texas. Document No. 020018. PBS\&J, Austin.

Foster, L. L.

2001 Forgotten Texas Census: First Annual Report of the Agriculture Bureau of the Department of Agriculture, Insurance, Statistics, and History, 1887-88. L. L. Foster, commissioner. Original publication, 1889 by the State Printing Office, Austin. Original reproduced in 2001 edition with introduction by Barbara J. Rozek. Texas State Historical Association, Austin.

Fox, Anne A.

1984 A Study of Five Historic Cemeteries at Choke Canyon Reservoir, Live Oak and McMullen Counties, Texas. Choke Canyon Series, Vol. 9. Center for Archaeological Research, University of Texas at San Antonio.

Freedom Casket Company

1921 Revised Price List Applying to Catalogue "E” (May 2, 1921). Freedom Casket Company, Freedom, Pennsylvania.

1923 Revised Price List Applying to Catalogue "E" (February 26, 1923). Freedom Casket Company, Freedom, Pennsylvania.

Freeman, Martha Doty, Douglas K. Boyd, Cory Julian Broehm, and Lisa B. Hunter

2006 Historical and Archeological Investigations of a Possible Historic Cemetery, 41HI294, in Hill County, Texas. Letter Report No. 725. Prewitt and Associates, Inc., Austin.

Fremmer, Ray 1973 Dishes in Colonial Graves: Evidence from Jamaica. Historical Archaeology 3:59-60. 
Gadus, E. Frances, Joan E. Baker, and Amy E. Dase

2002 "A Mother Left to Mourn": Archaeological and Historical Investigations at a NineteenthCentury Family Cemetery at the Jewett Mine, Freestone County, Texas. Report of Investigations No. 136. Prewitt and Associates, Inc., Austin, Texas.

Gardner, J.

2009 Union Bethel AME Church Cemetery Relocation. Brockington and Associates, Inc., Jacksonville, Florida.

Garner, Beverly, Irena Miklavcic, and Terri Brennan

2001 The Kniseley Family Cemetery, Lots 27 and 28, Concession 3, Elm Street, City of Port Colborne, Ontario. Archaeological Services, Inc., Toronto.

Garrow, Patrick H.

1985 A Preliminary Seriation of Coffin Hardware Forms in Nineteenth and Twentieth Century Georgia. Early Georgia 15(1-2):19-45.

1990 Archaeological Investigations of the Sandy Creek Cemetery, Lot 31, Block "B," Sandy Creek Estates, Clark County, Georgia. Garrow and Associates, Atlanta, Georgia.

Garrow, Patrick H., and Steven A. Symes

1987 The Big Lazer Creek Unmarked Cemetery: A Multidisciplinary Investigation. Garrow and Associates, Atlanta, Georgia.

Garrow, Patrick H., Steve A. Symes, and Henry W. Case

1985 Physical Anthropology and Archaeological Investigations of the Nancy Creek Primitive Baptist Church Cemetery, Chamblee, Georgia. Garrow \& Associates, Inc., Atlanta, Georgia.

Gate City Coffin Company

ca. 1904 Catalogue No. G, Illustrating Coffin and Casket Hardware and Undertakers' Supplies, Embalming Instruments, etc. Gate City Coffin Company, Atlanta, Georgia.

Gilbert, Charlene, and Quinn Eli

2000 Homecoming: The Story of African-American Farmers. Beacon Press, Boston Massachusetts.

Gill, George W., and Stanley Rhine (editors)

1990 Skeletal Attribution of Race: Methods for Forensic Anthropology. Anthropological Papers No. 4. Maxwell Museum of Anthropology, University of New Mexico, Albuquerque.

Glasrud, Bruce A.

2008 Time of Transition: Black Women in Early Twentieth-Century Texas, 1900-1930. In Black Women in Texas History, edited by Bruce A. Glasrud and Merline Pitre, pp. 99-128. Texas A\&M University Press, College Station.

Globe Casket Manufacturing Company

n.d. Illustrated Catalogue of Cloth Covered Burial Caskets. Globe Casket Mfg. Co., Kalamazoo, Michigan.

ca. 1935 Casket Catalogue No. 12. Globe Casket Mfg. Co., Kalamazoo, Michigan.

Godden, Geoffrey A.

1991 Encyclopaedia of British Pottery and Porcelain Marks. Barrie \& Jenkins, London. Originally published in 1964.

Goldstein, L. G., and Jane E. Buikstra

2004 A Nineteenth-Century Rural Irish Cemetery in McDonough County, Illinois. In An Upper Great Lakes Archaeological Odyssey: Essays in Honor of Charles E. Cleland, edited by W. A. Lovis, pp. 43-63. Cranbrook Institute of Science, Wayne State University Press, Detroit. 
Graham, Lain

2014 A Bioarchaeological Comparison of Oral Health at Three Postbellum African American Cemeteries in Coastal and Central Georgia. M.A. thesis, Department of Anthropology, Georgia State University, Atlanta. Electronic document, http:// scholarworks.gsu.edu/anthro_theses/82, accessed May 28, 2015.

Green, Helen B.

2010 Handbook of Texas Online, s.v. "Hill, William Green." Electronic document, https:// tshaonline.org/handbook/online/articles/fhi27, accessed June 8, 2015.

Gregory, James N.

2005 The Southern Diaspora: How the Great Migrations of Black and White Southerners Transformed America. University of North Carolina Press, Chapel Hill.

Gresham, T. H., and Gordon Martin

1999 Archaeological Disinterment of the Brassel Cemetery, Jefferson County, Georgia. Southeastern Archaeological Services, Inc., Athens, Georgia.

Grey, Amy E., M. Drake Patten, and Mark S. Warner

1993 A Preliminary Archaeological Assessment of the Venable Lane Site. University of Virginia, Department of Anthropology.

Griggs, John

2008 Letter from John Griggs (Chappel Hill, Texas) to Bob Anderson (Chief of Recreation Grants, Midwest Regional Office, National Park Service), July 20, 2008, regarding Land and Water Conservation Fund involvement in activities at Fort Fisher Park (formerly Lake Brazos Recreation Park) and First Street Cemetery, Waco, McLennan County, Texas. Electronic document, http://www.firststreetcemetery.org/uploads/ Letter_-_Section_106_eligibility_072008.pdf, accessed April 30, 2015.

Gust, Sherri, Amy Diaz, and Kelly Houck

2006 The Historic Los Angeles Cemetery (CA-LAN-3553) Summary Report, Los Angeles Metro Gold Line Project, East Portal Area, Los Angeles, CA. Cogstone Resources Management Inc., Santa Ana, California.

Hacker, Debbi, and Michael Trinkley

2010 Analysis of Remains from Mount Olive Cemetery, Portsmouth, Virginia. Chicora Research Contribution No. 535. Chicora Foundation, Inc., Columbia, South Carolina.

Hacker-Norton, Debbi, and Michael Trinkley

1984 Remember Man Thou Art Dust: Coffin Hardware of the Early Twentieth Century. Research Series 2. Chicora Foundation, Inc., Columbia, South Carolina.

Hallstein, Anna

2010 Handbook of Texas Online, s.v. "Brazoria, Tx.” Electronic document, https://tshaonline. org/handbook/online/articles/HGB10, accessed April 1, 2014.

Hamilton, James

1841 Letter from James Hamilton to Abner Lipscomb, January 4, 1841. Original in Diplomatic Correspondence of the Republic of Texas, Annual Report of the American Historical Association for the Year 1908, edited by George Garrison. Washington, D.C.: Government Printing Office, 1911. Vol. 3:921-925. Reproduced in The Diplomatic Correspondence of the Republic of Texas, Texas Slavery Project online. Electronic document, http://www.texasslaveryproject.org/sources/ROTDC/display. php?f=TSP0225.xml, accessed May 12, 2015.

Hamilton Casket Company, Inc. ca. 1940 [Casket Advertising Sheet]. Hamilton Casket Company, Inc., Chicago, Illinois. 
Hamilton, Lemmon, Arnold \& Company

1879 June 7, 1879, Price List (Coffin Hardware). Hamilton, Lemmon, Arnold \& Company, Allegheny City, Pennsylvania, and Pittsburgh, Pennsylvania.

1880 Reduced Price List; Price List of Hardware and Trimmings (June 23, 1880). Hamilton, Lemmon, Arnold \& Company, Pittsburgh, Pennsylvania, and Allegheny, Pennsylvania.

1881 Revised Price List of the Excelsior Coffin and Casket Works (March 8, 1881). Hamilton, Lemmon, Arnold \& Company, Pittsburgh, Pennsylvania, and Allegheny, Pennsylvania.

1882 Illustrated Catalogue of Varnished and Cloth Covered Burial Cases and Caskets. Hamilton, Lemmon, Arnold \& Company, Pittsburgh, Pennsylvania, and Allegheny, Pennsylvania.

1882 Excelsior Coffin and Casket Works: Price Lists of Hardware, Robes, Linings, Trimmings, etc. Manufactured by Hamilton, Lemmon, Arnold \& Company (March 1, 1882). Hamilton, Lemmon, Arnold \& Company, Pittsburgh, Pennsylvania, and Allegheny, Pennsylvania.

1884 Excelsior Coffin \& Casket Works Price List of Hardware, Robes, Linings, Trimmings, \&C. Manufactured by Hamilton, Lemmon, Arnold \& Company. Hamilton, Lemmon, Arnold \& Company, Pittsburgh, Pennsylvania, and Allegheny, Pennsylvania.

1884 Revised Price List of Varnished \& Cloth-Covered Burial Cases and Caskets Manufactured by Hamilton, Lemmon, Arnold \& Company, Excelsior Coffin \& Casket Works (January 16, 1884). Hamilton, Lemmon, Arnold \& Company, Pittsburgh, Pennsylvania, and Allegheny, Pennsylvania.

1886 Excelsior Coffin \& Casket Works: Revised Price List of Coffin \& Casket Hardware, Manufactured by Hamilton, Lemmon, Arnold \& Company (November 1, 1886). Hamilton, Lemmon, Arnold \& Company, Pittsburgh, Pennsylvania, and Allegheny, Pennsylvania.

1886 Excelsior Coffin and Casket Works: Price List of Wrappers, Robes, Linings, Trimmings, \& etc. Manufactured by Hamilton, Lemmon, Arnold \& Company (November 1, 1886). Hamilton, Lemmon, Arnold \& Company, Pittsburgh, Pennsylvania and Allegheny, Pennsylvania.

1887 Price List and Telegraph Key of Varnished and Cloth Covered Burial Cases and Caskets. (January 1, 1887) Hamilton, Lemmon, Arnold \& Company, Pittsburgh, Pennsylvania, and Allegheny, Pennsylvania.

1888 Price List of Wrappers, Robes, Linings, Trimmings etc. (February 1, 1888). Hamilton, Lemmon, Arnold \& Company, Pittsburgh, Pennsylvania, and Allegheny, Pennsylvania.

1888 Revised Price List of Coffin \& Casket Hardware (February 1, 1888). Hamilton, Lemmon, Arnold \& Company, Pittsburgh, Pennsylvania, and Allegheny, Pennsylvania.

Handler, Jerome, and Frederick Lange

1978 Plantation Slavery in Barbados:An Archaeological and Historical Investigation. Harvard University Press, Cambridge, Massachusetts.

Harrisburg Burial Case Company

ca. 1885 Illustrated Catalogue of Coffins, Caskets, and Undertakers'Supplies. Harrisburg Burial Case Company, Harrisburg, Pennsylvania.

Hawley Bros. Hardware Company

1884 No. 15 Price List \& Illustrated Catalog of Hardware \& Agricultural Implements. Hawley Bros. Hardware Company, San Francisco, California. 
Heilen, Michael, and Marlesa A. Gray (editors)

2010 Deathways and Lifeways in the American Southwest: Tucson's Historic Alameda-Stone Cemetery and the Transformation of a Remote Outpost into an Urban City. 3 vols. Statistical Research, Inc., Tucson, Arizona.

Heringer, T. M., Coroner and Norman Haywood

1980 Preliminary Report on the Casket and Human Remains from the Site of Old St. Andrew Roman Catholic Cemetery. Wanikan (Newsletter of the Thunder Bay Chapter of the Ontario Archaeological Society) 80(4):7-10.

Herskovits, Melville J.

1941 The Myth of the Negro Past. Harper \& Brothers Publishers, New York. Electronic document, https://ia601400.us.archive.org/6/items/mythofthenegropa033515mbp/ mythofthenegropa033515mbp.pdf, accessed May 8, 2015.

Hicks, Ira R.

1902 The Rev. Ira R. Hicks Almanac 1901: Word and Works Quarterly Echoes. Vol. 7, No. 2. Word and Works Publishing Co., St. Louis, Missouri.

Hill, F. H. \& Company

ca. 1880 Price List to Accompany Illustrated Catalogue of 1880. F.H. Hill \& Co., Chicago, Illinois.

1881 Illustrated Catalogue of Burial Cases and Caskets, and Undertakers' Supplies. F.H. Hill \& Co., Chicago, Illinois.

1884 Prices of Wood Burial Cases and Caskets (associated with the No. 15 Catalogue (May 20, 1884). F.H. Hill \& Co., Chicago, Illinois.

Hill, M. C., and J. W. Pye

2012 New Home Cemetery (41FB334): Archaeological Search, Exhumation, and Reinterment of Multiple Historic Graves Along FM 1464, Sugar Land, Fort Bend County, Texas (CSJ 1415-02-032). Archeological Studies Program Report No. 145. Environmental Affairs Division, Texas Department of Transportation, Austin.

Hilliard, J., James Davidson, and Lela Donat

n.d. Archeological Investigation of the Droke Graveyard, 3BE655, Benton County, Arkansas. Ms. on file at the Arkansas Archeological Survey, Fayetteville.

Hillson, Simon

1996 Dental Anthropology. Cambridge University Press, Cambridge, United Kingdom. Crossref

Hinks, Stephen

1995 A Structural and Functional Analysis of Eighteenth Century Buttons. Volumes in Historical Archaeology No. 32. The South Carolina Institute of Archaeology and Anthropology, Columbia.

Historical Census Browser

2004 U.S. Census Data. The University of Virginia, Geospatial and Statistical Data Center. Electronic document, http://fisher.lib.virginia.edu/collections/stats/histcensus/index. html, accessed March 15, 2011.

Hogan, William Ransom

1969 The Texas Republic: A Social and Economic History. University of Texas Press, Austin.

Hogue, S. Homes, and Jeffrey S. Alvey

2006 Final Report on Archaeological Burial Recovery at Pepper Hill I Cemetery, 22LO998, Lowndes County, Mississippi. Cobb Institute of Archaeology, Mississippi State University, Mississippi State. 
Hollingsworth, John E. (Commissioner)

1892 Fourth Annual Report of the Agricultural Bureau of the Department of Agriculture, Insurance, Statistics, and History, 1890-91. Hutchings Printing House, Austin.

Houston, Sam

1842 Proclamation by the President of the Republic of Texas, September 16, 1842. Original printed version in H.P.H. Gammel, The Laws of Texas, 1822-1897, Vol. 2:889-904. Gammel Book Co., Austin, Texas, 1898. Reproduced in The Diplomatic Correspondence of the Republic of Texas, Texas Slavery Project online. Electronic document, http://www.texasslaveryproject.org/sources/LawsOfTexas/ display.php?f=TSP0178.xml, accessed May 12, 2015.

Howard, Donna

2009 Leadership Letter. The Medallion, November/December 2009, p. 2.

Hutcheson, Alexis, David Robertson, Annie Veilleux, and Ronald F. Williamson 2008 Cemetery Investigation at the Church of the Assumption of Our Lady, Part of Lots 535 and 536, Village of Bell Ewart, Town of Innisfil, Simcoe County, Ontario. Archaeological Services, Inc., Toronto.

Imperial Casket Company

1935 Price List: Wood Burial Caskets, Metal Caskets, Hardwood Caskets, Vaults, Burial Garments (April 18, 1935). Imperial Casket Company, Kansas City, Missouri.

ca. 1935 [Catalog]. Imperial Casket Company, Kansas City, Missouri.

Ives \& Allen

1871 Price List and Illustrated Catalogue of Hardware. Ives \& Allen, Montreal.

Jackson, F. L. C., A. Mayes, M. E. Mack, A. Froment, S. O. Y. Keita, R. A. Kittles, M. George, K. Shujaa, M. L. Blakey, and L. M. Rankin-Hill

2009 Origins of the New York African Burial Ground Population: Biological Evidence of Geographical and Macroethnic Affiliations Using Craniometrics, Dental Morphology, and Preliminary Genetic Analyses. In The New York African Burial Ground: Unearthing the African Presence in Colonial New York. Vol. 1. Skeletal Biology of the New York African Burial Ground. Part I, edited by Michael L. Blakey and Lesley M. Rankin-Hill, pp. 69-93. Howard University Press, Washington, D.C. Electronic document, http://www.gsa.gov/ largedocs/Vol1-Part1-TheSkeletalBiologyOfTheNYAGB.pdf, accessed May 12, 2015.

Jamieson, Ross W.

1995 Material Culture and Social Death: African American Burial Practices.

Historical Archaeology 29(4):39-58. Crossref

Jervis, Rick

2009 Development Projects Unearth Burial Grounds Across U.S. USA Today online. Posted March 23, 2009. Electronic document, http://usatoday30.usatoday.com/news/nation/200903-23-rangermuseum_N.htm, accessed April 30, 2015.

Jewitt, Llewellynn Frederick William

1883 The Ceramic Art of Great Britain. J. S. Virtue \& Co., Limited, London. Available from Google Books.

Johnson, Charles S.

1934 Shadow of the Plantation. University of Chicago Press, Chicago, Illinois.

Jones, B. C.

1992 Archaeological Evaluation of Lions Club Lot in Cedar Key, Florida: Salvage of Historic Burials and Preservation of Weeden Island (Pasco) Burial Area. Florida Archaeological Reports No. 9. Bureau of Archaeological Research, Division of Historical Resources, Florida Department of State, Tallahassee. 
Jones, J. B., Steven C. Pullins, Courtney Birkett, Elizabeth J. Monroe, Melissa E. Lamb, and William H. Moore

2006 Archaeological Data Recovery at Site 44PO126 Associated with the Proposed Route 288 Project, Powhatan County, Virginia. VDOT Project: 0288-072-104. William and Mary Center for Archaeological Research, The College of William and Mary, Williamsburg, Virginia.

Jones, Marie Beth

2010 Handbook of Texas Online, s.v. "Monroe Edwards." Electronic document, https:// tshaonline.org/handbook/online/articles/fed07, accessed June 5, 2015.

Jordan, Terry G.

1982 Texas Graveyards: A Cultural Legacy. University of Texas Press, Austin.

Joseph, J. W., Mary Beth Reed, and Charles E. Cantley

1991 Agrarian Life, Romantic Death:Archaeological and Historical Testing and Data Recovery For the I-85 Northern Alternative, Spartanburg County, South Carolina. New South Associates Technical Report 39. New South Associates, Stone Mountain, Georgia.

Kalter, Ardi, Sally Victor, and Gary Rutenberg

2005 Identification, Removal, and Reinterment of an Unidentified Female Burial from the Moore Road Cemetery (41TV150), Travis County, Texas. Archeological Studies Program Report No. 79. Environmental Affairs Division, Texas Department of Transportation, Austin.

Katz, Susana R., and Michaele Haynes

1986 Twixt God and Man: An Historical Study of the Seven Rivers Cemetery. Ms. on file, Bureau of Reclamation, Denver, Colorado.

Kelley, Jennifer Olsen, and J. Lawrence Angel

1983 The Workers of Catoctin Furnace. Maryland Archeology 19(1):2-17.

1987 Life Stresses of Slavery. American Journal of Physical Anthropology 74:199-211.

Kelley, Sean M.

2008 Blackbirds and Bozales: African-Born Slaves on the Lower Brazos River of Texas in the Nineteenth Century. Civil War History 59(4):406-423. Crossref

2010 Los Brazos de Dios: A Plantation Society in the Texas Borderlands, 1821-1865. Louisiana State University Press, Baton Rouge.

King, Charlotte

2010 Separated by Death and Color: The African American Cemetery of New Philadelphia, Illinois. Historical Archaeology 44(1):125-137. Crossref

King, Julia A., and Douglas H. Ubelaker

1996 Living and Dying on the 17th Century Patuxent Frontier. The Maryland Historical Trust Press, Crownsville, Maryland.

King, Marsha K., and Beth P. Miller

1991 Archaeological Investigations, Haul Road Trenching, and Disturbance Documentation of the Piggery Point Burials on Deer Island, Boston, Massachusetts. The Public Archaeology Laboratory, Inc., Pawtucket, Rhode Island.

Kiple, Kenneth F., and Virginia Himmelsteib King

1981 Another Dimension to the Black Diaspora. Cambridge University Press, Cambridge, United Kingdom. Crossref

Kleiner, Diana J.

2010 Handbook of Texas Online, s.v. "Brazoria County." Electronic document, http://www. tshaonline.org/handbook/online/articles/hcb12, accessed April 29, 2015. 
Kogon, Stephen L., and Robert G. Mayer

1995 Analysis of Coffin Hardware from Unmarked Burials Former Weselyan Methodist Church Cemetery, Weston, Ontario. North American Archaeologist 16(2):133-162. Crossref

Krogman, Wilton Marion, and Mehmet Yasar Iscan

1986 The Human Skeleton in Forensic Medicine. 2nd ed. Charles C. Thomas, Springfield, Illinois.

Kyriakoudes, Louis, M.

1998 Southern Black Rural-Urban Migration in the Era of the Great Migration: Nashville and Middle Tennessee, 1890-1930. Agricultural History 72(2):341-351.

Lamb, Louis J.

ca. 1895 Catalog of sheet metal coffins and ornaments (with price list). Louis J. Lamb, Attleboro, Massachusetts.

ca. 1895 No. 2 Price List of Sheet Metal Coffin hardware. Louis J. Lamb, Attleboro, Massachusetts.

Landtech Consultants, Inc.

n.d. $\quad$ State Highway 332 Project Map Showing Pioneer Cemetery and Surrounding Blocks of the Old Townsite of Brazoria, and Locations of Unmarked Graves Found In 2003. Sheet 1 of Control No. 0847, Section No. 03, Job No. 029. Landtech Consultants, Inc., Houston, Texas. Map on file at Archeological Studies Program, Environmental Affairs Division, Texas Department of Transportation, Austin.

Langsjoen, Odin

1998 Diseases of the Dentition. In The Cambridge Encyclopedia of Human Paleopathology, by Arthur C. Aufderheide and Conrado Rodríguez-Martín, pp. 393-412. Cambridge University Press, Cambridge, United Kingdom.

Larsen, Clark Spencer

1997 Bioarchaeology. Cambridge University Press, Cambridge, United Kingdom. Crossref

Lawrence, John W., Paul W. Schopp, and Robert J. Lore

2009 "They Even Threaten the Sick That They Will Not Be Buried in the Churchyard": Salvage Archaeology of the Raritan-in-the-Hills Cemetery, Somerset County, New Jersey. Historical Archaeology 43(1):93-114.

Lebo, Susan A.

1988 An Archaeological and Bioarchaeological Perspective:The Tucker (41DT104) and Sinclair (41DT105) Cemeteries of Delta County, Texas. Institute of Applied Sciences, Department of Biological Sciences, University of North Texas, Denton.

Lee, A. B.

2002 Report of Field Investigations for the Relocation of the Hosier Family Cemetery, Butler Township, Montgomery County, Ohio, MOT-75-3.842 (PID19070). Hardlines Design Company, Columbus, Ohio.

Lee, Nedra Kristina

2009 RIP Bull Hill Cemetery: Archaeological and Historical Investigation and Descendant Community Outreach on an African American Graveyard in Marlin, Falls County, Texas. M.A. thesis, Department of Anthropology, University of Texas at Austin.

Lee, Nedra, and Jim Bruseth

2008 Archeological and Historical Investigation and Descendant Community Outreach on an African American Graveyard: The Case of Bull Hill Cemetery, Falls County, Texas. Report submitted to the Summerlee Foundation of Texas and the Summerfield G. Roberts Foundation. Texas Historical Commission, Austin. 
LeeDecker, Charles H., Jonathan Bloom, Ingrid Wuebber, and Marie-Lorraine Pipes

1995 Final Archaeological Excavations at a Late 18th-Century Family Cemetery for the U.S.

Route 113 Dualization, Milford to Georgetown, Sussex County, Delaware. DelDOT Archaeology Series No. 134. The Cultural Resource Group, Louis Berger \& Associates, Inc., East Orange, New Jersey, with Karen R. Rosenberg, Department of Anthropology, University of Delaware.

LeeDecker, C., Jason Shellenhamer, and Stephanie Jacobe

2009 "A Vapor That Appeareth for a Little Time and Then Vanisheth Away": Archaeology of the Wrenn-Hutchison Cemetery, Chantilly, Virginia. Louis Berger Group, Inc., Washington, D.C.

Lefferts, Peter M.

2012 Black US Army Bands and Their Bandmasters in World War I. Paper No. 25.

Faculty Publications: School of Music. Paper No. 25. Digital Commons, University of Nebraska-Lincoln. Electronic document, http://digitalcommons.unl.edu/ musicfacpub/25?utm_source=digitalcommons.unl.edu\%2Fmusicfacpub\%2F25\&utm medium=PDF\&utm_campaign=PDFCoverPages, accessed March 25, 2015.

Leone, Mark P., Jennifer Babiarz, and Cheryl LaRoche

2005 The Archaeology of Black Americans in Recent Times. Annual Review of Anthropology 34:575-598. Crossref

Lillie, Robin M., and Jennifer E. Mack

2013 Bioarchaeology and History of Dubuque's Third Street Cemetery, 13DB476, Dubuque County, Iowa. Research Papers Vol. 37, No. 1. Office of the State Archeologist, University of Iowa, Iowa City. Electronic document, http://www.academia.edu/6118271/ Bioarchaeology_and_History_of_Dubuques_Third_Street_Cemetery_13DB476_ Dubuque_County_Iowa.

Lipovitch, David, Eva MacDonald, Irena Miklavcic, David Robertson, and Ronald Williamson 2003 Archaeological Investigations of the Elmbank Church and Cemetery, former Lot 8, Concession 5, Toronto Township, Peel County, Ontario. Archaeological Services, Inc.

Little, Barbara J., Kim M. Lanphear, and Douglas W. Owsley

1992 Mortuary Display and Status in a Nineteenth-Century Anglo-American Cemetery in Manassas, Virginia. American Antiquity 57(3):397-418. Crossref

Little, M. Ruth

1989 Afro-American Gravemarkers in North Carolina. Markers VI: Journal of the Association for Gravestone Studies:103-137. Edited by Theodore Chase. Electronic document, https:// archive.org/details/markers06asso, accessed March 9, 2015.

Litwack, Leon F.

1998 Trouble in Mind: Black Southerners in the Age of Jim Crow. Vintage Books, Random House, New York.

Lockhart, William L.

1881 Wholesale Price List of Caskets and Coffins. Wm. L. Lockhart, East Cambridge, Massachusetts.

1883 Price List and Telegraph Key of Solid Mahogany and Cloth Covered Caskets as Shown in Advance Plates. Wm. L. Lockhart, East Cambridge, Massachusetts.

Long, Christopher

2010 Handbook of Texas Online, s.v. “Old Three Hundred.” Electronic Document, http:// www.tshaonline.org/handbook/online/articles/umo01, accessed March 26, 2015.

Louisville Coffin Company

1893 Price List Wood Burial Cases and Caskets and Cloth covered Caskets. Louisville Coffin Company, Louisville, Kentucky. 
Lovejoy, C. O., R. S. Meindl, T. R. Pryzbeck, and R. P. Mensforth

1985 Chronological Metamorphosis of the Auricular Surface of the Ilium: A New Method for the Determination of Adult Skeletal Age at Death. American Journal of Physical Anthropology 68:15-28.

MacHart, Charles, and Ellen Stephenson

1997 Interview with Caretakers of Pioneer Cemetery in Brazoria, Texas. In Historical and Archeological Investigation of the SH 332 Crossing of the Brazos River, Brazoria County, Texas, by Diane C. Dismukes and Allen C. Bettis, Jr., p. 53. Texas Department of Transportation, Austin.

Magoon, D., Lynette Norr, Dale L. Hutchinson, and Charles R. Ewen

2001 An Analysis of Human Skeletal Materials from the Snow Beach Site (8WA52). Southeastern Archaeology 20(1):18-30.

Mainfort, Robert C., Jr., and James M. Davidson (editors)

2006 Two Historic Cemeteries in Crawford County, Arkansas. Arkansas Archeological Survey Research Series No. 62. Arkansas Archeological Survey, Fayetteville.

Manger, E.C. \& Son Company

ca. 1890 Catalogue No. 2. E.C. Manger \& Son Company, Green Bay, Wisconsin.

1920s Casket Catalog C. E.C. Manger \& Son Company, Green Bay, Wisconsin.

Markham \& Strong

1865 Revised Price List of Goods Manufactured by Markham \& Strong, East Hampton, Connecticut. Markham \& Strong, East Hampton, Connecticut.

Marks, George E.

1988 Marks' Patent Artificial Limbs with Rubber Hands \& Feet. A. A. Marks, New York. Electronic document, http://babel.hathitrust.org/cgi/pt?id=loc.ark:/13960/ t6h14501h;view=1up;seq=59, accessed September 9, 2015.

Marsellus, John, Casket Company

ca. 1948 Semi-Centennial Catalog. John Marsellus Casket Company, Syracuse, New York.

Maryland Burial Case Company

1887 Price List - Wood coffins \& Caskets. Maryland Burial Case Company, Baltimore, Maryland.

Mathews, T. J., and Marian F. MacDorman

2010 Infant Mortality Statistics from the 2006 Period Linked Birth/Infant Death Data Set. National Vital Statistics Reports 58(17). U.S. Centers for Disease Control, Atlanta, Georgia.

Matternes, Hugh B.

1998a The Cool Branch Cemetery (40HK9). In A Final Report on Archaeological Investigations of Sites 40HK5, 40HK6, 40HK7, and 40HK9, State Route 31 Corridor from Mountain Valley Road, Hancock County, Tennessee, edited by S. Meters, Hugh B. Matternes, C. Bentz, and B. J. Duggan, pp. 130-186. Transportation Research Center, University of Tennessee, Knoxville.

1998b Who Are the People in Cool Branch Cemetery (40HK9)? A Bioanthropological Case Study. Tennessee Anthropologist 23(1 \& 2):73-85.

Matternes, Hugh B., and Karen Serio

2005 1SC320: A Rural 19th Century Cemetery on the Outskirts of Ragland, Alabama, Saint Clair County, Alabama. In New South Associates Technical Report No. 1274. New South Associates, Stone Mountain, Georgia. 
McCarthy, John P.

1997 Material Culture and the Performance of Sociocultural Identity: Community, Ethnicity, and Agency in the Burial Practice at the First African Baptist Church Cemeteries, Philadelphia, 1810. In American Material Culture: The Shape of the Field, edited by Ann Smart Martin and J. Ritchie Garrison, pp. 359-379. Henry Francis du Pont Winterthur Museum, Winterthur, Delaware.

1998 Plates in Graves: An Africanism? African Diaspora Archaeology Newsletter 5(2):Article 3. Electronic document, http://scholarworks.umass.edu/adan/vol5/iss2/3, accessed March 13, 2015.

McGhee, Fred Lee

2000 The Black Crop: Slavery and Slave Trading in Nineteenth Century Texas. Ph.D. dissertation, Department of Anthropology, The University of Texas at Austin.

McKee, Larry

1998 Some Thoughts on the Past, Present, and Future of the Archaeology of the African Diaspora. African-American Archaeology 21 (Spring 1998). Online Newsletter of the African-American Archaeology Network. Electronic document, http://www.diaspora. uiuc.edu/A-AAnewsletter/newsletter21.html, accessed November 12, 2010.

McLain, Neal

2009 The Old Three Hundred in Brazoria County. Culture History Series, Texas Master Naturalist Program, Cradle of Texas Chapter. Electronic document, http://txmn.org/ cradle/files/2010/07/download103.pdf, accessed May 26, 2015.

McReynolds, M. J.

1981 Archaeological Investigations at the Laredo Cemetery Site (41WB22), Webb County, Texas. Report of Investigations No. 11. Prewitt and Associates, Inc., Austin.

McWilliams, Jennifer K., Catrina Banks Whitley, Jeremy W. Pye, Terri Myers, James T. Abbott, and Douglas K. Boyd

2014 Historic Archeological Investigations at Roberts Cemetery Near Troy, Bell County, Texas. Reports of Investigations No. 169, Prewitt and Associates, Inc., Austin. Archeological Studies Program Report No. 160, Environmental Affairs Division, Texas Department of Transportation, Austin.

Mears, Michelle M.

2009 And Grace Will Lead Me Home: African American Freedmen Communities of Austin, Texas, 1865-1928. Texas Tech University Press, Lubbock.

Mechanicstown Burial Case Company

1888 Illustrated Catalogue of Coffins, Caskets, and Undertakers' Supplies, mfg and sold by Mechanicstown Burial Case Company Mechanicstown Burial Case Company, Mechanicstown, Maryland.

Medford, Edna Greene (editor)

2009 The New York African Burial Ground:Unearthing the African Presence in Colonial New York. Vol. 3. Historical Perspectives of the African Burial Ground: New York Blacks and the Diaspora. Howard University Press, Washington, D.C. Electronic document, http:// www.gsa.gov/largedocs/Vol3-HistoricalPerspectivesOfTheNYABG.pdf, accessed May 12, 2015.

Meer, R. M.

1990 Report of Investigations of Skeletal Remains Recovered from the Stoltz Site (B0Z0048/198807), Ozaukee County, Wisconsin. State Historical Society of Wisconsin, Burial Site Preservation Program, Madison, Wisconsin. 
Meindl, Richard S., and C. Owen Lovejoy

1985 Ectocranial Suture Closure: A Revised Method for the Determination of Skeletal Age at Death Based on the Lateral-Anterior Sutures. American Journal of Physical Anthropology 68:57-66.

Mercado-Allinger, Pat, and James Bruseth

2011 Unraveling the Mystery of James Coryell, Texas Ranger. Current Archeology in Texas 13(1):1-3.

Meriden Britannia Company

1869 Illustrated and Descriptive Price List of Coffin and Casket Trimmings. Meriden Britannia Company, Meriden, Connecticut.

1876 Second 1876 Supplement of Wm. M. Smith's original designs of Casket Trimmings. Meriden Britannia Company, West Meriden, Connecticut.

1880 Illustrated catalogue of Wm. M. Smith's fin silver, bronze, etc Casket trimmings. Meriden Britannia Company, West Meriden, Connecticut.

Merit Company

1954 Metal Caskets (November 15, 1954). Merit Company, Chicago, Illinois.

Meskell, Lynn

2002 The Intersections of Identity and Politics in Archaeology. Annual Review of Anthropology 31:279-301. Crossref

Meyer, Richard E.

1989 Cemeteries and Gravemarkers: Voices of American Culture. Utah State University Press, Logan.

Miklavcic, Irena

2001 Archaeological Assessment of the South Boundary of St. Paul's Pioneer Cemetery-Project P.50.15.2000, Town of Newmarket, Regional Municipality of York, Ontario. Archaeological Services, Inc., Toronto.

Miles, A. E. W.

1962 Assessment of the Ages of a Population of Anglo-Saxons from Their Dentitions. Proceedings of the Royal Society of Medicine 55:881-886.

Miller Bros. \& Company

ca. 1871 Illustrated Catalogue of Coffin Trimmings. Miller Bros. \& Company, Boston, Massachusetts.

Miller, K. A.

1996 Archaeological Investigations at 41TV1696 - The Givens Grave Site, Travis County, Texas. Archaeological Report No. 96-57. SWCA, Inc., Environmental Consultants, Austin, Texas.

Mills, Ellen S.

1979 Graves in the Gravel: The Unmarked Cemetery of Las Vegas, New Mexico. Master's thesis, New Mexico Highlands University, Las Vegas, New Mexico.

Milwaukee Casket Company

ca. 1911 Casket Catalogue D: Manufacturers \& Jobbers of a complete line of.... Milwaukee Casket Company, Milwaukee, Wisconsin.

Minnesota Casket Company

1923 Catalogue "B", manufacturers of caskets of redwood, resist decay. Minnesota Casket Company, Minneapolis, Minnesota. 
Mitchell Casket Company ca. 1900 Cloth Covered Caskets. Mitchell Casket Company, Mitchell, Indiana.

Montgomery Ward and Company

1895 Montgomery Ward \& Co. Catalog and Buyers' Guide, Spring \& Summer 1895. An unabridged reprint of the original edition with a new introduction by Boris Emmet. Dover Publications, Inc., New York.

Moorrees, Coenraad F. A., Elizabeth A. Fanning, and Edward E. Hunt, Jr.

1963a Formation and Resorption of Three Deciduous Teeth in Children. American Journal of Physical Anthropology 21:205-213.

1963b Age Variation of Formation Stages for Ten Permanent Teeth. Journal of Dental Research 42:1490-1502.

Mound Coffin Company

1920 (unnamed); Contains caskets, robes, linings Mound Coffin Company, St. Louis, Missouri.

1924 Wholesale Price List (for) Metal, Cloth and Varnished Coffins; metal linings; funeral dry goods, sundries, etc. Mound Coffin Company, St. Louis, Missouri.

Mountain States Casket Company

1916 Price List. Mountain States Casket Company, Denver, Colorado.

Murphy, John \& Company

ca. 1900 [Catalogue]. John Murphy \& Co., Pittsburgh, Pennsylvania.

ca. 1900 Price List of Hardware, Robes, Linings, and Undertakers'Supplies. John Murphy \& Co., Pittsburgh, Pennsylvania.

1923 Price List Applying to 1922 Catalogue (February 9. 1923). John Murphy \& Co., Pittsburgh, Pennsylvania.

National Casket Company

1891 Catalogue A. National Casket Company, New York.

1896 Complete Price List of Burial Robes, Linings, and Miscellaneous Dry Goods. National Casket Company, New York.

ca. 1896 Supplement to Pocket Edition of Casket Catalogue B. National Casket Company, New York.

1897 Catalogue No. 12, Illustrating Undertakers’ Hardware. National Casket Company, New York.

1899 National Casket Company Complete Price List and Telegraph Code Accompanying Pocket Catalogue " $D$ ". National Casket Company, New York.

ca. 1905 Catalogue “K” (caskets). National Casket Company, New York.

1908 Catalogue “L” (caskets). National Casket Company, New York.

1910 Wholesale Price List for Casket Catalogue "L” National Casket Company, New York.

1911 Catalogue M. National Casket Company, New York.

1922 Catalogue Q. National Casket Company, Baltimore, Maryland. 
1922

1922

1922

1923

1923

1923

1923

1923

1924

1931

1931

1931

Price List Applying to Catalogue "Q" (March 23, 1922). National Casket Company, Pittsburgh, Pennsylvania.

[Supplement] New Pine Box Prices (October 30, 1922). National Casket Company, Pittsburgh, Pennsylvania.

Price List Applying to Catalogue “Q” (November 1, 1922). National Casket Company, Pittsburgh, Pennsylvania.

Bronze Sarcophagi, Illustrating and Describing some Ancient Customs, Past Masterpieces and Present Tendencies in the Finest Types of Burial Enclosures. National Casket Company, Albany, New York.

[Supplement] Casket and Outer Box Prices (January 29, 1923). National Casket Company, Pittsburgh, Pennsylvania.

[Supplement] Burial Robes and Lining Prices (February 12, 1923). National Casket Company, Pittsburgh, Pennsylvania.

Price List Applying to Catalogue "Q” (June 11, 1923). National Casket Company, Pittsburgh, Pennsylvania.

Price List Applying to Catalogue “Q” (October 1, 1923). National Casket Company, Pittsburgh, Pennsylvania.

Price List Applying to Catalogue “Q” (February 23, 1924). National Casket Company, Pittsburgh, Pennsylvania.

Price List Applying to Catalogue “Q” (December 1, 1924). National Casket Company, Pittsburgh, Pennsylvania.

Dry Goods Price List (April 1, 1925). National Casket Company, Pittsburgh, Pennsylvania.

Price List Applying to Catalogue “Q” (December 27, 1927). National Casket Company, Baltimore, Maryland.

Catalog “RC”, Covered Caskets. National Casket Company, New York.

[Supplement] New Numbers for Caskets Shown in Metal Casket Catalog RM (December 1, 1930). National Casket Company, Pittsburgh, Pennsylvania.

[Supplement] New Numbers for Caskets Shown in Catalog RC and RH (February 10, 1931). National Casket Company, Pittsburgh, Pennsylvania.

Price List-Casket Catalogues $R C$, $R H$, and $R M$ (February 15, 1931). National Casket Company, Pittsburgh, Pennsylvania.

Price List-Casket Catalogues RC, RH, and RM (February 24, 1931). National Casket Company, New York.

Catalog "SMHC", Metal Hardwood, and Cloth Covered Caskets. National Casket Company, Syracuse, New York.

Catalog “T” Metal, Hardwood, and Covered Caskets. National Casket Company, Philadelphia, Pennsylvania.

National Metal Products Company

n.d. [Casket Hardware Advertising Cards] National Metal Products Company, Connersville, Indiana. 
National Park Service

n.d. Draft Management Recommendations for the African Burial Ground. Northeast Region, African Burying Ground National Historic Landmark, National Park Service African Burial Ground Technical Assistance Project, U.S. Department of the Interior. Philadelphia, Pennsylvania. Electronic document, http://parkplanning.nps.gov/ document.cfm?parkID=467\&projectID=13667\&documentID=12695, accessed May 12, 2015.

New York African Burial Ground Project

2009 The New York African Burial Ground: Unearthing the African Presence in Colonial New York. Howard University Press, Washington, D.C. Electronic documents, http:// www.gsa.gov/portal/mediaId/172603/fileName/Acknowledgment+Credits_Vol_5_ GenAudNYABG_2-2.action, and http://www.gsa.gov/largedocs/Vol5_GenAud_NYABG_2. pdf, accessed May 12, 2015.

Noble, Diana

2008 Letter from Diana Noble, Director of Environmental Affairs Division, Texas Department of Transportation, to F. Lawerence Oaks, State Historic Preservation Officer, Texas Historical Commission, December 15, 2008. On file at the Archeological Studies Program, Environmental Affairs Division, Texas Department of Transportation, Austin.

Norris, C., Sidney, \& Company

ca. 1880 Illustrated Catalogue of Coffin Handles and Undertakers' Trimmings. C. Sidney Norris \& Company, Boston, Massachusetts.

ca. 1880 Price List of Coffin Handles and Undertakers' Trimmings. C. Sidney Norris \& Company, Boston, Massachusetts.

Okuda, T., I. Baba, Y. Fujimoto, N. Tanaka, T. Sumida, H. Manabe, Y. Hayashi, and M. Ochi

2004 The Pathology of Ligamentum Flavum in Degenerative Lumbar Disease. Spine 29:1689-1697.

Oregon Casket Company

ca. 1932 Catalogue " $G$ ". Oregon Casket Company, Portland, Oregon.

Orser, Charles E., Jr., Annette M. Nekola, and James L. Roark

1987 Exploring the Rustic Life: Multidisciplinary Research at Millwood Plantation, a Large Piedmont Plantation in Abberville County, South Carolina, and Elbert County, Georgia. Russell Papers. Mid-American Research Center, Loyola University of Chicago.

Ortner, Donald J.

2003 Identification of Pathological Conditions in Human Skeletal Remains. 2nd ed. Academic Press, San Diego, California.

Oster, Warren J., Guy G. Weaver, Jamison P. Richardson, and Jason M. Wyatt

2005 Archaeological and Osteological Investigations of the Providence Baptist Church Cemetery (40SY619), Memphis-Shelby County Airport, Memphis, Shelby County, Tennessee. Weaver \& Associates, LLC., Memphis, Tennessee.

Owens, Victoria M.

2000 Personal, Clothing, and Miscellaneous Items Associated with Excavated Burials. In Freedman's Cemetery: A Legacy of a Pioneer Black Community in Dallas, Texas, Vol. 2, edited by Duane E. Peter, Marsha Prior, Melissa M. Green, and Victoria G. Clow, pp. 409-447. Special Publications No. 6, Geo-Marine, Inc., Plano, Texas. Archeology Studies Program Report No. 21, Environmental Affairs Division, Texas Department of Transportation, Austin.

Owsley, Douglas W.

1994 Bioarchaeology on a Battlefield: The Abortive Confederate Campaign in New Mexico. Archaeology Notes No. 142. Office of Archaeological Studies, Museum of New Mexico, Santa Fe. 
1995 Contributions of Bioarchaeological Research to Knowledge of Nineteenth-Century Surgery. In Grave Reflections: Portraying the Past through Cemetery Studies, edited by Shelley R. Saunders and Ann Herring, pp. 119-151. Canadian Scholar's Press, Inc., Toronto.

Owsley, Douglas W., James K. Krakker, Milton Jacobs, and Robert W. Mann

1992 The History and Archaeology of St. James Episcopal Church, Brandy Station, Virginia (Site No. 44CU90). Bookcrafters, Fredricksburg, Virginia.

Owsley, Douglas W., William F. Hanna, Malcom L. Richardson, and Laurie E. Burgess 2003 [2001] Bioarcheological and Geophysical Investigation: The Soldiers Plot, Emmanuel Lutheran Church Cemetery, New Market, Virginia (Site No. 44SH364). ASV Special Publication Number 41. Archeological Society of Virginia. Spectrum Press, Richmond, Virginia.

Owsley, Douglas W., Charles E. Orser, Jr., Robert W. Mann, Peer H. Moore-Jansen, and Robert L. Montgomery

1987 Demography and Pathology of an Urban Slave Population from New Orleans. American Journal of Physical Anthropology 74:185-197.

Owsley, Douglas W., Charles E. Orser, Jr., Robert Montgomery, and Claudia C. Holland

1985 An Archaeological and Physical Anthropological Study of the First Cemetery in New Orleans, Louisiana. Department of Geography and Anthropology, Louisiana State University, Baton Rouge.

Painter, Mary, Ann L. Magennis, Christian J. Zier, Nell Mitchell, Lawrence B. Conyers, and John D. Kennedy

2002 Archaeological and Osteological Investigations of Cemetery 2 on the Grounds of the Colorado Mental Health Institute at Pueblo, Pueblo County, Colorado. Centennial Archaeology, Inc. and Colorado State University, Fort Collins, Colorado.

Pantazis, G., P. Tsitopoulos, A. Bibis, C. Mihas, I. Chatzistamou, and C. Kouzelis

2008 Symptomatic Ossification of the Ligamentum fFavum at the Lumbar Spine: A Retrospective Study. Spine 33:306-311.

Parrington, Michael, Daniel G. Roberts, Stephanie A. Pinter, and Janet C. Wideman

1989 The First African Baptist Church Cemetery: Bioarchaeology, Demography, and Acculturation of Early Nineteenth Century Philadelphia Blacks. John Milner Associates, Inc., Philadelphia, Pennsylvania.

Parson's Casket Hardware Company

$194749^{\text {th }}$ Annual Edition Catalogue. Parson's Casket Hardware Company, Belvidere, Illinois.

Paxson, Comfort \& Company

ca. 1870 Illustrated Catalogue of Wood and Metallic Burial caskets, Coffins, Corpse Preservers and Linings. Paxson, Comfort \& Company, Philadelphia, Pennsylvania.

pre-1878 Illustrated Catalogue of Undertakers' Supplies. Paxson, Comfort \& Company, Philadelphia, Pennsylvania.

1881 Illustrated Catalogue of Undertakers' Supplies., Philadelphia, Pennsylvania.

1884 Illustrated and descriptive catalogue of wood, metallic, and cloth covered burial caskets. Paxson, Comfort \& Company, Philadelphia, Pennsylvania.

1884 Reduced Wholesale Price List, to Accompany Illustrated Catalogue of December 1881. Paxson, Comfort \& Company, Philadelphia, Pennsylvania.

1886 Supplementary Catalogue of Undertakers' Hardware. Paxson, Comfort \& Company, Philadelphia, Pennsylvania. 
1889 Wholesale Price List of Untrimmed Coffins and Caskets for Sale to the Trade Only, By Paxson, Comfort \& Company Paxson, Comfort \& Company, Philadelphia, Pennsylvania.

ca. 1890 Catalogue of Burial Caskets for Sale to the Trade only by The Paxson \& Comfort Company Paxson, Comfort \& Company, Philadelphia, Pennsylvania.

ca. 1890 Price List of Elegant Emblems Made from Natural Flowers, Also Preserved Flowers and Prepared Italian Wheat Adapted Especially for Funeral Purposes. Paxson, Comfort \& Company, Philadelphia, Pennsylvania.

ca. 1890 Wholesale Pricelist of Burial Robes, Wrappers, Dresses, Suits, Habits, \&c., \&c. Manufactured by Paxson, Comfort \& Company Paxson, Comfort \& Company , Philadelphia, Pennsylvania.

1893 Illustrated and Descriptive Catalogue of Wood, Metallic, and Cloth Covered Burial Caskets and Coffins. Paxson, Comfort \& Company, Philadelphia, Pennsylvania.

1898 Illustrated and Descriptive Catalogue of Wood, Cloth-covered and Metallic Burial Caskets and Coffins For Sale to the Trade Only by Paxson, Comfort \& Company Paxson, Comfort \& Company, Philadelphia, Pennsylvania.

Pearce, Robert J.

1989 Excavation of the Wise Family Pioneer Cemetery and Homestead, Lot 17, Concession 2, Town of Richmond Hill. Museum of Indian Archaeology, London, and Affiliate of the University of Western Ontario.

Pearson, C. E.

1978 The Rabbit Hill Site: A Late Nineteenth Century Southern Plains Indian Burial at Fort Sill, Oklahoma. Bulletin of the Oklahoma Anthropological Society 27:171-178.

Peck \& Walter Manufacturing Company

1853 Price list.... Peck \& Walter Mfg. Company, New Britain, Connecticut.

Peck \& Walter Manufacturing Company \& Sargent \& Bros.

1857 Cabinet Maker's Hardware. Peck \& Walter Mfg. Company, \& Sargent \& Bros., New Haven, Connecticut.

Perry, Warren R.

2009 Epilogue. In The New York African Burial Ground: Unearthing the African Presence in Colonial New York. Vol. 2. The Archaeology of the New York African Burial Ground. Part 1, edited by Warren R. Perry, Jean Howson, and Barbara A. Bianco, pp. 375-376. Howard University Press, Washington, D.C. Electronic document, http://www.gsa.gov/ largedocs/Vol2-Part1-TheArchaeologyOfTheNYABG.pdf, accessed May 12, 2015.

Perry, Warren R., Jean Howson, and Barbara A. Bianco

2009 Summary and Conclusions. In The New York African Burial Ground: Unearthing the African Presence in Colonial New York. Vol. 2. The Archaeology of the New York African Burial Ground. Part 1, edited by Warren R. Perry, Jean Howson, and Barbara A. Bianco, pp. 367-374. Howard University Press, Washington, D.C. Electronic document, http:// www.gsa.gov/largedocs/Vol2-Part1-TheArchaeologyOfTheNYABG.pdf, accessed May 12, 2015.

Perry, Warren R., Jean Howson, and Barbara A. Bianco (editors)

2009a The New York African Burial Ground: Unearthing the African Presence in Colonial New York. Vol. 2. The Archaeology of the New York African Burial Ground. Part 1. Howard University Press, Washington, D.C. Electronic document, http://www.gsa.gov/largedocs/ Vol2-Part1-TheArchaeologyOfTheNYABG.pdf, accessed May 12, 2015. 
2009b The New York African Burial Ground: Unearthing the African Presence in Colonial New York. Vol. 2. The Archaeology of the New York African Burial Ground. Part 2: Descriptions of Burials. Howard University Press, Washington, D.C. Electronic document, http://www. gsa.gov/largedocs/Vol2-Part2-ArchOfNYABG-BurialDescriptions.pdf, accessed May 12, 2015 .

Peter, Duane E., Marsha Prior, Melissa M. Green, and Victoria G. Clow (editors)

2000 Freedman's Cemetery: A Legacy of a Pioneer Black Community in Dallas, Texas. 2 vols. Special Publications No. 6, Geo-Marine, Inc., Plano, Texas. Archeology Studies Program Report No. 21, Environmental Affairs Division, Texas Department of Transportation, Austin.

Phenice, T. W.

1969 A Newly Developed Visual Method of Sexing the Os Pubis. American Journal of Physical Anthropology 30:297-302. Crossref

Philadelphia Manufacturing Company

1949 Casket Hardware by Philadelphia. Philadelphia Mfg. Company, Philadelphia, Pennsylvania.

ca. 1950 Casket Hardware. Philadelphia Mfg. Company, Philadelphia, Pennsylvania.

Piper, H. M., and Jacquelyn G. Piper

1982 Archaeological Excavations at the Quad Block Site, 8-Hi-998, Located at the Site of the Old Fort Brooke Municipal Garage, Tampa, Florida. Piper Archaeological Research, Inc., St. Petersburg, Florida.

Pomfret, J.

2003 Disinterment and Relocation of an Abandoned Cemetery in Stewart County, Georgia. GDOT Project No. EDS-27(173). Cultural Resources Division, Georgia Department of Transportation, Atlanta.

Powdermaker, Hortense

1939 After Freedom: A Cultural Study in the Deep South. Viking Press, New York.

Powell, G. S.

2000 Emergency Excavations and Preliminary Analyses of Artifacts and Skeletal Remains from the St. Francis Regis Cemetery, Kansas City, Missouri. CAR Project 1128. Center for Archaeological Research, Southwest Missouri State University, Springfield.

Powell, Leah Carson

1998 Folk Narratives, Archaeology, and Descendant Communities: A Case Study of the Albert J. Phillips Memorial Cemetery (41GV125), Galveston County, Texas. M.A. thesis, Department of Anthropology, Texas A\&M University, College Station.

Powers \& Walker Casket Company

ca. 1896 Catalogue C, High Class Cloth Covered and Varnished Caskets. Powers \& Walker Casket Company, Grand Rapids, Michigan.

Prewitt and Associates, Inc.

2011 Final Analysis and Reporting Plan for Pioneer Cemetery Burial Excavations, 41BO202, Brazoria County, Texas. Management document, September 30, 2011. Submitted to the Archeological Studies Program, Environmental Affairs Division, Texas Department of Transportation, Austin.

Prior, Marsha, and Terry Anne Schulte

2000 Freedmen's Town/North Dallas: The Convergence and Development of an African American Community. In Freedman's Cemetery: A Legacy of a Pioneer Black Community in Dallas, Texas, Vol. 1, edited by Duane E. Peter, Marsha Prior, Melissa M. Green, and Victoria G. Clow, pp. 69-116. Special Publications No. 6. Geo-Marine, Inc., Plano, Texas. Archeology Studies Program Report No. 21, Environmental Affairs Division, Texas Department of Transportation, Austin. 
Puckett, Newbell Niles

1926 Folk Beliefs of the Southern Negro. University of North Carolina Press, Chapel Hill.

Pye, Jeremy W.

2007 A Look Through the Viewing Glass: Social Status and Grave Analysis in a 19th Century Kansas Cemetery. M.A. thesis, University of Arkansas, Fayetteville.

2010a Analysis of Burial Container Construction and Elaboration at the Tucson City Cemetery, Tucson, Arizona. Department of Anthropology, University of Florida, Gainesville.

2010b Typology and Analysis of Burial Container Hardware Recovered from the Excavation of Rambo Cemetery, Rome, Georgia. University of Florida, Gainesville, Florida.

Raemsch, Carol A., and J. W. Bouchard

2000 The Henry Lehman Family Cemetery: A Unique Contribution to Nineteenth-Century Domestic Archaeology. In Nineteenth and Early Twentieth-Century Domestic Site Archaeology in New York State, edited by J. P. Hart, and Charles L. Fisher. New York State Museum Bulletin, No. 495. The University of the State of New York, New York State Education Department, Albany, New York.

Rainville, Lynn

2009 Home at Last: Mortuary Commemoration at Virginia Slave Cemeteries. In Markers XXVI: Journal of the Association of Gravestone Studies, pp. 54-83. Greenfield, Massachusetts.

Rathbun, Ted A.

1987 Health and Disease at a South Carolina Plantation, 1840-1870. American Journal of Physical Anthropology 74:239-253. Crossref

Reynolds, M., and Erin Kane

2010 Relocation of the Rambo Family Cemetery, Rome, Floyd County, Georgia: Final Report. Brockington and Associates, Inc., Atlanta, Georgia.

Rhine, Stanley

1990 Non-Metric Skull Racing. In Skeletal Attribution of Race: Methods for Forensic Anthropology, edited by George W. Gill and Stanley Rhine, pp. 9-20. Anthropological Papers No. 4, Maxwell Museum of Anthropology, University of New Mexico, Albuquerque.

Rice, Lawrence D.

1971 The Negro in Texas, 1874-1900. Louisiana State University Press, Baton Rouge.

Rice, Mitchell F., and Woodrow Jones, Jr.

1990 Health of Black Americans from Post Reconstruction to Integration, 1871-1969: An Annotated Bibliography of Contemporary Sources. Greenwood Press, New York.

Richards, Patricia B.

1997 Unknown Man No. 198: The Archaeology of the Milwaukee County Poor Farm Cemetery. Ph.D. dissertation, Department of Anthropology, The University of Wisconsin, Milwaukee, Wisconsin. University Microfilms International, Ann Arbor, Michigan.

Richards, Patricia B., and Matthias W. Kastell

1993 Archaeological Excavations at the Almshouse Burial Ground, Milwaukee County Poorhouse, Wauwatosa, Wisconsin. 2 vols. Great Lakes Archaeological Research Center, Inc., Report of Investigations, Number 333. Milwaukee, Wisconsin.

Rinehart, Charlie J., Megan Rupnik, J. Lee Tippett, Stephanie Jacobe, Stuart Fiedel, and Eric Voigt 2009 Data Recovery at Guinea Road Cemetery (Site 44Fx1664) Route 236 (Little River Turnpike), Fairfax County, Virginia. VDOT Project:0236-029-120, RW201; PPMS No.:17671; VDHR File No.:2004-0680. The Louis Berger Group, Richmond, Virginia. 
Robbins, Fred

1972 The Origins and Development of the African Slave Trade into Texas, 1816-1860. M.A. thesis, University of Houston, Houston, Texas.

Rock Fall Mfg Company ca. 1890 Columbian Catalogue No. 7. Rock Falls Manufacturing Company, Sterling, Illinois.

Rockwell Casket Company n.d. (>1899) [Advertising card of standard measurements for caskets, outside boxes and vaults] Rockwell Casket Company, Rockwell, North Carolina.

Roediger, David R.

1981 And Die in Dixie: Funerals, Death, \& Heaven in the Slave Community 1700-1865. The Massachusetts Review 22(1):163-183.

Rogers, Juliet, and Tony Waldron

1995 A Field Guide to Joint Disease in Archaeology. John Wiley \& Sons, Chichester, United Kingdom.

Rogers, Mary Nixon

1958 A History of Brazoria County, Texas. In History of Brazoria County, TX, by Travis L. Smith, pp. 5-12.

Rose, Jerome C.

1989 Biological Consequences of Segregation and Economic Deprivation: A PostSlavery Population from Southwest Arkansas. The Journal of Economic History 49(2):351-360. Crossref

Rose, Jerome C. (editor)

1983 Cedar Grove Historic Cemetery:A Study in Bio-History. Arkansas Archaeological Survey, Fayetteville. Project No. 528.

1985 Gone to a Better Land:A Biohistory of a Rural Black Cemetery in the Post-Reconstruction South. Research Series No. 25. Arkansas Archaeological Survey, Fayetteville.

Rose, Jerome C., and Lawrence Gene Santeford

1985 Cedar Grove Burial Interpretation. In Gone to a Better Land: A Biohistory of a Rural Black Cemetery in the Post-Reconstruction South, edited by Jerome C. Rose, pp. 130-145. Research Series No. 25. Arkansas Archaeological Survey, Fayetteville.

Rotundo, Barbara

1997 A Modern Gravestone Maker: Some Lessons for Gravestone Historians. In Markers XIV: Journal of the Association for Gravestone Studies, edited by Richard E. Meyer, pp. 86-109. Electronic document, https://archive.org/details/markers14asso, accessed March 9, 2015.

Russell \& Erwin Manufacturing Company

1980[1865] Illustrated Catalogue of American Hardware of the Russell and Erwin Manufacturing Company. Association of Preservation Technology, Manufactory, New Britain, Connecticut.

Santiago, F. R., P. P Alcázar Romero, E. P. Machado, and M. A. Garcia Espona

1997 Calcification of Lumbar Ligamentum Flavum and Facet Joints Capsule. Spine 22:1730-1734.

Sargent \& Company

1866 Prices of Hardware. Sargent \& Company, New Haven, Connecticut.

1869 Price List and Illustrated Catalogue. Sargent \& Company, New Haven, Connecticut. 
1871 Price List and Illustrated Catalogue of Hardware mfg and for Sale by Sargent \& Company Sargent \& Company, New Haven, Connecticut.

1874 Price List and Illustrated Catalogue of Hardware mfg and for Sale by Sargent \& Company Sargent \& Company, New Haven, Connecticut.

1877 Price List and Illustrated Catalogue of Hardware mfg and for sale by Sargent \& Company Sargent \& Company, New Haven, Connecticut.

1888 Price List and Illustrated Catalogue of Hardware mfg and for sale by Sargent \& Company Sargent \& Company, New Haven, Connecticut.

ca. 1921 Catalogue No. 17: Casket Hardware, Box Hardware, and Miscellaneous Goods used by Casket Manufacturers... Sargent \& Company, New Haven, Connecticut.

Sargent \& Company (J.B.)

1861 Hardware Catalog. Sargent \& Company (J.B.), New Britain, Connecticut.

Saunders, Shelley R., and Richard Lazenby

1991 The Links That Bind: The Harvie Family Nineteenth Century Burying Ground. In Occasional Papers in Northeastern Archaeology No. 5. Copetown Press, Dundas, Ontario.

Sauter, William

1883 Illustrated Catalogue No. 268. William Sauter, Baltimore, Maryland.

1888 Wholesale Price List. William Sauter, Baltimore, Maryland.

Savitt, Todd L.

1978 Medicine and Slavery. University of Illinois Press, Urbana.

Schermer, Shirley J., Robin M. Lillie, Jonathan R. Sellars, and Marlin Ingalls

2006 Investigation of Inadvertent Discovery of Historic Grave at Tallyn's Ranch, at the South Boundary of Site 13DA185, West Des Moines, Dallas County, Iowa. Contract Completion Report, No. 1466. Office of the State Archaeologist, The University of Iowa, Iowa City.

Scheuer, Louise, and Sue Black

2000 Developmental Juvenile Osteology. Academic Press, San Diego, California.

Schmidt Manufacturing Company

ca. 1905 Catalogue of Coffin Studs, Plates and Ornaments. Schmidt Mfg. Company, Dubuque, Iowa.

ca. 1910 Illustrated Catalogue of Casket Hardware Manufactured by Schmidt Manufacturing Company, Dubuque, Iowa. Schmidt Mfg. Company, Dubuque, Iowa.

ca. 1934 Illustrated Catalog of Casket Hardware, Catalogue No. 29. Schmid Manufacturing Company, Dubuque, Iowa.

Schwartz, Jeffrey H.

1995 Skeleton Keys. Oxford University Press, New York.

Scott, E. C.

1979 Dental Wear Scoring Technique.American Journal of Physical Anthropology 51:213-218. Crossref

Scott, G. Richard, and Christy G. Turner II

1997 The Anthropology of Modern Human Teeth. Cambridge University Press, Cambridge, United Kingdom. Crossref

Sears, Roebuck and Company

1902a The 1902 Sears, Roebuck, \& Co. Catalogue. Electronic version on CD-ROM. Princeton Imaging, Princeton, New Jersey. Available from www.princetonimaging.com. 
1902b The 1902 Edition of the Sears, Roebuck Catalogue with an Introduction by Cleveland Amory. Reprinted 1993 by Gramercy Books, New York.

Sewell, Kristin, and Patrick Stanton

2008 Dove Cemetery: Reflections on Cultural Identity at the Edge of Western Expansion - The Excavation and Interpretation of Dove Cemetery, CA-SLO-1892H, San Luis Obispo County, California. Technical Report 06-55. Statistical Research, Inc., Redlands, California.

Sharpless, Rebecca

2008 "Us Has Ever Lived De Useful Life": African American Women in Texas, 1874-1900. In Black Women in Texas History, edited by Bruce A. Glasrud and Merline Pitre, pp. 73-98. Texas A\&M University Press, College Station.

Shogren, Michael G., Kenneth R. Turner, and Jody C. Perroni

1989 Elko Switch Cemetery: An Archaeological Perspective. Report of Investigations No. 58. Alabama State Museum of Natural History, Division of Archaeology, Tuscaloosa.

Shuler, K. A., Eric C. Poplin, and Ralph Bailey, Jr.

2005 Cemetery Relocation at Site 38CH1648, Johnson Hagood Stadium, The Citadel, Charleston, South Carolina. Brockington and Associates, Inc., Charleston, South Carolina.

Silverthorne, Elizabeth

1986 Plantation Life in Texas. Texas A\&M University Press, College Station.

Simmons Hardware Company

1902 Catalogue No. 421, Builder's Hardware. Simmons Hardware Company, Inc., St. Louis, Missouri.

1903 Catalogue No. 443. Builders Hardware (general hardware, with some coffin trimmings). Simmons Hardware Company, Inc., St. Louis, Missouri.

1918 Catalogue No. P, complete catalogue. (general hardware, with a page of coffin trimmings). Simmons Hardware Company, Philadelphia, Pennsylvania.

Sitton, Thad, and James H. Conrad

2005 Freedom Colonies: Independent Black Texans in the Time of Jim Crow. University of Texas Press, Austin.

Skocpol, Theda, Ariane Liazos, and Marshall Ganz

2006 What a Mighty Power We Can Be:African American Fraternal Groups and the Struggle for Racial Equality. Princeton University Press, United Kingdom.

Smith, B. Holly

1984 Patterns of Molar Wear in Hunter-Gatherers and Agriculturalists. American Journal of Physical Anthropology 63:39-56. Crossref

Smith, James

n.d.a Osceola Plantation. Life On The Brazos River, Archives for Brazoria County History, Brazosport Archaeological Society. Electronic document, http://lifeonthebrazosriver. com/BrazoriaCountySugarPlantationNamedOsceola.pdf, accessed June 8, 2015.

n.d.b Chenango Plantation. Life On The Brazos River, Archives for Brazoria County History, Brazosport Archaeological Society. Electronic document, http:// lifeonthebrazosriver.com/ChenangoPlantation.pdf, accessed June 8, 2015.

n.d.c Joseph Mims, James Walker Fannin, James Calvin McNeill Plantation. Life On The Brazos River, Archives for Brazoria County History, Brazosport Archaeological Society. Electronic document, http://lifeonthebrazosriver.com/Joseph-MimsPlantation.pdf, accessed June 8, 2015. 
Smith, J. B.

2008 Cemetery "Debacle" at Ranger Museum Site Will Bring About New Legislation, Lawmaker Says. Waco Tribune Herald, October 29, 2008.

2015 First Street Cemetery Board Will Oversee Reburials of Exhumed Remains. WacoTrib. com, Posted November 6, 2013, updated March 28, 2015. Electronic document, http:// www.wacotrib.com/news/city_of_waco/first-street-cemetery-board-will-overseereburials-of-exhumed-remains/article_376ade19-c014-511d-8772-18d1ed2aec71.html, accessed April 30, 2015.

Smits, N. J., and Jo Reese

2005 Archaeological Exploration of Multnomah County's Morrison Property at SE 20th and Morrison, Portland, Oregon. Archaeological Investigations Northwest, Inc., Portland, Washington.

South, S. A.

1979 The General, the Major, and the Angel: The Discovery of General William Moultrie's Grave. Research Manuscript Series, No. 146. Institute of Archeology and Anthropology, University of South Carolina, Columbia.

Spencer, Susan D.

2002 Manslick Road Cemetery, Burial \#34. In unpublished manuscript. Program of Archaeology, University of Louisville, Louisville, Kentucky.

Sprague, Roderick

2002 China or Prosser Button Identification and Dating. Historical Archaeology 36(2):111-127. Crossref

Stampp, Kenneth M.

1956 The Peculiar Institution: Slavery in the Ante-Bellum South. Alfred A. Knopf, New York.

Statistical Research, Inc.

2009 The New York African Burial Ground: Unearthing the African Presence in Colonial New York. Vol. 4. The Skeletal Biology, Archaeology, and History of the New York African Burial Ground: A Synthesis of Vols. 1, 2, and 3. Howard University Press, Washington, D.C. Electronic document, http://www.gsa.gov/largedocs/ABG-SYNTHESIS.pdf, accessed May 12, 2015.

Steiner, Ralph

1913 Biennial Report of the Texas State Board of Health from September 1, 1910, to August 31, 1912. Von Boeckmann-Jones Company, Austin.

1915 Biennial Report of the Texas State Board of Health from September 1, 1912, to August 31, 1914. Von Boeckmann-Jones Company, Austin.

Stewart, T. D.

1979 Essentials of Forensic Anthropology. Charles C. Thomas, Springfield, Illinois.

St. Louis Coffin Company

1901 Souvenir Catalog, No. 20. Illustrating Highest Types of Our Art. St. Louis Coffin Company, St. Louis, Missouri.

ca. 1901 Estimated Undertaker's Selling Prices... (for) Art Book No. 20. St. Louis Coffin Company, St. Louis, Missouri.

1911 Catalog No. 22 (coffins, caskets, vaults, hearses) St. Louis Coffin Company , St. Louis, Missouri.

1918 The St. Louis Patented Copper-Bearing Steel Caskets (August 1, 1918). St. Louis Coffin Company, St. Louis, Missouri. 
Stein Manufacturing Company

1882 Telegraph Key and Price List for Untrimmed Caskets. Stein Mfg. Company, Rochester, New York.

1885 Supplement to our Book of Designs. Stein Mfg. Company, Rochester, New York.

1887 Revised Price List and Telegraph Key for Stein Mfg. Company producer of Fine Funeral Supplies and Textile Covered Caskets (June 1, 1887). Stein Mfg. Company, Rochester, New York.

ca. 1890 [Catalog of Casket Designs]. Stein Mfg. Company, Rochester, New York.

Stolts, Russell \& Company

1880 Illustrated and Descriptive Catalogue of Undertakers' Supplies. Stolts, Russell \& Company, New York.

Strezewski, M.

2003 "Ellen We Miss Thee At Home": Archaeological Investigations at the Michigan City Old Graveyard (12Le348), LaPorte County, Indiana. Reports of Investigations 308. IPFW Archaeological Survey. Indiana University-Purdue University at Fort Wayne, Indiana.

Strobel, Abner J.

1926 The Old Plantation and Their Owners of Brazoria County, Texas. Revised edition 1930, Bowman and Ross, Houston. Reprinted 1980, Shelby, Austin.

Styles, Sharon Johnson, and Kristina Lee

2010a Bull Hill Cemetery Takes Its Place Among Historical Landmarks in the State of Texas. The Marlin Democrat online, posted July 21, 2010. Electronic document, http://www. marlindemocrat.com/news/article_603c3afe-ab94-5327-a520-78763e7b89e1.html, accessed March 28, 2015.

2010b Bull Hill Dedication. Current Archeology in Texas 12(2):20-21. Electronic document, http:// www.thc.state.tx.us/public/upload/publications/current-archeology-november-2010.pdf, accessed March 28, 2015.

Suchey, J. M., and D. Katz

1986 Skeletal Age Standards Derived from an Extensive Multiracial Sample of Modern Americans. Paper presented at the 55th meeting of the American Association of Physical Anthropologists, Albuquerque, April 9-12 1986. Abstract in American Journal of Physical Anthropology 69:269.

Sunbury Coffin and Casket Works

1882 Wholesale Price List of Untrimmed Coffins and Caskets. Sunbury Coffin and Casket Works, Sunbury, Pennsylvania.

1883 Wholesale Price List of Untrimmed Coffins and Caskets. Sunbury Coffin and Casket Works, Sunbury, Pennsylvania.

Sutherland, Fred

2006 Use, Reuse, and Desecration: Analysis and Interpretation of the Lucy Kimball Mead Tomb, Littleton, Massachusetts. Bachelor's thesis, Boston University, Boston, Massachusetts.

Swauger, J. L.

1959 An American Burial Technique of the Early 19th Century. Pennsylvania Archaeologist 29(1):38-39.

Swearingen, R. M.

1884 Report of Texas Quarantine for 1883-4. State Printing Office of D\&D Asylum, Austin. 
Symes, S. A., and R. L. Jantz

1983 Discriminant Function Sexing of the Tibia. Paper presented at the 35th Annual Meeting of the American Academy of Forensic Sciences, Cincinnati, Ohio.

Tabor, George R.

1904 Biennial Report of the State Health Officer of Texas to the Governor from September 1, 1902, to August 31, 1904. Von Boeckmann-Jones Company, Austin.

Tadman, Michael

1996 Speculators and Slaves: Masters, Traders, and Slaves in the Old South. University of Wisconsin Press, Madison.

Taylor, A. J., Anne A. Fox, and I. Waynne Cox

1986 Archaeological Investigations at Morgan Chapel Cemetery (41BP200), A Historic Cemetery in Bastrop County, Texas. Archaeological Survey Report, No. 146. Center for Archaeological Research, University of Texas at San Antonio.

Taylor, H. E., \& Company

1872 (1871) Illustrated catalogue of caskets, coffins, shrouds, trimmings, etc. Taylor \& Company, New York.

1875 Illustrated Catalogue of Undertakers'Sundries. No. 163. H.E. Taylor \& Company, Bowery, New York.

1884 Robes and Linings. H.E. Taylor \& Company, Bowery, New York.

Taylor, Sterling R.

2015 An American Treasure: Prince Hall Affiliated Freemasons. Most Worshipful Prince Hall Grand Lodge of Alaska. Electronic document, http://mwphglalaska.com/grand-lodge-2/ the-history-of-prince-hall-masonry, accessed June 25, 2015.

Texas Department of State Health Services

2011 Texas Vital Statistics 2008 Annual Report. Texas Department of State Health Services. Electronic document, http://wwwprod.dshs.state.tx.us/chs/vstat/latest/anrpt.shtm, accessed May 9, 2011.

Texas Department of Transportation Staff

n.d. Background Investigation-Deed Record. In Historical and Archeological Investigation of the SH 332 Crossing of the Brazos River, Brazoria County, Texas, by Diane C. Dismukes and Allen C. Bettis, Jr., pp. 50-52. Texas Department of Transportation, Austin.

Texas Historical Cemetery Guardianship Association

2015 TX Historical Cemetery Guardianship Assoc. TXGenWeb Project. Electronic document, http://www.rootsweb.ancestry.com/ txbrazor/old_pages\%20\%282007-2011\%29/ cemeteries_tx_historical_cemetery_guardianship_assoc.htm, accessed March 24, 2015.

Texas Historical Commission

1991 Brazoria Bridge. Texas Historic Marker Application, Texas Historical Commission. The Portal to Texas History, University of North Texas Libraries. Electronic document, http://texashistory.unt.edu/ark:/67531/metapth460210/m1/?q=Keliher\%20Construction, accessed April 28, 2015.

2015a Brazoria Bridge. National Register Listing, Reference No. 91000783, Texas Historic Sites Atlas Online. Electronic document, http://atlas.thc.state.tx.us.

2015b Brazoria Bridge. Texas Historical Marker No. 9531. Texas Historic Sites Atlas Online. Electronic document, http://atlas.thc.state.tx.us. 
2015c Cemetery Laws. Texas Historical Commission website. Electronic document, http:// www.thc.state.tx.us/preserve/projects-and-programs/cemetery-preservation/cemeterylaws\#sthash.I15XUboI.dpuf, accessed April 28, 2015.

Texas Historical Guardianship Association

2015 Brazoria County Cemeteries, TXGenWeb Project:. Electronic document, http://www. rootsweb.ancestry.com/ txbrazor/old_pages\%20\%282007-2011\%29/cemeteries_tx_ historical_cemetery_guardianship_assoc.htm, accessed March 11, 2015.

Thiel, J. H., and Michael M. Margolis

2007 Excavation and Analysis of Burials 13 and 14 from the Court Street Cemetery, AZ BB:13:156 (ASM), Tucson, Pima County, Arizona. Project Report No. 07-136. Desert Archaeology, Inc., Tucson, Arizona.

Thompson, Robert Farris

1983 Flash of the Spirit: African and Afro-American Art and Philosophy. Random House, New York.

Thoms, Alston V. (editor)

2001 Matagorda Cemetery Project: Unmarked Graves and Community Heritage. Technical Report No. 5. Center for Ecological Archaeology, Texas A\&M University, College Station.

Tiné, Angela L.

2000 Understanding Life and Death Through Freedmen's Cemetery: A Comparative Bioarcheological Study of African American Health. In Freedman's Cemetery: A Legacy of a Pioneer Black Community in Dallas, Texas, Vol. 2, edited by Duane E. Peter, Marsha Prior, Melissa M. Green, and Victoria G. Clow, pp. 461-517. Special Publications No. 6. Geo-Marine, Inc., Plano, Texas. Archeology Studies Program Report No. 21, Environmental Affairs Division, Texas Department of Transportation, Austin.

Tiné, Angela L., and Douglas K. Boyd

2003 Archeological Excavation and Reburial of Unmarked Historic Graves in the Pioneer Cemetery (41BO202), Brazoria County, Texas. Reports of Investigations No. 139. Prewitt and Associates, Inc, Austin.

Tiné, Angela L., Judy Cooper, and Michelle Wurtz

2002 Archaeological and Bioarchaeological Investigations at Potter's Field/Greenwood Cemetery Along Clyde Lane, Dallas, Texas. Miscellaneous Reports of Investigations, Number 241. Geo-Marine, Inc., Plano, Texas.

Tiné, Angela L., S. Alan Skinner, and Jesse Todd

2007 Archaeological Investigation at the Sonntag Family Cemetery, Collin County, Texas. Cultural Resources Report 2007-07, AR Consultants, Inc., Dallas, Texas.

Todd, T. Wingate

1920 Age Changes in the Pubic Bone. I: The White Male Pubis. American Journal of Physical Anthropology 3:285-334.

1921 Age Changes in the Pubic Bone. II-IV. American Journal of Physical Anthropology $4: 1-70$.

Torget, Andrew J.

2015 The Diplomatic Correspondence of the Republic of Texas. Texas Slavery Project online. Electronic document, http://www.texasslaveryproject.org/sources/ROTDC/index.php, accessed May 12, 2015.

Trinkley, Michael, and Debi Hacker-Norton

1984 Analysis of Coffin Hardware From 38CH778, Charleston County, South Carolina. In Chicora Foundation Research Series No. 3. Chicora Foundation, Inc., Columbia, South Carolina. 
Turner, Christy G., Christian R. Nichol, and G. Richard Scott

1991 Scoring Traits for Key Morphological Traits of the Dentition: The Arizona State University Dental Anthropology System. In Advances in Dental Anthropology, edited by M. A. Kelley and C. S. Larsen, pp. 13-31. Wiley-Liss, New York.

Turpin, Solveig A., and Leland C. Bement

2002a Relocation of the Craddock Cemetery, 41BP581, Three Oaks Mine, Bastrop County, Texas. Technical Report 17. TAS, Inc., Austin, Texas.

2002b Relocation of the Nisbett and Anderson Cemeteries, 41RT189 and 41RT350, Pit 6, Calvert Mine, Robertson County, Texas. Technical Report 19. TAS, Inc. Austin, Texas.

Ubelaker, D. H.

1989 Human Skeletal Remains: Excavation, Analysis, Interpretation. 2nd ed. Taraxacum, Washington.

Union Casket Company

1881 Telephonic \& telegraphic key and wholesale price list combined, of untrimmed cloth covered caskets. Union Casket Company, Boston, Massachusetts.

United States Casket Company

1922 [Supplement] Notice: Outside Box Prices Reduced (March 20, 1922). United States Casket Company, Pittsburgh, Pennsylvania.

1922 Price List Applying to Catalogue "D" (May 25, 1922). United States Casket Company, Pittsburgh, Pennsylvania.

1922 [Supplement] Price Changes (November 1, 1922). United States Casket Company, Pittsburgh, Pennsylvania.

1922 Price List Applying to Catalogue "D" (December 1, 1922). United States Casket Company, Pittsburgh, Pennsylvania.

1923 Price List Applying to Catalogue "D" (July 1, 1923). United States Casket Company, Pittsburgh, Pennsylvania.

1923 Price List Applying to Catalogue "D" (November 1, 1923). United States Casket Company, Pittsburgh, Pennsylvania.

1924 Price List Applying to Catalogue “D” (March 25, 1924). United States Casket Company, Pittsburgh, Pennsylvania.

1925 Price List Applying to Catalogue "D" (June 20, 1925). United States Casket Company, Pittsburgh, Pennsylvania.

University of Virginia

2004 Historical Census Browser. University of Virginia, Geospatial and Statistical Data Center. University of Virginia Libraries online. Electronic document, http://www.fisher. lib.virginia.edu/census, accessed April 1, 2015.

Unknown

1889 Photograph of Washington Edwards, 103 years old, 1889, by unknown photographer. Photograph catalog No. 1905/011-1. Prints and Photographs Collection, Texas State Library and Archives Commission. Image used in online exhibit by the State Preservation Board and the Texas State Library and Archives Commission: "Forever Free: Nineteenth Century African-American Legislators and Constitutional Convention Delegates of Texas." Electronic document, https://www.tsl.texas.gov/exhibits/forever/ freedom/page2.html, accessed March 9, 2015. 
U.S. Bureau of the Census

Brazoria County 1870, Town of Brazoria

Brazoria County 1880, Enumeration District 1, Election Precinct 1

U.S. Bureau of Labor Statistics

n.d. Databases, Tables \& Calculators by Subject. U.S. Department of Labor, Bureau of Labor Statistics. Electronic document, http://www.bls.gov/data, accessed May 9, 2011.

U.S. Census Bureau

2010 Income, Poverty and Health Insurance in the United States. U.S. Census Bureau. Electronic document, http:/www.census.gov/hhes/www/poverty/data/incpovhlth/2009/ index.html, accessed May 11, 2011.

United States Department of Agriculture

1981 Soil Survey of Brazoria County, Texas. The U.S. Department of Agriculture, Soil Conservation Service, in cooperation with the Texas Agricultural Experiment Station.

U.S. Department of Health and Human Services

2010 Women's Health USA 2010. U.S. Department of Health and Human Services, Health Resources and Services Administration, Maternal and Child Health, Rockville, Maryland.

Veilleux, Annie, and David Robertson

2008 Stage 2 Archaeological Assessment, Bridgepoint Health Master Plan, City of Toronto, Ontario. Archaeological Services, Inc., Toronto.

Victor Casket Hardware Company

1956 Catalogue No. 6. Victor Casket Hardware Company, Galesburg, Illinois.

1959 Price List Applying to Catalogue No. 6 (May 20, 1959). Victor Casket Hardware Company, Galesburg, Illinois.

Vlach, John Michael

1978 The Afro-American Tradition in Decorative Arts. The Cleveland Museum of Art, Cleveland, Ohio.

1990 Graveyard Decoration. In The Afro-American Tradition in Decorative Arts, by John Michael Vlach, pp. 139-150, 157. Brown Thrasher Books, University of Georgia Press, Athens.

1991 By the Work of the Their Hands: Studies in Afro-American Folklife. University Press of Virginia, Charlottesville.

Wade, Lizzie

2015 DNA Reveals History of Buried Slaves. Posted March 9, 2015 on Sciencemag.org, online journal of the American Association for the Advancement of Science. Electronic document, http://news.sciencemag.org/africa/2015/03/dna-reveals-history-buried-slaves, accessed September 4, 2015.

Walker, Philip L., Rhonda R. Bathhurst, Rebecca Richman, Thor Gjerdrum, and Valerie A. Andrushko 2009 The Causes of Porotic Hyperostosis and Cribra Orbitalia: A Reappraisal of the IronDeficiency-Anemia Hypothesis. American Journal of Physical Anthropology 139:109-125.

Walwer, G. F.

1996 Combining Archival and Archeological Research: The Connecticut School for Boys Cemetery. CRM 19(10):8-11. 
Ward, T., and Martha Graham

1978 The Archaeo-Osteology of Three Historic Cemeteries in Person County, N.C. The Research Laboratories of Anthropology, University of North Carolina, Chapel Hill.

Warfield \& Rohr

ca. 1878 Illustrated Catalogue of Undertakers' Supplies. Warfield \& Rohr, Baltimore, Maryland.

ca. 1878 Wholesale Price List of Undertakers' Supplies. Warfield \& Rohr, Baltimore, Maryland.

ca. 1880 Illustrated and descriptive catalogue of undertakers' trimmings and cabinet hardware. Warfield \& Rohr, Baltimore, Maryland.

1886 Wholesale Price-List of Coffin and Casket Trimmings, Linings, Robes and Wrappers. Warfield \& Rohr, Baltimore, Maryland.

ca. 1890 Illustrated Catalogue of Warfield \& Rohr, Manufacturers and Jobbers of Wood Coffins and Caskets, Cloth Covered Caskets, Metallic Caskets, Air-Tight Zinc and Copper Linings, Etc. Warfield \& Rohr, Baltimore, Maryland.

1893 (Nov 1, 1893) Revised Price-List of Coffin and Casket Hardware, Robes, Linings, and Undertakers' Sundries. Warfield \& Rohr, Baltimore, Maryland.

Wayne, J. L., \& Sons

1874 Illustrated Catalogue of Casket and Coffin Trimmings, Manufactured by the Wayne Hardware Company J.L. Wayne \& Sons, Cincinnati, Ohio; Chicago, Illinois; and New York.

WHO, UNICEF, UNFPA, and World Bank

2007 Maternal Mortality in 2005: Estimates Developed by WHO, UNICEF, UNFPA, and The World Bank. World Heath Organization, Geneva, Switzerland.

Wilczak, C., R. Watkins, C. Null, and M. L. Blakey

2006 Skeletal Indicators of Work: Musculoskeletal, Arthritic, and Traumatic Effects. In New York African Burial Ground Archaeology Final Report, vol. 1, edited by Warren R. Perry, Jean Howson, and Barbara A. Bianco, pp. 403-460. Prepared by Howard University, Washington, D.C., for United States General Services Administration Northeastern and Caribbean Region.

Wilkerson, Isabel

2010 The Warmth of Other Suns:The Epic Story of America's Great Migration. Random House, New York.

Williamson, Christian

2005 Sacred Trust: The Voluntary Removal and Reburial of Human Remains from a Historic Cemetery in Louisiana. Master's thesis, Louisiana State University, Baton Rouge.

Wilmarth, W. D., \& Company

1894 Illustrated and descriptive catalogue of Coffin and Casket Trimmings, Atlanta, Georgia.

Wilson, Kristin J.

1998a Archaeological Disinterment/Reinterment of the Pine Ridge Cemetery, Butts County, Georgia. TRC Garrow Associates, Inc., Atlanta, Georgia.

1998b Archaeological Disinterment of the Oliver Family Grave Sites, Roanoke, Virginia. TRC Garrow Associates, Inc., Atlanta, Georgia.

1998c Archaeological Disinterment of the Turner Cemetery, Marshal County, Mississippi. TRC Garrow Associates, Inc. Atlanta, Georgia. 
Wilson, Kristin J., and Jeffrey L. Holland

1998 Archaeological Disinterment of the Fuller Cemetery, Calhoun, Georgia. TRC Garrow Associates, Inc. Atlanta, Georgia.

Wilson, $\mathrm{M}$.

1968 Two Historic Burials in the Three Forks Locale. Bulletin of the Oklahoma Anthropological Society 17:75-86.

Winchell, Frank, Jerome C. Rose, and Randall W. Moir

1992 Bioanthropological Investigation of Nineteenth Century Burials at Site 41DT105: Cultural Resource Studies for Cooper Lake, Delta County, Texas. Archaeology Research Program, Department of Anthropology, Southern Methodist University. Dallas, Texas.

Wood, J. W., G. R. Milner, H. C. Harpending, and K. M. Weiss

1992 The Osteological Paradox: Problems of Inferring Prehistoric Health from Skeletal Samples. Current Anthropology 33(4):343-370.

Wood, W. D.

2008 Report on the Disinterment and Relocation of the James and Sarah Barnes Cemetery, Bibb County, Georgia. Southern Research, Historic Preservation Consultants, Inc., Ellerslie, Georgia.

Wood, W. D., Karen Ramey Burns, and Steve R. Lee

1986 The Mt. Gilead Cemetery Study: An Example of Biocultural Analysis From Western Georgia. Southeastern Archaeological Services, Inc., Athens, Georgia.

Woodley, P. J.

1992 The Stirrup Court Cemetery Coffin Hardware. Ontario Archaeology 53:45-63.

Wright, Cheryl L.

1994 I Heard It Through the Grapevine: Oral Tradition in a Rural African American Community in Brazoria, Texas. M.A. thesis, Department of Anthropology, University of Houston, Houston, Texas.

1998 Oral History Information: Birth, Death, and Everything in Between. Excerpts from "I Heard It Through the Grapevine: Oral Tradition in a Rural African American Community in Brazoria, Texas," by Cheryl Wright, 1994. On the Levi Jordan website by Carol McDavid. Electronic document, http://www.webarchaeology.com/html/cheroral. htm, accessed July 7, 2011.

Zanesville Coffin Company

1880 Illustrated Catalogue. Zanesville Coffin Company, Zanesville, Ohio. 

APPENDIX A: Published

Historic Cemetery

Archeological Reports

Consulted for the Pioneer Cemetery

Burial Container

Analysis

Compiled by Jeremy W. Pye 

This appendix lists the published archeological reports on historic cemeteries that were consulted for comparisons with the Pioneer Cemetery mortuary data. The references for these reports are in the References Cited section of the main report. 


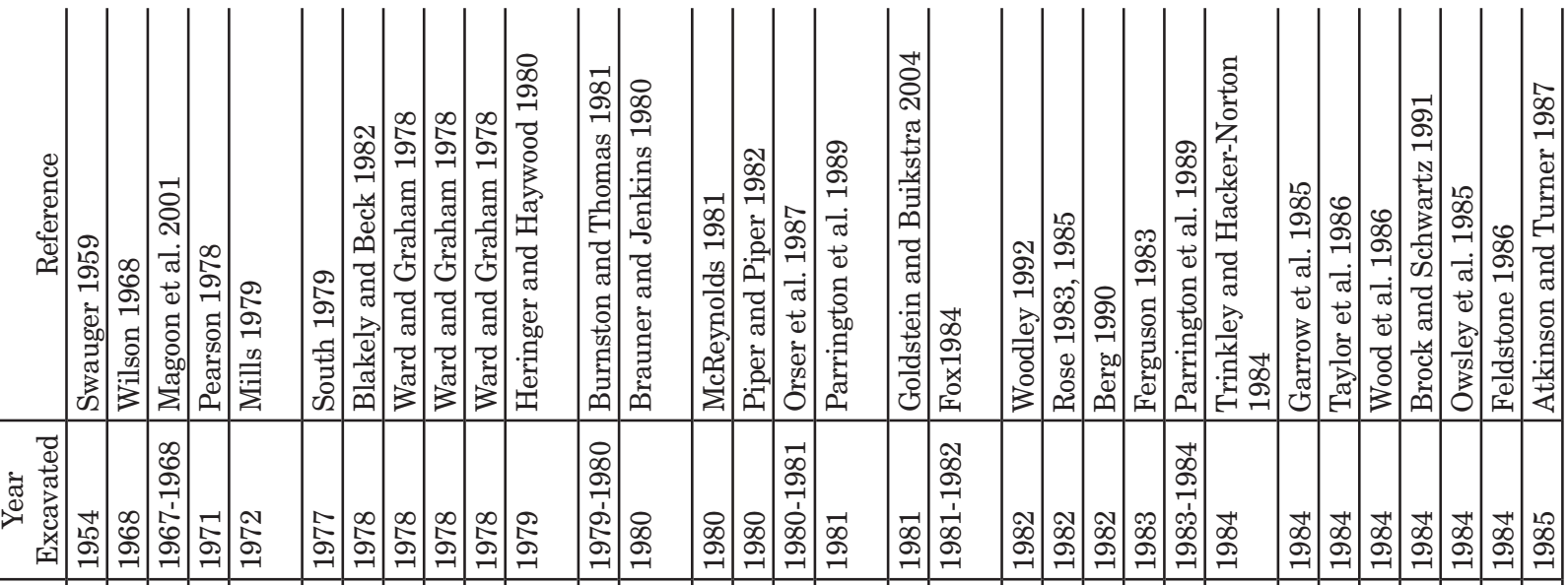

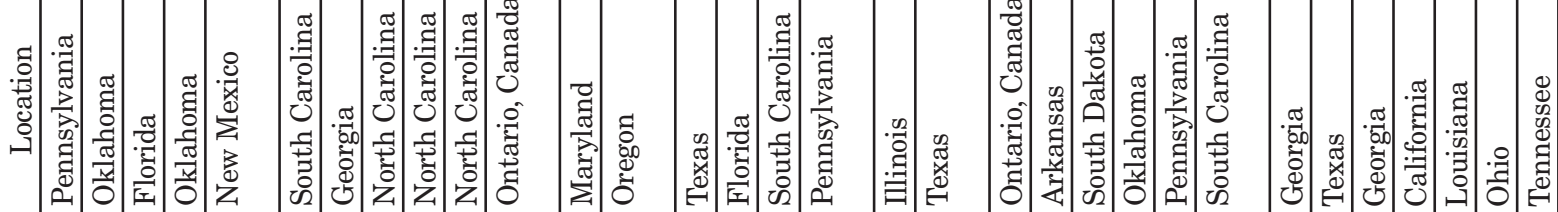

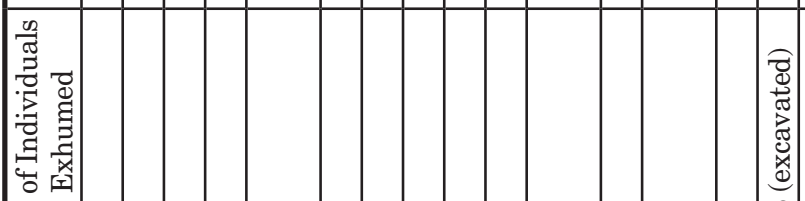

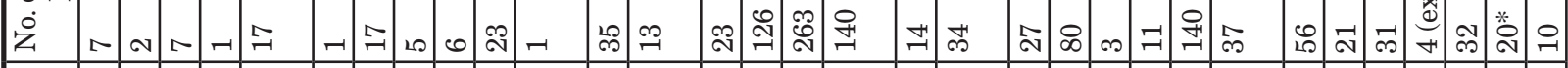

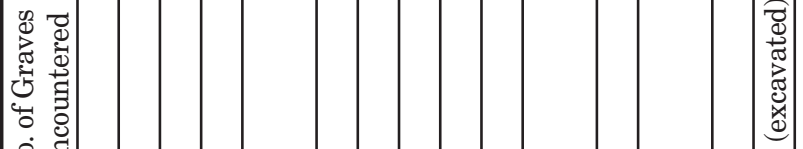

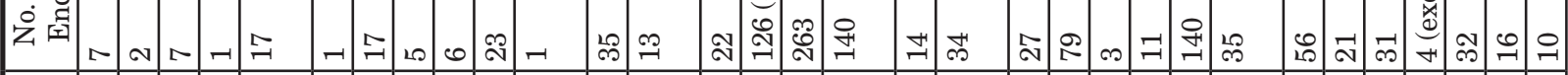

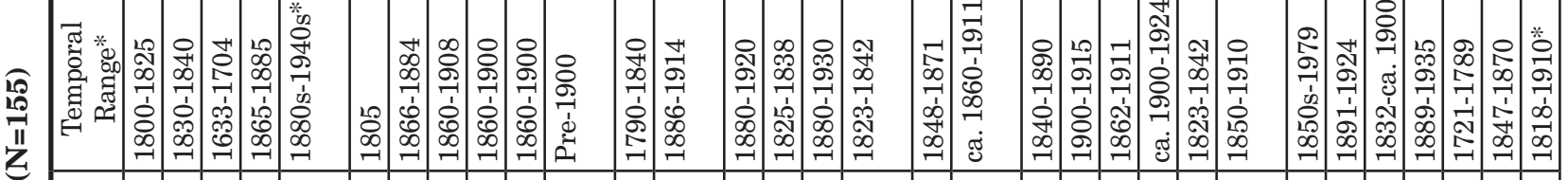

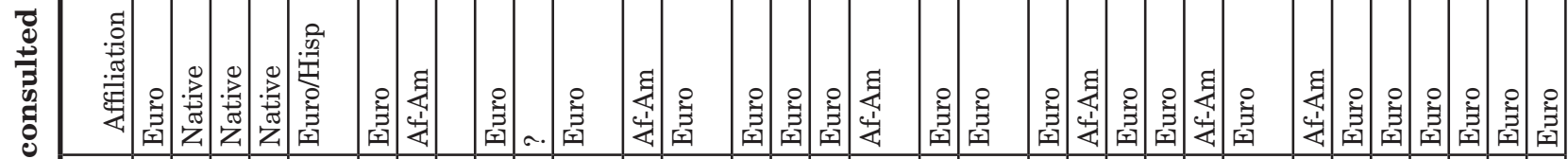

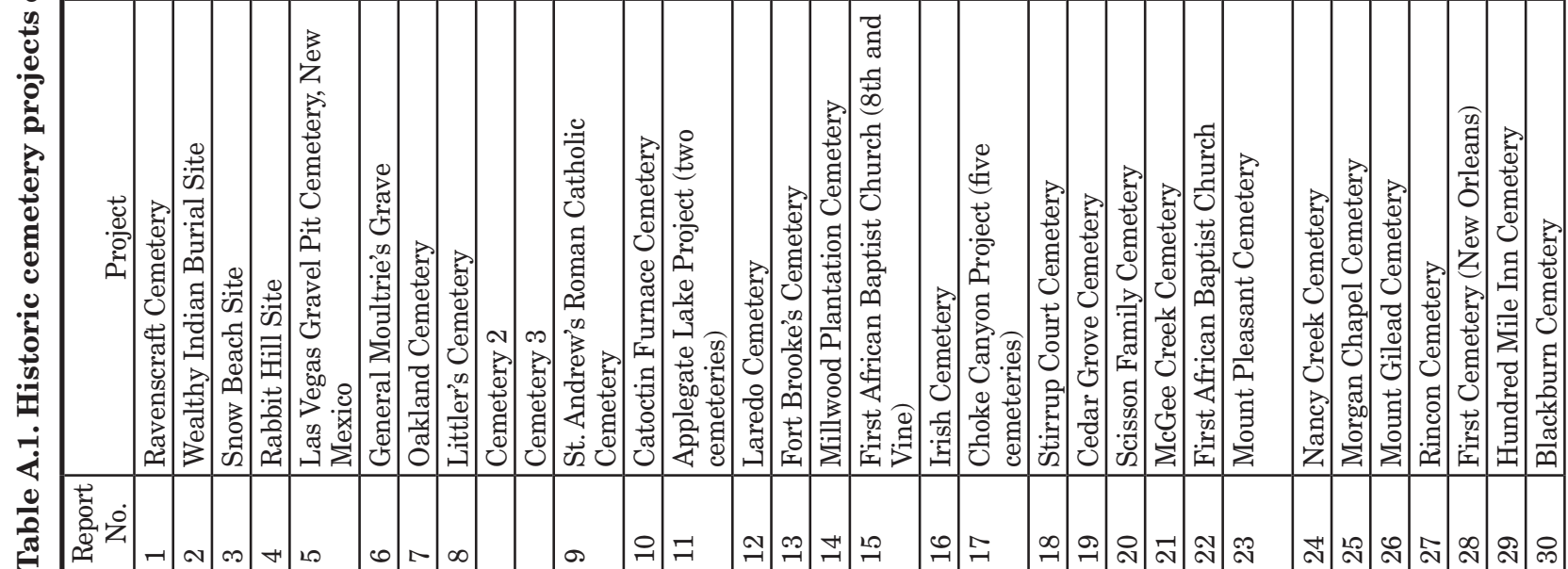




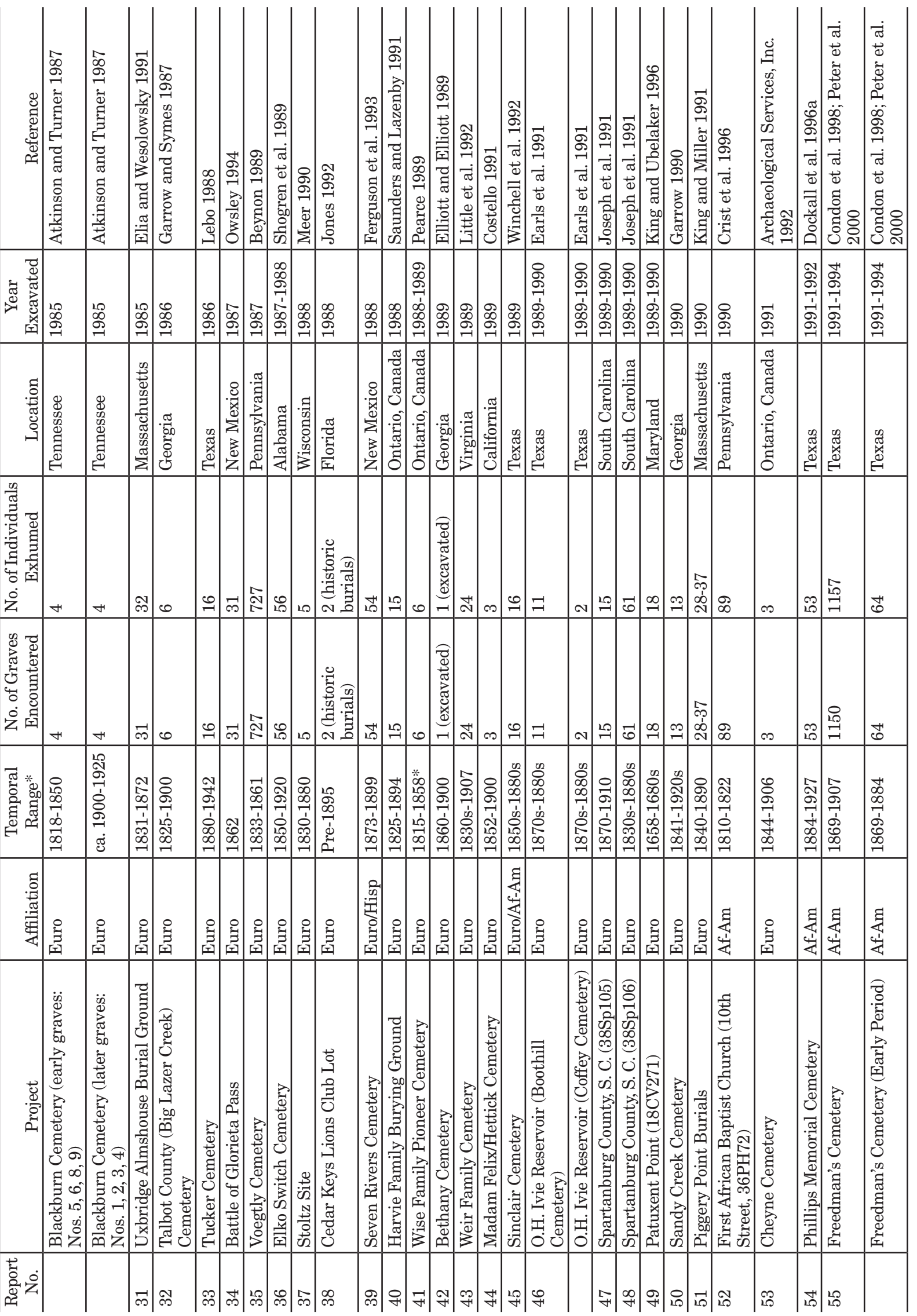




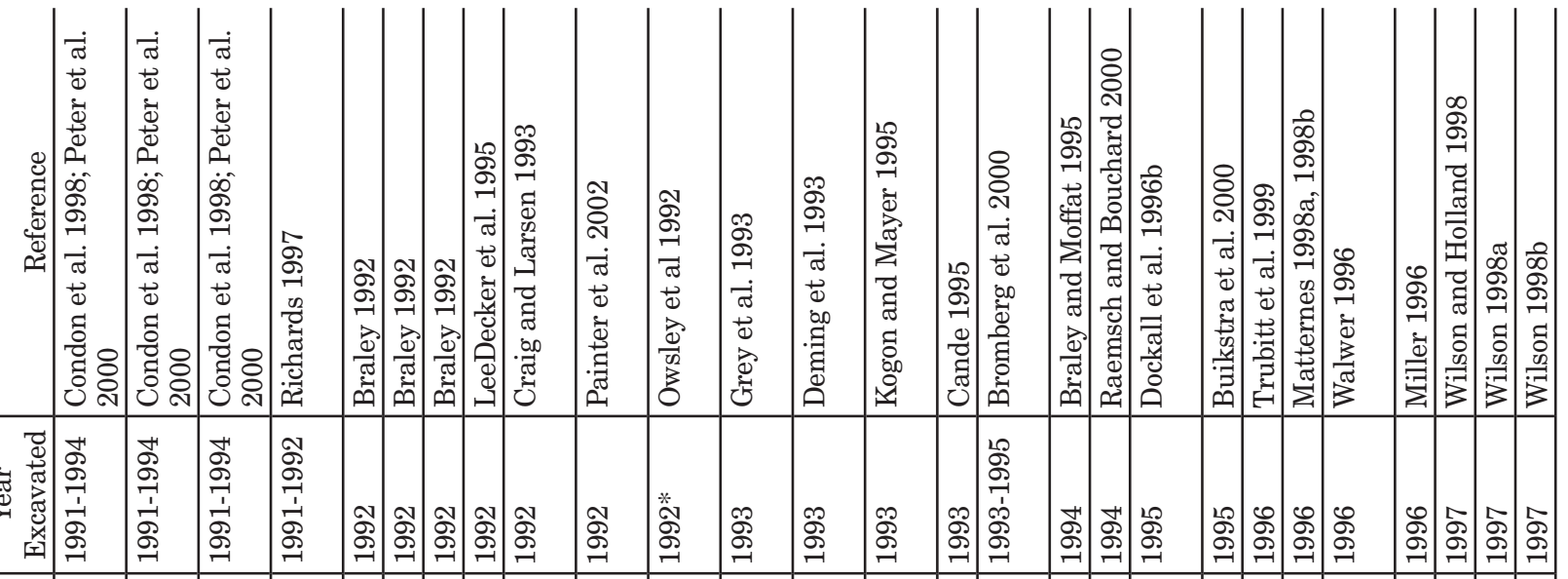

\begin{tabular}{|c|c|c|c|c|c|c|c|c|c|c|c|c|c|c|c|c|c|c|c|c|c|}
\hline 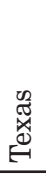 & 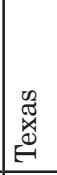 & 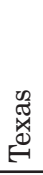 & 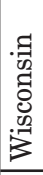 & 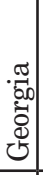 & 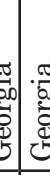 & 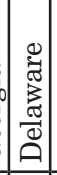 & \begin{tabular}{|l|}
.02 \\
.0 \\
.9 \\
\end{tabular} & 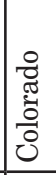 & 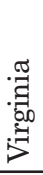 & 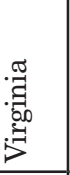 & \begin{tabular}{l}
$\frac{\pi}{0}$ \\
$\frac{0}{2}$ \\
\multicolumn{1}{|c|}{}
\end{tabular} & 葛 & $\tau^{2}$ & & 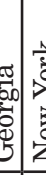 & 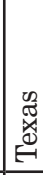 & 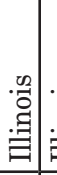 & 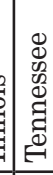 & 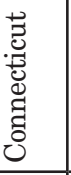 & & 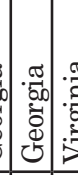 \\
\hline 독 & 灾 & $\begin{array}{l}+ \\
\infty \\
\infty\end{array}$ & 疋 & S & 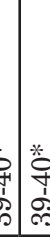 & o & I & $\vec{m}$ & $\Sigma$ & 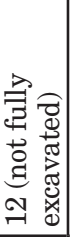 & 드 & 告 & N & & 0 & in & 令 & مـ| & 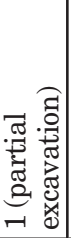 & 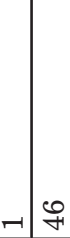 & $\exists=$ \\
\hline R & 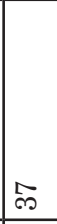 & $\begin{array}{c}\infty \\
\infty \\
\infty \\
\infty\end{array}$ & ఫે & 2 & 利 & $\infty$ & 尺 & $\stackrel{\vec{m}}{-1}$ & $\Sigma$ & 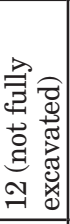 & ㅇำ & 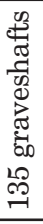 & & 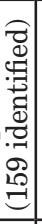 & 5 & in & 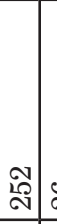 & هـ & 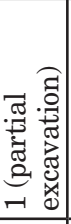 & -1 & $=$ \\
\hline
\end{tabular}

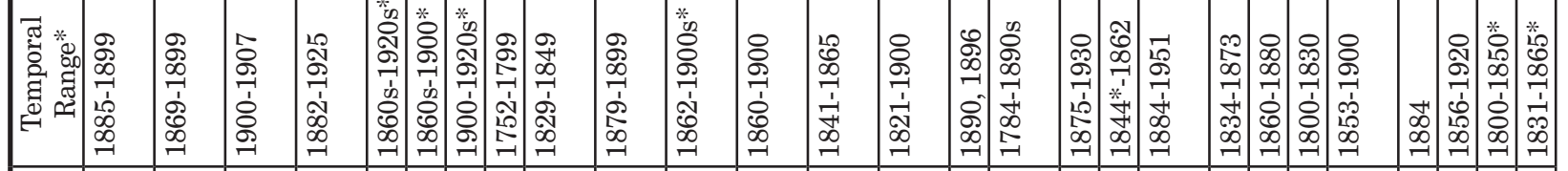

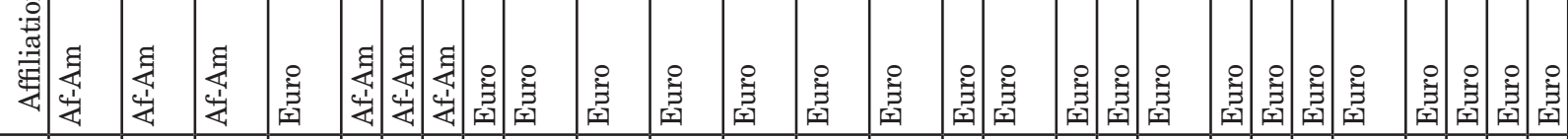

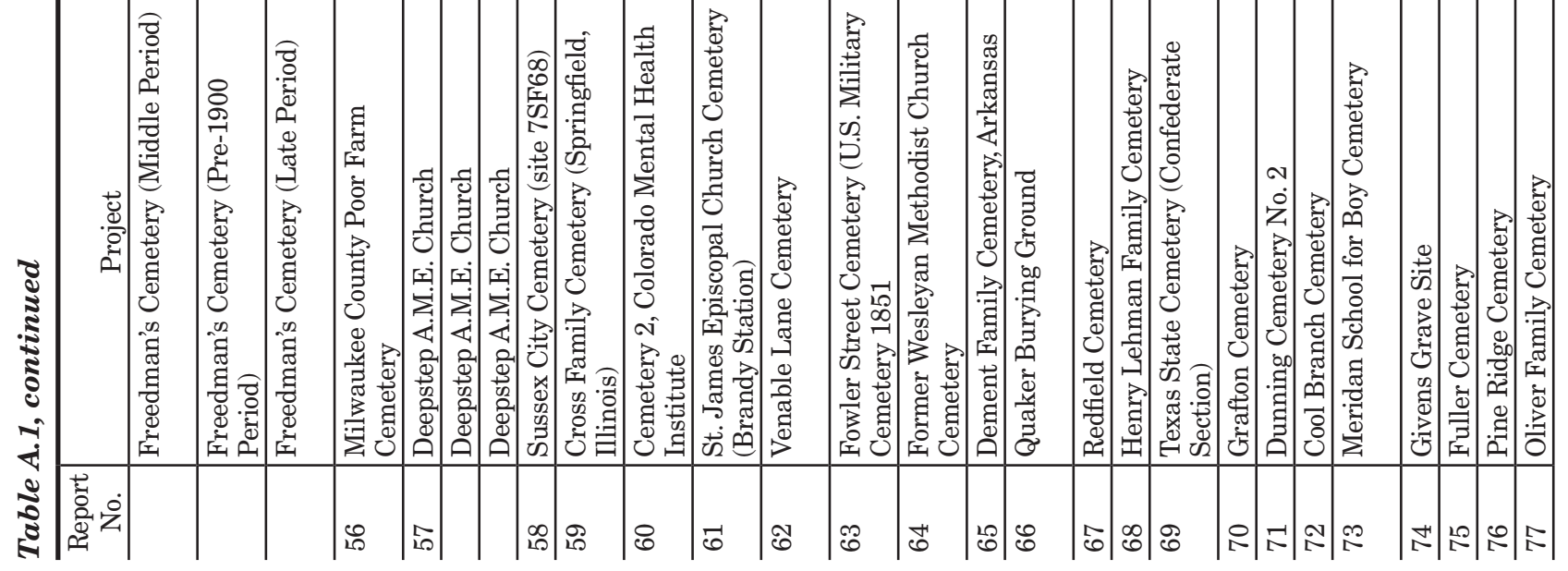




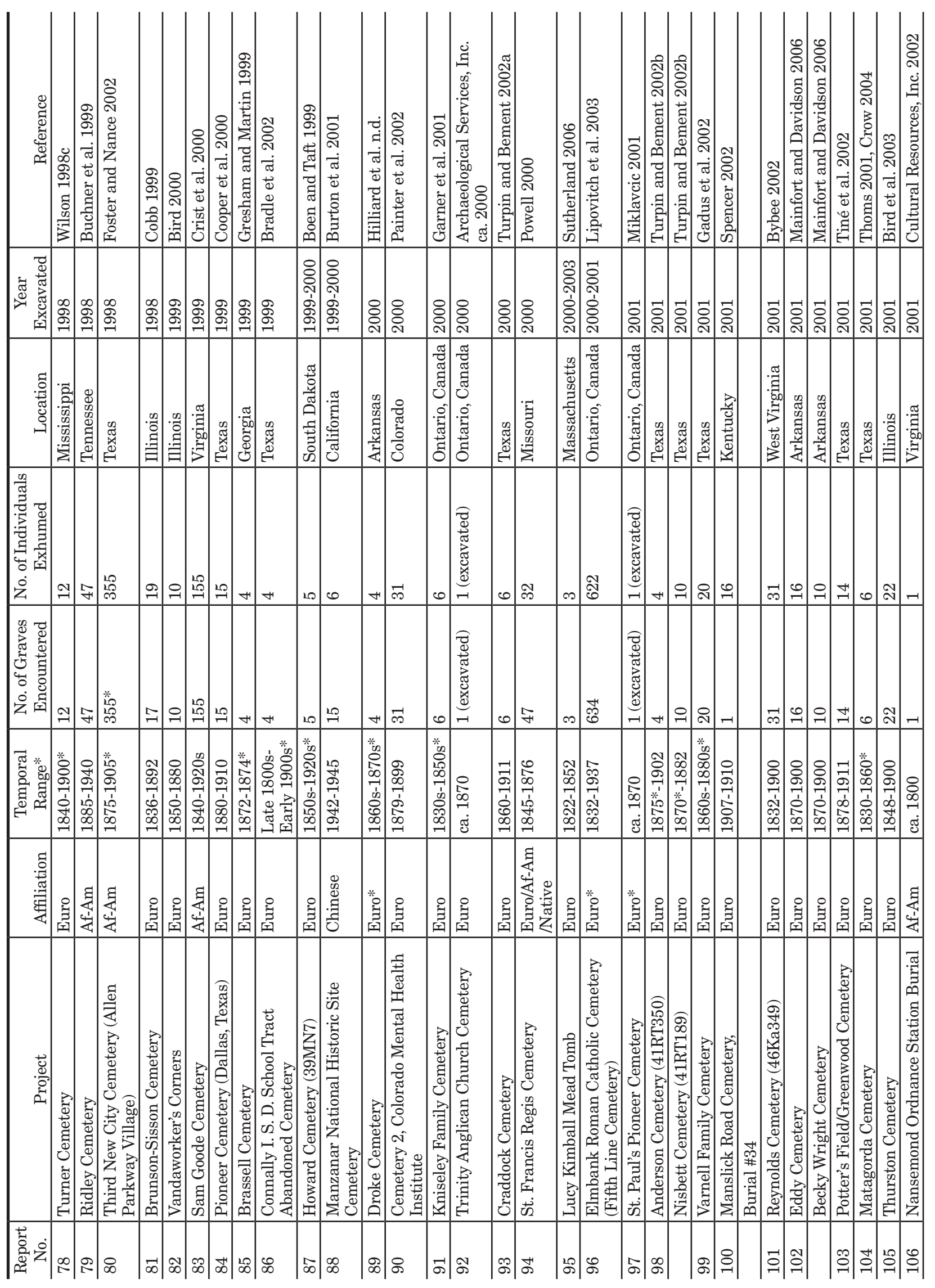




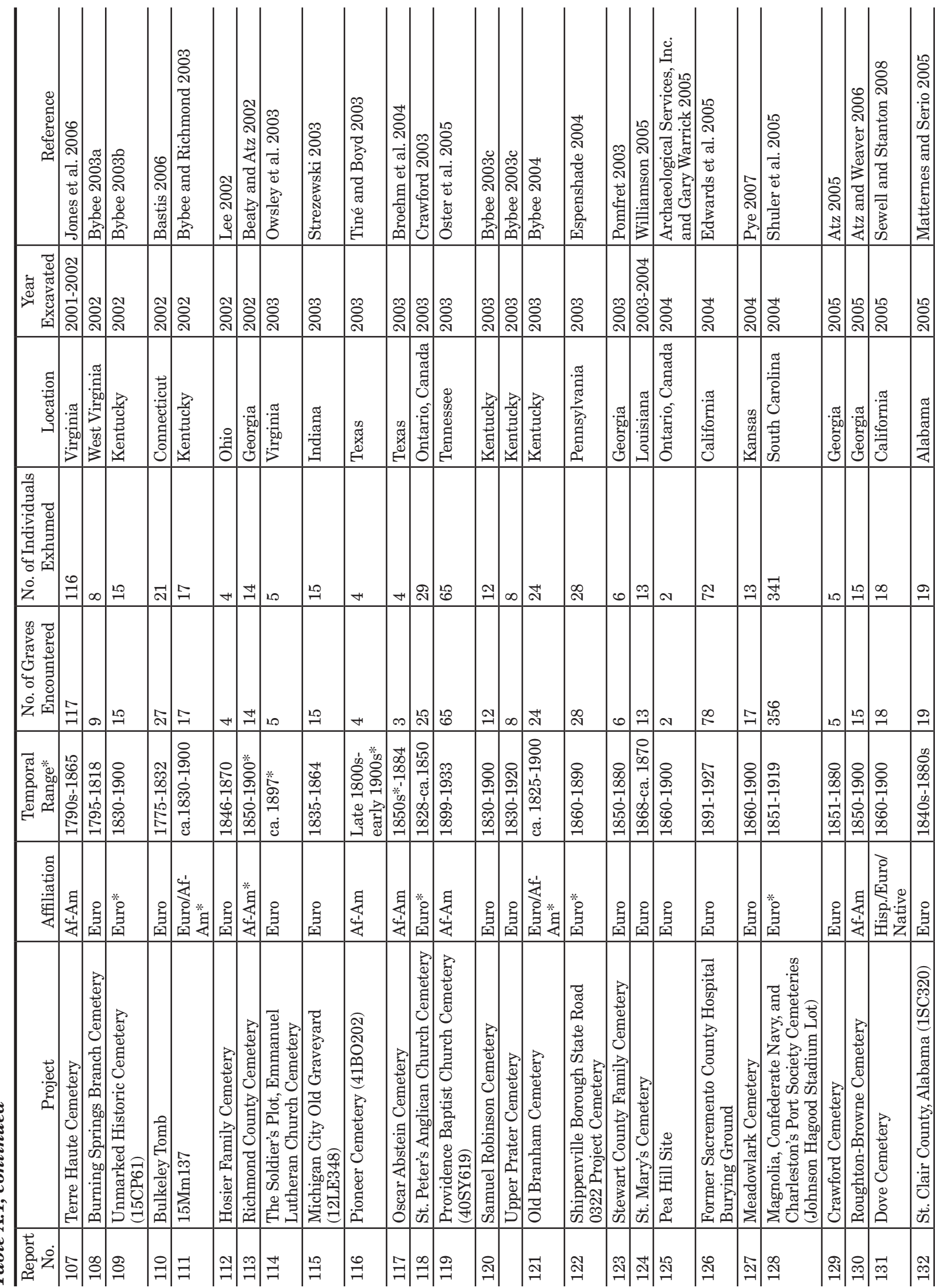




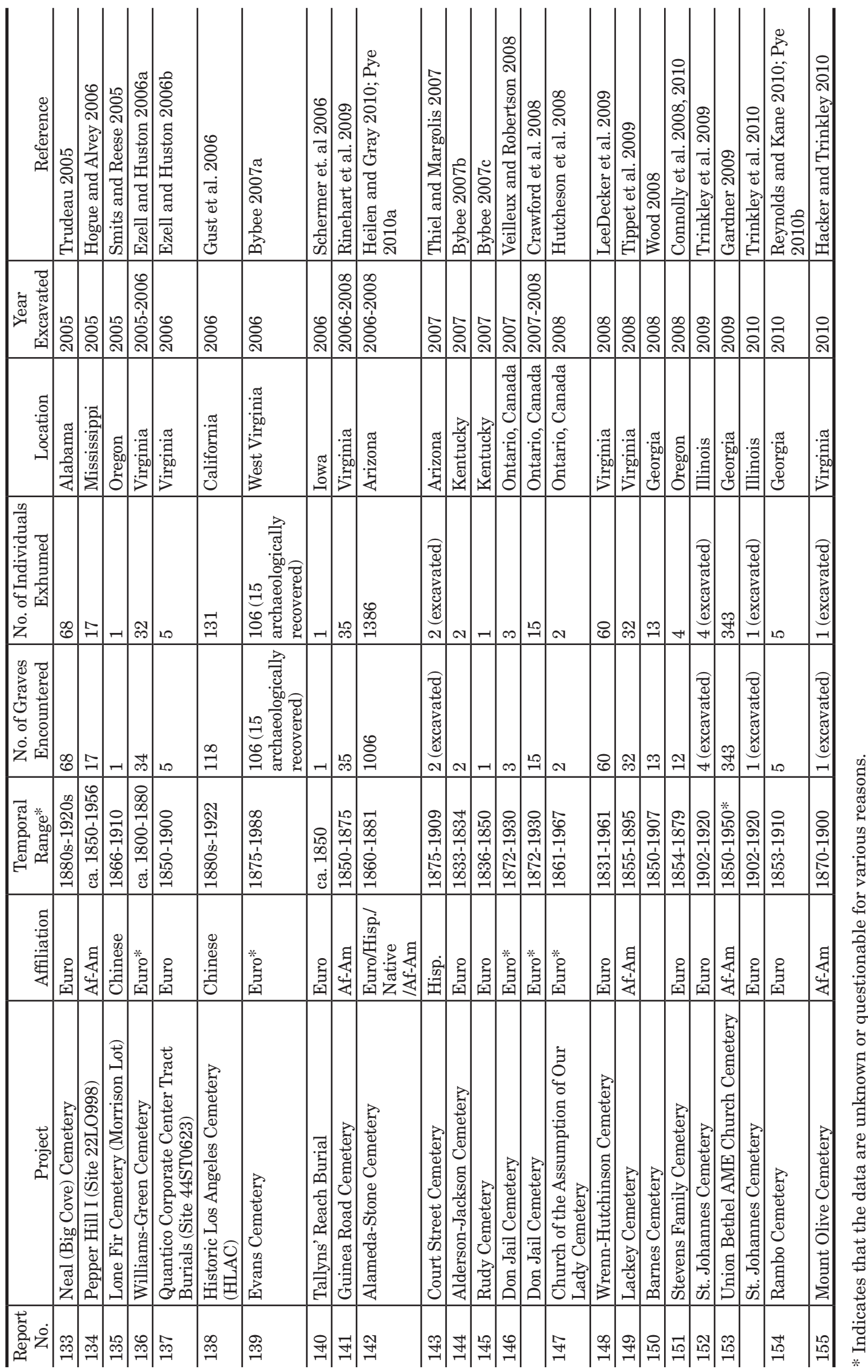





\section{APPENDIX B: Historic Mortuary Hardware Catalogs Consulted}

Compiled by Jeremy W. Pye 

This appendix lists the mortuary hardware catalogs that were consulted for the analysis of the Pioneer Cemetery burial containers. The references for these catalogs are in the References Cited section of the main report. 


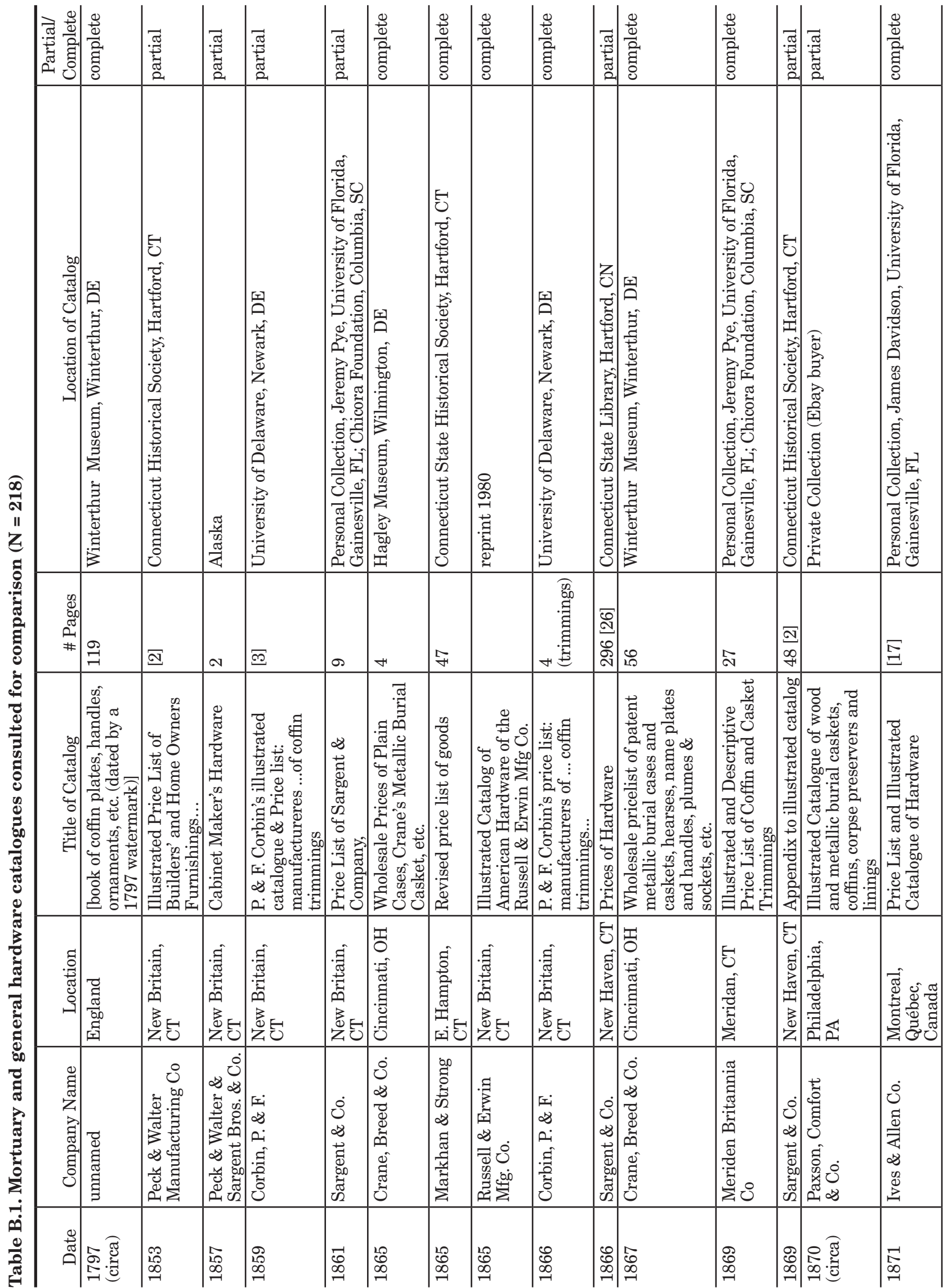




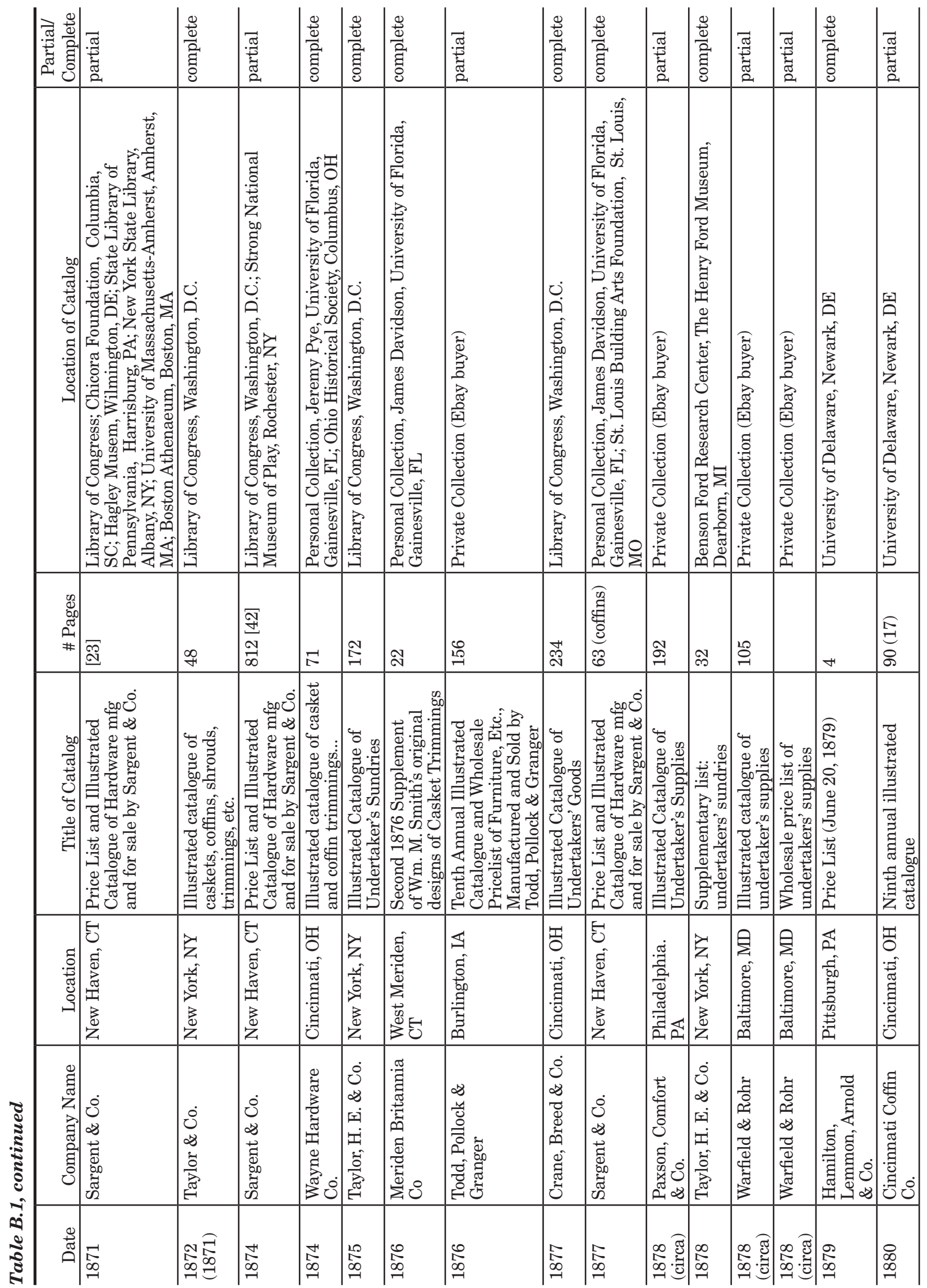




\begin{tabular}{|c|c|c|c|c|c|c|c|c|c|c|c|c|c|c|c|}
\hline 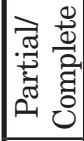 & 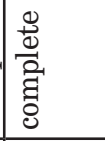 & 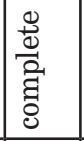 & 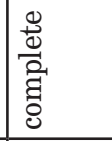 & 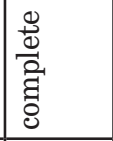 & 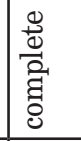 & 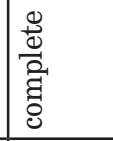 & 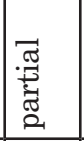 & 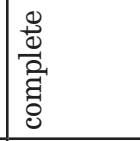 & 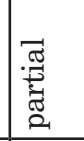 & 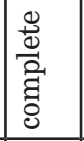 & 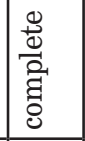 & 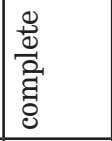 & 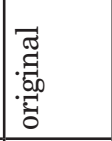 & 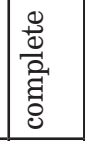 & 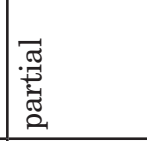 \\
\hline 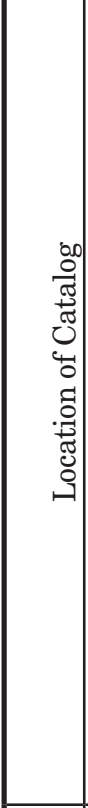 & 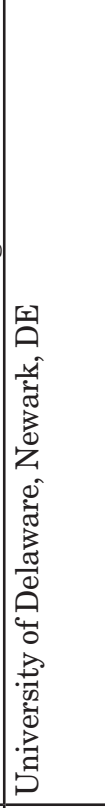 & 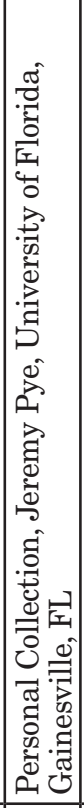 & 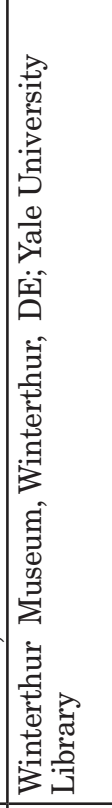 & 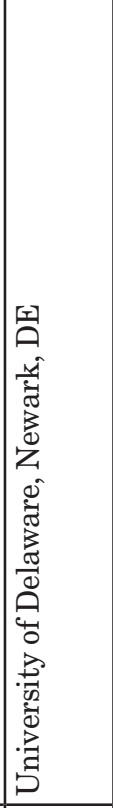 & 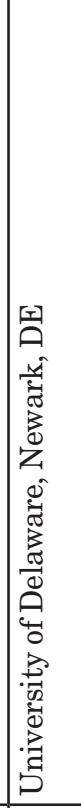 & 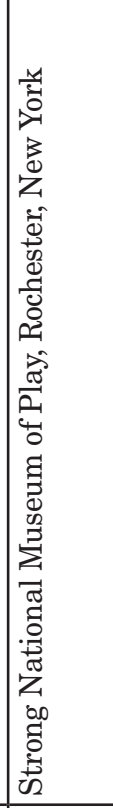 & 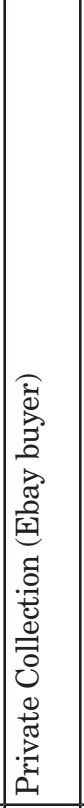 & 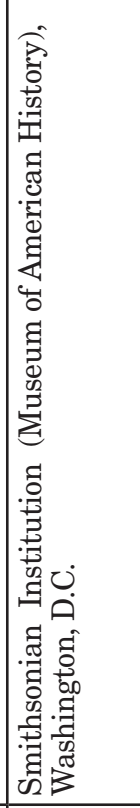 & 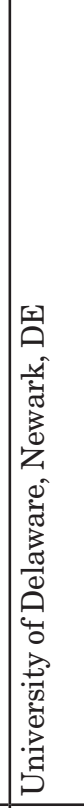 & 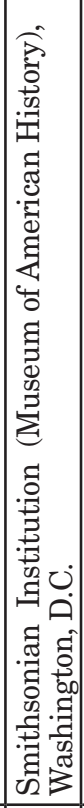 & 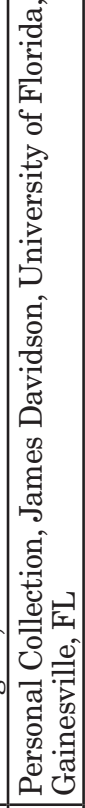 & 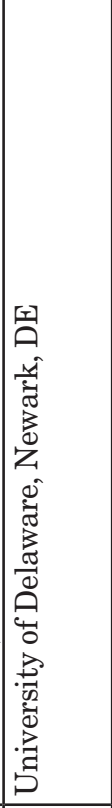 & 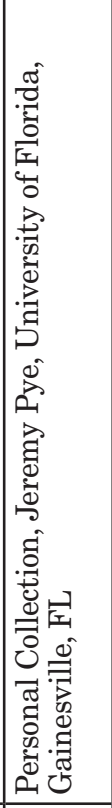 & 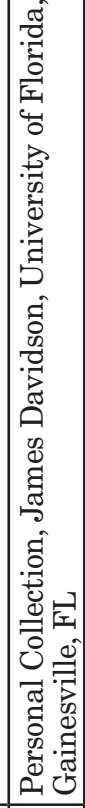 & 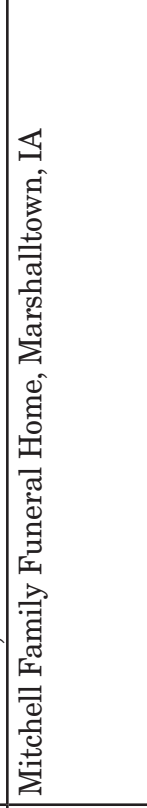 \\
\hline 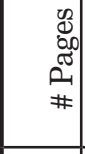 & -1 & \begin{tabular}{|l}
0 \\
0 \\
0 \\
0 \\
0 \\
0 \\
0 \\
0 \\
0 \\
\end{tabular} & $\stackrel{\infty}{\stackrel{\infty}{+}}$ & \begin{tabular}{|l}
$\infty$ \\
0 \\
\end{tabular} & 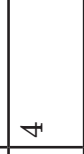 & & & 沉 & $\begin{array}{l}\stackrel{8}{0} \\
\stackrel{2}{\circ} \\
\mathscr{8}\end{array}$ & N & $\infty$ & 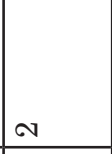 & $\frac{10}{12}$ & $\bar{\infty}$ & \\
\hline 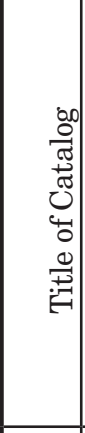 & 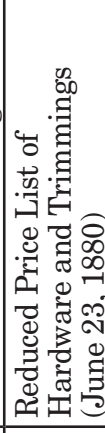 & 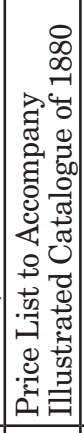 & 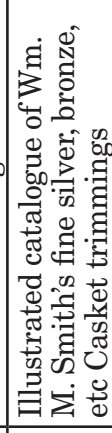 & 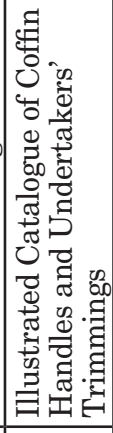 & 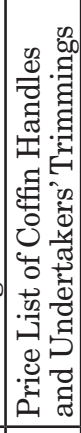 & 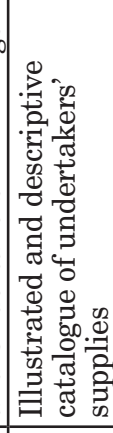 & 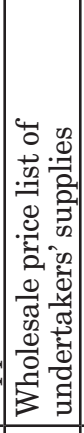 & 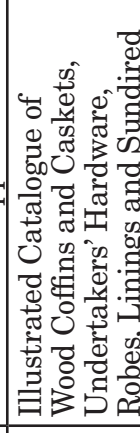 & 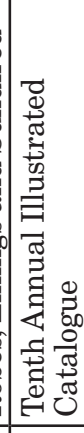 & 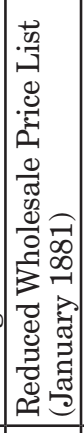 & 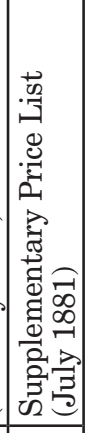 & 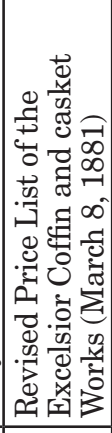 & 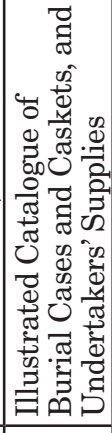 & 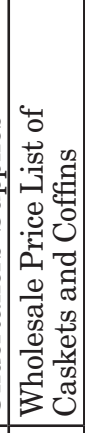 & 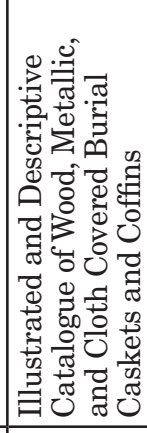 \\
\hline 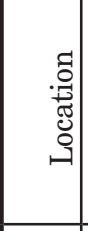 & 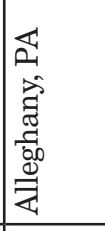 & 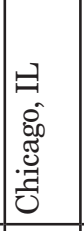 & 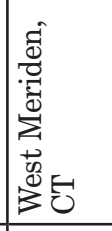 & 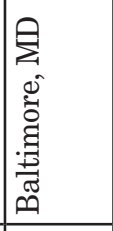 & 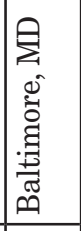 & 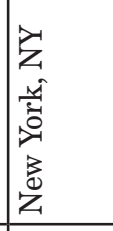 & 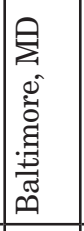 & 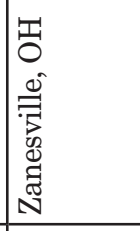 & 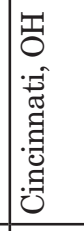 & 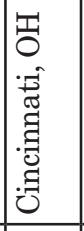 & 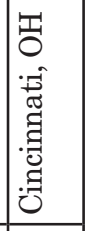 & 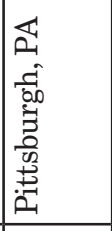 & 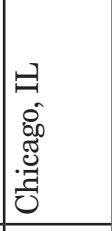 & 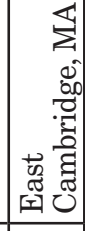 & 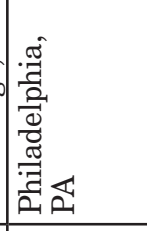 \\
\hline 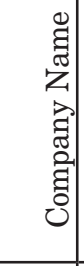 & 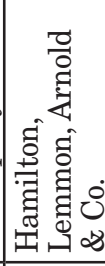 & 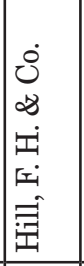 & 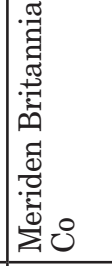 & 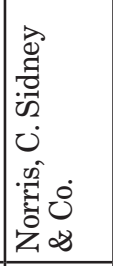 & 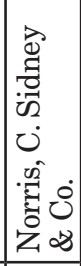 & 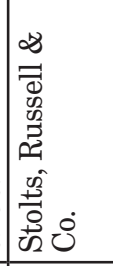 & 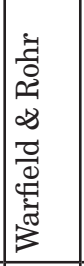 & 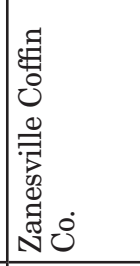 & 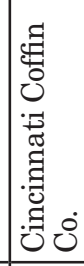 & 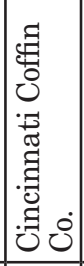 & 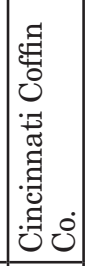 & 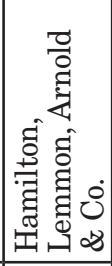 & 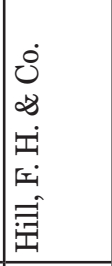 & 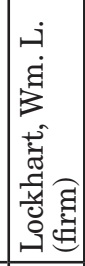 & 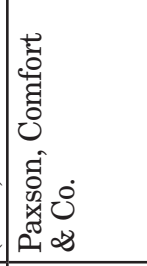 \\
\hline ค & & $\begin{array}{ll}\infty & 0 \\
\infty & 0.0 \\
\infty\end{array}$ & $\infty$ & $\mid \begin{array}{ll}\infty \\
\infty \\
\infty \\
\infty\end{array}$ & \& & $\begin{array}{l}8 \\
0 \\
0 \\
0\end{array}$ & 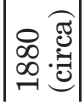 & $\mid \begin{array}{l}\infty \\
\infty \\
-\infty\end{array}$ & 亦 & $\begin{array}{c}\infty \\
\infty \\
-\infty \\
-1\end{array}$ & 亦 & $\stackrel{\infty}{-}$ & $\stackrel{\infty}{-1}$ & $\mid \begin{array}{l}\infty \\
\infty \\
-1\end{array}$ & 我 \\
\hline
\end{tabular}




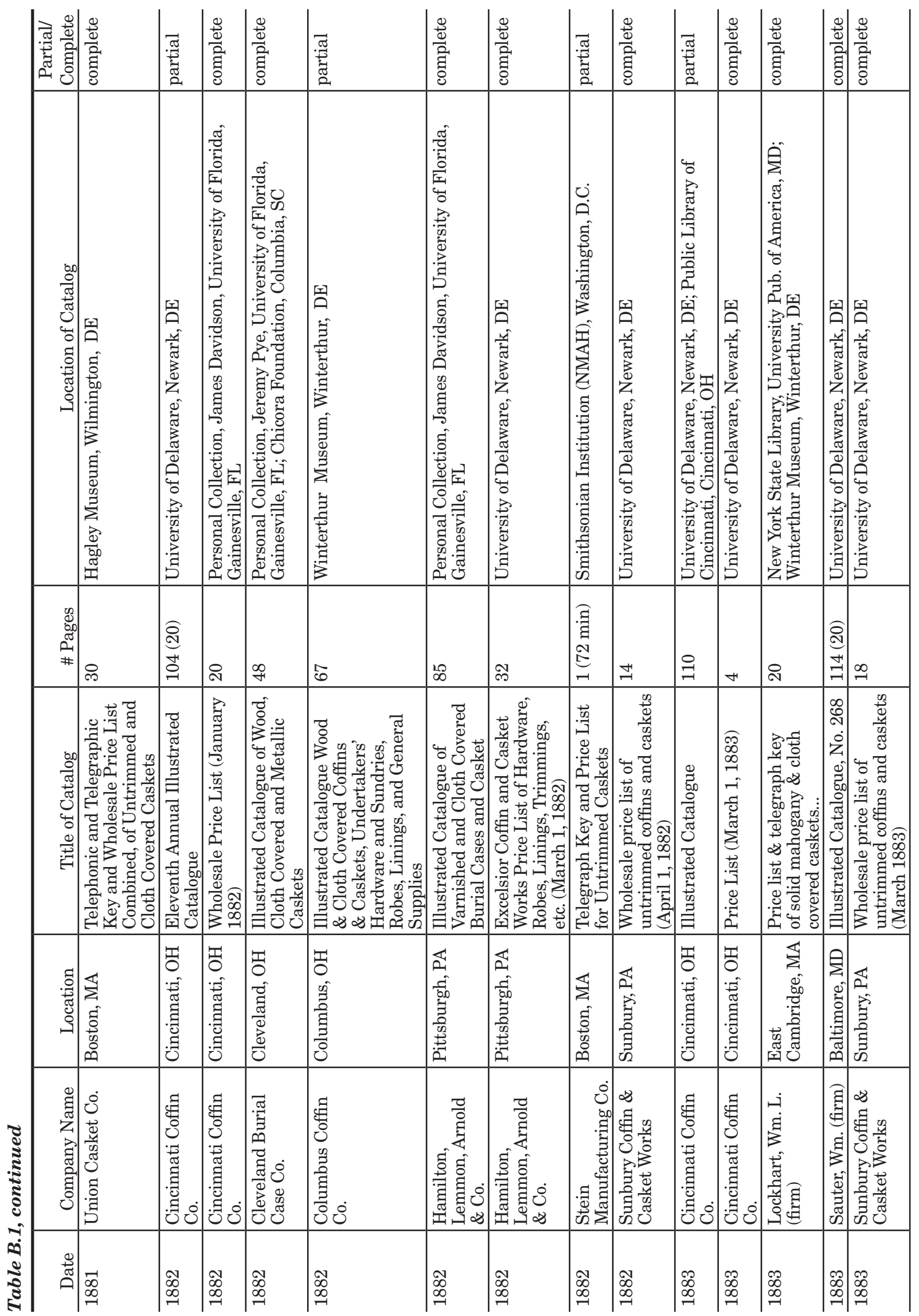




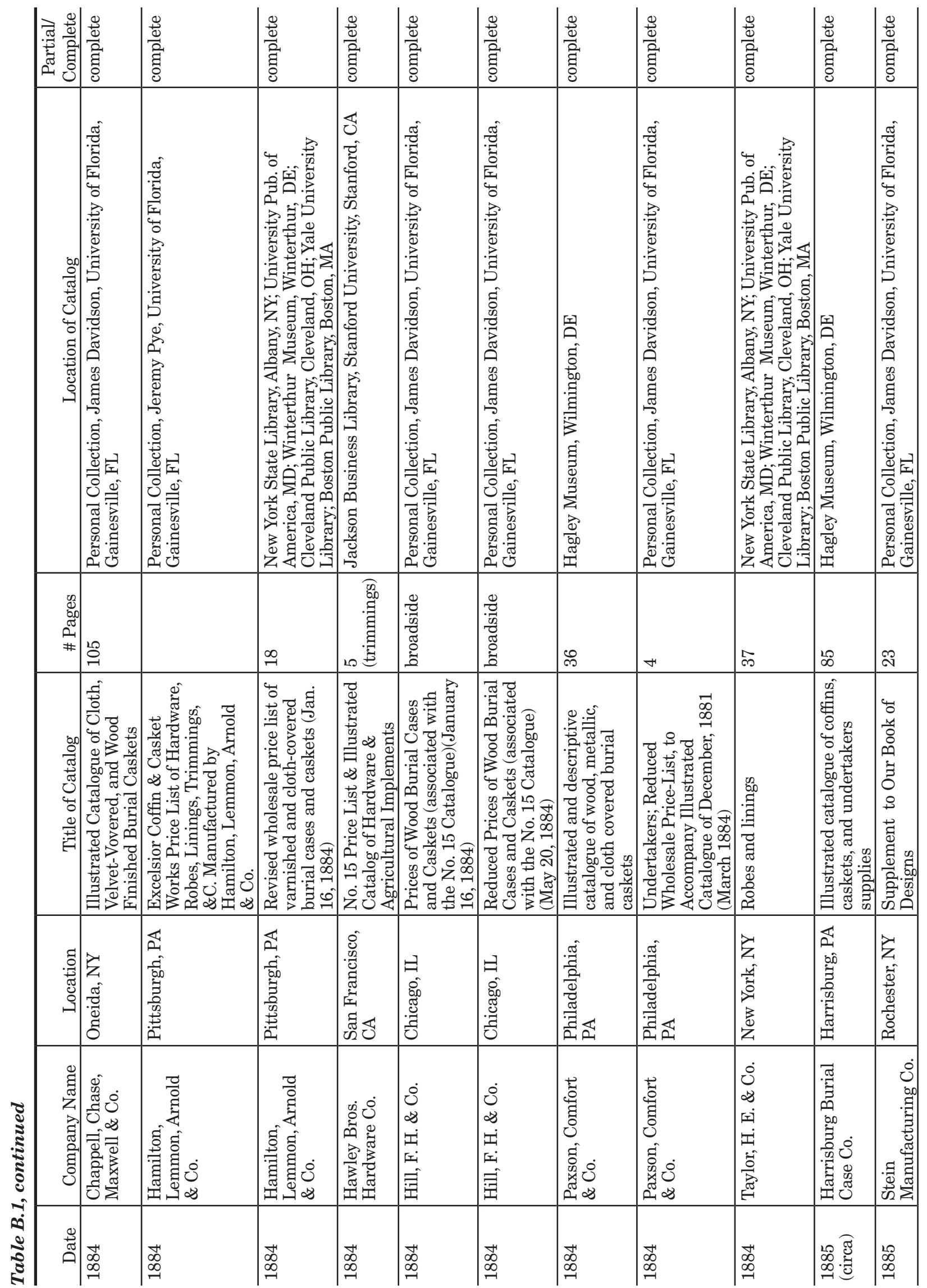




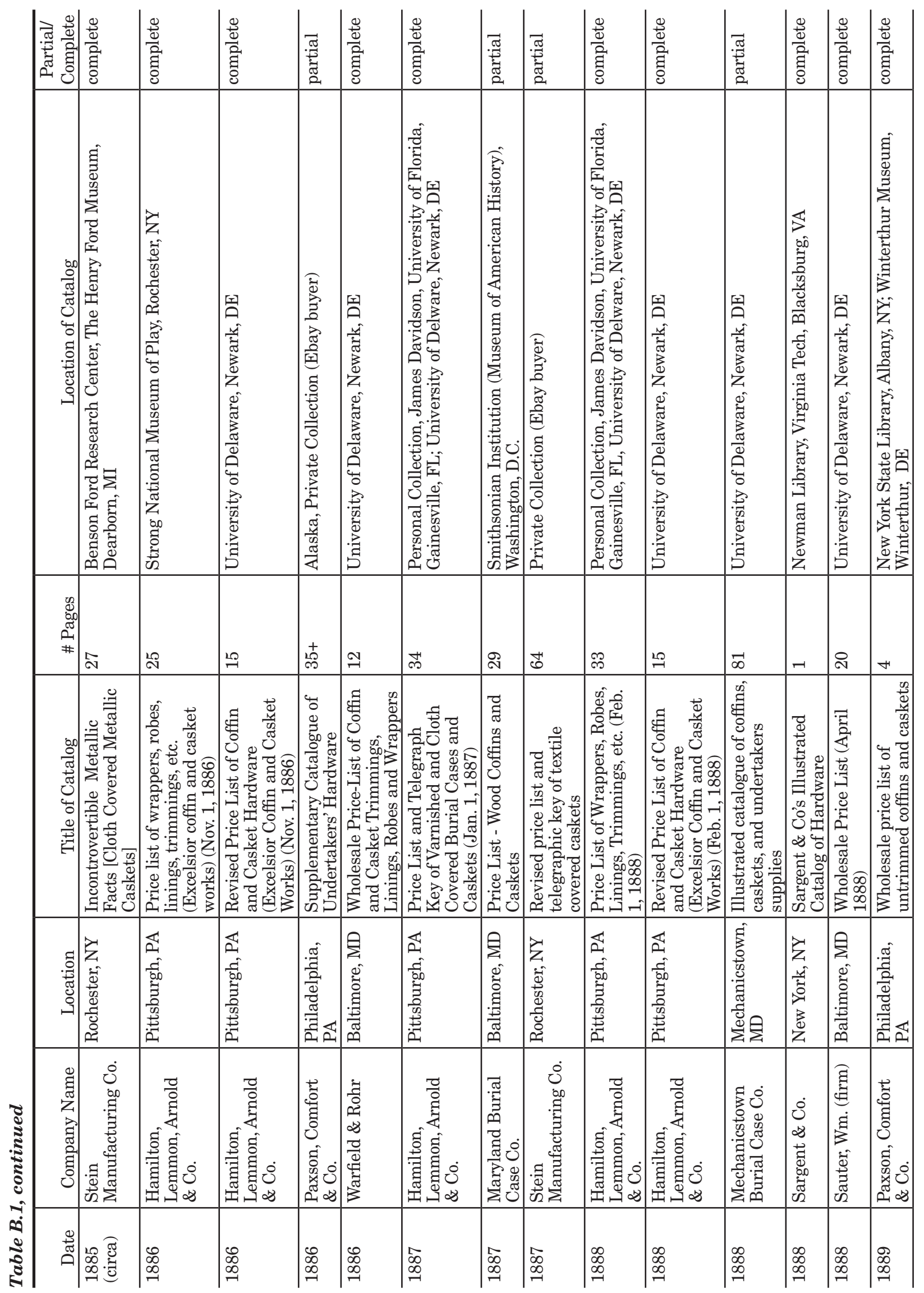




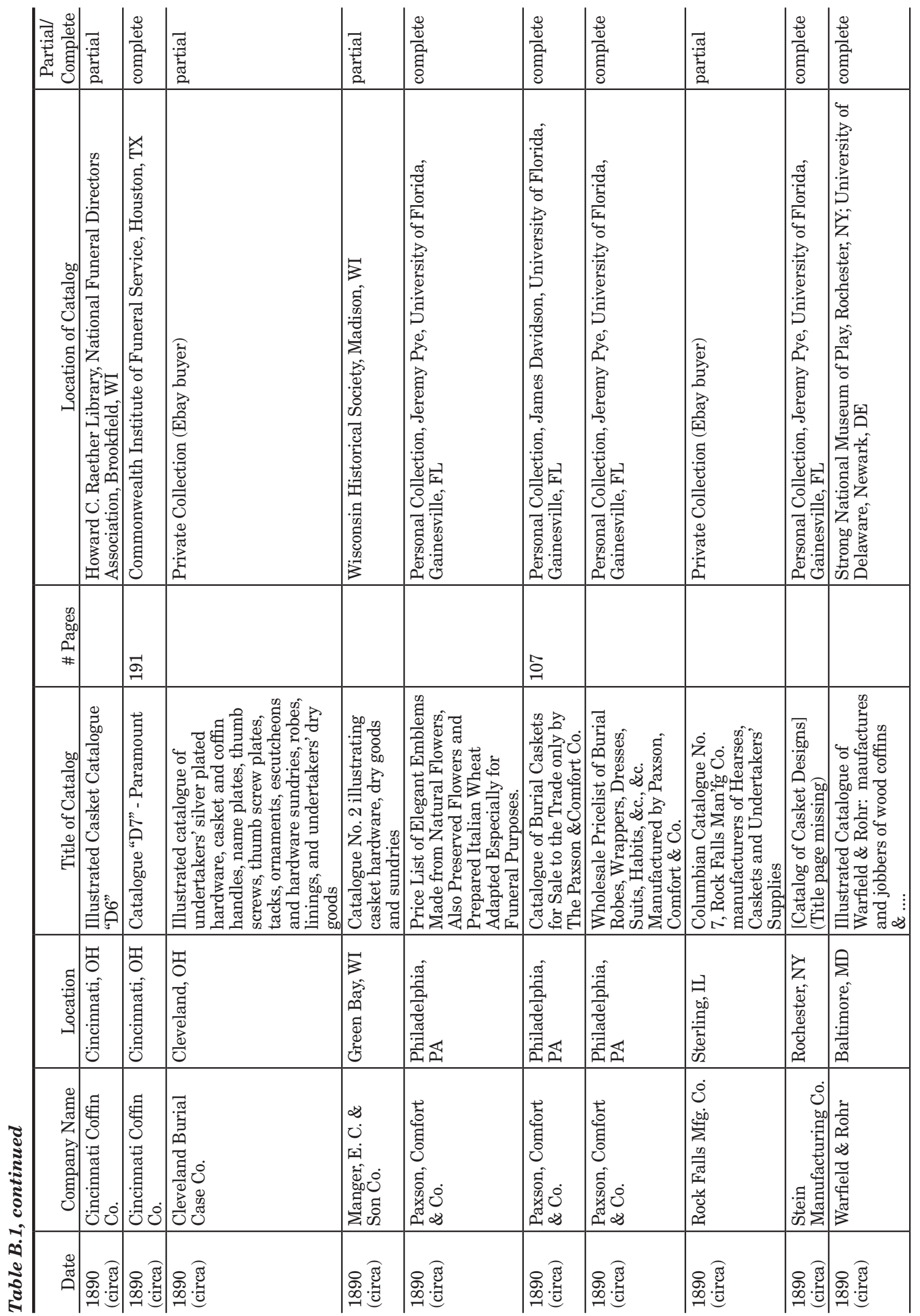




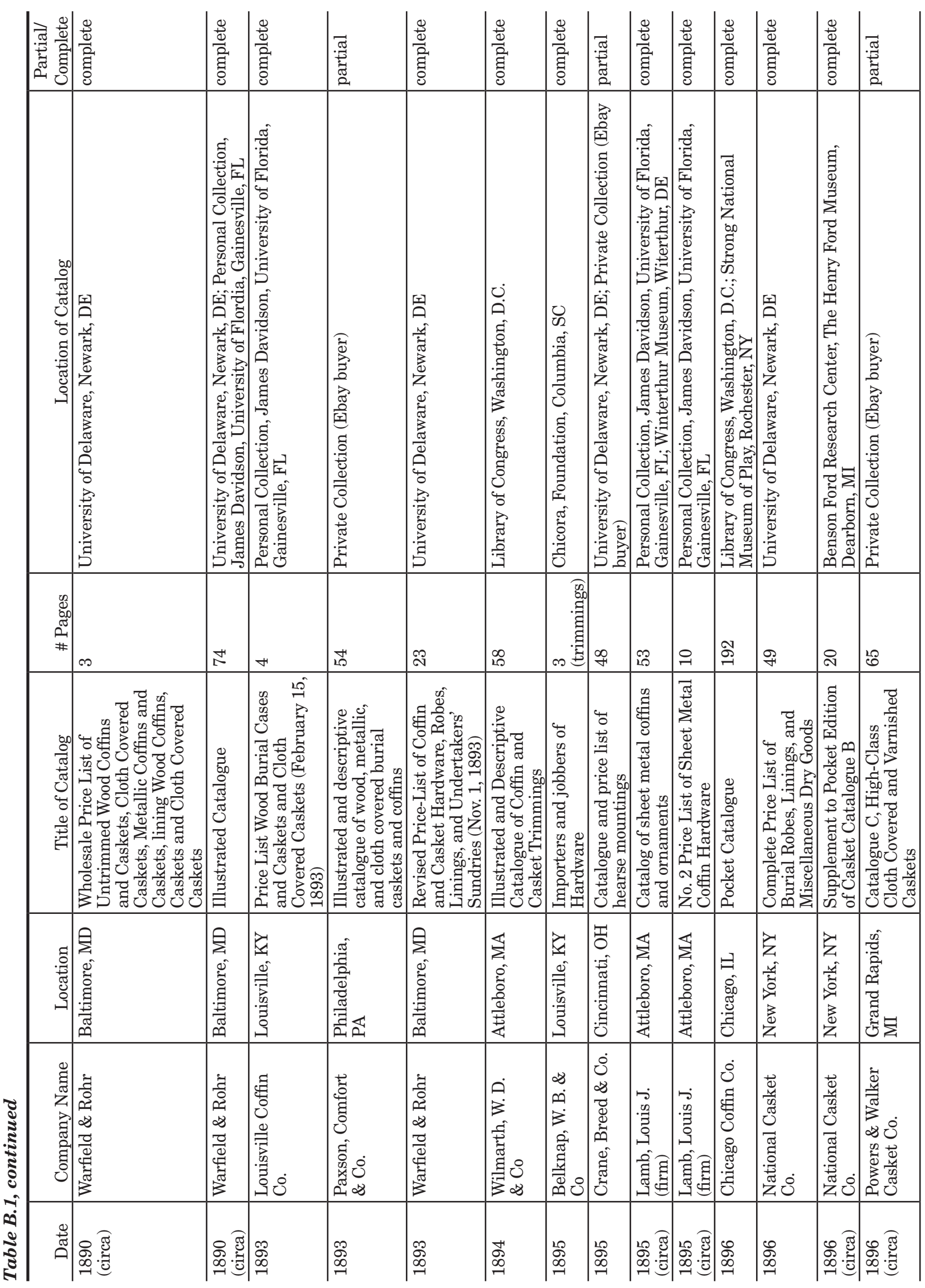




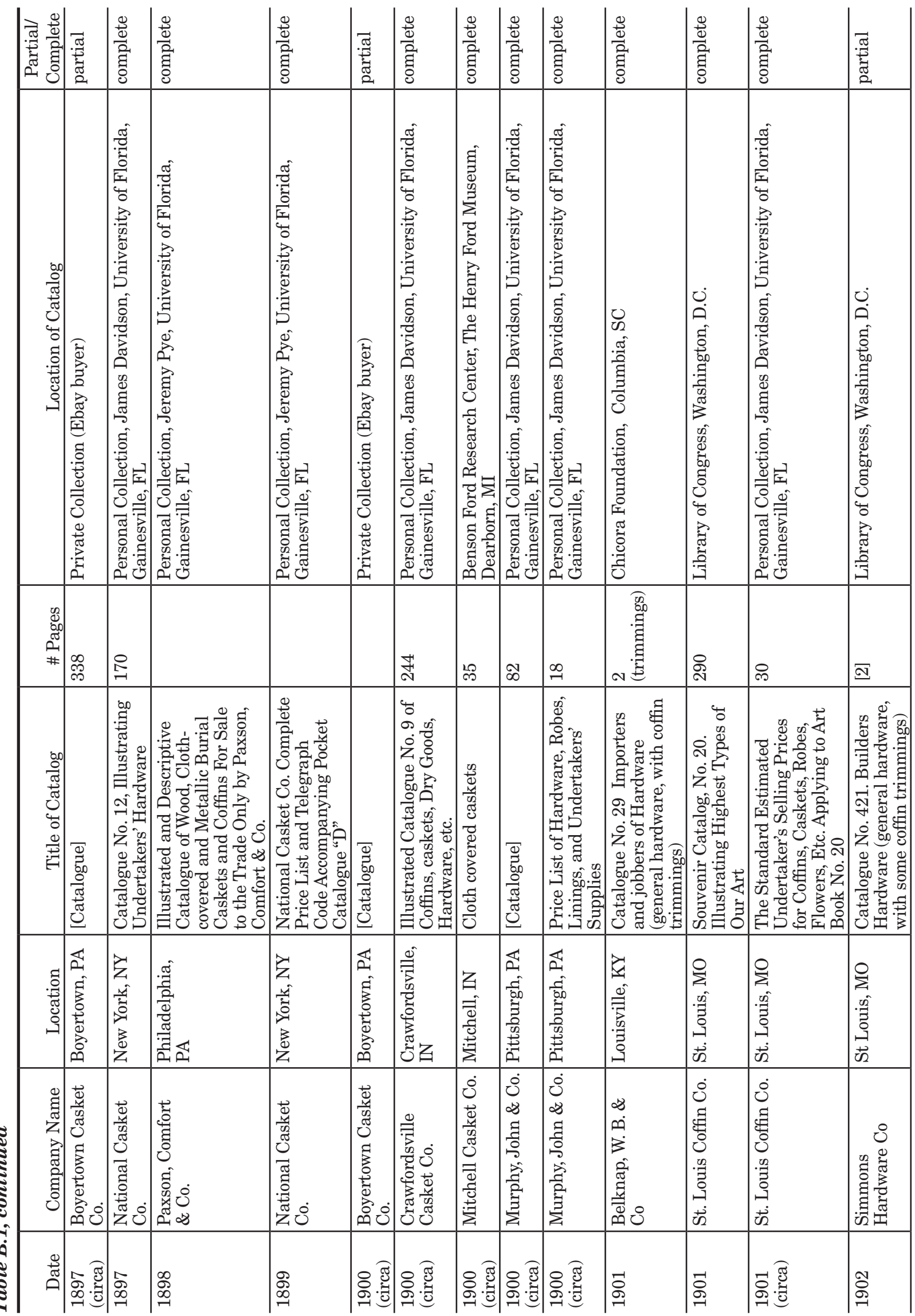




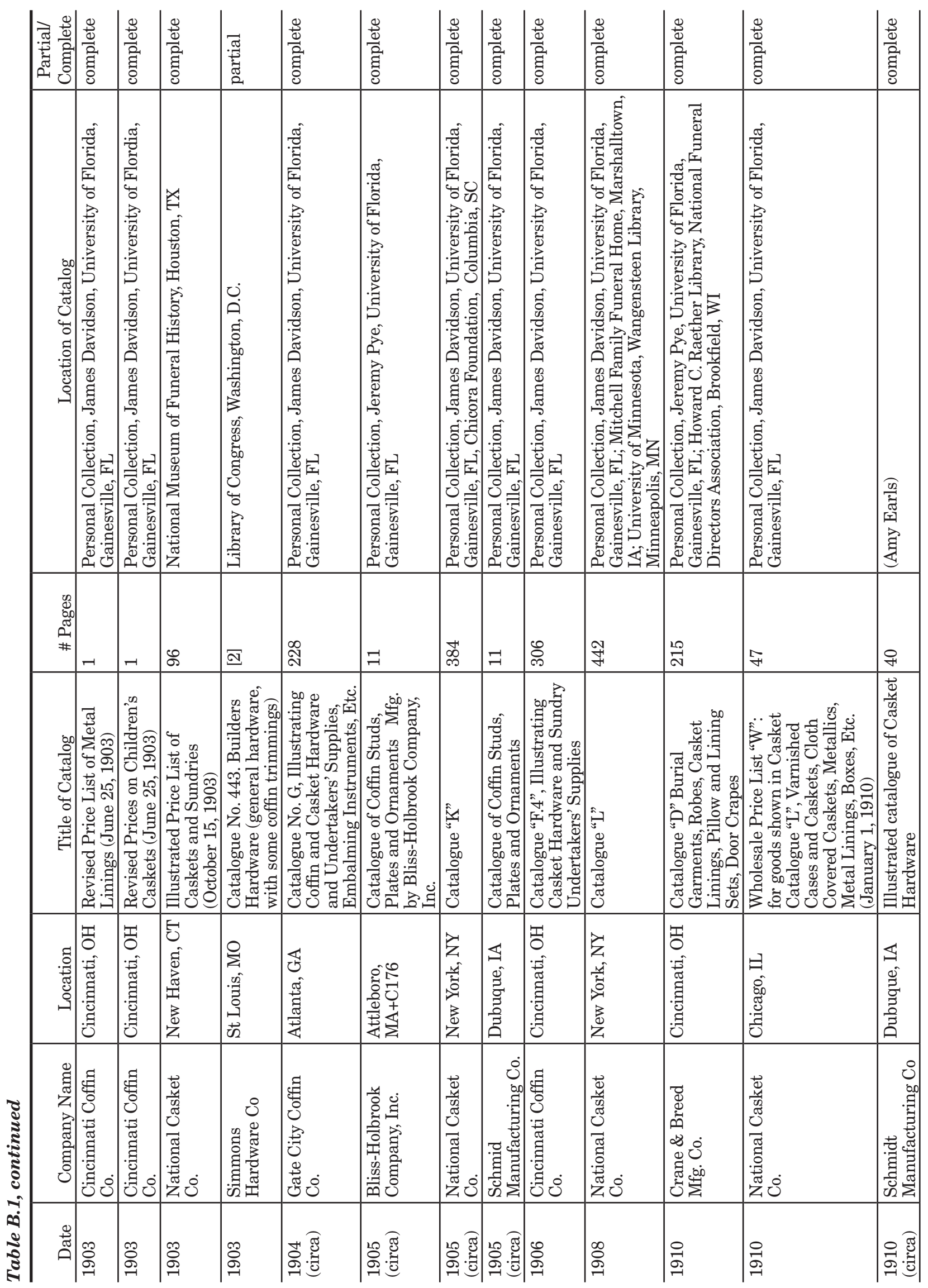




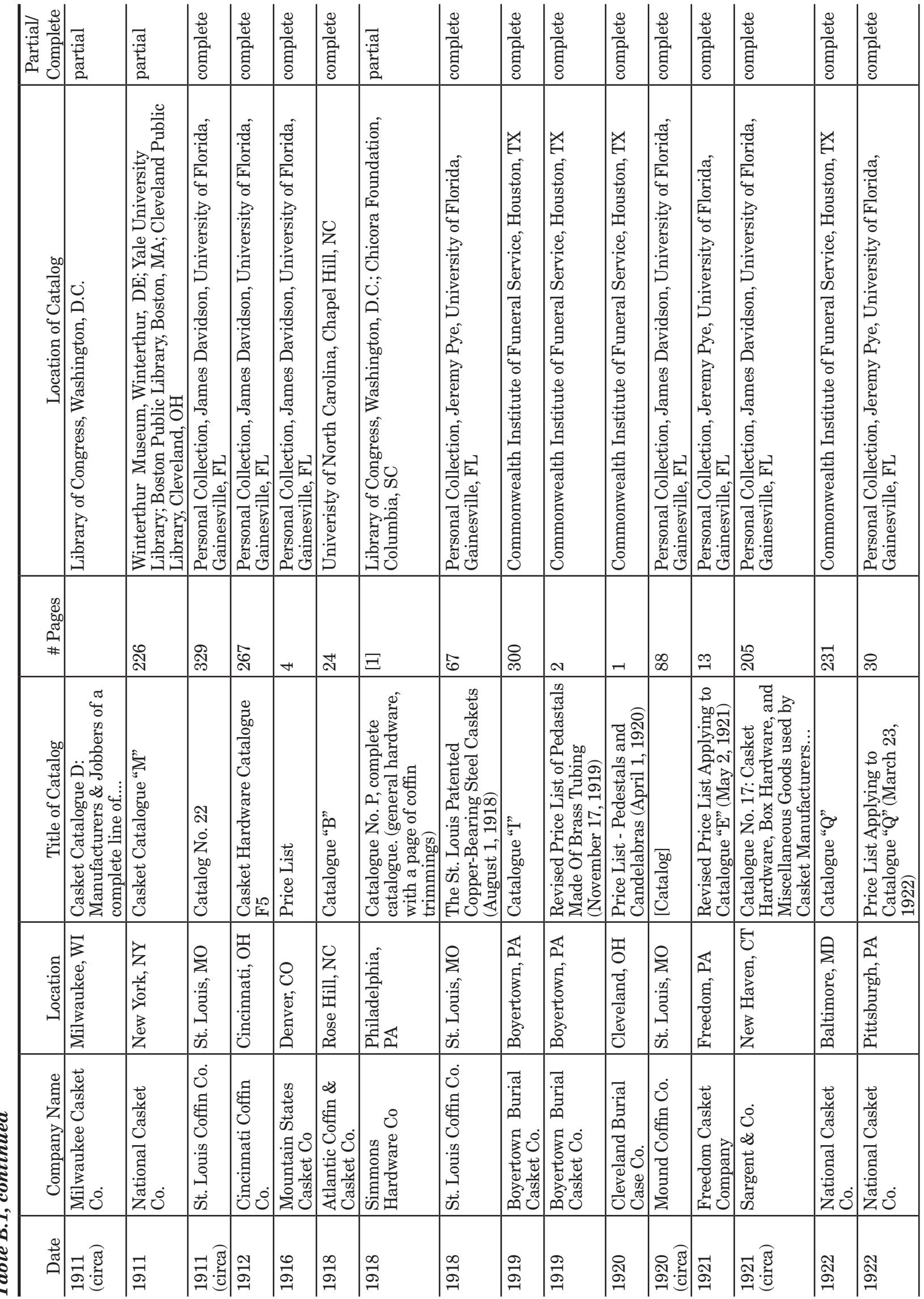




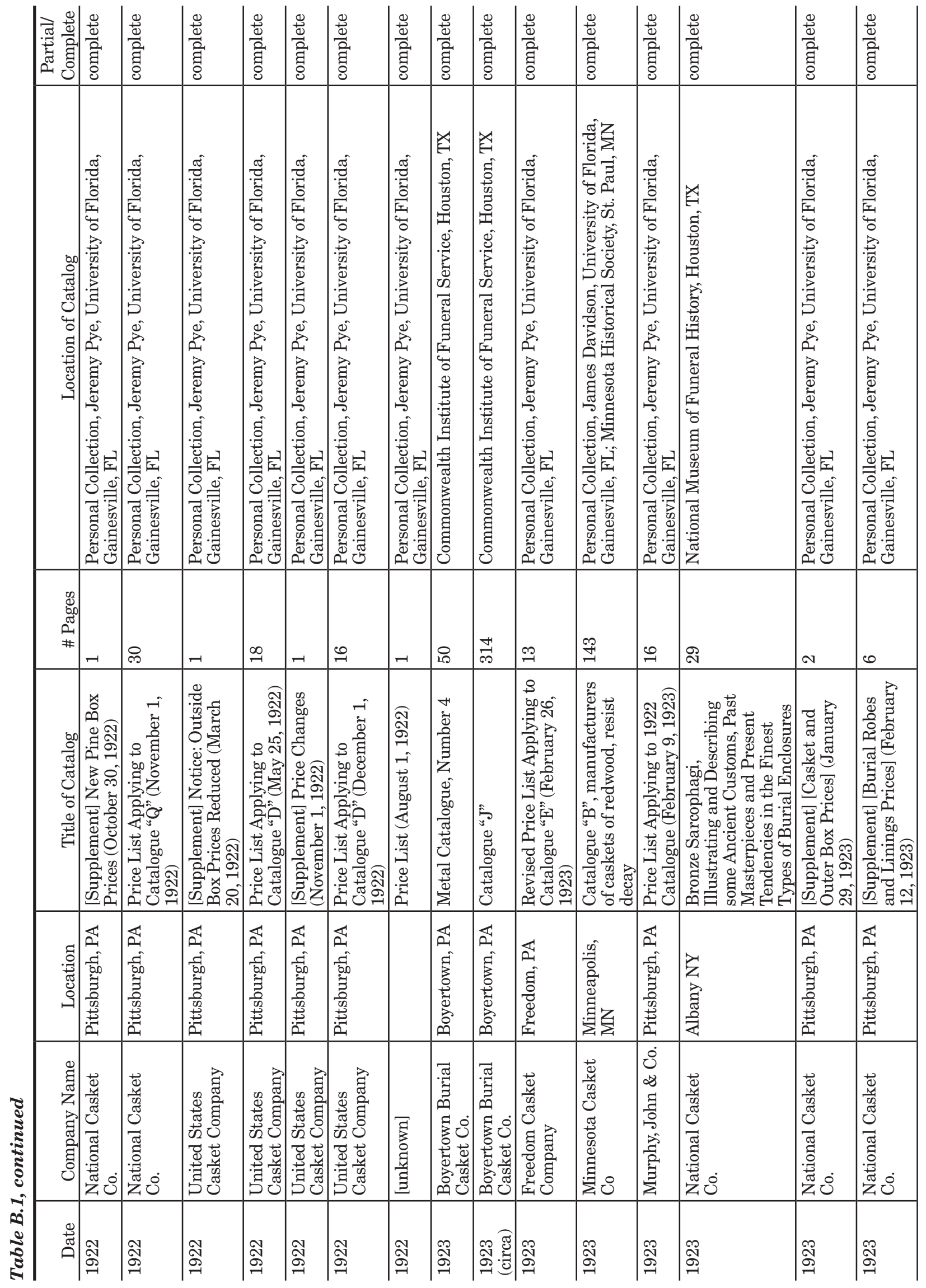




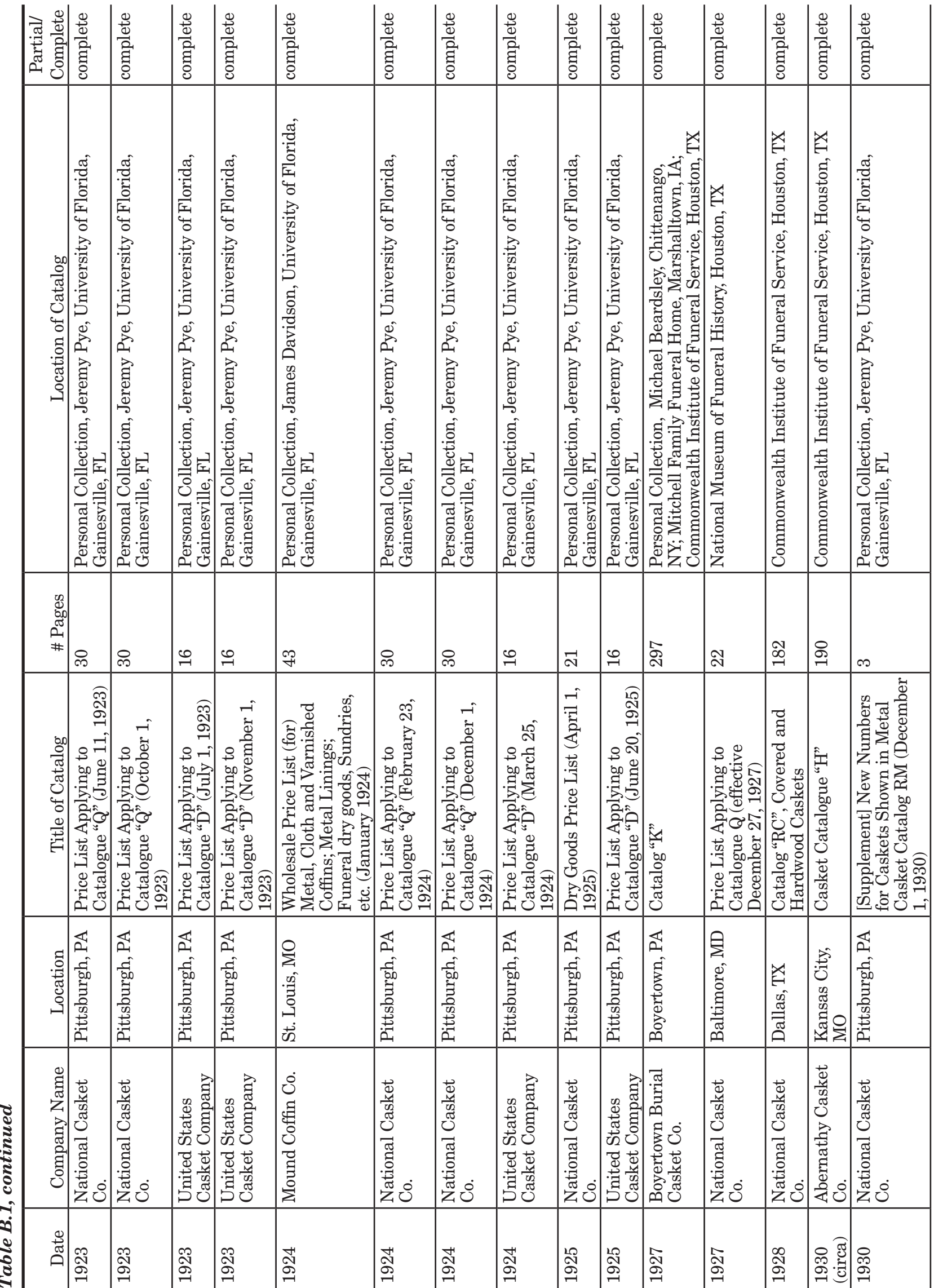









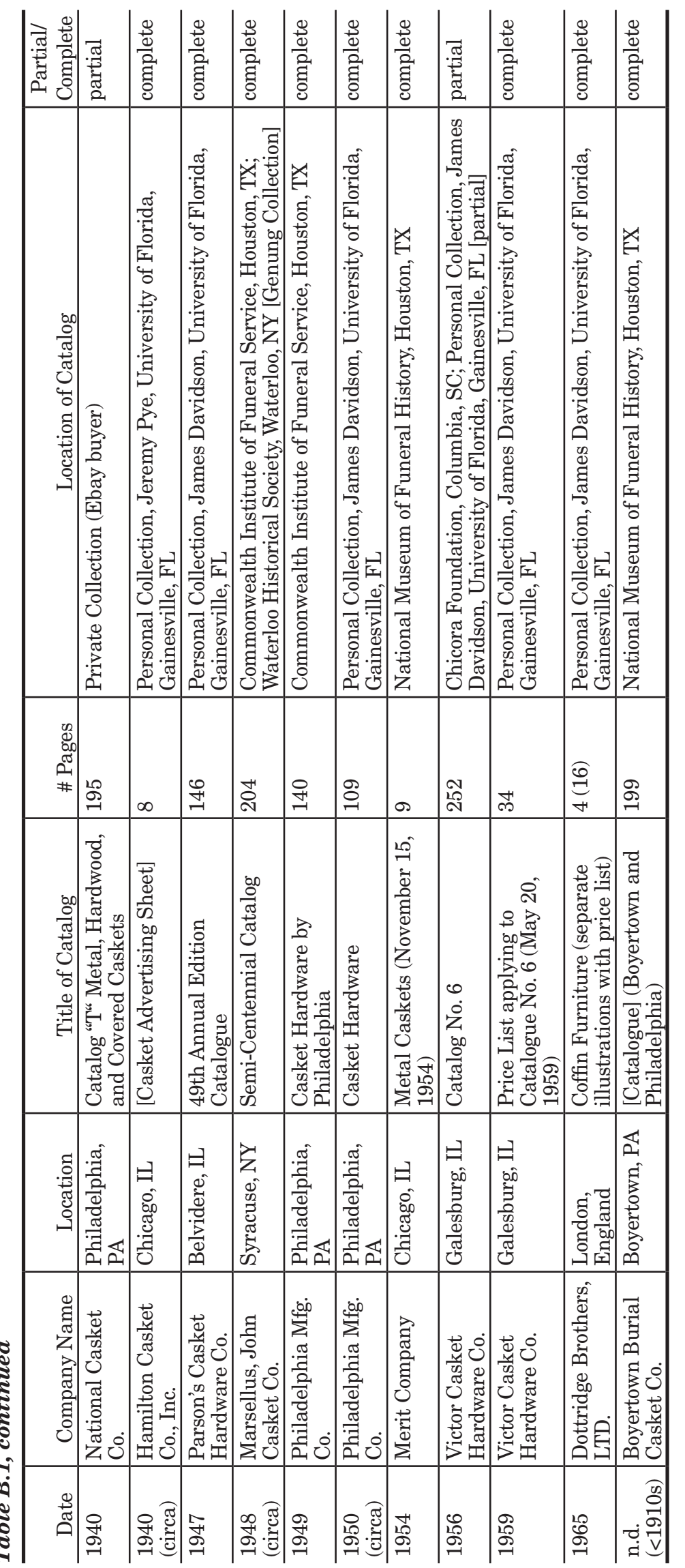




\title{
APPENDIX C: Osteological Data
}

\author{
Compiled by Cory J. Broehm
}



The 12 tables of osteological data presented in this appendix detail the inventory and analysis of skeletal remains from Pioneer Cemetery that were excavated in two separate phases archeological investigations. The first, completed in 2003, is Tiné and Boyd's (2003) analysis of Burials 1, 3, and 4. The second is Cory Broehm's analysis of the skeletal remains of 11 individuals from Burials 7-17, excavated in 2008-2009 (see Chapter 7). To the extent possible, methods of osteological analysis for were identical to those used in the earlier investigation. However, slight differences in the data reporting were unavoidable due to poor bone preservation. As a result, the osteological data for Burials 7-17 may include fields for unsided skeletal elements. Also, vertebral data for the latter burials is more condensed than that recorded in 2003. Due to these slight differences, the tables detailing these osteological analyses have been kept separate.

\section{REFERENCE CITED}

Tiné, Angela L., and Douglas K. Boyd

2003 Archeological Excavation and Reburial of Unmarked Historic Graves in the Pioneer Cemetery (41BO202), Brazoria County, Texas. Reports of Investigations No. 139. Prewitt and Associates, Inc., Austin. 
Table C.1. Skeletal inventory for Pioneer Cemetery

\begin{tabular}{|c|c|c|c|c|c|c|c|c|c|c|c|}
\hline \multirow[b]{2}{*}{ Element } & \multicolumn{11}{|c|}{ Burial } \\
\hline & 7 & 8 & 9 & 10 & 11 & 12 & 13 & 14 & 15 & 16 & 17 \\
\hline L frontal & 2 & 1 & $1-2$ & $1-2$ & 3 & 3 & 1 & 3 & 1 & 1 & 3 \\
\hline $\mathrm{R}$ frontal & 2 & 1 & $1-2$ & $1-2$ & 3 & 3 & 1 & & 1 & 1 & 3 \\
\hline L parietal & 2 & 1 & 2 & 1 & 3 & 3 & $1-2$ & 3 & 1 & 1 & 3 \\
\hline $\mathrm{R}$ parietal & 2 & 1 & 2 & 1 & 3 & 3 & 1-2 & 3 & 1 & 1 & 3 \\
\hline L occipital & 2 & 1 & 2 & 2 & 3 & 3 & 2 & 3 & 2 & 1 & 3 \\
\hline $\mathrm{R}$ occipital & 2 & 1 & 2 & 2 & 3 & 3 & 2 & & 2 & 1 & 3 \\
\hline L temporal & $2-3$ & 1 & $1-2$ & $1-2$ & & 3 & 1 & 3 & 1 & 2 & 3 \\
\hline $\mathrm{R}$ temporal & $2-3$ & 1 & $1-2$ & $1-2$ & & 3 & 2 & 3 & 1 & 2 & 3 \\
\hline L TMJ & 1 & 1 & 1 & 1 & & & & & 1 & 1 & \\
\hline R TMJ & 1 & 1 & 1 & 1 & & & & & 1 & 1 & \\
\hline L sphenoid & 2 & & 3 & 3 & & & 2 & & & 3 & \\
\hline $\mathrm{R}$ sphenoid & & 3 & 3 & 3 & & & 2 & & & 3 & \\
\hline unsided sphenoid & & & & & & & & & 3 & & \\
\hline L zygomatic & 1 & 1 & 1 & 2 & & & 1 & & 2 & 1 & \\
\hline R zygomatic & 1 & & 2 & 2 & & & 1 & 1 & 1 & 2 & \\
\hline L maxilla & & 1 & 3 & 1 & & & & & 2 & 3 & \\
\hline $\mathrm{R}$ maxilla & & 1 & 1 & 1 & & & & & 2 & 3 & \\
\hline L mandible & 2 & 1 & 2 & 2 & & & 2 & 1 & 1 & 1 & \\
\hline $\mathrm{R}$ mandible & & 1 & $1-2$ & 2 & & 1 & 3 & 1 & 3 & 1 & \\
\hline L clavicle & 1 & $2-3$ & $1-2$ & 2 & & & 2 & 2 & 1 & 1 & \\
\hline $\mathrm{R}$ clavicle & 1 & $2-3$ & 2 & & & & 1 & 2 & 2 & 1 & \\
\hline unsided clavicle & & & & & 3 & & & & & & \\
\hline L scap. body & 3 & 3 & 3 & 3 & & & 3 & 3 & 3 & 3 & \\
\hline R scap. body & 3 & 3 & 3 & 3 & & & 3 & 3 & 3 & 3 & \\
\hline L scap. glenoid & & 3 & 2 & 2 & & & 1 & & 2 & & \\
\hline $\mathrm{R}$ scap. glenoid & 1 & 3 & & & & & 1 & & 1 & 3 & \\
\hline L patella & 1 & 1 & 2 & & 3 & & 2 & 3 & 2 & 2 & \\
\hline $\mathrm{R}$ patella & 1 & 2 & & & & & 1 & & 1 & 1 & \\
\hline sacrum & 2 & 2 & & & & & 2 & 3 & 2 & 2 & \\
\hline L ilium & & & 3 & & & & 2 & & 2 & 2 & \\
\hline $\mathrm{R}$ ilium & 2 & & 3 & 3 & & & & & 2 & 2 & \\
\hline unsided ilium & & & & & & & & 3 & & & \\
\hline L ischium & & & & & & & & & 1 & & \\
\hline $\mathrm{R}$ ischium & 2 & & & & & & 2 & & 2 & 2 & \\
\hline unsided ischium & & & & & & & & 3 & & & \\
\hline L pubis & 1 & & & & & & & & & & \\
\hline $\mathrm{R}$ pubis & 2 & & & & & & & & & & \\
\hline $\mathrm{L}$ acetabulum & & 3 & & & & & 3 & & 2 & 2 & \\
\hline $\mathrm{R}$ acetabulum & 1 & 3 & & & & & 3 & & 1 & 2 & \\
\hline Unsided acetabulum & & & 3 & 3 & & & & & & & \\
\hline L aur. surf. & & & & & & & 1 & & 1 & 1 & \\
\hline $\mathrm{R}$ aur. surf. & 1 & & & & & & & 3 & & 1 & 3 \\
\hline Unidentified os coxae & & 3 & & & & & & & & & \\
\hline $\mathrm{C} 1$ & 1 & 1 & 2 & 1 & & & 1 & 3 & 1 & 1 & \\
\hline C2 centrum & 1 & 1 & 1 & 1 & & & 1 & 1 & 1 & 1 & \\
\hline C2 neural arch & 3 & 1 & 2 & 1 & & & 1 & 1 & 1 & 1 & \\
\hline C3-7 centrum* & $4 / 3$ & $3 / 3$ & $3 / 2$ & $0 / 0$ & & & $5 / 5$ & & $4 / 3$ & $5 / 5$ & \\
\hline
\end{tabular}


Table C.1, continued

\begin{tabular}{|c|c|c|c|c|c|c|c|c|c|c|c|}
\hline \multirow[b]{2}{*}{ Element } & \multicolumn{11}{|c|}{ Burial } \\
\hline & 7 & 8 & 9 & 10 & 11 & 12 & 13 & 14 & 15 & 16 & 17 \\
\hline C3-7 neural arch* & $3+/ 1$ & $4+/ 0$ & $2+/ 1$ & $4+/ 0$ & & & $4+/ 1$ & & $4+/ 0$ & $4 / 4$ & \\
\hline T1-T12 centrum* & $12 / 7$ & $2+/ 0$ & $2 / 2$ & $0 / 0$ & & & $12 / 7$ & & $10 / 4$ & $11 / 9$ & \\
\hline T1-T12 neural arch* & $11+/ 4$ & $2+/ 1$ & $4+/ 2$ & $7+/ 0$ & & & $7+/ 1$ & & $9+/ 3+$ & $8+/ 4$ & \\
\hline L1-L5 centrum* & $4 / 4$ & $0 / 0$ & $2 / 1$ & $0 / 0$ & & & $3 / 2$ & & $4 / 3$ & $3 / 3$ & \\
\hline L1-L5 neural arch* & $4 / 3$ & $1+/ 0$ & $2 / 2$ & $2+/ 0$ & & & $5 / 4$ & $1 / 1$ & $5 / 2$ & $5 / 5$ & \\
\hline $\begin{array}{l}\text { cervical or thoracic } \\
\text { centrum* }\end{array}$ & & & & $6 / 0$ & & & & & & & \\
\hline $\begin{array}{l}\text { thoracic or lumbar } \\
\text { centrum* }\end{array}$ & & & & & & & & $2 / 0$ & & & \\
\hline $\begin{array}{l}\text { unidentified neural } \\
\text { arch }\end{array}$ & & & & & & & & & & & 4 \\
\hline manubrium & 2 & & & & & & & & & & \\
\hline sternal body & 3 & & & & & & & & & & \\
\hline L rib 1 & 1 & & & & & & & & & 2 & \\
\hline $\mathrm{R}$ rib 1 & 1 & & 2 & & & & & & 1 & & \\
\hline \multicolumn{12}{|l|}{ L rib 2} \\
\hline \multicolumn{12}{|l|}{$\mathrm{R}$ rib 2} \\
\hline L ribs $3-10^{*}$ & $5+/ 0$ & & $4 / 0$ & & & & & & & $6 / 0$ & \\
\hline $\mathrm{R}$ ribs $3-10^{*}$ & $7+/ 0$ & & $2 / 0$ & & & & & & & $9 / 0$ & \\
\hline \multicolumn{12}{|l|}{ L rib 11} \\
\hline $\mathrm{R}$ rib 11 & $2 ?$ & & & & & & & & & & \\
\hline \multicolumn{12}{|l|}{$\mathrm{L}$ rib 12} \\
\hline \multicolumn{12}{|l|}{$\mathrm{R}$ rib 12} \\
\hline Unsided rib frags. (\#) & $20+$ & $\mathrm{NC}$ & 41 & 5 & & & $47+$ & 6 & $47+$ & $40+$ & $3+$ \\
\hline $\begin{array}{l}\text { unidentified long } \\
\text { bone frags. }\end{array}$ & & & & & & $\mathrm{NC}$ & & & & & \\
\hline L hum. prox. epiph. & 1 & 3 & & 3 & & & 2 & 2 & 2 & & \\
\hline L hum. prox. $1 / 3$ & 3 & & 2 & 2 & & & 1 & & & 1 & \\
\hline L hum. middle $1 / 3$ & & & 1 & 1 & & & 1 & & 2 & 1 & \\
\hline L hum. dist. $1 / 3$ & & 1 & 1 & 1 & 3 & & 1 & 1 & 1 & 1 & \\
\hline L hum. dist. epiph. & 3 & 3 & & 1 & & & & 3 & 2 & 2 & \\
\hline R hum. prox. epiph. & 3 & 3 & & 2 & & & & & & & \\
\hline $\mathrm{R}$ hum. prox. $1 / 3$ & & 2 & 2 & 2 & & & 1 & 3 & 2 & & \\
\hline $\mathrm{R}$ hum. middle $1 / 3$ & 2 & 1 & 1 & 1 & & & 1 & 3 & 1 & & \\
\hline $\mathrm{R}$ hum. dist. $1 / 3$ & 1 & 1 & 1 & 1 & & & 1 & 2 & 1 & & \\
\hline R hum. dist. epiph. & 1 & $1-2$ & & 1 & & & & & 1 & 2 & \\
\hline $\begin{array}{l}\text { Unisided hum. dist. } \\
\text { epiph. }\end{array}$ & & & 3 & & & & & & & & \\
\hline L rad. prox. epiph. & 1 & 2 & 1 & 2 & & & & & 1 & 2 & \\
\hline $\mathrm{L}$ rad. prox. $1 / 3$ & 1 & $2-3$ & 1 & 1 & & & & 1 & 2 & 1 & \\
\hline $\mathrm{L}$ rad. middle $1 / 3$ & 1 & 1 & 1 & 1 & 3 & & 1 & & 1 & 1 & \\
\hline L rad. dist. $1 / 3$ & 1 & $2-3$ & $1-2$ & 1 & & & & & 3 & 1 & \\
\hline L rad. dist. epiph. & 1 & 3 & & 0 & & & & & & & \\
\hline $\mathrm{R}$ rad. prox. epiph. & & 1 & 2 & 3 & & & & & 1 & & \\
\hline $\mathrm{R}$ rad. prox. $1 / 3$ & & 1 & 1 & 1 & & & 3 & 3 & 1 & 2 & \\
\hline $\mathrm{R}$ rad. middle $1 / 3$ & & 1 & 1 & 1 & & & 1 & & 1 & 1 & \\
\hline $\mathrm{R}$ rad. dist. $1 / 3$ & & $1-2$ & $1-2$ & 2 & & & 3 & & 2 & 1 & \\
\hline $\mathrm{R}$ rad. dist. epiph. & & & 2 & & & & & & & & \\
\hline L ulna prox. epiph. & & $1-2$ & & 1 & & & & 1 & 1 & & \\
\hline
\end{tabular}


Table C.1, continued

\begin{tabular}{|c|c|c|c|c|c|c|c|c|c|c|c|}
\hline \multirow[b]{2}{*}{ Element } & \multicolumn{11}{|c|}{ Burial } \\
\hline & 7 & 8 & 9 & 10 & 11 & 12 & 13 & 14 & 15 & 16 & 17 \\
\hline L ulna prox. $1 / 3$ & & 1 & 2 & 1 & 3 & & 2 & 1 & 1 & 2 & \\
\hline L ulna middle $1 / 3$ & & $1-2$ & 1 & 1 & 3 & & 1 & & 1 & 1 & \\
\hline L ulna dist. $1 / 3$ & & & 3 & 1 & & & 2 & & 1 & 2 & \\
\hline \multicolumn{12}{|l|}{ L ulna dist. epiph. } \\
\hline R ulna prox. epiph. & 2 & 1 & & 2 & & & & 2 & 1 & & \\
\hline $\mathrm{R}$ ulna prox. $1 / 3$ & 1 & 1 & 2 & 1 & & & 3 & & 1 & 2 & \\
\hline $\mathrm{R}$ ulna middle $1 / 3$ & 1 & & 1 & 2 & & & 1 & & 1 & 1 & \\
\hline $\mathrm{R}$ ulna dist. $1 / 3$ & 3 & & 1 & & & & 1 & & 2 & & \\
\hline $\mathrm{R}$ ulna dist. epiph. & 1 & & & & & & & & 2 & & \\
\hline unsided dist. Ulna & & & & & & & & & & 2 & \\
\hline L femur prox. epiph. & & 3 & & & & & 1 & 1 & & 2 & \\
\hline L femur prox. $1 / 3$ & 2 & 1 & 2 & & & & 1 & 1 & 1 & 1 & \\
\hline $\mathrm{L}$ femur middle $1 / 3$ & 1 & $1-2$ & 1 & & & & 1 & 1 & 1 & 1 & \\
\hline $\mathrm{L}$ femur dist. $1 / 3$ & 2 & $2-3$ & $1-2$ & & & & 1 & & 3 & 2 & \\
\hline L femur dist. epiph. & & 3 & 3 & & & & 3 & & & & \\
\hline $\mathrm{R}$ femur prox. epiph. & 2 & 3 & & & & & 1 & 2 & 1 & 3 & \\
\hline $\mathrm{R}$ femur prox. $1 / 3$ & 1 & 2 & 3 & & 3 & & 1 & 2 & 1 & 1 & \\
\hline $\mathrm{R}$ femur middle $1 / 3$ & 1 & 1 & 1 & & 3 & & 1 & 1 & 1 & 1 & \\
\hline $\mathrm{R}$ femur dist. $1 / 3$ & 1 & 2 & 2 & & 3 & & 2 & 3 & 1 & 2 & \\
\hline $\mathrm{R}$ femur dist. epiph. & 2 & 3 & & & & & 2 & & & & \\
\hline $\begin{array}{l}\text { Unsided femur dist. } \\
\text { epiph. }\end{array}$ & & & 3 & & & & & & 3 & & \\
\hline L tibia prox. epiph. & & 3 & & & & & & & 2 & & \\
\hline L tibia prox. $1 / 3$ & 2 & 2 & 2 & & 3 & & & 3 & 2 & 2 & \\
\hline L tibia middle $1 / 3$ & 1 & 1 & 1 & & 3 & & 3 & 3 & 1 & 1 & \\
\hline L tibia dist. $1 / 3$ & 2 & 1 & $1-2$ & & 3 & & & 3 & 1 & 2 & \\
\hline L tibia dist. epiph. & & 1 & & & & & & & & & \\
\hline R tibia prox. epiph. & & 3 & & & & & & & & & \\
\hline $\mathrm{R}$ tibia prox. $1 / 3$ & 2 & 1 & & & & & 2 & 3 & 2 & 3 & \\
\hline $\mathrm{R}$ tibia middle $1 / 3$ & 1 & 1 & & & & & 1 & 2 & 1 & 1 & \\
\hline $\mathrm{R}$ tibia dist. $1 / 3$ & 2 & 1 & & & & & 3 & & 2 & 2 & \\
\hline $\mathrm{R}$ tibia dist. epiph. & & 1 & & & & & & & & & \\
\hline $\begin{array}{l}\text { Unsided tibia prox. } \\
\text { epiph. }\end{array}$ & 3 & & 3 & & & & & & & & \\
\hline $\begin{array}{l}\text { Unsided tibia dist. } \\
\text { epiph. }\end{array}$ & 3 & & & & & & 3 & & & 3 & \\
\hline \multicolumn{12}{|l|}{ L fibula prox. epiph. } \\
\hline L fibula prox. $1 / 3$ & 3 & 2 & 2 & & 3 & & 1 & 1 & 2 & 2 & \\
\hline L fibula middle $1 / 3$ & 1 & 1 & 1 & & 3 & & 1 & 1 & 1 & 2 & \\
\hline L fibula dist. $1 / 3$ & 3 & 1 & 2 & & 3 & & 1 & 1 & 1 & 2 & \\
\hline L fibula dist. epiph. & & 1 & & & & & & & 1 & & \\
\hline \multicolumn{12}{|l|}{ R fibula prox. epiph. } \\
\hline $\mathrm{R}$ fibula prox. $1 / 3$ & 3 & 1 & & & & & 1 & 1 & 1 & 2 & \\
\hline $\mathrm{R}$ fibula middle $1 / 3$ & 1 & 1 & & & & & 1 & 1 & 1 & 2 & \\
\hline $\mathrm{R}$ fibula dist. $1 / 3$ & 3 & 1 & & & & & 1 & 1 & 1 & 2 & \\
\hline $\mathrm{R}$ fibula dist. epiph. & 3 & 1 & & & & & & & 1 & & \\
\hline $\begin{array}{l}\text { unsided fibula prox. } \\
\text { Epiph. }\end{array}$ & & & & & & & & & 2 & & \\
\hline
\end{tabular}


Table C.1, continued

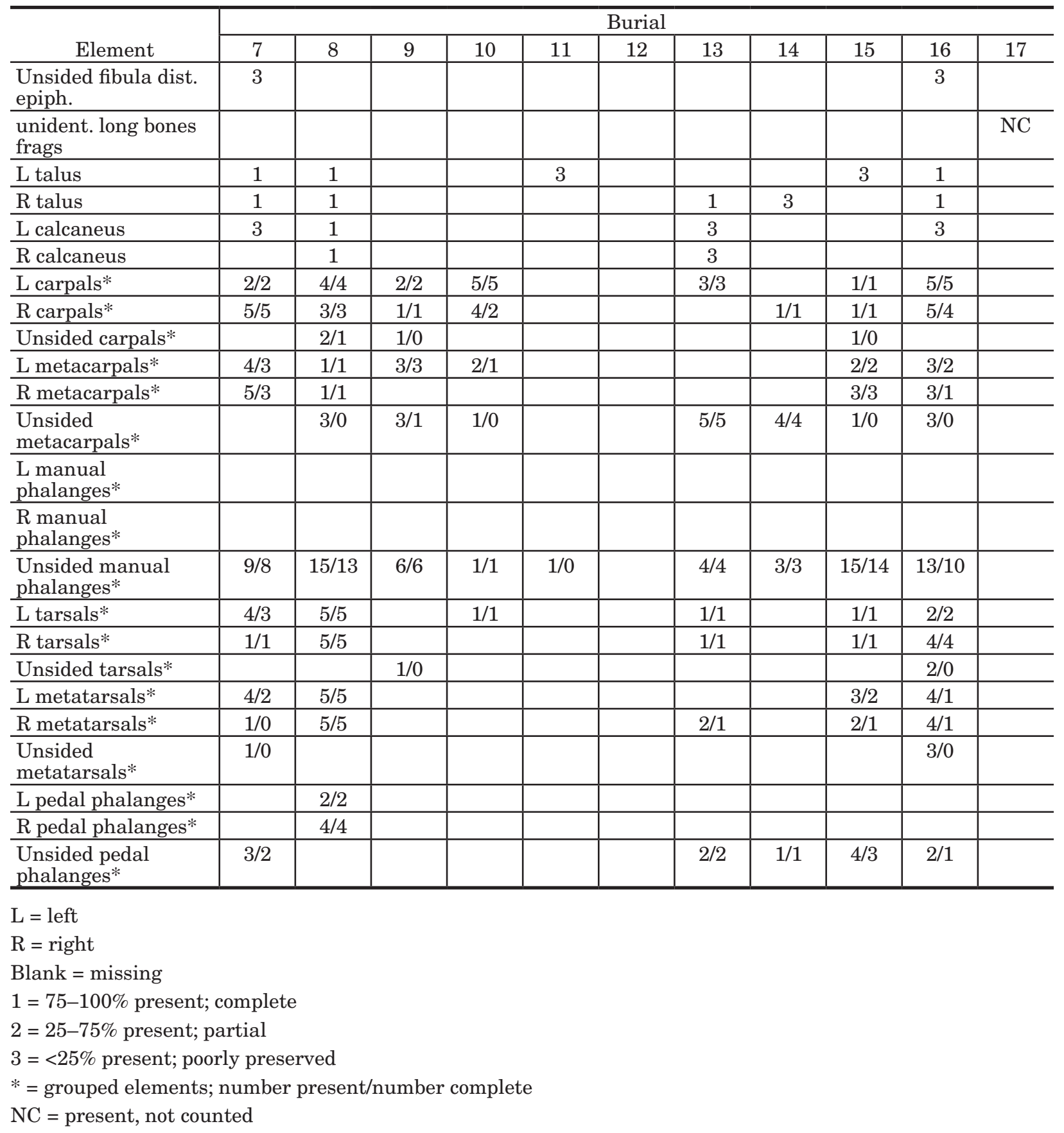


Table C.2. Adult sex determinations for Pioneer Cemetery

\begin{tabular}{|c|c|c|c|c|c|c|}
\hline \multirow[b]{2}{*}{ Trait } & \multicolumn{6}{|c|}{ Burial } \\
\hline & 7 & 8 & 9 & 10 & 15 & 16 \\
\hline L Ventral arc & 1 & & & & & \\
\hline \multicolumn{7}{|l|}{$\mathrm{R}$ Ventral arc } \\
\hline \multicolumn{7}{|l|}{ L Subpubic concavity } \\
\hline \multicolumn{7}{|l|}{ R Subpubic concavity } \\
\hline \multicolumn{7}{|l|}{ L Ischiopubic ramus ridge } \\
\hline \multicolumn{7}{|l|}{$\mathrm{R}$ Ischiopubic ramus ridge } \\
\hline L Greater sciatic notch & & & $2-3$ & & 1 & \\
\hline R Greater sciatic notch & 2 & & & 3 & & $1-2$ \\
\hline L Preauricular sulcus* & & & & & & 0 \\
\hline R Preauricular sulcus* & & & & & & 0 \\
\hline M Nuchal crest & $1-2$ & 4 & 4 & & 1 & $2-3$ \\
\hline L Mastoid process & 1 & 1 & 2 & 4 & $1-2$ & \\
\hline R Mastoid process & 2 & 1 & 2 & 4 & $1-2$ & \\
\hline L Supraorbital margin & & 3 & 4 & $4-5$ & & 2 \\
\hline R Supraorbital margin & & 3 & $3-4$ & $4-5$ & 2 & 2 \\
\hline M Glabella & & $3-4$ & & $3-4$ & 1 & \\
\hline M Mental eminence & & $2-3$ & 4 & 2 & 1 & 2 \\
\hline
\end{tabular}

$\mathrm{L}=$ left

$\mathrm{R}=$ right

$\mathrm{M}=$ middle

*Pre-auricular sulcus scores

$0=$ sulcus absent

$1=$ sulcus is wide and deep

$2=$ sulcus is wide and shallow

$3=$ sulcus is well-defined but narrow

$4=$ sulcus is narrow, shallow, and smooth-walled depression 
Table C.3. Adult age determinations for Pioneer Cemetery

\begin{tabular}{|c|c|c|c|c|c|c|}
\hline \multirow[b]{2}{*}{ Age Criteria } & \multicolumn{6}{|c|}{ Burial } \\
\hline & 7 & 8 & 9 & 10 & 15 & 16 \\
\hline L Pub. symph. Todd phase* & 8 & & & & & \\
\hline \multicolumn{7}{|l|}{ R Pub. symph. Todd phase* } \\
\hline L Pub. symph. Suchey-Brooks phase* & 4 & & & & & \\
\hline \multicolumn{7}{|l|}{ R Pub. symph. Suchey-Brooks phase* } \\
\hline L Auricular surface* & & & & & $3-4$ & $4-5$ \\
\hline R Auricular surface* & $6-7$ & & & & & $4-5$ \\
\hline Midlambdoid & & & 2 & 2 & 0 & \\
\hline Lambda & & & & & 0 & \\
\hline Obelion & 3 & & & $2-3$ & 1 & \\
\hline Anterior-Sagittal & 3 & & $2-3$ & $2-3$ & 0 & \\
\hline Bregma & 3 & & 2 & 3 & 1 & \\
\hline Midcoronal & $3 \mathrm{R}$ & $2 \mathrm{R}$ & 1 & $2-3$ & 0 & $1-2$ \\
\hline \multicolumn{7}{|l|}{ Pterion } \\
\hline \multicolumn{7}{|l|}{ Sphenofrontal } \\
\hline Inf. sphenotemporal & & $0-1$ & & & & \\
\hline \multicolumn{7}{|l|}{ Sup. sphenotemporal } \\
\hline Incisive & & 3 & 3 & 3 & & \\
\hline Ant. median palatine & & $0-1$ & & & & \\
\hline \multicolumn{7}{|l|}{ Post. median palatine } \\
\hline \multicolumn{7}{|l|}{ Transverse palatine } \\
\hline Sagittal (internal) & 3 & & 3 & $1-2$ & & \\
\hline L Lambdoid (internal) & & $3 \mathrm{R}$ & & & & \\
\hline L Coronal (internal) & & $3 \mathrm{R}$ & 3 & 3 & 3 & 2 \\
\hline
\end{tabular}

$\mathrm{R}=$ Right

Blank $=$ not observable

$0=$ open

$1=$ minimal

$2=$ significant

3 = complete

*See Buikstra and Ubelaker (1994) for phase descriptions 
Table C.4. Bone union and ephiphyseal closure for Pioneer Cemetery

\begin{tabular}{|c|c|c|c|}
\hline \multirow[b]{2}{*}{ Element } & \multicolumn{3}{|c|}{ Burial } \\
\hline & 11 & 13 & 17 \\
\hline Cervical vert.--superior & & 2 & \\
\hline Cervical vert.--inferior & & 2 & \\
\hline Thoracic vert.--superior & & 0 & \\
\hline Thoracic vert.--inferior & & 0 & \\
\hline Lumbar vert.--superior & & 0 & \\
\hline Lumbar vert.--inferior & & 0 & \\
\hline \multicolumn{4}{|l|}{ L coracoid } \\
\hline $\mathrm{R}$ coracoid & & 0 & \\
\hline L acromion & & 0 & \\
\hline $\mathrm{R}$ acromion & & 0 & \\
\hline L clavicle--sternal & & 0 & \\
\hline $\mathrm{R}$ clavicle--sternal & & 0 & \\
\hline L humeral head & & 0 & \\
\hline $\mathrm{R}$ humeral head & & 0 & \\
\hline L dist. humerus & & 0 & \\
\hline $\mathrm{R}$ dist. humerus & & 0 & \\
\hline L medial epicondyle & & 0 & \\
\hline $\mathrm{R}$ medial epicondyle & & 0 & \\
\hline \multicolumn{4}{|l|}{ L prox. radius } \\
\hline \multicolumn{4}{|l|}{$\mathrm{R}$ prox. radius } \\
\hline \multicolumn{4}{|l|}{$\mathrm{L}$ distal radius } \\
\hline \multicolumn{4}{|l|}{$\mathrm{R}$ distal radius } \\
\hline \multicolumn{4}{|l|}{ L prox. ulna } \\
\hline \multicolumn{4}{|l|}{$\mathrm{R}$ prox. ulna } \\
\hline \multicolumn{4}{|l|}{ L distal ulna } \\
\hline $\mathrm{R}$ distal ulna & & 0 & \\
\hline L iliac crest & & 0 & \\
\hline \multicolumn{4}{|l|}{$\mathrm{R}$ iliac crest } \\
\hline \multicolumn{4}{|l|}{ L ischial tuberosity } \\
\hline \multicolumn{4}{|l|}{$\mathrm{R}$ ischial tuberosity } \\
\hline L femoral head & & 0 & \\
\hline $\mathrm{R}$ femoral head & & 0 & \\
\hline L gr. trochanter & & 0 & \\
\hline $\mathrm{R}$ gr. trochanter & & 0 & \\
\hline \multicolumn{4}{|l|}{ L lsr. trochanter } \\
\hline $\mathrm{R}$ lsr. trochanter & & & \\
\hline
\end{tabular}

\begin{tabular}{|c|c|c|c|}
\hline \multirow[b]{2}{*}{ Element } & \multicolumn{3}{|c|}{ Burial } \\
\hline & 11 & 13 & 17 \\
\hline L distal femur & & 0 & \\
\hline $\mathrm{R}$ distal femur & & 0 & \\
\hline \multicolumn{4}{|l|}{ L prox. tibia } \\
\hline $\mathrm{R}$ prox. tibia & & 0 & \\
\hline $\mathrm{L}$ distal tibia & & 0 & \\
\hline $\mathrm{R}$ distal tibia & & 0 & \\
\hline \multicolumn{4}{|l|}{ L prox. fibula } \\
\hline \multicolumn{4}{|l|}{$\mathrm{R}$ prox. fibula } \\
\hline \multicolumn{4}{|l|}{ L distal fibula } \\
\hline \multicolumn{4}{|l|}{$\mathrm{R}$ distal fibula } \\
\hline prox. or dist. Femur & 0 & & \\
\hline unident. long bone frags & 0 & & \\
\hline \multicolumn{4}{|l|}{ ilium-pubis } \\
\hline \multicolumn{4}{|l|}{ ischium-pubis } \\
\hline \multicolumn{4}{|l|}{ ischium-ilium } \\
\hline \multicolumn{4}{|l|}{ S1-S2 } \\
\hline \multicolumn{4}{|l|}{ S2-S3 } \\
\hline \multicolumn{4}{|l|}{ S3-S4 } \\
\hline \multicolumn{4}{|l|}{ S4-S5 } \\
\hline cervical neural arch halves & & 2 & \\
\hline $\begin{array}{l}\text { cervical neural arches to } \\
\text { centrum }\end{array}$ & & 2 & \\
\hline thoracic neural arch halves & & 2 & \\
\hline $\begin{array}{l}\text { thoracic neural arches to } \\
\text { centrum }\end{array}$ & & 2 & \\
\hline lumbar neural arch halves & & 2 & \\
\hline lumbar neural arches to centrum & & 2 & \\
\hline unid. neural arch halves & & & 0 \\
\hline spheno-occipital synchondrosis & & 0 & \\
\hline lateral occipital to squama & & $2 ?$ & \\
\hline basilar occipital to lateral & & 2 & \\
\hline $\begin{array}{l}\text { Blank = not observable } \\
0=\text { open } \\
1=\text { partial union } \\
2=\text { complete union }\end{array}$ & & & \\
\hline
\end{tabular}


Table C.5. Cranial measurements in adults for Pioneer Cemetery

\begin{tabular}{|c|c|c|c|c|c|c|}
\hline \multirow[b]{2}{*}{ Measurement } & \multicolumn{6}{|c|}{ Burial } \\
\hline & 7 & 8 & 9 & 10 & 15 & 16 \\
\hline \multicolumn{7}{|l|}{ Max. length } \\
\hline \multicolumn{7}{|l|}{ Max. breadth } \\
\hline \multicolumn{7}{|l|}{ Bizygomatic diam. } \\
\hline \multicolumn{7}{|l|}{ Basion-bregma height } \\
\hline \multicolumn{7}{|l|}{ Crainal base length } \\
\hline \multicolumn{7}{|l|}{ Maxillo-alveolar breadth } \\
\hline \multicolumn{7}{|l|}{ Maxillo-alveolar length } \\
\hline \multicolumn{7}{|l|}{ Biauricular breadth } \\
\hline \multicolumn{7}{|l|}{ Upper facial height } \\
\hline \multicolumn{7}{|l|}{ Min. frontal breadth } \\
\hline \multicolumn{7}{|l|}{ Upper facial breadth } \\
\hline \multicolumn{7}{|l|}{ Nasal height } \\
\hline \multicolumn{7}{|l|}{ Nasal breadth } \\
\hline \multicolumn{7}{|l|}{ Orbital breadth } \\
\hline \multicolumn{7}{|l|}{ Orbital height } \\
\hline \multicolumn{7}{|l|}{ Biorbital breadth } \\
\hline \multicolumn{7}{|l|}{ Interorbital breadth } \\
\hline \multicolumn{7}{|l|}{ Frontal chord } \\
\hline \multicolumn{7}{|l|}{ Parietal chord } \\
\hline \multicolumn{7}{|l|}{ Occipital chord } \\
\hline \multicolumn{7}{|l|}{ Foramen magnum length } \\
\hline \multicolumn{7}{|l|}{ Foramen magnum breadth } \\
\hline \multicolumn{7}{|l|}{ Mastoid length } \\
\hline Chin height & & 32.7 & & & & 34.2 \\
\hline Height of mandibular body & & & & & & 30.3 \\
\hline Breadth of mandibular body & 11.4 & $13.1 \mathrm{R}$ & & 13.2 & 9.95 & 9.3 \\
\hline \multicolumn{7}{|l|}{ Bigonial width } \\
\hline \multicolumn{7}{|l|}{ Bicondylar breadth } \\
\hline Min. ramus breadth & & & $33.0 \mathrm{R}$ & & 32.48 & 31.2 \\
\hline Max. ramux breadth & & & & & 43.06 & \\
\hline Max. ramus height & & & & & 52.35 & \\
\hline \multicolumn{7}{|l|}{ Mandibular length } \\
\hline Mandibular angle & & & & & & \\
\hline
\end{tabular}

Left side standard; $(\mathrm{R})$ indicates that measurement was taken from the right side

Measurements in millimeters

Blank = not measurable 
Table C.6. Postcranial measurements in adults for Pioneer Cemetery

\begin{tabular}{|c|c|c|c|c|c|c|c|}
\hline \multirow[b]{2}{*}{ Measurement } & \multicolumn{7}{|c|}{ Burial } \\
\hline & 7 & 8 & 9 & 10 & 14 & 15 & 16 \\
\hline Clavicle: max. length & 135 & & & & & & \\
\hline Clavicle: A-P diam. at midshaft & 12.64 & & $13.87^{*}$ & & & 13.15 & \\
\hline Clavicle: S-I diam. at midshaft & 10.28 & & $12.41^{*}$ & & & 7.51 & \\
\hline \multicolumn{8}{|l|}{ Scapula: height } \\
\hline \multicolumn{8}{|l|}{ Scapula: breadth } \\
\hline \multicolumn{8}{|l|}{ Humerus: max. length } \\
\hline Humerus: epicondylar length & $61.83 \mathrm{R}$ & & & $64.70 \mathrm{R}$ & & $57.69 \mathrm{R}$ & \\
\hline Humerus: vert. diam. of head & 42.89 & & & & & & \\
\hline Humerus: Max. diam. at midshaft & & $25.57 \mathrm{R}^{*}$ & $25.63 *$ & $25.30 *$ & & $21.89 * \mathrm{R}$ & \\
\hline Humerus: Min. diam. at midshaft & & $20.00 \mathrm{R}^{*}$ & $18.66^{*}$ & $20.10^{*}$ & & $18.68 * \mathrm{R}$ & \\
\hline Radius: max. length & 234 & & & & & & \\
\hline Radius: A-P diam. at midshaft & 12.08 & & $12.61 \mathrm{R}^{*}$ & 13.80 & & $10.61^{*}$ & \\
\hline Radius: M-L diam. at midshaft & 15.40 & & $16.83 \mathrm{R}^{*}$ & 17.80 & & $13.39 *$ & \\
\hline \multicolumn{8}{|l|}{ Ulna: max. length. } \\
\hline Ulna: A-P diam. & & & $13.72 \mathrm{R}$ & $13.90^{*}$ & & 17.02 & \\
\hline Ulna: M-L diam. & & & $17.12 \mathrm{R}$ & $15.60 *$ & & 12.77 & \\
\hline \multicolumn{8}{|l|}{ Ulna: physiological length } \\
\hline Ulna: min. circumference & & & $43.00 \mathrm{R}$ & & & & \\
\hline \multicolumn{8}{|l|}{ Sacrum: A length } \\
\hline \multicolumn{8}{|l|}{ Sacrum: A S breadth } \\
\hline \multicolumn{8}{|l|}{ Sacrum: max. transverse diam. base } \\
\hline \multicolumn{8}{|l|}{ Os coxae: height } \\
\hline \multicolumn{8}{|l|}{ Os coxae: iliac breadth } \\
\hline \multicolumn{8}{|l|}{ Os coxae: pubis length } \\
\hline \multicolumn{8}{|l|}{ Os coxae: ischium length } \\
\hline Femur: max. length & $398.5 \mathrm{R}^{*}$ & & & & & & \\
\hline \multicolumn{8}{|l|}{ Femur: bicondylar length } \\
\hline \multicolumn{8}{|l|}{ Femur: epicondylar breadth } \\
\hline Femur: max. diam. of head & & & & & $39.8^{*}$ & $44.44 \mathrm{R}^{*}$ & \\
\hline Femur: A-P subtrochanteric diam. & & & & & & $24.88 \mathrm{R}$ & \\
\hline Femur: M-L subtrochanteric diam. & & & & & & $32.83 \mathrm{R}$ & \\
\hline Femur: A-P midshaft diam. & $24.42 \mathrm{R}$ & $29.47^{*}$ & & & $27.9^{*}$ & $29.37 \mathrm{R}^{*}$ & \\
\hline Femur: M-L midshaft diam. & $29.53 \mathrm{R}$ & $30.38^{*}$ & $29.54^{*}$ & & $25.2^{*}$ & $25.80 \mathrm{R}^{*}$ & \\
\hline Femur: midshaft circumference & $92 \mathrm{R}$ & $100^{*}$ & $96.00 *$ & & $88.0^{*}$ & $88.0 \mathrm{R}^{*}$ & \\
\hline \multicolumn{8}{|l|}{ Tibia: length } \\
\hline \multicolumn{8}{|l|}{ Tibia: max. prox. epiphyseal length } \\
\hline \multicolumn{8}{|l|}{ Tibia: max. dist. epiphyseal length } \\
\hline Tibia: max. diam. at nutrient foramen & 31.64 & 37.45 & & & & 24.42 & 32.5 \\
\hline Tibia: M-L diam. at nutrient foramen & 24.86 & 30.19 & & & & 28.88 & 25.8 \\
\hline Tibia: circumference at nutrient foramen & 92 & 105 & & & & 92.0 & 90 \\
\hline \multicolumn{8}{|l|}{ Fibula: max. length } \\
\hline Fibula: max. diam. at midshaft & & $18.08^{*}$ & & & & $17.02 *$ & \\
\hline Calcaneus: max. length & & $89.24 \mathrm{R}$ & & & & & \\
\hline Calcaneus: middle breadth & & $42.42 \mathrm{R}^{*}$ & & & & & \\
\hline
\end{tabular}

Left side standard; " $R$ " indicates that measurement was taken from the right side Measurements in millimeters

Blank = not measurable

$*$ location estimated

$\mathrm{A}=$ anterior

$\mathrm{P}=$ posterior

$\mathrm{S}=$ superior

$\mathrm{I}=$ inferior

$\mathrm{M}=$ medial

$\mathrm{L}$ = lateral 
Table C.7. Primary nonmetric traits for Pioneer Cemetery

\begin{tabular}{|c|c|c|c|c|c|c|c|c|}
\hline \multirow[b]{2}{*}{ Trait } & \multicolumn{8}{|c|}{ Burial } \\
\hline & 7 & 8 & 9 & 10 & 13 & 14 & 15 & 16 \\
\hline Metopic suture & 0 & 0 & 0 & 0 & 0 & 9 & 0 & 0 \\
\hline L supraorbital notch & 9 & 0 & 9 & 0 & 9 & 9 & 9 & 9 \\
\hline $\mathrm{R}$ supraorbital notch & 9 & 0 & 9 & 0 & 0 & 9 & 9 & 9 \\
\hline L supraorbital foramen & 9 & 0 & 9 & 0 & 9 & 9 & 9 & 9 \\
\hline $\mathrm{R}$ supraorbital foramen & 9 & 1 & 9 & 0 & 0 & 9 & 0 & 9 \\
\hline L infraorbital suture & 0 & 0 & 9 & 9 & 9 & 9 & 9 & 9 \\
\hline $\mathrm{R}$ infraorbital suture & 0 & 0 & 0 & 9 & 9 & 9 & 9 & 9 \\
\hline L mult. infraorbital foramina & 9 & 0 & 9 & 9 & 9 & 9 & 9 & 9 \\
\hline $\mathrm{R}$ mult. infraorbital foramina & 9 & 0 & 0 & 9 & 9 & 9 & 9 & 9 \\
\hline L zygomatico-facial foramina & 1 & 0 & 0 & 2 & 1 & 9 & 5 & 0 \\
\hline $\mathrm{R}$ zygomatico-facial foramina & 2 & 9 & 5 & 2 & 1 & 9 & 5 & 5 \\
\hline L parietal foramen & 1 & 0 & 9 & 0 & 9 & 9 & 0 & 0 \\
\hline $\mathrm{R}$ parietal foramen & 0 & 1 & 9 & 0 & 1 & 9 & 0 & 1 \\
\hline L epipteric bone & 9 & 9 & 9 & 9 & 9 & 9 & 0 & 9 \\
\hline $\mathrm{R}$ epipteric bone & 9 & 9 & 9 & 9 & 9 & 9 & 0 & 9 \\
\hline L coronal ossicle & 9 & 9 & 0 & 0 & 9 & 9 & 0 & 9 \\
\hline $\mathrm{R}$ coronal ossicle & 0 & 9 & 0 & 0 & 9 & 9 & 0 & 9 \\
\hline Bregmatic bone & 0 & 9 & 0 & 0 & 0 & 9 & 0 & 9 \\
\hline Sagittal ossicle & 0 & 9 & $0 / 9$ & 0 & 0 & 9 & 1 & 9 \\
\hline Apical bone & 9 & 9 & 9 & 9 & 9 & 9 & 0 & 9 \\
\hline L lambdoid ossicle & 9 & 9 & 9 & 9 & 0 & 9 & 1 & 9 \\
\hline R lambdoid ossicle & 9 & 9 & 9 & 9 & 0 & 9 & 1 & 9 \\
\hline $\mathrm{L}$ asterionic bone & 9 & 9 & 9 & 9 & 9 & 9 & 9 & 9 \\
\hline $\mathrm{R}$ asterionic bone & 9 & 9 & 9 & 9 & 9 & 9 & 9 & 9 \\
\hline L ossicle in occipito-mastoid suture & 9 & 9 & 9 & 9 & 9 & 9 & 9 & 9 \\
\hline $\mathrm{R}$ ossicle in occipito-mastoid suture & 9 & 9 & 9 & 9 & 9 & 9 & 9 & 9 \\
\hline L parietal notch bone & $1 ?$ & 9 & 0 & 9 & 9 & 9 & 9 & 9 \\
\hline $\mathrm{R}$ parietal notch bone & 9 & 9 & 0 & 9 & 9 & 9 & 9 & 9 \\
\hline Inca bone & 9 & 0 & 9 & 0 & 0 & 9 & 9 & 9 \\
\hline L condylar canal & 9 & 9 & 9 & 9 & 9 & 9 & 9 & 9 \\
\hline $\mathrm{R}$ condylar canal & 9 & 9 & 9 & 9 & 1 & 9 & 9 & 9 \\
\hline L divided hypoglossal canal & 9 & 0 & 9 & 9 & 4 & 9 & 0 & 4 \\
\hline $\mathrm{R}$ divided hypoglossal canal & 0 & 9 & 0 & 9 & 0 & 9 & 0 & 9 \\
\hline Flexure of superior sagittal sulcus & 9 & 3 & 9 & 9 & 9 & 9 & 1 & 1 \\
\hline L foramen ovale incomplete & 9 & 9 & 9 & 9 & 9 & 9 & 9 & 9 \\
\hline $\mathrm{R}$ foramen ovale incomplete & 9 & 9 & 9 & 9 & 0 & 9 & 9 & 9 \\
\hline L foramen spinosum incomplete & 9 & 9 & 9 & 9 & 9 & 9 & 9 & 9 \\
\hline $\mathrm{R}$ foramen spinosum incomplete & 9 & 9 & 9 & 9 & 9 & 9 & 9 & 9 \\
\hline L pterygo-spinous bridge & 9 & 9 & 9 & 9 & 9 & 9 & 9 & 9 \\
\hline R pterygo-spinous bridge & 9 & 9 & 9 & 9 & 9 & 9 & 9 & 9 \\
\hline L pterygo-alar bridge & 9 & 9 & 9 & 9 & 9 & 9 & 9 & 9 \\
\hline $\mathrm{R}$ pterygo-alar bridge & 9 & 9 & 9 & 9 & 9 & 9 & 9 & 9 \\
\hline L tympanic dihiscence & 9 & 9 & 0 & 9 & 0 & 9 & 9 & 9 \\
\hline $\mathrm{R}$ tympanic dihiscence & 9 & 0 & 0 & 0 & 0 & 9 & 9 & 9 \\
\hline
\end{tabular}


Table C.7, continued

\begin{tabular}{|c|c|c|c|c|c|c|c|c|}
\hline \multirow[b]{2}{*}{ Trait } & \multicolumn{8}{|c|}{ Burial } \\
\hline & 7 & 8 & 9 & 10 & 13 & 14 & 15 & 16 \\
\hline L auditory exostoses & 0 & 0 & 0 & 9 & 0 & 9 & 0 & 9 \\
\hline $\mathrm{R}$ auditory exostoses & 0 & 0 & 0 & 9 & 0 & 9 & 9 & 0 \\
\hline L mastoid foramen location & 9 & 1 & 9 & 4 & 0 & 9 & 9 & 9 \\
\hline $\mathrm{R}$ mastoid foramen location & 9 & 9 & 9 & 9 & 1 & 9 & 9 & 9 \\
\hline L mastoid foramen number & 9 & 2 & 9 & 2 & 0 & 9 & 9 & 9 \\
\hline $\mathrm{R}$ mastoid foramen number & 9 & 9 & 9 & 9 & 1 & 9 & 9 & 9 \\
\hline L mental foramen & 2 & 1 & 9 & 1 & 9 & 9 & 1 & 1 \\
\hline $\mathrm{R}$ mental foramen & 1 & 1 & 1 & 1 & 9 & 1 & 9 & 1 \\
\hline L mandibular torus & 0 & 0 & 0 & 0 & 9 & 9 & 0 & 0 \\
\hline $\mathrm{R}$ mandibular torus & 0 & 0 & 0 & 0 & 9 & 9 & 9 & 0 \\
\hline L mylohyoid bridge location & 9 & 0 & 0 & 0 & 0 & 9 & 0 & 0 \\
\hline $\mathrm{R}$ mylohyoid bridge location & 9 & 0 & 0 & 9 & 0 & 9 & 9 & 0 \\
\hline L mylohyoid bridge degree & 9 & 0 & 0 & 0 & 0 & 9 & 0 & 0 \\
\hline R mylohyoid bridge degree & 9 & 0 & 0 & 9 & 0 & 9 & 9 & 0 \\
\hline L lateral atlas bridging & 9 & 9 & 9 & 0 & 9 & 9 & 0 & 0 \\
\hline $\mathrm{R}$ lateral atlas bridging & 9 & 9 & 9 & 0 & 9 & 9 & 0 & 0 \\
\hline $\mathrm{L}$ posterior atlas bridging & 9 & 9 & 9 & 0 & 9 & 9 & 2 & 0 \\
\hline $\mathrm{R}$ posterior atlas bridging & 9 & 9 & 9 & 0 & 9 & 9 & 1 & 0 \\
\hline L accessory transverse foramina $(\mathrm{C} 7)$ & 9 & 9 & 9 & 9 & 9 & 9 & 9 & 9 \\
\hline $\mathrm{R}$ accessory transverse foramina $(\mathrm{C} 7)$ & 9 & 9 & 9 & 9 & 9 & 9 & 9 & 9 \\
\hline L septal aperture & 9 & 9 & 9 & 0 & 9 & 9 & 9 & 9 \\
\hline $\mathrm{R}$ septal aperture & 0 & 0 & 9 & 0 & 2 & 1 & 0 & 0 \\
\hline
\end{tabular}

$\mathrm{L}=$ left

$\mathrm{R}=$ right

$\mathrm{C}=$ cervical

See Buikstra and Ubelaker (1994) for code definitions 


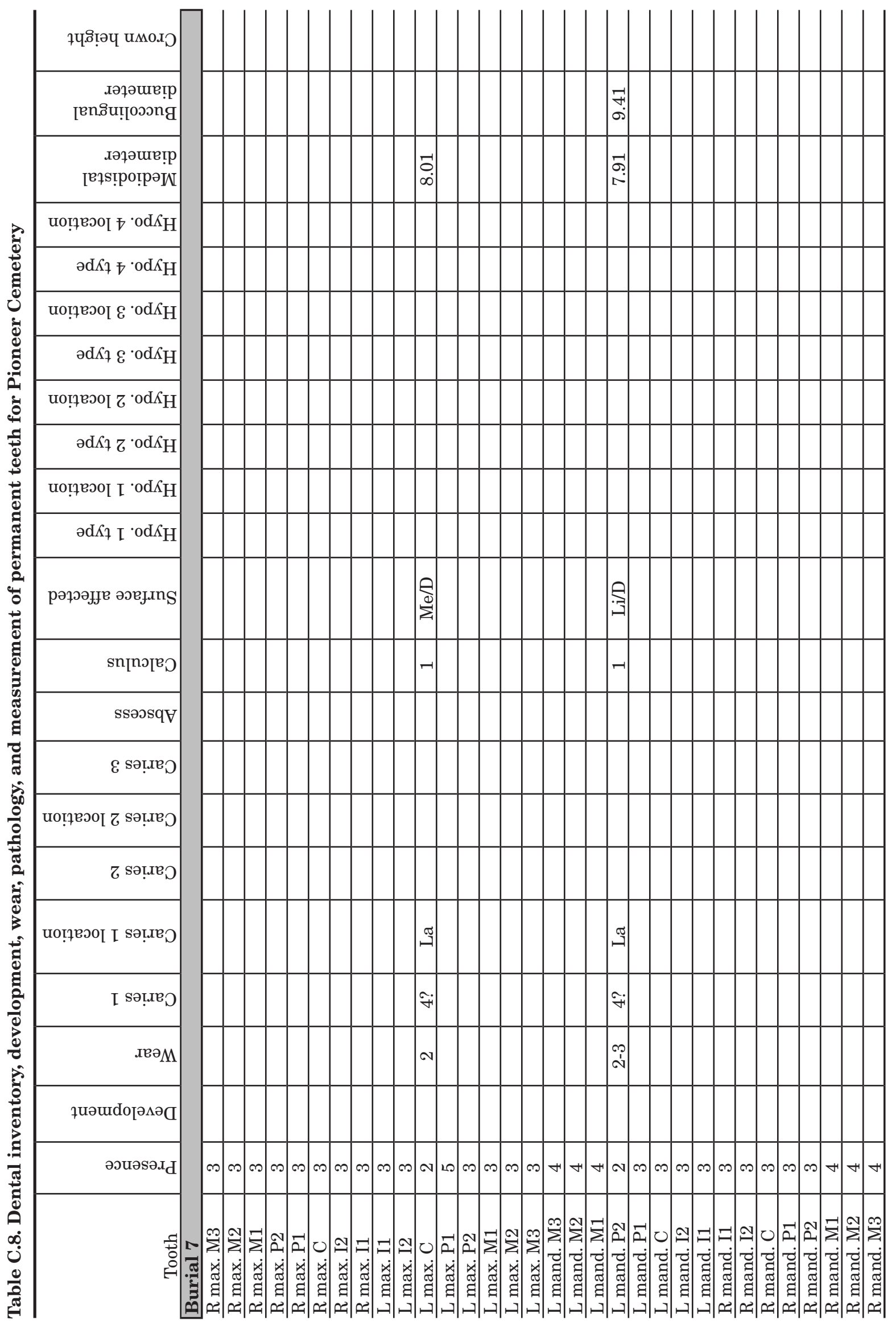




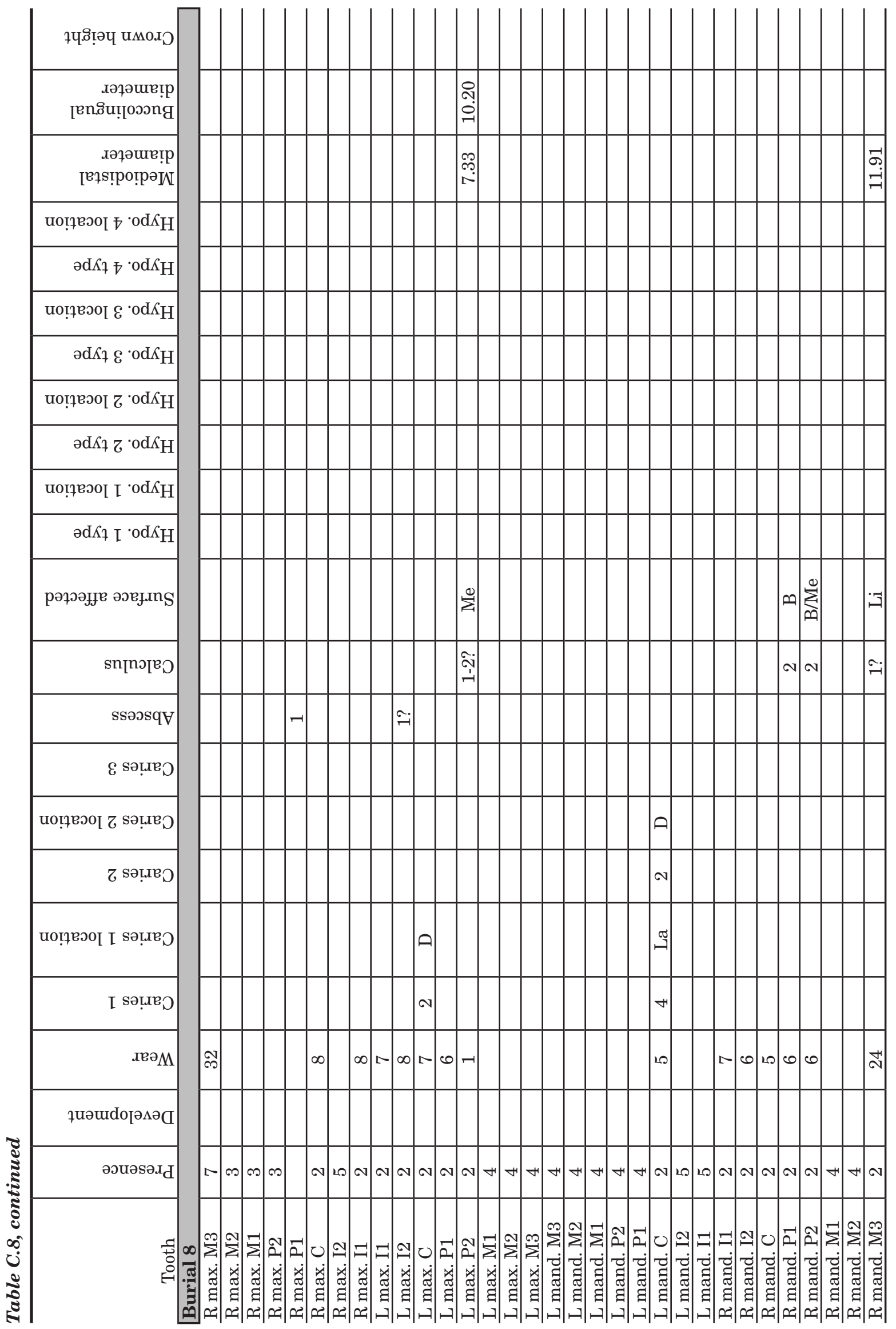




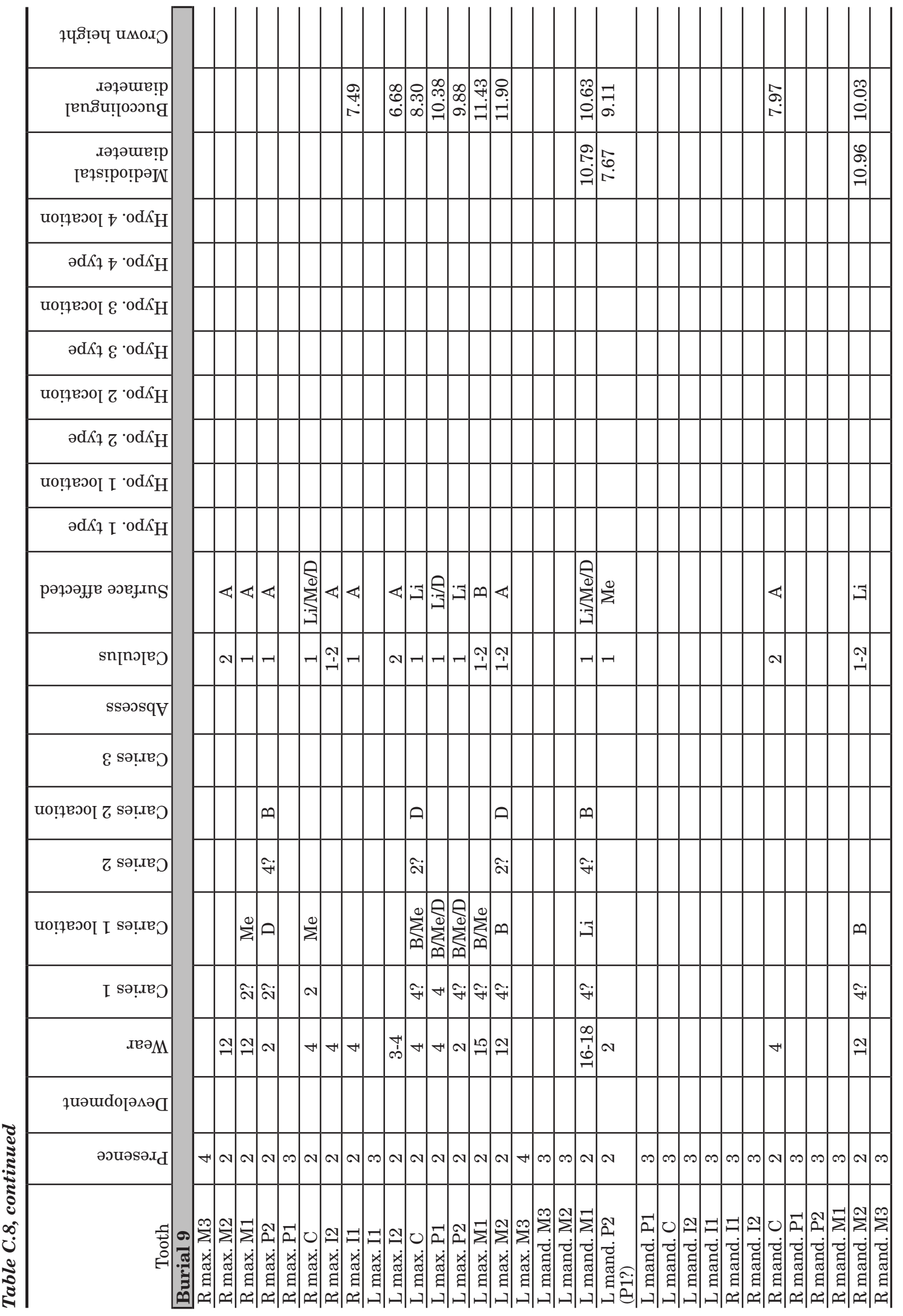




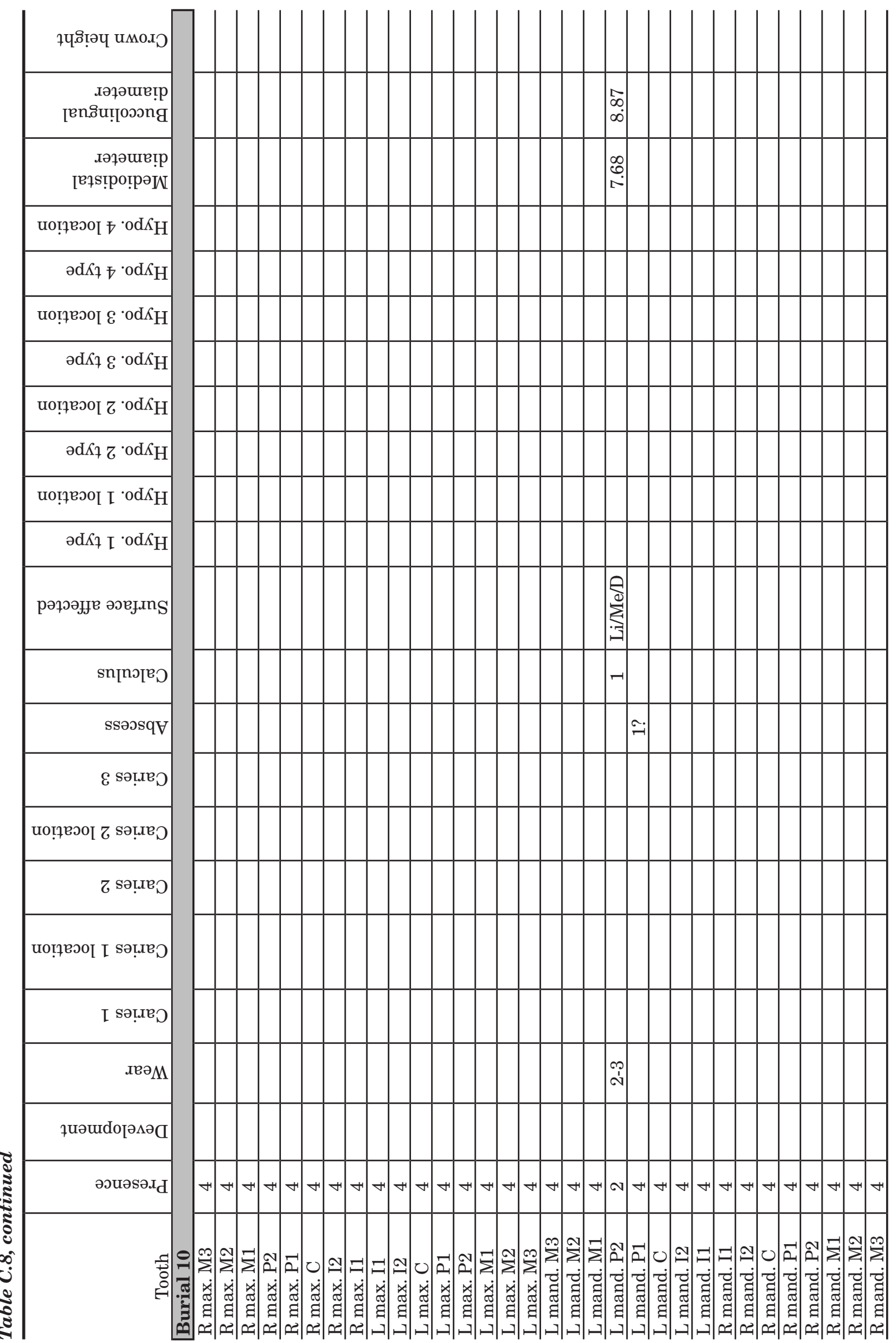




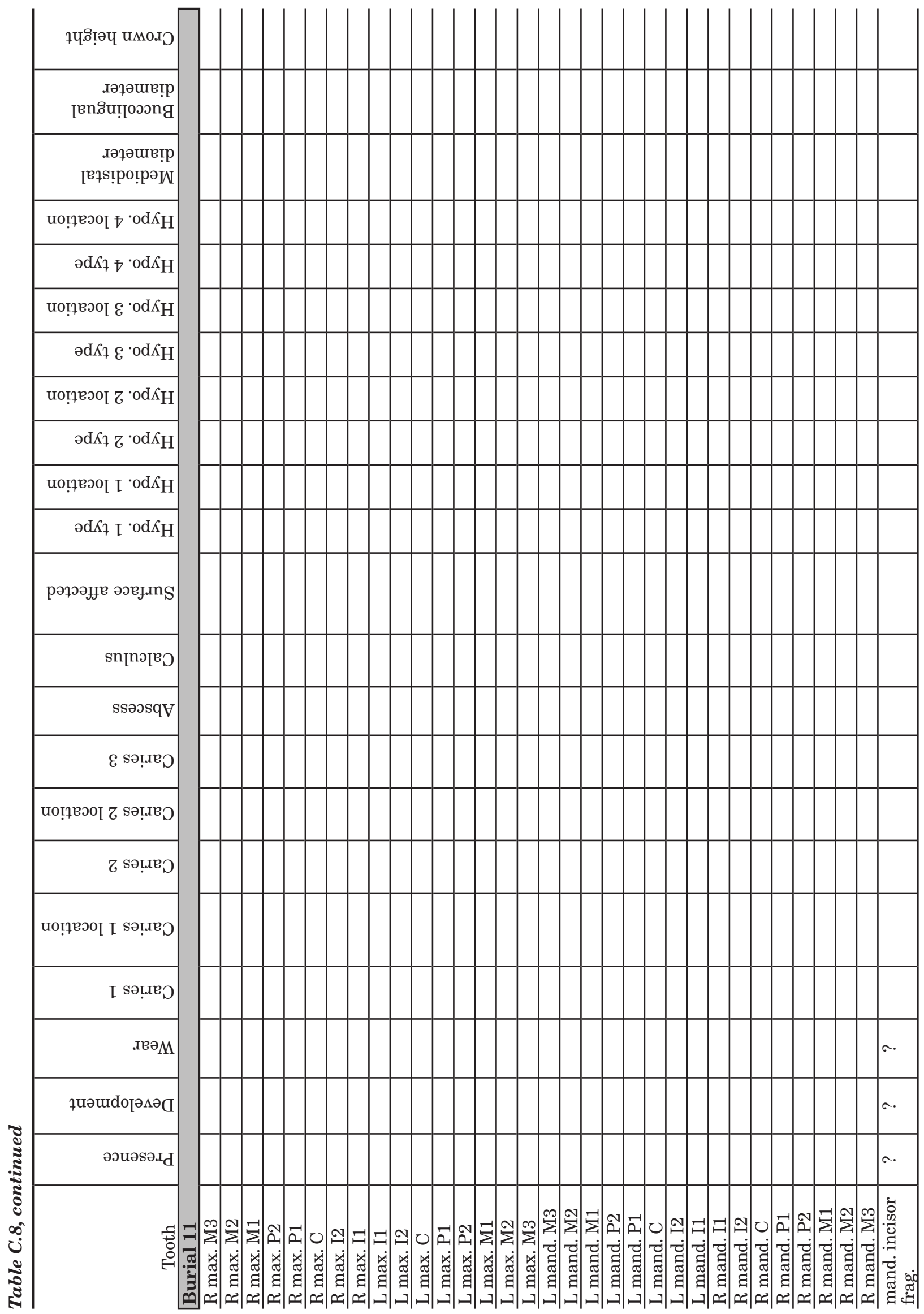




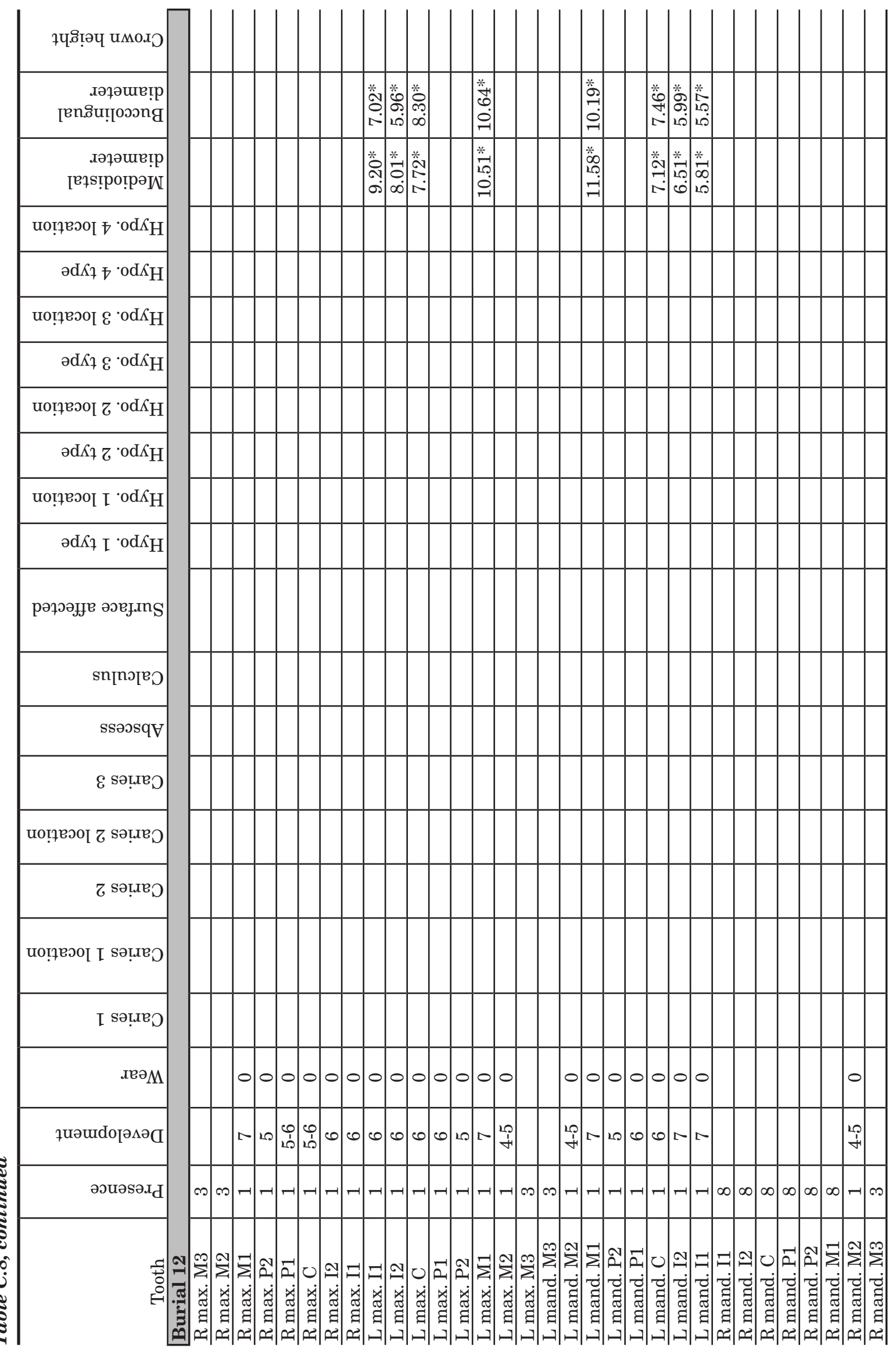




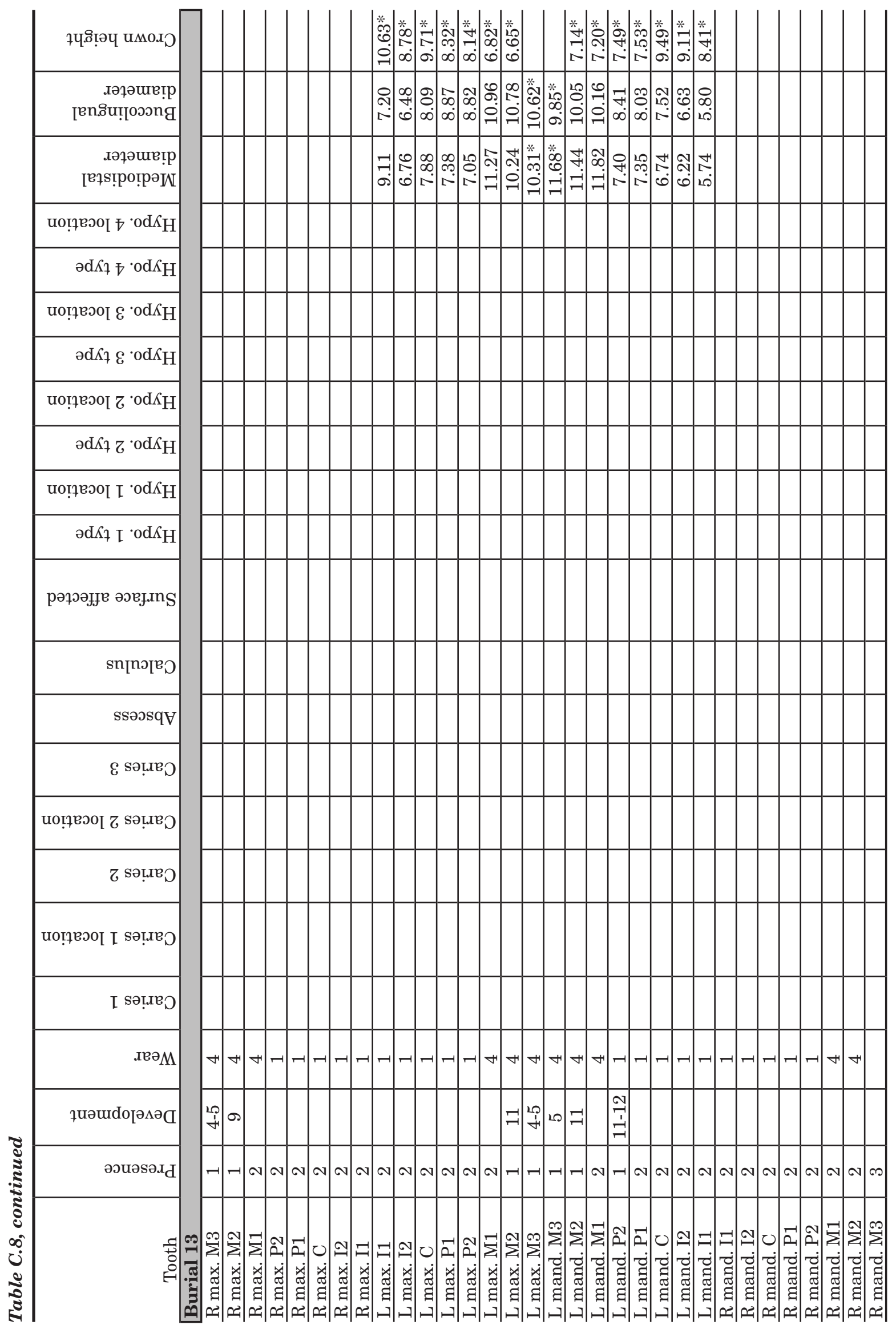




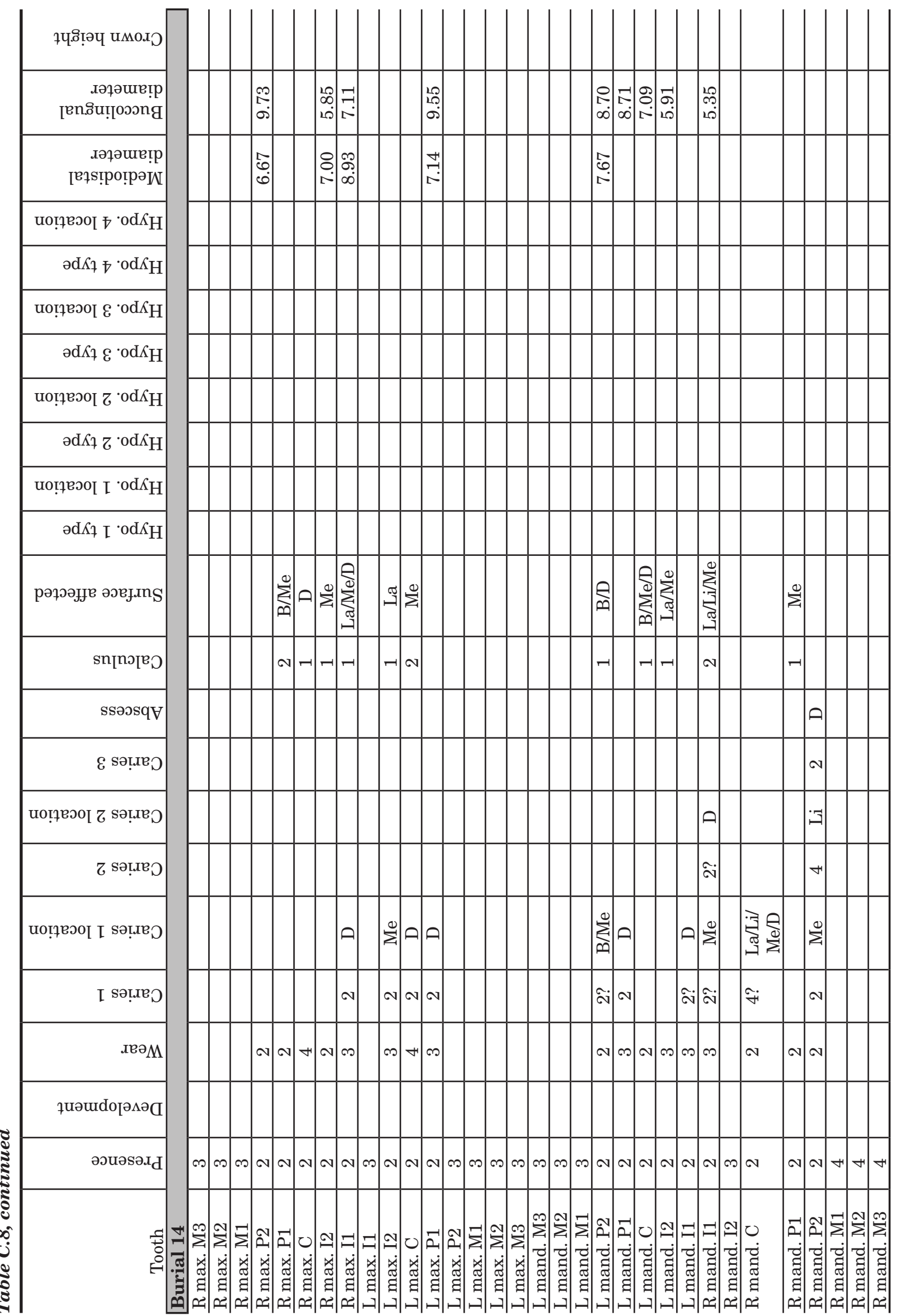




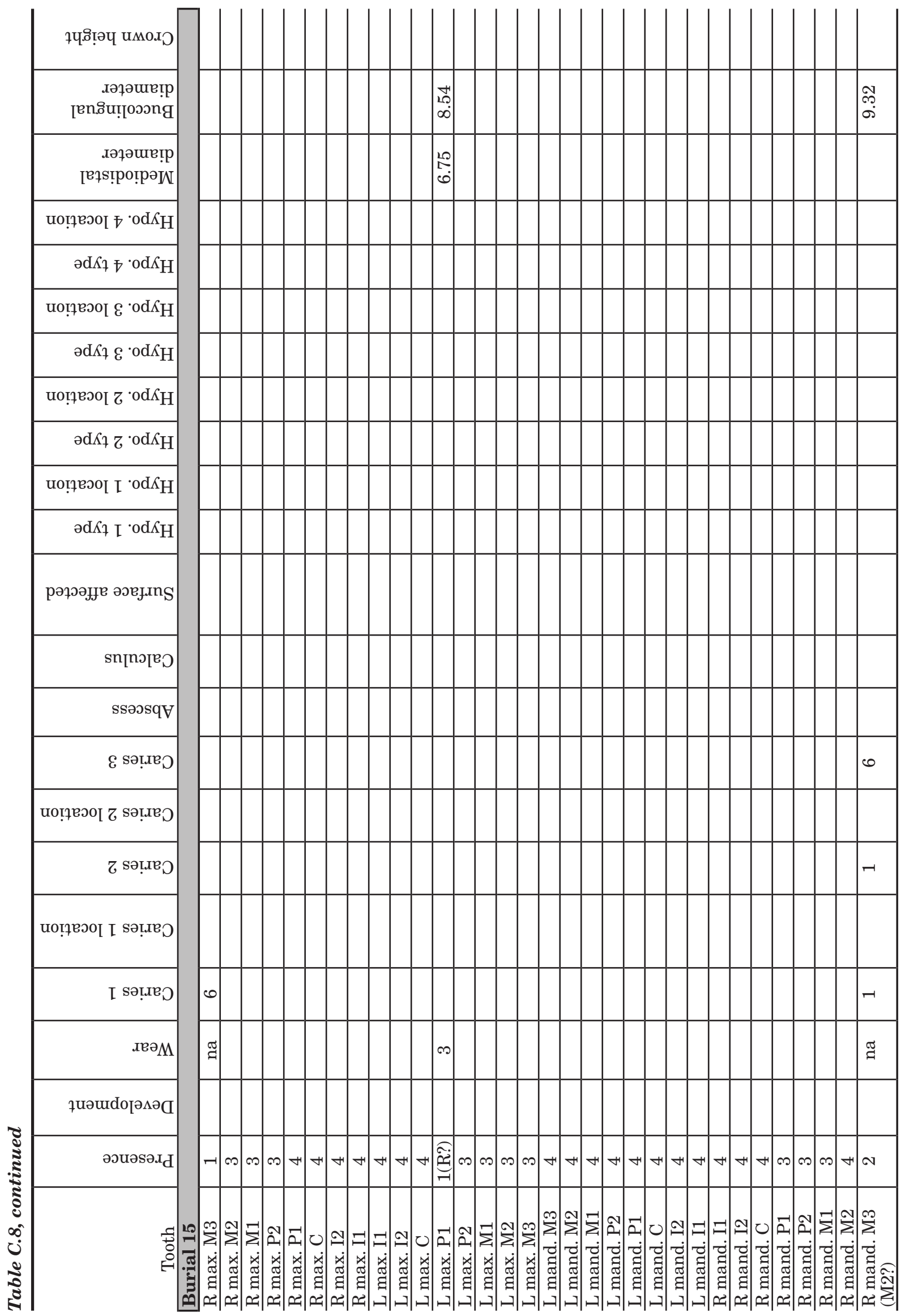









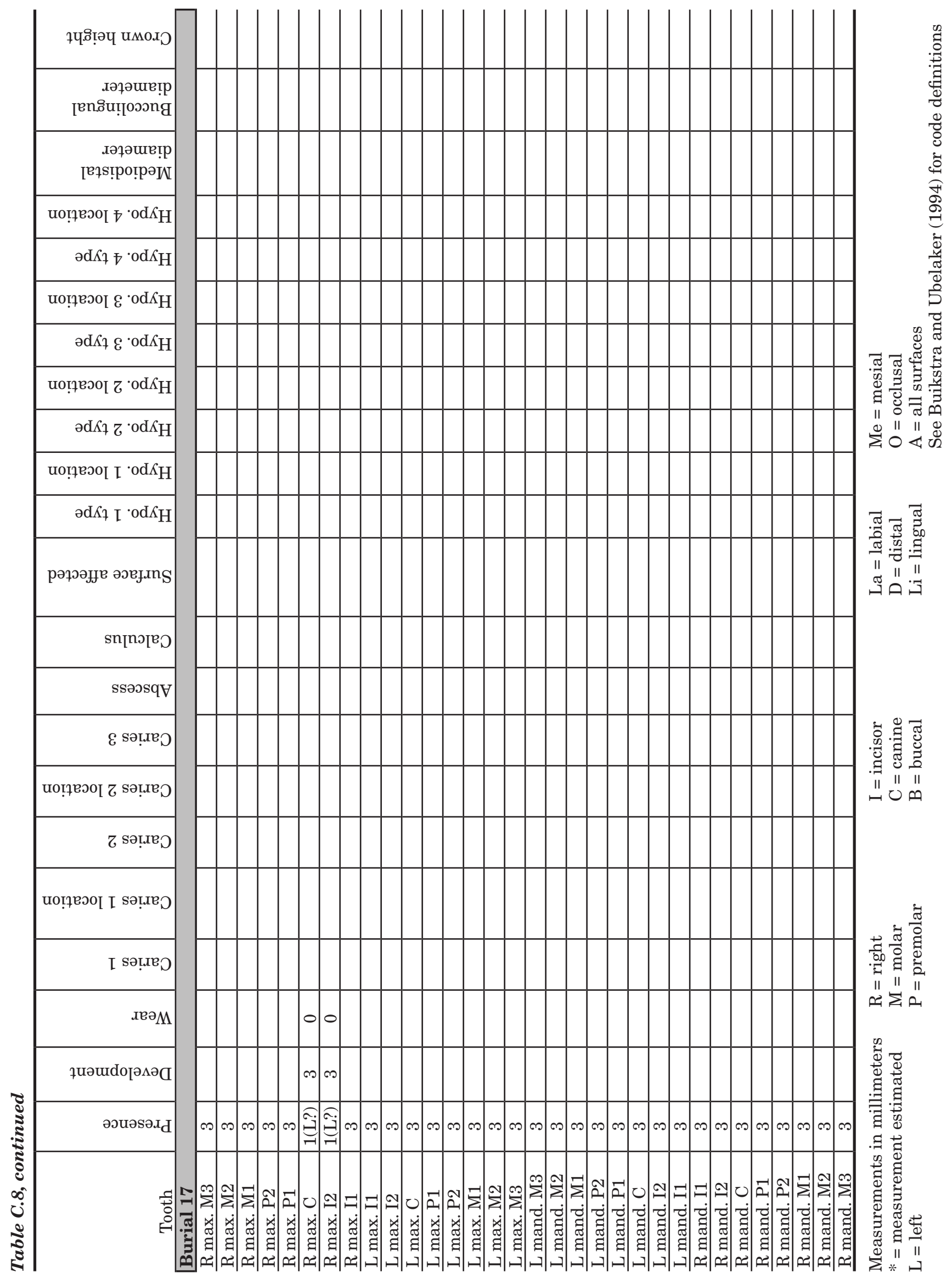




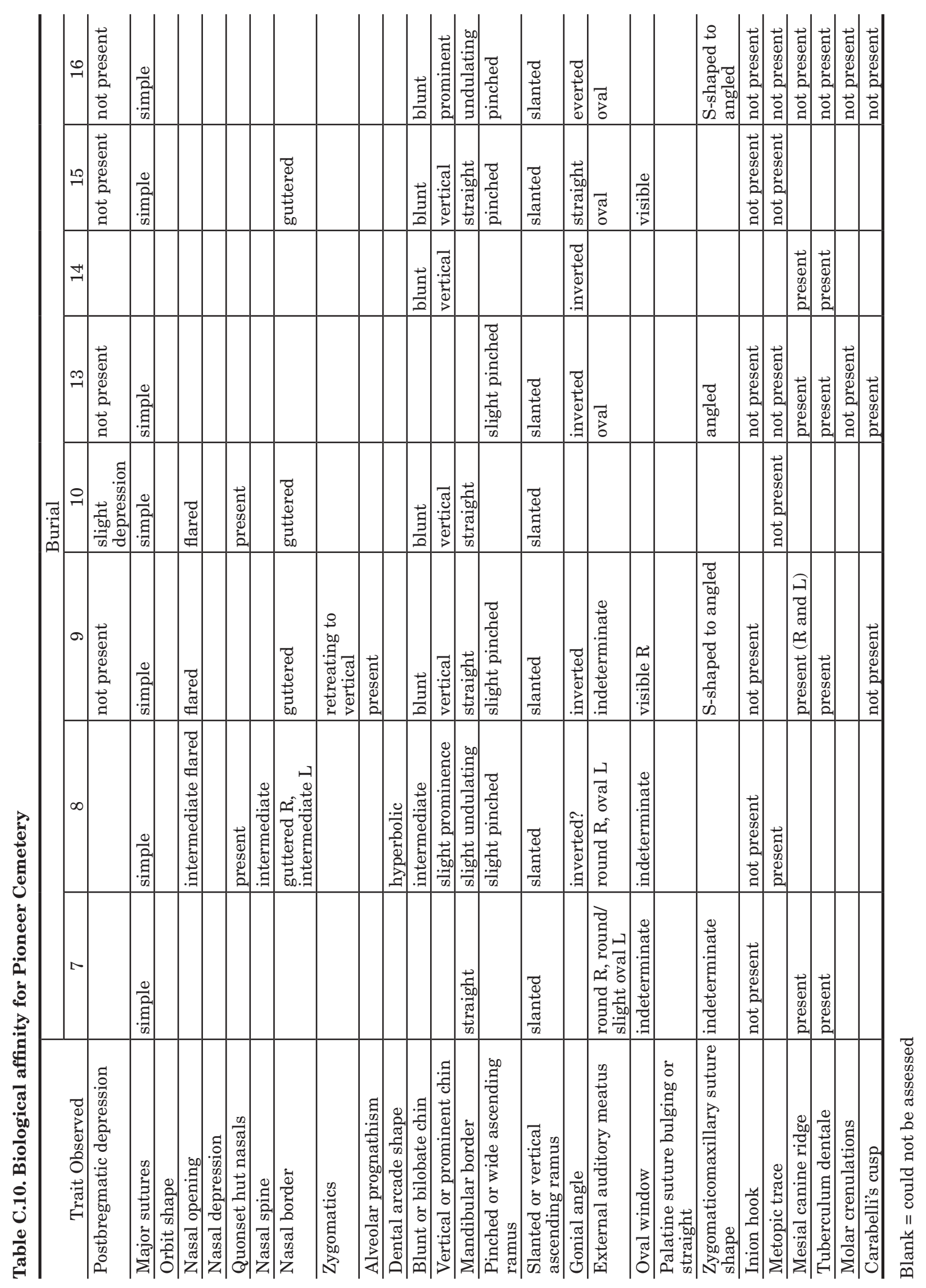




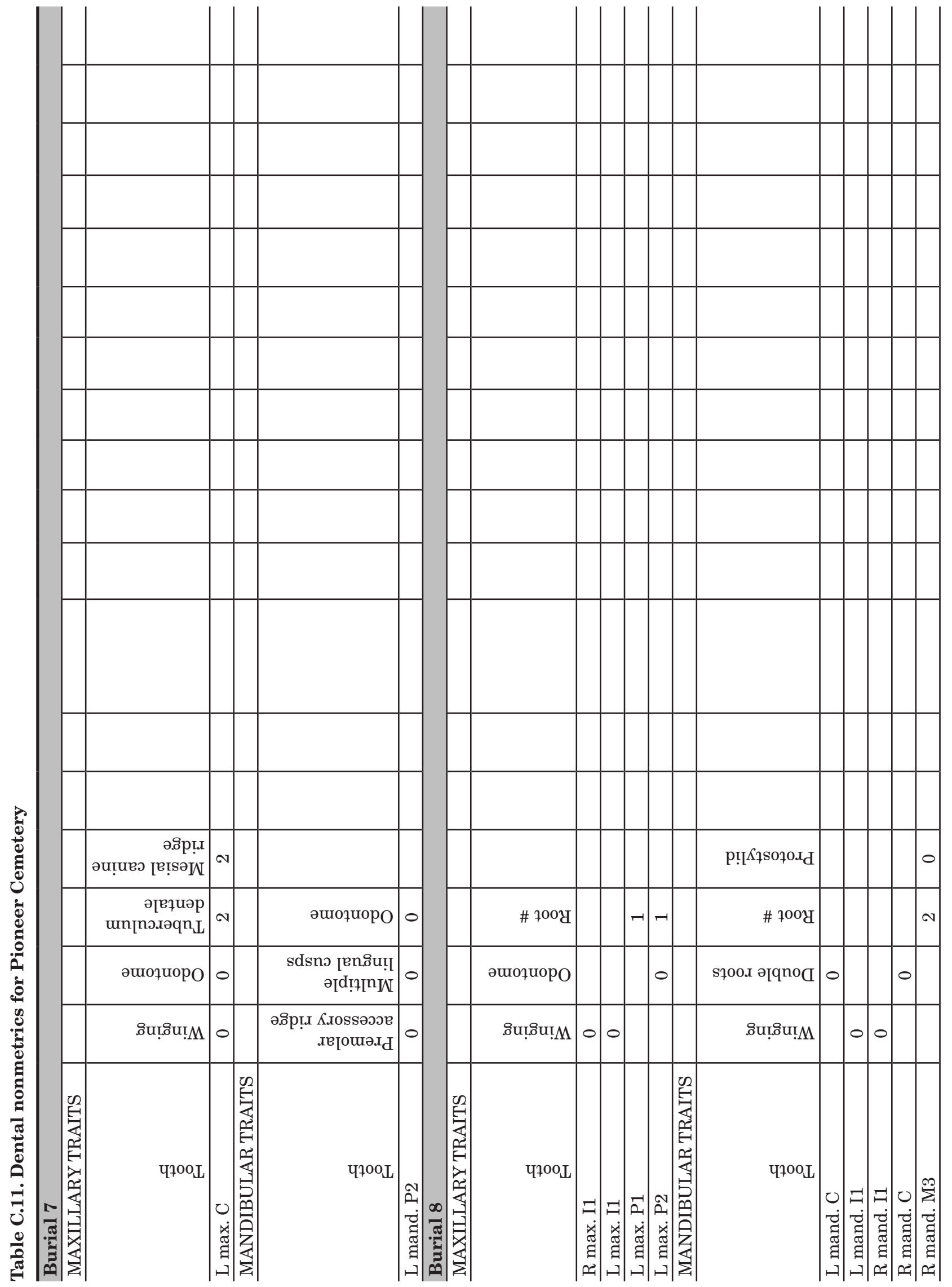




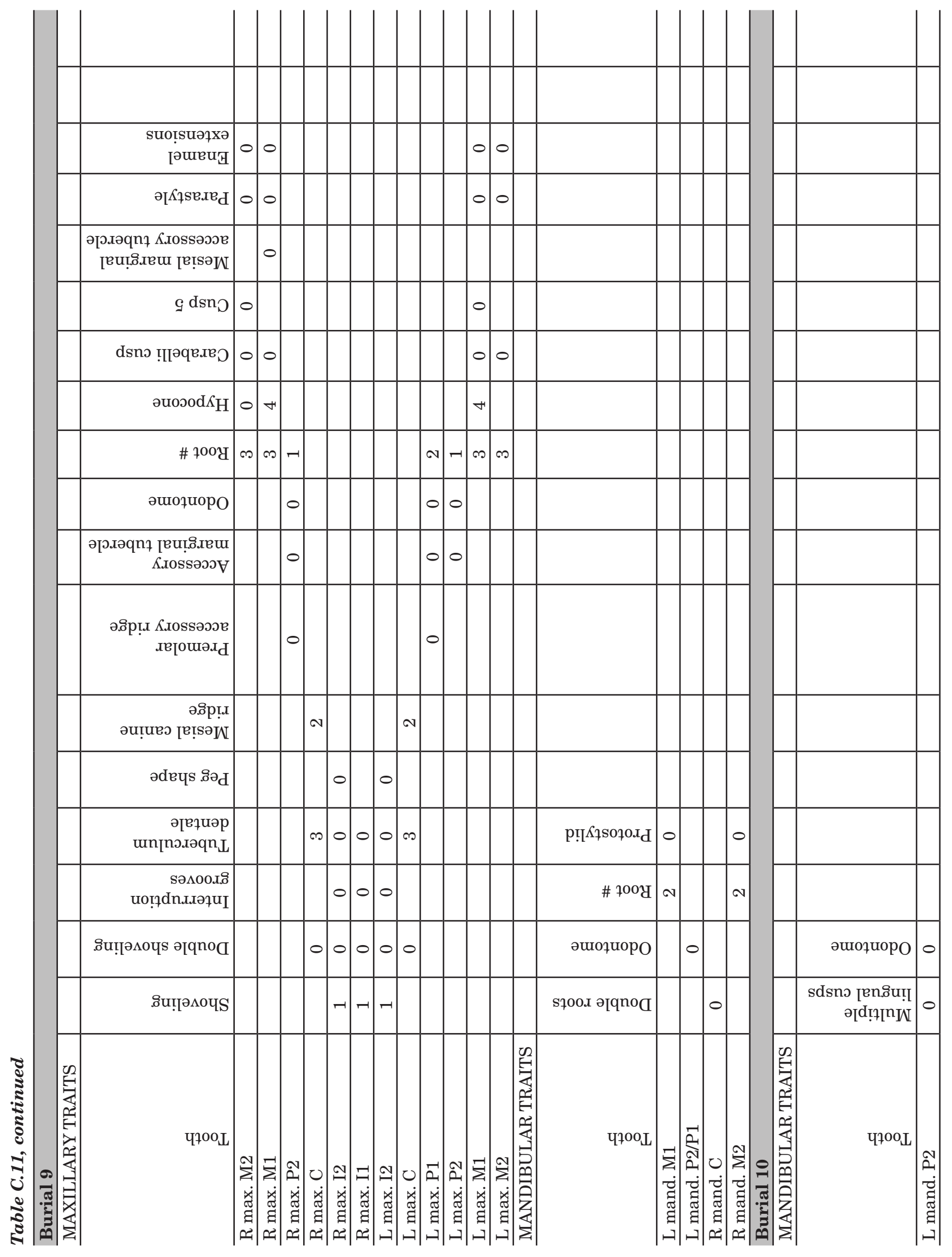




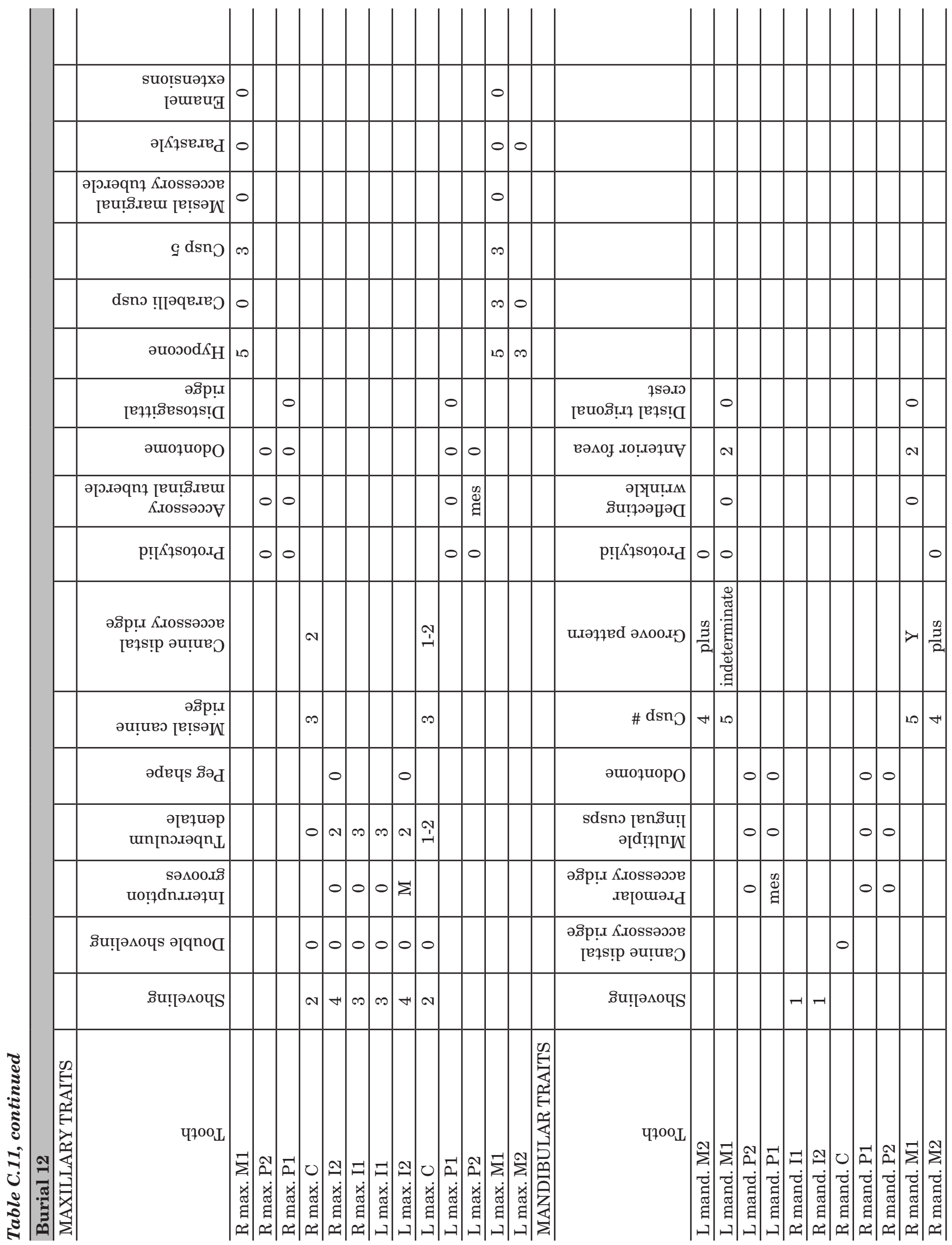




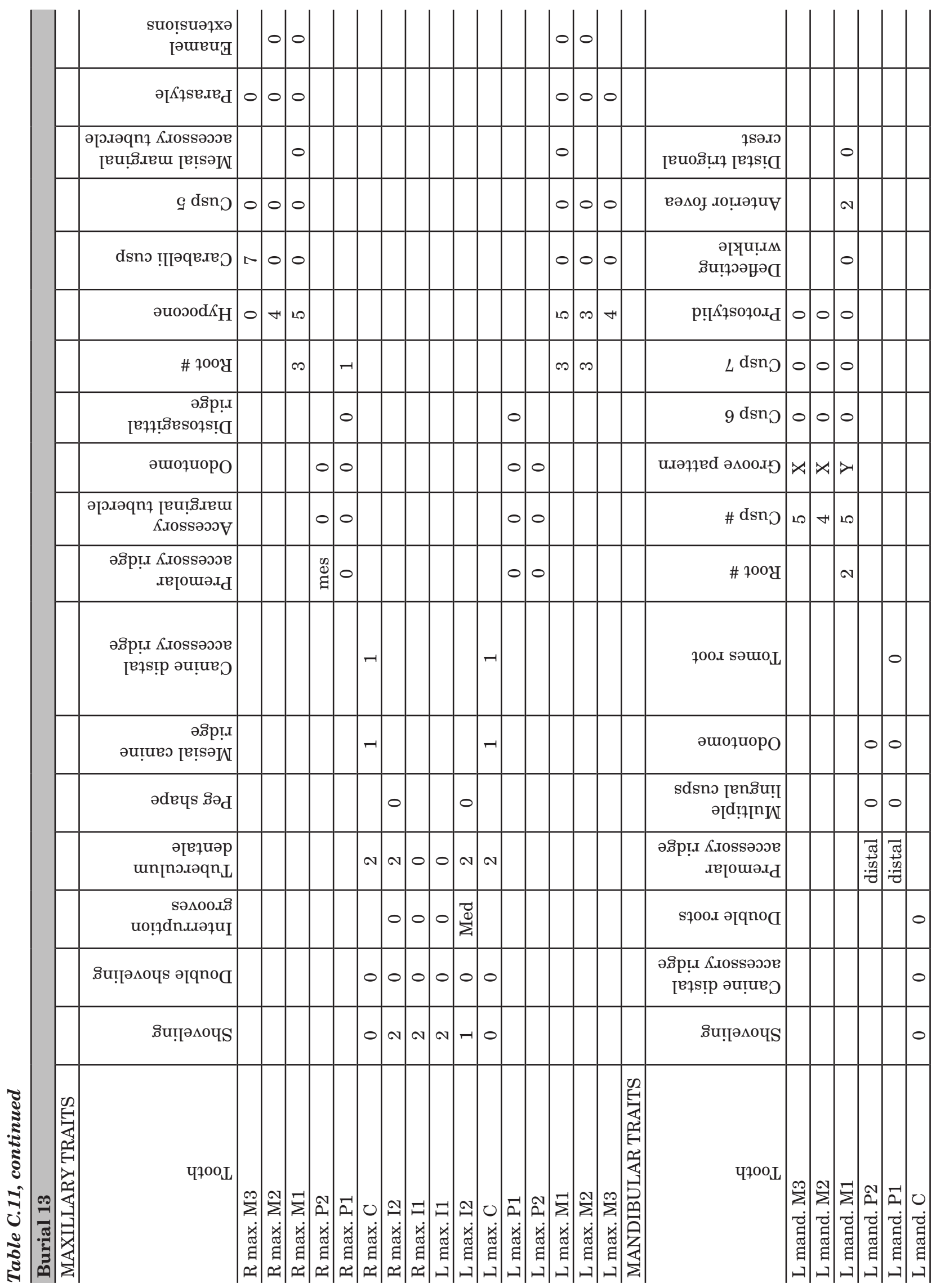




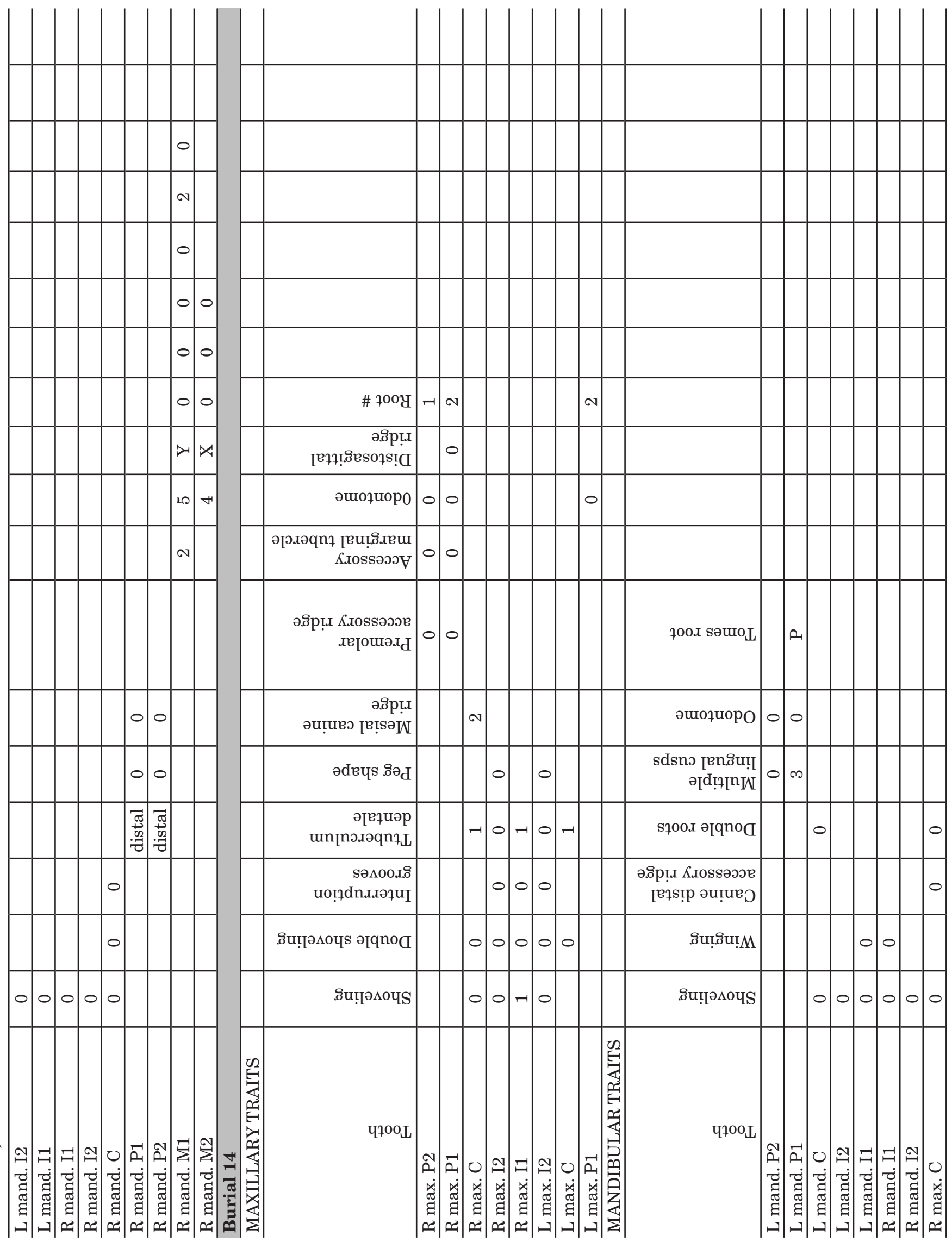




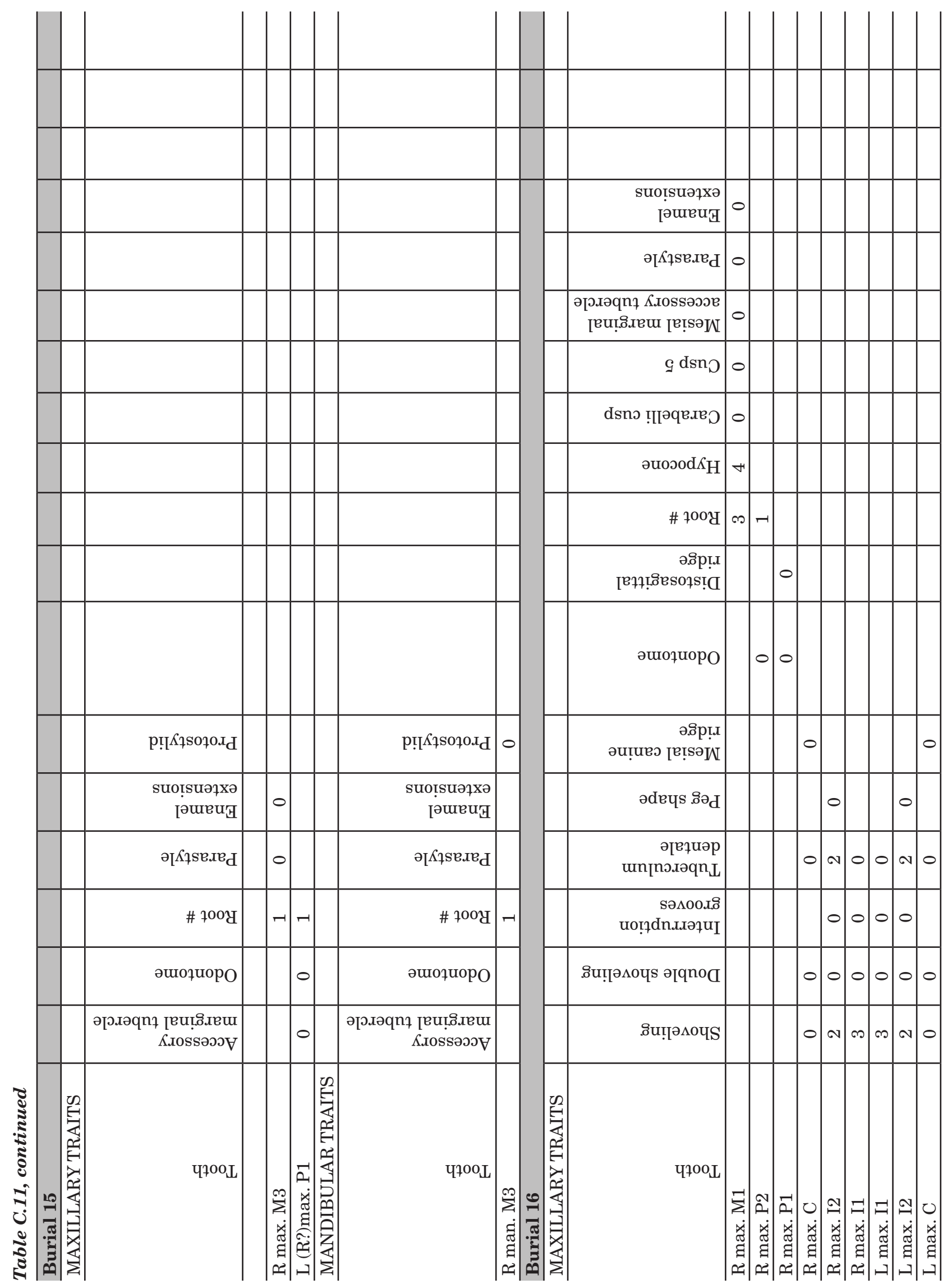




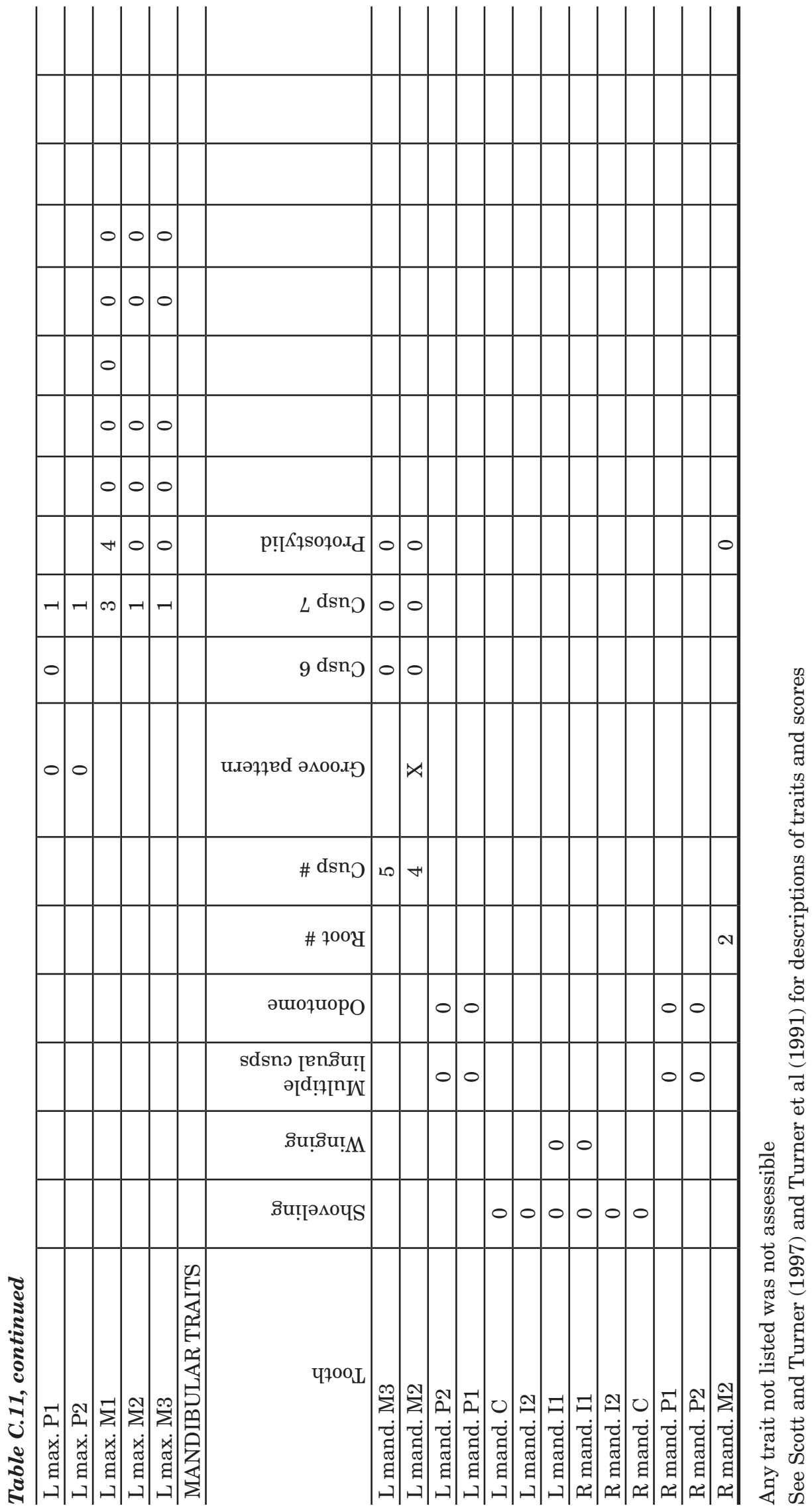


Table C.12. Degenerative joint disease for Pioneer Cemetery

\begin{tabular}{|c|c|c|c|c|c|c|c|c|c|}
\hline ATTRIBUTE & $\mathrm{A}$ & $\mathrm{B}$ & $\mathrm{C}$ & $\mathrm{D}$ & $\mathrm{E}$ & $\mathrm{F}$ & $\bar{G}$ & $\mathrm{H}$ & $\mathrm{I}$ \\
\hline \multicolumn{10}{|l|}{ BURIAL \# 7} \\
\hline \multicolumn{10}{|l|}{ VERTEBRA } \\
\hline Atlas-sup facet & 3 & 3 & $2-3$ & 0 & $\mathrm{~N}$ & 0 & 0 & & \\
\hline sup facet & 2 & 2 & $2-2$ & 0 & $\mathrm{~N}$ & 0 & 0 & & \\
\hline inf facet & 3 & 2 & $1 / 2-2$ & 0 & $\mathrm{~N}$ & 0 & 0 & & \\
\hline inf facet & 2 & 2 & $1 / 2-2$ & 0 & $\mathrm{~N}$ & 0 & 0 & & \\
\hline Axis- odontoid & 3 & 3 & $2-3$ & 0 & $\mathrm{~N}$ & 0 & 0 & & \\
\hline centrum & 3 & 3 & $2-3$ & 0 & $\mathrm{~N}$ & 0 & 0 & $\mathrm{~N}$ & $\mathrm{~N}$ \\
\hline sup facet & 3 & 3 & $2-3$ & 0 & $\mathrm{~N}$ & 0 & 0 & & \\
\hline Cervical facet & 3 & 3 & $1 / 2-3$ & 0 & $\mathrm{~N}$ & 0 & 0 & & \\
\hline Cervical facet & 3 & 3 & $1 / 2-3$ & 0 & $\mathrm{~N}$ & 0 & 0 & & \\
\hline Cervical facet & 3 & 2 & $2-3$ & 0 & $\mathrm{Y}$ & 0 & 0 & & \\
\hline Cervical facet & 3 & 3 & $1 / 2-2$ & 0 & $\mathrm{~N}$ & 0 & 0 & & \\
\hline Cervical facet & 3 & 2 & $1 / 2-2$ & 0 & $\mathrm{~N}$ & 0 & 0 & & \\
\hline Cervical centrum & 3 & 3 & $2-3$ & 0 & & 0 & 0 & $\mathrm{Y}$ & $\mathrm{Y}(\mathrm{sup})$ \\
\hline sup facet & 3 & 3 & $2-3$ & 0 & $\mathrm{~N}$ & 0 & 0 & & \\
\hline sup facet & 3 & 2 & $1 / 2-2$ & 0 & $\mathrm{~N}$ & 0 & 0 & & \\
\hline inf facet & 3 & 3 & $2-3$ & 0 & $\mathrm{~N}$ & 0 & 0 & & \\
\hline inf facet & 3 & 2 & $2-2$ & 0 & $\mathrm{~N}$ & 0 & 0 & & \\
\hline Cervical centrum & 3 & 3 & $2-2$ & 0 & & 0 & 0 & $\mathrm{Y}$ & $\mathrm{Y}$ (inf) \\
\hline sup facet & 3 & 3 & $1 / 2-3$ & 0 & $\mathrm{~N}$ & 0 & 0 & & \\
\hline inf facet & 2 & 2 & $1-2$ & 0 & $\mathrm{~N}$ & 0 & 0 & & \\
\hline Cervical centrum & 3 & 3 & $2-2$ & 0 & & 0 & 0 & $\mathrm{Y}$ & $\mathrm{N}$ \\
\hline Cervical centrum & 2 & 2 & $2-2$ & 0 & & 0 & 0 & $\mathrm{Y}$ & $\mathrm{N}$ \\
\hline Thoracic centrum & 1 & 2 & 0 & 0 & & 0 & 0 & $\mathrm{n} / \mathrm{a}$ & $\mathrm{N}$ \\
\hline sup facet & 2 & 1 & 0 & 0 & $\mathrm{~N}$ & 0 & 0 & & \\
\hline sup facet & 3 & 3 & 0 & 0 & $\mathrm{~N}$ & 0 & 0 & & \\
\hline inf facet & 2 & 2 & $1-2$ & 0 & $\mathrm{~N}$ & 0 & 0 & & \\
\hline inf facet & 2 & 2 & $1-2$ & 0 & $\mathrm{~N}$ & 0 & 0 & & \\
\hline Thoracic centrum & 3 & 0 & $\mathrm{n} / \mathrm{a}$ & 0 & & 0 & 0 & $\mathrm{~N}$ & $\mathrm{Y}$ (inf) \\
\hline sup facet & 3 & 2 & 0 & 0 & $\mathrm{~N}$ & 0 & 0 & & \\
\hline sup facet & 3 & 2 & 0 & 0 & $\mathrm{~N}$ & 0 & 0 & & \\
\hline Thoracic centrum & 3 & 0 & $\mathrm{n} / \mathrm{a}$ & 0 & & 0 & 0 & $\mathrm{~N}$ & $\mathrm{~N}$ \\
\hline sup facet & 2 & 0 & $\mathrm{n} / \mathrm{a}$ & 0 & $\mathrm{~N}$ & 0 & 0 & & \\
\hline sup facet & 3 & 0 & $\mathrm{n} / \mathrm{a}$ & 0 & $\mathrm{~N}$ & 0 & 0 & & \\
\hline Thoracic centrum & 3 & 0 & $\mathrm{n} / \mathrm{a}$ & 0 & & 0 & 0 & $\mathrm{~N}$ & $\mathrm{Y}$ (inf) \\
\hline sup facet & 3 & 2 & $1-2$ & 0 & $\mathrm{~N}$ & 0 & 0 & & \\
\hline Thoracic centrum & 2 & 0 & $\mathrm{n} / \mathrm{a}$ & 0 & & 0 & 0 & $\mathrm{~N}$ & Y (Surf?) \\
\hline Thoracic centrum & 2 & 0 & $\mathrm{n} / \mathrm{a}$ & 0 & & 0 & 0 & $\mathrm{~N}$ & $\mathrm{~N}$ \\
\hline Thoracic centrum & 3 & 1 & 0 & 0 & & 0 & 0 & $\mathrm{~N}$ & $\mathrm{~N}$ \\
\hline Thoracic centrum & 1 & 0 & $\mathrm{n} / \mathrm{a}$ & 0 & & 0 & 0 & $\mathrm{~N}$ & $\mathrm{~N}$ \\
\hline Thoracic centrum & 1 & 0 & $\mathrm{n} / \mathrm{a}$ & 0 & & 0 & 0 & $\mathrm{~N}$ & $\mathrm{~N}$ \\
\hline Thoracic centrum & 3 & 1 & 0 & 0 & & 0 & 0 & $\mathrm{~N}$ & $\mathrm{~N}$ \\
\hline Thoracic centrum & 1 & 0 & $\mathrm{n} / \mathrm{a}$ & 0 & & 0 & 0 & $\mathrm{~N}$ & $\mathrm{~N}$ \\
\hline Thoracic -inf facet & 3 & 2 & $1-2$ & 0 & $\mathrm{~N}$ & 0 & 0 & & \\
\hline inf facet & 3 & 2 & 0 & 0 & $\mathrm{~N}$ & 0 & 0 & & \\
\hline Thoracic-inf facet & 3 & 3 & 1-3 & 0 & $\mathrm{~N}$ & 0 & 0 & & \\
\hline inf facet & 3 & 3 & $1-3$ & 0 & $\mathrm{~N}$ & 0 & 0 & & \\
\hline sup facet & 2 & 2 & $1-1$ & 0 & $\mathrm{~N}$ & 0 & 0 & & \\
\hline Thoracic -inf facet & 3 & 2 & $1-2$ & 0 & $\mathrm{~N}$ & 0 & 0 & & \\
\hline
\end{tabular}


Table C.12, continued

\begin{tabular}{|c|c|c|c|c|c|c|c|c|c|}
\hline ATTRIBUTE & $\mathrm{A}$ & $\mathrm{B}$ & $\mathrm{C}$ & $\mathrm{D}$ & $\mathrm{E}$ & $\mathrm{F}$ & $\mathrm{G}$ & $\mathrm{H}$ & $\mathrm{I}$ \\
\hline inf facet & 2 & 2 & $1-2 / 3$ & 0 & $\mathrm{~N}$ & 0 & 0 & & \\
\hline Thoracic-sup facet & 2 & 2 & $2-2$ & 0 & $\mathrm{~N}$ & 0 & 0 & & \\
\hline inf facet & 2 & 2 & $1 / 2-2$ & 0 & $\mathrm{~N}$ & 0 & 0 & & \\
\hline inf facet & 2 & 2 & $1 / 2-2$ & 0 & $\mathrm{~N}$ & 0 & 0 & & \\
\hline Thoracic-centrum & 3 & 1 & 0 & 0 & & 0 & 0 & $\mathrm{~N}$ & $\mathrm{Y}$ (sup/inf) \\
\hline sup facet & 3 & 2 & $1 / 2-2$ & 0 & $\mathrm{~N}$ & 0 & 0 & & \\
\hline sup facet & 3 & 2 & $1 / 2-2$ & 0 & $\mathrm{~N}$ & 0 & 0 & & \\
\hline inf facet & 3 & 2 & $1-2$ & 0 & $\mathrm{~N}$ & 0 & 0 & & \\
\hline inf facet & 3 & 2 & $1-2$ & 0 & $\mathrm{~N}$ & 0 & 0 & & \\
\hline T12-centrum & 3 & 1 & 0 & 0 & & 0 & 0 & $\mathrm{~N}$ & $\mathrm{Y}$ (inf) \\
\hline sup facet & 3 & 2 & $1-2$ & 0 & $\mathrm{~N}$ & 0 & 0 & & \\
\hline sup facet & 3 & 2 & $1-2$ & 0 & $\mathrm{~N}$ & 0 & 0 & & \\
\hline inf facet & 3 & 3 & $2-3$ & 0 & $\mathrm{~N}$ & 0 & 0 & & \\
\hline inf facet & 3 & 3 & $2-3$ & 0 & $\mathrm{~N}$ & 0 & 0 & & \\
\hline Lumbar-centrum & 3 & 1 & 0 & 0 & & 0 & 0 & $\mathrm{~N}$ & $\mathrm{Y}$ (inf) \\
\hline sup facet & 3 & 2 & $1-2$ & 0 & $\mathrm{~N}$ & 0 & 0 & & \\
\hline inf facet & 2 & 2 & $1-2$ & 0 & $\mathrm{~N}$ & 0 & 0 & & \\
\hline Lumbar-centrum & 3 & 1 & 0 & 0 & & 0 & 0 & $\mathrm{~N}$ & $\mathrm{~N}$ \\
\hline sup facet & 3 & 1 & 0 & 0 & $Y ?$ & 0 & $2 ?$ & & \\
\hline sup facet & 3 & 1 & 0 & 0 & $Y ?$ & 0 & $2 ?$ & & \\
\hline inf facet & 3 & 2 & $1-2$ & 0 & $\mathrm{~N}$ & 0 & 0 & & \\
\hline Lumbar-centrum & 3 & 1 & 0 & 0 & & 0 & 0 & $\mathrm{~N}$ & $\mathrm{~N}$ \\
\hline sup facet & 3 & 2 & $2-2$ & 0 & $\mathrm{~N}$ & 0 & 0 & & \\
\hline sup facet & 3 & 2 & $1 / 2-2$ & 0 & $\mathrm{~N}$ & 0 & 0 & & \\
\hline inf facet & 3 & 2 & $2-2$ & 0 & $\mathrm{~N}$ & 0 & 0 & & \\
\hline inf facet & 3 & 2 & $2-2$ & 2 & $\mathrm{~N}$ & 0 & 0 & & \\
\hline Lumbar-centrum & 3 & 1 & $2-1$ & 0 & & 0 & 0 & $\mathrm{~N}$ & $\mathrm{~N}$ \\
\hline sup facet & 3 & 2 & $1 / 2-2$ & 0 & $\mathrm{~N}$ & 0 & 0 & & \\
\hline sup facet & 3 & 3 & $2-2 / 3$ & 0 & $Y ?$ & 0 & 2 & & \\
\hline inf facet & 3 & 3 & $2 / 3-3$ & $3-1$ & $\mathrm{Y}$ & 0 & 0 & & \\
\hline inf facet & 3 & 3 & $3-3$ & $3-3$ & $\mathrm{Y}$ & $2-1$ & 0 & & \\
\hline lumbar facet (L5) & 3 & 3 & $3-3$ & $3-3$ & $\mathrm{Y}$ & $2-1$ & 0 & & \\
\hline cervical facet? & 3 & 3 & $1-2$ & 0 & $\mathrm{~N}$ & 0 & 0 & & \\
\hline inf facet (thoracic?) & 3 & 3 & $2-3$ & $2-1$ & $\mathrm{~N}$ & 0 & 0 & & \\
\hline inf facet (thoracic?) & 2 & 2 & $1 / 2-2$ & $1-1$ & $\mathrm{~N}$ & 0 & 0 & & \\
\hline inf facet (thoracic?) & 3 & 3 & $1 / 2-3$ & 0 & $\mathrm{~N}$ & 0 & 0 & & \\
\hline inf facet (thoracic?) & 3 & 2 & $1-2$ & 0 & $\mathrm{~N}$ & 0 & 0 & & \\
\hline inf facet (thoracic?) & 2 & 2 & $1-2$ & 0 & $\mathrm{~N}$ & 0 & 0 & & \\
\hline inf facet (thoracic?) & 2 & 2 & $1-2$ & 0 & $\mathrm{~N}$ & 0 & 0 & & \\
\hline inf facet (thoracic?) & 1 & 1 & $1-1$ & 0 & $\mathrm{~N}$ & 0 & 0 & & \\
\hline undientified facet & 3 & 3 & $1 / 2-2$ & 0 & $\mathrm{~N}$ & 0 & 0 & & \\
\hline unidentified facet & 3 & 2 & $2-1$ & 0 & $\mathrm{~N}$ & 0 & 0 & & \\
\hline
\end{tabular}

\section{ELEMENT}

Occipital Condyle-R

TMJ-R

TMJ-L

Clavicle-Sternal-R

Clavicle-Acromial-R

Clavicle-Sternal-L

Clavicle-Acromial-L

Glenoid Fossa-R

\begin{tabular}{|c|c|c|c|c|}
\hline 3 & 3 & $2-2$ & 0 & $\mathrm{~N}$ \\
\hline 3 & 2 & 0 & $1-1$ & $\mathrm{~N}$ \\
\hline 3 & 1 & 0 & $3-1$ & $\mathrm{~N}$ \\
\hline 3 & 2 & 0 & 0 & $\mathrm{~N}$ \\
\hline 1 & 1 & 0 & 0 & $\mathrm{~N}$ \\
\hline 3 & 0 & $\mathrm{n} / \mathrm{a}$ & 0 & $\mathrm{~N}$ \\
\hline 2 & 0 & $\mathrm{n} / \mathrm{a}$ & 0 & $\mathrm{~N}$ \\
\hline 2 & 2 & $1-1$ & 0 & $\mathrm{~N}$ \\
\hline
\end{tabular}

\begin{tabular}{l|l|l|l}
0 & 0 & $*$ & $*$ \\
\hline 0 & 2 & $*$ & $*$ \\
\hline 0 & 2 & $*$ & $*$ \\
\hline 0 & 0 & $*$ & $*$ \\
\hline 0 & 0 & $*$ & $*$ \\
\hline 0 & 0 & $*$ & $*$ \\
\hline 0 & 0 & $*$ & $*$ \\
\hline 0 & 0 & $*$ & $*$ \\
\hline
\end{tabular}


Table C.12, continued

\begin{tabular}{|c|c|c|c|c|c|c|c|c|c|}
\hline ATTRIBUTE & $\mathrm{A}$ & $\mathrm{B}$ & $\mathrm{C}$ & $\mathrm{D}$ & $\mathrm{E}$ & $\mathrm{F}$ & $\mathrm{G}$ & $\mathrm{H}$ & $\mathrm{I}$ \\
\hline Humeral Head-R & 2 & 1 & 0 & 0 & $\mathrm{~N}$ & 0 & 0 & $*$ & $*$ \\
\hline Humeral Head-L & 3 & 3 & $1 / 2-1$ & 0 & $\mathrm{~N}$ & 0 & 0 & $*$ & $*$ \\
\hline Humerus-Trochlea/Capitulum-R & 3 & 1 & $1-1$ & 0 & $\mathrm{~N}$ & 0 & 0 & $*$ & $*$ \\
\hline Humerus-Trochlea/Capitulum-L & 3 & 0 & $\mathrm{n} / \mathrm{a}$ & 0 & $\mathrm{~N}$ & 0 & 0 & $*$ & $*$ \\
\hline Radius-Proximal-L & 2 & 1 & 0 & 0 & $\mathrm{~N}$ & 0 & 0 & $*$ & $*$ \\
\hline Radius-Distal-L & 3 & 1 & 0 & 0 & $\mathrm{~N}$ & 0 & 0 & $*$ & $*$ \\
\hline Ulna-Proximal-R & 2 & 1 & $1-1$ & 0 & $\mathrm{~N}$ & 0 & 0 & $*$ & $*$ \\
\hline Ulna-Distal-R & 2 & 1 & 0 & 0 & $\mathrm{~N}$ & 0 & 0 & $*$ & $*$ \\
\hline Scaphoid-R-radial facet & 3 & 3 & 0 & 0 & $\mathrm{~N}$ & 0 & 0 & $*$ & $*$ \\
\hline Scaphoid-R-capitate facet & 3 & 3 & 0 & 0 & $\mathrm{~N}$ & 0 & 0 & $*$ & $*$ \\
\hline Scaphoid-R-trapezium facet & 3 & 3 & 0 & 0 & $\mathrm{~N}$ & 0 & 0 & $*$ & $*$ \\
\hline Scaphoid-R-trapezoid facet & 3 & 3 & $1 / 2-2$ & 0 & $\mathrm{~N}$ & 0 & 0 & $*$ & $*$ \\
\hline Scaphoid-R-lunate facet & 3 & 3 & 0 & 0 & $\mathrm{~N}$ & 0 & 0 & $*$ & $*$ \\
\hline Scaphoid-L-general & 3 & 3 & $1-2$ & 0 & $\mathrm{~N}$ & 0 & 0 & $*$ & $*$ \\
\hline Lunate-R-radial facet & 3 & 3 & 0 & 0 & $\mathrm{~N}$ & 0 & 0 & $*$ & $*$ \\
\hline Lunate-R-scaphoid facet & 3 & 2 & 0 & 0 & $\mathrm{~N}$ & 0 & 0 & $*$ & $*$ \\
\hline Lunate-R-capitate facet & 3 & 2 & $1-2$ & 0 & $\mathrm{~N}$ & 0 & 0 & $*$ & $*$ \\
\hline Lunate-R-triquetral facet & 3 & 2 & $1-2$ & 0 & $\mathrm{~N}$ & 0 & 0 & $*$ & $*$ \\
\hline Lunate-R-hamate facet & 3 & 2 & $1-2$ & 0 & $\mathrm{~N}$ & 0 & 0 & $*$ & $*$ \\
\hline Triquetral-R-pisiform facet & 2 & 1 & 0 & 0 & $\mathrm{~N}$ & 0 & 0 & $*$ & $*$ \\
\hline Triquetral-R-lunate facet & 2 & 1 & 0 & 0 & $\mathrm{~N}$ & 0 & 0 & $*$ & $*$ \\
\hline Triquetral R-hamate facet & 2 & 1 & 0 & 0 & $\mathrm{~N}$ & 0 & 0 & $*$ & $*$ \\
\hline Capitate-R-scaphoid facet & 3 & 2 & $1-1$ & 0 & $\mathrm{~N}$ & 0 & 0 & $*$ & $*$ \\
\hline Capitate-R-MCIII facet & 3 & 2 & $1-1$ & 0 & $\mathrm{~N}$ & 0 & 0 & $*$ & $*$ \\
\hline Capitate-R-trapezoid facet & 3 & 2 & $1-1$ & 0 & $\mathrm{~N}$ & 0 & 0 & $*$ & $*$ \\
\hline Capitate-R-lunate facet & 3 & 2 & $1-1$ & 0 & $\mathrm{~N}$ & 0 & 0 & $*$ & $*$ \\
\hline Capitate-R-hamate facet & 3 & 2 & $1-1$ & 0 & $\mathrm{~N}$ & 0 & 0 & $*$ & $*$ \\
\hline Capitate-L-general & 3 & 3 & $2-2$ & $2-2$ & $\mathrm{Y}$ & 0 & 0 & $*$ & * \\
\hline Trapezoid-R-trapezium facet & 3 & 3 & $1-2$ & 0 & $\mathrm{~N}$ & 0 & 0 & $*$ & $*$ \\
\hline Trapezoid-R-MCII facet & 3 & 3 & $1-2$ & 0 & $\mathrm{~N}$ & 0 & 0 & $*$ & $*$ \\
\hline Trapezoid-R-scaphoid facet & 3 & 3 & $1-2$ & 0 & $\mathrm{~N}$ & 0 & 0 & $*$ & $*$ \\
\hline Trapezoid-R-capitate facet & 3 & 3 & $1-2$ & 0 & $\mathrm{~N}$ & 0 & 0 & $*$ & $*$ \\
\hline Metacarpal I-Proximal-R & 3 & 2 & $1-2$ & 0 & $\mathrm{~N}$ & 0 & 0 & $*$ & $*$ \\
\hline Metacarpal I-Distal-R & 3 & 2 & 0 & 0 & $\mathrm{~N}$ & 0 & 0 & $*$ & $*$ \\
\hline Metacarpal II-Distal-R & 3 & 2 & 0 & $1-1$ & $\mathrm{~N}$ & 0 & 0 & $*$ & $*$ \\
\hline Metacarpal II-Proximal-L & 3 & 2 & $1-1$ & $2-2$ & $\mathrm{Y}$ & 0 & 0 & $*$ & $*$ \\
\hline Metacarpal II-Distal-L & 3 & 0 & $\mathrm{n} / \mathrm{a}$ & 0 & $\mathrm{~N}$ & 0 & 0 & $*$ & $*$ \\
\hline Metacarpal III-Proximal-R & 3 & 3 & $1-1$ & 0 & $\mathrm{~N}$ & 0 & 0 & $*$ & * \\
\hline Metacarpal III-Proximal-L & 3 & 2 & $1-1$ & $2-2$ & $\mathrm{Y}$ & 0 & 0 & $*$ & $*$ \\
\hline Metacarpal IV-Proximal-R & 2 & 2 & $1-1$ & 0 & $\mathrm{~N}$ & 0 & 0 & $*$ & $*$ \\
\hline Metacarpal IV-Distal-R & 2 & 0 & $\mathrm{n} / \mathrm{a}$ & 0 & $\mathrm{~N}$ & 0 & 0 & $*$ & * \\
\hline Metacarpal IV-Proximal-L & 2 & 2 & $1-2$ & 0 & $\mathrm{~N}$ & 0 & 0 & $*$ & $*$ \\
\hline Metacarpal IV-Distal-L & 2 & 0 & $\mathrm{n} / \mathrm{a}$ & 0 & $\mathrm{~N}$ & 0 & 0 & $*$ & $*$ \\
\hline Metacarpal V-Distal-R & 2 & 1 & 0 & 0 & $\mathrm{~N}$ & 0 & 0 & $*$ & $*$ \\
\hline Metacarpal V-Proximal-L & 2 & 1 & $1-1$ & 0 & $\mathrm{~N}$ & 0 & 0 & $*$ & $*$ \\
\hline Acetabulum-R & 3 & 3 & $2-1$ & $2-1$ & $\mathrm{~N}$ & 0 & 2 & $*$ & $*$ \\
\hline Femoral Head-R & 2 & 1 & 0 & 0 & $\mathrm{~N}$ & 0 & 0 & $*$ & $*$ \\
\hline Femoral Condyles-R & 2 & 0 & $\mathrm{n} / \mathrm{a}$ & 0 & $\mathrm{~N}$ & 0 & 0 & $*$ & $*$ \\
\hline Patella-R & 2 & 1 & $2-1$ & 0 & $\mathrm{~N}$ & 0 & 2 & $*$ & $*$ \\
\hline Patella-L & 3 & 1 & $1 / 2-1$ & 0 & $\mathrm{~N}$ & 0 & 0 & $*$ & $*$ \\
\hline Fibula-Distal-R & 2 & 1 & $1-1$ & 0 & $\mathrm{~N}$ & 0 & 0 & $*$ & $*$ \\
\hline
\end{tabular}


Table C.12, continued

\begin{tabular}{|c|c|c|c|c|c|c|c|c|c|}
\hline ATTRIBUTE & $\mathrm{A}$ & $\mathrm{B}$ & $\mathrm{C}$ & $\mathrm{D}$ & $\mathrm{E}$ & $\mathrm{F}$ & $\mathrm{G}$ & $\mathrm{H}$ & $\mathrm{I}$ \\
\hline Talus-R-tibial facet & 3 & 2 & $1-1$ & 0 & $\mathrm{~N}$ & 0 & 0 & $*$ & $*$ \\
\hline Talus-R-ant/med calc. facet & 1 & 1 & 0 & 0 & $\mathrm{~N}$ & 0 & 0 & $*$ & $*$ \\
\hline Talus-R-post. Calc. facet & 3 & 2 & 0 & 0 & $\mathrm{~N}$ & 0 & 0 & $*$ & $*$ \\
\hline Talus-R-navicular facet & 2 & 1 & 0 & 0 & $\mathrm{~N}$ & 0 & 0 & $*$ & $*$ \\
\hline Talus-L-tibial facet & 3 & 2 & 0 & 0 & $\mathrm{~N}$ & 0 & 0 & $*$ & $*$ \\
\hline Talus-L-ant/med calc. facet & 1 & 1 & 0 & 0 & $\mathrm{~N}$ & 0 & 0 & $*$ & $*$ \\
\hline Talus-L-post. Calc. facet & 3 & 2 & $1-1$ & $1-1$ & $\mathrm{~N}$ & 0 & 0 & $*$ & $*$ \\
\hline Calcaneus-L-ant/med talar facet & 2 & 2 & $2-2$ & 0 & $\mathrm{~N}$ & 0 & 0 & $*$ & $*$ \\
\hline Calcaneus-L-post. Talar facet & 3 & 2 & $2-1$ & 0 & $\mathrm{~N}$ & 0 & 0 & $*$ & $*$ \\
\hline Navicular-L-talar facet & 2 & 1 & 0 & 0 & $\mathrm{~N}$ & 0 & 0 & $*$ & $*$ \\
\hline Navicular-L-int.cune. Facet & 2 & 1 & 0 & 0 & $\mathrm{~N}$ & 0 & 0 & $*$ & $*$ \\
\hline Navicular-L-lat.cune. Facet & 2 & 1 & 0 & 0 & $\mathrm{~N}$ & 0 & 0 & $*$ & $*$ \\
\hline Medial Cun-L-navicular facet & 3 & 2 & 0 & 0 & $\mathrm{~N}$ & 0 & 0 & $*$ & $*$ \\
\hline Medial Cun-L-MTI facet & 3 & 2 & $1 / 2-2$ & 0 & $\mathrm{~N}$ & 0 & 0 & $*$ & $*$ \\
\hline Int Cun-L-MTII facet & 2 & 2 & $1 / 2-2$ & 0 & $\mathrm{~N}$ & 0 & 0 & $*$ & $*$ \\
\hline Int Cun-L-navicular facet & 2 & 2 & $1 / 2-2$ & 0 & $\mathrm{~N}$ & 0 & 0 & $*$ & $*$ \\
\hline Lat Cun-R-MTIII facet & 2 & 2 & $1 / 2-2$ & 0 & $\mathrm{~N}$ & 0 & 0 & $*$ & $*$ \\
\hline Lat Cun-R-navicular facet & 2 & 2 & $1 / 2-2$ & 0 & $\mathrm{~N}$ & 0 & 0 & $*$ & $*$ \\
\hline Lat Cun-L-MTIII facet & 2 & 1 & 0 & 0 & $\mathrm{~N}$ & 0 & 0 & $*$ & $*$ \\
\hline Lat Cun-L-navicular facet & 2 & 1 & 0 & 0 & $\mathrm{~N}$ & 0 & 0 & $*$ & $*$ \\
\hline Metatarsal I-Proximal-R & 2 & 2 & $1 / 2-1$ & 0 & $\mathrm{~N}$ & 0 & 0 & $*$ & $*$ \\
\hline Metatarsal I-Proximal-L & 2 & 1 & 0 & 0 & $\mathrm{~N}$ & 0 & 0 & $*$ & $*$ \\
\hline Metatarsal I-Distal-L & 3 & 1 & 0 & 0 & $\mathrm{~N}$ & 0 & 0 & $*$ & $*$ \\
\hline Metatarsal II-Proximal-L & 3 & 2 & $1 / 2-2$ & 0 & $\mathrm{~N}$ & 0 & 0 & $*$ & $*$ \\
\hline Metatarsal III-Proximal-L & 3 & 2 & $1-2$ & 0 & $\mathrm{~N}$ & 0 & 0 & $*$ & $*$ \\
\hline Metatarsal IV-Proximal-L & 2 & 2 & $2-2$ & 0 & $\mathrm{~N}$ & 0 & 0 & $*$ & $*$ \\
\hline distal metatarsal & 3 & 2 & 0 & 0 & $\mathrm{~N}$ & 0 & 0 & $*$ & $*$ \\
\hline
\end{tabular}

\section{PHALANGES}

\section{Manual}

\begin{tabular}{l|c|c|c|c|c|c|c|c|c|c}
\hline 1.Proximal-Prox. Surf & 2 & 1 & 0 & 0 & $\mathrm{~N}$ & 0 & 0 & $*$ & $*$ \\
\hline 2.Proximal-Prox. Surf & 2 & 1 & 0 & 0 & $\mathrm{~N}$ & 0 & 0 & $*$ & $*$ \\
\hline Distal Surf & 2 & 1 & 0 & 0 & $\mathrm{~N}$ & 0 & 0 & $*$ & $*$ \\
\hline 3.Proximal-Prox. Surf & 2 & 1 & 0 & 0 & $\mathrm{~N}$ & 0 & 0 & $*$ & $*$ \\
\hline Distal Surf & 3 & 1 & 0 & 0 & $\mathrm{~N}$ & 0 & 0 & $*$ & $*$ \\
\hline 4.Proximal-Prox. Surf & 3 & 2 & $1-1$ & 0 & $\mathrm{~N}$ & 0 & 0 & $*$ & $*$ \\
\hline Distal Surf & 2 & 2 & $1-1$ & 0 & $\mathrm{~N}$ & 0 & 0 & $*$ & $*$ \\
\hline 5.Proximal-Prox. Surf & 3 & 2 & $1-1$ & 0 & $\mathrm{~N}$ & 0 & 0 & $*$ & $*$ \\
\hline Distal Surf & 3 & 3 & $1 / 2-3$ & 0 & $\mathrm{~N}$ & 0 & 0 & $*$ & $*$ \\
\hline 6.Middle-Prox. Surf & 3 & 1 & 0 & 0 & $\mathrm{~N}$ & 0 & 0 & $*$ & $*$ \\
\hline Distal Surf & 3 & 2 & 0 & 0 & $\mathrm{~N}$ & 0 & 0 & $*$ & $*$ \\
\hline 7.Middle-Prox. Surf & 2 & 1 & 0 & 0 & $\mathrm{~N}$ & 0 & 0 & $*$ & $*$ \\
\hline Distal Surf & 3 & 2 & 0 & 0 & $\mathrm{~N}$ & 0 & 0 & $*$ & $*$ \\
\hline 8.Middle-Prox. Surf & 2 & 1 & 0 & 0 & $\mathrm{~N}$ & 0 & 0 & $*$ & $*$ \\
\hline Distal Surf & 3 & 2 & 0 & 0 & $\mathrm{~N}$ & 0 & 0 & $*$ & $*$ \\
\hline 9.Middle-Prox. Surf & 3 & 2 & 0 & 0 & $\mathrm{~N}$ & 0 & 0 & $*$ & $*$ \\
\hline Distal Surf & 3 & 2 & $1 ?$ & 0 & $\mathrm{~N}$ & 0 & 0 & $*$ & $*$ \\
\hline Pedal & & & & & & $*$
\end{tabular}

\section{Pedal}

1.Proximal-Prox. Surf

Distal Surf

2.Proximal-Distal Surf

3.Middle-Prox. Surf

Distal Surf

\begin{tabular}{|l|l|l|l|}
\hline 2 & 1 & 0 & \\
\hline 2 & 2 & 0 & \\
\hline 2 & 2 & & \\
\hline 2 & 1 & 0 & \\
\hline 2 & 2 & 0 & \\
\hline
\end{tabular}

\begin{tabular}{l|l|l|l|l|l}
0 & $\mathrm{~N}$ & 0 & 0 & $*$ & $*$ \\
\hline 0 & $\mathrm{~N}$ & 0 & 0 & $*$ & $*$ \\
\hline 0 & $\mathrm{~N}$ & 0 & 0 & $*$ & $*$ \\
\hline 0 & $\mathrm{~N}$ & 0 & 0 & $*$ & $*$ \\
\hline 0 & $\mathrm{~N}$ & 0 & 0 & $*$ & $*$ \\
\hline
\end{tabular}


Table C.12, continued

\begin{tabular}{|c|c|c|c|c|c|c|c|c|c|}
\hline ATTRIBUTE & $\mathrm{A}$ & $\mathrm{B}$ & $\mathrm{C}$ & $\mathrm{D}$ & $\mathrm{E}$ & $\mathrm{F}$ & $\mathrm{G}$ & $\mathrm{H}$ & $\mathrm{I}$ \\
\hline \multicolumn{10}{|l|}{ BURIAL \# 8} \\
\hline \multicolumn{10}{|l|}{ VERTEBRA } \\
\hline Atlas-sup facet & 3 & 3 & $1-3$ & 0 & $\mathrm{~N}$ & 0 & 0 & & \\
\hline sup facet & 3 & 3 & $2-3$ & 0 & $\mathrm{~N}$ & 0 & 0 & & \\
\hline inf facet & 3 & 3 & $1-3$ & 0 & $\mathrm{~N}$ & 0 & 0 & & \\
\hline inf facet & 2 & 2 & $1-2$ & 0 & $\mathrm{~N}$ & 0 & 0 & & \\
\hline Axis-sup facet & 3 & 3 & $1 / 2-3$ & 0 & $\mathrm{~N}$ & 0 & 0 & & \\
\hline sup facet & 3 & 2 & $1 / 2-2$ & 0 & $\mathrm{~N}$ & 0 & 0 & & \\
\hline inf facet & 3 & 3 & 0 & 0 & $\mathrm{~N}$ & 0 & 0 & & \\
\hline centrum & 2 & 2 & $1-2$ & 0 & & 0 & 0 & $\mathrm{~N}$ & $\mathrm{~N}$ \\
\hline Lower Cervical-centrum & 3 & 3 & $3-3$ & $2-1$ & & 0 & 2 & $\mathrm{Y}$ & $\mathrm{N}$ \\
\hline sup facet & 3 & 3 & $1 / 2-3$ & 0 & $\mathrm{~N}$ & 0 & 0 & & \\
\hline inf facet & 2 & 2 & $1 / 2-2$ & 0 & $\mathrm{~N}$ & 0 & 0 & & \\
\hline Cervical centrum & 3 & 3 & $3-3$ & $2-1$ & & 0 & 2 & $\mathrm{Y}$ & $\mathrm{N}$ \\
\hline Lower Cervical-centrum & 3 & 3 & $3-3$ & $3-2$ & & $2-1$ & 2 & $\mathrm{Y}$ & $\mathrm{N}$ \\
\hline sup facet & 3 & 3 & $2-3$ & 0 & $\mathrm{~N}$ & 0 & 0 & & \\
\hline Cervical-Sup Facet & 3 & 3 & $2-3$ & 0 & $\mathrm{~N}$ & 0 & 0 & & \\
\hline inf facet & 3 & 3 & $2-3$ & 0 & $\mathrm{~N}$ & $2-1$ & 0 & & \\
\hline Cervical-Sup Facet & 3 & 3 & $2-3$ & 0 & $\mathrm{~N}$ & $2-1$ & 0 & & \\
\hline inf facet & 3 & 2 & $1 / 2-2$ & 0 & $\mathrm{~N}$ & 0 & 0 & & \\
\hline Cervical-Sup Facet & 3 & 3 & $2-3$ & 0 & $\mathrm{~N}$ & 0 & 0 & & \\
\hline inf facet & 3 & 3 & $2 / 3-3$ & 0 & $\mathrm{~N}$ & $2-1$ & 0 & & \\
\hline Cervical-Inf Facet & 3 & 2 & $1-2$ & 0 & $\mathrm{~N}$ & 0 & 0 & & \\
\hline inf facet & 3 & 3 & $1-3 ?$ & 0 & $\mathrm{~N}$ & 0 & 0 & & \\
\hline Thoracic-Sup Facet & 3 & 3 & 0 & 0 & $\mathrm{~N}$ & 0 & 0 & & \\
\hline inf facet & 3 & 2 & 0 & 0 & $\mathrm{~N}$ & 0 & 0 & & \\
\hline Thoracic-Sup Facet & 3 & 3 & 0 & 0 & $\mathrm{~N}$ & 0 & 0 & & \\
\hline inf facet & 3 & 3 & $1-3$ & 0 & $\mathrm{~N}$ & 0 & 0 & & \\
\hline inf facet & 3 & 3 & $1-3$ & 0 & $\mathrm{~N}$ & 0 & 0 & & \\
\hline Thoracic-Sup Facet & 3 & 3 & $2-3$ & 0 & $\mathrm{~N}$ & 0 & 0 & & \\
\hline Thoracic facet & 3 & 3 & $2-3$ & 0 & $\mathrm{~N}$ & 0 & 0 & & \\
\hline Thoracic facet & 3 & 2 & $1-2$ & 0 & $\mathrm{~N}$ & 0 & 0 & & \\
\hline Thoracic facet & 3 & 2 & $1-2$ & 0 & $\mathrm{~N}$ & 0 & 0 & & \\
\hline Thoracic centrum & 1 & 1 & 0 & 0 & & 0 & 0 & $\mathrm{~N}$ & $\mathrm{n} / \mathrm{a}$ \\
\hline Thoracic centrum & 1 & 1 & $2-1$ & 0 & & 0 & 0 & $\mathrm{~N}$ & $\mathrm{~N}$ \\
\hline Thoracic centrum & 1 & 1 & $2-1$ & 0 & & 0 & 2 & $\mathrm{~N}$ & $\mathrm{~N}$ \\
\hline Lumbar-Inf Facet & 3 & 3 & $2-3$ & 0 & $\mathrm{~N}$ & 0 & $1 ?$ & & \\
\hline Lumbar-Inf Facet & 3 & 2 & $2-1$ & 0 & $\mathrm{~N}$ & 0 & 0 & & \\
\hline unidentified facet (lumbar?) & 3 & 1 & 0 & $2-1$ & $\mathrm{~N}$ & $2-1$ & 0 & & \\
\hline unidentified facet (lumbar?) & 3 & 2 & $1-2$ & 0 & $\mathrm{~N}$ & 0 & 0 & & \\
\hline sacral promontory & 2 & 2 & $2-2$ & 0 & $\mathrm{~N}$ & 0 & 0 & & \\
\hline
\end{tabular}

\section{ELEMENT}

Occipital Condyle-R

Occipital Condyle-L

TMJ-R

TMJ-L

Mandibular Condyle-R

Glenoid Fossa-R

Glenoid Fossa-L

Humeral Head-R

Humeral Head-L

\begin{tabular}{c|c|c|c|c}
3 & 3 & 0 & 0 & $\mathrm{~N}$ \\
\hline 3 & 3 & 0 & 0 & $\mathrm{~N}$ \\
\hline 3 & 3 & 0 & 0 & $\mathrm{~N}$ \\
\hline 3 & 3 & 0 & 0 & $\mathrm{~N}$ \\
\hline 2 & 2 & 0 & 0 & $\mathrm{~N}$ \\
\hline 1 & 0 & $\mathrm{n} / \mathrm{a}$ & 0 & $\mathrm{~N}$ \\
\hline 1 & 0 & $\mathrm{n} / \mathrm{a}$ & 0 & $\mathrm{~N}$ \\
\hline 3 & 0 & $\mathrm{n} / \mathrm{a}$ & 0 & $\mathrm{~N}$ \\
\hline 3 & 0 & $\mathrm{n} / \mathrm{a}$ & 0 & $\mathrm{~N}$ \\
\hline
\end{tabular}

\begin{tabular}{l|l|l|l|l}
$\mathrm{N}$ & 0 & 0 & $*$ & $*$ \\
\hline $\mathrm{N}$ & 0 & 0 & $*$ & $*$ \\
$\mathrm{~N}$ & 0 & 2 & $*$ & $*$ \\
$\mathrm{~N}$ & 0 & 2 & $*$ & $*$ \\
$\mathrm{~N}$ & 0 & 0 & $*$ & $*$ \\
$\mathrm{~N}$ & 0 & 0 & $*$ & $*$ \\
\hline $\mathrm{N}$ & 0 & 0 & $*$ & $*$ \\
\hline $\mathrm{N}$ & 0 & 0 & $*$ & $*$ \\
\hline $\mathrm{N}$ & 0 & 0 & $*$ & $*$ \\
\hline
\end{tabular}


Table C.12, continued

\begin{tabular}{|c|c|c|c|c|c|c|c|c|c|}
\hline ATTRIBUTE & $\mathrm{A}$ & $\mathrm{B}$ & $\mathrm{C}$ & $\mathrm{D}$ & $\mathrm{E}$ & $\mathrm{F}$ & $G$ & $\mathrm{H}$ & $\mathrm{I}$ \\
\hline Humerus-Trochlea/Capitulum-R & 2 & 1 & 0 & 0 & $\mathrm{~N}$ & 0 & 0 & $*$ & $*$ \\
\hline Humerus-Trochlea/Capitulum-L & 3 & 1 & 0 & 0 & $\mathrm{~N}$ & 0 & 2 & $*$ & $*$ \\
\hline Radius-Proximal-R & 3 & 3 & 0 & 0 & $\mathrm{~N}$ & 0 & 0 & $*$ & $*$ \\
\hline Ulna-Proximal-R & 3 & 2 & 0 & 0 & $\mathrm{~N}$ & 0 & 0 & $*$ & $*$ \\
\hline Ulna-Proximal-L & 3 & 1 & 0 & 0 & $\mathrm{~N}$ & 0 & 0 & $*$ & * \\
\hline Scaphoid-L-general & 3 & 3 & $2-2$ & 0 & $\mathrm{~N}$ & 0 & 0 & $*$ & $*$ \\
\hline Scaphoid-L-trapezoid facet & 3 & 3 & & 0 & $\mathrm{~N}$ & $2-1$ & 0 & $*$ & * \\
\hline Lunate-R-general & 3 & 3 & 0 & 0 & $\mathrm{~N}$ & 0 & 0 & $*$ & $*$ \\
\hline Lunate-R-capitate facet & & & & & & $2-1$ & & $*$ & $*$ \\
\hline Lunate-L-general & 3 & 3 & $2-2$ & 0 & $\mathrm{~N}$ & 0 & 0 & $*$ & * \\
\hline Lunate-L-capitate facet & & & & & & $2-1$ & & $*$ & $*$ \\
\hline Pisiform-unsided & 2 & 2 & 0 & 0 & $\mathrm{~N}$ & 0 & 0 & $*$ & $*$ \\
\hline Triquetral-R-general & 3 & 2 & $1-2$ & 0 & $\mathrm{~N}$ & 0 & 0 & $*$ & $*$ \\
\hline Capitate-R-general & 3 & 3 & $2-3$ & 0 & $\mathrm{~N}$ & 0 & 0 & $*$ & * \\
\hline Capitate-R-lunate facet & & & & & & $2-1$ & & $*$ & $*$ \\
\hline Capitate-L-general & 3 & 3 & $1 / 2-2$ & 0 & $\mathrm{~N}$ & 0 & 0 & $*$ & * \\
\hline Capitate-L-lunate facet & & & & & & $2-1$ & & $*$ & $*$ \\
\hline Trapezoid-L-general & 3 & 3 & $2-2 ?$ & 0 & $\mathrm{~N}$ & 0 & 0 & $*$ & * \\
\hline Trapezoid-L-scaphoid facet & & & & & & $2-1$ & & $*$ & $*$ \\
\hline Hamate-unsided & 1 & 1 & $2-1$ & 0 & $\mathrm{~N}$ & 0 & 0 & $*$ & * \\
\hline Metacarpal II-Distal-L & 3 & 2 & 0 & 0 & $\mathrm{~N}$ & 0 & 0 & $*$ & $*$ \\
\hline Metacarpal V-Proximal-R & 3 & 0 & $\mathrm{n} / \mathrm{a}$ & 0 & $\mathrm{~N}$ & 0 & 0 & $*$ & $*$ \\
\hline Acetabulum-R & 1 & 0 & $\mathrm{n} / \mathrm{a}$ & 0 & $\mathrm{~N}$ & 0 & 0 & $*$ & * \\
\hline Acetabulum-L & 1 & 0 & $\mathrm{n} / \mathrm{a}$ & 0 & $\mathrm{~N}$ & 0 & 0 & $*$ & $*$ \\
\hline Femoral Head-R & 2 & 0 & $\mathrm{n} / \mathrm{a}$ & $1-2$ & $\mathrm{~N}$ & 0 & 0 & $*$ & $*$ \\
\hline Femoral Head-L & 2 & 0 & $\mathrm{n} / \mathrm{a}$ & $1-2$ & $\mathrm{~N}$ & 0 & 0 & $*$ & $*$ \\
\hline Femoral Condyles-R & 3 & 1 & $1-1$ & 0 & $\mathrm{~N}$ & 0 & 0 & $*$ & * \\
\hline Femoral Condyles-L & 1 & 0 & $\mathrm{n} / \mathrm{a}$ & 0 & $\mathrm{~N}$ & 0 & 0 & $*$ & * \\
\hline Tibia-Proximal-R & 1 & 0 & $\mathrm{n} / \mathrm{a}$ & 0 & $\mathrm{~N}$ & 0 & 0 & $*$ & * \\
\hline Tibia-Proximal-L & 1 & 0 & $\mathrm{n} / \mathrm{a}$ & 0 & $\mathrm{~N}$ & 0 & 0 & $*$ & * \\
\hline Tibia-Distal-R & 3 & 1 & 0 & 0 & $\mathrm{~N}$ & 0 & 0 & * & * \\
\hline Tibia-Distal-L & 3 & 1 & 0 & 0 & $\mathrm{~N}$ & 0 & 0 & $*$ & * \\
\hline Patella-R & 2 & 1 & 0 & $1-1$ & $\mathrm{~N}$ & 0 & 0 & $*$ & * \\
\hline Patella-L & 3 & 1 & 0 & $1-1$ & $\mathrm{~N}$ & 0 & 0 & * & * \\
\hline Fibula-Distal-R & 3 & 3 & 0 & 0 & $\mathrm{~N}$ & 0 & 0 & $*$ & * \\
\hline Fibula-Distal-L & 3 & 3 & 0 & 0 & $\mathrm{~N}$ & 0 & 0 & $*$ & * \\
\hline Talus-R-tibial facet & 3 & 3 & 0 & $1-1$ & $\mathrm{~N}$ & 0 & 0 & $*$ & * \\
\hline Talus-R-ant/med calc. facet & 3 & 2 & 0 & 0 & $\mathrm{~N}$ & 0 & 0 & * & * \\
\hline Talus-R-post. Calc. facet & 3 & 2 & 0 & $1-1$ & $\mathrm{~N}$ & 0 & $\frac{1}{1}$ & * & * \\
\hline Talus-R-navicular facet & 3 & 2 & 0 & $1-1$ & $\mathrm{~N}$ & 0 & 0 & $*$ & * \\
\hline Talus-L-tibial facet & 3 & 3 & 0 & $1-1$ & $\mathrm{~N}$ & $2-1$ & 0 & $*$ & * \\
\hline Talus-L-ant/med calc. facet & 3 & 1 & 0 & 0 & $\mathrm{~N}$ & 0 & 0 & $*$ & * \\
\hline Talus-L-post. Calc. facet & 3 & 1 & 0 & $1-1$ & $\mathrm{~N}$ & 0 & 0 & $*$ & * \\
\hline Talus-L-navicular facet & 3 & 2 & 0 & $1-1$ & $\mathrm{~N}$ & 0 & 0 & $*$ & * \\
\hline Calcaneus-R-ant/med talar facet & 3 & 2 & 0 & 0 & $\mathrm{~N}$ & 0 & 0 & $*$ & * \\
\hline Calcaneus-R-post. Talar facet & 3 & 2 & 0 & $1-2$ & $\mathrm{~N}$ & 0 & 0 & $*$ & * \\
\hline Calcaneus-R-cuboid facet & 3 & 1 & 0 & 0 & $\mathrm{~N}$ & 0 & 0 & $*$ & * \\
\hline Calcaneus-L-ant/med talar facet & 3 & 3 & 0 & 0 & $\mathrm{~N}$ & 0 & 0 & $*$ & * \\
\hline Calcaneus-L-post. Talar facet & 3 & 2 & 0 & $1-1$ & $\mathrm{~N}$ & 0 & 0 & $*$ & * \\
\hline Calcaneus-L-cuboid facet & 2 & 1 & 0 & 0 & $\mathrm{~N}$ & 0 & 0 & $*$ & * \\
\hline Navicular-R-talar facet & 3 & 2 & 0 & 0 & $\mathrm{~N}$ & 0 & 0 & $*$ & * \\
\hline
\end{tabular}


Table C.12, continued

\begin{tabular}{|c|c|c|c|c|c|c|c|c|c|}
\hline ATTRIBUTE & $\mathrm{A}$ & $\mathrm{B}$ & $\mathrm{C}$ & $\mathrm{D}$ & $\mathrm{E}$ & $\mathrm{F}$ & $\mathrm{G}$ & $\overline{\mathrm{H}}$ & $\mathrm{I}$ \\
\hline Navicular-R-med.cune. Facet & 3 & 2 & 0 & 0 & $\mathrm{~N}$ & 0 & 0 & $*$ & * \\
\hline Navicular-R-int.cune. Facet & 3 & 3 & 0 & 0 & $\mathrm{~N}$ & 0 & 0 & $*$ & * \\
\hline Navicular-R-lat.cune. Facet & 3 & 2 & 0 & 0 & $\mathrm{~N}$ & 0 & 0 & $*$ & * \\
\hline Navicular-L-talar facet & 3 & 1 & 0 & 0 & $\mathrm{~N}$ & 0 & 0 & $*$ & * \\
\hline Navicular-L-med.cune. Facet & 3 & 1 & 0 & 0 & $\mathrm{~N}$ & 0 & 0 & $*$ & * \\
\hline Navicular-L-int.cune. Facet & 3 & 3 & 0 & 0 & $\mathrm{~N}$ & 0 & 0 & $*$ & * \\
\hline Navicular-L-lat.cune. Facet & 3 & 1 & 0 & 0 & $\mathrm{~N}$ & 0 & 0 & $*$ & * \\
\hline Cuboid-R-calcaneus facet & 3 & 1 & 0 & 0 & $\mathrm{~N}$ & 0 & 0 & $*$ & * \\
\hline Cuboid-R-MTIV facet & 3 & 0 & $\mathrm{n} / \mathrm{a}$ & 0 & $\mathrm{~N}$ & 0 & 0 & $*$ & * \\
\hline Cuboid-R-MTV facet & 3 & 0 & $\mathrm{n} / \mathrm{a}$ & 0 & $\mathrm{~N}$ & 0 & 0 & * & * \\
\hline Cuboid-L-calcaneus facet & 3 & 0 & $\mathrm{n} / \mathrm{a}$ & 0 & $\mathrm{~N}$ & 0 & 0 & $*$ & $*$ \\
\hline Cuboid-L-MTIV facet & 3 & 0 & $\mathrm{n} / \mathrm{a}$ & 0 & $\overline{\mathrm{N}}$ & 0 & 0 & $*$ & * \\
\hline Cuboid-L-MTV facet & 3 & 0 & $\mathrm{n} / \mathrm{a}$ & 0 & $\mathrm{~N}$ & 0 & 0 & $*$ & * \\
\hline Medial Cun-R-navicular facet & 3 & 1 & 0 & 0 & $\mathrm{~N}$ & 0 & 0 & $*$ & $*$ \\
\hline Medial Cun-R-MTI facet & 3 & 3 & 0 & 0 & $\mathrm{~N}$ & 0 & 0 & * & $*$ \\
\hline Medial Cun-L-navicular facet & 3 & 1 & 0 & 0 & $\mathrm{~N}$ & 0 & 0 & $*$ & $*$ \\
\hline Medial Cun-L-MTI facet & 3 & 2 & 1-1? & 0 & $\mathrm{~N}$ & 0 & 0 & $*$ & $*$ \\
\hline Int Cun-R-MTII facet & 3 & 2 & 0 & 0 & $\mathrm{~N}$ & 0 & 0 & * & $*$ \\
\hline Int Cun-R-navicular facet & 3 & 3 & 0 & 0 & $\mathrm{~N}$ & 0 & 0 & $*$ & * \\
\hline Int Cun-L-MTII facet & 3 & 1 & $1-1 ?$ & 0 & $\mathrm{~N}$ & 0 & 0 & * & * \\
\hline Int Cun-L-navicular facet & 3 & 0 & $\mathrm{n} / \mathrm{a}$ & 0 & $\mathrm{~N}$ & 0 & 0 & * & $*$ \\
\hline Lat Cun-R-MTIII facet & 3 & 1 & 0 & 0 & $\mathrm{~N}$ & 0 & 0 & * & $*$ \\
\hline Lat Cun-R-navicular facet & 3 & 2 & 0 & 0 & $\mathrm{~N}$ & 0 & 0 & * & $*$ \\
\hline Lat Cun-L-MTIII facet & 3 & 2 & 0 & 0 & $\mathrm{~N}$ & 0 & 0 & * & * \\
\hline Lat Cun-L-navicular facet & 3 & 1 & 0 & 0 & $\mathrm{~N}$ & 0 & 0 & * & * \\
\hline Metatarsal I-Proximal-R & 3 & 1 & 0 & 0 & $\mathrm{~N}$ & 0 & 0 & * & * \\
\hline Metatarsal I-Distal-R & 3 & 0 & $\mathrm{n} / \mathrm{a}$ & 0 & $\mathrm{~N}$ & 0 & 2 & $*$ & * \\
\hline Metatarsal I-Proximal-L & 2 & 1 & 0 & 0 & $\mathrm{~N}$ & 0 & 0 & $*$ & * \\
\hline Metatarsal I-Distal-L & 2 & 2 & 0 & 0 & $\mathrm{~N}$ & $2-1$ & 0 & * & * \\
\hline Metatarsal II-Proximal-R & 3 & 1 & 0 & 0 & $\mathrm{~N}$ & 0 & 0 & * & * \\
\hline Metatarsal II-Proximal-L & 3 & 2 & 0 & 0 & $\mathrm{~N}$ & 0 & 0 & $*$ & * \\
\hline Metatarsal III-Proximal-R & 3 & 2 & 0 & 0 & $\mathrm{~N}$ & 0 & 0 & $*$ & * \\
\hline Metatarsal III-Proximal-L & 3 & 2 & $1-1 ?$ & 0 & $\mathrm{~N}$ & 0 & 0 & * & * \\
\hline Metatarsal IV-Proximal-R & 3 & 1 & 0 & 0 & $\mathrm{~N}$ & 0 & 0 & * & * \\
\hline Metatarsal IV-Proximal-L & 2 & 1 & 0 & 0 & $\mathrm{~N}$ & 0 & 0 & * & * \\
\hline Metatarsal V-Proximal-R & 3 & 1 & 0 & 0 & $\mathrm{~N}$ & 0 & 0 & $*$ & * \\
\hline Metatarsal V-Proximal-L & 3 & 2 & 0 & 0 & $\mathrm{~N}$ & 0 & 0 & $*$ & * \\
\hline \multicolumn{10}{|l|}{ PHALANGES } \\
\hline \multicolumn{10}{|l|}{ Manual } \\
\hline 1.Proximal-Distal Surf & 3 & 2 & 0 & 0 & $\mathrm{~N}$ & 0 & 0 & $*$ & * \\
\hline 2.Proximal-Prox. Surf & 3 & 2 & 0 & 0 & $\mathrm{~N}$ & 0 & 0 & $*$ & * \\
\hline Distal Surf & 3 & 2 & $2-1 ?$ & 0 & $\mathrm{~N}$ & 0 & 0 & $*$ & * \\
\hline 3.Proximal-Prox. Surf & 3 & 3 & 0 & 0 & $\mathrm{~N}$ & 0 & 0 & $*$ & * \\
\hline Distal Surf & 3 & 2 & $1-1 ?$ & 0 & $\mathrm{~N}$ & 0 & 0 & $*$ & * \\
\hline 4.Proximal-Prox. Surf & 3 & 1 & 0 & 0 & $\mathrm{~N}$ & 0 & 0 & $*$ & * \\
\hline 5.Proximal-Prox. Surf & 3 & 2 & $1-1 ?$ & 0 & $\mathrm{~N}$ & 0 & 0 & $*$ & * \\
\hline Distal Surf & 3 & 3 & 0 & 0 & $\mathrm{~N}$ & 0 & 0 & $*$ & * \\
\hline 6.Middle-Distal Surf & 3 & 3 & 0 & 0 & $\mathrm{~N}$ & 0 & 0 & $*$ & * \\
\hline 7.Middle-Distal Surf & 3 & 2 & $2-1 ?$ & 0 & $\mathrm{~N}$ & 0 & 0 & $*$ & * \\
\hline 8.Middle-Prox. Surf & 3 & 2 & $1-1 ?$ & 0 & $\mathrm{~N}$ & 0 & 0 & $*$ & * \\
\hline Distal Surf & 3 & 2 & 0 & 0 & $\mathrm{~N}$ & 0 & 0 & $*$ & * \\
\hline
\end{tabular}


Table C.12, continued

\begin{tabular}{|c|c|c|c|c|c|c|c|c|c|}
\hline ATTRIBUTE & $\mathrm{A}$ & $\mathrm{B}$ & $\mathrm{C}$ & $\mathrm{D}$ & $\mathrm{E}$ & $\mathrm{F}$ & $\mathrm{G}$ & $\mathrm{H}$ & $\mathrm{I}$ \\
\hline 9.Middle-Prox. Surf & 3 & 2 & 0 & 0 & $\mathrm{~N}$ & 0 & 0 & $*$ & $*$ \\
\hline 10.Middle-Prox. Surf & 3 & 2 & $1-1 ?$ & 0 & $\mathrm{~N}$ & 0 & 0 & $*$ & $*$ \\
\hline Distal Surf & 3 & 3 & 0 & 0 & $\mathrm{~N}$ & 0 & 0 & $*$ & $*$ \\
\hline 11.Distal & 3 & 3 & 0 & 0 & $\mathrm{~N}$ & 0 & 0 & $*$ & $*$ \\
\hline 12.Distal & 3 & 3 & 0 & 0 & $\mathrm{~N}$ & 0 & 0 & $*$ & $*$ \\
\hline 13.Distal & 3 & 3 & $2-2 ?$ & 0 & $\mathrm{~N}$ & 0 & 0 & $*$ & $*$ \\
\hline \multicolumn{10}{|l|}{ Pedal } \\
\hline 1.Proximal?-Distal Surf & 3 & 3 & $2-3$ & 0 & $\mathrm{~N}$ & 0 & 0 & $*$ & $*$ \\
\hline 2.Proximal?-Prox. Surf & 3 & 2 & 0 & 0 & $\mathrm{~N}$ & 0 & 0 & $*$ & $*$ \\
\hline Distal Surf & 3 & 2 & $1-2 ?$ & 0 & $\mathrm{~N}$ & 0 & 0 & $*$ & $*$ \\
\hline 3.Proximal-Dist Surf & 3 & 2 & $2-2$ & 0 & $\mathrm{~N}$ & 0 & 0 & $*$ & $*$ \\
\hline 4.Proximal-Dist Surf & 3 & 3 & 0 & 0 & $\mathrm{~N}$ & 0 & 0 & $*$ & $*$ \\
\hline 5.Proximal-Prox. Surf & 3 & 1 & 0 & 0 & $\mathrm{~N}$ & 0 & 0 & $*$ & $*$ \\
\hline 6.Proximal first-Prox. Surf & 3 & 0 & $\mathrm{n} / \mathrm{a}$ & 0 & $\mathrm{~N}$ & 0 & 0 & $*$ & $*$ \\
\hline Distal Surf & 2 & 1 & $2-1$ & 0 & $\mathrm{~N}$ & 0 & 0 & $*$ & $*$ \\
\hline \multicolumn{10}{|l|}{ BURIAL \# 9} \\
\hline \multicolumn{10}{|l|}{ VERTEBRA } \\
\hline Atlas-sup facet & 3 & 3 & 0 & 0 & $\mathrm{~N}$ & 0 & 0 & & \\
\hline inf facet & 2 & 2 & 0 & 0 & $\mathrm{~N}$ & 0 & 0 & & \\
\hline Axis-odontoid & 3 & 3 & 0 & 0 & $\mathrm{~N}$ & 0 & 0 & & \\
\hline sup facet & 3 & 2 & 0 & 0 & $\mathrm{~N}$ & 0 & 0 & & \\
\hline sup facet & 2 & 2 & 0 & 0 & $\mathrm{~N}$ & 0 & 0 & & \\
\hline Cervical-centrum & 3 & 3 & $2-3$ & 0 & & 0 & 2 & $\mathrm{~N}$ & $\mathrm{~N}$ \\
\hline sup facet & 3 & 3 & $2-3$ & $2-1$ & $\mathrm{Y}$ & $2-1$ & 2 & & \\
\hline sup facet & 3 & 3 & $2-3$ & 0 & $\mathrm{Y}$ & $2-1$ & 2 & & \\
\hline inf facet & 3 & 2 & 0 & 0 & $\mathrm{~N}$ & 0 & 2 & & \\
\hline inf facet & 3 & 2 & $2-2$ & $3-2$ & $\mathrm{Y}$ & $2-2$ & 2 & & \\
\hline Cervical-centrum & 3 & 3 & $1-3$ & 0 & & 0 & 0 & $\mathrm{~N}$ & $\mathrm{Y}$ (sup/inf) \\
\hline Cervical-centrum & 2 & 2 & $1-2$ & 0 & & 0 & 0 & $\mathrm{~N}$ & $\mathrm{Y}(\mathrm{sup})$ \\
\hline sup facet & 2 & 2 & $1-1$ & 0 & $\mathrm{~N}$ & 0 & 0 & & \\
\hline inf facet & 3 & 3 & $1-1$ & 0 & $\mathrm{~N}$ & 0 & 0 & & \\
\hline Cervical-facet & 3 & 3 & $1-3$ & 0 & $\mathrm{~N}$ & 0 & 0 & & \\
\hline Thoracic-centrum & 3 & 2 & $1-2$ & 0 & & 0 & 0 & $\mathrm{~N}$ & Y(inf) \\
\hline sup facet & 3 & 3 & 0 & 0 & $\mathrm{~N}$ & 0 & 0 & & \\
\hline sup facet & 3 & 3 & 0 & 0 & $\mathrm{~N}$ & 0 & 0 & & \\
\hline inf facet & 3 & 2 & $1-1$ & 0 & $\mathrm{~N}$ & 0 & 0 & & \\
\hline Thoracic-centrum & 3 & 2 & $2-2$ & 0 & & 0 & 0 & $\mathrm{~N}$ & $\mathrm{~N}$ \\
\hline sup facet & 3 & 2 & $1-2$ & $2-1$ & $\mathrm{~N}$ & 0 & 0 & & \\
\hline inf facet & 3 & 3 & $1-2 / 3$ & 0 & $\mathrm{~N}$ & 0 & 0 & & \\
\hline inf facet & 3 & 3 & $1-2 / 3$ & 0 & $\mathrm{~N}$ & 0 & 0 & & \\
\hline Thoracic facet & 2 & 2 & 0 & 0 & $\mathrm{~N}$ & 0 & 0 & & \\
\hline Thoracic facet & 3 & 2 & $1-2$ & 0 & $\mathrm{~N}$ & 0 & 0 & & \\
\hline Thoracic facet & 3 & 2 & $1-2$ & $3-1$ & $\mathrm{Y} ?$ & 0 & $1-2$ & & \\
\hline Thoracic facet & 3 & 2 & $2-2$ & $2-2$ & $\mathrm{Y}$ & 0 & 0 & & \\
\hline Thoracic facet & 3 & 2 & $2-2$ & $1-1$ & $\mathrm{Y}$ & 0 & $1-2$ & & \\
\hline Thoracic facet & 3 & 2 & $2-2$ & 0 & $\mathrm{~N}$ & 0 & 0 & & \\
\hline Thoracic facet & 3 & 2 & $1-2$ & 0 & $\mathrm{~N}$ & 0 & 0 & & \\
\hline Thoracic facet & 3 & 3 & $1-1$ & 0 & $\mathrm{~N}$ & 0 & 0 & & \\
\hline Thoracic facet & 2 & 1 & 0 & 0 & $\mathrm{~N}$ & 0 & 0 & & \\
\hline Lumbar-sup facet & 3 & 2 & $1-2$ & 0 & $\mathrm{~N}$ & 0 & 0 & & \\
\hline inf facet & 3 & 2 & $2-2$ & 0 & $\mathrm{~N}$ & 0 & 0 & & \\
\hline
\end{tabular}


Table C.12, continued

\begin{tabular}{l|c|c|c|c|c|c|c|c|c}
\hline \multicolumn{1}{c|}{ ATTRIBUTE } & $\mathrm{A}$ & $\mathrm{B}$ & $\mathrm{C}$ & $\mathrm{D}$ & $\mathrm{E}$ & $\mathrm{F}$ & $\mathrm{G}$ & $\mathrm{H}$ & $\mathrm{I}$ \\
\hline inf facet & 2 & 1 & $1-1$ & $3-2$ & $\mathrm{~N}$ & 0 & 2 & & \\
\hline Lumbar-centrum & 3 & 2 & $2-2$ & 0 & & 0 & 0 & $\mathrm{~N}$ & $\mathrm{Y}(\mathrm{inf})$ \\
\hline sup facet & 3 & 3 & 0 & 0 & $\mathrm{~N}$ & 0 & 0 & & \\
\hline inf facet & 3 & 3 & $1-3$ & 0 & $\mathrm{~N}$ & 0 & 0 & & \\
\hline inf facet & 3 & 2 & $1 / 2-2$ & 0 & $\mathrm{~N}$ & 0 & 0 & & \\
\hline Lumbar-centrum & 2 & 2 & $2-2$ & 0 & & 0 & 0 & $\mathrm{~N}$ & $\mathrm{Y}(\mathrm{inf})$ \\
\hline unidentified facet & 3 & 3 & $1-1$ & 0 & $\mathrm{~N}$ & 0 & 0 & & \\
\hline unidentified facet & 3 & 3 & $1-3$ & 0 & $\mathrm{~N}$ & 0 & 0 & & \\
\hline unidentified facet & 2 & 2 & 0 & 0 & $\mathrm{~N}$ & 0 & 0 & & \\
\hline unidentified facet & 2 & 2 & $1-1$ & 0 & $\mathrm{~N}$ & 0 & 0 & & \\
\hline unidentified facet & 3 & 3 & $1-1$ & 0 & $\mathrm{~N}$ & 0 & 0 & & \\
\hline unidentified facet & 3 & 3 & $2-3$ & 0 & $\mathrm{~N}$ & 0 & 0 & & \\
\hline unidentified facet & 3 & 3 & $1-1$ & 0 & $\mathrm{~N}$ & 0 & 0 & & \\
\hline unidentified centrum & 3 & 3 & $1-1$ & 0 & $\mathrm{~N}$ & 0 & 0 & & \\
\hline unidentified centrum & 1 & 1 & 0 & 0 & & 0 & 0 & $\mathrm{~N}$ & $\mathrm{~N}$ \\
\hline
\end{tabular}

\section{ELEMENT}

Occipital Condyle-R

TMJ-R

TMJ-L

Mandibular Condyle-R

Mandibular Condyle-L

Clavicle-Sternal-L

Glenoid Fossa-L

Humeral Head-unsided

Humerus-Trochlea/Capitulum-u

Radius-Proximal-R

Radius-Proximal-L

Radius-Distal-R

Ulna-Distal-unsided

Lunate-L-radial facet

\begin{tabular}{l|l}
3 & \\
3 & \\
\hline 3 & \\
\hline 2 & \\
\hline 1 & \\
\hline 2 & \\
\hline 2 & \\
\hline 1 & \\
\hline 2 & \\
\hline 1 & \\
\hline 3 & \\
\hline 2 & \\
\hline
\end{tabular}

\begin{tabular}{l|l}
2 & 0 \\
\hline
\end{tabular}

\begin{tabular}{|c|c|c|c|c|c}
\hline 0 & $\mathrm{~N}$ & 0 & 0 & $*$ & $*$ \\
\hline $1-1$ & $\mathrm{~N}$ & 0 & 0 & $*$ & $*$ \\
\hline 0 & $\mathrm{~N}$ & 0 & 0 & $*$ & $*$
\end{tabular}

Lunate-L-scaphoid facet

Lunate-L-capitate facet

Lunate-L-triquetral facet

Lunate-L-hamate facet

Triquetral-R-pisiform facet

Triquetral-R-lunate facet

Triquetral R-hamate facet

Capitate-L-scaphoid facet

Capitate-L-MCIII facet

Capitate-L-trapezoid facet

Capitate-L-lunate facet

Capitate-L-hamate facet

Metacarpal I-Distal-L

Metacarpal III-Proximal-L

2

3

3

$\mid$

\begin{tabular}{c|c|c|}
0 & 0 & \\
0 & $1-1$ & \\
0 & 0 & $N$ \\
\hline & 0 & $N$
\end{tabular}

Metacarpal III-Distal-L

Metacarpal V-Proximal-L

Acetabulum-unsided

Femoral Condyles-L

Tibia-Proximal-unsided

Patella-L

3

\begin{tabular}{l|l}
0 & $\mathrm{n} / \mathrm{a}$
\end{tabular}

\begin{tabular}{l|l}
1 & 0 \\
\hline
\end{tabular}

\begin{tabular}{c|c}
2 & 0 \\
0 & n/a
\end{tabular}

\begin{tabular}{l|l}
0 & $\mathrm{n} / \mathrm{a}$ \\
\hline 1 & $1-1$
\end{tabular}

\begin{tabular}{l|l}
1 & $1-1$ \\
\hline
\end{tabular}

\begin{tabular}{c|c}
2 & $1-3$ \\
2 & 0 \\
\hline
\end{tabular}

\begin{tabular}{l}
0 \\
0 \\
0 \\
\hline
\end{tabular}

\begin{tabular}{l|l}
$\mathrm{N}$ & \\
$\mathrm{N}$ & \\
\hline
\end{tabular}

\begin{tabular}{l|l|l|}
0 & 0 & \\
\hline 0 & 0 & \\
\hline 0 & 0 & \\
\hline & 0 &
\end{tabular}

\begin{tabular}{c|c}
\hline$*$ & $*$ \\
\hline$*$ & $*$ \\
\hline$*$ & $*$ \\
\hline$*$ &
\end{tabular}


Table C.12, continued

\begin{tabular}{|c|c|c|c|c|c|c|c|c|c|}
\hline ATTRIBUTE & $\mathrm{A}$ & $\mathrm{B}$ & $\mathrm{C}$ & $\mathrm{D}$ & $\mathrm{E}$ & $\mathrm{F}$ & $\mathrm{G}$ & $\mathrm{H}$ & $\mathrm{I}$ \\
\hline \multicolumn{10}{|l|}{ PHALANGES } \\
\hline \multicolumn{10}{|l|}{ Manual } \\
\hline 1.Proximal-Prox. Surf & 2 & 2 & 0 & 0 & $\mathrm{~N}$ & 0 & 0 & $*$ & $*$ \\
\hline Distal Surf & 3 & 1 & 0 & 0 & $\mathrm{~N}$ & 0 & 0 & $*$ & $*$ \\
\hline 2.Proximal-Prox. Surf & 2 & 2 & 0 & 0 & $\mathrm{~N}$ & 0 & 0 & $*$ & $*$ \\
\hline Distal Surf & 3 & 3 & 0 & 0 & $\mathrm{~N}$ & 0 & 0 & $*$ & $*$ \\
\hline 3.Proximal-Prox. Surf & 3 & 2 & 0 & 0 & $\mathrm{~N}$ & 0 & 0 & $*$ & $*$ \\
\hline 4.Middle-Prox. Surf & 3 & 2 & 0 & 0 & $\mathrm{~N}$ & 0 & 0 & $*$ & $*$ \\
\hline Distal Surf & 3 & 3 & 0 & 0 & $\mathrm{~N}$ & 0 & 0 & $*$ & $*$ \\
\hline 5.Distal-Prox. Surf & 3 & 3 & 0 & 0 & $\mathrm{~N}$ & 0 & 0 & $*$ & $*$ \\
\hline 6.Distal-Prox. Surf & 3 & 3 & 0 & 0 & $\mathrm{~N}$ & 0 & 0 & $*$ & $*$ \\
\hline \multicolumn{10}{|l|}{ BURIAL \# 10} \\
\hline \multicolumn{10}{|l|}{ VERTEBRA } \\
\hline Atlas-sup facet & 3 & 3 & $1-2 / 3$ & 0 & $\mathrm{~N}$ & $2-1$ & 0 & & \\
\hline sup facet & 3 & 3 & $1-2 / 3$ & 0 & $\mathrm{~N}$ & 0 & 0 & & \\
\hline inf facet & 3 & 3 & $1 ?$ & 0 & $\mathrm{~N}$ & 0 & 0 & & \\
\hline inf facet & 3 & 2 & $1 ?$ & 0 & $\mathrm{~N}$ & 0 & 0 & & \\
\hline Axis-sup facet & 3 & 3 & $1-3$ & 0 & $\mathrm{~N}$ & 0 & 0 & & \\
\hline sup facet & 3 & 3 & $1-3$ & 0 & $\mathrm{~N}$ & 0 & 0 & & \\
\hline inf facet & 2 & 2 & $1-2$ & 0 & $\mathrm{~N}$ & 0 & 0 & & \\
\hline centrum & 3 & 3 & $2-3$ & 0 & & 0 & 2 & $\mathrm{Y}$ & $\mathrm{Y}$ (inf) \\
\hline Cervical-sup facet & 2 & 2 & 0 & 0 & $\mathrm{~N}$ & 0 & 0 & & \\
\hline inf facet & 2 & 2 & $2-2$ & 0 & $\mathrm{Y}$ & 0 & 0 & & \\
\hline Cervical-sup facet & 3 & 3 & 0 & 0 & $\mathrm{~N}$ & 0 & 0 & & \\
\hline inf facet & 3 & 3 & $1-3$ & 0 & $\mathrm{~N}$ & 0 & 0 & & \\
\hline Cervical-sup facet & 3 & 3 & $2 / 3-3$ & $2-1$ & $\mathrm{Y}$ & $2-1$ & 0 & & \\
\hline inf facet & 2 & 2 & $2-2$ & 0 & $\mathrm{~N}$ & 0 & 2 & & \\
\hline Cervical-sup facet & 3 & 2 & $2-2$ & 0 & $\mathrm{~N}$ & $2-1$ & 0 & & \\
\hline inf facet & 3 & 3 & $3-3$ & $2-2$ & $\mathrm{Y}$ & $2-1$ & 0 & & \\
\hline Cervical facet & 3 & 3 & $3-3$ & $1-2$ & $\mathrm{~N}$ & $2-2$ & 0 & & \\
\hline Cervical-sup facet & 3 & 3 & $2-3$ & 0 & $\mathrm{~N}$ & $2-1$ & 0 & & \\
\hline inf facet & 3 & 3 & $2-3$ & 0 & $\mathrm{~N}$ & 0 & 0 & & \\
\hline Cervical-sup facet & 3 & 3 & $2-3$ & 0 & $\mathrm{~N}$ & 0 & 0 & & \\
\hline inf facet & 3 & 3 & $2 / 3-3$ & 0 & $\mathrm{~N}$ & $2-1$ & 0 & & \\
\hline Cervical/Upper thoracic-centrum & 3 & 3 & $3-3$ & $3-3$ & & 0 & 2 & $\mathrm{Y}$ & $\mathrm{Y}$ (inf) \\
\hline sup facet & 3 & 3 & $2-3$ & 0 & $\mathrm{~N}$ & 0 & 0 & & \\
\hline inf facet & 3 & 3 & $2-3$ & 0 & $\mathrm{~N}$ & 0 & 0 & & \\
\hline Cervical/Upper thoracic-centrum & 3 & 3 & $3-3$ & $3-3$ & $\mathrm{Y}$ & 0 & 2 & $\mathrm{Y}$ & $\mathrm{Y}$ (sup/inf) \\
\hline sup facet & 3 & 3 & $2-3$ & $1-1$ & $\mathrm{~N}$ & 0 & 0 & & \\
\hline inf facet & 3 & 3 & $1 / 2-3$ & 0 & $\mathrm{~N}$ & 0 & 0 & & \\
\hline Cervical/Upper thoracic-centrum & 3 & 3 & $3-3$ & $3-3$ & & 0 & 2 & $\mathrm{Y}$ & $\mathrm{N}$ \\
\hline Cervical/Upper thoracic-centrum & 3 & 3 & $3-3$ & $3-3$ & & $2-1$ & 2 & $\mathrm{Y}$ & $\mathrm{N}$ \\
\hline Cervical/Upper thoracic-centrum & 2 & 2 & $3-2$ & $3-2$ & & $2-1$ & 2 & $\mathrm{Y}$ & $\mathrm{N}$ \\
\hline Thoracic facet & 3 & 3 & $2-3$ & $2-2$ & $\mathrm{~N}$ & 0 & 2 & & \\
\hline Thoracic facet & 3 & 3 & $2-3$ & $3-1$ & $\mathrm{Y}$ & $2-3$ & 2 & & \\
\hline Thoracic facet-sup & 3 & 3 & $3-3$ & $3-2$ & $\mathrm{Y}$ & 0 & 2 & & \\
\hline Thoracic facet & 3 & 3 & $3-3$ & $3-2$ & $\mathrm{Y}$ & $2-2$ & 2 & & \\
\hline Thoracic facet & 3 & 2 & 0 & 0 & $\mathrm{~N}$ & 0 & 0 & & \\
\hline Thoracic facet & 3 & 3 & $3-3$ & $3-3$ & $\mathrm{Y}$ & $2-2$ & 2 & & \\
\hline Thoracic facet-inf & 3 & 3 & $3-3$ & $2-2$ & $\mathrm{~N}$ & 0 & 2 & & \\
\hline Thoracic facet & 2 & 2 & $1-2$ & 0 & $\mathrm{~N}$ & 0 & 0 & & \\
\hline
\end{tabular}


Table C.12, continued

\begin{tabular}{|c|c|c|c|c|c|c|c|c|c|}
\hline ATTRIBUTE & $\mathrm{A}$ & $\mathrm{B}$ & $\mathrm{C}$ & $\mathrm{D}$ & $\mathrm{E}$ & $\mathrm{F}$ & $\mathrm{G}$ & $\mathrm{H}$ & $\mathrm{I}$ \\
\hline Thoracic facet-sup facet & 2 & 2 & $3-2$ & $3-2$ & $\mathrm{~N}$ & $2-2$ & 2 & & \\
\hline inf facet & 3 & 3 & $3-3$ & $2-1$ & $\mathrm{~N}$ & $2-2$ & 1 & & \\
\hline Thoracic facet-sup facet & 3 & 2 & $3-2$ & $3-2$ & $\mathrm{~N}$ & $2-2$ & 2 & & \\
\hline inf facet & 3 & 3 & $2 / 3-3$ & $2-1$ & $\mathrm{~N}$ & $2-2$ & 0 & & \\
\hline Thoracic facet & 3 & 2 & $2-2$ & 0 & $\mathrm{~N}$ & 0 & 0 & & \\
\hline Thoracic facet & 2 & 2 & $3-2$ & $2-1$ & $\mathrm{~N}$ & $2-1$ & 2 & & \\
\hline Thoracic facet & 3 & 3 & $3-3$ & $2-2$ & $\mathrm{Y}$ & $2-2$ & 2 & & \\
\hline Thoracic facet & 2 & 2 & $2-2$ & 0 & $\mathrm{~N}$ & 0 & 0 & & \\
\hline Thoracic facet & 2 & 2 & 0 & 0 & $\mathrm{~N}$ & 0 & 0 & & \\
\hline Thoracic facet-sup & 3 & 3 & $3-3$ & $3-3$ & $\mathrm{Y}$ & 0 & 2 & & \\
\hline inf facet & 2 & 0 & $\mathrm{n} / \mathrm{a}$ & $2-1$ & $\mathrm{~N}$ & $2-1$ & 2 & & \\
\hline Thoracic facet & 2 & 1 & $2-1$ & 0 & $\mathrm{~N}$ & 0 & 0 & & \\
\hline Thoracic facet-inf & 1 & 1 & $2-1$ & 0 & $\mathrm{~N}$ & $2-1$ & 2 & & \\
\hline Lumbar-sup facet & 2 & 2 & $2-2$ & 0 & $\mathrm{~N}$ & 0 & 0 & & \\
\hline inf facet & 3 & 3 & $3-3$ & $3-3$ & $\mathrm{Y}$ & $2-1$ & 2 & & \\
\hline Lumbar-sup facet & 3 & 2 & $2-2$ & 0 & $\mathrm{~N}$ & 0 & 0 & & \\
\hline inf facet & 3 & 3 & $3-3$ & 0 & $\mathrm{Y}$ & 0 & $\mathrm{n} / \mathrm{a}$ & & \\
\hline Lumbar-sup facet & 3 & 3 & $3-3$ & $3-2$ & $Y ?$ & $2-1$ & 2 & & \\
\hline facet (thoracic?) & 3 & 3 & $3-3$ & $2-1$ & $\mathrm{~N}$ & $2-2$ & 2 & & \\
\hline facet (thoracic?) & 2 & 2 & $2-2$ & $2-2$ & $\mathrm{~N}$ & $2-2$ & 1 & & \\
\hline facet (thoracic?) & 3 & 3 & $2-3$ & 0 & $\mathrm{~N}$ & 0 & 0 & & \\
\hline facet (lumbar?) & 3 & 3 & $2-3$ & $1-3$ & $\mathrm{~N}$ & 0 & 0 & & \\
\hline facet (lumbar?) & 2 & 1 & $1-1$ & 0 & $\mathrm{~N}$ & 0 & 0 & & \\
\hline facet-unidentified & 3 & 3 & $2-3$ & 0 & $\mathrm{~N}$ & 0 & 0 & & \\
\hline facet-unidentified & 3 & 3 & $3-3$ & $3-2$ & $\mathrm{~N}$ & $2-1$ & 2 & & \\
\hline \multicolumn{10}{|l|}{ ELEMENT } \\
\hline Occipital Condyle-R & 3 & 3 & $2-1$ & 0 & $\mathrm{~N}$ & $2-1$ & 0 & $*$ & $*$ \\
\hline TMJ-R & 3 & 3 & $2-3$ & $3-1$ & $\mathrm{Y}$ & 0 & 1 & $*$ & $*$ \\
\hline TMJ-L & 3 & 3 & $2-3$ & $3-2$ & $\mathrm{Y}$ & 0 & 1 & $*$ & * \\
\hline Clavicle-Acromial-L & 3 & 3 & $3-3$ & $2-3$ & $\mathrm{~N}$ & 0 & 2 & $*$ & $*$ \\
\hline Glenoid Fossa-L & 2 & 2 & $2 / 3-2$ & $2-2$ & $\mathrm{~N}$ & $2-1$ & 0 & $*$ & $*$ \\
\hline Humeral Head-R & 2 & 1 & $2-2$ & 1 & $\mathrm{~N}$ & 0 & 2 & $*$ & $*$ \\
\hline Humeral Head-L & 2 & 0 & $\mathrm{n} / \mathrm{a}$ & 0 & $\mathrm{~N}$ & 2 & 2 & $*$ & $*$ \\
\hline Humerus-Trochlea/Capitulum-R & 3 & 1 & 1 & $1-1$ & $\mathrm{~N}$ & 0 & 1 & $*$ & $*$ \\
\hline Humerus-Trochlea/Capitulum-L & 3 & 1 & $2-1$ & 0 & $\mathrm{~N}$ & 0 & 0 & $*$ & $*$ \\
\hline Radius-Proximal-R & 2 & 2 & $1-1$ & $3-1$ & $\mathrm{~N}$ & 0 & 0 & $*$ & $*$ \\
\hline Radius-Proximal-L & 3 & 2 & $1-1$ & $3-2$ & $\mathrm{~N}$ & 0 & 0 & $*$ & $*$ \\
\hline Ulna-Proximal-R & 2 & 2 & $1-1$ & $2-1$ & $\mathrm{~N}$ & 0 & 1 & $*$ & $*$ \\
\hline Ulna-Proximal-L & 3 & 2 & $2 / 3-2$ & $3-1$ & $\mathrm{~N}$ & 0 & 0 & $*$ & $*$ \\
\hline Scaphoid-L-radial facet & & & & & & $1-2$ & & $*$ & $*$ \\
\hline Scaphoid-L-general & 3 & 3 & $2-2$ & 0 & $\mathrm{~N}$ & 0 & 0 & $*$ & $*$ \\
\hline Scaphoid-L-trapezium facet & & & & & & $1-1$ & & $*$ & $*$ \\
\hline Lunate-R-general & 2 & 1 & 0 & $1-2$ & $\mathrm{~N}$ & 0 & 0 & $*$ & $*$ \\
\hline Lunate-L-general & 3 & 3 & $2-3$ & $1-2$ & $\mathrm{~N}$ & 0 & 0 & $*$ & $*$ \\
\hline Capitate-R-general & 3 & 3 & $1-3$ & $1-2$ & $\mathrm{~N}$ & 0 & 0 & $*$ & $*$ \\
\hline Capitate-R-lunate facet & & & & & & $1-1$ & & $*$ & $*$ \\
\hline Capitate-L-general & 3 & 2 & $1-1$ & $1-1$ & $\mathrm{~N}$ & 0 & 0 & $*$ & $*$ \\
\hline Trapezoid-L-general & 3 & 3 & $2-3$ & 0 & $\mathrm{~N}$ & 0 & 0 & $*$ & $*$ \\
\hline Trapezium-R-MCI facet & 3 & 2 & $2-2$ & 0 & $\mathrm{~N}$ & $1-2$ & 0 & $*$ & $*$ \\
\hline Trapezium-R-scaphoid facet & 3 & 1 & $1-1$ & 0 & $\mathrm{~N}$ & $1-2$ & 0 & $*$ & $*$ \\
\hline Trapezium-R-trapezoid facet & 3 & 2 & $1-1$ & 0 & $\mathrm{~N}$ & 0 & 0 & $*$ & * \\
\hline
\end{tabular}


Table C.12, continued

\begin{tabular}{|c|c|c|c|c|c|c|c|c|c|}
\hline ATTRIBUTE & $\mathrm{A}$ & $\mathrm{B}$ & $\mathrm{C}$ & $\mathrm{D}$ & $\mathrm{E}$ & $\mathrm{F}$ & $\mathrm{G}$ & $\mathrm{H}$ & $\mathrm{I}$ \\
\hline Hamate-R-general & 3 & 3 & $1-2$ & 0 & $\mathrm{~N}$ & 0 & 0 & $*$ & $*$ \\
\hline Hamate-R-lunate facet & & & & & & $1-1$ & & $*$ & $*$ \\
\hline Hamate-L-general & 3 & 2 & $1-2$ & $1-1$ & $\mathrm{~N}$ & 0 & 0 & $*$ & $*$ \\
\hline Metacarpal II-Proximal-L & 3 & 3 & $1-1$ & $1-1$ & $\mathrm{~N}$ & 0 & 0 & $*$ & $*$ \\
\hline Metacarpal III-Proximal-L & 3 & 3 & $1-1$ & 0 & $\mathrm{~N}$ & 0 & 0 & $*$ & $*$ \\
\hline Acetabulum-unsided & 1 & 1 & $1-1$ & 0 & $\mathrm{~N}$ & 0 & 2 & $*$ & $*$ \\
\hline Lat Cun-L-MTIII facet & 2 & 2 & 0 & 0 & $\mathrm{~N}$ & 0 & 0 & $*$ & $*$ \\
\hline Lat Cun-L-navicular facet & 3 & 2 & $1-1$ & $1-2$ & $\mathrm{~N}$ & 0 & 0 & $*$ & $*$ \\
\hline \multicolumn{10}{|l|}{ PHALANGES } \\
\hline \multicolumn{10}{|l|}{ Manual } \\
\hline 1.Middle-Dist Surf & 3 & 3 & $1-2$ & 0 & $\mathrm{~N}$ & 0 & 0 & $*$ & $*$ \\
\hline \multicolumn{10}{|l|}{ BURIAL \# 14} \\
\hline \multicolumn{10}{|l|}{ VERTEBRA } \\
\hline Atlas-sup facet & 3 & 3 & 0 & 0 & $\mathrm{~N}$ & 0 & 0 & & \\
\hline Axis-centrum & 3 & 2 & $1-1$ & 0 & & 0 & 0 & $\mathrm{~N}$ & $\mathrm{~N}$ \\
\hline sup facet & 3 & 3 & $1-3$ & 0 & $\mathrm{~N}$ & 0 & 0 & & \\
\hline sup facet & 3 & 2 & 0 & 0 & $\mathrm{~N}$ & 0 & 0 & & \\
\hline inf facet & 3 & 2 & 0 & 0 & $\mathrm{~N}$ & 0 & 0 & & \\
\hline Lumbar-sup facet & 2 & 1 & 0 & 0 & $\mathrm{~N}$ & 0 & 0 & & \\
\hline sup facet & 3 & 1 & 0 & 0 & $\mathrm{~N}$ & 0 & 0 & & \\
\hline inf facet & 3 & 2 & 0 & 0 & $\mathrm{~N}$ & 0 & 0 & & \\
\hline inf facet & 3 & 3 & 0 & 0 & $\mathrm{~N}$ & 0 & 0 & & \\
\hline Thoracic or Lumbar centrum & 2 & 0 & $\mathrm{n} / \mathrm{a}$ & 0 & & 0 & 0 & $\mathrm{~N}$ & $\mathrm{~N}$ \\
\hline Thoracic or Lumbar centrum & 2 & 2 & 0 & 0 & & 0 & 0 & $\mathrm{~N}$ & $\mathrm{~N}$ \\
\hline \multicolumn{10}{|l|}{ ELEMENT } \\
\hline Humeral Head-L & 2 & 0 & $\mathrm{n} / \mathrm{a}$ & 0 & $\mathrm{~N}$ & 0 & 0 & $*$ & $*$ \\
\hline Humerus-Trochlea/Capitulum-L & 1 & 0 & $\mathrm{n} / \mathrm{a}$ & 0 & $\mathrm{~N}$ & 0 & 0 & $*$ & $*$ \\
\hline Ulna-Proximal-R & 2 & 1 & 0 & 0 & $\mathrm{~N}$ & 0 & 0 & $*$ & $*$ \\
\hline Ulna-Proximal-L & 3 & 1 & 0 & 0 & $\mathrm{~N}$ & 0 & 0 & $*$ & $*$ \\
\hline Scaphoid-R-general & 3 & 3 & 0 & 0 & $\mathrm{~N}$ & 0 & 0 & $*$ & $*$ \\
\hline Femoral Head-R & 2 & 0 & $\mathrm{n} / \mathrm{a}$ & 0 & $\mathrm{~N}$ & 0 & 0 & $*$ & $*$ \\
\hline Femoral Head-L & 3 & 0 & $\mathrm{n} / \mathrm{a}$ & 0 & $\mathrm{~N}$ & 0 & 0 & $*$ & $*$ \\
\hline Talus-R-post. Calc. facet & 3 & 2 & 0 & 0 & $\mathrm{~N}$ & 0 & 0 & $*$ & $*$ \\
\hline \multicolumn{10}{|l|}{ PHALANGES } \\
\hline \multicolumn{10}{|l|}{ Manual } \\
\hline 1.Middle-Dist. Surf & 3 & 2 & 0 & 0 & $\mathrm{~N}$ & 0 & 0 & $*$ & $*$ \\
\hline 2.Middle-Prox. Surf & 3 & 1 & 0 & 0 & $\mathrm{~N}$ & 0 & 0 & $*$ & $*$ \\
\hline \multicolumn{10}{|l|}{ BURIAL \# 15} \\
\hline \multicolumn{10}{|l|}{ VERTEBRA } \\
\hline Atlas-sup facet & 3 & 3 & 0 & 0 & $\mathrm{~N}$ & 0 & 0 & & \\
\hline sup facet & 3 & 3 & 0 & 0 & $\mathrm{~N}$ & 0 & 0 & & \\
\hline inf facet & 3 & 3 & 0 & 0 & $\mathrm{~N}$ & 0 & 0 & & \\
\hline inf facet & 3 & 3 & 0 & 0 & $\mathrm{~N}$ & 0 & 0 & & \\
\hline Axis-sup facet & 3 & 3 & 0 & 0 & $\mathrm{~N}$ & 0 & 0 & & \\
\hline sup facet & 2 & 2 & 0 & 0 & $\mathrm{~N}$ & 0 & 0 & & \\
\hline inf facet & 3 & 2 & 0 & 0 & $\mathrm{~N}$ & 0 & 0 & & \\
\hline inf facet & 3 & 2 & 0 & 0 & $\mathrm{~N}$ & 0 & 0 & & \\
\hline centrum & 3 & 3 & 0 & 0 & & 0 & 0 & $\mathrm{~N}$ & $\mathrm{~N}$ \\
\hline Cervical-centrum & 3 & 2 & $1 / 2-2$ & 0 & & 0 & 0 & $\mathrm{~N}$ & $\mathrm{~N}$ \\
\hline sup facet & 3 & 3 & $3-1$ & 0 & $\mathrm{~N}$ & 0 & 0 & & \\
\hline sup facet & 3 & 3 & 0 & 0 & $\mathrm{~N}$ & 0 & 0 & & \\
\hline
\end{tabular}


Table C.12, continued

\begin{tabular}{|c|c|c|c|c|c|c|c|c|c|}
\hline ATTRIBUTE & $\mathrm{A}$ & $\mathrm{B}$ & $\mathrm{C}$ & $\mathrm{D}$ & $\mathrm{E}$ & $\mathrm{F}$ & $\mathrm{G}$ & $\mathrm{H}$ & $\mathrm{I}$ \\
\hline inf facet & 3 & 3 & 0 & 0 & $\mathrm{~N}$ & 0 & 0 & & \\
\hline inf facet & 3 & 3 & 0 & 0 & $\mathrm{~N}$ & 0 & 0 & & \\
\hline Cervical-centrum & 3 & 3 & 0 & 0 & & 0 & 0 & $\mathrm{~N}$ & $\mathrm{~N}$ \\
\hline sup facet & 3 & 3 & 0 & 0 & $\mathrm{~N}$ & 0 & 0 & & \\
\hline inf facet & 3 & 3 & 0 & 0 & $\mathrm{~N}$ & 0 & 0 & & \\
\hline inf facet & 3 & 3 & 0 & 0 & $\mathrm{~N}$ & 0 & 0 & & \\
\hline Cervical-centrum & 3 & 3 & 0 & 0 & & 0 & 0 & $\mathrm{~N}$ & $\mathrm{~N}$ \\
\hline Cervical-centrum & 1 & 1 & 0 & 0 & & 0 & 0 & $\mathrm{~N}$ & $\mathrm{~N}$ \\
\hline Cervical-facet & 3 & 2 & 0 & 0 & $\mathrm{~N}$ & 0 & 0 & & \\
\hline Cervical-sup facet & 3 & 3 & $1-1$ & 0 & $\mathrm{~N}$ & 0 & 0 & & \\
\hline inf facet & 3 & 3 & $1-1$ & 0 & $\mathrm{~N}$ & 0 & 0 & & \\
\hline Cervical-sup facet & 3 & 3 & 0 & 0 & $\mathrm{~N}$ & 0 & 0 & & \\
\hline inf facet & 2 & 2 & 0 & 0 & $\mathrm{~N}$ & 0 & 0 & & \\
\hline Cervical-sup facet & 3 & 3 & 0 & 0 & $\mathrm{~N}$ & 0 & 0 & & \\
\hline inf facet & 3 & 3 & $2-1$ & 0 & $\mathrm{~N}$ & 0 & 0 & & \\
\hline Cervical-sup facet & 3 & 2 & 0 & 0 & $\mathrm{~N}$ & 0 & 0 & & \\
\hline inf facet & 2 & 1 & 0 & 0 & $\mathrm{~N}$ & 0 & 0 & & \\
\hline Thoracic-centrum & 3 & 3 & 0 & 0 & & 0 & 0 & $\mathrm{~N}$ & $\mathrm{~N}$ \\
\hline Thoracic-centrum & 3 & 2 & 0 & 0 & & 0 & 0 & $\mathrm{~N}$ & $\mathrm{~N}$ \\
\hline Thoracic-centrum & 2 & 1 & 0 & 0 & & 0 & 0 & $\mathrm{~N}$ & $\mathrm{~N}$ \\
\hline Thoracic-centrum & 3 & 1 & 0 & 0 & & 0 & 0 & $\mathrm{~N}$ & $\mathrm{~N}$ \\
\hline Thoracic-centrum & 1 & 1 & 0 & 0 & & 0 & 0 & $\mathrm{~N}$ & $\mathrm{Y}$ (side?) \\
\hline Thoracic-centrum & 2 & 1 & 0 & 0 & & 0 & 0 & $\mathrm{~N}$ & $\mathrm{~N}$ \\
\hline Thoracic-centrum & 2 & 1 & 0 & 0 & & 0 & 0 & $\mathrm{~N}$ & $\mathrm{~N}$ \\
\hline Thoracic-centrum & 1 & 1 & 0 & 0 & & 0 & 0 & $\mathrm{~N}$ & $\mathrm{~N}$ \\
\hline Thoracic-centrum & 2 & 1 & $3-1$ & 0 & & 0 & 0 & $\mathrm{~N}$ & $\mathrm{Y}$ (sup/inf) \\
\hline Thoracic-centrum & 2 & 1 & 0 & 0 & & 0 & 0 & $\mathrm{~N}$ & $\mathrm{~N}$ \\
\hline Thoracic-sup facet & 3 & 3 & 0 & 0 & $\mathrm{~N}$ & 0 & 0 & & \\
\hline Thoracic-sup facet & 3 & 3 & 0 & 0 & $\mathrm{~N}$ & 0 & 0 & & \\
\hline Thoracic-sup facet & 3 & 2 & 0 & 0 & $\mathrm{~N}$ & 0 & 0 & & \\
\hline Thoracic-sup facet & 2 & 2 & 0 & 0 & $\mathrm{~N}$ & 0 & 0 & & \\
\hline Thoracic-sup facet & 3 & 2 & 0 & 0 & $\mathrm{~N}$ & 0 & 0 & & \\
\hline sup facet & 3 & 3 & 1-1 & 0 & $\mathrm{~N}$ & 0 & 0 & & \\
\hline inf facet & 3 & 3 & $1-2$ & 0 & $\mathrm{~N}$ & 0 & 0 & & \\
\hline Thoracic-sup facet & 2 & 2 & 0 & 0 & $\mathrm{~N}$ & 0 & 0 & & \\
\hline inf facet & 2 & 2 & 0 & 0 & $\mathrm{~N}$ & 0 & 0 & & \\
\hline Thoracic-inf facet & 3 & 2 & 0 & 0 & $\mathrm{~N}$ & 0 & 0 & & \\
\hline inf facet & 3 & 2 & $1-1$ & 0 & $\mathrm{~N}$ & 0 & 0 & & \\
\hline Thoracic-sup facet & 3 & 3 & 0 & 0 & $\mathrm{~N}$ & 0 & 0 & & \\
\hline inf facet & 3 & 2 & 0 & 0 & $\mathrm{~N}$ & 0 & 0 & & \\
\hline inf facet & 3 & 3 & 0 & 0 & $\mathrm{~N}$ & 0 & 0 & & \\
\hline Thoracic-sup facet & 1 & 1 & 0 & 0 & $\mathrm{~N}$ & 0 & 0 & & \\
\hline inf facet & 3 & 3 & 0 & 0 & $\mathrm{~N}$ & 0 & 0 & & \\
\hline Thoracic-sup facet & 3 & 3 & 0 & 0 & $\mathrm{~N}$ & 0 & 0 & & \\
\hline Thoracic-sup facet & 3 & 3 & 0 & 0 & $\mathrm{~N}$ & 0 & 0 & & \\
\hline inf facet & 2 & 2 & 0 & 0 & $\mathrm{~N}$ & 0 & 0 & & \\
\hline inf facet & 3 & 2 & 0 & 0 & $\mathrm{~N}$ & 0 & 0 & & \\
\hline Thoracic-inf facet & 3 & 3 & $3-1$ & 0 & $\mathrm{~N}$ & 0 & 0 & & \\
\hline Thoracic-inf facet & 3 & 2 & 0 & 0 & $\mathrm{~N}$ & 0 & 0 & & \\
\hline inf facet & 3 & 3 & $2-1$ & 0 & $\mathrm{~N}$ & 0 & 0 & & \\
\hline Thoracic-sup facet & 3 & 3 & 0 & 0 & $\mathrm{~N}$ & 0 & 0 & & \\
\hline
\end{tabular}


Table C.12, continued

\begin{tabular}{l|c|c|c|c|c|c|c|c|c}
\hline \multicolumn{1}{c|}{ ATTRIBUTE } & $\mathrm{A}$ & $\mathrm{B}$ & $\mathrm{C}$ & $\mathrm{D}$ & $\mathrm{E}$ & $\mathrm{F}$ & $\mathrm{G}$ & $\mathrm{H}$ & $\mathrm{I}$ \\
\hline inf facet & 3 & 3 & $1-2$ & 0 & $\mathrm{~N}$ & 0 & 0 & & \\
\hline Lumbar-centrum & 3 & 1 & 0 & 0 & & 0 & 0 & $\mathrm{~N}$ & $\mathrm{~N}$ \\
\hline sup facet & 3 & 2 & 0 & 0 & $\mathrm{~N}$ & 0 & 0 & & \\
\hline sup facet & 3 & 2 & 0 & 0 & $\mathrm{~N}$ & 0 & 0 & & \\
\hline inf facet & 3 & 2 & 0 & 0 & $\mathrm{~N}$ & 0 & 0 & & \\
\hline Lumbar-centrum & 2 & 2 & 0 & 0 & & 0 & 0 & $\mathrm{~N}$ & $\mathrm{~N}$ \\
\hline Lumbar-sup facet & 3 & 2 & 0 & 0 & $\mathrm{~N}$ & 0 & 0 & & \\
\hline sup facet & 3 & 3 & 0 & 0 & $\mathrm{~N}$ & 0 & 0 & & \\
\hline centrum & 2 & 1 & 0 & 0 & & 0 & 0 & $\mathrm{~N}$ & $\mathrm{~N}$ \\
\hline Lumbar-centrum & 2 & 1 & 0 & 0 & & 0 & 0 & $\mathrm{~N}$ & $\mathrm{~N}$ \\
\hline Lumbar-inf facet & 2 & 2 & 0 & 0 & $\mathrm{~N}$ & 0 & 0 & & \\
\hline inf facet & 3 & 3 & 0 & 0 & $\mathrm{~N}$ & 0 & 0 & & \\
\hline Lumbar-sup facet & 3 & 3 & 0 & 0 & $\mathrm{~N}$ & 0 & 0 & & \\
\hline inf facet & 3 & 3 & 0 & 0 & $\mathrm{~N}$ & 0 & 0 & & \\
\hline inf facet & 2 & 2 & 0 & 0 & $\mathrm{~N}$ & 0 & 0 & & \\
\hline
\end{tabular}

\section{ELEMENT}

Occipital Condyle-R

Occipital Condyle-L

TMJ-R

TMJ-L

Mandibular Condyle-R

Mandibular Condyle-L

Clavicle-Sternal-R

Clavicle-Sternal-L

Clavicle-Acromial-L

Glenoid Fossa-R

Glenoid Fossa-L

Humeral Head-L

Humerus-Trochlea/Capitulum-R

Humerus-Trochlea/Capitulum-L

Radius-Proximal-R

Radius-Proximal-L

Ulna-Proximal-R

Ulna-Proximal-L

Ulna-Distal-R

Scaphoid-L-general

Scaphoid-L-trapezoid facet

Lunate-L-general

Triquetral-R-pisiform facet

Triquetral-R-lunate facet

Triquetral R-hamate facet

Metacarpal I-Distal-unsided

Metacarpal II-Proximal-R

Metacarpal II-Distal-R

Metacarpal II-Proximal-L

Metacarpal III-Proximal-R

Metacarpal III-Distal-R

Metacarpal III-Proximal-L

Metacarpal III-Distal-L

Metacarpal IV_Proximal-R

\begin{tabular}{|c|c|c|c|c|c|c|c|c|}
\hline 3 & 3 & 0 & 0 & $\mathrm{~N}$ & 0 & 0 & $*$ & $*$ \\
\hline 3 & 3 & 0 & 0 & $\mathrm{~N}$ & 0 & 0 & $*$ & $*$ \\
\hline 3 & 2 & 0 & 0 & $\mathrm{~N}$ & 0 & 0 & $*$ & $*$ \\
\hline 3 & 2 & 0 & 0 & $\mathrm{~N}$ & 0 & 0 & $*$ & $*$ \\
\hline 2 & 2 & 0 & 0 & $\mathrm{~N}$ & 0 & 0 & $*$ & $*$ \\
\hline 3 & 3 & 0 & 0 & $\mathrm{~N}$ & 0 & 0 & $*$ & $*$ \\
\hline 3 & 2 & 0 & 0 & $\mathrm{~N}$ & 0 & 0 & $*$ & $*$ \\
\hline 3 & 2 & 0 & 0 & $\mathrm{~N}$ & 0 & 0 & $*$ & $*$ \\
\hline 1 & 1 & 0 & 0 & $\mathrm{~N}$ & 0 & 0 & $*$ & $*$ \\
\hline 3 & 2 & $2-1$ & 0 & $\mathrm{~N}$ & 0 & 0 & $*$ & $*$ \\
\hline 3 & 1 & 0 & 0 & $\mathrm{~N}$ & 0 & 0 & $*$ & $*$ \\
\hline 1 & 1 & 0 & 0 & $\mathrm{~N}$ & 0 & 0 & $*$ & $*$ \\
\hline 3 & 2 & 0 & 0 & $\mathrm{~N}$ & 0 & 0 & $*$ & $*$ \\
\hline 2 & 0 & $\mathrm{n} / \mathrm{a}$ & 0 & $\mathrm{~N}$ & 0 & 0 & $*$ & $*$ \\
\hline 3 & 2 & 0 & 0 & $\mathrm{~N}$ & 0 & 0 & $*$ & $*$ \\
\hline 3 & 2 & 0 & 0 & $\mathrm{~N}$ & 0 & 0 & $*$ & $*$ \\
\hline 3 & 3 & $2-1$ & 0 & $\mathrm{~N}$ & 0 & 0 & $*$ & $*$ \\
\hline 3 & 2 & 0 & 0 & $\mathrm{~N}$ & 0 & 0 & $*$ & $*$ \\
\hline 2 & 1 & 0 & 0 & $\mathrm{~N}$ & 0 & 0 & $*$ & $*$ \\
\hline 3 & 3 & 0 & 0 & $\mathrm{~N}$ & 0 & 0 & $*$ & $*$ \\
\hline & & & & & $2-1$ & & $*$ & $*$ \\
\hline 2 & 2 & 0 & 0 & $\mathrm{~N}$ & 0 & 0 & $*$ & $*$ \\
\hline 2 & 2 & 0 & 0 & $\mathrm{~N}$ & 0 & 0 & $*$ & $*$ \\
\hline 3 & 2 & 0 & 0 & $\mathrm{~N}$ & 0 & 0 & $*$ & $*$ \\
\hline 3 & 2 & 0 & 0 & $\mathrm{~N}$ & 0 & 0 & $*$ & $*$ \\
\hline 2 & 1 & 0 & 0 & $\mathrm{~N}$ & 0 & 0 & $*$ & $*$ \\
\hline 3 & 2 & 0 & 0 & $\mathrm{~N}$ & 0 & 0 & $*$ & $*$ \\
\hline 3 & 3 & 0 & 0 & $\mathrm{~N}$ & 0 & 0 & $*$ & $*$ \\
\hline 2 & 1 & 0 & 0 & $\mathrm{~N}$ & 0 & 0 & $*$ & $*$ \\
\hline 3 & 2 & 0 & 0 & $\mathrm{~N}$ & 0 & 0 & $*$ & $*$ \\
\hline 2 & 2 & 0 & 0 & $\mathrm{~N}$ & 0 & 0 & $*$ & $*$ \\
\hline 2 & 1 & 0 & 0 & $\mathrm{~N}$ & 0 & 0 & $*$ & $*$ \\
\hline 1 & 1 & 0 & 0 & $\mathrm{~N}$ & 0 & 0 & $*$ & $*$ \\
\hline 3 & 2 & 0 & 0 & $\mathrm{~N}$ & 0 & 0 & $*$ & $*$ \\
\hline
\end{tabular}


Table C.12, continued

\begin{tabular}{|c|c|c|c|c|c|c|c|c|c|}
\hline ATTRIBUTE & $\mathrm{A}$ & $\mathrm{B}$ & $\mathrm{C}$ & $\mathrm{D}$ & $\mathrm{E}$ & $\mathrm{F}$ & $\mathrm{G}$ & $\mathrm{H}$ & $\mathrm{I}$ \\
\hline Metacarpal IV-Distal-R & 2 & 1 & 0 & 0 & $\mathrm{~N}$ & 0 & 0 & $*$ & $*$ \\
\hline Acetabulum-R & 1 & 0 & $\mathrm{n} / \mathrm{a}$ & 0 & $\mathrm{~N}$ & 0 & 0 & $*$ & $*$ \\
\hline Acetabulum-L & 2 & 1 & 0 & 0 & $\mathrm{~N}$ & 0 & 0 & $*$ & $*$ \\
\hline Femoral Head-R & 3 & 1 & 0 & 0 & $\mathrm{~N}$ & 0 & 0 & $*$ & $*$ \\
\hline Femoral Condyles-unsided & 1 & 0 & $\mathrm{n} / \mathrm{a}$ & 0 & $\mathrm{~N}$ & 0 & 0 & $*$ & $*$ \\
\hline Tibia-Proximal-L & 2 & 0 & $\mathrm{n} / \mathrm{a}$ & 0 & $\mathrm{~N}$ & 0 & 0 & $*$ & $*$ \\
\hline Patella-R & 3 & 1 & 0 & 0 & $\mathrm{~N}$ & 0 & 0 & $*$ & $*$ \\
\hline Patella-L & 2 & 1 & 0 & 0 & $\mathrm{~N}$ & 0 & 0 & $*$ & $*$ \\
\hline Fibula-Proximal-unsided & 2 & 1 & 0 & 0 & $\mathrm{~N}$ & 0 & 0 & $*$ & $*$ \\
\hline Fibula-Distal-R & 3 & 1 & 0 & 0 & $\mathrm{~N}$ & 0 & 0 & $*$ & $*$ \\
\hline Fibula-Distal-L & 3 & 2 & 0 & 0 & $\mathrm{~N}$ & 0 & 0 & $*$ & $*$ \\
\hline Talus-L-tibial facet & 1 & 1 & 0 & 0 & $\mathrm{~N}$ & 0 & 0 & $*$ & $*$ \\
\hline Talus-L-post. Calc. facet & 2 & 1 & 0 & 0 & $\mathrm{~N}$ & 0 & 0 & $*$ & $*$ \\
\hline Talus-L-navicular facet & 2 & 1 & 0 & 0 & $\mathrm{~N}$ & 0 & 0 & $*$ & $*$ \\
\hline Int Cun-L-MTII facet & 3 & 2 & 0 & 0 & $\mathrm{~N}$ & 0 & 0 & $*$ & $*$ \\
\hline Int Cun-L-navicular facet & 2 & 2 & 0 & 0 & $\mathrm{~N}$ & 0 & 0 & $*$ & $*$ \\
\hline Lat Cun-R-MTIII facet & 3 & 1 & 0 & 0 & $\mathrm{~N}$ & 0 & 0 & $*$ & $*$ \\
\hline Lat Cun-R-navicular facet & 2 & 1 & 0 & 0 & $\mathrm{~N}$ & 0 & 0 & $*$ & $*$ \\
\hline Metatarsal I-Proximal-L & 2 & 0 & $\mathrm{n} / \mathrm{a}$ & 0 & $\mathrm{~N}$ & 0 & 0 & $*$ & $*$ \\
\hline Metatarsal III-Proximal-R & 2 & 0 & $\mathrm{n} / \mathrm{a}$ & 0 & $\mathrm{~N}$ & 0 & 0 & $*$ & $*$ \\
\hline Metatarsal III-Proximal-L & 2 & 0 & $\mathrm{n} / \mathrm{a}$ & 0 & $\mathrm{~N}$ & 0 & 0 & $*$ & $*$ \\
\hline Metatarsal IV-Proximal-R & 1 & 1 & 0 & 0 & $\mathrm{~N}$ & 0 & 0 & $*$ & $*$ \\
\hline Metatarsal V-Proximal-L & 2 & 0 & $\mathrm{n} / \mathrm{a}$ & 0 & $\mathrm{~N}$ & 0 & 0 & $*$ & $*$ \\
\hline
\end{tabular}

\section{PHALANGES}

\section{Manual}

\begin{tabular}{l|l|l|l|l|l|l|l|l|l}
\hline 1.Proximal-Prox. Surf & 3 & 3 & 0 & 0 & $\mathrm{~N}$ & 0 & 0 & $*$ & $*$ \\
\hline Distal Surf & 2 & 1 & 0 & 0 & $\mathrm{~N}$ & 0 & 0 & $*$ & $*$ \\
\hline 2.Proximal-Prox. Surf & 3 & 2 & 0 & 0 & $\mathrm{~N}$ & 0 & 0 & $*$ & $*$ \\
\hline Distal Surf & 3 & 1 & 0 & 0 & $\mathrm{~N}$ & 0 & 0 & $*$ & $*$ \\
\hline 3.Proximal-Prox. Surf & 3 & 2 & 0 & 0 & $\mathrm{~N}$ & 0 & 0 & $*$ & $*$ \\
\hline Distal Surf & 2 & 2 & 0 & 0 & $\mathrm{~N}$ & 0 & 0 & $*$ & $*$ \\
\hline 4.Proximal-Prox. Surf & 3 & 3 & 0 & 0 & $\mathrm{~N}$ & 0 & 0 & $*$ & $*$ \\
\hline 5.Proximal-Dist. Surf & 3 & 3 & 0 & 0 & $\mathrm{~N}$ & 0 & 0 & $*$ & $*$ \\
\hline 6.Proximal-Prox. Surf & 2 & 2 & 0 & 0 & $\mathrm{~N}$ & $1-1$ & 0 & $*$ & $*$ \\
\hline Distal Surf & 2 & 2 & 0 & 0 & $\mathrm{~N}$ & 0 & 0 & $*$ & $*$ \\
\hline 7.Proximal-Dist. Surf & 2 & 1 & 0 & 0 & $\mathrm{~N}$ & 0 & 0 & $*$ & $*$ \\
\hline 8.Middle-Prox. Surf & 2 & 2 & 0 & 0 & $\mathrm{~N}$ & 0 & 0 & $*$ & $*$ \\
\hline Distal Surf & 3 & 2 & 0 & 0 & $\mathrm{~N}$ & 0 & 0 & $*$ & $*$ \\
\hline 9.Middle-Prox. Surf & 3 & 1 & 0 & 0 & $\mathrm{~N}$ & 0 & 0 & $*$ & $*$ \\
\hline Distal Surf & 3 & 3 & 0 & 0 & $\mathrm{~N}$ & 0 & 0 & $*$ & $*$ \\
\hline 10.Middle-Prox. Surf & 3 & 3 & 0 & 0 & $\mathrm{~N}$ & 0 & 0 & $*$ & $*$ \\
\hline Distal Surf & 3 & 2 & 0 & 0 & $\mathrm{~N}$ & 0 & 0 & $*$ & $*$ \\
\hline 11.Middle-Prox. Surf & 3 & 2 & 0 & 0 & $\mathrm{~N}$ & 0 & 0 & $*$ & $*$ \\
\hline Distal Surf & 3 & 1 & 0 & 0 & $\mathrm{~N}$ & 0 & 0 & $*$ & $*$ \\
\hline 12.Middle-Prox. Surf & 3 & 3 & 0 & 0 & $\mathrm{~N}$ & 0 & 0 & $*$ & $*$ \\
\hline 13.Middle-Dist. Surf & 3 & 2 & 0 & 0 & $\mathrm{~N}$ & 0 & 0 & $*$ & $*$ \\
\hline 14.Distal & 3 & 1 & 0 & 0 & $\mathrm{~N}$ & 0 & 0 & $*$ & $*$ \\
\hline Pedal & & & & $*$ & $*$ \\
\hline
\end{tabular}

\section{Pedal}

1.Proximal-Prox. Surf

2.Proximal-Prox. Surf

3.Proximal-Prox. Surf

Distal Surf

4.Distal

\begin{tabular}{c|c|c}
2 & 0 & $\mathrm{n} / \mathrm{a}$ \\
3 & 0 & $\mathrm{n} /$ \\
\hline 3 & 1 & 0 \\
2 & 2 & 0 \\
3 & 1 & 0 \\
\hline
\end{tabular}

\begin{tabular}{c|c|c|c}
\hline $\mathrm{n} / \mathrm{a}$ & 0 & $\mathrm{~N}$ & \\
$\mathrm{n} / \mathrm{a}$ & 0 & $\mathrm{~N}$ & 0 \\
\hline 0 & 0 & $\mathrm{~N}$ & \\
\hline 0 & 0 & $\mathrm{~N}$ & 0 \\
0 & 0 & $\mathrm{~N}$ & 0 \\
\hline
\end{tabular}

\begin{tabular}{c|c|c|c}
0 & 0 & $*$ & $*$ \\
\hline 0 & 0 & $*$ & $*$ \\
\hline 0 & 0 & $*$ & $*$ \\
\hline 0 & 0 & $*$ & $*$ \\
\hline 0 & 0 & $*$ & $*$ \\
\hline
\end{tabular}


Table C.12, continued

\begin{tabular}{|c|c|c|c|c|c|c|c|c|c|}
\hline ATTRIBUTE & $\mathrm{A}$ & $\mathrm{B}$ & $\mathrm{C}$ & $\mathrm{D}$ & $\mathrm{E}$ & $\mathrm{F}$ & $\bar{G}$ & $\mathrm{H}$ & $\mathrm{I}$ \\
\hline \multicolumn{10}{|l|}{ BURIAL \# 16} \\
\hline \multicolumn{10}{|l|}{ VERTEBRA } \\
\hline C1 complete & 3 & 3 & 0 & 0 & $\mathrm{~N}$ & 0 & 0 & $\mathrm{~N}$ & $\mathrm{~N}$ \\
\hline C2 complete & 3 & 3 & 0 & 0 & $\mathrm{~N}$ & 0 & 0 & $\mathrm{~N}$ & $\mathrm{~N}$ \\
\hline C3 complete & 3 & 3 & 0 & 0 & $\mathrm{~N}$ & 0 & 0 & $\mathrm{~N}$ & $\mathrm{~N}$ \\
\hline C4 complete & 3 & 3 & 2-2 (body) & 0 & $\mathrm{~N}$ & 0 & 0 & $\mathrm{~N}$ & $\mathrm{Y}(\mathrm{sup})$ \\
\hline C5 complete & 3 & 3 & $2-2$ (body) & 0 & $\mathrm{~N}$ & 0 & 0 & $\mathrm{~N}$ & $\mathrm{~N}$ \\
\hline C6 complete & 3 & 3 & 2-2 (body) & 0 & $\mathrm{~N}$ & 0 & 0 & $\mathrm{~N}$ & $\mathrm{~N}$ \\
\hline C7 centrum & 3 & 3 & 0 & 0 & $\mathrm{~N}$ & 0 & 0 & $\mathrm{~N}$ & $\mathrm{~N}$ \\
\hline Thoracic-centrum & 1 & 1 & 0 & 0 & & 0 & 0 & $\mathrm{~N}$ & $\mathrm{~N}$ \\
\hline Thoracic-centrum & 3 & 2 & 0 & 0 & & 0 & 0 & $\mathrm{~N}$ & $\mathrm{~N}$ \\
\hline Thoracic-centrum & 3 & 3 & 0 & 0 & & 0 & 0 & $\mathrm{~N}$ & $\mathrm{~N}$ \\
\hline sup facet & 3 & 3 & 0 & 0 & $\mathrm{~N}$ & 0 & 0 & & \\
\hline Thoracic-centrum & 3 & 2 & 0 & 0 & & 0 & 0 & $\mathrm{~N}$ & $\mathrm{~N}$ \\
\hline Thoracic-centrum & 2 & 1 & 0 & 0 & & 0 & 0 & $\mathrm{~N}$ & $\mathrm{~N}$ \\
\hline Thoracic-centrum & 2 & 1 & $2-1$ & 0 & & 0 & 0 & $\mathrm{~N}$ & $\mathrm{~N}$ \\
\hline Thoracic-centrum & 3 & 2 & $2-1$ & 0 & & 0 & 0 & $\mathrm{~N}$ & $\mathrm{~N}$ \\
\hline Thoracic-centrum & 3 & 0 & $\mathrm{n} / \mathrm{a}$ & 0 & & 0 & 0 & $\mathrm{~N}$ & $\mathrm{~N}$ \\
\hline Thoracic-centrum & 2 & 1 & 0 & 0 & & 0 & 0 & $\mathrm{~N}$ & $\mathrm{~N}$ \\
\hline sup facet & 3 & 1 & 0 & 0 & $\mathrm{~N}$ & 0 & 0 & & \\
\hline Thoracic-centrum & 3 & 0 & $\mathrm{n} / \mathrm{a}$ & 0 & & 0 & 0 & $\mathrm{~N}$ & $\mathrm{~N}$ \\
\hline Thoracic-centrum & 3 & 3 & 0 & 0 & & 0 & 0 & $\mathrm{~N}$ & $\mathrm{~N}$ \\
\hline sup facet & 3 & 3 & 0 & 0 & $\mathrm{~N}$ & 0 & 0 & & \\
\hline sup facet & 3 & 3 & 0 & 0 & $\mathrm{~N}$ & 0 & 0 & & \\
\hline inf facet & 1 & 1 & 0 & 0 & $\mathrm{~N}$ & 0 & 0 & & \\
\hline inf facet & 3 & 3 & 0 & 0 & $\mathrm{~N}$ & 0 & 0 & & \\
\hline Thoracic-inf facet & 3 & 3 & 0 & 0 & $\mathrm{~N}$ & 0 & 0 & & \\
\hline Thoracic-sup facet & 3 & 3 & 0 & 0 & $\mathrm{~N}$ & 0 & 0 & & \\
\hline inf facet & 3 & 3 & 0 & 0 & $\mathrm{~N}$ & 0 & 0 & & \\
\hline inf facet & 3 & 3 & 0 & 0 & $\mathrm{~N}$ & 0 & 0 & & \\
\hline Thoracic-sup facet & 3 & 3 & 0 & 0 & $\mathrm{~N}$ & 0 & 0 & & \\
\hline inf facet & 3 & 2 & 0 & 0 & $\mathrm{~N}$ & 0 & 0 & & \\
\hline Thoracic-inf facet & 3 & 3 & 0 & 0 & $\mathrm{~N}$ & 0 & 0 & & \\
\hline Thoracic-inf facet & 3 & 3 & 0 & 0 & $\mathrm{~N}$ & 0 & 0 & & \\
\hline Thoracic-inf facet & 2 & 2 & 0 & 0 & $\mathrm{~N}$ & 0 & 0 & & \\
\hline Thoracic-sup facet & 3 & 2 & 0 & 0 & $\mathrm{~N}$ & 0 & 0 & & \\
\hline Thoracic facet & 3 & 3 & 0 & 0 & $\mathrm{~N}$ & 0 & 0 & & \\
\hline Thoracic-sup facet & 3 & 2 & 0 & 0 & $\mathrm{~N}$ & 0 & 0 & & \\
\hline inf facet & 3 & 3 & 0 & 0 & $\mathrm{~N}$ & 0 & 0 & & \\
\hline Thoracic-inf facet & 3 & 2 & 0 & 0 & $\mathrm{~N}$ & 0 & 0 & & \\
\hline inf facet & 3 & 3 & 0 & 0 & $\mathrm{~N}$ & 0 & 0 & & \\
\hline Lumbar-centrum & 3 & 2 & 0 & 0 & & 0 & 0 & $\mathrm{~N}$ & $\mathrm{~N}$ \\
\hline sup facet & 3 & 3 & 0 & 0 & $\mathrm{~N}$ & 0 & 0 & & \\
\hline sup facet & 3 & 3 & 0 & 0 & $\mathrm{~N}$ & 0 & 0 & & \\
\hline inf facet & 3 & 3 & 0 & 0 & $\mathrm{~N}$ & 0 & 0 & & \\
\hline inf facet & 3 & 3 & 0 & 0 & $\mathrm{~N}$ & 0 & 0 & & \\
\hline Lumbar-centrum & 3 & 2 & 0 & 0 & & 0 & 0 & $\mathrm{~N}$ & $\mathrm{~N}$ \\
\hline Lumbar-centrum & 2 & 2 & 0 & 0 & & 0 & 0 & $\mathrm{~N}$ & $\mathrm{~N}$ \\
\hline Lumbar-inf facet & 3 & 3 & 0 & 0 & $\mathrm{~N}$ & 0 & 0 & & \\
\hline inf facet & 3 & 3 & 0 & 0 & $\mathrm{~N}$ & 0 & 0 & & \\
\hline Lumbar-inf facet & 3 & 2 & $2-1$ & 0 & $\mathrm{~N}$ & 0 & 0 & & \\
\hline
\end{tabular}


Table C.12, continued

\begin{tabular}{|c|c|c|c|c|c|c|c|c|c|}
\hline ATTRIBUTE & $\mathrm{A}$ & $\mathrm{B}$ & $\mathrm{C}$ & $\mathrm{D}$ & $\mathrm{E}$ & $\mathrm{F}$ & $\mathrm{G}$ & $\mathrm{H}$ & $\mathrm{I}$ \\
\hline inf facet & 3 & 2 & 0 & 0 & $\mathrm{~N}$ & 0 & 0 & & \\
\hline Lumbar-inf facet & 3 & 2 & 0 & 0 & $\mathrm{~N}$ & 0 & 0 & & \\
\hline Lumbar-inf facet & 3 & 3 & 0 & 0 & $\mathrm{~N}$ & 0 & 0 & & \\
\hline Lumbar-inf facet & 3 & 3 & 0 & 0 & $\mathrm{~N}$ & 0 & 0 & & \\
\hline Lumbar-sup facet & 3 & 2 & 0 & 0 & $\mathrm{~N}$ & 0 & 0 & & \\
\hline Lumbar-sup facet & 3 & 3 & $2-1$ & 0 & $\mathrm{~N}$ & 0 & 0 & & \\
\hline Lumbar-sup facet & 3 & 3 & 0 & 0 & $\mathrm{~N}$ & 0 & 0 & & \\
\hline Lumbar-sup facet & 3 & 3 & 0 & 0 & $\mathrm{~N}$ & 0 & 0 & & \\
\hline Lumbar-sup facet & 3 & 3 & 0 & 0 & $\mathrm{~N}$ & 0 & 0 & & \\
\hline \multicolumn{10}{|l|}{ ELEMENT } \\
\hline Occipital Condyle-L & 3 & 2 & 0 & 0 & $\mathrm{~N}$ & 0 & 0 & $*$ & $*$ \\
\hline TMJ-R & 3 & 3 & 0 & 0 & $\mathrm{~N}$ & 0 & 0 & $*$ & $*$ \\
\hline TMJ-L & 3 & 3 & 0 & 0 & $\mathrm{~N}$ & 0 & 0 & $*$ & $*$ \\
\hline Clavicle-Sternal-R & 3 & 3 & 0 & 0 & $\mathrm{~N}$ & 0 & 0 & $*$ & $*$ \\
\hline Clavicle-Acromial-R & 3 & 2 & 0 & 0 & $\mathrm{~N}$ & 0 & 0 & $*$ & $*$ \\
\hline Glenoid Fossa-R & 1 & 1 & 0 & $2-1$ & $\mathrm{~N}$ & 0 & 0 & $*$ & $*$ \\
\hline Humerus-Trochlea/Capitulum-R & 2 & 1 & 0 & 0 & $\mathrm{~N}$ & 0 & 0 & $*$ & $*$ \\
\hline Humerus-Trochlea/Capitulum-L & 2 & 1 & 0 & 0 & $\mathrm{~N}$ & 0 & 0 & $*$ & $*$ \\
\hline Radius-Proximal-L & 2 & 1 & 0 & 0 & $\mathrm{~N}$ & 0 & 0 & $*$ & $*$ \\
\hline Ulna-Distal-L & 2 & 1 & 0 & 0 & $\mathrm{~N}$ & 0 & 0 & $*$ & $*$ \\
\hline Scaphoid-R-general & 3 & 3 & 0 & 0 & $\mathrm{~N}$ & 0 & 0 & $*$ & $*$ \\
\hline Scaphoid-L-general & 3 & 2 & 0 & 0 & $\mathrm{~N}$ & 0 & 0 & $*$ & $*$ \\
\hline Lunate-R-general & 2 & 1 & 0 & 0 & $\mathrm{~N}$ & 0 & 0 & $*$ & $*$ \\
\hline Lunate-L-general & 3 & 2 & 0 & 0 & $\mathrm{~N}$ & 0 & 0 & $*$ & $*$ \\
\hline Capitate-R-general & 3 & 2 & 0 & 0 & $\mathrm{~N}$ & 0 & 0 & $*$ & $*$ \\
\hline Capitate-L-general & 2 & 2 & 0 & 0 & $\mathrm{~N}$ & 0 & 0 & $*$ & $*$ \\
\hline Trapezoid-R-general & 2 & 1 & 0 & 0 & $\mathrm{~N}$ & 0 & 0 & $*$ & $*$ \\
\hline Trapezoid-L-general & 2 & 1 & 0 & 0 & $\mathrm{~N}$ & 0 & 0 & $*$ & $*$ \\
\hline Trapezium-R-general & 2 & 1 & 0 & 0 & $\mathrm{~N}$ & 0 & 0 & $*$ & $*$ \\
\hline Hamate-L-general & 3 & 2 & 0 & 0 & $\mathrm{~N}$ & 0 & 0 & $*$ & $*$ \\
\hline Metacarpal I-Proximal-R & 3 & 3 & 0 & 0 & $\mathrm{~N}$ & 0 & 0 & $*$ & $*$ \\
\hline Metacarpal I-Distal-R & 3 & 2 & 0 & 0 & $\mathrm{~N}$ & 0 & 0 & $*$ & $*$ \\
\hline Metacarpal I-Proximal-L & 2 & 1 & 0 & 0 & $\mathrm{~N}$ & $1-1 ?$ & 0 & $*$ & $*$ \\
\hline Metacarpal I-Distal-L & 3 & 2 & 0 & 0 & $\mathrm{~N}$ & 0 & 0 & $*$ & $*$ \\
\hline Metacarpal II-Proximal-R & 2 & 1 & 0 & 0 & $\mathrm{~N}$ & 0 & 0 & $*$ & $*$ \\
\hline Metacarpal II-Proximal-L & 3 & 2 & 0 & 0 & $\mathrm{~N}$ & 0 & 0 & $*$ & $*$ \\
\hline Metacarpal II-Distal-L & 3 & 1 & 0 & 0 & $\mathrm{~N}$ & 0 & 0 & $*$ & $*$ \\
\hline Metacarpal III-Proximal-R & 2 & 0 & $\mathrm{n} / \mathrm{a}$ & 0 & $\mathrm{~N}$ & 0 & 0 & $*$ & $*$ \\
\hline Metacarpal III-Proximal-L & 3 & 1 & 0 & 0 & $\mathrm{~N}$ & 0 & 0 & $*$ & $*$ \\
\hline Acetabulum-R & 2 & 2 & 0 & 0 & $\mathrm{~N}$ & 0 & 0 & $*$ & $*$ \\
\hline Acetabulum-L & 2 & 2 & 0 & 0 & $\mathrm{~N}$ & 0 & 0 & $*$ & $*$ \\
\hline Femoral Head-R & 1 & 1 & 0 & 0 & $\mathrm{~N}$ & 0 & 0 & $*$ & $*$ \\
\hline Femoral Head-L & 2 & 2 & 0 & 0 & $\mathrm{~N}$ & 0 & 0 & $*$ & $*$ \\
\hline Tibia-Distal-unsided & 1 & 0 & $\mathrm{n} / \mathrm{a}$ & 0 & $\mathrm{~N}$ & 0 & 0 & $*$ & $*$ \\
\hline Patella-R & 3 & 1 & 0 & 0 & $\mathrm{~N}$ & 0 & 0 & $*$ & $*$ \\
\hline Patella-L & 2 & 1 & 0 & 0 & $\mathrm{~N}$ & 0 & 0 & $*$ & $*$ \\
\hline Fibula-Distal-unsided & 2 & 0 & $\mathrm{n} / \mathrm{a}$ & 0 & $\mathrm{~N}$ & 0 & 0 & $*$ & $*$ \\
\hline Talus-R-tibial facet & 3 & 1 & 0 & 0 & $\mathrm{~N}$ & 0 & 0 & $*$ & $*$ \\
\hline Talus-R-ant/med calc. facet & 1 & 1 & 0 & 0 & $\mathrm{~N}$ & 0 & 0 & $*$ & $*$ \\
\hline Talus-R-post. Calc. facet & 2 & 1 & 0 & 0 & $\mathrm{~N}$ & 0 & 0 & $*$ & $*$ \\
\hline Talus-R-navicular facet & 2 & 0 & $\mathrm{n} / \mathrm{a}$ & 0 & $\mathrm{~N}$ & 0 & 0 & $*$ & $*$ \\
\hline
\end{tabular}


Table C.12, continued

\begin{tabular}{|c|c|c|c|c|c|c|c|c|c|}
\hline ATTRIBUTE & $\mathrm{A}$ & $\mathrm{B}$ & $\mathrm{C}$ & $\mathrm{D}$ & $\mathrm{E}$ & $\mathrm{F}$ & $\mathrm{G}$ & $\mathrm{H}$ & $\mathrm{I}$ \\
\hline Talus-L-tibial facet & 2 & 1 & 0 & 0 & $\mathrm{~N}$ & 0 & 0 & $*$ & $*$ \\
\hline Talus-L-ant/med calc. facet & 1 & 1 & 0 & 0 & $\mathrm{~N}$ & 0 & 0 & $*$ & $*$ \\
\hline Talus-L-post. Calc. facet & 3 & 2 & 0 & 0 & $\mathrm{~N}$ & 0 & 0 & $*$ & * \\
\hline Talus-L-navicular facet & 3 & 0 & $\mathrm{n} / \mathrm{a}$ & 0 & $\mathrm{~N}$ & 0 & 0 & $*$ & * \\
\hline Calcaneus-L-ant/med talar facet & 3 & 1 & 0 & 0 & $\mathrm{~N}$ & 0 & 0 & $*$ & $*$ \\
\hline Calcaneus-L-post. Talar facet & 2 & 0 & $\mathrm{n} / \mathrm{a}$ & 0 & $\mathrm{~N}$ & 0 & 0 & $*$ & $*$ \\
\hline Calcaneus-L-cuboid facet & 2 & 0 & $\mathrm{n} / \mathrm{a}$ & 0 & $\mathrm{~N}$ & 0 & 0 & $*$ & $*$ \\
\hline Navicular-R-talar facet & 3 & 2 & 0 & 0 & $\mathrm{~N}$ & 0 & 0 & $*$ & $*$ \\
\hline Navicular-R-med.cune. Facet & 2 & 1 & 0 & 0 & $\mathrm{~N}$ & 0 & 0 & $*$ & $*$ \\
\hline Navicular-R-int.cune. Facet & 2 & 1 & 0 & 0 & $\mathrm{~N}$ & 0 & 0 & $*$ & * \\
\hline Navicular-R-lat.cune. Facet & 2 & 1 & 0 & 0 & $\mathrm{~N}$ & 0 & 0 & $*$ & * \\
\hline Navicular-L-talar facet & 2 & 1 & 0 & 0 & $\mathrm{~N}$ & 0 & 0 & $*$ & $*$ \\
\hline Navicular-L-med.cune. Facet & 3 & 2 & 0 & 0 & $\mathrm{~N}$ & 0 & 0 & $*$ & $*$ \\
\hline Navicular-L-int.cune. Facet & 3 & 2 & 0 & 0 & $\mathrm{~N}$ & 0 & 0 & $*$ & $*$ \\
\hline Navicular-L-lat.cune. Facet & 3 & 2 & 0 & 0 & $\mathrm{~N}$ & 0 & 0 & $*$ & $*$ \\
\hline Cuboid-R-calcaneus facet & 3 & 0 & $\mathrm{n} / \mathrm{a}$ & 0 & $\mathrm{~N}$ & 0 & 0 & $*$ & $*$ \\
\hline Cuboid-R-MTIV facet & 1 & 0 & $\mathrm{n} / \mathrm{a}$ & 0 & $\mathrm{~N}$ & 0 & 0 & $*$ & $*$ \\
\hline Cuboid-R-MTV facet & 1 & 0 & $\mathrm{n} / \mathrm{a}$ & 0 & $\mathrm{~N}$ & 0 & 0 & $*$ & $*$ \\
\hline Medial Cun-R-navicular facet & 3 & 1 & 0 & 0 & $\mathrm{~N}$ & 0 & 0 & $*$ & $*$ \\
\hline Medial Cun-R-MTI facet & 2 & 1 & 0 & 0 & $\mathrm{~N}$ & 0 & 0 & $*$ & $*$ \\
\hline Int Cun-R-MTII facet & 3 & 1 & 0 & 0 & $\mathrm{~N}$ & 0 & 0 & $*$ & $*$ \\
\hline Int Cun-R-navicular facet & 3 & 2 & 0 & 0 & $\mathrm{~N}$ & 0 & 0 & $*$ & $*$ \\
\hline Int Cun-L-MTII facet & 3 & 2 & 0 & 0 & $\mathrm{~N}$ & 0 & 0 & $*$ & $*$ \\
\hline Int Cun-L-navicular facet & 3 & 2 & 0 & 0 & $\mathrm{~N}$ & 0 & 0 & $*$ & $*$ \\
\hline Metatarsal I-Proximal-R & 2 & 1 & 0 & 0 & $\mathrm{~N}$ & 0 & 0 & $*$ & $*$ \\
\hline Metatarsal I-Proximal-L & 2 & 1 & 0 & 0 & $\mathrm{~N}$ & 0 & 0 & $*$ & $*$ \\
\hline Metatarsal II-Proximal-R & 2 & 0 & $\mathrm{n} / \mathrm{a}$ & 0 & $\mathrm{~N}$ & 0 & 0 & $*$ & $*$ \\
\hline Metatarsal II-Proximal-L & 2 & 0 & $\mathrm{n} / \mathrm{a}$ & 0 & $\mathrm{~N}$ & 0 & 0 & $*$ & $*$ \\
\hline Metatarsal III-Proximal-R & 2 & 0 & $\mathrm{n} / \mathrm{a}$ & 0 & $\mathrm{~N}$ & 0 & 0 & $*$ & $*$ \\
\hline Metatarsal III-Proximal-L & 1 & 0 & $\mathrm{n} / \mathrm{a}$ & 0 & $\mathrm{~N}$ & 0 & 0 & $*$ & $*$ \\
\hline unidentified distal metatarsal & 2 & 1 & 0 & 0 & $\mathrm{~N}$ & 0 & 0 & $*$ & $*$ \\
\hline Metatarsal V-Proximal-R & 1 & 0 & $\mathrm{n} / \mathrm{a}$ & 0 & $\mathrm{~N}$ & 0 & 0 & $*$ & $*$ \\
\hline Metatarsal V-Proximal-L & 2 & 0 & $\mathrm{n} / \mathrm{a}$ & 0 & $\mathrm{~N}$ & 0 & 0 & $*$ & $*$ \\
\hline
\end{tabular}

\section{PHALANGES}

\section{Manual}

\begin{tabular}{l|c|c|c|c|c|c|c|c|c|c}
\hline 1.Proximal-Prox. Surf & 2 & 2 & 0 & 0 & $\mathrm{~N}$ & 0 & 0 & $*$ & $*$ \\
\hline Distal Surf & 2 & 1 & 0 & 0 & $\mathrm{~N}$ & 0 & 0 & $*$ & $*$ \\
\hline 2.Proximal-Dist. Surf & 3 & 3 & $1-1 ?$ & 0 & $\mathrm{~N}$ & 0 & 0 & $*$ & $*$ \\
\hline 3.Proximal-Prox. Surf & 1 & 0 & $\mathrm{n} / \mathrm{a}$ & 0 & $\mathrm{~N}$ & 0 & 0 & $*$ & $*$ \\
\hline 4.Proximal-Prox. Surf & 2 & 2 & 0 & 0 & $\mathrm{~N}$ & 0 & 0 & $*$ & $*$ \\
\hline Distal Surf & 3 & 2 & 0 & 0 & $\mathrm{~N}$ & 0 & 0 & $*$ & $*$ \\
\hline 5.Proximal-Dist. Surf & 3 & 1 & 0 & 0 & $\mathrm{~N}$ & 0 & 0 & $*$ & $*$ \\
\hline 6.Proximal-Prox. Surf & 3 & 2 & 0 & 0 & $\mathrm{~N}$ & 0 & 0 & $*$ & $*$ \\
\hline Distal Surf & 3 & 3 & 0 & 0 & $\mathrm{~N}$ & 0 & 0 & $*$ & $*$ \\
\hline 7.Middle-Prox. Surf & 3 & 2 & 0 & 0 & $\mathrm{~N}$ & 0 & 0 & $*$ & $*$ \\
\hline Distal Surf & 3 & 3 & 0 & 0 & $\mathrm{~N}$ & 0 & 0 & $*$ & $*$ \\
\hline 8.Middle-Prox. Surf & 3 & 2 & 0 & 0 & $\mathrm{~N}$ & 0 & 0 & $*$ & $*$ \\
\hline Distal Surf & 3 & 2 & 0 & 0 & $\mathrm{~N}$ & 0 & 0 & $*$ & $*$ \\
\hline 9.Middle-Prox. Surf & 3 & 2 & 0 & 0 & $\mathrm{~N}$ & 0 & 0 & $*$ & $*$ \\
\hline Distal Surf & 3 & 2 & 0 & 0 & $\mathrm{~N}$ & 0 & 0 & $*$ & $*$ \\
\hline
\end{tabular}


Table C.12, continued

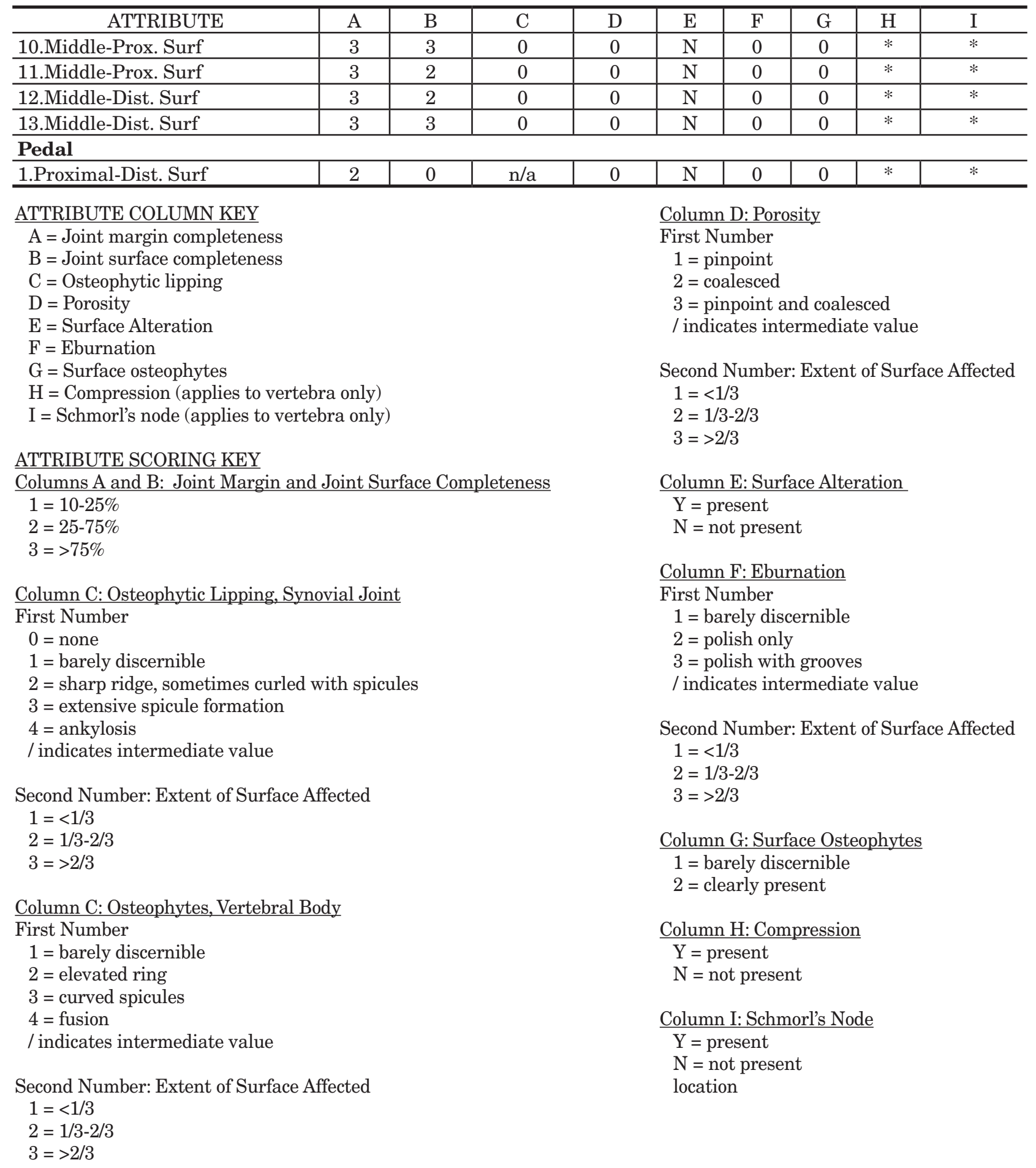





\section{APPENDIX D: Wood Identifications}

Leslie L. Bush, Ph.D., R.P.A.

Macrobotanical Analysis

Manchaca, Texas 

Twenty-eight samples of wood associated with burials from the Pioneer Cemetery (41BO202) in Brazoria County, Texas, were submitted for identification. The samples consisted of wood from coffin boxes or associated handles except for one, which was from an iron and wood prosthesis associated with Burial 9.

\section{METHODS}

Because the material was dry and relatively fragile, clean sections for identification were usually obtained by snapping the wood in the manner of wood charcoal identification rather than cutting it. Occasionally, wood samples were cut with a razor blade to obtain clean sections. Wood fragments were snapped or cut to reveal a transverse section and examined under a stereoscopic microscope at 28-180x magnification. When necessary, tangential or radial sections were examined for ray seriation, presence of spiral thickenings, types and sizes of cross-field pitting, and other minute characteristics that can only be seen at the higher magnifications of this range (Hoadley 1990). Wood specimens materials were identified to the lowest possible taxonomic level by comparison to materials in the Macrobotanical Analysis comparative collection and through the use of standard reference works (e.g., Core et al. 1979; Hoadley 1990; InsideWood 2004; Panshin and de Zeeuw 1980).

Some aspects of wood anatomy were deteriorated in the Pioneer Cemetery specimens. Epithelial cells were sometimes missing from resin canals in pine specimens, and insect damage was evident in many samples. Nevertheless, placement to a subgroup within the genus was possible for all specimens.

\section{RESULTS}

Identifications of wood samples from the Pioneer Cemetery burials are provided in Table D.1. Twenty-seven samples, including that from the prosthesis, were identified as pine wood. Their relative hardness, abrupt transition from earlywood to latewood, and conspicuous, dense latewood place them in the southern yellow pine group of the hard pines. The 11 species of southern yellow pine group include all 4 of the common pines of East Texas (Hoadley 1990). These are longleaf pine (Pinus palustris), shortleaf pine (P. echinata), loblolly pine (P. taeda), and slash pine (P. elliottii) (Turner et al. 2003).

Southern yellow pines have a straight grain and medium texture (Alden 1997). At 12 percent moisture, their specific gravity ranges from 0.51 to 0.61 (Alden 1997; Hoadley 1990). They are heavy, strong, and stiff with high to moderately high shock resistance (Alden 1997 softwoods). Southern yellow pines are difficult to work using hand tools and are difficult to glue, but they hold nails well. They are rated low to moderately resistant to decay (Alden 1997; Hoadley 1990).

The final sample, from Burial 12, is a ring-porous hardwood with almost completely deteriorated latewood. The large rays and large earlywood pores containing tyloses made it possible to identify the specimen to the white group of the oak genus (Quercus subgenus Quercus).

Common trees of the white oak group include bur oak (Quercus macrocarpa), chestnut oak (Q. prinus), chinkapin oak (Q. muehlenbergii), post oak (Q. stellata), swamp white oak (Q. bicolor), and white oak (Q. alba). Specific gravities at 12 percent moisture range from 64 
to 72 (Alden 1995). Oaks tend to split when nailed, but they glue well. White oaks are rated resistant or very resistant to decay (Alden 1995; Hoadley 1990).

Table D.1. Wood samples from Pioneer Cemetery

\begin{tabular}{|c|c|c|c|c|c|c|}
\hline $\begin{array}{c}\text { Burial } \\
\text { No. }\end{array}$ & $\begin{array}{l}\text { Sample } \\
\text { No. }\end{array}$ & Description & Identification & Common Name & $\begin{array}{l}\text { No. of } \\
\text { Pieces }\end{array}$ & $\begin{array}{l}\text { Weight } \\
(\mathrm{g})\end{array}$ \\
\hline 3 & $(18-1)^{*}$ & outer box wood (bottom) & Pinus spp. & southern yellow pine & 2 & 68.04 \\
\hline \multirow[t]{3}{*}{7} & $7-1$ & coffin wood & Pinus spp. & southern yellow pine & 3 & 1723.65 \\
\hline & $7-2$ & coffin wood & Pinus spp. & southern yellow pine & 2 & 1556.39 \\
\hline & $7-3$ & coffin wood & Pinus spp. & southern yellow pine & 4 & 997.90 \\
\hline \multirow[t]{6}{*}{8} & $8-1$ & coffin wood & Pinus spp. & southern yellow pine & 2 & 652.04 \\
\hline & $8-2$ & coffin wood & Pinus spp. & southern yellow pine & 1 & 311.84 \\
\hline & $8-3$ & outer box & Pinus spp. & southern yellow pine & 2 & 37.68 \\
\hline & $8-4$ & outer box wood (base) & Pinus spp. & southern yellow pine & 1 & 360.04 \\
\hline & $8-5$ & outer box & Pinus spp. & southern yellow pine & 1 & 2.57 \\
\hline & $8-6$ & outer box wood & Pinus spp. & southern yellow pine & 2 & 130.41 \\
\hline \multirow[t]{3}{*}{9} & $9-1 \mathrm{a}$ & casket wood & Pinus spp. & southern yellow pine & 1 & 90.72 \\
\hline & $9-1 b$ & casket wood & Pinus spp. & southern yellow pine & 1 & 453.59 \\
\hline & $9-\mathrm{x}$ & prosthesis wood & Pinus spp. & southern yellow pine & 6 & 10.25 \\
\hline 10 & $10-1$ & coffin wood & Pinus spp. & southern yellow pine & 3 & 249.48 \\
\hline 11 & $11-1$ & casket wood & Pinus spp. & southern yellow pine & 2 & 119.07 \\
\hline \multirow[t]{4}{*}{12} & $12-1$ & coffin wood & Pinus spp. & southern yellow pine & 1 & 229.63 \\
\hline & $12-2$ & coffin wood & Pinus spp. & southern yellow pine & 3 & 198.45 \\
\hline & $12-3$ & outer box wood & Quercus subg. Quercus & White group oak & 3 & 73.71 \\
\hline & $12-4$ & coffin wood & Pinus spp. & southern yellow pine & 1 & 172.93 \\
\hline \multirow[t]{2}{*}{13} & $13-1$ & coffin wood & Pinus spp. & southern yellow pine & 1 & 328.85 \\
\hline & $13-2$ & coffin wood & Pinus spp. & southern yellow pine & 1 & 121.90 \\
\hline 14 & $14-1$ & casket wood & Pinus spp. & southern yellow pine & 1 & 1227.53 \\
\hline \multirow[t]{2}{*}{15} & $15-1$ & casket wood & Pinus spp. & southern yellow pine & 1 & 206.95 \\
\hline & $15-2$ & outer box wood & Pinus spp. & southern yellow pine & 2 & 450.76 \\
\hline \multirow[t]{3}{*}{16} & $16-1$ & casket wood & Pinus spp. & southern yellow pine & 1 & 309.01 \\
\hline & $16-2$ & grave arch wood & Pinus spp. & southern yellow pine & 1 & 498.95 \\
\hline & $16-\mathrm{x}$ & $\begin{array}{l}\text { wood section from from } \\
\text { extension bar casket handle }\end{array}$ & Pinus spp. & southern yellow pine & 2 & 388.39 \\
\hline 17 & $17-1$ & casket wood & Pinus spp. & southern yellow pine & 1 & 65.20 \\
\hline
\end{tabular}

* Sample 18-1 was thought to be from a separate burial but was later discovered to be associated with Burial 3. 


\section{REFERENCES CITED}

Alden, Harry A.

1995 Hardwoods of North America. U.S. Department of Agriculture, Forest Service, Forest Products Laboratory. FPL-GTR-83. Madison, Wisconsin.

1997 Softwoods of North America. U.S. Department of Agriculture, Forest Service, Forest Products Laboratory. FPL-GTR-102. Madison, Wisconsin.

Core, H. A., W. A. Cote, and A. C. Day

1979 Wood Structure and Identification. 2nd ed. Syracuse University Press, Syracuse, New York.

Hoadley, R. Bruce

1990 Identifying Wood:Accurate Results with Simple Tools. The Taunton Press, Newtown, Connecticut.

InsideWood

2004-onwards The InsideWood Database. Electronic document, http://insidewood.lib.ncsu.edu/search, accessed April 27, 2009.

Panshin, A. J., and Carol de Zeeuw

1980 Textbook of Wood Technology: Structure, Identification, Properties, and Uses of the Commercial Woods of the United States and Canada. 4th ed. McGraw-Hill Book Company, New York.

Turner, Billie L., Holly Nichols, Geoffrey Denny, and Oded Doron

2003 Atlas of the Vascular Plants of Texas, Vol. 2: Monocots. Sida, Botanical Miscellany 24(2):Ferns, Gymnosperms, Monocots. BRIT Press, Fort Worth, Texas. 



\section{APPENDIX E: Analysis of Textile Samples}

Helen Dewolf and Haley Streuding

Conservation Research Laboratory

Center for Maritime Archaeology

and Conservation

Texas A\&M University

College Station, Texas 



\section{INTRODUCTION}

This appendix reports the preliminary analyses, experimental tests, and final identifications of textile samples recovered from the 2008 and 2009 excavations of unmarked historic graves at Pioneer Cemetery in Brazoria, Texas. This cemetery was reportedly established in 1888 as a burial ground for the parishioners of local African American churches. The submitted materials consist of 14 textile samples recovered from four unmarked graves that date from the late-nineteenth or early-twentieth century:

7 samples from Burial 8

3 samples from Burial 9

3 samples from Burial 10

1 sample from Burial 13

As described below, the samples were first subjected to a preliminary analysis in March 2009. A more comprehensive analysis was conducted in 2010-2011.

The preliminary analysis was conducted by Dr. Helen Dewolf based on a cursory examination of the materials submitted to the Conservation Research Lab (CRL). Preliminary identifications were made, but adhering soils and staining of the textiles proved to significantly hamper the identification of the fibers used to construct the textiles. Consequently, these identifications were considered tentative and incomplete, and it was recommended that additional analyses were needed to confirm the preliminary results.

The comprehensive textile analysis was conducted by Haley Streuding, a Texas A\&M Nautical Archaeology Program graduate student, who worked under the guidance of Drs. C. Wayne Smith and Helen Dewolf. The same textile samples underwent additional cleaning, secondary testing, and detailed analysis. Streuding's analysis was conducted in 2010, and Smith and Dewolf corroborated the work. The final reporting was completed by Dewolf in May 2011. ${ }^{34}$ This appendix includes all of the information presented in that report.

\section{METHODS}

When presented with an artifact or collection of artifacts to be conserved, a conservator must identify the material of which the object or objects is composed. This could entail doing background research, conducting various experimental tests, or some combination of both. The identification of the material to be conserved is essential since this will determine what conservation treatment will be used. Although in this case the samples were not to be conserved, the analysis aimed to identify as accurately as possible the textile that makes up the cloth samples recovered from Pioneer Cemetery burials.

The materials submitted for identification consisted of 14 fabric samples. Seven samples came from Burial 8 (samples 8-1A, 8-1B, 8-2, 8-3A, 8-3B, 8-4A, and 8-4B); three samples came from Burial 9 (samples 9-1A, 9-1B, and 9-1C); three samples came from Burial 10 (samples 10-1, 10-2, and 10-3); and one sample came from Burial 13 (sample 13-1). ${ }^{35}$ Additional equipment and materials used were a camera, Orvus WA paste, deionized water, utility lighter, and a microscope.

$\overline{34}$ The final report on the 2010-2011 textile analysis was submitted to Prewitt and Associates, Inc. on May $31,2011$.

${ }^{35}$ The samples were numbered sequentially within each burial, and the letter designations within a sample number denote two different types of fabric within one sample. 
Macro photographs were taken of each sample before it was cleaned. Some of the samples were then cleaned using Orvus WA paste and deionized water. The samples from Burials 8 and 9 were cleaned, though not as thoroughly as desired because they were in such a fragile state. The samples from Burials 10 and 13 were too fragile to wash and would have come apart with even the slightest bit of agitation. Ideally, if these samples were to be conserved, they would be treated with a polymer, such as silicone oil, prior to cleaning. This would stabilize the material enough to properly wash them in preparation for analysis. However, because these samples were not to be conserved, they had to be analyzed in their current fragile condition. It is important to note that the lack of cleaning may have an effect on the appearance of the fiber sample when viewed under a microscope and thus can skew the results of the analyses.

The next step was to take a few strands of fibers from each sample to be used in a burn test. Although a burn test will not necessarily help to identify a specific fiber, it can narrow down the results by indicating general groupings. For example, the test can identify whether a material is natural or manmade and whether the fiber is cellulose-based or protein-based fiber. For each sample, a few yarn fibers were held in a pair of forceps and then moved toward a flame. The reaction of each yarn as it interacted with the flame was observed, paying special attention to the way the fiber burned, the color of the smoke emitted, any odor given off, and the ash or residue left behind.

After the burn test, the remaining fibers from each burial sample were placed on a glass slide and viewed under a microscope set at 40x magnification. Only the longitudinal view of the fibers were observed and analyzed.

\section{SAMPLE DESCRIPTIONS}

\section{Burial 8}

Sample 8-1A:This sample appears to be a twill, single weave with both the warp and weft composed of single-ply yarn. The yarn of the warp and weft also appear to be the same material. One or maybe both sides seem to have been fulled and brushed. Some stitching holes still visible and may represent the location of some type of embroidery (maybe a regalia?) in which the thread has disappeared. The holes of the stitching are continuous and evenly spaced, indicating that a sewing machine was used. Some of the edges were folded over, possibly indicating that the cloth had been hemmed.

Sample 8-1B: This sample appears to be a $2 / 1$ weft-faced loose twill weave. The warp yarn, which is degraded and missing in some sections of the fabric, appears to be finer than the weft one yarn. The continuity and spacing of the stitching holes suggests the use of a machine.

Sample 8-2: This textile appears to be a twill weave composed of a single-ply yarn. There are stitching holes still visible. Holes are evenly spaced, so a sewing machine was most likely used. The fabric appears to have been fulled on both sides.

Sample 8-3A: This fabric seems to be a twill weave with both warp and weft made of single-ply yarn. This sample is similar to sample 8-1A.

Sample 8-3B: This sample appears to be a loose twill weave with a fine warp and heavier weft. It is similar to sample 8-1B.

Sample 8-4A: This sample is a twill weave, similar to samples 8-1A and 8-3A, that appears to have been fulled on both sides. The cloth could have had a single or double weave. 
Sample 8-4B: This sample is a loose twill weave that is most similar to samples $8-1 \mathrm{~B}$ and $8-3 \mathrm{~B}$.

\section{Burial 9}

Sample 9-1A: Made of a fine, 2-ply yarn, this sample appears to be a knitted textile.

Sample 9-1B:This sample appears to be a $2 / 1$ weft-faced twill weave. Both the warp and weft appear to be single ply. Stitching holes are still visible. The fabric was probably machine sewn. A secondary sewing thread that had a different thickness and luster than the warp and weft yarns was noted on the sample. It appears to be 3 ply.

Sample 9-1C: This sample appears to be a plain or tabby weave with a single-ply yarn forming both the warp and weft. Stitching holes indicate machine sewing, and the fabric appears to have been fulled or brushed on one side.

\section{Burial 10}

Sample 10-1: This textile is a loose, 2/1 weft-faced twill weave. Both the warp and weft are of a single-ply yarn. However, the weft yarn is heavier than the warp yarn, which is very fine. The fabric appears to be seamed.

Sample 10-2: This sample appears to be a loose, plain weave with single-ply yarn for warp and weft. Portions of the fabric appear to have been rolled and hemmed, although no stitching holes are visible.

Sample 10-3: This fabric appears to be a single-ply, loose twill weave with some finished edges, meaning that the edges have been rolled and hemmed. Stitching holes indicate the use of a sewing machine. A secondary sewing thread located on the sample appears to be either 2- or 3-ply.

\section{Burial 13}

Sample 13-1: This sample is a single-ply twill weave with a fine warp and heavier weft. The seams appear to have been machine sewn. This sample closely resembles samples $8-1 \mathrm{~B}$, 8-3B, 8-4B, and 10-1A.

\section{BURN TESTS RESULTS}

The burn tests for all of the samples yielded very similar if not identical results. Specific details are provided below for each of the Burial 8 samples, but the other samples are described as a group because the results were essentially the same.

\section{Burial 8}

Sample 8-1A: The fiber was ignited very easily but also went out easily. It was selfextinguishing, meaning the flame went out on its own without being put out by someone. Some gray smoke was emitted by the burning sample. The burned fiber yielded light gray ash that was very brittle and blew away easily. The individual fibers were still visible. This is probably due to the fact that this particular textile is slow burning, and the sample was not allowed to 
burn long enough. Finally, the odor smelled very distinctly like burning hair, which is a good indicator for protein-based fibers.

Sample 8-1B: This sample was also easily ignited and burned slowly. The flame was orange in color, and the sample was self-extinguishing. It emitted a light gray smoke that was minimal. The ash was very charred and black in color. The ash's texture was harsh and gritty. Like the previous sample, the burning fibers smelled like burning hair.

Sample 8-2: The fibers were ignited on contact but kept going out and had to be re-lit, which signals that they were self-extinguishing. The flame was also slow-burning and produced minimal gray smoke. The ash was dark gray/black and very gritty. There was some beading as well. The sample smelled like burning hair.

Sample 8-3A: This sample showed all the same characteristics as the previous three samples. It ignited easily but also extinguished easily. It was slow burning and produced gray smoke that was very minimal. The fabric curled away from the flame. The ash or residue was charred with some beading. It was dark gray/black in color, and the texture was harsh and gritty. The sample smelled like burning hair.

Sample 8-3B: This sample shared the same burning characteristics as the previous samples.

\section{Samples from Burials 9, 10, and 13}

It would be unnecessary to list every sample from the other three burials since the results of the burn test were practically identical. Even the samples of the secondary sewing thread yielded the same results, which indicate they are of a similar if not the same material than the primary thread fibers. It is important to note that since the samples were not thoroughly washed-and in some cases, not washed at all - the results might not be completely accurate. For example, the fact that the fibers were still dirty might have an effect on the color of the smoke produced by the flame. Even with this constraint, it still seems a safe assumption that these samples are protein-based textiles.

\section{MICROSCOPIC ANALYSIS}

After these samples were classified into the somewhat narrow grouping of protein-based material, further analysis was carried out to try to identify the specific fiber types. This was achieved through microscopic analysis of the samples' longitudinal view. The fibers from the samples were placed on a glass slide and placed under the microscope lens. The samples were initially analyzed using 10x magnification. However, this seemed insufficient, so the samples were then observed through the 40x magnification lens. This magnification was adequate to provide an accurate picture of each sample.

The samples yielded very similar if not identical results. All of the fibers appeared to be transparent, rod-like structures that had a very rough surface. There appeared to be definite markings that looked like striations or scales. The fibers had a medium luster and were a tan color. 


\section{CONCLUSION}

The results from the burn tests and the microscopic analysis led the authors to conclude that these textile fibers are more than likely wool. The characteristics resemble protein-based fibers, and although there are several variations of protein-based fibers, such as alpaca, camel, llama, mohair, and silk, wool was probably more common in coastal Texas at the turn of the century than any of these other textiles.

It must be noted, however, that some of the samples were too friable to clean, and therefore the identifications are not certain. Taking into account the other samples and the similarity of many of the samples it is possible to reach likely conclusions in the identification of the majority of the fiber types as protein-based and likely made from a wool source. Many of the textiles exhibit stitching lines and seams or hems indicating that they were likely sewn with a sewing machine. The similarity of these textiles from different burials may indicate a commonality among the burials. These textiles may represent clothing or body coverings (shrouds), or perhaps fabric coffin lining common to the burials. It is difficult to reach any other definitive conclusions without a larger set of samples or a comparative collection of burial textiles from this locality and time period. 



\section{APPENDIX F: Recorded Graves at Pioneer Cemetery}

From data compiled by the Cemetery Committee, Brazoria County Historical

Museum, Angleton, Texas 

This appendix consists of two tables listing data for 59 deceased persons buried at Pioneer Cemetery as recorded from gravestones. Table F.1 lists the deceased alphabetically, and Table F.2 lists them chronologically by death year. The data in both tables are taken from the Pioneer Cemetery grave inventory lists provided by Nancy Howard of Brazoria, Texas, and compiled by the Cemetery Committee of the Brazoria County Historical Museum.

Ms. Howard provided a first inventory list to Prewitt and Associates, Inc. (PAI) by email on February 11, 2003, and it had 47 graves listed. The second list was a paper copy provided to PAI in early April 2003, and it was dated March 2003. This second list had 58 entries on it, and it included all of the entries on the first list except for one. This one extra entry on the first list was added to the second list, bringing the total number of recorded graves at Pioneer Cemetery to 59. To make these final lists presented in this appendix easier to view and use, PAI added created separate data columns for name of the deceased, birth year, death year, age at death, inferred sex, and group affiliation.

It is notable that the online Find A Grave (2015) database, which contains data recorded in August 2009, lists only 33 marked graves for Pioneer Cemetery, as opposed to 59 in the earlier museum inventory. The reasons for this discrepancy are unclear. When the two data sets were compared, all 33 entries in the Find A Grave inventory were found in the earlier museum list. The names, birth years, and death years also were compared, and when discrepancies in names or death dates were noted, the Find A Grave photograph of the grave marker was examined. In this manner, several corrections were made to the Brazoria County Historical Museum grave inventory. The corrected data are denoted by shaded cells in Tables F.1 and F.2 and described in Table F.1.

\section{REFERENCE CITED}

Find A Grave

2015 Pioneer Cemetery, Brazoria County, Texas, USA. Electronic document, http://www.findagrave.com/ cgi-bin/fg.cgi?page=cr\&CRid=2316771, accessed March 23, 2015. 


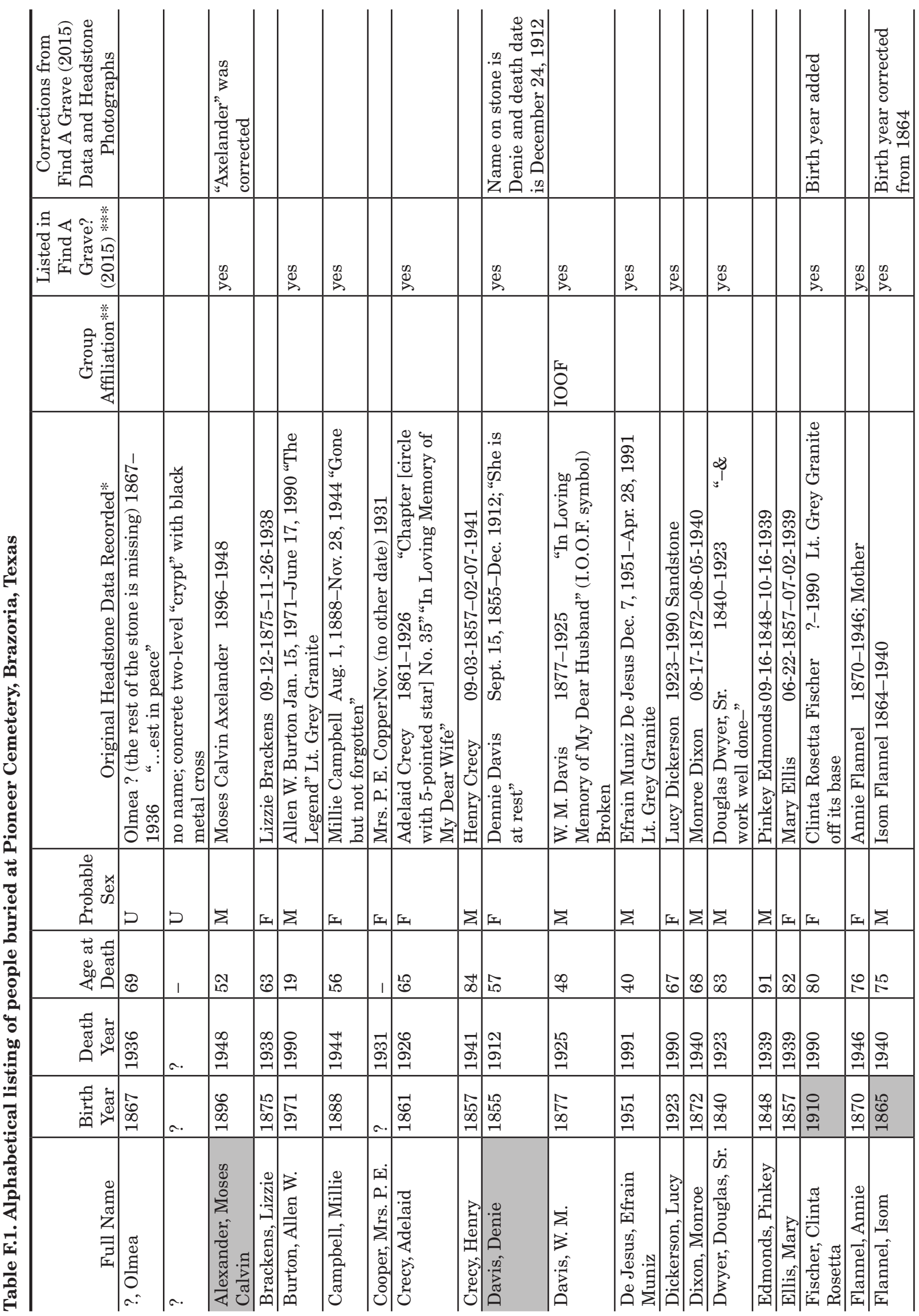




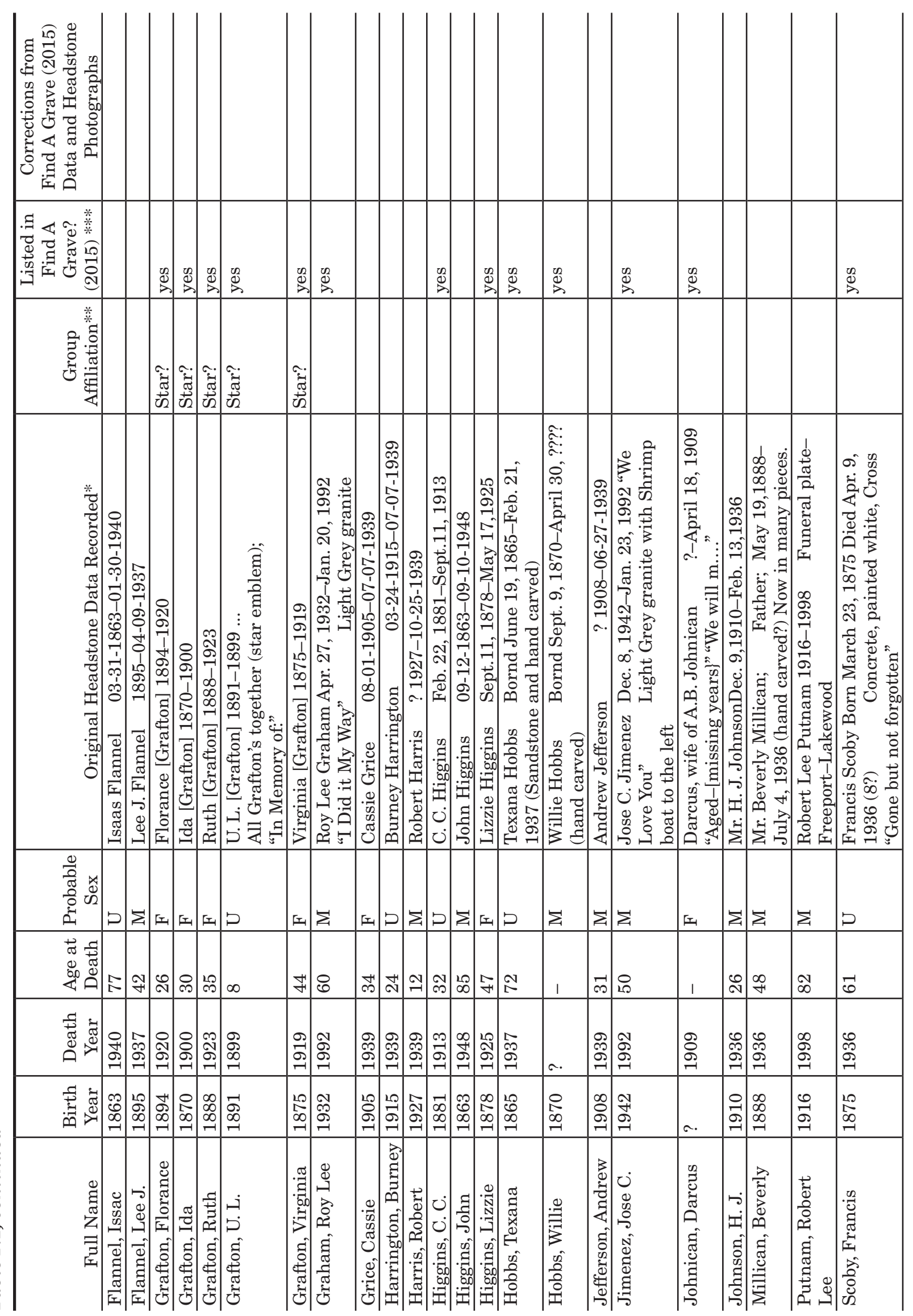




\begin{tabular}{|c|c|c|c|c|c|c|c|c|c|c|c|c|c|c|c|c|c|}
\hline 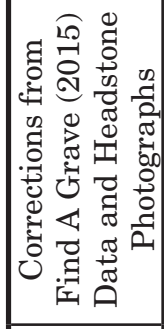 & & & & & & & & 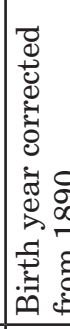 & 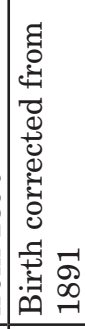 & & 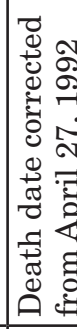 & & & & 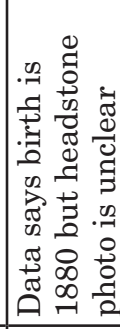 & & \\
\hline 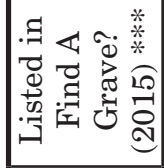 & & & $\begin{array}{l}\text { Un } \\
0 \\
\lambda\end{array}$ & 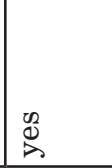 & $\underbrace{\infty}_{\lambda}$ & & & \& & $\mid \begin{array}{l}0 \\
0 \\
2\end{array}$ & & $\begin{array}{l}c_{2}^{2} \\
\stackrel{2}{2}\end{array}$ & & & & $\underset{D}{\beth}$ & D. & . \\
\hline 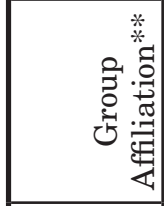 & & & 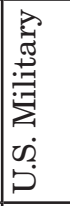 & 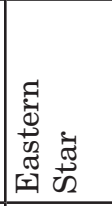 & 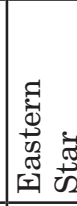 & $\sum_{i=1}^{E}$ & & 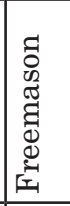 & 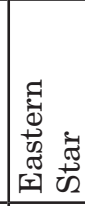 & & & & & & & & 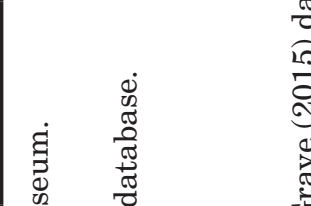 \\
\hline 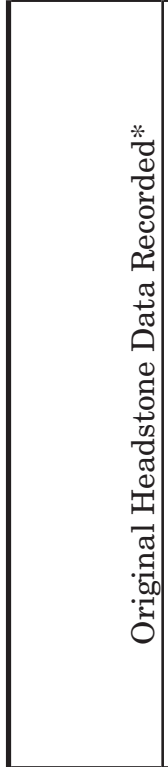 & 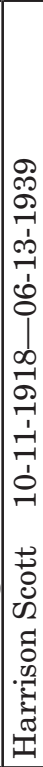 & 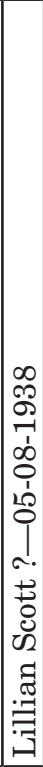 & 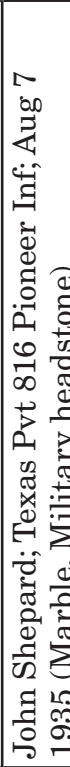 & 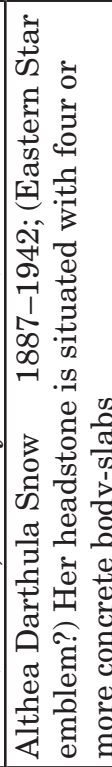 & 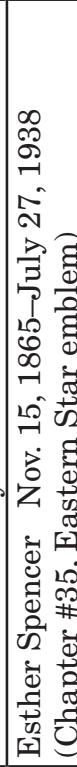 & 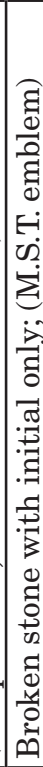 & 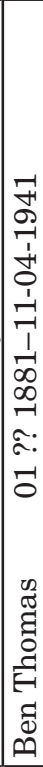 & 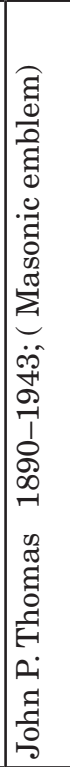 & 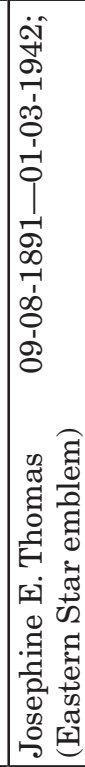 & 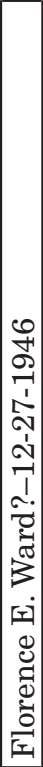 & 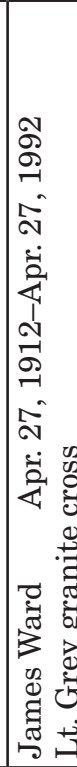 & 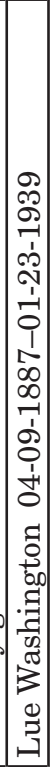 & 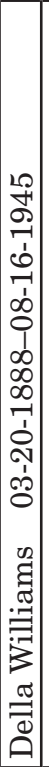 & 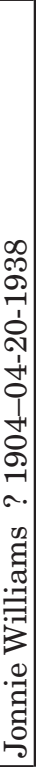 & 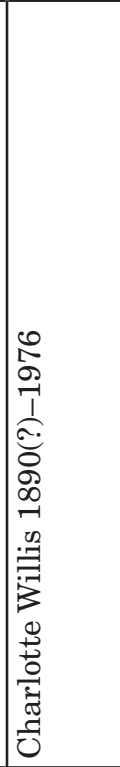 & 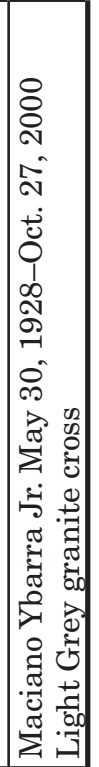 & 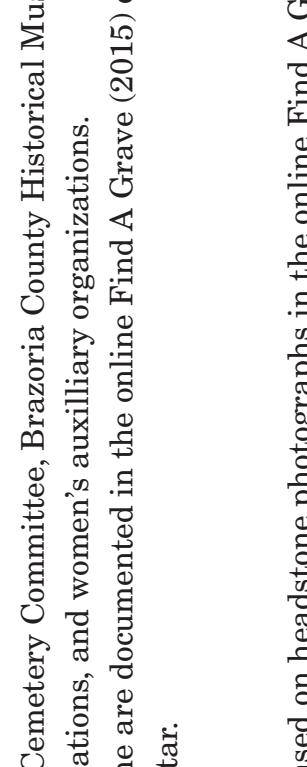 \\
\hline 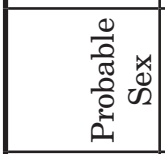 & $\Sigma$ & I. & $\Sigma$ & I工工 & LI & $p$ & $\Sigma$ & $\Sigma$ & 厌 & {$\left[\Phi_{1}\right.$} & $\Sigma$ & $P$ & I & $\sum$ & ⿷匚 & $\Sigma$ & 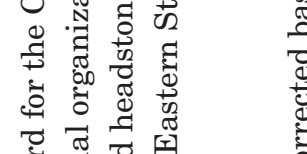 \\
\hline 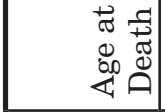 & $\vec{N}$ & 11 & 1 & $\begin{array}{l}10 \\
10\end{array}$ & $\underset{i}{\mathfrak{T}}$ & 1 & 8 & $\stackrel{\infty}{N}$ & ลิ & 1 & 10 & 旋 & م0 & ભ & 1 & $\stackrel{N}{N}$ & 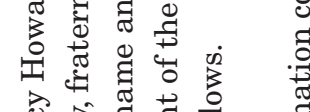 \\
\hline 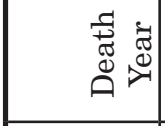 & ळ్ & 恶 & 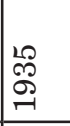 & $\underset{\mathscr{J}}{\stackrel{\sim}{-}}$ & 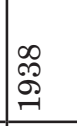 & a. & 节 & 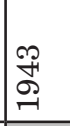 & Iี & 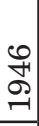 & 命 & 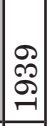 & 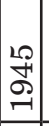 & & \begin{tabular}{l}
0 \\
\multirow{2}{2}{} \\
-1
\end{tabular} & ஜ̊ి & 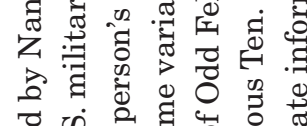 \\
\hline 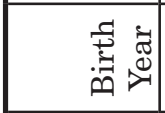 & $\begin{array}{l}\infty \\
\sigma \\
-\end{array}$ & & a. & $\begin{array}{l}\infty \\
\infty \\
\infty \\
\sim\end{array}$ & $\begin{array}{l}18 \\
0 \\
-10 \\
-1\end{array}$ & a. & $\mid \begin{array}{l}\infty \\
\infty \\
\sim \\
\sim\end{array}$ & 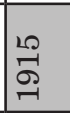 & $\begin{array}{l}\stackrel{8}{\infty} \\
-1 \\
-1\end{array}$ & & $\stackrel{\sim}{\stackrel{2}{-}}$ & & -1 & & $\begin{array}{l}\tilde{0} \\
\dot{8} \\
\infty \\
-1\end{array}$ & $\begin{array}{l}\infty \\
\stackrel{N}{-} \\
\stackrel{-}{-}\end{array}$ & 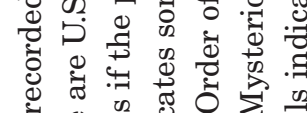 \\
\hline 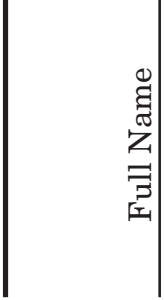 & 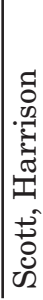 & 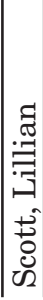 & 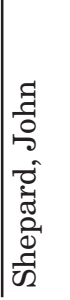 & 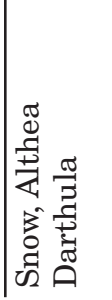 & 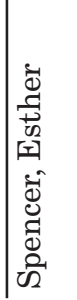 & & & 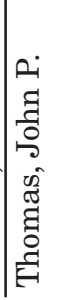 & 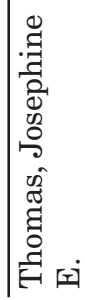 & & 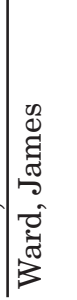 & 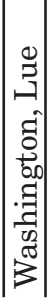 & 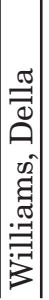 & & 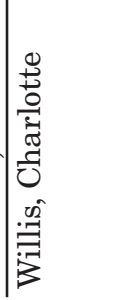 & 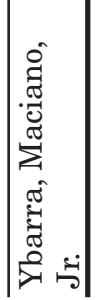 & 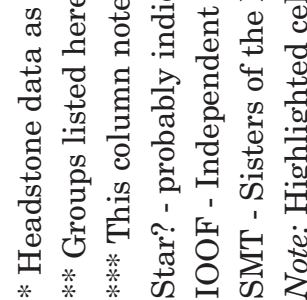 \\
\hline
\end{tabular}


Table F.2. Chronological listing of people buried in Pioneer Cemetery, Brazoria, Texas

\begin{tabular}{|c|c|c|c|c|c|c|}
\hline $\begin{array}{l}\text { Birth } \\
\text { Year }\end{array}$ & \begin{tabular}{|c|} 
Death \\
Year \\
\end{tabular} & \begin{tabular}{|l|} 
Age at \\
Death \\
\end{tabular} & Last Name & $\begin{array}{c}\text { Probable } \\
\text { Sex }\end{array}$ & Original Headstone Data Recorded* & $\begin{array}{c}\text { Group } \\
\text { Affiliation } * *\end{array}$ \\
\hline 1891 & 1899 & 8 & Grafton & $\mathrm{U}$ & $\begin{array}{l}\text { U. L. [Grafton] 1891-1899 ...All Grafton's } \\
\text { together (star emblem); "In Memory of:" }\end{array}$ & Star? \\
\hline 1870 & 1900 & 30 & Grafton & $\mathrm{F}$ & Ida [Grafton] 1870-1900 & Star? \\
\hline$?$ & 1909 & -- & Johnican & $\mathrm{F}$ & \begin{tabular}{|ll} 
Darcus, wife of A.B. Johnican & ?-April 18, \\
1909 & "Aged-[missing years]" "We will m...."
\end{tabular} & \\
\hline 1855 & 1912 & 57 & Davis & $\mathrm{F}$ & $\begin{array}{l}\text { Dennie Davis } \quad \text { Sept. 15, 1855-Dec. 1912; } \\
\text { "She is at rest". }\end{array}$ & \\
\hline 1881 & 1913 & 32 & Higgins & $\mathrm{U}$ & C. C. Higgins $\quad$ Feb. 22, 1881-Sept.11, 1913 & \\
\hline 1875 & 1919 & 44 & Grafton & $\mathrm{F}$ & Virginia [Grafton] 1875-1919 & Star? \\
\hline 1894 & 1920 & 26 & Grafton & $\mathrm{F}$ & Florance [Grafton] 1894-1920 & Star? \\
\hline 1840 & 1923 & 83 & Dwyer & M & $\begin{array}{|lll|}\begin{array}{l}\text { Douglas Dwyer, Sr. } \\
\text { work well done-" }\end{array} & 1840-1923 \quad \text { “\& } \\
\end{array}$ & \\
\hline 1888 & 1923 & 35 & Grafton & $\mathrm{F}$ & Ruth [Grafton] 1888-1923 & Star? \\
\hline 1877 & 1925 & 48 & Davis & M & $\begin{array}{l}\text { W. M. Davis 1877-1925 "In Loving } \\
\text { Memory of My Dear Husband" (I.O.O.F. } \\
\text { symbol) Broken }\end{array}$ & IOOF \\
\hline 1878 & 1925 & 47 & Higgins & $\mathrm{F}$ & Lizzie Higgins $\quad$ Sept.11, 1878-May 17,1925 & \\
\hline 1861 & 1926 & 65 & Crecy & $\mathrm{F}$ & $\begin{array}{l}\text { Adelaid Crecy 1861-1926 "Chapter } \\
\text { [circle with 5-pointed star] No. 35" "In Loving } \\
\text { Memory of My Dear Wife" }\end{array}$ & \\
\hline$?$ & 1931 & -- & Copper & $\mathrm{F}$ & Mrs. P. E. CopperNov. (no other date) 1931 & \\
\hline$?$ & 1935 & -- & Shepard & $\mathrm{M}$ & $\begin{array}{l}\text { John Shepard; Texas Pvt } 816 \text { Pioneer Inf; Aug } \\
71935 \text { (Marble, Military headstone) }\end{array}$ & Military \\
\hline 1867 & 1936 & 69 & ?, Olmea & $\mathrm{U}$ & \begin{tabular}{|l|} 
Olmea ? (the rest of the stone is missing) $1867-$ \\
1936 "...est in peace"
\end{tabular} & \\
\hline 1910 & 1936 & 26 & Johnson & M & Mr. H. J. JohnsonDec. 9,1910-Feb. 13,1936 & \\
\hline 1888 & 1936 & 48 & Millican & M & $\begin{array}{l}\text { Mr. Beverly Millican; Father; May } \\
\text { 19,1888-July 4, } 1936 \text { (hand carved?) Now in } \\
\text { many pieces. }\end{array}$ & \\
\hline 1875 & 1936 & 61 & Scoby & $\mathrm{U}$ & $\begin{array}{l}\text { Francis Scoby Born March 23, } 1875 \text { Died Apr. } \\
9,1936 \text { (8?) Concrete, painted white, } \\
\text { Cross "Gone but not forgotten" }\end{array}$ & \\
\hline 1895 & 1937 & 42 & Flannel & $\mathrm{M}$ & Lee J. Flannel 1895-04-09-1937 & \\
\hline 1865 & 1937 & 72 & Hobbs & $\mathrm{U}$ & \begin{tabular}{|l|} 
Texana Hobbs Bornd June 19, 1865-Feb. 21, \\
1937 (Sandstone and hand carved) \\
\end{tabular} & \\
\hline 1875 & 1938 & 63 & Brackens & $\mathrm{F}$ & Lizzie Brackens 09-12-1875-11-26-1938 & \\
\hline$?$ & 1938 & -- & Scott & $\mathrm{F}$ & Lillian Scott ?-05-08-1938 & \\
\hline 1865 & 1938 & 73 & Spenser & $\mathrm{F}$ & $\begin{array}{l}\text { Esther Spencer Nov. 15, 1865-July 27, } 1938 \\
\text { (Chapter \#35, Eastern Star emblem) }\end{array}$ & Eastern Star \\
\hline 1904 & 1938 & 34 & Williams & $\mathrm{M}$ & Jonnie Williams ?-1904-04-20-1938 & \\
\hline 1848 & 1939 & 91 & Edmonds & $\mathrm{M}$ & Pinkey Edmonds 09-16-1848-10-16-1939 & \\
\hline 1857 & 1939 & 82 & Ellis & $\mathrm{F}$ & 06-22-1857-07-02-1939 & \\
\hline 1905 & 1939 & 34 & Grice & $\mathrm{F}$ & 08-01-1905-07-07-1939 & \\
\hline 1915 & 1939 & 24 & Harrington & $\mathrm{U}$ & $\begin{array}{l}\text { Burney Harrington } \\
1939\end{array}$ & \\
\hline 1927 & 1939 & 12 & Harris & $\mathrm{M}$ & Robert Harris $\quad ?-1927-10-25-1939$ & \\
\hline 1908 & 1939 & 31 & Jefferson & $\mathrm{M}$ & ?-1908-06-27-1939 & \\
\hline 1918 & 1939 & 21 & Scott & $\mathrm{M}$ & Harrison Scott $\quad$ 10-11-1918-06-13-1939 & \\
\hline 1887 & 1939 & 52 & Washington & $\mathrm{U}$ & Lue Washington 04-09-1887-01-23-1939 & \\
\hline 1872 & 1940 & 68 & Dixon & $\mathrm{M}$ & 08-17-1872--08-05-1940 & \\
\hline
\end{tabular}


Table F.2, continued

\begin{tabular}{|c|c|c|c|c|c|c|}
\hline $\begin{array}{l}\text { Birth } \\
\text { Year }\end{array}$ & $\begin{array}{l}\text { Death } \\
\text { Year }\end{array}$ & \begin{tabular}{|l|} 
Age at \\
Death \\
\end{tabular} & Last Name & \begin{tabular}{|c|} 
Probable \\
Sex
\end{tabular} & Original Headstone Data Recorded* & $\begin{array}{c}\text { Group } \\
\text { Affiliation } * *\end{array}$ \\
\hline 1863 & 1940 & 77 & Flannel & $\mathrm{U}$ & 03-31-1863-01-30-1940 & \\
\hline 1865 & 1940 & 75 & Flannel & $\mathrm{M}$ & Isom Flannel 1864-1940 & \\
\hline 1857 & 1941 & 84 & Crecy & $\mathrm{M}$ & 09-03-1857-02-07-1941 & \\
\hline 1881 & 1941 & 60 & Thomas & $\mathrm{M}$ & 01-??-1881-11-04-1941 & \\
\hline 1887 & 1942 & 55 & Snow & $\mathrm{F}$ & $\begin{array}{l}\text { Althea Darthula Snow 1887-1942; (Eastern } \\
\text { Star emblem?) Her headstone is situated with } \\
\text { four or more concrete body-slabs }\end{array}$ & Eastern Star \\
\hline 1890 & 1942 & 52 & Thomas & $\mathrm{F}$ & $\begin{array}{l}\text { Josephine E. Thomas } \quad 09-08-1891-01-03- \\
1942 ; \quad \text { (Eastern Star emblem) }\end{array}$ & Eastern Star \\
\hline 1915 & 1943 & 28 & Thomas & $\mathrm{M}$ & $\begin{array}{l}\text { John P. Thomas 1890-1943; ( Masonic } \\
\text { emblem) }\end{array}$ & Freemason \\
\hline 1888 & 1944 & 56 & Campbell & $\mathrm{F}$ & $\begin{array}{l}\text { Millie Campbell Aug. 1, 1888-Nov. 28, } 1944 \\
\text { "Gone but not forgotten" }\end{array}$ & \\
\hline 1888 & 1945 & 57 & Williams & $\mathrm{F}$ & Della Williams $\quad 03-20-1888-08-16-1945$ & \\
\hline 1870 & 1946 & 76 & Flannel & $\mathrm{F}$ & Annie Flannel $\quad$ 1870-1946; Mother & \\
\hline$?$ & 1946 & -- & Ward & $\mathrm{F}$ & Florence E. Ward?-12-27-1946 & \\
\hline 1896 & 1948 & 52 & Alexander & $\mathrm{M}$ & Moses Calvin Axelander $\quad 1896-1948$ & \\
\hline 1863 & 1948 & 85 & Higgins & $\mathrm{M}$ & John Higgins $\quad$ 09-12-1863-09-10-1948 & \\
\hline $\begin{array}{l}1890 \\
?\end{array}$ & 1976 & -- & Willis & $\mathrm{F}$ & Charlotte Willis 1890(?)-1976 & \\
\hline 1971 & 1990 & 19 & Burton & $\mathrm{M}$ & $\begin{array}{l}\text { Allen W. Burton Jan. 15, 1971-June 17, } 1990 \\
\text { "The Legend" Lt. Grey Granite }\end{array}$ & \\
\hline 1923 & 1990 & 67 & Dickerson & $\mathrm{F}$ & Lucy Dickerson $1923-1990$ Sandstone & \\
\hline 1910 & 1990 & 80 & Fischer & $\mathrm{F}$ & $\begin{array}{l}\text { Clinta Rosetta Fischer ?-1990 Lt. Grey } \\
\text { Granite off its base }\end{array}$ & \\
\hline 1951 & 1991 & 40 & De Jesus & M & $\begin{array}{l}\text { Efrain Muniz De Jesus Dec. 7, 1951-Apr. 28, } \\
1991 \text { Lt. Grey Granite }\end{array}$ & \\
\hline 1932 & 1992 & 60 & Graham & M & $\begin{array}{l}\text { Roy Lee Graham Apr. 27, 1932-Jan. 20, } 1992 \text { "I } \\
\text { Did it My Way" Light Grey granite }\end{array}$ & \\
\hline 1942 & 1992 & 50 & Jimenez & $\mathrm{M}$ & $\begin{array}{l}\text { Jose C. Jimenez Dec. 8, 1942-Jan. 23, } 1992 \\
\text { "We Love You" Light Grey granite with } \\
\text { Shrimp boat to the left }\end{array}$ & \\
\hline 1912 & 1997 & 85 & Ward & M & $\begin{array}{l}\text { James Ward Apr. 27, 1912-Apr. 27, } 1992 \\
\text { Lt. Grey granite cross }\end{array}$ & \\
\hline 1916 & 1998 & 82 & Putnam & M & $\begin{array}{l}\text { Robert Lee Putnam 1916-1998 } \\
\text { plate--Freeport--Lakewood }\end{array}$ & \\
\hline 1928 & 2000 & 72 & Ybarra & $\mathrm{M}$ & $\begin{array}{l}\text { Maciano Ybarra Jr. May 30, 1928-Oct. 27, } 2000 \\
\text { Light Grey granite cross }\end{array}$ & \\
\hline$?$ & $?$ & -- & $?$ & $\mathrm{U}$ & $\begin{array}{l}\text { no name; concrete two-level "crypt" with black } \\
\text { metal cross }\end{array}$ & \\
\hline 1870 & $?$ & -- & Hobbs & M & $\begin{array}{l}\text { Willie Hobbs Bornd Sept. 9, 1870-April 30, } \\
\text { ???? (hand carved) }\end{array}$ & \\
\hline$?$ & $?$ & -- & T.? & $\mathrm{U}(\mathrm{F} ?)$ & Broken stone with initial only; (M.S.T. emblem) & SMT \\
\hline
\end{tabular}

* Headstone data as recorded by Nancy Howard for the Cemetery Committee, Brazoria County Historical Museum.

** Groups listed here are U. S. military, fraternal organizations, and women's auxilliary organizations.

Star? - probably indicates some variant of the Eastern Star.

IOOF - Independent Order of Odd Fellows.

SMT - Sisters of the Mysterious Ten.

Note: A highlighted cell indicates data were corrected after examining headstone photographs in the online Find A Grave (2015) database. 